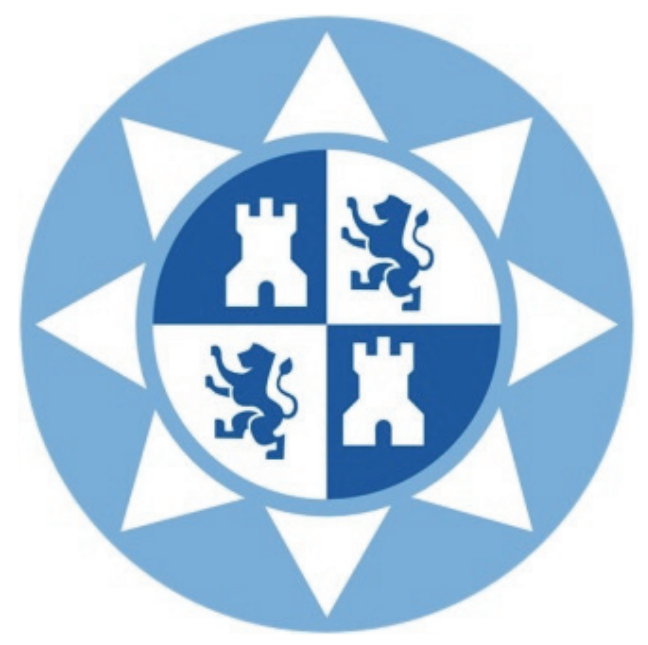

Universidad Politécnica de Cartagena

Departamento de Economía

\title{
EL TRÁFICO DE CRUCEROS EN EL MEDITERRÁNEO ESPAÑOL Y LOS AGENTES TERRESTRES Y MARÍTIMOS RELEVANTES PARA LOS ITINERARIOS
}

\section{TESIS DOCTORAL}

Jerónimo Antonio Esteve Pérez

Director

Antonio García Sánchez 



\section{CONFORMIDAD DE DEPÓSITO DE TESIS DOCTORAL POR LA COMISIÓN ACADÉMICA DEL PROGRAMA}

D. Carmelo Reverte Maya, Presidente de la Comisión Académica del Programa de Doctorado "Administración y Dirección de Empresas"

\section{INFORMA:}

Que la Tesis Doctoral titulada "El tráfico de cruceros en el Mediterráneo español y los agentes maritimos y terrestres relevantes para los itinerarios", ha sido realizada, dentro del mencionado programa de doctorado, por D. Jerónimo A. Esteve Pérez, bajo la dirección y supervisión del Dr. Antonio García Sánchez.

En reunión de la Comisión Académica de fecha 20/11/2014, visto que en la misma se acreditan los indicios de calidad correspondientes y la autorización del Director de la misma, se acordó dar la conformidad, con la finalidad de que sea autorizado su depósito por la Comisión de Doctorado.

La Rama de conocimiento por la que esta tesis ha sido desarrollada es:

$\square$ Ciencias

X Ciencias Sociales y Jurídicas

$\square$ Ingeniería y Arquitectura

En Cartagena, a 20 de noviembre de 2014

EL PRESIDENTE DE LA COMISIÓN ACADÉMICA DEL PROGRAMA

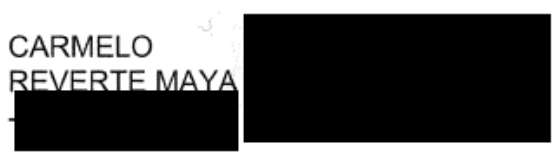

Fdo: Carmelo Reverte Maya 



\section{Universidad}

Politécnica

de Cartagena

DT-16

\section{CONFORMIDAD DE SOLICITUD DEAUTORIZACIÓN DE DEPÓSITO DE TESIS DOCTORAL POR EL/LA DIRECTOR/A DE LA TESIS}

D. Antonio García Sánchez Director de la Tesis doctoral El tráfico de cruceros en el Mediterráneo español y los agentes marítimos y terrestres relevantes para los itinerarios

\section{INFORMA:}

Que la referida Tesis Doctoral, ha sido realizada por D. Jerónimo A. Esteve Pérez, dentro del programa de doctorado Administración y Dirección de Empresas, dando mi conformidad para que sea presentada ante la Comisión de Doctorado para ser autorizado su depósito.

La rama de conocimiento en la que esta tesis ha sido desarrollada es:

$\square$ Ciencias

$\mathrm{X}$ Ciencias Sociales y Jurídicas

Ingeniería y Arquitectura

En Cartagena, a 18 de noviembre de 2014

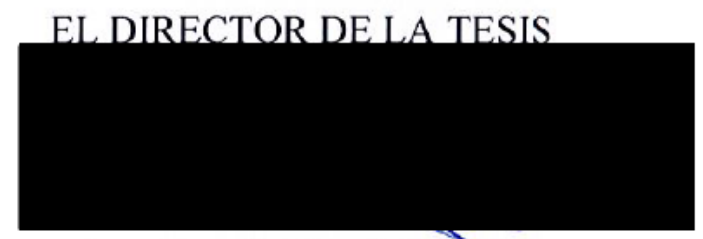

Fdo.: Antonio García Sánchez

\section{COMISIÓN DE DOCTORADO}



El aprendizaje es un simple apéndice de nosotros mismos; dondequiera que estemos, está también nuestro aprendizaje.

William Shakespeare 



\section{Agradecimientos}

La presente tesis doctoral no hubiera sido posible sin el apoyo incondicional de un sinfín de personas a las cuales quiero agradecer su ayuda dedicándoles unas breves líneas. En primer lugar, a toda mi familia, y especialmente a mis padres, por todo su ánimo, ayuda, compresión y el afán de superación que me han inculcado para superar obstáculos y alcanzar metas superiores en cualquier actividad. También tengo que agradecer a mis tíos maternos la inquietud por los asuntos de la mar que me han transmitido, pues sin ella no podría haber focalizado el ámbito de estudio de la tesis doctoral. Todos ellos han supuesto un impulso positivo en el transcurso de la elaboración de la tesis.

A mi Director de Tesis, el Doctor Antonio García Sánchez, por su absoluta y desinteresada dedicación durante este periodo. Cualquier momento, tanto de forma presencial como telefónica, ha sido adecuado para comentar las múltiples cuestiones que me han surgido durante esta incursión en el mundo de los cruceros. Sin duda alguna, su apoyo y sus ideas, razonamientos críticos, planteamientos, orientaciones y consejos han sido determinantes en el desarrollo de la tesis. Sin él hubiera sido imposible culminar esta singladura por la industria de cruceros. Todo lo que he aprendido de él, me ha hecho crecer no solo como profesional, sino también, y más importante, como persona.

No puedo olvidarme de mi compañero de hazañas investigadoras el Doctor José Enrique Gutiérrez Romero, sin su ánimo y ayuda esta etapa no hubiera sido posible. En este mismo sentido, también tengo que agradecer al Doctor Tomás López Maestre su inmenso apoyo incondicional y el interés y afán que despertó en mí por los asuntos relacionados con el tráfico marítimo. Asimismo tengo que agradecer especialmente a mis compañeros del Departamento de Tecnología Naval el ánimo recibido por su parte y todos los conocimientos que me han transmitido durante mi etapa formativa como ingeniero naval, sin ellos no podría haber alcanzado esta meta.

Por supuesto, también quiero agradecer a todas las personas que han atendido mis consultas, telefónicamente o por correo electrónico, en las numerosas Autoridades Portuarias españolas a las que he consultado, su atención, colaboración y datos facilitados.

A todas las personas que durante este periodo de mi vida en que decidí embarcarme en la tarea de elaborar una tesis doctoral me han ayudado, apoyado, orientado, e incluso, comprendido, muchas gracias. 



\section{Resumen}

La desaparición de las líneas transoceánicas de transporte marítimo de pasajeros a finales de los años 60 y en la década de 1970 dio lugar a la creación de un nuevo negocio marítimo y tipología turística, el tráfico y turismo de cruceros. La industria de cruceros presenta un notable dinamismo durante las dos últimas décadas con una tasa media de crecimiento anual entre 1990 y 2013 del 7,84\%, medida por el número de pasajeros de crucero mundiales. Además, su tasa de penetración en la población mundial es muy reducida, lo que le confiere magníficas perspectivas de crecimiento para los próximos años.

En el turismo de cruceros se combina una componente marítima, el buque, con dos terrestres, el puerto y el hinterland turístico, para dar lugar a su elemento central, el itinerario. La cadena de valor del producto turismo de cruceros presenta una notable concentración en diversos eslabones, dando lugar a fuertes poderes de mercado. Las concentraciones más relevantes se registran en las regiones de destino, el mercado de navieras de crucero, los mercados emisores de cruceristas y en la red global de puertos. De las seis principales regiones de crucero, el Caribe y el Mediterráneo concentran más del 50\% de la capacidad de buques desplegada. El mercado de navieras de crucero tiene una naturaleza oligopólica con elevada concentración tanto horizontal como vertical. En los mercados emisores de pasajeros de crucero se da una situación similar pues entre 1990 y 2013 el 91,2\% de los pasajeros procedían de Norteamérica y Europa. Respecto a la red mundial de puertos de crucero, existe una gran diferencia entre el número de puertos de escala y puertos base disponibles, siendo más numeroso el primer tipo.

La costa española no ha pasado inadvertida ante el dinamismo de la industria de cruceros con una tasa media de crecimiento de la cifra de pasajeros entre 1990 y 2013 del $14,77 \%$. La costa mediterránea española y atlántica andaluza ha concentrado durante este periodo la mayor actividad crucerística con tres cuartas partes de los pasajeros de cruceros registrados. Los puertos de crucero españoles durante el periodo del año 2000 a 2013 se encuadran, fundamentalmente, en dos posiciones competitivas positivas, líder maduro y elevado potencial. Además, España cuenta con puertos base en todas sus zonas litorales. La potencia turística de España también se refleja en los puertos de crucero. En concreto, los puertos de la costa mediterránea y atlántica andaluza tienen un amplio hinterland turístico dando lugar además a cinco tipos de puertos atendiendo al flujo turístico del puerto hacia el hinterland.

El análisis empírico realizado focaliza la atención en dos aspectos, particularizados ambos para los puertos de crucero de la costa mediterránea y atlántica andaluza. El primero, permite desde un modelo econométrico explicar la cifra de pasajeros de crucero que registra un puerto. Se emplean análisis de componentes principales y regresión por mínimos cuadrados ordinarios. Las variables explicativas están relacionadas con el atractivo del hinterland turístico, la infraestructura turística y los costes de escala. El segundo aspecto, alude a la determinación del patrón de estacionalidad, y su evolución, durante el periodo de 
2000 a 2013. Para ello se ha analizado una serie temporal compuesta de 168 observaciones, además de, calcular el coeficiente de Variación y el de Gini y la tasa de variación interanual mes a mes. 


\section{Abstract}

The demise of the passenger transoceanic liner services in the late $60 \mathrm{~s}$ and in the $70 \mathrm{~s}$ gave rise to creation of a new maritime business and tourist typology: the cruise traffic. The cruise industry has been dynamically advancing over the last decades with an average annual growth rate in the worldwide number of cruise passengers of 7.84 per cent between 1990 and 2013. Furthermore, it has a low penetration rate in the worldwide population, which gives great growth prospects for the coming years.

The cruise tourism combine a maritime component, the cruise ship, with two land components, the port and the tourist hinterland, these yield to its main element, the itinerary. The value chain of cruise tourism has a remarkable concentration in various stages, leading to strong market powers. The most significant concentrations are found in destinations regions, the cruise lines market, source markets and in the global cruise port network. Among the six major cruise regions, the Caribbean and the Mediterranean account for more than 50 per cent of the vessel capacity deployed. The cruise lines market has an oligopolistic nature, with high levels of horizontal and vertical concentration. In the cruise passenger source markets there is a similar situation because 91.2 per cent of the cruise passengers were from North America and Europe between 1990 and 2013. With respect to the global cruise port network, there is a large difference between the number of ports of call and homeports available; the first type is much more numerous.

The growing trend of the cruise industry has not gone unnoticed in Spain, with an average annual growth rate of 14.77 per cent between 1990 and 2013. During the same period, the Mediterranean coastal ports and the Andalusian Atlantic ports accounted for approximately 75 per cent of the total cruise passengers. Spanish cruise ports during the period 2000 to 2013 were located primarily on two positive competitive positions, mature leader and high potential. Furthermore, Spain has homeports in its three coastal areas. The Spanish tourist power is also reflected in the cruise ports. In particular, Mediterranean and Andalusian Atlantic coastal ports have a wide tourist hinterland, in addition, are identified five types of ports according to the tourist flow from the port towards the hinterland.

The empirical analysis focuses on two aspects, both particularized for Mediterranean and Andalusian Atlantic coastal ports. The first allows explaining the number of cruise passengers registered in a port from an econometric model. Principal component analysis and least squares regression are used. The explanatory variables are related to the tourist attractiveness, the port infrastructure and port costs. The second aspect refers to the determination of the seasonal pattern and its evolution during the period 2000-2013. To do this, a time series of 168 observations is analyzed, in addition to calculate the coefficient of Variation, the Gini coefficient and the interannual variation rate by month. 



\section{Índice}

Capítulo I. Introducción 1

Capítulo II. La industria de cruceros: características, situación y perspectivas 7

2.1 El origen del tráfico/turismo de cruceros $\quad 7$

2.2 El producto crucero 9

2.3 Evolución mundial del tráfico de cruceros $\quad 12$

$\begin{array}{ll}2.4 \text { Principales zonas de operación: itinerarios y destinos } & 14\end{array}$

$\begin{array}{ll}2.4 .1 \text { Caribe } & 15\end{array}$

$\begin{array}{ll}2.4 .2 \text { Alaska } & 19\end{array}$

2.4.3 Sudamérica y la Antártida 20

2.4.4 Asia-Pacífico 23

2.4.4.1 Pacífico Sur $\quad 24$

2.4.4.2 Extremo Oriente $\quad 24$

2.4.4.3 Transpacífico 25

2.4.5 Norte de Europa 25

2.4.6 Mediterráneo 34

2.4.7 Destinos emergentes 42

2.5 Tipos de itinerarios de crucero $\quad 43$

2.6 Tipología de buques de crucero $\quad 47$

2.7 Segmentación del mercado mundial $\quad 50$

2.8 Principales países emisores de pasajeros de crucero 52

2.8.1 Mercado emisor europeo $\quad 55$

2.8.1.1 Mercado emisor británico $\quad 57$

2.8.1.2 Mercado emisor alemán $\quad 58$

2.8.1.3 Mercado emisor italiano $\quad 59$

2.8.1.4 Mercado emisor español $\quad 60$

2.8.1.5 Mercado emisor francés $\quad 61$

2.8.1.6 Otros mercados emisores europeos 62 Capítulo III. Características y funciones de los agentes implicados en la 65
industria de cruceros

3.1 El mercado de navieras de crucero $\quad 65$

$\begin{array}{ll}\text { 3.1.1 Grupo Carnival Corporation \& plc } & 67\end{array}$

3.1.2 Grupo Royal Caribbean Cruises Limited $\quad 70$

3.1.3 Grupo Genting Hong Kong Limited 73 
3.1.4 Grupo de navieras independientes

3.1.5 Análisis global de la flota de buques de crucero $\quad 79$

3.1.5.1 Otras características relevantes de la flota de buques de crucero $\quad 80$

$\begin{array}{ll}3.2 \text { Los puertos de crucero } & 88\end{array}$

3.2.1 Función desempeñada por el puerto en el tráfico de cruceros 88

3.2.1.1 Puerto público 102

3.2.1.2 Puerto tool 102

3.2.1.3 Puerto Landlord 103

3.2.1.4 Puerto privado 103

3.2.2 Análisis del tráfico de cruceros en el Sistema Portuario Español 105

3.2.2.1 Puertos de la costa mediterránea y atlántica andaluza 110

3.2.2.2 Puertos de las islas Canarias $\quad 119$

3.2.2.3 Puertos del mar Cantábrico y la costa atlántica gallega 122

3.2.3 Instalaciones dedicadas al tráfico de cruceros en el litoral Mediterráneo y Atlántico andaluz

3.2.3.1 Puertos líderes maduros $\quad 125$

3.2.3.2 Puertos con elevado potencial 127

$\begin{array}{ll}\text { 3.2.3.3 Puertos participantes minoritarios } & 130\end{array}$

3.3 Hinterlands turísticos 132

Capítulo IV. Análisis empírico $\quad 141$

4.1 Análisis econométrico de las variables influyentes en el tráfico de cruceros registrado por un puerto

$\begin{array}{ll}\text { 4.1.1 Definición de la variable dependiente } & 142\end{array}$

4.1.2 Definición de las variables explicativas 143

$\begin{array}{ll}\text { 4.1.3 Análisis de componentes principales } & 146\end{array}$

$\begin{array}{ll}\text { 4.1.4 Resultados de la regresión } & 147\end{array}$

$\begin{array}{ll}\text { 4.1.5 Discusión de resultados } & 148\end{array}$

4.2 Análisis de estacionalidad en el tráfico de cruceros en los puertos de la costa mediterránea y atlántica andaluza

4.2.1 Método

4.2.2 Análisis agregado de la estacionalidad del tráfico de cruceros en los puertos de la costa mediterránea y atlántica andaluza

4.2.3 Análisis segregado de la estacionalidad del tráfico de cruceros en los puertos de la costa mediterránea y atlántica andaluza 
5.2 Futuras líneas de investigación

I.1 Grupo Carnival Corporation \& plc

I.1.1 Carnival Cruise Line

I.1.2 Princess Cruises

I.1.3 Costa Cruises

I.1.4 Holland America Line

180

I.1.5 AIDA Cruises

I.1.6 P\&O Cruises

I.1.7 Cunard Line

I.1.8 P\&O Cruises Australia

I.1.9 Iberocruceros

I.1.10 Seabourn Cruise Line 186

I.2 Grupo Royal Caribbean Cruises Limited 186

I.2.1 Royal Caribbean International

I.2.2 Celebrity Cruises

I.2.3 Pullmantur 188

I.2.4 Croisières de France

I.3 Grupo Genting Hong Kong Limited

I.3.1 Norwegian Cruise Line

I.4 Grupo de navieras independientes

I.4.2 Disney Cruise Line

I.4.7 Fred. Olsen Cruise Lines 200

I.4.8 Louis Cruises $\quad 202$

I.4.9 Phoenix Reisen 203

I.4.10 Silversea Cruises 204

I.4.11 Cruise \& Maritime Voyages 205

$\begin{array}{ll}\text { I.4.12 Portuscale Cruises } & 206\end{array}$ 
$\begin{array}{ll}\text { I.4.13 Crystal Cruises } & 207\end{array}$

I.4.14 Regent Seven Seas Cruises 208

$\begin{array}{ll}\text { I.4.15 Hapag-Lloyd Cruises } & 209\end{array}$

I.4.16 Celebration Cruise Line 209

$\begin{array}{ll}\text { I.4.17 Saga Cruises } & 210\end{array}$

$\begin{array}{ll}\text { I.4.18 Compagnie du Ponant } & 211\end{array}$

$\begin{array}{ll}\text { I.4.19 Windstar Cruises } & 211\end{array}$

I.4.20 Lindblad Expeditions 213

$\begin{array}{ll}\text { I.4.21 Star Clippers } & 213\end{array}$

$\begin{array}{ll}\text { I.4.22 Voyages of Discovery } & 214\end{array}$

$\begin{array}{ll}\text { I.4.23 Paul Gauguin Cruises } & 215\end{array}$

I.4.24 Swan Hellenic 216

$\begin{array}{ll}\text { I.4.25 Voyages to Antiquity } & 217\end{array}$

$\begin{array}{ll}\text { I.4.26 Seadream Yacht Club } & 217\end{array}$

$\begin{array}{ll}\text { I.4.27 Pearl Seas Cruises } & 218\end{array}$

$\begin{array}{ll}\text { I.4.28 Blount Small Ship Adventures } & 219\end{array}$

I.4.29 Hebridean Island Cruises 219

Anexo II. Instalaciones para cruceros y perfil de estacionalidad de los puertos del litoral Mediterráneo español y Atlántico andaluz

$\begin{array}{ll}\text { II.1 Puertos líderes maduros } & 221\end{array}$

$\begin{array}{ll}\text { II.1.1 Puerto de Barcelona } & 221\end{array}$

$\begin{array}{ll}\text { II.1.2 Puerto de Palma de Mallorca } & 230\end{array}$

$\begin{array}{ll}\text { II.1.3 Puerto de Málaga } & 234\end{array}$

$\begin{array}{ll}\text { II.1.4 Puerto de Cádiz } & 240\end{array}$

II.2 Puertos con elevado potencial 243

II.2.1 Puerto de Valencia 243

$\begin{array}{ll}\text { II.2.2 Puerto de Ibiza } & 248\end{array}$

II.2.3 Puerto de Cartagena 251

II.2.4 Puerto de Motril 254

$\begin{array}{ll}\text { II.2.5 Puerto de Sevilla } & 257\end{array}$

II.2.6 Puerto de Tarragona $\quad 262$

II.3 Puertos participantes minoritarios 265

II.3.1 Puerto de Alicante 265

II.3.2 Puerto de Almería $\quad 269$

$\begin{array}{ll}\text { II.3.3 Puerto de Mahón } & 272\end{array}$ 
$\begin{array}{ll}\text { II.3.4 Puerto de Ceuta } & 275\end{array}$

$\begin{array}{ll}\text { II.3.5 Puerto de Castellón } & 278\end{array}$

II.3.6 Puerto de Huelva 280

$\begin{array}{ll}\text { II.3.7 Puerto de La Savina } & 282\end{array}$

$\begin{array}{ll}\text { II.3.8 Puerto de Melilla } & 284\end{array}$

$\begin{array}{ll}\text { Referencias bibliográficas } & \mathbf{2 8 7}\end{array}$

$\begin{array}{ll}\text { Siglas } & 301\end{array}$ 



\section{Índice de figuras}

$\begin{array}{ll}\text { Figura 2.1: Buque de crucero fluvial } & 10\end{array}$

$\begin{array}{ll}\text { Figura 2.2: Buque de crucero oceánico } & 10\end{array}$

Figura 2.3: Ríos con cruceros fluviales en Centroeuropa 11

Figura 2.4: Ríos con cruceros fluviales en Europa del Este 11

Figura 2.5: Ríos con cruceros fluviales en España y Portugal 11

Figura 2.6: Itinerario de crucero por el río Nilo 11

Figura 2.7: Itinerario de crucero por el río Mississippi 12

Figura 2.8: Itinerario de crucero por el río Amazonas $\quad 12$

Figura 2.9: Itinerario de crucero por el río Yangtze 12

Figura 2.10: Itinerario de crucero por el río Mekong $\quad 12$

Figura 2.11: Ciclo de vida del producto crucero por regiones de demanda 14

Figura 2.12: Principales regiones de destino de cruceros $\quad 14$

Figura 2.13: Áreas de operación en el Caribe $\quad 16$

Figura 2.14: Configuración de terminales de crucero en el puerto de Miami 16

Figura 2.15: Itinerario de crucero por el Caribe Occidental 18

Figura 2.16: Itinerario de crucero por el Caribe Oriental 18

Figura 2.17: Itinerario de crucero por Bahamas $\quad 19$

Figura 2.18: Ejemplo de itinerario de crucero por Alaska 20

Figura 2.19: Ejemplo de itinerario de crucero por Sudamérica 21

Figura 2.20: Sectores de cruceros en la región Asia-Pacífico 23

Figura 2.21: Sectores de cruceros en la región Asia-Pacífico 23

Figura 2.22: Zonas de operación en el Norte de Europa 26

Figura 2.23: Principales puertos de crucero en el mar Báltico 27

Figura 2.24: Puertos de crucero en Noruega 28

Figura 2.25: Puertos de crucero en las islas Británicas 29

Figura 2.26: Puertos de crucero en Islandia e Islas Feroe 30

Figura 2.27: Puertos de crucero en la costa occidental europea 30

Figura 2.28: Puertos de crucero en las islas Azores 32

Figura 2.29: Puertos de crucero en Madeira 32

Figura 2.30: Puertos de crucero en las islas Canarias 33

Figura 2.31: Zonas de operación en el Mediterráneo 35

Figura 2.32: Puertos de crucero en el mar Adriático $\quad 40$

Figura 2.33: Puertos de crucero en el mar Negro $\quad 41$ 
Figura 2.34: Itinerario de crucero por Emiratos Árabes Unidos y Omán

Figura 2.35: Itinerario de crucero de reposicionamiento Mediterráneo-Caribe

Figura 2.36: Itinerario de crucero "cerrado" por el mar Mediterráneo

Figura 2.37: Itinerario de crucero "abierto" por el mar Mediterráneo

Figura 2.38: Comparativa de tamaños de buques de crucero

Figura 2.39: Ejemplo de distribución de tipos de camarotes en dos cubiertas

Figura 3.1: Coexistencia de tráfico de cruceros y mercancía general en la dársena de Cartagena del puerto de Cartagena

Figura 3.2: Representación conceptual de la intermodalidad presente en el producto crucero con el inicio del itinerario

Figura 3.3: Representación conceptual de la intermodalidad presente en el producto crucero asociada a la escala en un puerto

Figura 3.4: Proceso de consolidación y dispersión de los pasajeros de cruceros desde/hacia sus países de origen en relación con un puerto base de cruceros

Figura 3.5. Proceso de dispersión y consolidación de los pasajeros de crucero hacia/desde el hinterland turístico en relación con un puerto de escala

Figura 3.6: Dimensiones espaciales relacionadas con un puerto de cruceros

Figura 3.7: Zona de intermediación con relación espacial positiva y negativa asociada al puerto de Palma de Mallorca

Figura 3.8: Mapa de puertos de Interés General del Sistema Portuario Español

Figura 3.9: Matriz crecimiento-cuota de mercado de BCG aplicada al sector portuario

Figura 3.10: Representación conceptual del hinterland turístico de un puerto base de cruceros

Figura 3.11: Representación conceptual del hinterland turístico de un puerto de escala de cruceros

Figura 3.12: Representación conceptual del hinterland turístico primario y competitivo de un puerto de escala de cruceros

Figura 3.13: Representación conceptual de los conceptos hinterland turístico y foreland de un puerto base de cruceros

Figura 3.14: Representación conceptual de las cinco tipologías de puertos de crucero atendiendo al flujo turístico del puerto hacia el hinterland

Figura 4.1: Esquema conceptual del proceso de análisis de la estacionalidad aplicado

Figura II.1: Ubicación de los muelles para cruceros en el puerto de Barcelona

Figura II.2: Instalaciones para buques de crucero en el muelle Adossat del puerto de Barcelona

Figura II.3: Instalaciones para buques de crucero en el muelle Barcelona (atraques Norte, Sur y Este) del puerto de Barcelona 
Figura II.4: Instalaciones para buques de crucero en el muelle España del puerto de Barcelona

Figura II.5: Ubicación de los muelles de pasajeros de crucero en el puerto de Palma de Mallorca

Figura II.6: Instalaciones para buques de crucero en el puerto de Málaga

Figura II.7: Muelle de Levante para el atraque de cruceros en el puerto de Málaga

Figura II.8: Terminales de pasajeros A y B y atraques de cruceros Norte y Sur en el puerto de Málaga

Figura II.9: Terminal de pasajeros El Palmeral y muelle de cruceros $\mathrm{N}^{\circ} 2$ del puerto de Málaga

Figura II.10: Ubicación de los muelles para cruceros en el puerto de Cádiz

Figura II.11: Muelles destinados a buques de cruceros en el puerto de Valencia

Figura II.12: Ubicación de los muelles para buques de crucero en el puerto de Ibiza

Figura II.13: Instalaciones para buques de crucero en el puerto de Cartagena

Figura II.14: Muelles destinados a buques de crucero en el puerto de Motril

Figura II.15: Esclusa de acceso y muelle destinado a tráfico de cruceros en el puerto de Sevilla

Figura II.16: Muelles destinados a buques de crucero en el puerto de Tarragona

Figura II.17: Ubicación del muelle y terminal de pasajeros de crucero en el puerto de Alicante

Figura II.18: Pasarela móvil cubierta (finger) para el embarque/desembarque de pasajeros

Figura II.19: Embarque de pasajeros con la pasarela del buque

Figura II.20: Ubicación de los muelles de pasajeros de crucero en el puerto de Almería

Figura II.21: Ubicación de los muelles para buques de crucero en el puerto de Mahón

Figura II.22: Instalaciones para buques de crucero en el puerto de Ceuta

Figura II.23: Instalaciones para buques de crucero en el puerto de Castellón

Figura II.24: Detalle del muelle Sur del puerto de Huelva e imagen de buque de crucero atracado en este muelle

Figura II.25: Ubicación del muelle para buques de crucero en el puerto de La Savina

Figura II.26: Muelles destinados a buques de crucero en el puerto de Melilla 



\section{Índice de gráficos}

Gráfico 2.1: Evolución del número de pasajeros de crucero mundiales entre los años 1990 y 2013 y previsión hasta 2018

Gráfico 2.2: Cifras de cruceristas registradas en los 10 principales puertos del mar Báltico entre 2009 y 2013

Gráfico 2.3: Cifras de cruceristas registradas en los 10 principales puertos de Noruega entre 2009 y 2013

Gráfico 2.4: Cifras de cruceristas registradas en los 10 principales puertos de las islas Británicas entre 2009 y 2013

Gráfico 2.5: Cifras de cruceristas registradas en los 10 principales puertos de la costa occidental de Europa entre 2009 y 2013

Gráfico 2.6: Cifras de cruceristas registradas en los puertos de las islas Atlánticas entre 2009 y 2013

Gráfico 2.7: Evolución de la cifra de pasajeros de crucero en la región del Mediterráneo entre el año 2000 y 2013, cifras segregadas por sectores y total de la región

Gráfico 2.8: Concentración de pasajeros de crucero por países en el mar Mediterráneo durante el periodo comprendido entre el año 2009 y 2013

Gráfico 2.9: Cifras de pasajeros de crucero de los diez principales puertos del Mediterráneo Occidental durante el año 2013, pasajeros totales y segregados en inicio y fin de itinerario

Gráfico 2.10: Cifras de pasajeros de crucero de los diez principales puertos del Mediterráneo Oriental durante el periodo 2009-2013

Gráfico 2.11: Cifras de pasajeros de crucero de los diez principales puertos del mar Adriático durante el año 2013, pasajeros totales y segregados en inicio y fin de itinerario

Gráfico 2.12: Cifras de pasajeros de crucero de los cinco principales puertos del mar Negro durante el periodo 2009-2013

Gráfico 2.13: Evolución de los mercados mundiales emisores de pasajeros de crucero entre los años 1990 y 2013

Gráfico 2.14: Evolución de la cifra de pasajeros de origen español entre los años 1992 y 2013

Gráfico 3.1: Relación capacidad de pasajeros vs número de buques de la flota de las navieras de Carnival Corporation \& plc

Gráfico 3.2: Relación capacidad de pasajeros vs número de buques de la flota de las navieras de Royal Caribbean Cruises Limited

Gráfico 3.3: Relación capacidad de pasajeros vs número de buques de la flota de las navieras de Genting Hong Kong Limited 
Gráfico 3.4: Relación capacidad de pasajeros vs número de buques de la flota de navieras independientes

Gráfico 3.5: Relación capacidad de pasajeros vs número de buques por naviera, agrupadas por grupo al que pertenecen

Gráfico 3.6: Distribución de pabellones en la flota mundial de buques de crucero

Gráfico 3.7: Distribución de la flota mundial de buques de crucero, puesta en servicio entre el año 2000 y 2014, por astillero de construcción

Gráfico 3.8: Evolución de la cifra de pasajeros de crucero a nivel mundial e incrementos de capacidad de la flota mundial de buques de crucero entre 1990 y 2013

Gráfico 3.9: Evolución de la cifra de pasajeros de crucero en el SPE entre el año 1994 y 2013

Gráfico 3.10: Cifras de pasajeros de crucero, segregadas en inicio y fin de itinerario y total agregado, para los puertos de Barcelona y Palma de Mallorca

Gráfico 3.11: Cifras de pasajeros de crucero, segregadas en inicio y fin de itinerario y total agregado, para los puertos de Málaga y Valencia y total agregado para Cádiz

Gráfico 3.12: Cifras anuales de pasajeros de crucero, segregadas en inicio y fin de itinerario y tránsito, en el puerto de Málaga entre el año 2000 y 2013

Gráfico 3.13: Cifras de pasajeros de crucero anuales, segregadas en inicio y fin de itinerario y tránsito, en el puerto de Valencia entre el año 2000 y 2013

Gráfico 3.14: Evolución de la cifra de cruceristas en los puertos de Alicante, Almería, Cartagena, Ibiza y Mahón entre el año 2000 y 2013

Gráfico 3.15: Evolución de la cifra de cruceristas en los puertos de Ceuta, Motril y Sevilla entre el año 2000 y 2013

Gráfico 3.16: Evolución de la cifra de cruceristas en los puertos de Castellón, Huelva, La Savina, Melilla y Tarragona entre el año 2000 y 2013

Gráfico 3.17: Análisis portfolio de los puertos de crucero del Mediterráneo español y la costa atlántica andaluza entre el año 2000 y 2013

Gráfico 3.18: Evolución del ratio pasajeros/escala en los puertos del Mediterráneo español y la costa atlántica andaluza entre 1994 y 2013

Gráfico 3.19: Análisis portfolio de los puertos de crucero de las islas Canarias entre el año 2000 y 2013

Gráfico 3.20: Análisis portfolio de los puertos de crucero de la costa del mar Cantábrico y atlántica gallega entre el año 2000 y 2013

Gráfico 3.21: Evolución de la cifra de cruceristas en los puertos de Ferrol, Gijón, Santander y Vilagarcía de Arousa entre el año 2000 y 2013

Gráfico 4.1: Distribución mensual de la cifra de pasajeros de crucero en el Mediterráneo durante los años 2010 y 2013

Gráfico 4.2: Serie temporal de pasajeros de crucero en los puertos de la costa mediterránea y atlántica andaluza entre los años 2000 y 2013 
Gráfico 4.3: Distribución de la desviación típica y media anual de pasajeros de crucero en los puertos de la costa mediterránea y atlántica andaluza entre los años 2000 y 2013

Gráfico 4.4: Curvas de evolución de la cifra de pasajeros de crucero y del C.V. adimensionalizadas para el periodo de 2000 a 2013$$
\text { : Curva de Lorenz asociada a la cifra de cruceristas de }
$$

Gráfico 4.5: Curva de Lorenz asociada a la cifra de cruceristas de los años 2000, 2007 y 2013

Gráfico 4.6: Tasa de variación mensual acumulada y promedio para el periodo del año 2000 a 2013

Gráfico 4.7: Representación gráfica de la cifra de pasajeros de crucero mensual acumulada entre el año 2000 y 2013 para los puertos con un solo máximo

Gráfico 4.8: Comparativa entre las curvas de IVE para el conjunto de puertos de la costa mediterránea y el puerto de Barcelona

Gráfico 4.9: Comparativa entre las curvas de IVE para el conjunto de puertos de la costa mediterránea y el puerto de Palma de Mallorca

Gráfico 4.10: Comparativa entre las curvas de IVE para el conjunto de puertos de la costa mediterránea y el puerto de Valencia

Gráfico 4.11: Representación gráfica de la cifra de pasajeros de crucero mensual acumulada entre el año 2000 y 2013 para los puertos con dos máximos

Gráfico 4.12: Comparativa entre las curvas de IVE para el conjunto de puertos de la costa mediterránea y el puerto de Cádiz

Gráfico 4.13: Comparativa entre las curvas de IVE para el conjunto de puertos de la costa mediterránea y el puerto de Cartagena

Gráfico 4.14: Comparativa entre las curvas de IVE para el conjunto de puertos de la costa mediterránea y el puerto de Málaga

Gráfico II.1: Distribución de la cifra de cruceristas en régimen de inicio y/o fin de itinerario en el puerto de Barcelona, agregada por meses, entre el año 2000 y 2013

Gráfico II.2: Distribución de la cifra de cruceristas en régimen de tránsito en el puerto de Barcelona, agregada por meses, entre el año 2000 y 2013

Gráfico II.3: Distribución mensual de la cifra de cruceristas en régimen de inicio y fin de itinerario en el puerto de Barcelona entre el año 2000 y 2013

Gráfico II.4: Distribución mensual de la cifra de cruceristas en régimen de tránsito en el puerto de Barcelona entre el año 2000 y 2013

Gráfico II.5: Distribución de la cifra de cruceristas en régimen de inicio y/o fin de itinerario en el puerto de Palma de Mallorca, agregada por meses, entre el año 2000 y 2013

Gráfico II.6: Distribución de la cifra de cruceristas en régimen de tránsito en el puerto de Palma de Mallorca, agregada por meses, entre el año 2000 y 2013 
Gráfico II.7: Distribución mensual de la cifra de cruceristas en régimen de inicio y fin de itinerario en el puerto de Palma de Mallorca entre el año 2000 y 2013

Gráfico II.8: Distribución mensual de la cifra de cruceristas en régimen de tránsito en el puerto de Palma de Mallorca entre el año 2000 y 2013

Gráfico II.9: Distribución de la cifra total de cruceristas en el puerto de Málaga, agregada por meses, entre el año 2000 y 2013

Gráfico II.10: Distribución mensual de la cifra total de cruceristas en el puerto de Málaga entre el año 2000 y 2013

Gráfico II.11: Distribución de la cifra total de cruceristas en el puerto de Cádiz, agregada por meses, entre el año 2000 y 2013

Gráfico II.12: Distribución mensual de la cifra total de cruceristas en el puerto de Cádiz entre el año 2000 y 2013

Gráfico II.13: Distribución de la cifra de cruceristas en régimen de inicio y/o fin de itinerario en el puerto de Valencia, agregada por meses, entre el año 2000 y 2013

Gráfico II.14: Distribución de la cifra de cruceristas en régimen de tránsito en el puerto de Valencia, agregada por meses, entre el año 2000 y 2013

Gráfico II.15: Distribución mensual de la cifra de cruceristas en régimen de inicio y fin de itinerario en el puerto de Valencia entre el año 2000 y 2013

Gráfico II.16: Distribución mensual de la cifra de cruceristas en régimen de tránsito en el puerto de Valencia entre el año 2000 y 2013

Gráfico II.17: Distribución de la cifra total de cruceristas en el puerto de Ibiza, agregada por meses, entre el año 2000 y 2013

Gráfico II.18: Distribución mensual de la cifra total de cruceristas en el puerto de Ibiza entre el año 2000 y 2013

Gráfico II.19: Distribución de la cifra total de cruceristas en el puerto de Cartagena, agregada por meses, entre el año 2000 y 2013

Gráfico II.20: Distribución mensual de la cifra total de cruceristas en el puerto de Cartagena entre el año 2000 y 2013

Gráfico II.21: Distribución de la cifra total de cruceristas en el puerto de Motril, agregada por meses, entre el año 2000 y 2013

Gráfico II.22: Distribución mensual de la cifra total de cruceristas en el puerto de Motril entre el año 2000 y 2013

Gráfico II.23: Distribución de la cifra de cruceristas en régimen de inicio y fin de itinerario en el puerto de Sevilla, agregada por meses, entre el año 2000 y 2013

Gráfico II.24: Distribución de la cifra de cruceristas en régimen de tránsito en el puerto de Sevilla, agregada por meses, entre el año 2000 y 2013

Gráfico II.25: Distribución mensual de la cifra de cruceristas en régimen de inicio y fin de itinerario en el puerto de Sevilla entre el año 2000 y 2013 
Gráfico II.26: Distribución mensual de la cifra de cruceristas en régimen de tránsito en el puerto de Sevilla entre el año 2000 y 2013

Gráfico II.27: Distribución mensual de la cifra total de cruceristas en el puerto de Tarragona entre el año 2000 y 2013

Gráfico II.28: Distribución de la cifra total de cruceristas en el puerto de Alicante, agregada por meses, entre el año 2000 y 2013

Gráfico II.29: Distribución mensual de la cifra total de cruceristas en el puerto de Alicante entre el año 2000 y 2013

Gráfico II.30: Distribución de la cifra total de cruceristas en el puerto de Almería, agregada por meses, entre el año 2000 y 2013

Gráfico II.31: Distribución mensual de la cifra total de cruceristas en el puerto de Almería entre el año 2000 y 2013

Gráfico II.32: Distribución de la cifra total de cruceristas en el puerto de Mahón, agregada por meses, entre el año 2000 y 2013

Gráfico II.33: Distribución mensual de la cifra total de cruceristas en el puerto de Mahón entre el año 2000 y 2013

Gráfico II.34: Distribución de la cifra total de cruceristas en el puerto de Ceuta, agregada por meses, entre el año 2000 y 2013

Gráfico II.35: Distribución mensual de la cifra total de cruceristas en el puerto de Ceuta entre el año 2000 y 2013

Gráfico II.36: Distribución mensual de la cifra total de cruceristas en el puerto de Castellón entre el año 2000 y 2013

Gráfico II.37: Distribución mensual de la cifra total de cruceristas en el puerto de Huelva entre el año 2000 y 2013

Gráfico II.38: Distribución mensual de la cifra total de cruceristas en el puerto de La Savina entre el año 2000 y 2013

Gráfico II.39: Distribución mensual de la cifra total de cruceristas en el puerto de Melilla entre el año 2000 y 2013 



\section{Índice de tablas}

Tabla 2.1: Cifras de pasajeros de crucero en los 10 principales puertos de la región Norte de Europa entre 2009 y 2013

Tabla 2.2: Cifras de pasajeros de crucero de inicio y fin de itinerario en los diez principales puertos base del Mediterráneo durante el periodo del año 2009 a 2013

Tabla 2.3: Cuotas de duración de cruceros en los años 1990 y 2010 en el mercado emisor norteamericano

Tabla 2.4: Rangos de valores de las variables significativas para los diferentes segmentos de cruceros

Tabla 2.5: Tasa de crecimiento de los mercados emisores de pasajeros de crucero entre 1990 y 2013, tasas agrupadas por quinquenios entre 1990 y 2004 , anuales entre 2005 y 2013 y promedio para el periodo

Tabla 2.6: Penetración del producto crucero en los principales mercados emisores europeos en 2011

Tabla 2.7: Cuota de los países europeos emisores de cruceristas entre 2010 y 2013

Tabla 2.8: Cuotas de los destinos elegidos por los cruceristas de origen europeo entre 2005 y 2011

Tabla 2.9: Cifras del mercado emisor de Reino Unido entre 1998 y 2013

Tabla 2.10: Cuotas de cruceros con embarques nacionales y fly \& cruise en el mercado emisor de Reino Unido entre 2004 y 2013

Tabla 2.11: Cifras del mercado emisor alemán entre 2000 y 2013

Tabla 2.12: Cifras del mercado emisor italiano entre 2003 y 2013

Tabla 2.13: Cifras del mercado emisor francés entre 2003 y 2013

Tabla 2.14: Cifras de otros mercados emisores europeos

Tabla 3.1: Número de buques, capacidad de pasajeros y cuota de mercado asociada a cada naviera de crucero

Tabla 3.2: Navieras de crucero pertenecientes al grupo Carnival Corporation $\&$ plc

Tabla 3.3: Estructura de la flota del grupo Carnival Corporation \& plc atendiendo al segmento de mercado y geográfico, edad media y composición por tamaños de buque

Tabla 3.4: Navieras de crucero pertenecientes al grupo Royal Caribbean Cruises Limited

Tabla 3.5: Estructura de la flota del grupo Royal Caribbean Cruises Limited atendiendo al segmento de mercado y geográfico, edad media y composición por tamaños de buque

Tabla 3.6: Navieras de crucero pertenecientes al grupo Genting Hong Kong Limited 
Tabla 3.7: Estructura de la flota del grupo Genting Hong Kong Limited atendiendo al segmento de mercado y geográfico, edad media y composición por tamaños de buque

Tabla 3.8: Estructura de la flota del grupo de navieras independientes atendiendo al segmento de mercado y geográfico, edad media y composición por tamaños de buque

Tabla 3.9: Número de buques y arqueo bruto asociado a los pabellones de la flota de cruceros

Tabla 3.10: Número de buques y arqueo bruto asociado a los cruceros construidos por astilleros europeos

Tabla 3.11: Cartera de pedidos de nuevas construcciones de buques de crucero a octubre de 2014

Tabla 3.12: Incremento de capacidad anual, en pasajeros, arqueo bruto y relación arqueo bruto/pasajero, de la flota mundial de buques de cruceros entre 1990 y 2014

Tabla 3.13: Infraestructuras y servicios requeridos por un buque de crucero en un puerto base

Tabla 3.14: Tráfico de cruceros en España, por zonas costeras, entre el año 1994 y 2013, pasajeros de crucero y porcentaje sobre el total del SPE

Tabla 3.15: Tráfico de cruceros en España entre el año 2000 y 2013, datos segregados en pasajeros de crucero en régimen de tránsito, inicio y fin de itinerario y total agregado.

Tabla 3.16: Tasas de concentración y variación de la cifra de pasajeros de crucero en los puertos de la costa mediterránea y atlántica andaluza, agrupadas por quinquenios, entre los años 1994 y 2013

Tabla 3.17: Tasas de concentración y variación de la cifra de pasajeros de crucero en los puertos de las islas Canarias, agrupadas por cuatrienios, entre los años 1997 y 2013

Tabla 3.18: Tráfico de cruceros en los puertos de Las Palmas de Gran Canaria y Santa Cruz de Tenerife entre el año 2004 y 2013, cifras segregadas en pasajeros de inicio y fin de itinerario, tránsito y total agregado

Tabla 3.19: Tasas de concentración y variación de la cifra de pasajeros de crucero en los puertos del mar Cantábrico y la costa atlántica gallega, agrupadas por quinquenios, entre los años 1994 y 2013

Tabla 3.20: Pasajeros de crucero en los puertos de A Coruña, Bilbao y Vigo entre el año 2000 y 2013, cifras segregadas en pasajeros en régimen de inicio y fin de itinerario y tránsito

Tabla 3.21: Características técnicas y perfil de estacionalidad de la cifra de pasajeros de crucero de los puertos de Barcelona, Palma de Mallorca, Málaga y Cádiz

Tabla 3.22: Características técnicas y perfil de estacionalidad de la cifra de pasajeros de crucero de los puertos de Valencia, Ibiza y Cartagena 
Tabla 3.23: Características técnicas y perfil de estacionalidad de la cifra de pasajeros de crucero de los puertos de Motril, Tarragona y Sevilla

Tabla 3.24: Características técnicas y perfil de estacionalidad de la cifra de pasajeros de crucero de los puertos de Alicante, Almería, Mahón y Ceuta

Tabla 3.25: Características técnicas y perfil de estacionalidad de la cifra de pasajeros de crucero de los puertos de Melilla, Castellón, Huelva y La Savina

Tabla 3.26: Hinterlands turísticos asociados con los 15 puertos de escala en la costa mediterránea y atlántica andaluza

Tabla 3.27: Clasificación de los 15 puertos de crucero de la costa mediterránea y atlántica andaluza de acuerdo con el flujo turístico regional

Tabla 4.1: Cifra media de pasajeros de crucero en los 18 puertos de crucero de la costa española y atlántica andaluza entre el año 2000 y 2011

Tabla 4.2: Resultados del análisis de componentes principales

Tabla 4.3: Resultados de la regresión

Tabla 4.4: Distribución de la cifra de pasajeros de crucero agrupada por trimestres durante los años 2010 y 2013 en los cuatro sectores del Mediterráneo

Tabla 4.5: Índices de variación estacional mensuales para la cifra de pasajeros de crucero registrada en los puertos de crucero del Mediterráneo español y la costa atlántica andaluza entre el año 2000 y 2013

Tabla 4.6: Valores del coeficiente de Variación anual de la cifra de pasajeros de crucero entre los años 2000 y 2013

Tabla 4.7: Valores del coeficiente de Gini para la cifra de pasajeros de crucero entre los años 2000 y 2013

Tabla I.1: Flota de Carnival Cruise Line

Tabla I.2: Flota de Princess Cruises

Tabla I.3: Flota de Costa Cruises

Tabla I.4: Flota de Holland America Line

Tabla I.5: Flota de AIDA Cruises

Tabla I.6: Flota de $P \& O$ Cruises

Tabla I.7: Flota de Cunard Line

Tabla I.8: Flota de $P \& O$ Cruises Australia 184

Tabla I.9: Flota de Iberocruceros $\quad 185$

Tabla I.10: Flota de Seabourn Cruise Line 186

Tabla I.11: Flota de Royal Caribbean International 187

Tabla I.12: Flota de Celebrity Cruises 188

Tabla I.13: Flota de Pullmantur 189

Tabla I.14: Flota de Croisières de France (CDF) 190 
Tabla I.15: Flota de Azamara Club Cruises

Tabla I.16: Flota de Norwegian Cruise Line

Tabla I.17: Flota de Star Cruises

Tabla I.18: Flota de MSC Cruises

Tabla I.19: Flota de Disney Cruise Line

Tabla I.20: Flota de Hurtigruten

Tabla I.21: Flota de Thomson Cruises

Tabla I.22: Flota de TUI Cruises

Tabla I.23: Flota de Oceania Cruises

Tabla I.24: Flota de Fred. Olsen Cruise Lines 200

Tabla I.25: Flota de Louis Cruises $\quad 202$

Tabla I.26. Flota de Phoenix Reisen 203

Tabla I.27: Flota de Silversea Cruises $\quad 204$

Tabla I.28: Flota de Cruise \& Maritime Voyages 205

Tabla I.29: Flota de Portuscale Cruises $\quad 207$

Tabla I.30: Flota de Crystal Cruises $\quad 207$

Tabla I.31: Flota de Regent Seven Seas Cruises 208

Tabla I.32: Flota de Hapag-Lloyd Cruises 209

Tabla I.33: Flota de Celebration Cruise Line $\quad 210$

Tabla I.34: Flota de Saga Cruises $\quad 210$

Tabla I.35: Flota de Compagnie du Ponant 211

Tabla I.36: Flota de Windstar Cruises $\quad 212$

Tabla I.37: Flota de Lindblad Expeditions-National Geographic 213

Tabla I.38: Flota de Star Clippers $\quad 214$

Tabla I.39: Flota de Voyages of Discovery $\quad 215$

Tabla I.40: Flota de Paul Gauguin Cruises 216

Tabla I.41: Flota de Swan Hellenic 216

Tabla I.42: Flota de Voyages to Antiquity $\quad 217$

Tabla I.43: Flota de Seadream Yacht Club 218

Tabla I.44: Flota de Pearl Seas Cruises $\quad 218$

Tabla I.45: Flota de Blount Small Ship Adventure $\quad 219$

Tabla I.46: Flota de Hebridean Island Cruises $\quad 219$

$\begin{gathered}\text { Tabla II.1: Características de los muelles destinados al atraque de buques de crucero } \\ \text { en el puerto de Palma de Mallorca }\end{gathered}$
230 
Tabla II.2: Características de los muelles destinados al atraque de buques de crucero en el puerto de Ibiza 



\section{Capítulo I. Introducción}

La pérdida de competitividad del transporte marítimo de pasajeros en largas distancias frente al transporte aéreo en la década de 1960 y 1970 facilitó la aparición de un nuevo negocio marítimo, el tráfico de cruceros, inicialmente creado para ocupar la parte del pasaje de los buques perdida a beneficio del tráfico aéreo. De esta forma, surgió un nuevo tipo de transporte marítimo, una nueva forma de disfrutar del mar y una nueva tipología turística. El turismo de cruceros tiene numerosas singularidades que lo diferencian del resto de actividades turísticas, constituyendo la principal peculiaridad el vehículo de transporte empleado y el tipo de alojamiento: el buque de cruceros. Además, esta tipología turística combina en un mismo producto dos ámbitos de actuación, marítimo y terrestre. La combinación de ambos da lugar al elemento central del crucero, el itinerario.

La aparición del tráfico y turismo de cruceros ha generado un cambio en varias industrias. En primera instancia, en la construcción naval, con la necesidad de construir buques específicamente diseñados para este fin. Por extensión, en los puertos, con objeto de adaptar las instalaciones portuarias a este tipo de buques y sus pasajeros. Y por supuesto, en la industria del turismo, con un producto totalmente nuevo y distinto a los demás, ofreciendo una oportunidad diferente de disfrutar del tiempo de ocio y las vacaciones.

Un buque de cruceros cumple, además de con la función primordial de la inmensa mayoría de buques, el transporte marítimo, con la función de alojamiento con todo lo que esto implica. Por ello el diseño del buque tiene que dotarlo necesariamente también de este carácter alojativo. A su vez, esta característica le confiere una gran ventaja al crucerista, evitar trasladar el equipaje entre destinos pues el propio "hotel" se desplaza de destino en destino. Esta función ha ido evolucionando con el tiempo hasta convertir a los buques de crucero no solo en un hotel sino alcanzar el grado de resort con un sinnúmero de instalaciones de ocio como teatros, cines, piscinas, tiendas, casinos, etc., con la complejidad asociada de montarlos sobre una plataforma que se desplaza en un medio dinámico, la mar. Por supuesto, no hay que olvidar el servicio de hostelería, lo cual lleva implícito una compleja estrategia logística para que el buque disponga a bordo de los víveres necesarios para satisfacer las necesidades del pasaje durante el itinerario.

De forma análoga a los establecimientos de alojamiento en tierra, los buques de crucero se dividen por tamaños y segmentos. Adicionalmente, en un mismo buque existen diversos tipos de camarotes. En cuanto a los tamaños, existen buques de pequeño tamaño, con capacidad aproximada de 100 pasajeros, focalizados en su mayoría en destinos exóticos y de ambiente exclusivo. Hasta mega-buques de crucero de 5.400 pasajeros de capacidad destinados a mercados más amplios y generalistas. Además, a la capacidad de pasajeros hay que incorporar la necesaria tripulación para el correcto funcionamiento de todas actividades del buque. Con lo que la complejidad de la instalación se hace aún más patente. Respecto a los segmentos, guardan una íntima relación con la proporción de tripulantes y pasajeros. Esta relación da pie al segmento más alto, el de lujo, con una relación pasajero-tripulante de uno 
o muy próxima a uno, hasta el segmento contemporary con una relación de 1 tripulante por cada 3-4 pasajeros. Obviamente, el coste del pasaje está condicionado por el segmento de que se trate. También, para un segmento dado, el precio estará influenciado por el tipo de camarote dependiendo de dos parámetros, la amplitud del mismo y la disponibilidad de vistas al mar.

El primer contacto terrestre de un itinerario de crucero está representado por los puertos. Desde la creación del tráfico de cruceros, los puertos han ido adaptando o construyendo terminales para este tráfico. Proceso de gran envergadura dado el carácter primario industrial de las instalaciones portuarias, adaptándose a la recepción de un tráfico turístico con necesidades específicas de instalaciones y servicios para el buque y el pasaje. Además, la influencia del tráfico de cruceros se extiende más allá de los límites del recinto portuario. El puerto constituye un eslabón en la cadena de experiencias turísticas que se desarrollan en tierra englobando a un área de mayores dimensiones, el denominado en este trabajo hinterland turístico. Esta área puede comprender únicamente la ciudad portuaria o bien extenderse a varias ciudades por medio de las populares excursiones asociadas a un itinerario de crucero.

Además, el turismo de cruceros está a la vanguardia de crecimiento en la industria del turismo, de hecho entre 1990 y 2013 es el subsector que más ha crecido. Sin embargo, su penetración en la población es todavía muy baja, constituyendo un producto que no ha alcanzado aún la madurez en ningún mercado. Por ejemplo, en el mercado más activo, Norteamérica, únicamente en torno al 3\% de la población ha ido en al menos un crucero y en Europa, el segundo mercado emisor mundial, la tasa de penetración en la población es aún menor y muy dispar entre los distintos países europeos. Mientras que en Asia la implantación se reduce a mínimos, con un tasa estimada de entre el $0,1 \%$ y $0,2 \%$ de la población. El aspecto de baja penetración en la población dota al turismo de cruceros de inmejorables perspectivas de crecimiento para los próximos años. En este sentido, las navieras de cruceros están realizando notables esfuerzos en posicionar buques en la región de Asia con objeto de estimular la demanda en ese mercado por la potencialidad de crecimiento que esto supone. Además, otras acciones que se están desarrollando para fomentar la penetración en la población del turismo de cruceros hacen referencia a los trámites burocráticos de visados pues suponen una barrera de acceso a este tipo de vacaciones en determinados mercados.

Asimismo, el turismo de cruceros tiene un carácter multidestinos. En un itinerario concreto se visitan varios destinos diferentes, pertenecientes, normalmente, a distintos países. Incluso se puede dar el caso extremo en el que los destinos visitados pertenezcan a continentes distintos. Por lo que otro de los elementos diferenciadores del turismo de cruceros es su marco de actuación global extendido a toda la geografía mundial. Además, tiene una enorme flexibilidad pues tiene la capacidad de desplazarse allí donde se encuentre la demanda. Respecto a la oferta, ésta no puede crecer rápidamente a corto plazo derivado del tiempo de proyecto y construcción de un buque de cruceros, dando lugar a un rígido crecimiento de la oferta. A esta condición hay que adicionar las elevadas inversiones 
necesarias para construir un buque de crucero, por ejemplo el coste de construcción de un mega-buque de crucero se sitúa en torno 450 millones de euros, por lo que complica en gran medida el acceso al mercado de nuevos actores.

El turismo de cruceros ha evolucionado con el tiempo ofreciendo un producto que prácticamente se adapta a los requisitos concretos de cada consumidor. Bajo la denominación de crucero se pueden encontrar itinerarios radicalmente opuestos, sirvan como ejemplos un crucero por el Mediterráneo de siete días de duración, un crucero de vuelta al mundo de 100 días de duración o un crucero de expedición por las islas Galápagos. Los tres itinerarios reciben la denominación de crucero pero sus características particulares difieren notablemente entre sí.

Junto a lo descrito anteriormente, el tráfico y turismo de cruceros, quizás por su relativa juventud, es un campo de investigación poco analizado en sus diversos aspectos científicos. Tomando como referencia las dos revistas internacionales en el campo de la economía y logística marítima, Maritime Economics and Logistics y Maritime Policy and Management, desde el año 1990 a 2013 únicamente se han publicado seis artículos de investigación en el ámbito de la industria de cruceros. La baja tasa de trabajos de investigación en tráfico de cruceros hace más atractivo, aún más si cabe a tenor de lo descrito en los párrafos anteriores, el desarrollar una investigación centrada en este tráfico marítimo y tipología turística.

Las características y peculiaridades enumeradas anteriormente han conducido a elegir como tema principal para el desarrollo de la presente tesis doctoral el tráfico de cruceros. Y más en concreto, con una visión particularizada para España, pues cumple con dos características fundamentales, su condición turística y marítima. España es una potencia mundial como receptora de turistas constituyéndose en 2013 como tercer destino mundial por el número de llegadas, con 60,6 millones de turistas no residentes en España. A esta condición hay que añadirle la extensa costa española incluyendo los archipiélagos de Baleares y Canarias. En este mismo sentido, España ocupa una posición marítima estratégica en el Sur de Europa conectando el océano Atlántico y el mar Mediterráneo. Por tanto, ambos conceptos justifican la elección de España como área geográfica en la que centrar las diversas etapas de análisis incluidas en la tesis.

El desarrollo de la presente tesis persigue encontrar respuestas a cuestiones tales como ¿Quién interviene en la configuración de un itinerario de crucero?, ¿Cuáles son los principales actores en el tráfico de cruceros?, ¿Es España un área crucerista?, ¿Cuándo hacen escala los buques en España? y sobre todo ¿Por qué un buque decide escalar en un puerto en concreto?

Para acometer las repuestas a las diversas cuestiones planteadas y a algunas otras que el lector encontrará analizadas a lo largo de este trabajo, la tesis se estructura en cinco capítulos. En su diverso contenido, los cinco capítulos siguen un esquema de análisis desde lo general a lo particular. El presente Capítulo I que constituye la introducción, presentación 
de los aspectos analizados y justificación de la elaboración de la tesis. El Capítulo II aglutina una serie de conceptos generales de la industria de cruceros para poner en antecedentes la investigación y poder determinar la magnitud de las cuestiones a resolver. De forma no exhaustiva trata los siguientes aspectos. El origen del tráfico y turismo de cruceros y su evolución desde la década de los años 90. Las principales regiones de destino con un análisis de la capacidad desplegada, su evolución, principales puertos y temporada de funcionamiento. En este mismo sentido, el análisis es mucho más detallado para la región del Mediterráneo y Norte de Europa por la influencia de España en esas regiones. También se estudian los tipos de itinerarios, tipos de buques y procedencia de los pasajeros de crucero. En este último punto, el análisis del mercado europeo, y sobre todo el apartado dedicado a España, cuenta con una mayor envergadura por las implicaciones directas que tiene en la elaboración de este trabajo.

Con la retroalimentación obtenida en la elaboración del Capítulo II se plantea el Capítulo III. Éste centra su atención en los principales agentes/actores que intervienen en la configuración de un itinerario de cruceros. El número de actores principales participantes es de tres, por lo que este capítulo se divide en tres apartados, cada uno de ellos dedicado a un actor en concreto. El primer apartado está dedicado a las navieras de crucero, agente con gran poder de negociación, que posee el vehículo de transporte y que por extensión posiciona sus buques en las regiones de destino. El estudio de las navieras se afronta desde dos puntos de vista. El primero, empresarial, para determinar las características de este mercado. El segundo, operativo, con objeto de conocer la configuración de la flota de cada naviera en cuanto a número, tamaño y edad de los buques, segmento y mercado emisor en el que se encuadran. Además, también se hace mención a parámetros particulares, como el país de abanderamiento o el astillero constructor de cada buque de crucero, con objeto de perfilar este actor de forma más precisa. El apartado 1 del Capítulo III tiene asociado el Anexo I. Éste contiene información empresarial pormenorizada de cada naviera y de su flota, además del historial de aquellos buques que han sido explotados por varias navieras a lo largo de su vida marinera.

El siguiente apartado está dedicado a los puertos de crucero, plataforma que conecta buque y tierra y que por tanto permite el acceso de los turistas del buque a tierra y viceversa. En este segundo apartado del Capítulo III se analizan las funciones de un puerto en el tráfico de cruceros y las relaciones geográficas asociadas, lo cual deriva en las tipologías fundamentales de puertos de crucero. Seguido de la determinación de una serie de condicionantes para albergar buques de cruceros. Además de, tratar las nuevas tendencias en la gestión y explotación de terminales de cruceros. También se analiza la presencia de tráfico de cruceros en España. Esta tarea se desarrolla de dos modos. En primera instancia, mediante un estudio de evolución entre los años 1994 y 2013 de este tráfico marítimo en el Sistema Portuario Español. En segundo lugar, se determinan las posiciones competitivas de los puertos de crucero españoles por medio de la aplicación de un análisis portfolio para el periodo de análisis de 2000 a 2013. Asimismo, se identifican las tipologías de puertos de crucero existentes en España y los itinerarios en que se incluyen. Junto a lo anterior, también se estudian las instalaciones para cruceros en la costa mediterránea y atlántica andaluza. El 
cometido de esta tarea reside en identificar posibles restricciones o limitaciones en el tráfico de cruceros que pueden albergar los puertos de esta zona litoral. Finalmente, se incluye, también para el mismo conjunto de puertos, el análisis de la distribución mensual de pasajeros de crucero entre los años 2000 y 2013. Este segundo apartado también tiene asociado un anexo, de forma análoga al apartado 1. El Anexo II incorpora una descripción detallada de las instalaciones y servicios para tráfico de cruceros en los puertos de la costa mediterránea y atlántica andaluza. Así como, la representación gráfica de la distribución mensual de pasajeros de crucero segregada y agregada por meses, para el mismo conjunto de puertos, durante los años 2000 a 2013.

El tercer apartado está dedicado a la segunda componente terrestre de un itinerario de cruceros: el hinterland turístico. Ésta es el área terrestre que dota de atractivo al itinerario y en la que se desarrollan las principales experiencias turísticas en tierra. En este apartado se presenta el marco teórico de estudio del concepto hinterland a un puerto de crucero. Los principales aspectos abordados aluden al tipo de hinterland según se trate de un puerto base o de escala, sus implicaciones en el tráfico de cruceros y la tipología de puertos según el flujo turístico. También se lleva a cabo una aplicación empírica de los aspectos relacionados con el hinterland turístico con los puertos de la costa mediterránea y atlántica andaluza. En concreto, se delimita el hinterland turístico de cada uno de ellos y se clasifican los puertos atendiendo a la función desempeñada en el flujo turístico entre el puerto y el hinterland.

A partir de la investigación realizada para elaborar los capítulos anteriores se desarrolla el Capítulo IV, el cual tiene una componente eminentemente de análisis empírico y econométrico. Este capítulo se estructura en dos apartados principales. El primero está dedicado al desarrollo de un análisis con el objetivo de plantear un modelo que explique los factores y variables influyentes en la cifra de pasajeros de crucero que registra un puerto dado. Para realizar el mencionado análisis, en primer lugar se define la variable dependiente del modelo y un conjunto de variables independientes con influencia en el tráfico de cruceros. Estas variables hacen referencia al atractivo del hinterland turístico, la infraestructura turística y los costes portuarios. El instrumental econométrico empleado está basado en un análisis de componentes principales, seguido de una regresión de mínimos cuadrados. El análisis de componentes principales se aplica con objeto de adoptar una interpretación global del conjunto de variables independientes seleccionadas. Los factores resultantes de esta etapa previa de análisis se regresan posteriormente con la cifra de cruceristas. Este modelo se desarrolla para el caso particular de los puertos de crucero de la costa mediterránea española y atlántica andaluza con datos del año 2011.

El segundo apartado de este Capítulo IV aborda el análisis de la distribución mensual de pasajeros de crucero para el conjunto de puertos de la costa mediterránea y atlántica andaluza, junto a su evolución en el periodo temporal desde el año 2000 al 2013. El objetivo es analizar y explicar uno de los problemas más importantes en la actividad turística: la estacionalidad. Ésta se analiza bajo la perspectiva de sus efectos perniciosos en la explotación de las terminales portuarias. La estacionalidad también está presente en el tráfico de cruceros en esta zona del Mediterráneo, y así se analiza la serie temporal de pasajeros de 
crucero compuesta de 168 observaciones correspondientes al periodo temporal antes mencionado. Respecto a la evolución de la estacionalidad para el mismo periodo, se cuantifica su comportamiento mediante dos coeficientes, el de Variación y el de Gini. En este caso, el análisis de evolución se segrega en las dos tipologías de pasajeros, inicio y fin de itinerario y tránsito. Por último, también se lleva a cabo un análisis segregado puerto a puerto para determinar patrones atípicos de distribución temporal.

Finalmente, la tesis concluye con el Capítulo $\mathrm{V}$ dedicado a las principales conclusiones obtenidas en la elaboración de la investigación. Asimismo, también incluye una mención a las implicaciones y limitaciones asociadas, para finalizar con las futuras líneas de investigación derivadas del trabajo realizado. 


\section{Capítulo II. La industria de cruceros: características, situación y perspectivas}

\subsection{El origen del tráfico/turismo de cruceros}

El origen del fenómeno del turismo de cruceros está ligado a la unión de la industria del ocio y del transporte marítimo de pasajeros. Los primeros buques de navegación oceánica no estaban concebidos en su construcción para el transporte de pasajeros, sino más bien su diseño se adaptaba a las exigencias de la carga a transportar.

Black Ball Line, originaria de Nueva York, en 1818 fue la primera naviera en ofrecer un servicio regular desde Estados Unidos a Inglaterra, y a su vez, la primera en interesarse por la comodidad de sus pasajeros. En la década de 1830 se introdujeron los buques de vapor dominando el mercado transatlántico de pasajeros y de transporte de correo. Las compañías inglesas dominaban el mercado en ese momento, lideradas por la British and North American Royal Mail Steam Packet (convirtiéndose más tarde en Cunard Line). El 4 de julio de 1840, el Britannia, el primer barco con el nombre de Cunard, zarpó de Liverpool con un rebaño de vacas a bordo para el suministro de leche fresca a los pasajeros durante la travesía transatlántica de 14 días de duración (Grace, 2008).

Durante los años 1850 y 1860 hubo una notable mejora en la calidad del viaje para los pasajeros. Los buques comenzaron a atender exclusivamente a los pasajeros, en lugar de a los contratos de carga o correo, y se añadieron lujos como luz eléctrica, más espacio en cubierta e instalaciones para el entretenimiento. Los buques también comenzaron a llevar a inmigrantes a Estados Unidos en la denominada tercera clase. En ésta, los pasajeros eran responsables de proveer su propia comida y dormir en cualquier espacio disponible en la bodega. Así, en un crucero coexistían dos tipos de pasajeros; el pasaje, por necesidad, y el turista, por ocio (CCINV, 2009).

A principios del siglo 20 el concepto de superliner fue desarrollado y Alemania lideró el mercado en el desarrollo de estos masivos y ornamentados hoteles flotantes. El diseño de estos buques trató de minimizar la incomodidad de los viajes oceánicos, ocultando el hecho de estar en la mar y las condiciones meteorológicas extremas en la medida de lo posible, a través de elegantes alojamientos y actividades planificadas. Los buques Mauritania y Lusitania, ambos propiedad de Cunard Line, comenzaron la tradición de la cena de gala y a anunciar el romanticismo del viaje. La velocidad seguía siendo el factor decisivo en el diseño de estos buques. La compañía White Star Line, propiedad del financiero estadounidense J.P. Morgan, introdujo los barcos de pasajeros más lujosos jamás vistos hasta el momento, el Olympic (equipado con piscina y pista de tenis) y el Titanic. El espacio y la comodidad de los pasajeros adquirieron precedencia sobre la velocidad en el diseño de estos barcos, dando lugar a buques de mayor tamaño. El hundimiento del Titanic en su viaje inaugural en 1912 
asoló la White Star Line. En 1934, Cunard compró la White Star, dando como resultado la empresa Cunard White Star.

La Primera Guerra Mundial interrumpió la construcción de nuevos buques, y muchos buques antiguos fueron utilizados como transporte de tropas. Los superliner alemanes fueron entregados a Gran Bretaña y Estados Unidos como indemnizaciones en el final de la guerra. El periodo entre 1920 y 1940 se consideraron los años más glamurosos para los buques transatlánticos de pasajeros. Los turistas norteamericanos interesados en visitar Europa reemplazaron a los pasajeros inmigrantes. La publicidad promovía la moda de los viajes transoceánicos, con la elegancia de la gastronomía y actividades a bordo.

Los buques de crucero de nuevo se convirtieron en transporte de tropas durante la Segunda Guerra Mundial y toda la actividad de cruceros transatlánticos cesó hasta después de la guerra. Las líneas europeas entonces cosecharon los beneficios del transporte de los refugiados de guerra a Estados Unidos y Canadá y los viajeros de negocios y turistas a Europa. La falta de buques de crucero estadounidenses en ese momento, y por tanto la pérdida de beneficios, impulsaron al gobierno de EE.UU. a subvencionar la construcción de buques transatlánticos. Además de lujosas instalaciones, los barcos fueron diseñados de acuerdo a las especificaciones necesarias para su posible conversión en transporte de tropas. Sin embargo, el aumento de los viajes aéreos y el primer vuelo sin escalas entre EE.UU. y Europa en 1958, marcó el final del negocio transatlántico para los buques. Esto supuso la venta de los buques de pasaje y multitud de navieras fueron a la quiebra por la falta de negocio.

Por ejemplo, uno de los últimos transatlánticos botados, el SS France que operó entre 1961 y 1974, se utilizó principalmente para el servicio transatlántico convencional entre Le Havre y Nueva York. Con el aumento de los precios del petróleo y la aparición de aviones más eficientes, incluyendo el Boeing 747 (introducido en 1970), el buque ya no era capaz de competir eficazmente en la ruta transatlántica. Mientras que un avión podía unir París o Londres con Nueva York en unas 8 horas, el buque necesitaba cerca de 4 días para cruzar el Atlántico, excluyendo el tramo de tren entre Londres y Southampton (o París y Le Havre). Ante la imposibilidad de generar los ingresos suficientes para justificar sus gastos de explotación, el SS France cesó su actividad en 1974 y fue adquirido por Norwegian Cruise Line (rebautizándolo como SS Norway). Sus años finales comerciales entre 1980 y 2003 los pasó como buque de crucero. Sin embargo, los transatlánticos no eran particularmente adecuados para los requisitos de la emergente industria de los cruceros. Por ejemplo, muchos transatlánticos fueron diseñados para operar en el Atlántico Norte a lo largo de todo el año en servicios regulares de pasajeros, sus instalaciones al aire libre como cubiertas de paseo y piscinas eran limitadas. Además, fueron construidos para velocidades, que era su principal característica comercial, con alto consumo de combustible.

La aparición de la industria de los cruceros, tal y como se conoce hoy en día, se remonta a la desaparición de los servicios de línea regular entre Europa y EE.UU. (transatlánticos) en la década de 1960, ya que fueron sustituidos por el transporte aéreo con 
el cual no podían competir. Los últimos transatlánticos se convirtieron en los primeros cruceros ya que la desaparición completa de los servicios transatlánticos tardó más de una década, teniendo en cuenta los 30 años de vida útil de un buque, asumiendo el transporte aéreo los viajes de larga distancia. La disponibilidad de una flota de transatlánticos, cuya utilidad ya no era comercialmente justificable, incitó su reconversión para formar la primera flota de buques de crucero (Rodrigue y Notteboom, 2013).

A partir de la década de los años 60 comenzaron a aparecer los barcos diseñados única y exclusivamente para el turismo crucerista. Es entonces cuando surgieron las principales compañías modernas: Norwegian Cruise Line, Carnival, Royal Caribbean Cruise Line o Princess. La década de 1960 fue testigo de los comienzos de la moderna industria del crucero. Las compañías de cruceros se concentraron en los viajes de vacaciones en el Caribe, crearon una imagen de Fun Ship, que atrajo a muchos pasajeros que nunca habían tenido la oportunidad de viajar en los superliners de la década de 1930 y 1940. Los cruceros se concentraron en la creación de un ambiente informal y proporcionar un amplio entretenimiento a bordo. Hubo una disminución en el papel de los buques para el transporte de personas a un destino en particular, ya que el énfasis estaba en el propio viaje (Grace, 2008).

\subsection{El producto crucero}

En su conjunto el producto crucero está compuesto de tres elementos básicos. Éstos son, transporte, caracterizado por un buque de crucero, el turismo y ocio, que resulta atractivo para los cruceristas, pasajeros o clientes y, por último, la componente de viajar que forma el itinerario del crucero (Wild y Dearing, 2000).

La actual concepción del buque de crucero turístico combina dos actividades básicas: la de alojamiento y la de transporte. Al crecer las instalaciones de ocio a bordo se le define, con propiedad como resort marino, más allá que un simple hotel flotante. Su carácter alojativo se refleja tanto en la distribución de espacios, con un gran atrium alrededor del cual se disponen los camarotes, como en la terminología hotelera que da nombre a diferentes puestos de trabajo a bordo, como el "hotel manager". Es un resort turístico porque incorpora todo tipo de instalaciones propias de un resort como centro de belleza, videoteca, biblioteca, planetario, tiendas, campos de golf, galería de arte, centro de negocios, cine, casino, spa, etc. La principal diferencia, y al mismo tiempo ventaja sobre el resort terrestre convencional, es su movilidad, pues permite una mayor flexibilidad del modelo de negocio, al poder llevar la capacidad alojativa allá donde sea conveniente (OMT, 2008).

El producto que la naviera ofrece en el mercado lo constituye la suma del buque más el itinerario/región. El itinerario, a su vez, es la suma de varios destinos/puertos, de ahí el carácter de producto multi-destino que tiene el crucero. El itinerario/región y el buque de crucero son dos variables que juegan un papel decisivo a la hora de la toma de decisiones de 
los potenciales cruceristas (CLIA, 2012). Por lo que aparece una imbricación entre destinos y buques, dada sus aportaciones a la experiencia del turismo de cruceros.

Atendiendo al ámbito de navegación por el que discurre el crucero es posible encontrar dos tipos de cruceros, cruceros fluviales y oceánicos o marítimos. Los primeros discurren por ríos y/o vías navegables tierra adentro. Mientras que los oceánicos o marítimos tienen como ámbito de navegación un sector de un océano o mar.

La principal diferencia entre ambos tipos de cruceros, además del ámbito de navegación, radica en el tipo de buque empleado. Los buques destinados a cruceros fluviales son radicalmente distintos a los barcos de cruceros marítimos, véase Figura 2.1 y 2.2. Los buques de navegación fluvial son de menores dimensiones y normalmente de fondo plano como consecuencia de la profundidad de los ríos y las limitaciones que imponen las rutas que recorren. La capacidad de pasajeros oscila entre los 70 y 300 pasajeros, frente a los más de 3.000 pasajeros que puede transportar un buque de navegación oceánica. Además, en este tipo de cruceros los alojamientos y servicios suelen ser más simples que los de un crucero marítimo. También existen diferencias asociadas a la disposición de los buques, dependiendo de las características de los ríos por los que navegan y de la finalidad para la que se han construido.

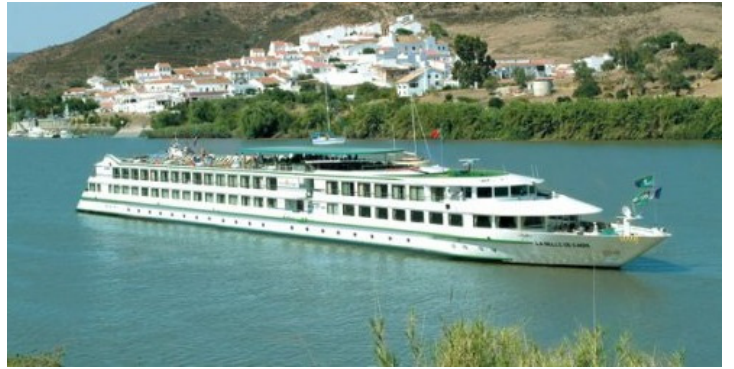

Figura 2.1: Buque de crucero fluvial. Fuente: Croisieurope (2013).

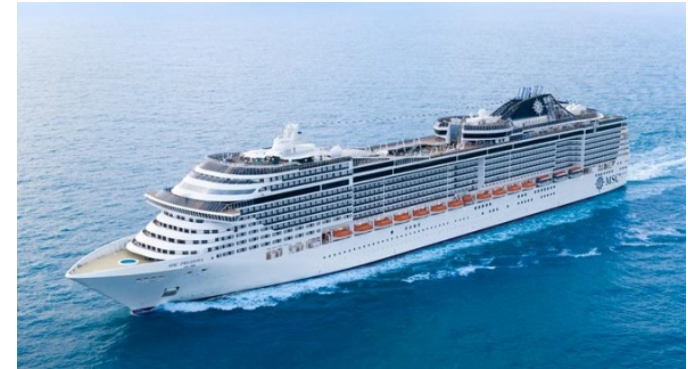

Figura 2.2: Buque de crucero oceánico. Fuente: MSC Cruises (2013).

Las limitaciones impuestas por el cauce de los ríos generan que durante la navegación se desarrollen velocidades inferiores a las de un crucero marítimo. De tal forma que en la mayoría de los casos es posible contemplar el paisaje, adoptando el carácter de cruceros paisajísticos y culturales, donde la naturaleza, la historia y el arte suelen estar presentes durante el recorrido, enriqueciendo enormemente el viaje. Es posible encontrar itinerarios de cruceros fluviales por todo el mundo, las áreas geográficas y los principales ríos por donde discurren estos cruceros son los siguientes.

\section{- Cruceros fluviales por Europa}

* Centroeuropa: Danubio, Main, Mosela, Rhin, Ródano y Sena, véase Figura 2.3.

Este de Europa: Dnieper y Volga, véase Figura 2.4.

- Sur de Europa: Duero y Guadalquivir, véase Figura 2.5. 


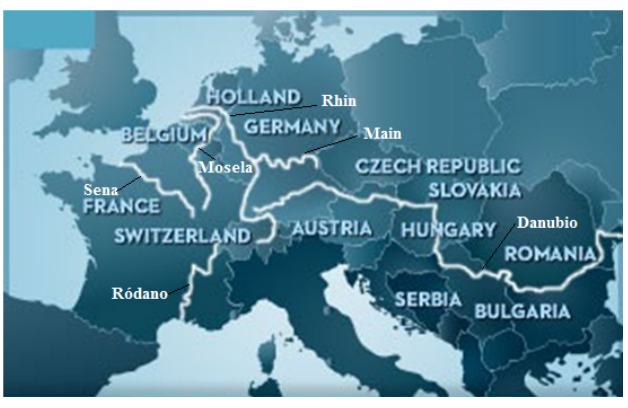

Figura 2.3: Ríos con cruceros fluviales en Centroeuropa.

Fuente: Elaboración propia.

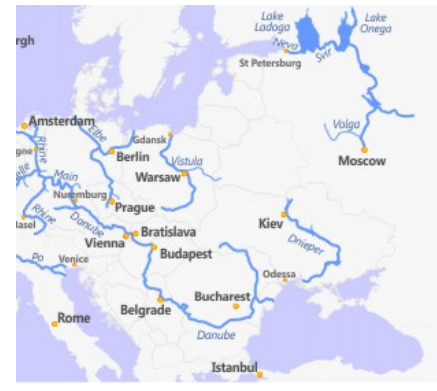

Figura 2.4: Ríos con cruceros fluviales en Europa del Este.

Fuente: Elaboración propia.

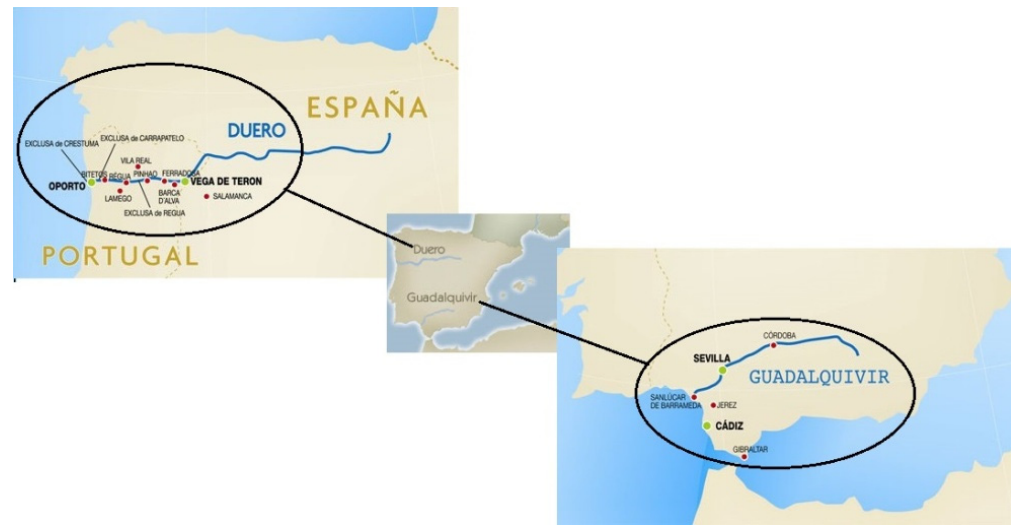

Figura 2.5: Ríos con cruceros fluviales en España y Portugal. Fuente: Elaboración propia.

- Cruceros fluviales por África

* Río Nilo, véase Figura 2.6.

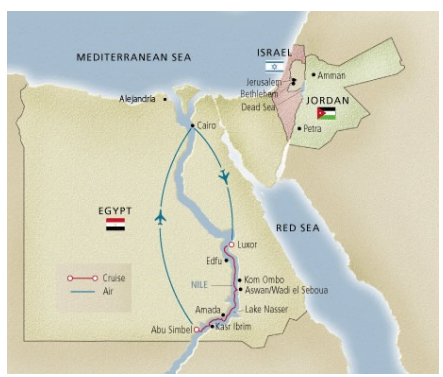

Figura 2.6: Itinerario de crucero por el río Nilo. Fuente: Farah Nile Cruises (2013).

\section{- Cruceros fluviales por América}

EE.UU.: Río Mississipi, véase Figura 2.7.

Sudamérica: Amazonas, véase Figura 2.8. 


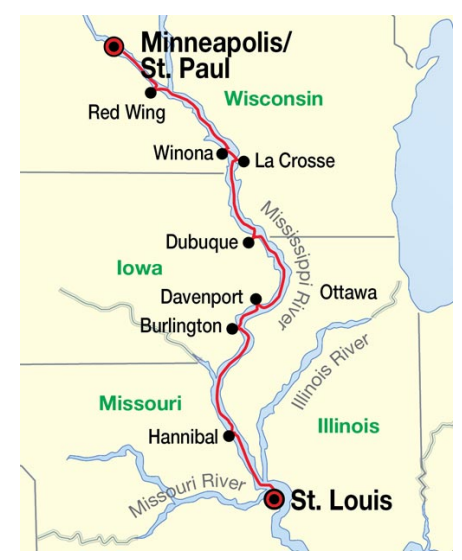

Figura 2.7: Itinerario de crucero por el río Mississippi.

Fuente: American Cruise Lines (2013).

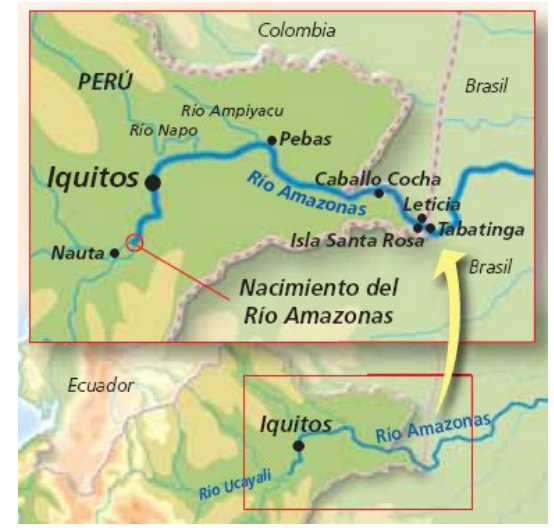

Figura 2.8: Itinerario de crucero por el río Amazonas.

Fuente: National Geographic Expeditions (2013).

\section{- Cruceros fluviales por Asia}

China: Río Yangtzé, véase Figura 2.9.

Camboya y Vietnam: Mekong, véase Figura 2.10.

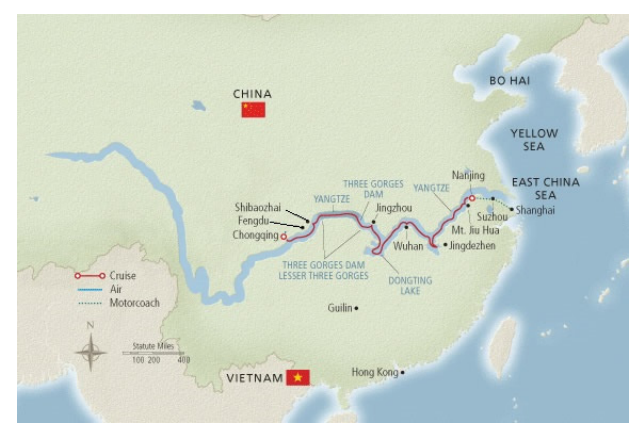

Figura 2.9: Itinerario de crucero por el río Yangtzé.

Fuente: Uniworld (2013).

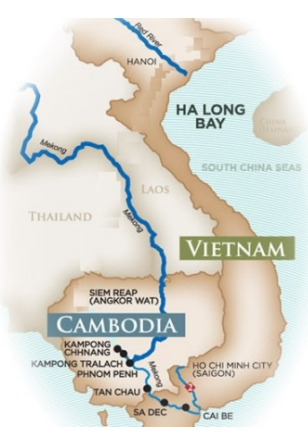

Figura 2.10: Itinerario de crucero por el río Mekong.

Fuente: AmaWaterways (2013).

Sin embargo, el ámbito de la tesis doctoral se centra exclusivamente en los cruceros oceánicos. Por lo que en los sucesivos apartados de este capítulo se presentan, de forma independiente, las características que atañen a este tráfico marítimo.

\subsection{Evolución mundial del tráfico de cruceros}

Desde el año 1990 el sector de los cruceros presenta una elevada tasa de crecimiento, entre 1990 y 2013 el número de pasajeros de crucero a nivel mundial ha crecido un 456\%, con una tasa media anual de crecimiento del 7,84\%, véase Gráfico 2.1. Además, las previsiones indican que en el año 2018 se superará la cifra de 24,15 millones de cruceristas a nivel mundial (Cruise Market Watch, 2014a). Focalizando la atención en los últimos 20 años, los quinquenios 1999-2003 y 2004-2008 han constituido los periodos de mayor crecimiento, con una tasa media anual del $10,25 \%$ y $10,76 \%$, respectivamente. 


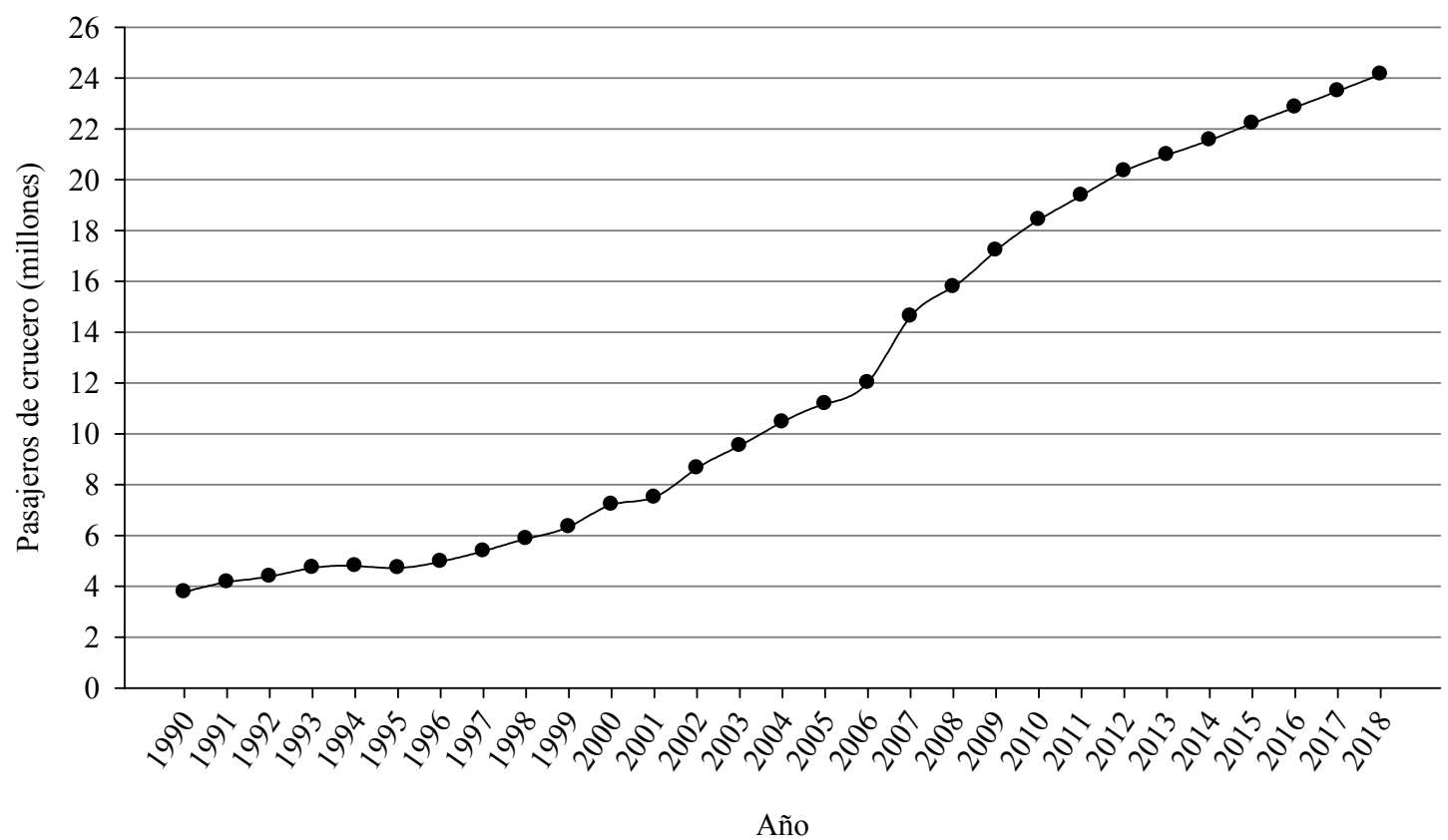

Gráfico 2.1: Evolución del número de pasajeros de crucero mundiales entre los años 1990 y 2013 y previsión hasta 2018.

Fuente: Elaboración propia basada en datos de Cruise Market Watch (2014a).

Las estrategias de crecimiento, hasta la fecha, han sido impulsadas por la mayor capacidad de pasajeros de los buques de nueva construcción, cruceros de menor duración, mayor número de puertos base, más destinos y nuevas actividades, tanto a bordo como en tierra, que responden mejor a la demanda de los cruceristas (OMT, 2008). Estas actividades ayudan a aumentar la penetración del turismo de cruceros en la población. Centrando la atención en el principal país emisor de cruceristas, Estados Unidos, sólo el 53\% del público objetivo en el mercado norteamericano alguna vez ha realizado un crucero oceánico. Extendiendo esta comparativa a términos mundiales, si todos los buques de crucero del mundo estuvieran a su máxima ocupación durante todo el año sólo representarían menos de la mitad del total de visitantes anuales a Las Vegas (Cruise Market Watch, 2014a).

La principal clave en la cual reside la elevada tasa de crecimiento del mercado de cruceros radica en que el crucero turístico es un producto que no ha entrado aún en fase de maduración, ni siquiera en el mercado estadounidense, el emisor más desarrollado. En las tres grandes regiones de demanda, Norteamérica, Europa y Asia está en la fase de introducción del producto o de crecimiento, dependiendo de la región, véase Figura 2.11. 


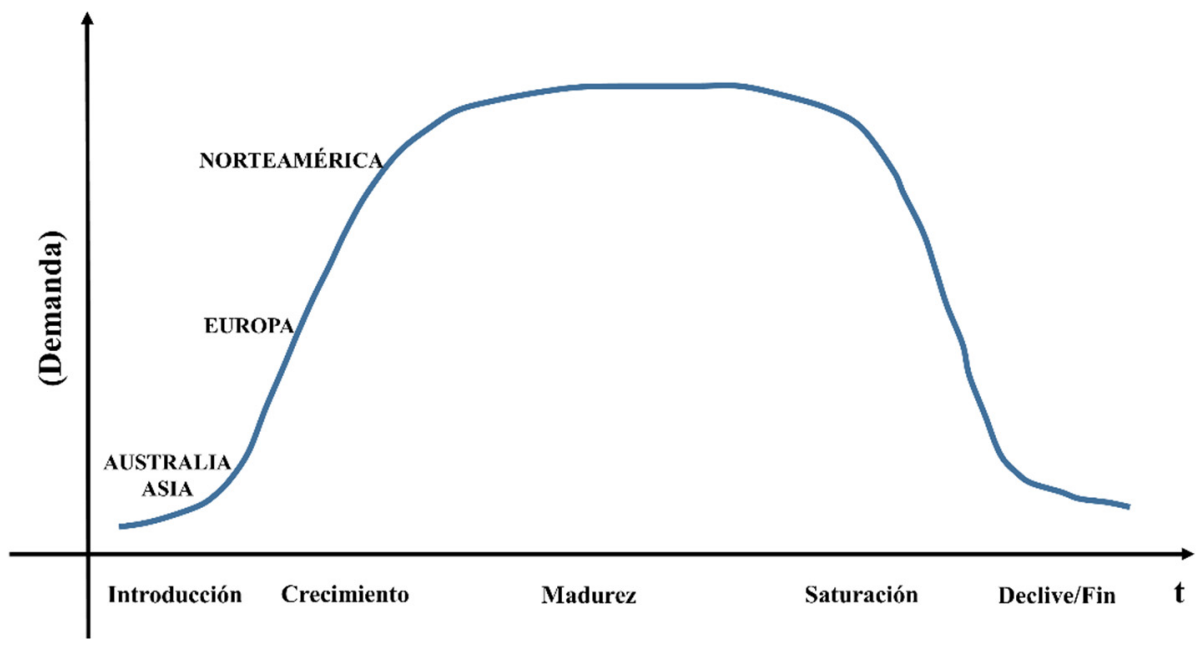

Figura 2.11: Ciclo de vida del producto crucero por regiones de demanda.

Fuente: Elaboración propia basada en datos de OMT (2008) y Cruise Market Watch (2014a).

Analizando la relación oferta-demanda del producto crucero se obtienen una serie de claves económicas relevantes: es un producto aún en fase de expansión/iniciación, ha experimentado un crecimiento consistente en las dos últimas décadas y aunque pueden existir variaciones anuales más o menos imprevistas, a las variaciones de la oferta se siguen correspondiendo variaciones paralelas de la demanda. Claves que explican el fuerte crecimiento del sector, así como, sus inmejorables perspectivas.

\subsection{Principales zonas de operación: itinerarios y destinos}

En el tráfico de cruceros es posible distinguir seis principales zonas de operación: Caribe, Mediterráneo, Norte de Europa, Alaska, América del Sur y la Antártida y AsiaPacífico, véase Figura 2.12. Junto a estas seis zonas aparecen nuevos destinos, denominados zonas emergentes, enfocadas sobre todo a cruceristas repetidores más que a primerizos.

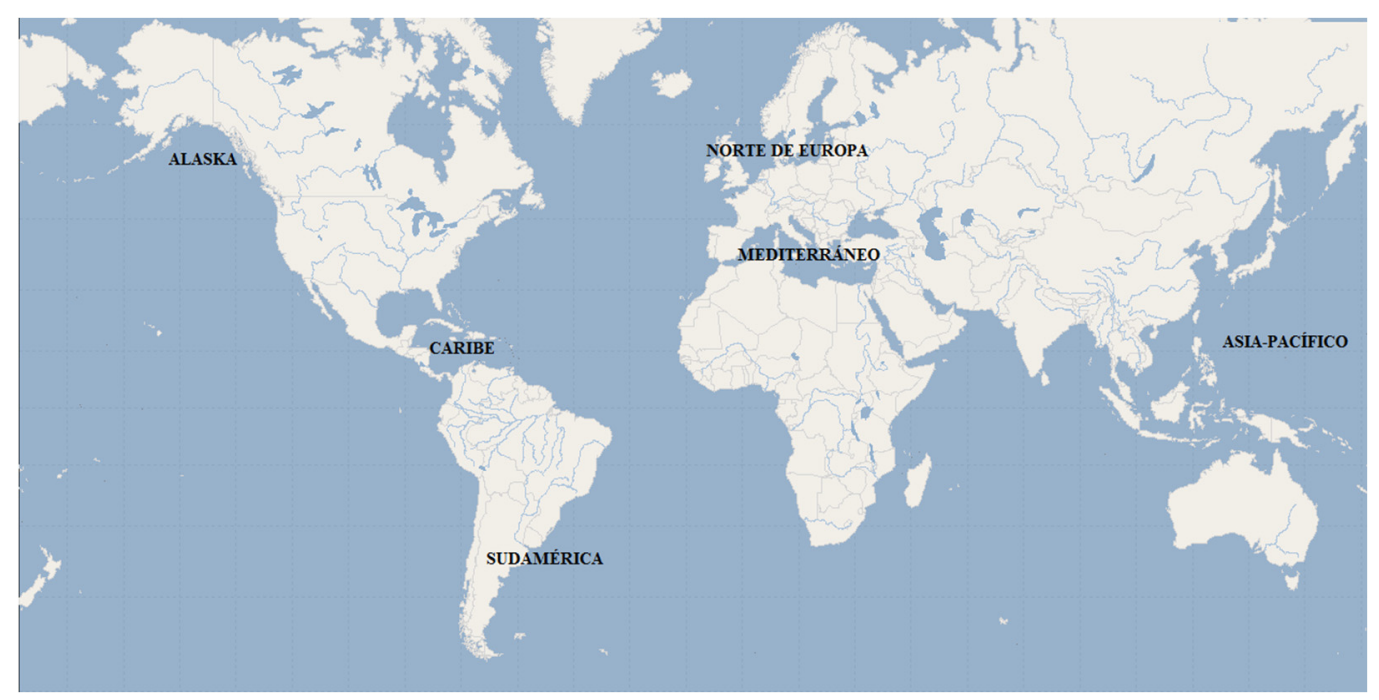

Figura 2.12: Principales regiones de destino de cruceros.

Fuente: Elaboración propia. 
El Caribe es la región más popular entre los cruceristas seguida del Mediterráneo. Estas dos zonas concentraron conjuntamente el 56,1\% de la capacidad desplegada en 2013 (CLIA, 2014). Además, ambas regiones son anuales, es decir, ofertan sus itinerarios durante todo el año (sobre todo el Caribe), frente al resto de regiones en que la oferta está sometida a mayor estacionalidad. A continuación, se procede a describir las características de cada una de las principales zonas de operación, junto con los destinos emergentes.

\subsubsection{Caribe}

La concepción moderna del crucero nace alrededor de Miami como puerto base, por lo que no es de extrañar que el mar Caribe sea la zona dominante, con una cuota mundial en 2013 del 34,4\% en términos de capacidad desplegada. Las claves de su éxito hay que buscarlas en: la proximidad al principal emisor del mundo, el clima benigno durante todo el año (clima subtropical), el empleo generalizado del dólar como medio de pago, la amplia población angloparlante, la diversidad cultural y la estabilidad política en general. Esta región se caracteriza por el hecho de que el buque es un destino en sí mismo, es el denominado concepto de "Fun Ship", los puertos de escala son adiciones al viaje. El buque se considera como un resort marino, de tal forma que se genera una competencia importante entre los cruceros y los destinos en tierra firme. Esta relación llega hasta el extremo de que cada gran compañía de cruceros posee una isla privada (Rodrigue y Notteboom, 2013). Estas islas privadas disponen de todo tipo de instalaciones, como centros comerciales, de vela, de buceo, etc.

La temporada alta del Caribe comprende los meses de otoño e invierno (del hemisferio norte). Mientras que la temporada baja se extiende entre los meses de agosto a octubre, por ser la temporada de huracanes en esta zona. Desde el punto de vista geográfico, el principal atractivo del Caribe está constituido por una cadena de islas muy cercanas entre sí, lo que implica cortos periodos de navegación entre puertos de escala. Además, existen gran variedad de paisajes, según la isla que se visite, que comprenden desde selvas tropicales a condiciones semi-áridas, así como, arrecifes de coral e islas de origen volcánico. Dentro de esta región, normalmente se consideran cuatro áreas de operación: Bahamas, Caribe Occidental, Caribe Oriental y Caribe Meridional, véase Figura 2.13.

Analizando la evolución de esta región entre los años 2000 y 2010, en términos de camas por día disponibles a bordo de buques de crucero, durante este periodo el crecimiento absoluto ha sido del $74,3 \%$, con un crecimiento medio anual del 6\%. En términos de capacidad desplegada, en el año 2000 concentraba el 45,9\% frente al 41,4\% en 2010 y 34,4\% en 2013 (CLIA, 2011; CLIA, 2014). El descenso de concentración registrado se debe, en parte, a que el Caribe como destino de cruceros está alcanzando la fase de madurez, así como, el límite de su capacidad operativa. De tal forma, que los incrementos en la flota mundial de buques de crucero deben ir asociados con nuevos destinos. 


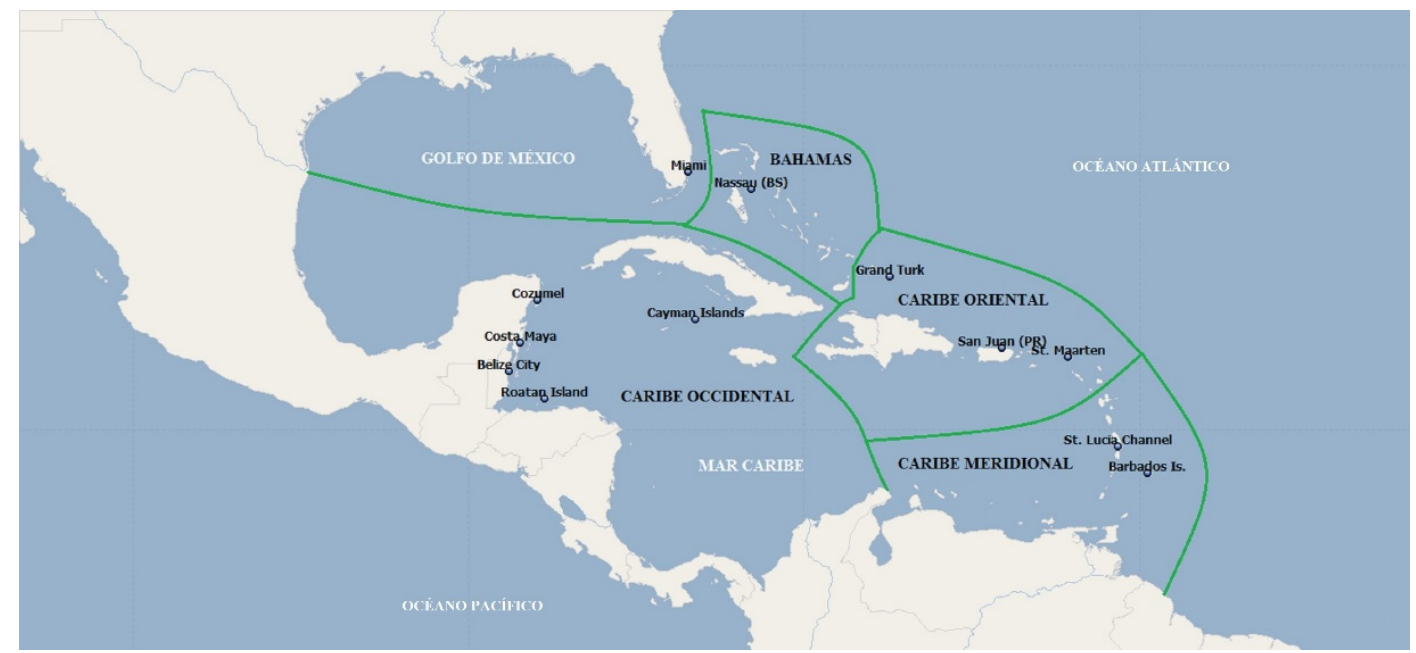

Figura 2.13: Áreas de operación en el Caribe.

Fuente: Elaboración propia.

Los cruceros con destino al Caribe, fundamentalmente, establecen su puerto base en Estados Unidos y en particular en los puertos del Estado de Florida. El principal puerto de esta región de destino es Miami (Florida, EE.UU.), con 3,77 millones de pasajeros de crucero en el año 2012 (Port Miami, 2012). Miami es el principal puerto base del mundo, con más de 30 buques en total (Port Miami, 2013), contando entre otros con la mayoría de los megabuques de crucero (VLCV; Very Large Cruise Vessels) en servicio, entre los que se encuentran los mayores buques el Oasis of the Seas y el Allure of the Seas propiedad de Royal Caribbean International. Por lo que se puede afirmar que está especializado en este tipo de cruceros. El puerto cuenta con siete terminales de cruceros, véase Figura 2.14. En 2014 un total de 13 compañías y 30 buques diferentes utilizaron estas terminales, que son: AIDA Cruises, Azamara Club Cruises, Carnival Cruise Line, Celebrity Cruises, Costa Cruises, Crystal Cruises, Disney Cruise Line, MSC Cruises, Norwegian Cruise Line, Oceania Cruises, Regent Seven Seas Cruises, Resorts World Bimini y Royal Caribbean International.

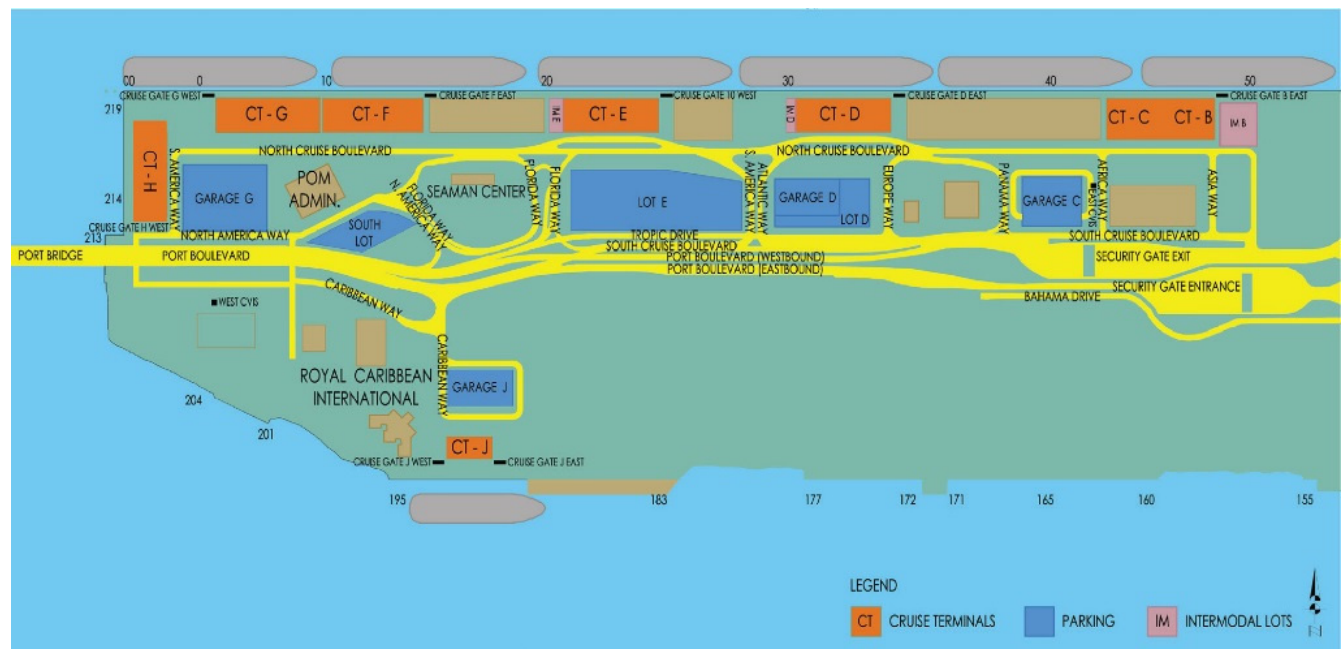

Figura 2.14: Configuración de terminales de crucero en el puerto de Miami.

Fuente: Port Miami (2014). 
El segundo y tercer puerto de esta región de destino, y a su vez del mundo, son Puerto Cañaveral y Port Everglades, respectivamente. Puerto Cañaveral registró 3,76 millones de pasajeros de crucero en 2012 en sus siete terminales (Port Canaveral, 2014). En cuanto a Port Everglades, registró 3,69 millones de pasajeros de crucero en 2012 (Cruise Insight, 2013). Este puerto cuenta con un total de 9 terminales de cruceros. Entre éstas se encuentra la mayor terminal para pasajeros de cruceros del mundo (terminal 18), inaugurada el 6 de noviembre de 2012, para dar servicio a mega-buques de crucero. En estas terminales operan como puerto base un total de 41 buques pertenecientes a 9 navieras de cruceros (Port Everglades, 2014).

El rápido desarrollo de Port Everglades y Puerto Cañaveral se explica por la necesidad de nuevas infraestructuras portuarias destinadas al tráfico de cruceros. Estas necesidades vienen motivadas por el crecimiento sostenido de la demanda del turismo de cruceros, la saturación alcanzada por el puerto de Miami, en lo que concierne al tráfico de cruceros; además de ser EE.UU. el principal país emisor de cruceristas a nivel mundial. De tal forma que los tres principales puertos de crucero a nivel mundial, por volumen de pasajeros, se encuentran en el Estado de Florida. En cruceros con destino al Caribe también destacan los puertos estadounidenses de Jacksonville al Sureste y Houston, Nueva Orleans, Tampa y Key West en el Golfo de México.

En el Caribe Occidental, véase Figura 2.15, los puertos de la costa caribeña de México están registrando un auge muy importante, contando como principal referente el puerto de Cozumel y sus instalaciones asociadas de Playa del Carmen y Cancún. En 2012 el puerto de Cozumel fue el $5^{\circ}$ puerto de cruceros del mundo con 2,74 millones de pasajeros. Junto a éste, Costa Maya es el siguiente puerto mexicano en tráfico de cruceros en la costa caribeña. Las Islas Caimán también registran una notable actividad crucerística, con 1,51 millones de pasajeros en 2012 (Cruise Insight, 2013).

Los puertos de la costa del Caribe pertenecientes a países centroamericanos (Belice, Guatemala, Honduras, El Salvador, Nicaragua, Costa Rica y Panamá), están adquiriendo mayor presencia en los itinerarios de crucero por el Caribe occidental. Esta circunstancia viene motivada sobre todo por el interés de las navieras de encontrar nuevos destinos evitando, de esta forma, sobrecargar los existentes. En esta zona destacan los puertos de Roatán (Honduras), Belice, y Colón y Balboa (Panamá). 


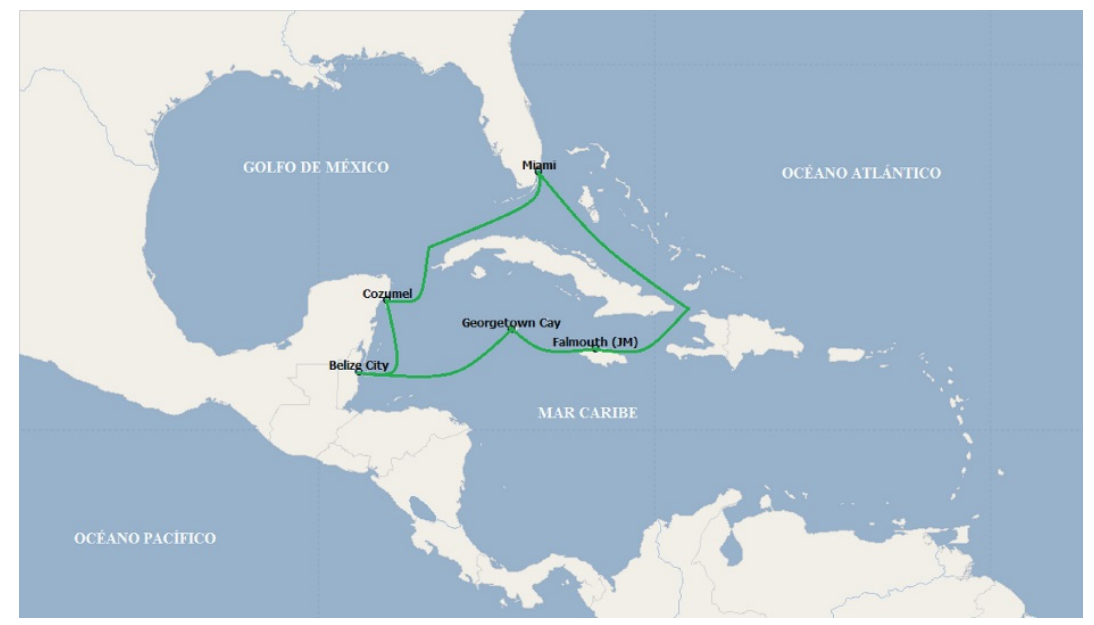

Figura 2.15: Itinerario de crucero por el Caribe Occidental. Fuente: Elaboración propia.

En el Caribe Oriental, véase Figura 2.16, Saint Thomas es el puerto de mayor tráfico, 1,90 millones de pasajeros en 2012, $9^{\circ}$ puerto en el ranking mundial. El puerto de Philipsburg en la parte holandesa de la Isla de Saint Maarten le sigue en importancia en esta zona del Caribe. En concreto, en 2012 fue el $11^{\circ}$ puerto de cruceros del mundo con 1,75 millones de pasajeros. Muy próximo en importancia a éste se sitúa San Juan de Puerto Rico, tanto por su carácter de puerto base como de escala, registrando en 2012 más de 1,05 millones de pasajeros. También es de destacar el puerto de Barbados con 517.000 pasajeros, junto con los puertos de El Gran Turco (Islas Turcas y Caicos), St. John (Antigua) y Castries (St. Lucia). El puerto de El Gran Turco destaca por la inmejorable situación de las Islas Turcas y Caicos en las rutas que van desde Florida (EE.UU.) al Caribe Oriental.

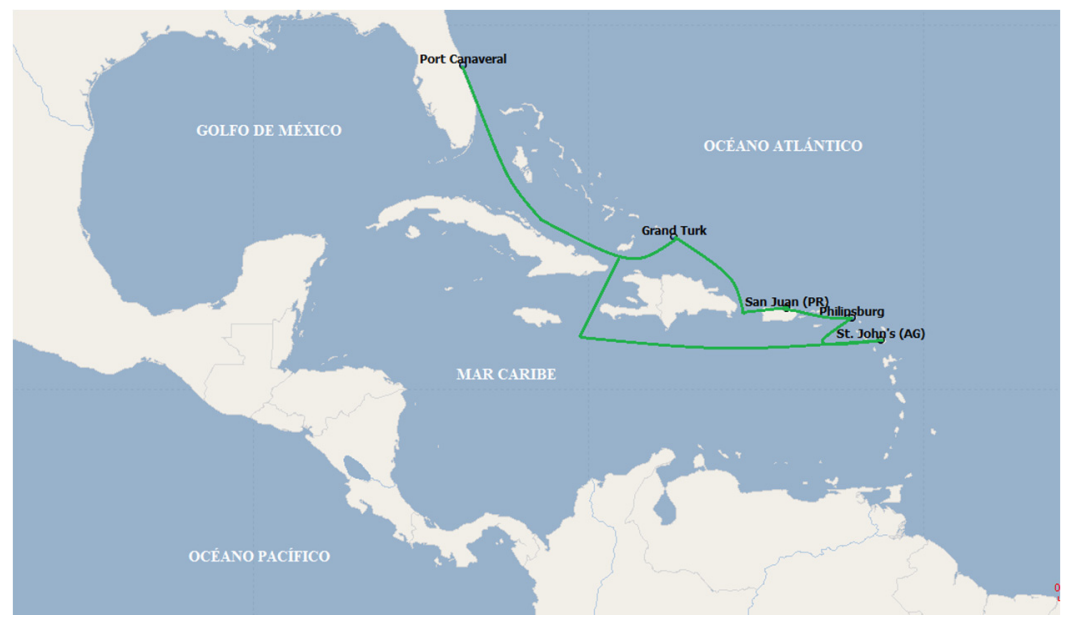

Figura 2.16: Itinerario de crucero por el Caribe Oriental. Fuente: Elaboración propia.

En Bahamas, véase Figura 2.17, destacan los puertos de Nassau y Freeport con 2,59 millones y 680.000 pasajeros en 2011, respectivamente (G.P. Wild International Limited, 2012). Por su posición geográfica estratégica, Bahamas suele utilizarse como punto de enlace entre los puertos base situados en Florida (EE.UU.), fundamentalmente, y las distintas áreas del Caribe. De tal forma que es práctica habitual de algunas navieras realizar una escala 
en Bahamas antes y/o después de dirigirse al área del Caribe objeto del crucero. Además, por su proximidad a EE.UU. se ofertan itinerarios de cuatro días de duración por las islas Bahamas exclusivamente. La cuota mundial asociada a la capacidad desplegada anualmente en Bahamas, entre los años 2000 y 2010, fue aproximadamente del 5,6\% (CLIA, 2011).

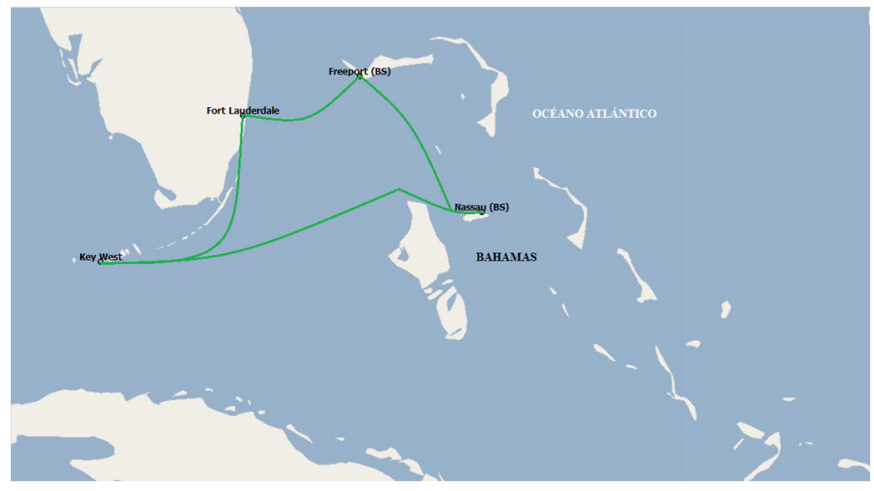

Figura 2.17: Itinerario de crucero por Bahamas.

Fuente: Elaboración propia.

Finalmente, las islas Bermudas es otro destino que habitualmente se oferta desde los puertos base situados en Florida, así como, desde Nueva York. En este último caso, también suele combinarse con travesías que se extienden hasta el Caribe, constituyendo las Bermudas una escala intermedia antes de alcanzar el Caribe.

\subsubsection{Alaska}

Alaska es la región más especializada, donde el turista busca naturaleza, en contraposición con el Caribe (sol, playa y mar). Su competidor en Europa son los fiordos noruegos. La oferta de excursiones en tierra es enormemente importante en la toma de decisión de los turistas que desean viajar a ella. Además, esta región se caracteriza por ser un destino para el segundo o tercer viaje en crucero, no tanto para primerizos (OMT, 2008). Impresionantes paisajes, glaciares resplandecientes, abundante vida salvaje y la cultura nativa americana constituyen algunas de las espectaculares atracciones que interesan a los turistas de cruceros en Alaska (CLIA, 2013a).

Los buques que visitan Alaska en un itinerario estándar de siete días normalmente navegan a lo largo de Inside Passage y visitan el Parque Nacional de Glacier Bay o Hubbard Glacier, haciendo escala en cuatro puertos a lo largo del itinerario, véase Figura 2.18. La mayoría de las líneas de cruceros también ofrecen la posibilidad de ampliar los paquetes de cruceros turísticos con opciones de viajes que llevan a los pasajeros al interior de Alaska en tren, e incluyen estancias en tierra en albergues y visitas al Parque Nacional Denali, haciendo su viaje a Alaska aún más completo (CLIA, 2013a). 


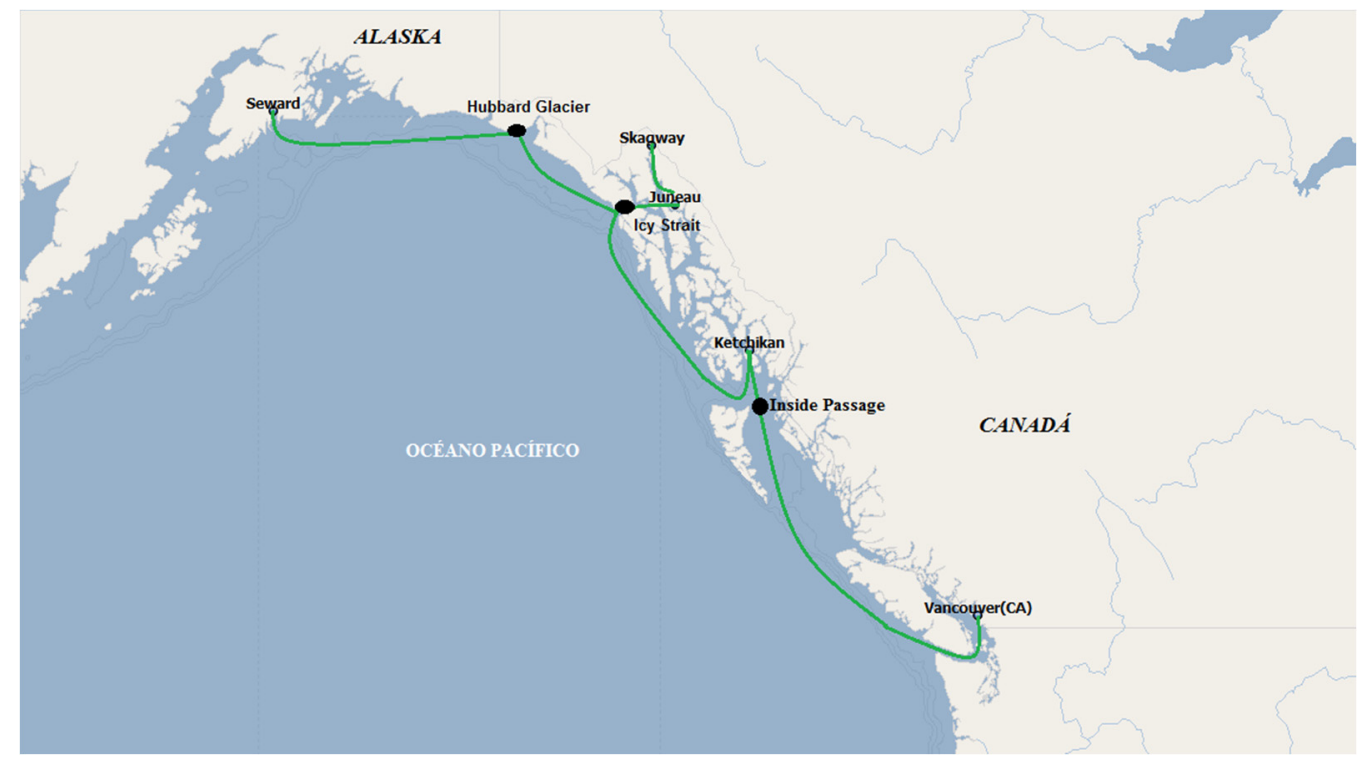

Figura 2.18: Ejemplo de itinerario de crucero por Alaska.

Fuente: Elaboración propia.

A efectos de clima y luz solar, los cruceros por Alaska navegan estrictamente durante los meses de verano, desde principios de mayo hasta mediados de septiembre. Los meses de junio, julio y agosto se pueden clasificar como temporada alta, registrándose una temperatura media de $24^{\circ} \mathrm{C}$. Alaska es una de las regiones de más rápido crecimiento, siguiendo en importancia al Caribe y Europa, con una cuota mundial en 2013 del 4,8\% medida por la capacidad desplegada en la región (CLIA, 2014). Entre los años 2000 y 2010 su crecimiento medio anual ha sido del 3,9\% (CLIA, 2011). Sin embargo, su crecimiento presenta dos factores limitativos:

- De infraestructura, los puertos están al límite de sus capacidades.

- Ecológicos, el acceso al espacio reservado Glacier Bay tiene un límite que ya se ha alcanzado (OMT, 2008).

Para los cruceros por Alaska existen dos puertos base principalmente, que están en fuerte competencia, Vancouver (Canadá) y Seattle (EE.UU.). En este sentido cabe destacar que el empleo de Seattle como puerto base implica que las navieras deben optar por buques más rápidos, al ser mayor la distancia navegada hasta alcanzar las zonas de interés turístico (OMT, 2008; CLIA, 2013b). En cuanto a los puertos de escala, los principales puertos en esta región de destino son Juneau, Ketchikan y Skagway, los dos primeros, en 2012, fueron los puertos de crucero número 29 y 31 del mundo respectivamente (Cruise Insight, 2013).

\subsubsection{Sudamérica y la Antártida}

América del Sur ofrece tierras fascinantes de cultura y belleza natural. El principal atractivo de esta zona se centra en la maravillosa arquitectura del viejo mundo de Montevideo, Uruguay; el atractivo de la ciudad y las playas de Río de Janeiro, Brasil; los 
secretos de Machu Picchu en Perú; descubrir y explorar la cascada Iguazú en la selva de Argentina y los lagos de aguas cristalinas y volcanes nevados de Puerto Montt, Chile (CLIA, 2013c).

En los últimos años esta zona está adquiriendo un importante auge en el tráfico de cruceros, acumulando en 2013 una cuota del 3,9\% en términos de capacidad desplegada. Entre los años 2000 y 2010 prácticamente se duplicó la capacidad desplegada en Sudamérica, con una tasa media anual de crecimiento del 15,5\% (CLIA, 2011). Los factores que inciden en esta circunstancia son (OMT, 2008):

- El benigno clima durante el invierno (del hemisferio norte), correspondiendo con el verano austral, que permite el reposicionamiento de los cruceros,

- El crecimiento sostenido de la demanda mundial de cruceros,

- Unas infraestructuras portuarias y turísticas que ya tienen un aceptable grado de desarrollo,

- La saturación de otras regiones como el Caribe, que hacen de Sudamérica un destino novedoso para los cruceristas repetidores,

- La seguridad de la región, alejada de conflictos bélicos,

- El atractivo turístico de sus ciudades, en especial Buenos Aires, y de su naturaleza intacta en la mayoría de los destinos.

Aunque los cruceros a Sudamérica se ofertan de octubre a abril, la temporada alta se alcanza durante los meses de diciembre, enero y febrero. Normalmente, los cruceros zarpan principalmente desde Río de Janeiro (Brasil), Valparaíso (Chile) y Buenos Aires (Argentina), véase Figura 2.19; pero algunos también comienzan en puertos Norteamericanos, como por ejemplo, San Diego, Nueva York y Port Everglades.

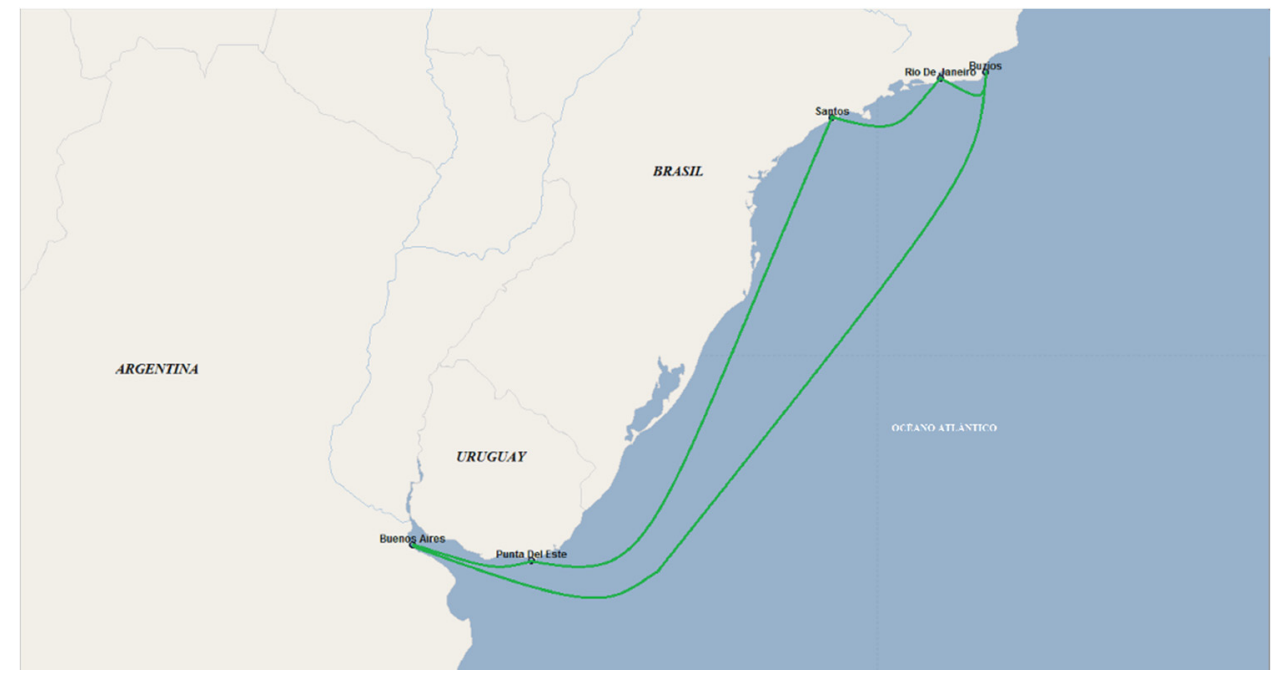

Figura 2.19: Ejemplo de itinerario de crucero por Sudamérica.

Fuente: Elaboración propia. 
Además de las escalas tradicionales en puertos de Sudamérica, los buques navegan alrededor del continente, incluyendo el tránsito por el Cabo de Hornos, haciendo escala a menudo en las Islas Malvinas y la Antártida, así como, en México y Costa Rica. Este tipo de itinerarios por Sudamérica tienen una duración de entre 13 a 40 días, y por lo general atrae a pasajeros con un perfil aventurero.

Un crucero por la Antártida, el gran "Continente Blanco", ofrece oportunidades únicas de encuentros cara a cara con la fauna que habita en este reino de hielo, tales como pingüinos, focas cangrejeras, ballenas jorobadas, orcas y gaviotas. Maravillosas vistas incluyen picos nevados, acantilados, icebergs y aguas de color azul. El área más fría y ventosa del mundo no tiene residentes humanos permanentes o nativos, sólo los científicos y especialistas que viven allí unos meses, a la par que los pasajeros de cruceros que disfrutan de la oportunidad única de visitarlo (CLIA, 2013d).

El itinerario exacto y los puertos de escala de cruceros que navegan a la Antártida dependen de las condiciones del hielo, el clima, la vida silvestre y la estricta protección medioambiental. Todas las actividades en la denominada Zona del Tratado Antártico deben de llevarse a cabo de acuerdo con la regulación medioambiental recogida en el Tratado Antártico de 1959 y en el sistema de regulaciones antárticas. La capacidad desplegada en la zona es muy reducida sobre todo por motivos medioambientales y meteorológicos. A pesar de estos factores limitantes, entre los años 2000 y 2010 se ha incrementado la capacidad desplegada a una tasa media anual del 22,5\%. Mientras en el año 2000 concentraba el 0,09\% de la cuota mundial, en 2010 alcanzaba el 0,23\% (CLIA, 2011).

Por lo general, los cruceros visitan la Antártida entre diciembre y febrero, cuando el rango de temperaturas es de $-7^{\circ} \mathrm{C}$ a $10^{\circ} \mathrm{C}$. Estos meses también entran en la categoría de pleno verano, cuando hay más de 20 horas de luz al día. Los cruceros generalmente utilizan los dos puertos base más australes de Sudamérica, Ushuaia (Argentina) y Punta Arenas (Chile) y en menor medida los puertos de Port Stanley (Islas Malvinas), Buenos Aires (Argentina) y Puerto Madryn (Argentina) (CLIA, 2013d).

La mayoría de los barcos que navegan a la Antártida tienen un arqueo bruto inferior a 23.000 GT y como requisito de proyecto tienen categoría de rompehielos o cuentan con casco reforzado capaz de soportar bajas temperaturas del agua de mar. Por limitaciones medioambientales, hay dos tipos de visitas; cruceros marítimos con desembarque de pasajeros permitido y los cruceros de gran porte sin desembarque permitido. En el caso de itinerarios con desembarque permitido, el propio buque de crucero no atraca en los puertos del itinerario sino que se realiza el desembarco con robustas embarcaciones de pequeño porte. Además, el número de pasajeros desembarcados en tierra firme de una sola vez, no puede superar la centena, según las Leyes del Tratado Antártico. 


\subsubsection{Asia-Pacífico}

Asia-Pacífico es uno de los destinos turísticos del mundo donde más crece el mercado. En 2013 registró una cuota de mercado del 8,4\%. Entre los años 2000 y 2010, la tasa media de crecimiento anual fue del $11,1 \%$, por lo que, en diez años se ha incrementado la capacidad desplegada en un $169 \%$. Tradicionalmente se divide en cuatro sectores, véase Figuras 2.20 y 2.21, Pacífico Sur (Australia, Nueva Zelanda, Islas Salomón, Indonesia y Papúa Nueva Guinea), Sudeste Asiático (Malasia, Filipinas, Singapur, Vietnam, Camboya y Tailandia), Extremo Oriente (Japón, República de Corea, República Democrática Popular de Corea y China) y Transpacífico (Islas Hawái, Isla de Guam, Fidji, Polinesia Francesa, etc.). Entre éstas, destacan por volumen de tráfico, el Pacífico Sur seguida del Sudeste Asiático.

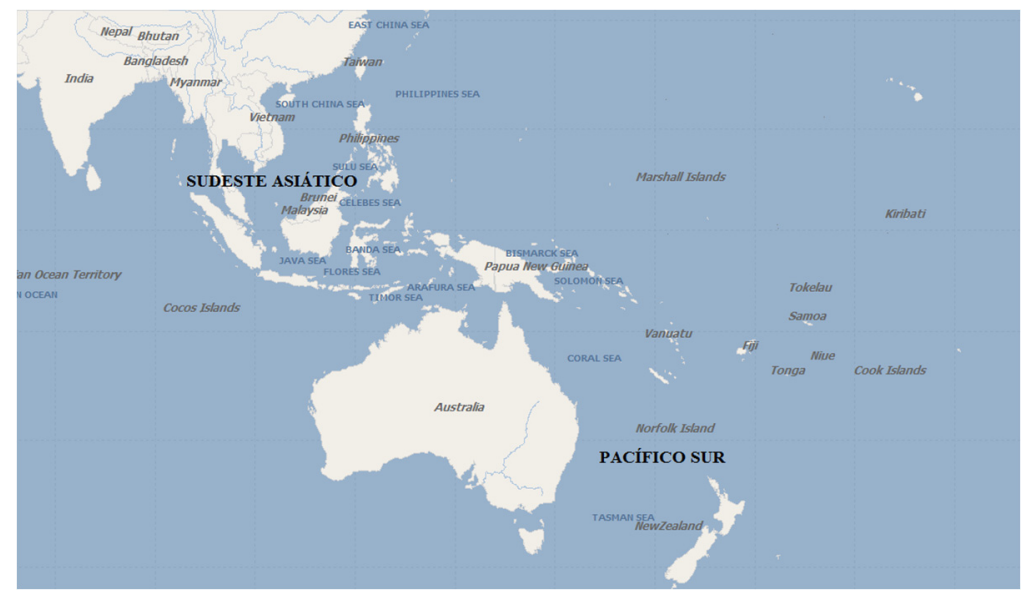

Figura 2.20: Sectores de cruceros en la región Asia-Pacífico. Fuente: Elaboración propia.

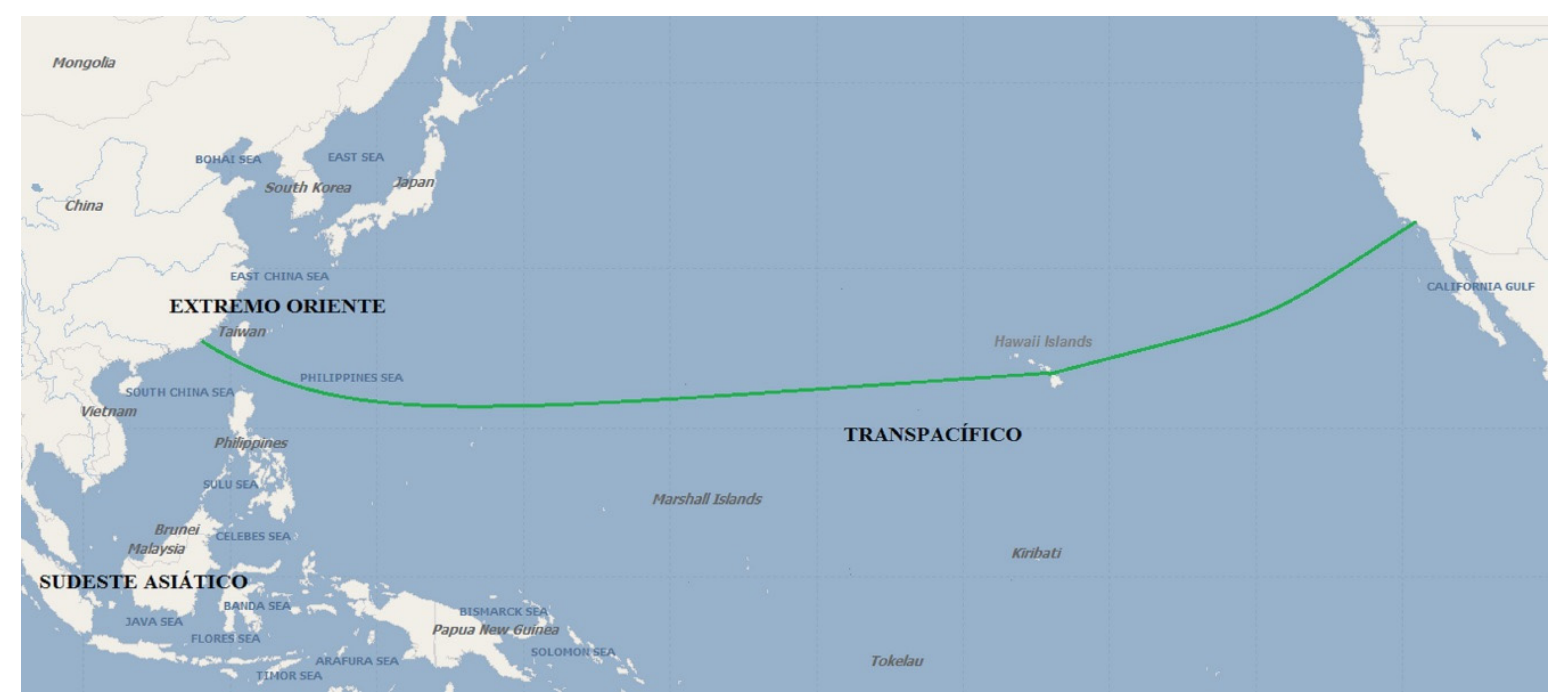

Figura 2.21: Sectores de cruceros en la región Asia-Pacífico.

Fuente: Elaboración propia.

La fortaleza de esta región estriba en sus múltiples destinos y diversidad cultural. A la diversidad de destinos hay que sumar el clima benigno del Sudeste Asiático, lo que permite 
ofrecer cruceros a lo largo de todo el año. En el caso de Australia, su atractivo adicional estriba en que es verano cuando es invierno en el hemisferio norte.

\subsubsection{Pacífico Sur}

Australia combina dos principales atractivos. Por un lado, abarca grandes extensiones de tierra salvaje, magníficas playas, grandes arrecifes de coral repletos de vida marina y una increíble variedad de vida silvestre. Por otro lado, la singularidad de Sydney, una de las grandes ciudades del mundo.

Al sureste de Australia en el Pacífico Sur, Nueva Zelanda comprende dos islas principales, conocidas simplemente como la Isla del Sur y la Isla del Norte, y numerosos pequeños islotes. Aunque de pequeño tamaño en comparación con su vecino, Nueva Zelanda cuenta con una amplia variedad de características naturales y oportunidades recreativas para competir con cualquier lugar del mundo. La Isla del Norte cuenta con la bulliciosa metrópolis y capital mundial de regatas de Auckland, exóticas playas de arena negra y exuberantes colinas verdes. Los terrenos montañosos de la Isla del Sur hacen que ésta se haya ganado el título de "La Suiza del Pacífico del Sur" (CLIA, 2013e).

Los cruceros que hacen escala en puertos de Australia y Nueva Zelanda, normalmente, se engloban en extensos itinerarios de crucero por el océano Pacífico o itinerarios de vuelta al mundo en crucero. Algunas navieras, sin embargo, programan itinerarios de crucero centrando la atención en estos dos destinos, bien de forma conjunta o por separado. Debido a que se encuentran en el hemisferio sur, el verano allí llega en diciembre, pero su clima templado, hace de estos dos destinos de cruceros, lugares atractivos en cualquier época del año (CLIA, 2013e). Entre los años 2000 y 2010 se ha duplicado la capacidad desplegada en este sector, con un incremento anual medio del 16,7\%. En 2013 alcanzó una capacidad desplegada correspondiente al 5\% mundial y las previsiones indican que en 2014 alcanzará el 5,9\% (CLIA, 2014).

\subsubsection{Extremo Oriente}

El Lejano Oriente define la esencia de los destinos exóticos. Estas tierras deslumbran y cautivan a los viajeros con sus fascinantes tradiciones, su belleza, su rica historia y un rico patrimonio cultural. Los diversos países y culturas de esta zona del mundo abarcan una vasta área y un sinnúmero de puertos de escala.

La mayoría de los cruceros en esta región se centran en áreas específicas, como Japón y el Este de China y el mar de China Meridional. También es posible encontrar escalas en los puertos clave de Asia, englobados en itinerarios de vuelta al mundo en crucero. El puerto más importante de Asia es Singapur con 913.000 pasajeros en 2012, además de ser el que más rápido crece del mundo. En China los principales puertos son Shanghái, Hong Kong y Xiamen, el primero compite de forma directa con Singapur. Aunque la mayor parte de los 
itinerarios tienen una duración de 10 días o más, existe una tendencia creciente a implementar también itinerarios de siete días. En 2010 la cuota mundial acumulada por este sector fue del 1,26\% (CLIA, 2011), lo que supone un incremento del 550\% respecto a la existente en el año 2000, con un crecimiento medio anual del 83\%, alcanzando en 2013 una cuota del 3,4\%. Durante los próximos años habrá que prestar especial atención a este sector debido a los cambios en el perfil demográfico de los residentes en esta región, lo cual hace presagiar un incremento notable de los viajes en crucero. En este sentido, también cabe mencionar que los buques deberán adaptar su diseño a las exigencias de los asiáticos, configurando un nuevo producto con mayores posibilidades de entretenimiento, en aspectos tales como karaoke o casinos; y disponer de restaurantes especializados en comida china o japonesa (OMT, 2008).

\subsubsection{Transpacífico}

Los cruceros de reposicionamiento entre la costa Oeste de Estados Unidos y Australia y Extremo Oriente, así como, en cruceros de vuelta al mundo, ofrecen escalas en las islas Hawái y la Polinesia.

Existe una amplia serie de opciones de cruceros disponibles por las islas Hawái incluyendo tres, cuatro y siete noches. Los cruceros de siete días entre las islas Hawái generalmente utilizan como puerto base Honolulu, pero varias líneas ofrecen itinerarios de mayor duración haciendo escala en Hawái desde Ensenada (México) y Vancouver (Canadá), antes y después de la temporada de cruceros durante el verano en Alaska (CLIA, 2013a).

Mientras que en el caso de los cruceros por las islas Polinesias parten de Papeete y Tahití, aunque algunos también operan desde Raiatea. De forma análoga al caso anterior, las escalas en estos puertos suelen englobarse en los cruceros de reposicionamiento Transpacífico y en itinerarios de vuelta al mundo.

\subsubsection{Norte de Europa}

El atractivo fundamental de esta región consiste en la diversidad cultural que ofrece el mar Báltico, con 10 países y 8 capitales, y la naturaleza de los fiordos noruegos. Con una cuota mundial en 2013 del 10,9\%. Se divide en cinco zonas de operación, véase Figura 2.22, los fiordos noruegos, el mar Báltico (ciudades escandinavas y San Petersburgo), las islas Británicas, Europa Occidental (el norte de Francia y España, así como Portugal) y las islas del Atlántico (Azores y Madeira (Portugal) y las islas Canarias (España)). Itinerarios clásicos son: Cabo Norte (con escalas en Copenhague y Oslo), Báltico (San Petersburgo, Estocolmo, Helsinki y Copenhague) y alrededor de Reino Unido (Irlanda, Gales, Escocia, Inglaterra e islas del Canal). 


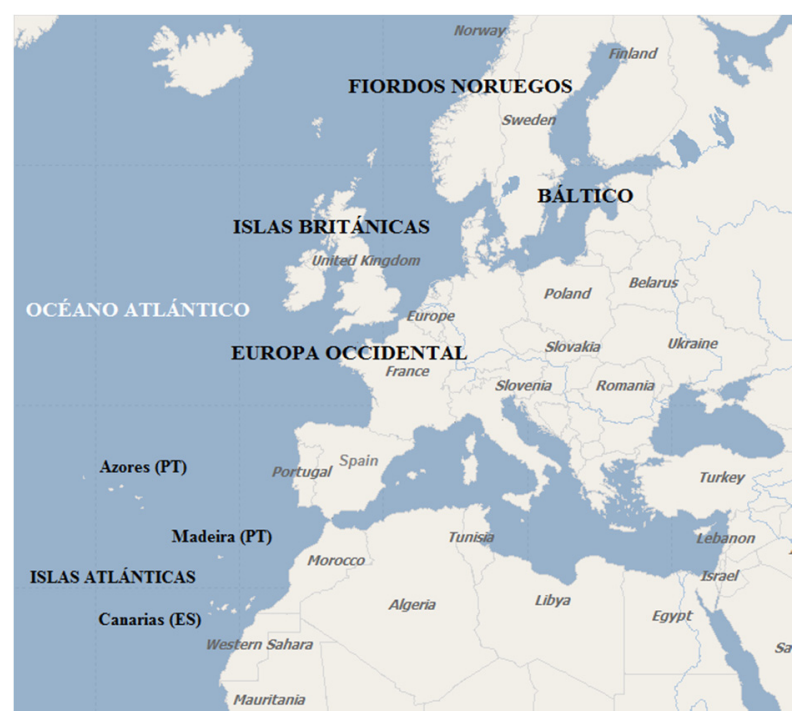

Figura 2.22: Zonas de operación en el Norte de Europa.

Fuente: Elaboración Propia.

La temporada comienza en la segunda quincena de mayo y finaliza en septiembre, aunque la tendencia es que comience más temprano, a principios de mayo, con una duración de las travesías ofertadas de 7 a 14 días. Los puntos fuertes de los puertos del Norte de Europa son (OMT, 2008):

- Enorme atractivo turístico, por la importante herencia cultural e histórica, y unas infraestructuras turísticas y de servicios con un alto nivel.

- Instalaciones portuarias excelentes con la gran experiencia que les ha aportado el intenso tráfico de ferries de la zona en el embarque y desembarque de grandes números de pasajeros en poco tiempo y con altos niveles de seguridad.

- Apoyo logístico de muy alta calidad, tanto en el aprovisionamiento de víveres como en las reparaciones y mantenimientos de equipos. Por esta razón se abarata de manera considerable el coste de explotación. No hay que olvidar que los principales astilleros especializados en la construcción de cruceros se ubican en Europa Occidental.

Entre el año 2000 y 2010 la capacidad de esta región ha crecido a una cuota anual media del 10,80\%. Con lo que la diferencia de la capacidad desplegada en el año 2010 respecto a la existente en el año 2000 fue del 141\% (CLIA, 2011). Los principales puertos por tráfico son Southampton y Copenhague, puertos de crucero número 12 y 30 del mundo en 2012 con 1,53 millones y 840.000 pasajeros respectivamente (Cruise Insight, 2013), seguidos por Estocolmo y San Petersburgo.

En la zona del Báltico los diez puertos con mayor cifra de pasajeros son: Copenhague, San Petersburgo, Tallin, Estocolmo, Helsinki, Oslo, Gdynia, Riga, Gotemburgo y Aarhus, véase Figura 2.23. 


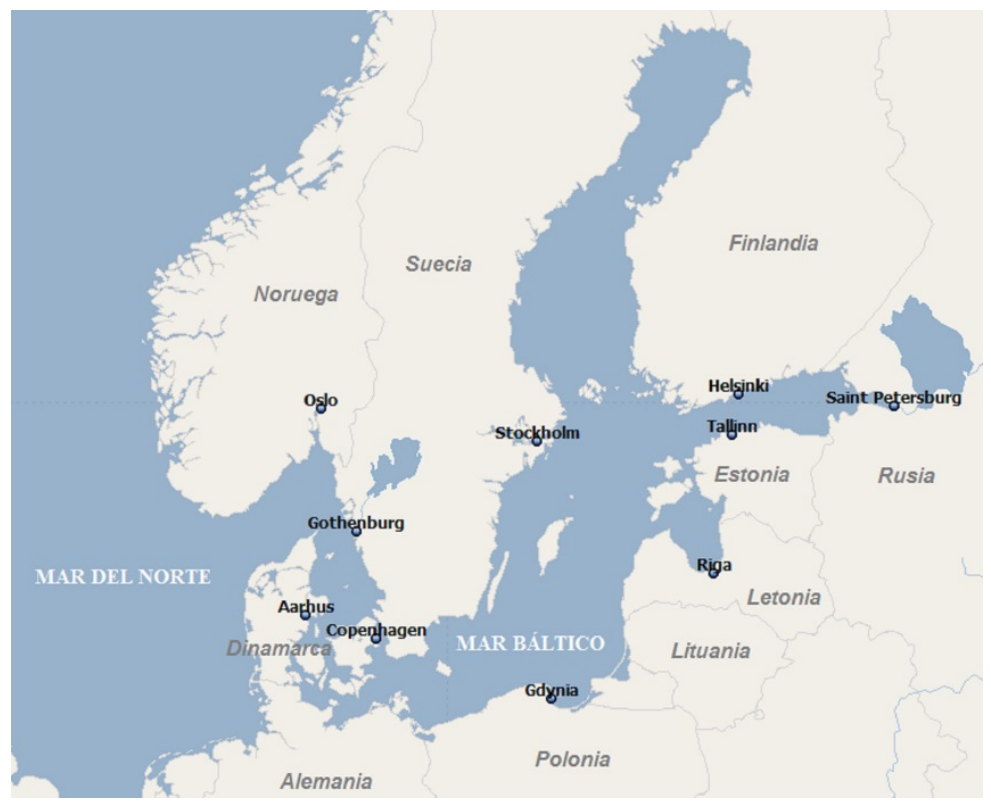

Figura 2.23: Principales puertos de crucero en el mar Báltico.

Fuente: Elaboración propia.

Copenhague es el principal puerto de esta zona seguido de San Petersburgo y Tallin, véase Gráfico 2.2. Copenhague cuenta con unas excelentes instalaciones de puerto base, además, su posición geográfica estratégica le permite establecerse como puerto base tanto para cruceros con destino al Báltico como a los fiordos noruegos. Mientras que San Petersburgo es una escala obligada para todos los cruceros que navegan por el Báltico debido a su gran atractivo histórico y cultural.

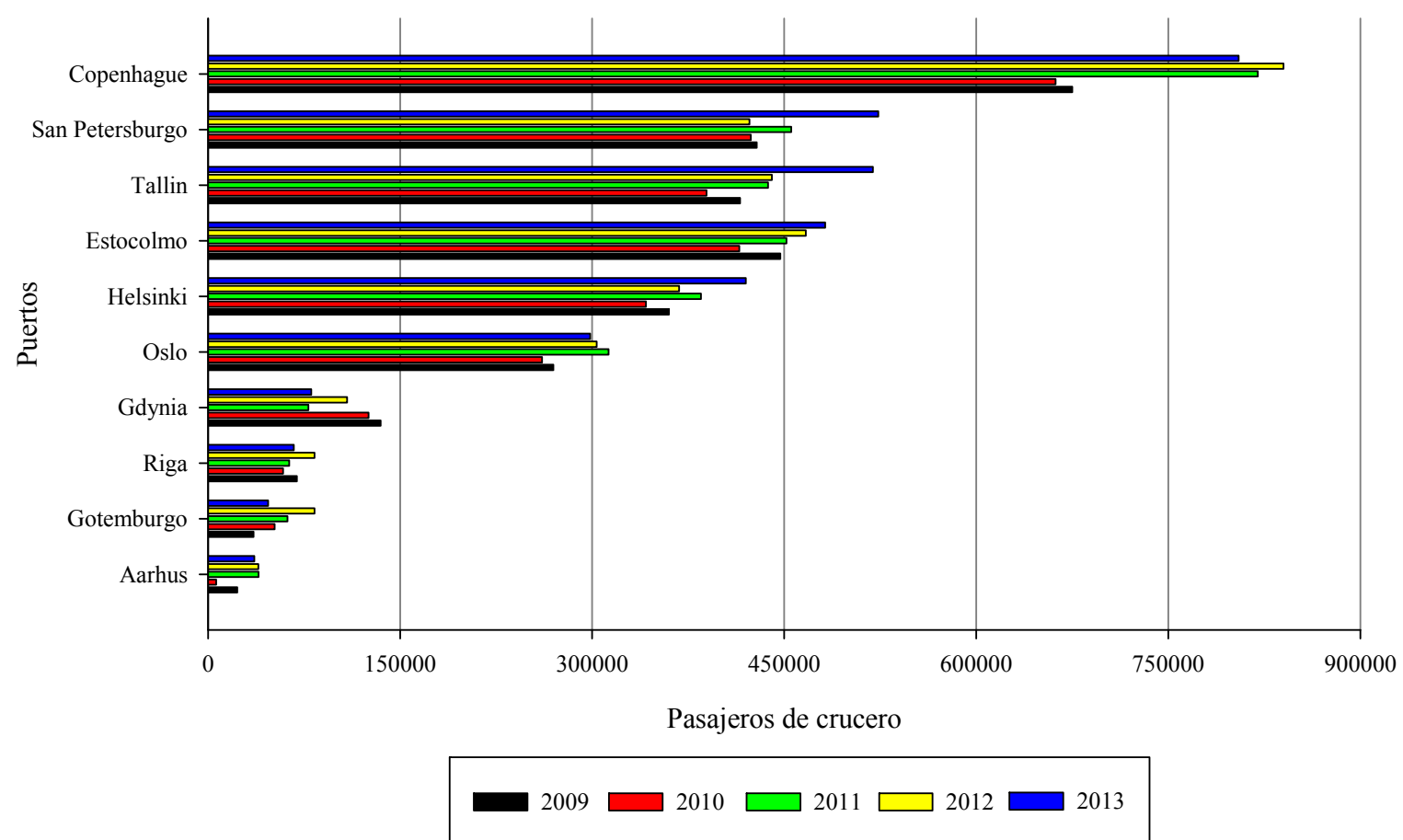

Gráfico 2.2: Cifras de cruceristas registradas en los 10 principales puertos del mar Báltico entre 2009 y 2013. Fuente: Elaboración propia a partir de estadísticas de Cruise Europe (2014). 
Noruega con una longitud de costa de 1.300 millas náuticas $(2.408 \mathrm{~km})$ ofrece inmensas posibilidades de creación de itinerarios interesantes. Actualmente, el número de puertos que registran tráfico de cruceros se sitúa en torno a los 41, véase Figura 2.24, (Cruise Norway, 2013).

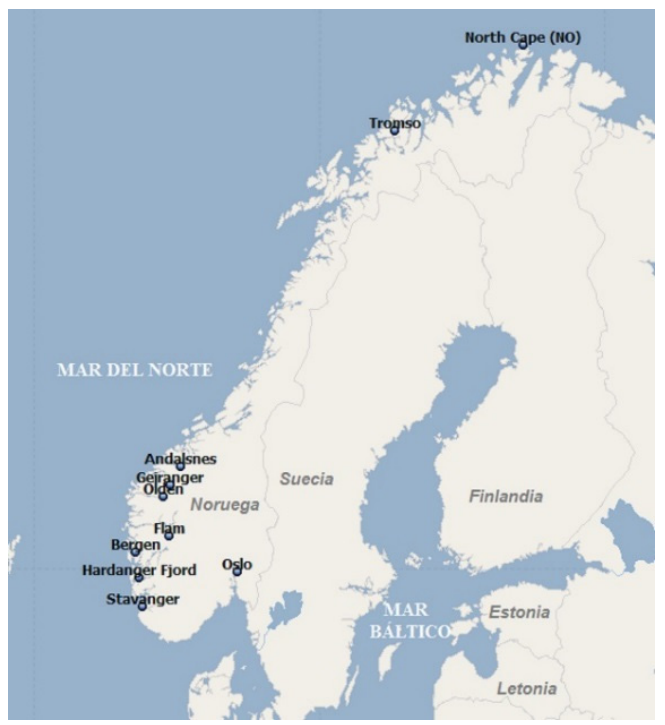

Figura 2.24: Puertos de crucero en Noruega.

Fuente: Elaboración propia.

Las áreas más populares de cruceros por Noruega son los fiordos, constituyendo Bergen el principal puerto base para este destino; Cabo Norte y el área Ártica. Su capital Oslo también registra una notable actividad crucerística con itinerarios a los fiordos y el mar Báltico por su cercanía e influencia con este mar, como se ha comentado anteriormente. Los diez puertos con mayor tráfico de cruceros en Noruega quedan reflejados en el Gráfico 2.3.

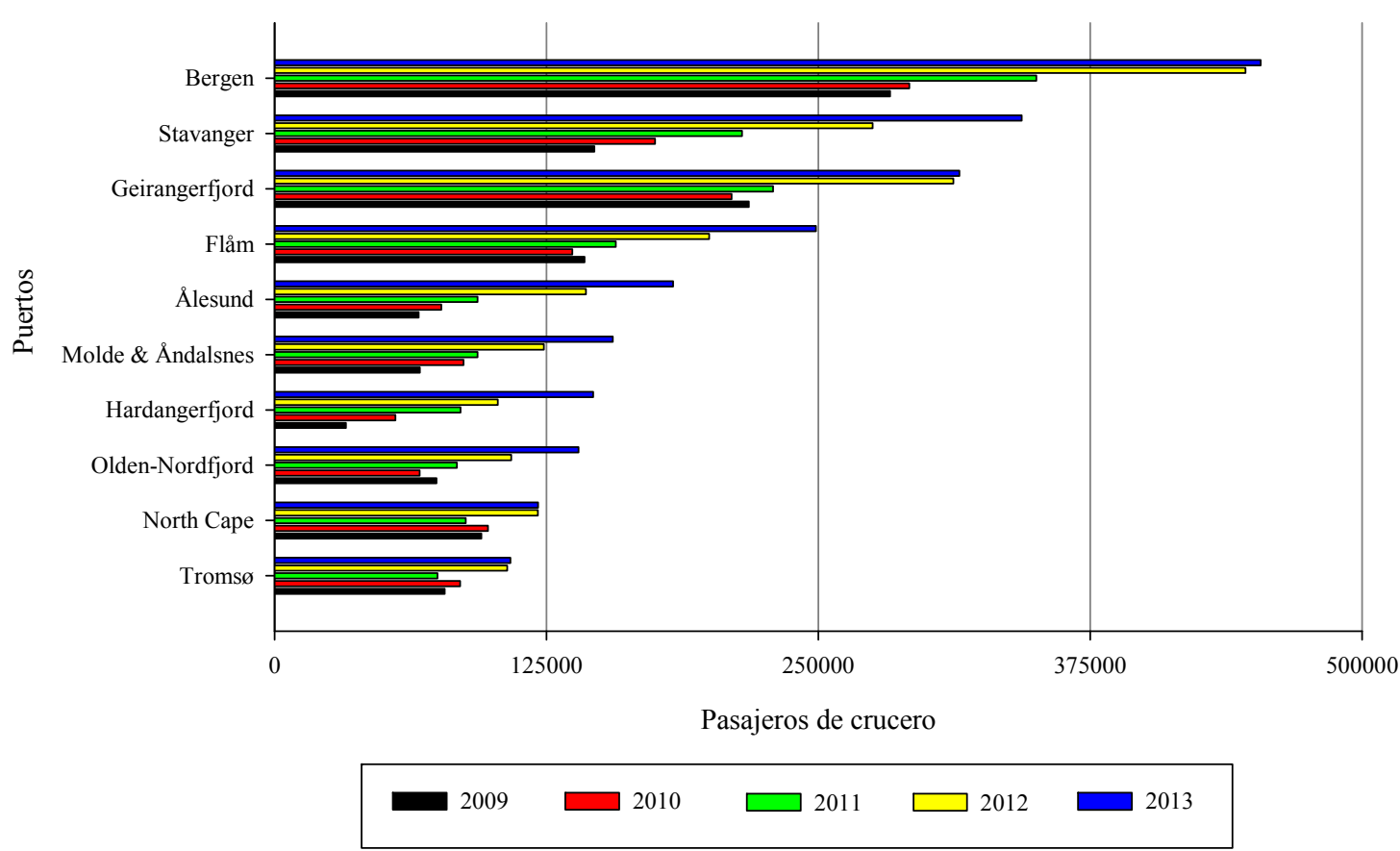

Gráfico 2.3: Cifras de cruceristas registradas en los 10 principales puertos de Noruega entre 2009 y 2013. Fuente: Elaboración propia basada en estadísticas de Cruise Europe (2014) y Cruise Norway (2014). 
En la islas Británicas, se combinan principalmente dos tipos de itinerarios, aquellos que discurren únicamente por aguas británicas escalando en puertos de Reino Unido e Irlanda, véase Figura 2.25, y por otro lado, los que combinan escalas en puertos de estas islas junto con puertos de Noruega, Islandia o Islas Feroe.

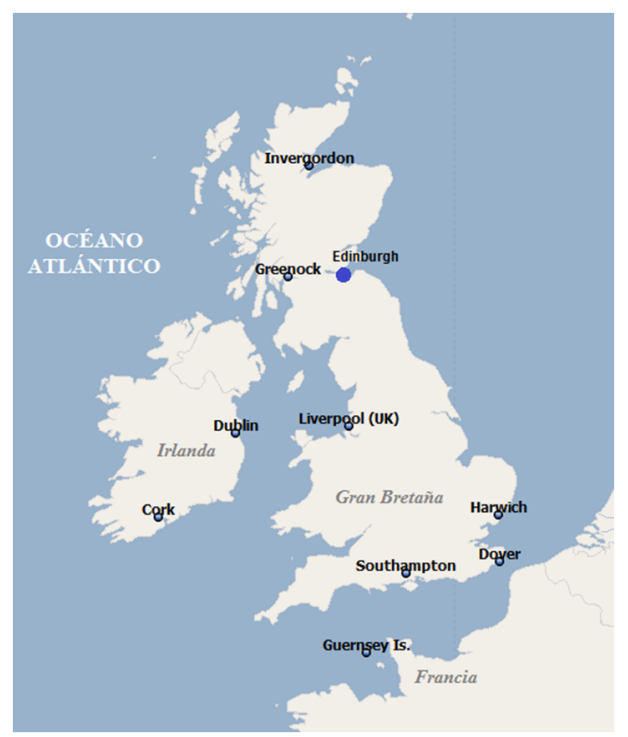

Figura 2.25: Puertos de crucero en las islas Británicas.

Fuente: Elaboración propia.

Además, en Gran Bretaña está situado el principal puerto base de cruceros del Norte de Europa, Southampton. Junto a éste, los diez principales puertos de crucero en las islas Británicas, atendiendo a la cifra de cruceristas que registran, se incluyen en el Gráfico 2.4.

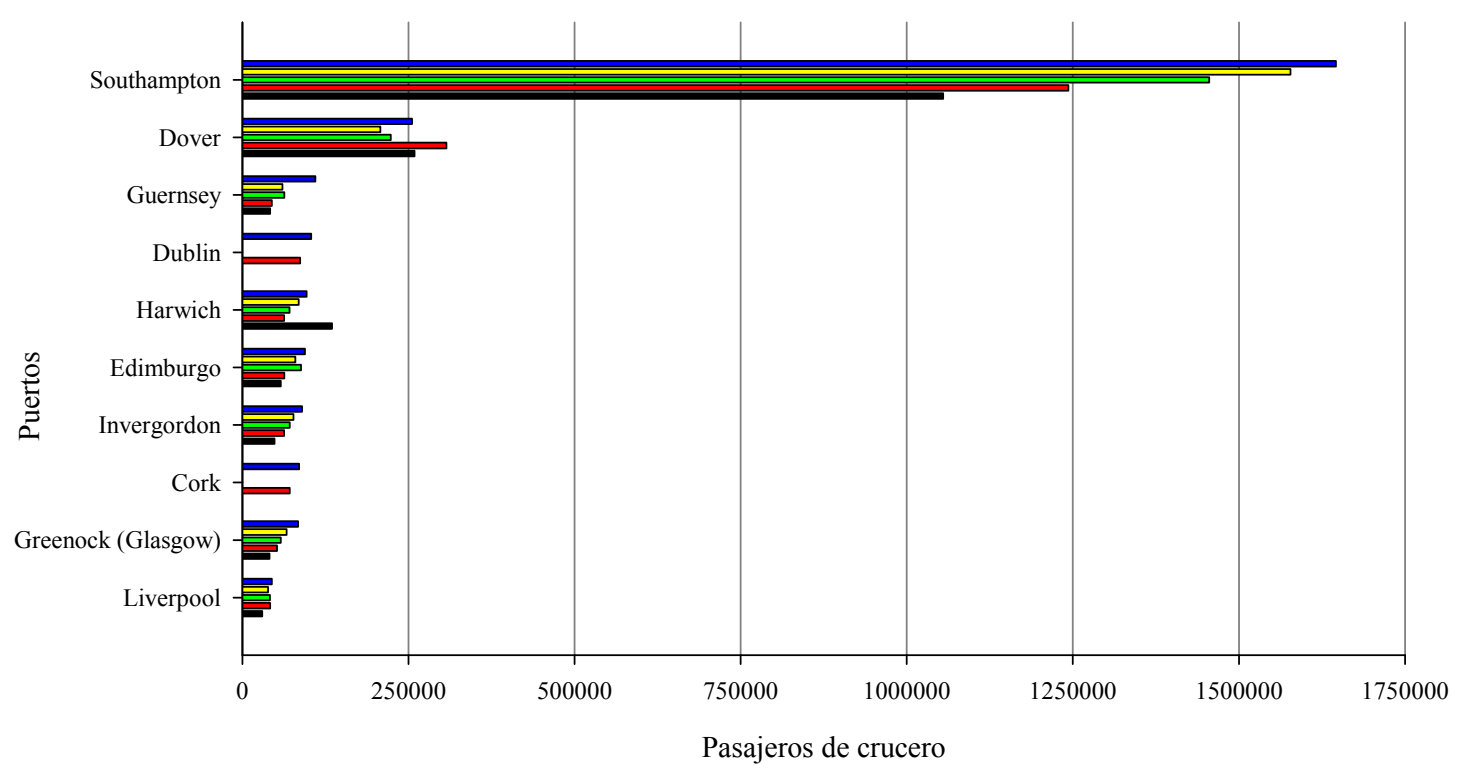

\begin{tabular}{|lllll|}
\hline & $2009 \quad \square 2010 \quad \square 2011 \quad \square 2012 \quad \square 2013$ \\
\hline
\end{tabular}

Gráfico 2.4: Cifras de cruceristas registradas en los 10 principales puertos de las islas Británicas entre 2009 y 2013. Nota: Las estadísticas de Dublín y Cork no están disponibles para los años 2009, 2011 y 2012.

Fuente: Elaboración propia basada en estadísticas de Cruise Europe (2014) y CLIA Europe (2014). 
En relación con los itinerarios de crucero que realizan escalas en Islandia y/o Islas Feroe, los principales puertos en estas islas atendiendo a la cifra de cruceristas que registran son Akureyri y Thorshavn, respectivamente, véase Figura 2.26. Entre 2009 y 2013, el puerto de Akureyri ha registrado una cifra media anual de 58.105 cruceristas; mientras que en el caso de Thorshavn ha sido de 31.134 cruceristas.

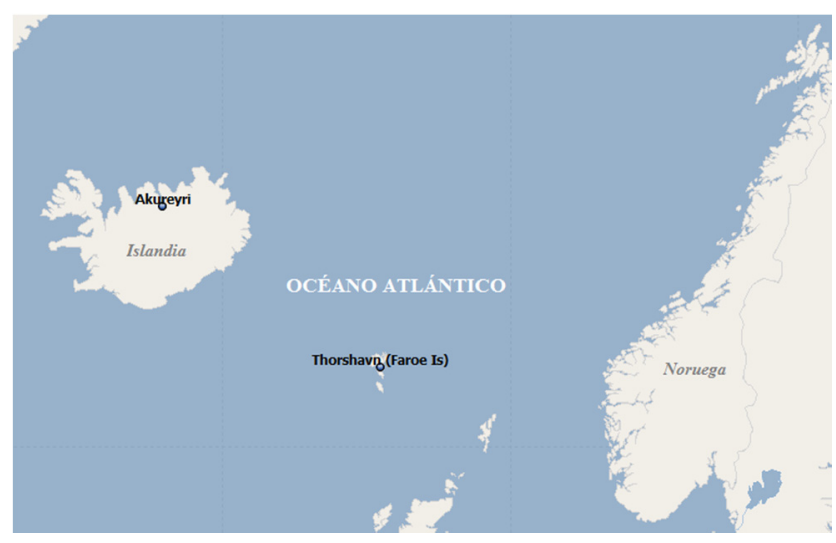

Figura 2.26: Puertos de crucero en Islandia e Islas Feroe.

Fuente: Elaboración propia.

El área de Europa Occidental está compuesta por puertos de Alemania, Bélgica, Holanda, Portugal, Norte y Oeste de Francia y Norte de España, véase Figura 2.27. Los diez puertos principales en esta zona por cifra de cruceristas son: Lisboa, Ámsterdam, Zeebruge, Le Havre, Vigo, A Coruña, Rotterdam, Bremerhaven, Ijmuiden y Bilbao, véase Gráfico 2.5.

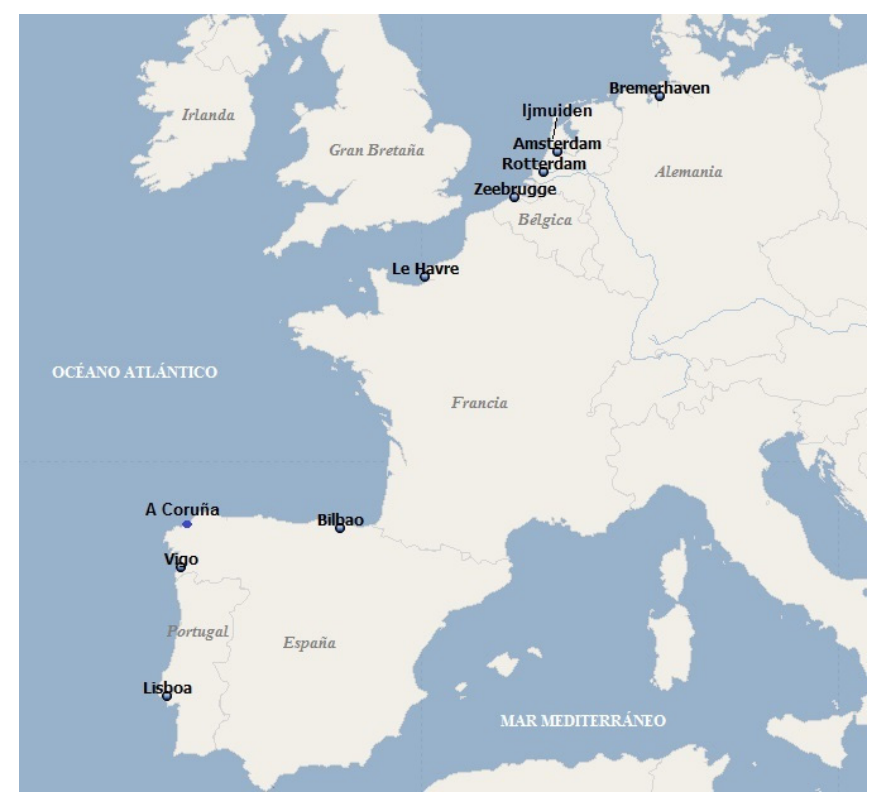

Figura 2.27: Puertos de crucero en la costa occidental europea. Fuente: Elaboración propia.

Lisboa está registrando un fuerte crecimiento durante los últimos años gracias a su excelente accesibilidad al centro de la ciudad y al aeropuerto. En concreto, el crecimiento medio del puerto lisboeta entre el año 2009 y 2013 ha sido del 7,67\%. 


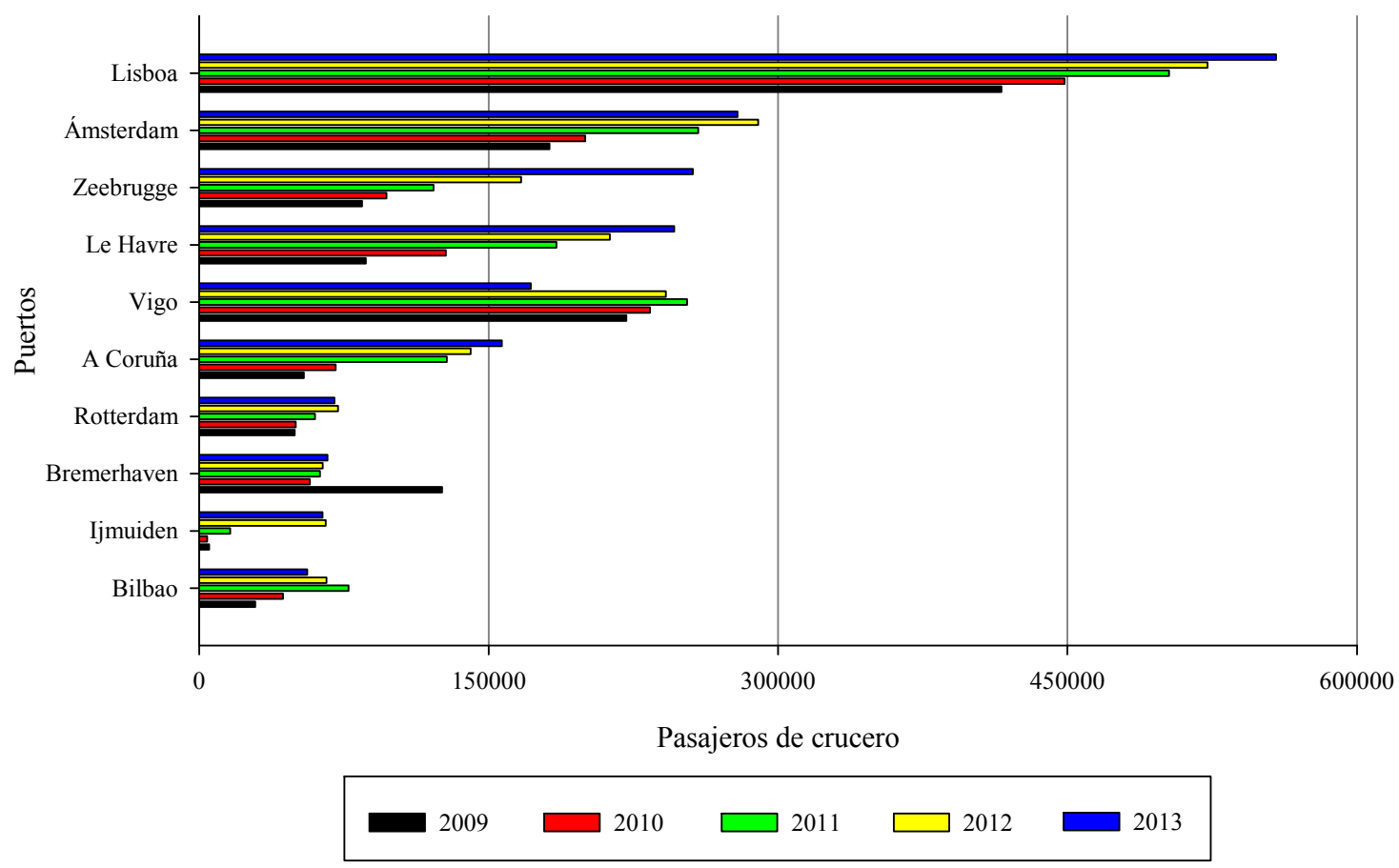

Gráfico 2.5: Cifras de cruceristas registradas en los 10 principales puertos de la costa occidental de Europa entre 2009 y 2013.

Fuente: Elaboración propia basada en estadísticas de Cruise Europe (2014) y Bremenports (2014).

Los archipiélagos portugueses de Azores y Madeira situados en el Atlántico NorOriental junto con las islas Canarias situadas en el Atlántico Centro-Oriental, constituyen la quinta zona de operación de cruceros adscrita a Europa. Debido a su situación geográfica estratégica, los tres archipiélagos se incluyen en cruceros de reposicionamiento entre el Mediterráneo y Norte de Europa hacia el Caribe y Sudamérica, y viceversa según el cambio de temporada.

El archipiélago de Azores está situado a 930 millas de Lisboa, lo conforman un total de nueve islas, de las cuales únicamente tres disponen de instalaciones portuarias con capacidad para albergar tráfico de cruceros, véase Figura 2.28. La isla de Sao Miguel es la de mayor tamaño y la más poblada, el principal puerto de la isla y del archipiélago es Ponta Delgada, el cual cuenta con una terminal de cruceros inaugurada en julio de 2008. Las otras dos islas con instalaciones específicas para cruceros son, Terceira, cuyo puerto es Praia da Vitoria, y Faial, con la instalación para cruceros del puerto de Horta, inauguradas en julio de 2012 (MedCruise, 2013a). Los itinerarios de crucero en que quedan englobadas las Azores normalmente discurren por Portugal y la costa norte de España. 


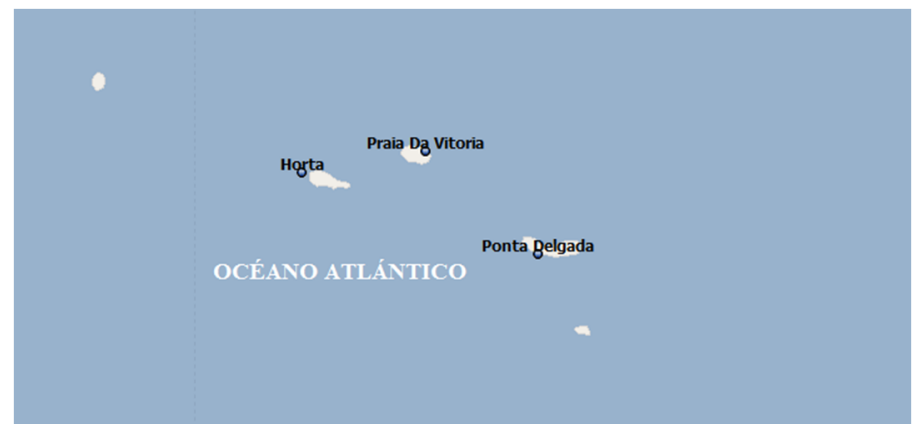

Figura 2.28: Puertos de crucero en las islas Azores.

Fuente: Elaboración propia.

El archipiélago de Madeira está situado a 570 millas de Lisboa y a 276 millas de Santa Cruz de Tenerife, lo componen cinco islas, de las cuales únicamente dos están habitadas, Madeira y Porto Santo, véase Figura 2.29. El principal puerto de cruceros de Madeira y del archipiélago es Funchal, Porto Santo también registra actividad de buques de crucero pero sus órdenes de magnitud respecto a Funchal son muy bajos. Madeira cuenta con dos tercios de su territorio como área forestal protegida. La configuración de itinerarios con escalas en Madeira se combina en la mayor parte de los casos con escalas en puertos de Canarias y el Norte de África por su proximidad geográfica.

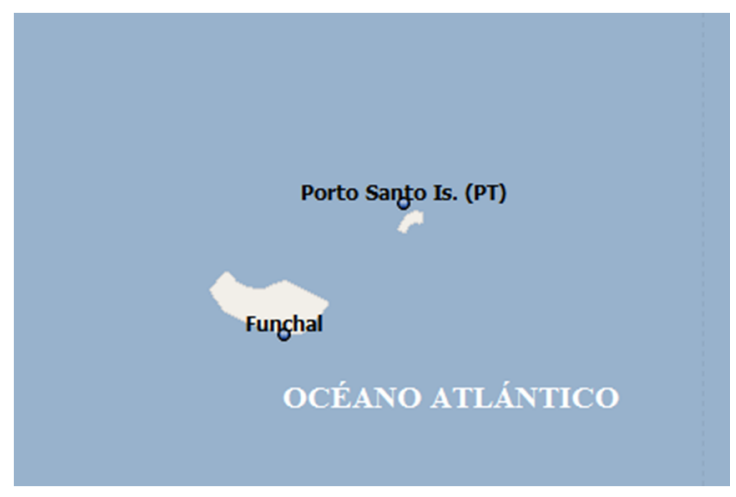

Figura 2.29: Puertos de crucero en Madeira.

Fuente: Elaboración propia.

Las islas Canarias cuentan con un total de 8 puertos con capacidad para albergar buques de crucero, gestionados por dos Autoridades Portuarias (AA.PP.), atendiendo al modelo de gestión portuaria LandLord Port del Sistema Portuario Español (IME y FEIN, 2009). La Autoridad Portuaria de Santa Cruz de Tenerife gestiona los puertos de San Sebastián de La Gomera, Los Cristianos, Santa Cruz de La Palma, La Estaca, así como, el propio puerto de Santa Cruz de Tenerife. Mientras que la Autoridad Portuaria de Las Palmas de Gran Canaria gestiona los puertos de Arrecife, Puerto del Rosario y Las Palmas, véase Figura 2.30 . 


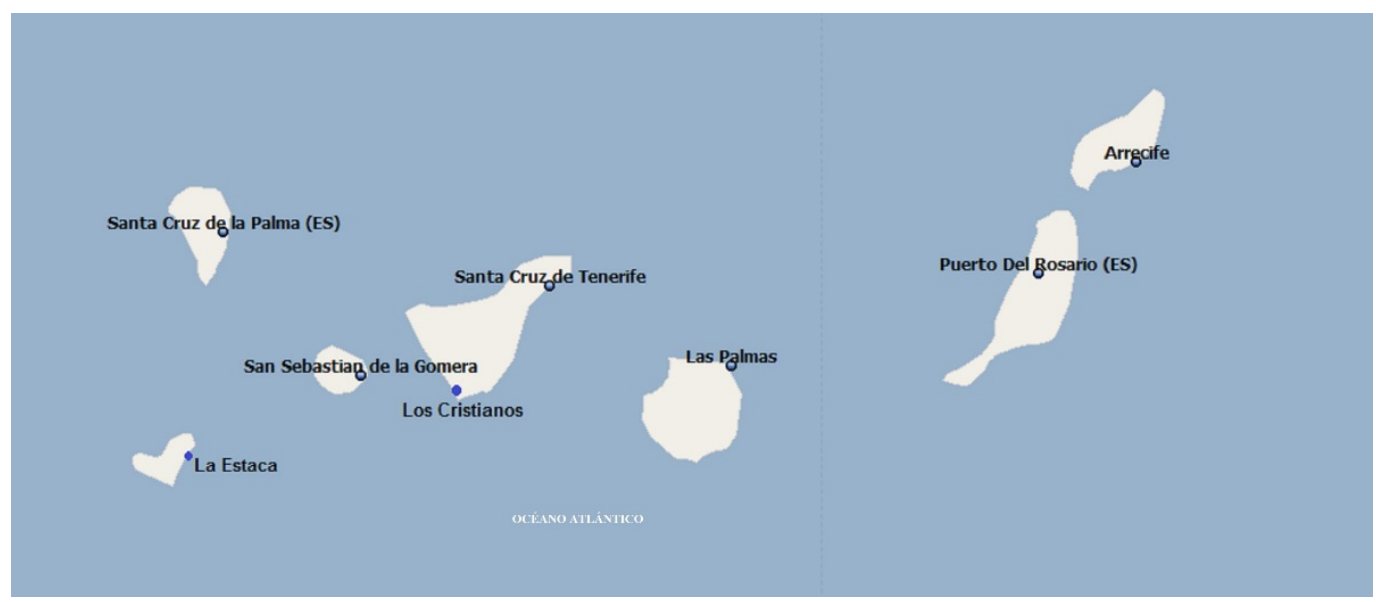

Figura 2.30: Puertos de crucero en las islas Canarias.

Fuente: Elaboración propia.

A diferencia de los archipiélagos anteriores, sus cifras de cruceristas no son sólo como puerto de escala sino también como puerto base. Debido a la extensión del archipiélago canario, y su disponibilidad de instalaciones portuarias, existen itinerarios de crucero que únicamente discurren por puertos canarios. También es habitual que junto a los puertos canarios, el itinerario combine escalas en puertos del Norte de África y del Sur de la Península Ibérica, fundamentalmente, con el puerto de Cádiz. Las islas Canarias registran las mayores cifras de cruceristas de los tres archipiélagos, véase Gráfico 2.6. Además, ambas Autoridades Portuarias canarias registran una evolución y órdenes de magnitud similares de la cifra de cruceristas.

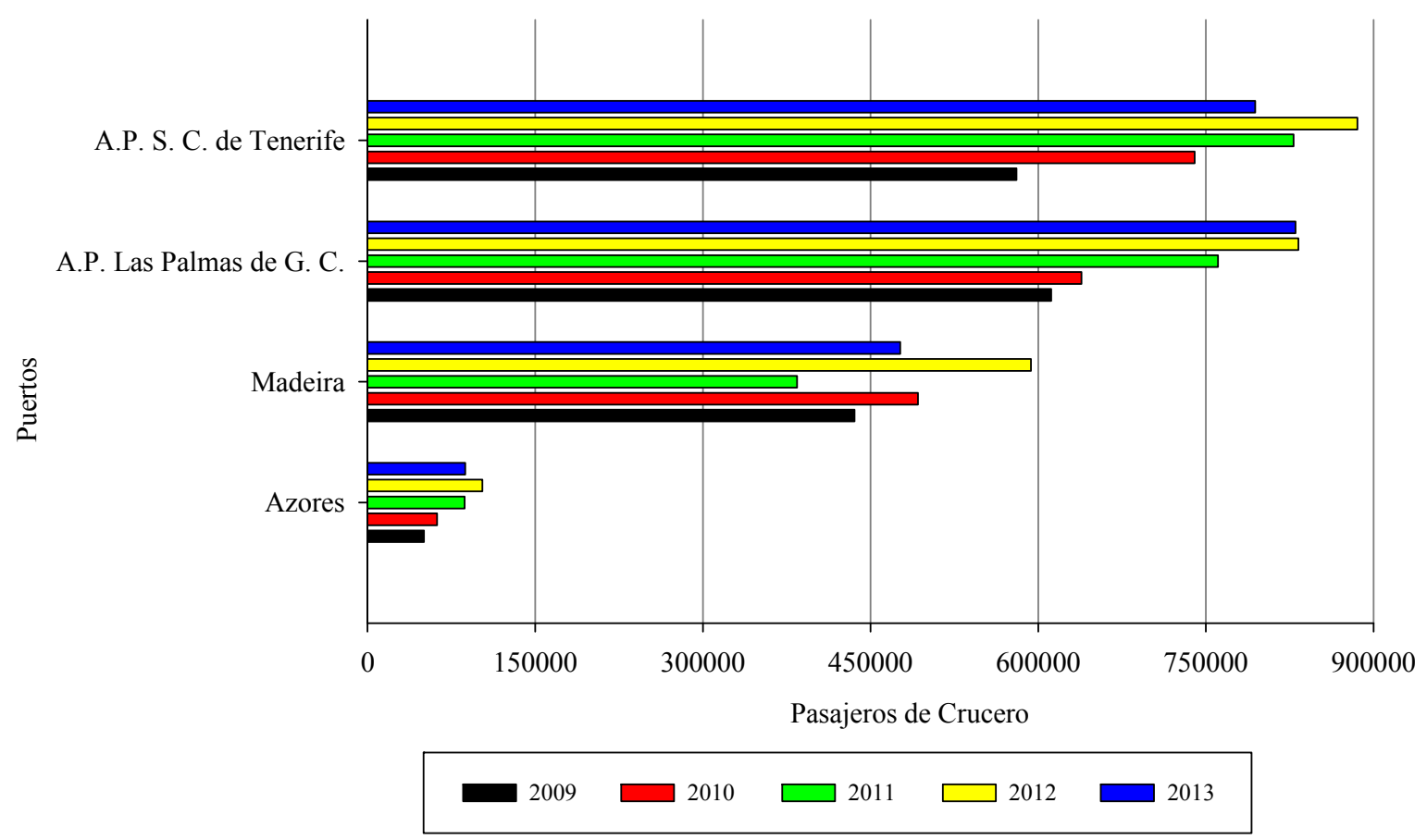

Gráfico 2.6: Cifras de cruceristas registradas en los puertos de las islas Atlánticas entre 2009 y 2013.

Fuente: Elaboración propia basada en estadísticas de MedCruise (2014), Portos da Madeira (2014) y Puertos del Estado (2014). 
Por tanto, en la región de destino Norte de Europa, con sus diversas áreas de operación, los diez puertos con mayores cifras de cruceristas entre los años 2009 y 2013 se muestran en la Tabla 2.1. Las cinco zonas de operación del Norte de Europa cuentan con representación entre los diez puertos principales de la región.

Tabla 2.1: Cifras de pasajeros de crucero en los 10 principales puertos de la región Norte de Europa entre 2009 y 2013

\begin{tabular}{lrrrrr}
\hline Puerto & $\mathbf{2 0 0 9}$ & $\mathbf{2 0 1 0}$ & $\mathbf{2 0 1 1}$ & $\mathbf{2 0 1 2}$ & $\mathbf{2 0 1 3}$ \\
\hline Southampton & 1.054 .900 & 1.243 .460 & 1.455 .245 & 1.577 .790 & 1.646 .000 \\
A.P. Las Palmas de Gran Canaria & 611.701 & 638.860 & 760.896 & 832.763 & 830.224 \\
Copenhague & 675.000 & 662.000 & 820.000 & 840.000 & 805.000 \\
A.P. Santa Cruz de Tenerife & 580.605 & 740.022 & 828.590 & 885.623 & 794.249 \\
Lisboa & 415.804 & 448.497 & 502.644 & 522.604 & 558.040 \\
San Petersburgo & 428.550 & 423.931 & 455.476 & 423.000 & 523.525 \\
Tallin & 415.575 & 389.370 & 437.517 & 440.504 & 519.319 \\
Estocolmo & 447.000 & 415.000 & 451.799 & 467.000 & 482.000 \\
Madeira & 435.821 & 492.500 & 384.192 & 593.550 & 476.625 \\
Bergen & 282.938 & 291.877 & 350.248 & 446.406 & 453.372 \\
\hline
\end{tabular}

Fuente: Elaboración propia basada en estadísticas de MedCruise (2014), Cruise Europe (2014) y Puertos del Estado (2014).

\subsubsection{Mediterráneo}

Entre el año 2000 y 2010, la capacidad desplegada en el Mediterráneo creció a una tasa media anual del $12,33 \%$, lo cual supone un crecimiento del $195,33 \%$ entre la capacidad existente en el año 2000 y la disponible en 2010. En términos absolutos en el año 2010 aglutinaba el 17,81\% de la capacidad mundial, incrementándose hasta el 21,7\% en 2013 (CLIA, 2014). Desde el año 2000 hacia el Mediterráneo se dirigen el 12\% del total de los cruceristas norteamericanos, mientras que en el caso de Europa oscila entre un $50 \%$ y un $80 \%$, dependiendo del país emisor. Así, en el caso de Alemania y el Reino Unido es de un 50\%, en Francia de un 65\% y en España e Italia un 80\% (OMT, 2008).

La región está desarrollando su enorme potencial de crecimiento, gracias a sus excelentes instalaciones portuarias, sus atractivos turísticos y su benigno clima. No hay que olvidar que España, Francia e Italia son países ribereños del Mediterráneo y líderes mundiales de turismo. De hecho, no hay ninguna otra área en el mundo que pueda igualar al Mediterráneo en cuanto al número de culturas y civilizaciones que han surgido de las costas de los países que se encuentran en este mar. Su riqueza se deriva en gran medida del hecho de que el mar está casi totalmente cerrado por tres continentes (África, Asia y Europa). Esto ha llevado a una constante interacción entre las poblaciones que habitan en ellos (MedCruise, 2013b). La región del Mediterráneo se puede dividir en dos grandes sectores, el Mediterráneo Oriental y Occidental, véase Figura 2.31, actuando la península Itálica como frontera entre ambos. Además, existen otras dos zonas, menores que las anteriores, que también albergan itinerarios de cruceros, son, la zona del mar Adriático y el mar Negro. En 
el Mediterráneo hay más de 150 puertos que pueden albergar buques de crucero pero la mayoría de ellos son puertos de escala. Además, los puertos base más importantes están localizados en la parte occidental del Mediterráneo y más en concreto en España e Italia.

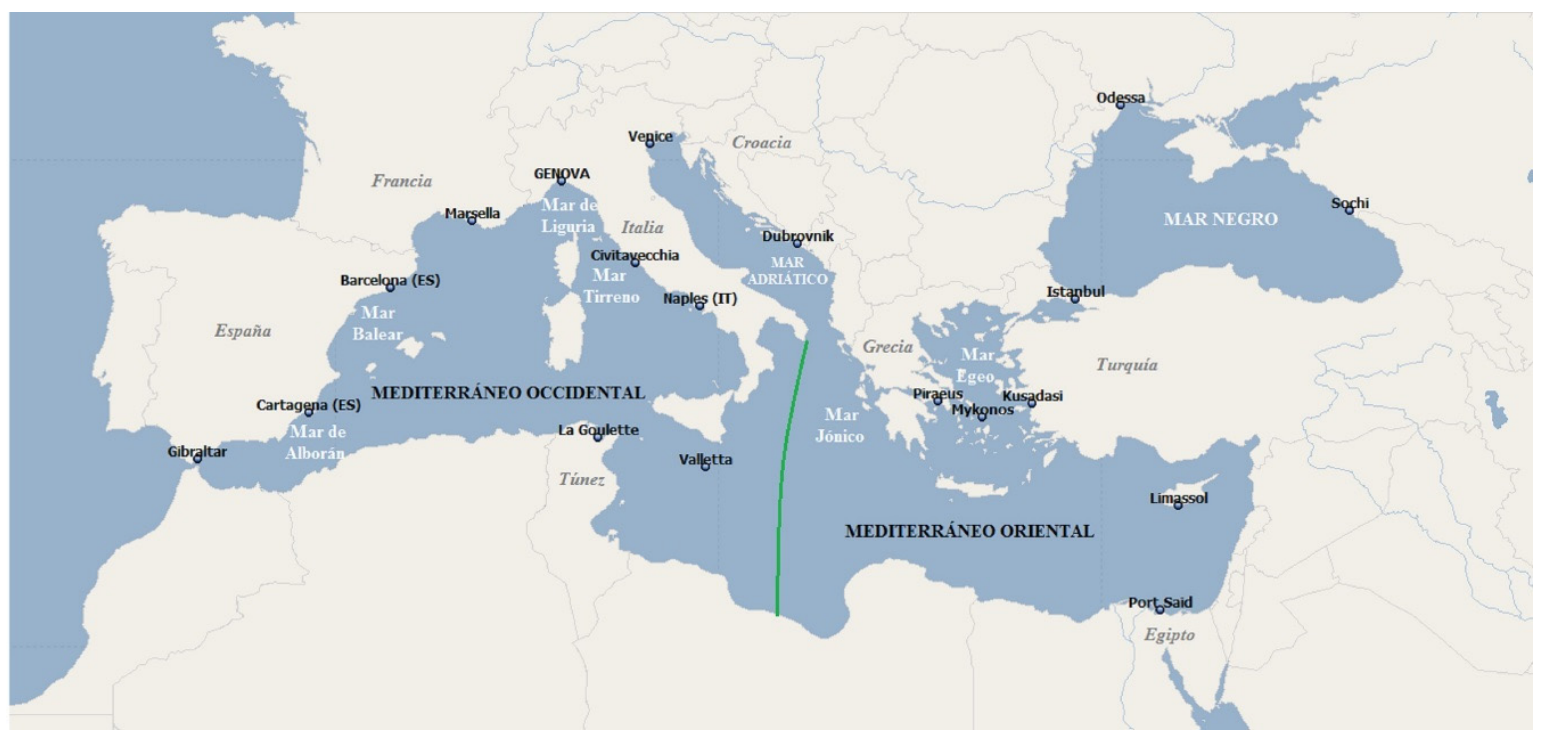

Figura 2.31: Zonas de operación en el Mediterráneo.

Fuente: Elaboración propia.

La temporada alta de cruceros en el Mediterráneo comprende de primavera a otoño, motivado en gran parte por unas condiciones meteorológicas estables. Incluso durante el invierno el clima es muy suave. De hecho, las ventajas de realizar un crucero fuera de la temporada alta son sin duda atractivas, desde la perspectiva de evitar las aglomeraciones a la hora de visitar las atracciones de interés turístico en destino.

En su conjunto esta región engloba a puertos de crucero pertenecientes a 19 países, con una amplia mayoría de puertos de escala respecto a puertos base. El Mediterráneo Occidental es el que mayor actividad crucerística registra. Entre el año 2000 y 2013 registró el 69,57\% del total de pasajeros de crucero del Mediterráneo, véase Gráfico 2.7. Le siguieron el mar Adriático y Mediterráneo Oriental, ambos con cuotas muy similares del 14,99\% y $14,60 \%$, respectivamente. En cuarto lugar se situó el mar Negro con el 0,84\% del total de pasajeros de crucero de la región del Mediterráneo (MedCruise, 2014).

En términos absolutos, entre el año 2000 y 2013 los cuatro sectores han registrado una evolución positiva. El mar Adriático ha registrado el mayor crecimiento de la cifra de pasajeros de crucero, con una tasa media anual del 20,14\%. En segundo lugar se situó el mar Negro con un $13,74 \%$, aunque sus magnitudes de cruceristas fueron muy inferiores respecto a los tres restantes sectores, como se comentó anteriormente. El Mediterráneo Occidental fue el tercer sector en crecimiento con una tasa del 10,57\%. Por último, el Mediterráneo Oriental presentó una evolución irregular frente a los otros sectores tal y como se puede observar en el Gráfico 2.7, en términos netos el crecimiento registrado fue del 6,23\%. 


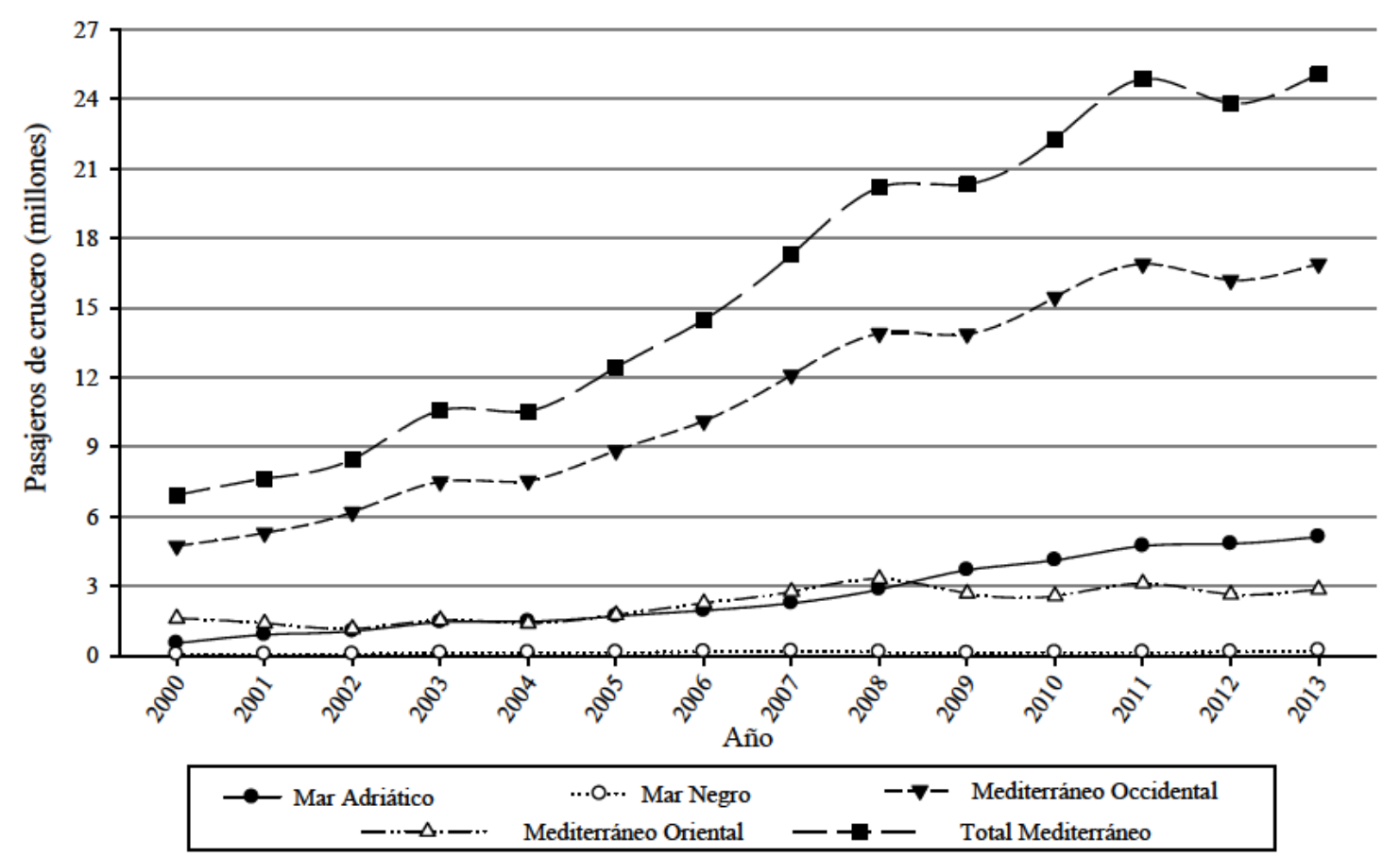

Gráfico 2.7: Evolución de la cifra de pasajeros de crucero en la región del Mediterráneo entre el año 2000 y 2013, cifras segregadas por sectores y total de la región.

Fuente: Elaboración propia basada en datos estadísticos de MedCruise (2011) y MedCruise (2014).

En cuanto a la concentración por países, Italia y España han concentrado entre 2009 y 2013 las mayores cifras de pasajeros de crucero de todo el Mediterráneo, conjuntamente sus puertos han registrado el $61,04 \%$ de los pasajeros de esta zona de operación, véase Gráfico 2.8. Italia ha sido el líder en el Mediterráneo con el $40,08 \%$ de los pasajeros registrados, esta magnitud se debe al enorme atractivo turístico de Italia así como a su extensión litoral con puertos de crucero situados en las costas del Mediterráneo Occidental y el mar Adriático. España ha sido el segundo país en registros de pasajeros de crucero en el Mediterráneo con una cuota del 20,96\%. De forma análoga a Italia, España es una potencia como destino turístico a lo que hay que adicionar su extensa longitud de costa mediterránea con un total de 18 puertos de crucero ubicados en ella. Grecia ha sido el tercer país por pasajeros de crucero en el Mediterráneo y líder en el sector de los países localizados en el Mediterráneo Oriental, constituyendo uno de sus principales atractivos los itinerarios por las islas Griegas. Del total de países mediterráneos que han registrado tráfico de cruceros, cinco han concentrado el $84,11 \%$ del total de pasajeros de crucero, dando lugar, por tanto, a una fuerte concentración geográfica.

Tomando como variable el número de escalas de buques de crucero, se han obtenido resultados análogos a los anteriores pues el Mediterráneo Occidental concentró entre 2009 y 2013 el 56,3\% de las escalas. En segundo lugar se situó el mar Adriático con el 24,22\% seguido del Mediterráneo Oriental y el mar Negro con el 17,23\% y 2,27\%, respectivamente. 


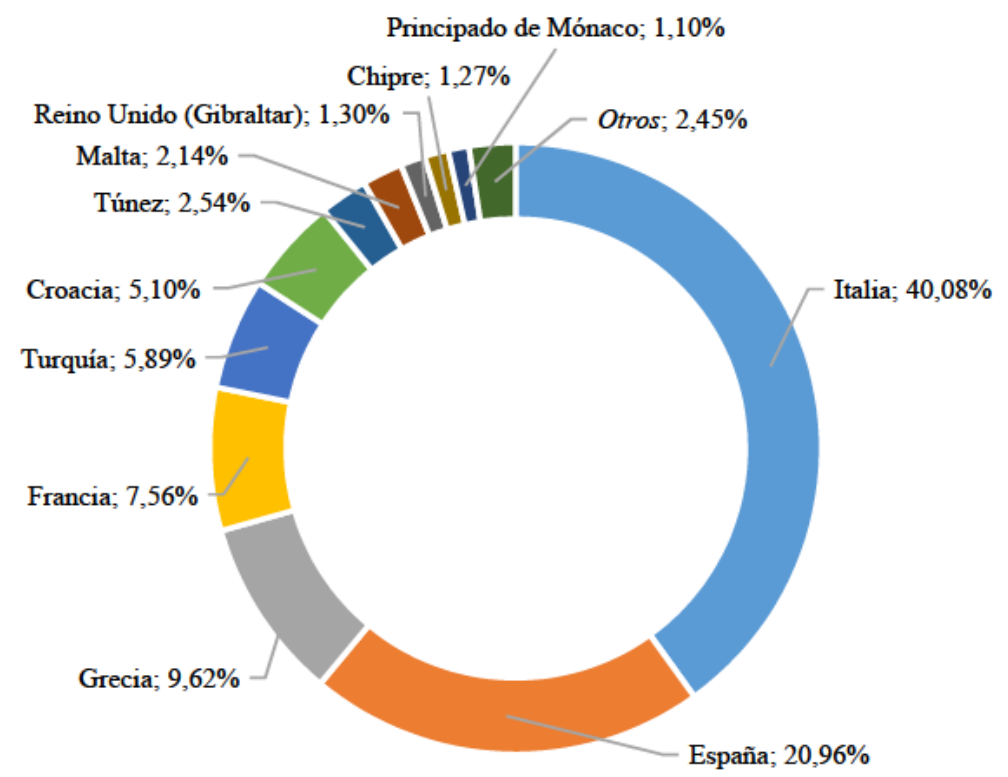

Gráfico 2.8: Concentración de pasajeros de crucero por países en el mar Mediterráneo durante el periodo comprendido entre el año 2009 y 2013.

Fuente: Elaboración propia basada en datos estadísticos de MedCruise (2014).

La concentración geográfica de pasajeros de crucero se hace patente tanto en la categoría de pasajeros de inicio y fin de itinerario como en la de tránsito. Entre el año 2009 y 2013 el Mediterráneo Occidental concentró el 67,92\% de los pasajeros de inicio y fin de itinerario seguido del mar Adriático con el 22,86\%. Extrapolando las cifras anteriores por países, Italia, España, Grecia y Francia han concentrado el 92,5\% de esta categoría de pasajeros. El liderazgo de Italia se asoció, fundamentalmente, a las cuotas del puerto Adriático de Venecia, líder en toda la región mediterránea, y a las de los puertos del Mediterráneo Occidental de Civitavecchia, Génova y Savona, véase Tabla 2.2. Mientras que en el caso de España su cuota estuvo asociada, principalmente, con los puertos de Barcelona y Palma de Mallorca. En cuanto al tercer y cuarto país en embarque y desembarque de pasajeros de inicio y fin de itinerario, sus operativas con esta categoría de pasajeros se asociaron, en su mayoría, al puerto de El Pireo y Marsella, respectivamente.

Tabla 2.2: Cifras de pasajeros de crucero de inicio y fin de itinerario en los diez principales puertos base del Mediterráneo durante el periodo del año 2009 a 2013

\begin{tabular}{lllrrrrr} 
& & & \multicolumn{5}{c}{ Año } \\
\cline { 3 - 8 } Puerto & Sector & País & $\mathbf{2 0 1 3}$ & $\mathbf{2 0 1 2}$ & $\mathbf{2 0 1 1}$ & $\mathbf{2 0 1 0}$ & $\mathbf{2 0 0 9}$ \\
\hline Venecia & Adriático & Italia & 1.512 .596 & 1.444 .100 & 1.448 .622 & 1.312 .895 & 1.170 .298 \\
Barcelona & Occidental & España & 1.506 .286 & 1.438 .383 & 1.499 .534 & 1.265 .613 & 1.180 .239 \\
Civitavecchia & Occidental & Italia & 989.998 & 920.612 & 972.850 & 643.772 & 720.451 \\
Savona & Occidental & Italia & 670.031 & 638.706 & 719.219 & 603.448 & 571.746 \\
Génova & Occidental & Italia & 649.282 & 530.872 & 562.492 & 571.582 & 436.385 \\
$\begin{array}{l}\text { Palma de } \\
\text { Mallorca }\end{array}$ & Occidental & España & 490.631 & 466.385 & 587.048 & 571.209 & 447.853
\end{tabular}




\begin{tabular}{lllrrrrr} 
& & & \multicolumn{5}{c}{ Año } \\
\cline { 3 - 8 } Puerto & Sector & País & $\mathbf{2 0 1 3}$ & $\mathbf{2 0 1 2}$ & $\mathbf{2 0 1 1}$ & $\mathbf{2 0 1 0}$ & $\mathbf{2 0 0 9}$ \\
\hline Marsella & Occidental & Francia & 381.318 & 313.322 & 264.703 & 268.451 & 175.000 \\
El Pireo & Oriental & Grecia & 308.705 & 329.168 & 454.284 & 426.147 & 415.260 \\
Kusadasi/ & & & & & & & \\
Bodrum/ & Oriental & Turquía & 190.087 & 167.424 & 143.913 & 114.657 & 157 \\
Antalya & & & & & & & \\
Bari & Adriático & Italia & 165.031 & 196.423 & 166.690 & 203.145 & 228.259 \\
& - & - & $\mathbf{7 . 7 7 4 . 1 6 6}$ & $\mathbf{8 . 7 6 8 . 9 4 4}$ & $\mathbf{7 . 9 1 2 . 1 8 0}$ & $\mathbf{6 . 9 7 0 . 9 8 1}$ & $\mathbf{6 . 2 7 1 . 3 5 2}$ \\
\hline
\end{tabular}

Fuente: Elaboración propia basada en datos estadísticos de MedCruise (2014).

El Mediterráneo Occidental engloba aproximadamente 53 puertos de crucero pertenecientes a España (vertiente mediterránea, islas Baleares y ciudades autónomas de Ceuta y Melilla, situadas en el Norte de África), Gibraltar, Francia (incluyendo la isla de Córcega), Principado de Mónaco, Italia (costa del mar Tirreno y de Liguria e islas de Sicilia y Cerdeña), Malta y Túnez. El Gráfico 2.9 muestra los diez principales puertos en el sector del Mediterráneo Occidental durante el año 2013 por cifra de pasajeros de crucero registradas. Además, las cifras también están segregadas en pasajeros de inicio y fin de itinerario. Barcelona y Civitavecchia son los líderes en este sector tanto por sus cifras de puerto base como de puerto de escala, en ambos casos la diferencia respecto al tercer puerto supera el millón de pasajeros.

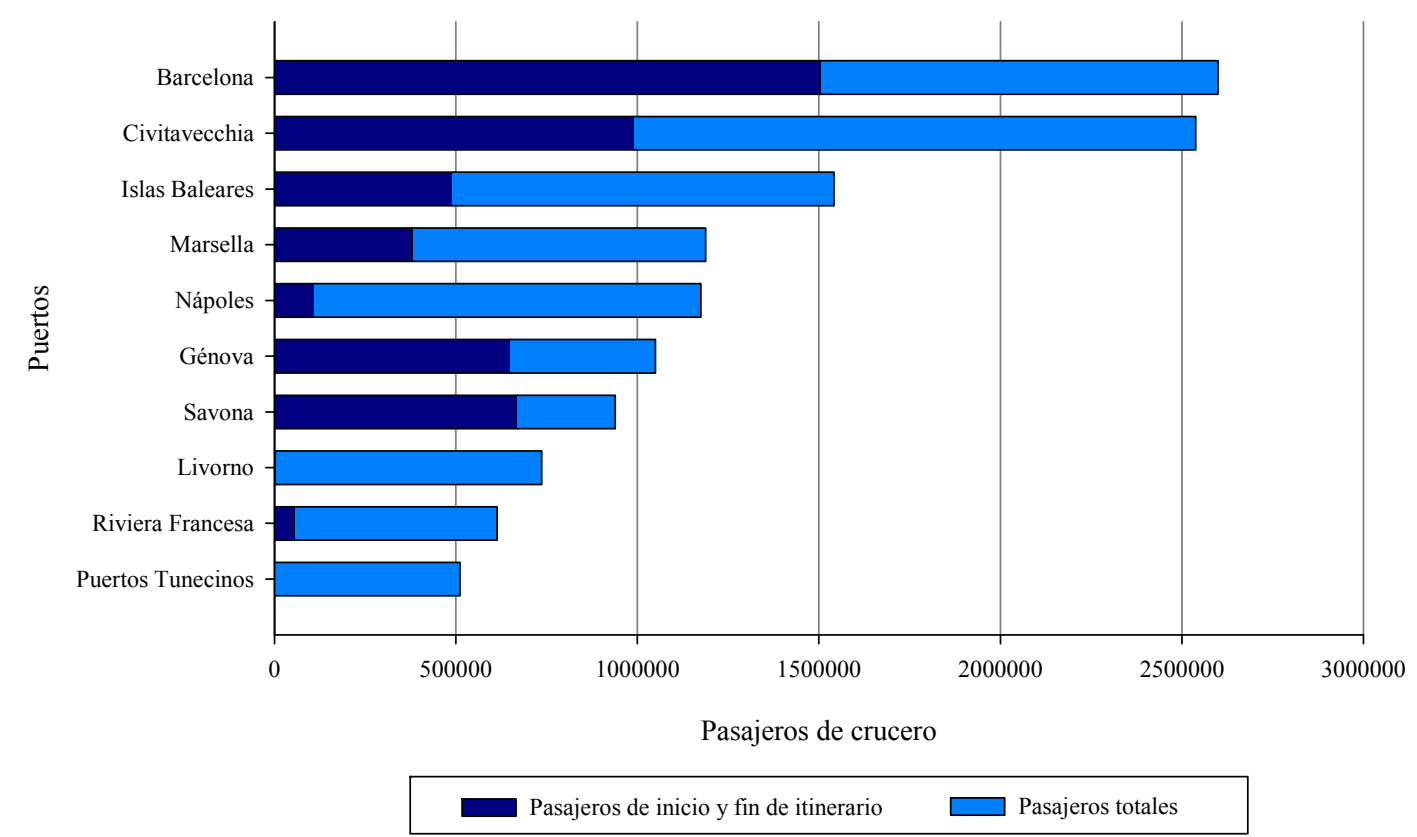

Gráfico 2.9: Cifras de pasajeros de crucero de los diez principales puertos del Mediterráneo Occidental durante el año 2013, pasajeros totales y segregados en inicio y fin de itinerario.

Fuente: Elaboración propia basada en datos estadísticos de MedCruise (2014).

En el Mediterráneo Oriental el número de puertos que cuentan en sus muelles con actividad crucerística se sitúa en torno a 38. Los países asociados a estos puertos son Chipre, 
Egipto, Grecia, Israel, Siria y Turquía (vertiente mediterránea). El Gráfico 2.10 representa la cifra de pasajeros de crucero en los 10 principales puertos de este sector durante el periodo 2009-2013. En este sentido, las estadísticas de tráfico de cruceros para algunos puertos de este sector no están disponibles, a pesar de que registren elevados órdenes de magnitud, de ahí que el Gráfico 2.10 no esté completo para el caso de determinados puertos. Por la posición geográfica del puerto de Estambul en el estrecho de Bósforo, a las puertas del mar Negro y el mar de Mármara, se ha incluido en el análisis del sector del Mediterráneo Oriental por su influencia en los itinerarios que discurren por este sector del Mediterráneo.

Grecia y Turquía concentran la mayor actividad crucerística en este sector. El atractivo de Grecia está asociado, entre otros, a su amplía y singular costa dotada de numerosas islas. Los itinerarios con mayor popularidad recorren el mar Egeo y Jónico, haciendo escala en la variada oferta de islas de la zona. En este sentido, es habitual que por el reducido tamaño de algunos puertos isleños no sea posible el atraque del buque y el desembarco de los pasajeros se realice por medio de botes con el buque fondeado, como sucede en el caso de Santorini (Grecia).

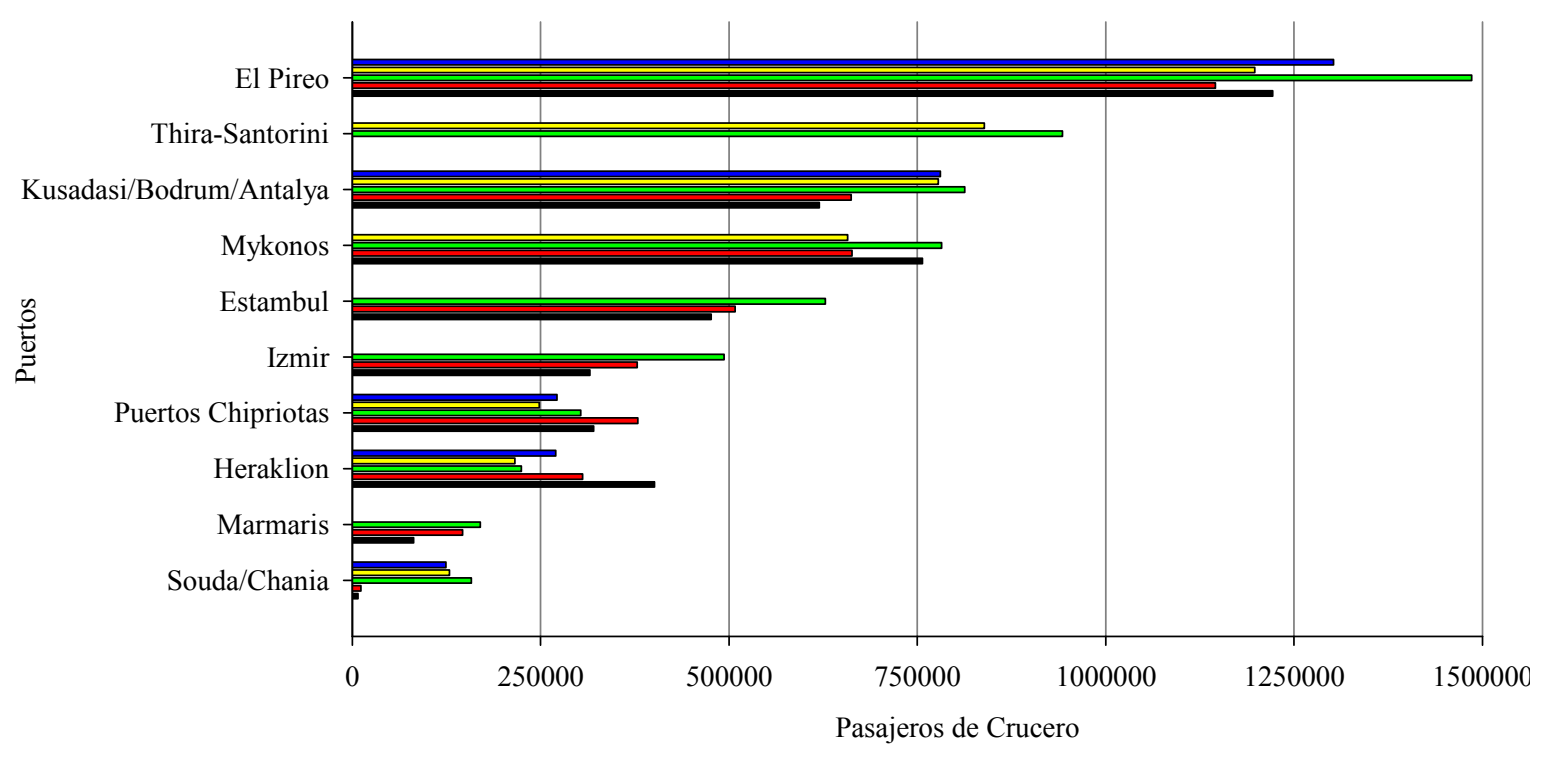

\begin{tabular}{|lllll|}
\hline$\square 2009$ & $\square 2010 \quad \square 2011 \quad \square 2012 \quad \square 2013$ \\
\hline
\end{tabular}

Gráfico 2.10: Cifras de pasajeros de crucero de los diez principales puertos del Mediterráneo Oriental durante el periodo 2009-2013.

Fuente: Elaboración propia basada en datos estadísticos de MedCruise (2014) y Greek Cruise Cluster (2014).

El Pireo es el principal puerto de este sector tanto por su carácter de puerto base como por el tráfico de cruceristas en tránsito. A diferencia de la parte occidental, el número de puertos base en esta zona del Mediterráneo es muy reducido. Las magnitudes de los restantes puertos están asociadas fundamentalmente con pasajeros en tránsito. Este es el caso de los puertos de Thira/Santorini y Mykonos en Grecia, y Estambul, Kusadasi e Izmir en Turquía. Es de notar el importante auge que durante los últimos años están adquiriendo los puertos turcos del Mediterráneo en lo que concierne al tráfico de cruceros, tanto como puertos de escala como puertos base. 
En el mar Adriático existen un total de 15 puertos con actividad crucerística en sus muelles, repartidos entre Italia, Croacia, Montenegro y Eslovenia. Los dos países predominantes en esta zona son Italia y Croacia con una cuota de pasajeros de crucero durante el periodo 2009-2013 de 54,3\% y 26,8\%, respectivamente. Dicha hegemonía se debe a la extensa longitud de costa de ambos países bañada por las aguas del mar Adriático, véase Figura 2.32.

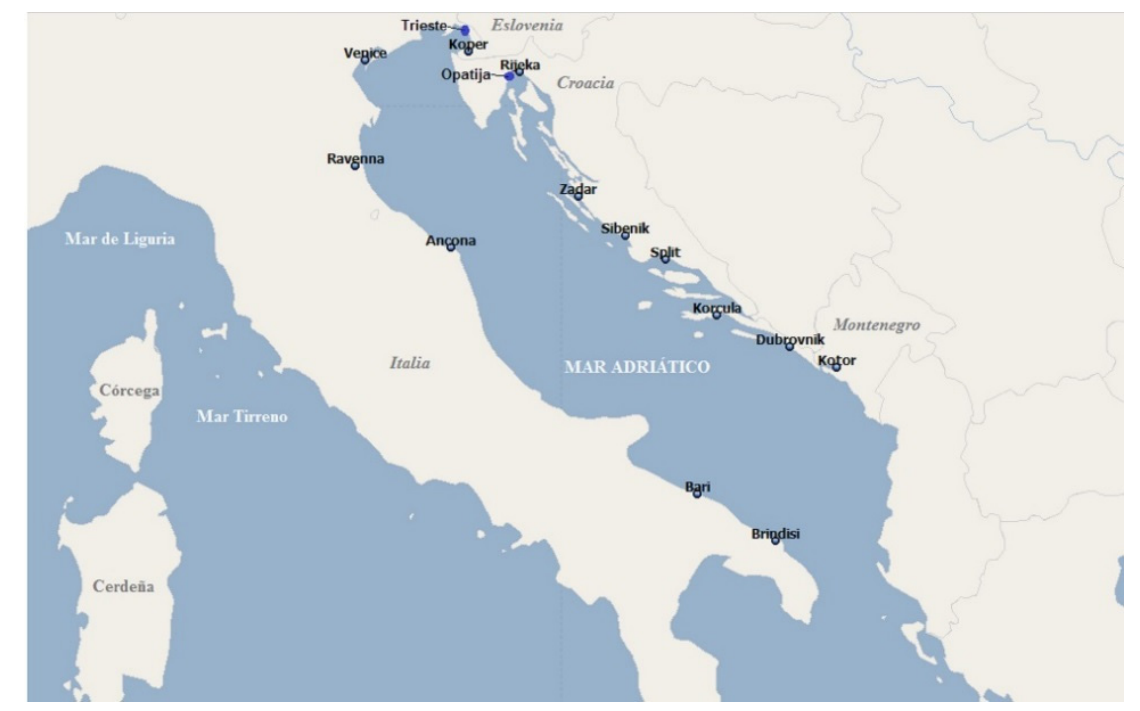

Figura 2.32: Puertos de crucero en el mar Adriático.

Fuente: Elaboración propia.

El Gráfico 2.11 representa los diez principales puertos en este sector durante el año 2013 por orden de magnitud de la cifra de cruceristas registrada. Venecia es el principal puerto base para los cruceros por el Adriático, también cumple esta función en cruceros que se dirigen al Mediterráneo Oriental, sus cifras, fundamentalmente, están asociadas con pasajeros de inicio y fin de itinerario. Mientras que en el caso de Dubrovnik, segundo puerto del sector, su función primordial es la de puerto de escala. Como puede observarse en el Gráfico 2.11, en este sector existen diferencias significativas entre los diversos puertos que lo componen, actuando la mayoría de ellos como puertos de escala. 


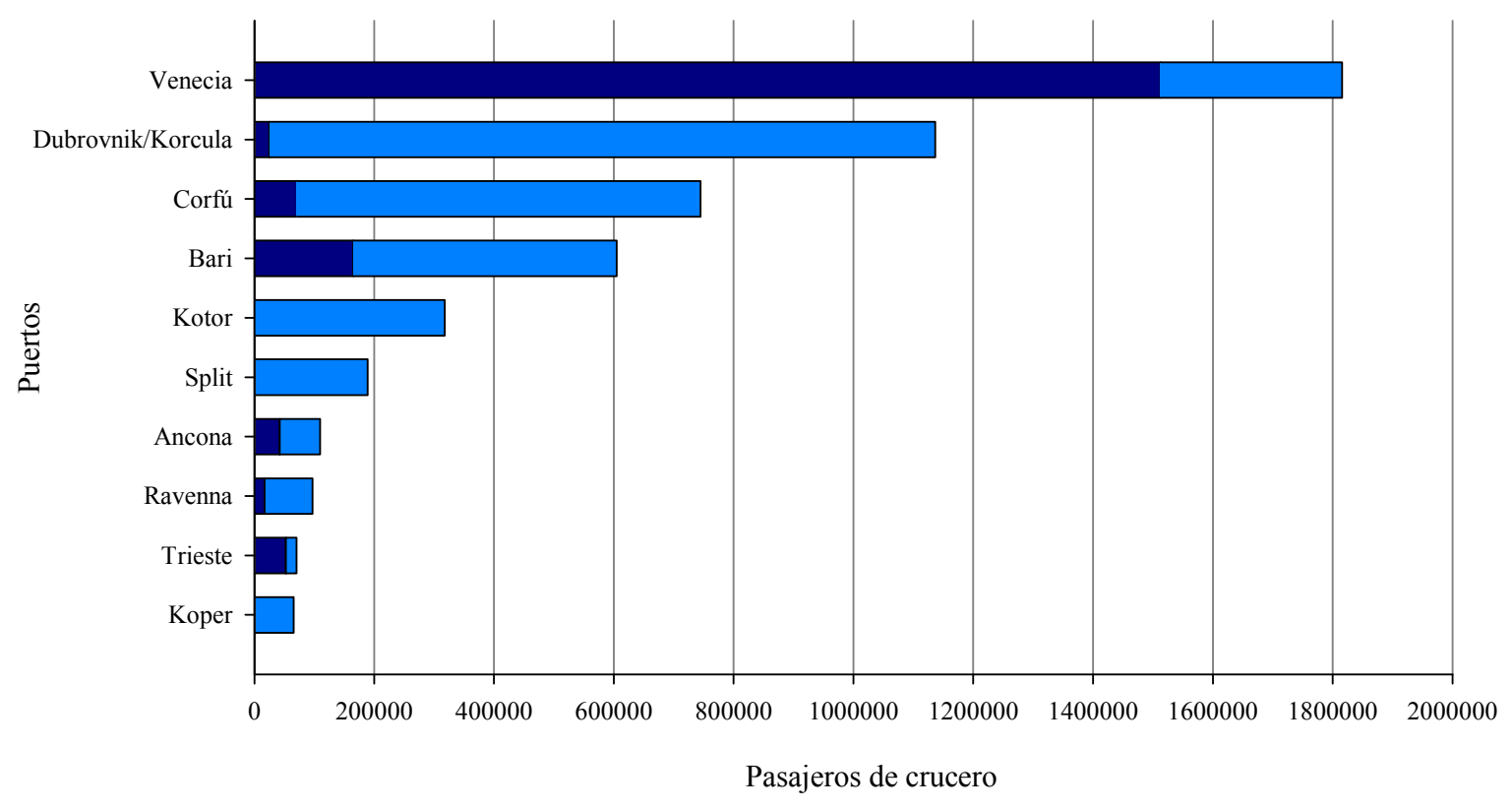

Pasajeros de inicio y fin de itinerario

Pasajeros totales

Gráfico 2.11: Cifras de pasajeros de crucero de los diez principales puertos del mar Adriático durante el año 2013, pasajeros totales y segregados en inicio y fin de itinerario.

Fuente: Elaboración propia basada en datos estadísticos de MedCruise (2014).

Aunque puede tratarse de forma totalmente independiente al mar Mediterráneo en sí, el mar Negro también se integra en este apartado de cruceros por el Mediterráneo, ya que su acceso se produce a través de este mar. Además, gran parte de los itinerarios comparten puertos del mar Egeo y el mar Negro. Este mar cuenta con 13 puertos que registran tráfico de cruceros, pertenecientes a Rusia, Ucrania, Rumanía, Georgia, Turquía y Bulgaria, véase Figura 2.33.

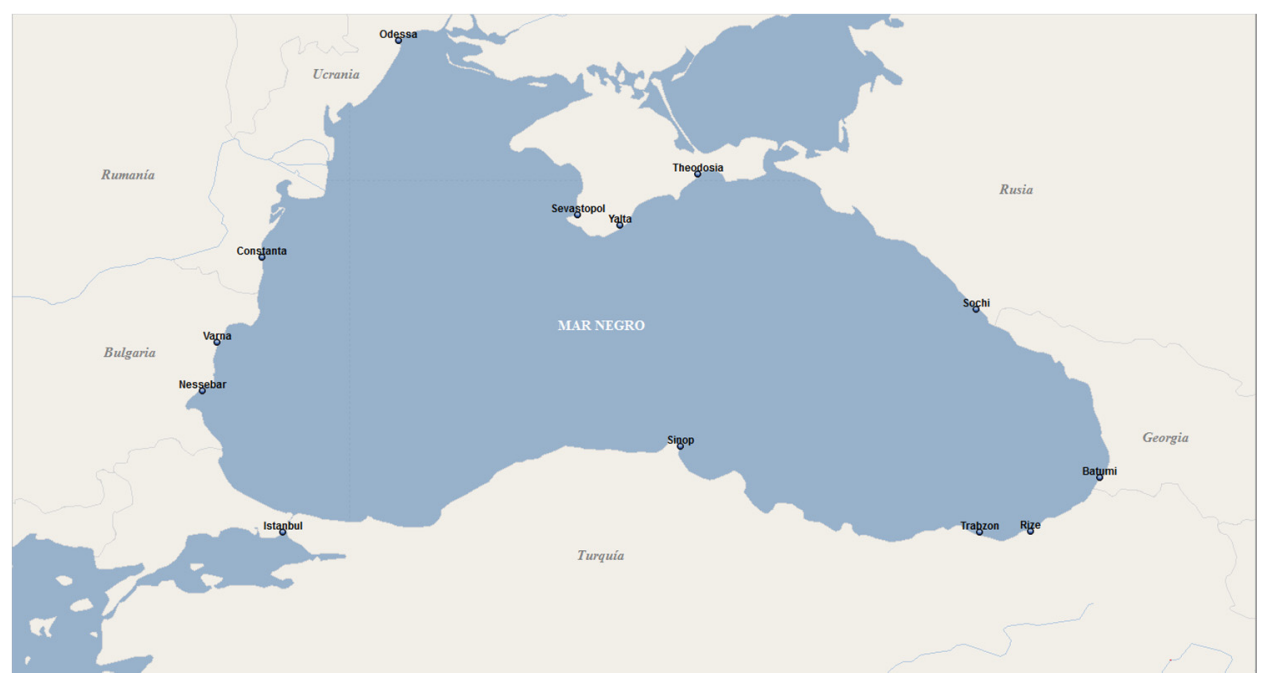

Figura 2.33: Puertos de crucero en el mar Negro.

Fuente: Elaboración propia.

El volumen de cruceristas registrado por los puertos de aguas ribereñas del mar Negro es muy inferior a los tres sectores analizados anteriormente. El Gráfico 2.12 muestra la cifra 
de pasajeros de crucero totales en los cinco principales puertos de este mar entre 2009 y 2013. Los puertos de Odessa (Ucrania) seguido de Constantza (Rumanía) han registrado el mayor tráfico durante este periodo. Por parte de los países ribereños del mar Negro se ha puesto en marcha una iniciativa para potenciar el tráfico de cruceros en este mar, a partir de la constitución del organismo Cruise Black Sea, el cual aglutina a los puertos de crucero del mar Negro. Durante los próximos años habrá que prestar especial atención a la evolución de esta zona asociada al crecimiento del turismo de origen ruso.

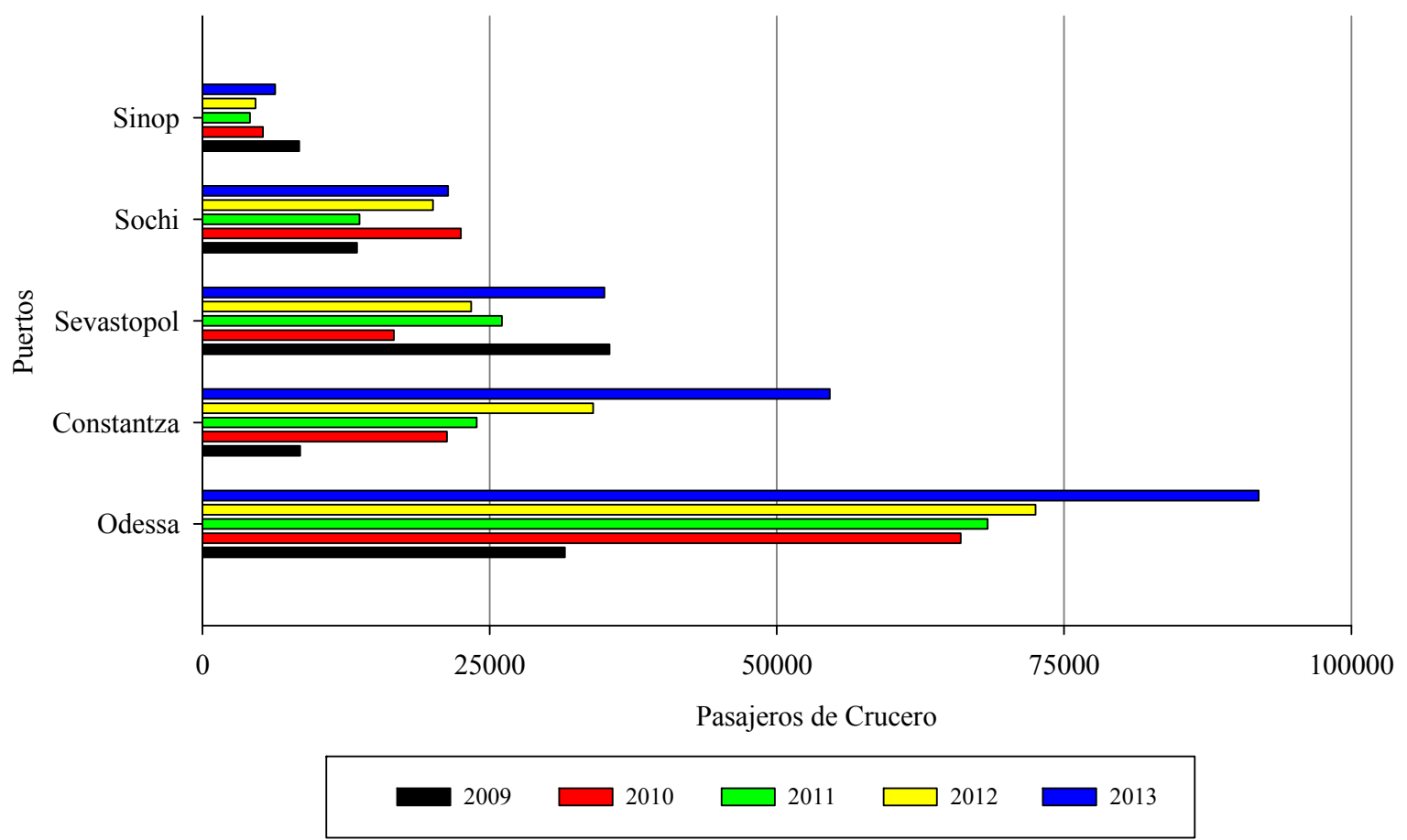

Gráfico 2.12: Cifras de pasajeros de crucero de los cinco principales puertos del mar Negro durante el periodo 2009-2013.

Fuente: Elaboración propia basada en datos estadísticos de MedCruise (2014).

\subsubsection{Destinos emergentes}

Los destinos emergentes están orientados para repetidores en el turismo de cruceros. Cada vez tienen más peso en la temporada de invierno, actuando como competidor de las islas Canarias y Azores en el Atlántico. Fundamentalmente, estos destinos se centran en Emiratos Árabes Unidos, Omán y el mar Rojo. Siendo el principal puerto base Dubai (EAU), véase Figura 2.34. El Golfo Arábigo está principalmente relacionado con cruceros de lujo y súper lujo, debido fundamentalmente a que su atractivo turístico combina dos productos que son cultura y actividades deportivas de alto nivel. En el océano Índico, Isla Mauricio es el principal destino emergente. En el Mar Rojo, el primer puerto es Aqaba (Jordania), que la mayoría de los cruceristas utilizan para visitar la ciudad de Petra. Además, los itinerarios de crucero de vuelta al mundo suelen incluir escalas en puertos de destinos emergentes. 


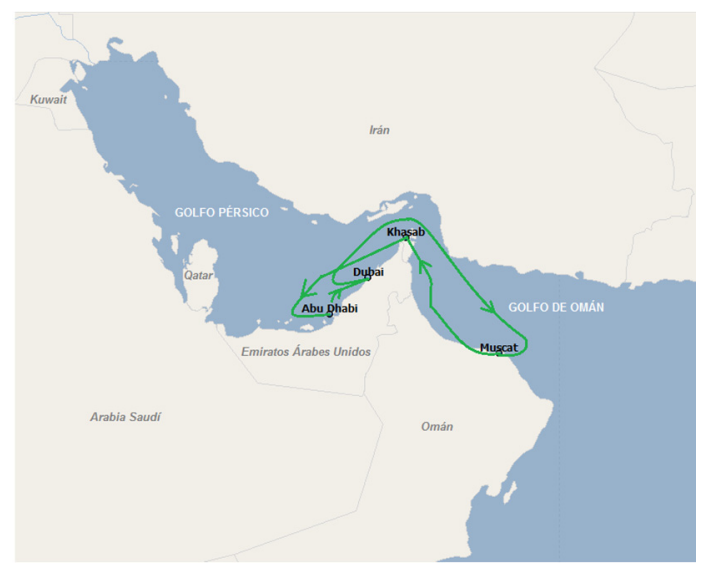

Figura 2.34: Itinerario de crucero por Emiratos Árabes Unidos y Omán. Fuente: Elaboración propia.

\subsection{Tipos de itinerarios de crucero}

Fundamentalmente existen dos conceptos con los cuales se asocian diferentes tipologías de itinerarios de crucero. Éstos son, la época del año durante la cual se ofertan itinerarios en una región de destino en concreto, y por otro, la configuración de puertos que constituyen un itinerario. Atendiendo al primer concepto, es posible encontrar la siguiente tipología de itinerarios de crucero.

Anuales, la región cubierta por el itinerario se oferta durante todo el año ya que se mantiene una fuerte demanda, lo cual se asocia con condiciones meteorológicas estables (clima subtropical) e itinerarios fijos y conocidos. Puede haber variaciones estacionales significativas en el número de buques desplegados, pero el destino sigue siendo atendido/ofertado durante todo el año. El Caribe es la región de destino anual más importante, con temporada baja en verano, el Mediterráneo también es atendido durante todo el año con temporada baja en invierno.

De temporada, las condiciones climatológicas es el factor dominante que explica la estacionalidad, lo que implica que algunas regiones tienen un potencial de mercado sólo durante un periodo o época del año específica. Éste es particularmente el caso de los cruceros por el Báltico, Noruega, Alaska y Nueva Inglaterra, los cuales únicamente se ofertan durante los meses de verano. Inversamente, los itinerarios por Sudamérica y Australia son atendidos durante los meses de invierno (del hemisferio norte).

Asociado a la estacionalidad de los itinerarios en determinadas regiones de destino, así como, a las variaciones de demanda en las regiones anuales, surge un tercer tipo de itinerario, son los denominados cruceros o itinerarios de Reposicionamiento. Con objeto de mantener altos índices de ocupación, así como, extender la operatividad de los buques de crucero al mayor número de días por año (exceptuando aquellos reservados para llevar a cabo las tareas de mantenimiento) los buques realizan rotaciones entre regiones de crucero. Las compañías de cruceros también ofertan estas navegaciones de cambio de zona de 
operación como viaje de crucero. Esta tipología de crucero presenta el inconveniente para el cliente de tener que realizar el viaje de ida o vuelta en avión, dado que los puertos de inicio y finalización del crucero no son los mismos.

El principal eje de rotación entre rutas de crucero es el Océano Atlántico, en la rotación de los buques de la temporada alta en el Caribe en invierno a la temporada alta en el Mediterráneo en verano (y viceversa), véase Figura 2.35. Además, durante los últimos años se está observando un creciente número de cruceros de reposicionamiento en el Atlántico cuyo eje de rotación es Mediterráneo-Sudamérica-Mediterráneo, debido a la saturación del Caribe en invierno (en el hemisferio norte). El principio y el final de la temporada en Alaska también se combinan con cruceros por Hawái, en el reposicionamiento de los buques en el eje Asia-Alaska. Además, está surgiendo un nuevo eje de rotación entre rutas de crucero entre el Mediterráneo y el mar Arábigo, cuyos principales puertos base son Barcelona y Dubái. Junto a las operativas anteriores también se registran rotaciones entre destinos europeos durante la temporada alta del Mediterráneo y el Norte de Europa. En concreto, parte de los buques que se posicionan en el Mediterráneo, procedentes del Caribe con el inicio de la temporada alta hacia mediados de marzo o principios de abril, no permanecen en él durante todo el periodo de temporada alta, sino que realizan una segunda rotación hacia el Norte de Europa, con el inicio de la temporada alta a mediados de mayo en este último destino. Tras finalizar la temporada alta en el Norte de Europa, a mediados de septiembre, estos buques regresan al Mediterráneo. En este destino permanecen hasta el final de la temporada alta, aproximadamente a mediados de noviembre, para reposicionarse de nuevo al Caribe durante el invierno del hemisferio norte.

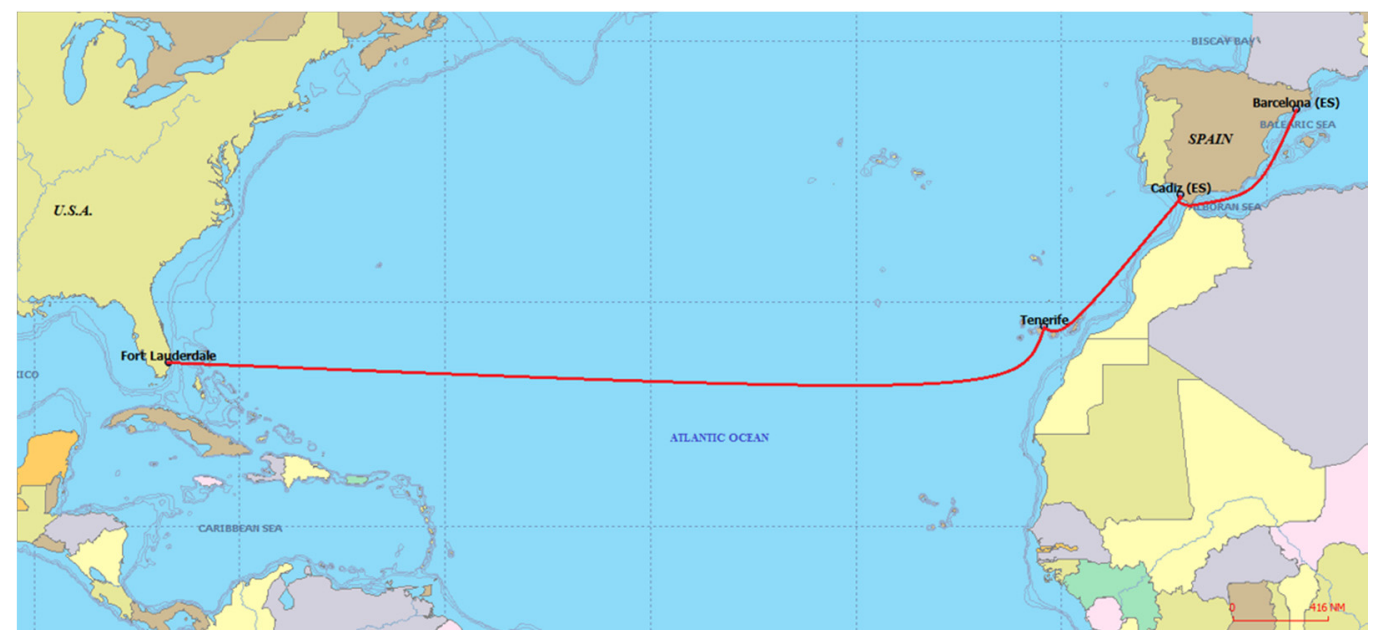

Figura 2.35: Itinerario de crucero de reposicionamiento Mediterráneo-Caribe.

Fuente: Elaboración propia.

Un tipo particular de itinerario son los denominados cruceros de vuelta al mundo. El itinerario comprende escalas en puertos de los cinco continentes y a menudo en destinos y puertos exóticos que los itinerarios de una región en concreto no suelen cubrir. La duración de estos itinerarios suele rondar los 90-100 días. 
Cualquier tipo de itinerario se caracteriza por estar compuesto de dos tipos de puertos atendiendo a las operativas que se realizan en ellos. De un lado el o los puerto/s base (homeport o turn around en terminología inglesa). En este tipo de puerto se establece el inicio y fin del crucero, por lo que deben cumplir con una serie de requisitos impuestos por un lado, por las necesidades de los cruceristas y, por otro lado, por las del propio buque.

Por otro lado, los puertos de escala (port of call en terminología inglesa), en los cuales el buque permanece un número limitado de horas para que los cruceristas puedan visitar la propia ciudad portuaria o lugares de interés turísticos a los cuales se ofertan excursiones desde ese puerto en concreto. En ocasiones, en algunos puertos de escala, que reúnan las características necesarias, se pueden realizar operaciones de embarque y desembarque parciales de pasajeros de inicio y fin de itinerario pero asociados a un pequeño porcentaje de pasajeros. Este tipo de operaciones reciben la denominación de interporting.

En lo que respecta a la configuración de puertos que constituyen un itinerario, principalmente, es posible identificar dos tipos de itinerarios. Itinerarios cerrados, en los que existe un sólo puerto base en el que inicia y finaliza el crucero, en este caso el itinerario es un bucle cerrado, véase Figura 2.36.

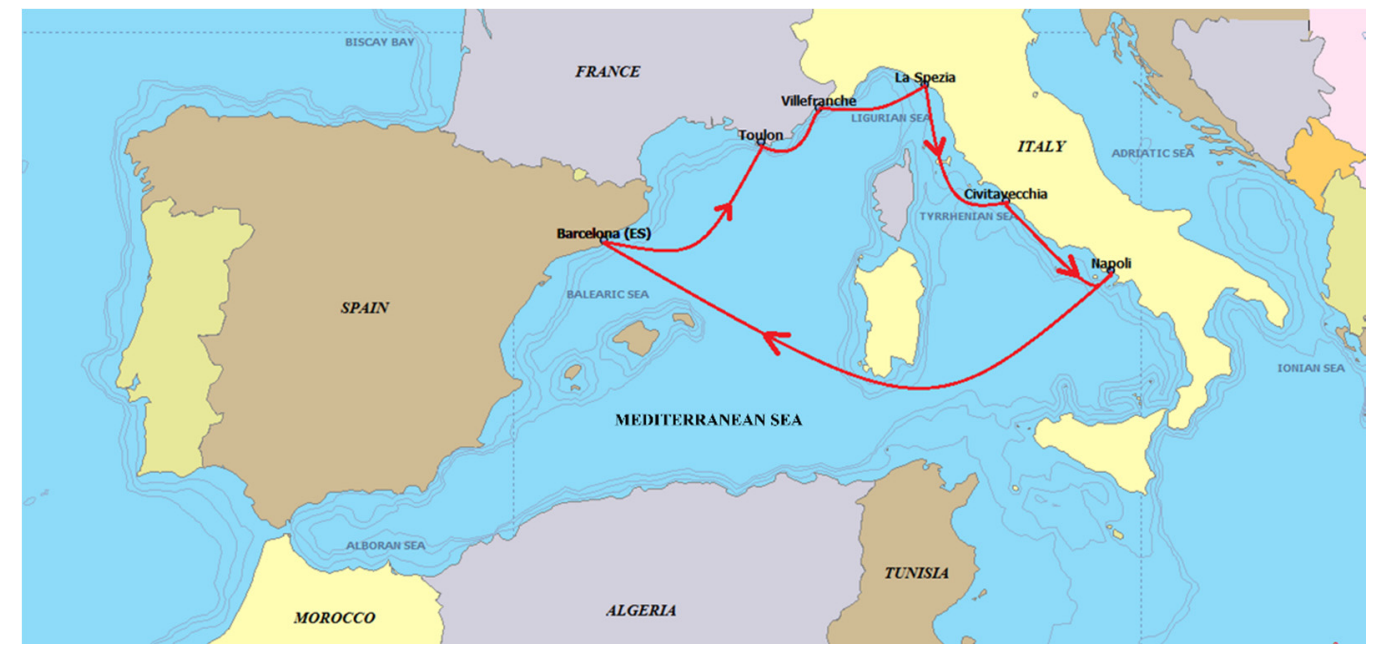

Figura 2.36: Itinerario de crucero "cerrado" por el mar Mediterráneo.

Fuente: Elaboración propia.

Así como, itinerarios abiertos, aquellos que cuentan con dos puertos base, ya que el inicio y fin del crucero se realiza en puertos distintos. En este último caso suele ser habitual que el bucle cerrado al cual se hace alusión en los itinerarios cerrados se desarrolle en dos etapas, ya que, el puerto base en el cual finaliza un crucero, constituye el inicio del siguiente, finalizando este último en el puerto base de embarque del primero, véase Figura 2.37. 


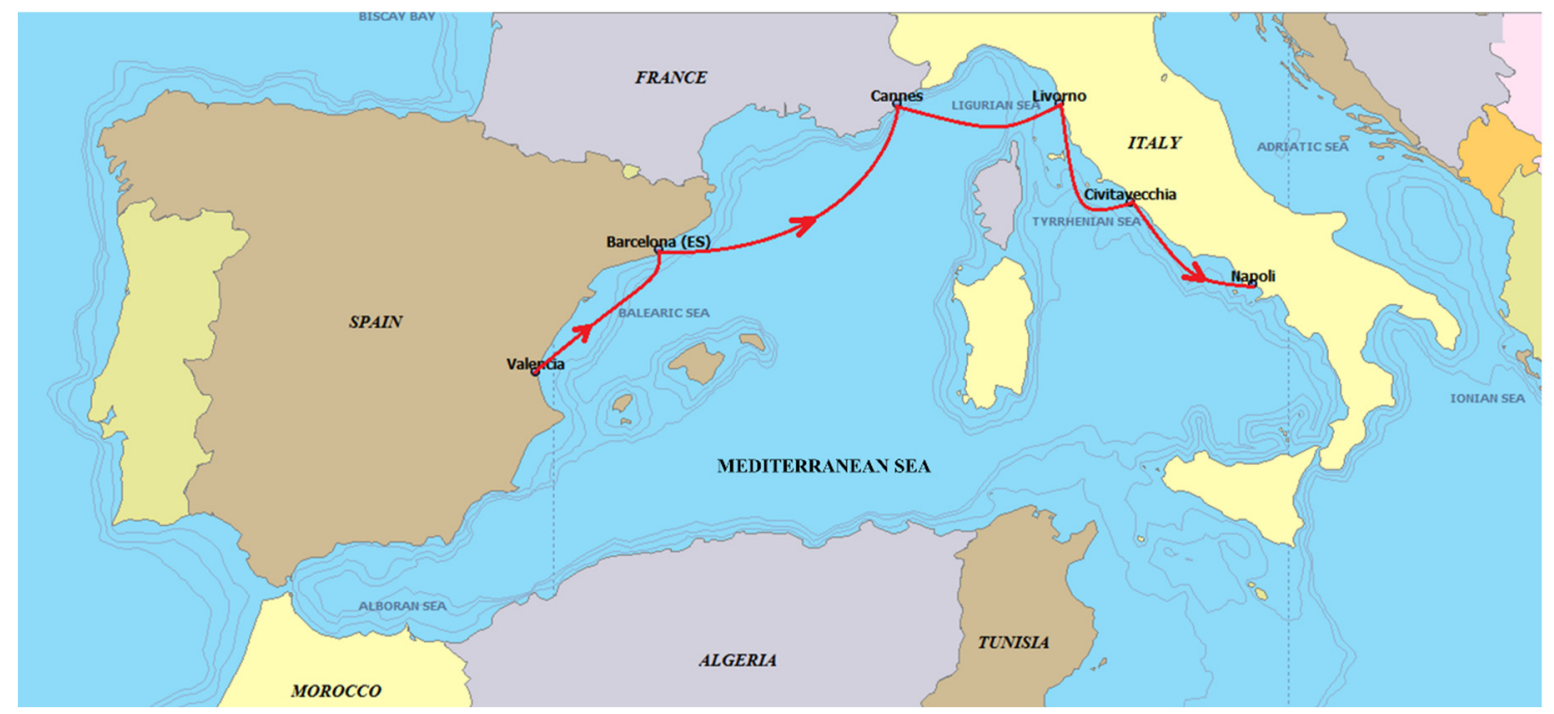

Figura 2.37: Itinerario de crucero "abierto" por el mar Mediterráneo.

Fuente: Elaboración propia.

Como regla general, los principales determinantes de la duración del itinerario son: el número y el orden de los puertos de escala, la distancia total de navegación en ambos sentidos y la velocidad del buque. Cuando se producen retrasos, a lo largo de la ruta y en puerto, que comprometen el cumplimiento de horarios, los operadores de buques de crucero habitualmente deciden recuperar el tiempo perdido incrementando la velocidad de navegación. Actualmente, se observa un cambio en la operativa de los cruceros, de tal forma que incrementan los periodos de estancia en la mar, reduciendo el número de puertos de escala. Esta nueva tendencia está motivada por los altos precios del combustible, de tal forma que incrementan la estancia en la mar a cambio de reducir la velocidad de navegación y, por extensión, se sitúan en consumos de combustible más moderados. El cumplimiento del horario es de suma importancia para los pasajeros de crucero, sobre todo cuando existe una estrecha sincronización entre su llegada al puerto base y la salida de sus vuelos internacionales.

La duración media del crucero está íntimamente ligada a la disponibilidad de tiempo libre de los consumidores y a la tendencia a fraccionar las vacaciones, variando de 6 a 9 días en EE.UU. y Europa, mientras que en Japón es de 3 a 6 días (OMT, 2008). Además, también se tiene que combinar con una serie de requisitos operacionales por parte de la naviera. Por lo tanto, las estrategias de despliegue de buques y el diseño del itinerario se ven afectados por las circunstancias del mercado y por requisitos, tales como, la estacionalidad de la demanda, la óptima duración de unas vacaciones en crucero, el equilibrio entre el tiempo de navegación y el tiempo en puerto, la existencia de destinos populares "must see ports" y la satisfacción global de los cruceristas. Al mismo tiempo, hay que tener en cuenta puras consideraciones operativas, como por ejemplo, la disponibilidad de atraque y accesibilidad a los puertos, la distancia entre los puertos de escala y la sincronización con vuelos internacionales (Rodrigue y Notteboom, 2013). 
La tipología de itinerarios, atendiendo a su duración, normalmente responde a la siguiente clasificación: 2-5 días, 6-8 días, 9-17 días y superior a 18 días (CLIA, 2011). El itinerario por excelencia, tanto en EE.UU. como en Europa, tiene una duración de 7 días (OMT, 2008). En itinerarios con esta duración la operativa habitual consiste en finalizar el crucero el sábado por la mañana, comenzando uno nuevo ese mismo día por la tarde. A modo de ejemplo, en el mercado emisor norteamericano prevalecen los cruceros de duración de 68 días y 2-5 días, véase Tabla 2.3. Éstos últimos normalmente tienen como destino las islas Bahamas. En este sentido, también se observa un incremento de los cruceros de duración 917 días, debido al creciente interés de norteamericanos por visitar Europa, y en consecuencia el incremento de tiempo asociado al trayecto aéreo.

Tabla 2.3: Cuotas de duración de cruceros en los años 1990 y 2010 en el mercado emisor norteamericano

\begin{tabular}{cccccc}
\multicolumn{5}{c}{ Duración (días) } \\
\hline Año & $\mathbf{2 - 5}$ & $\mathbf{6 - 8}$ & $\mathbf{9 - 1 7}$ & $\mathbf{1 8}+$ & Total \\
\hline 1990 & $38,00 \%$ & $52,10 \%$ & $9,50 \%$ & $0,40 \%$ & $100 \%$ \\
2010 & $27,20 \%$ & $53,20 \%$ & $18,00 \%$ & $1,60 \%$ & $100 \%$ \\
\hline
\end{tabular}

Fuente: Elaboración propia adaptada de CLIA (2011).

Finalmente, también cabe mencionar que desde el punto de vista del país de origen de los cruceristas, y el puerto desde el cual comienzan el crucero, se puede distinguir una tipología adicional de itinerario, los denominados fly \& cruise. En este tipo de itinerarios los cruceristas realizan un trayecto en avión para situarse en el puerto base de inicio del crucero. Generalmente esta circunstancia se da cuando el embarque se realiza en un puerto de un país distinto al de origen de los cruceristas.

\subsection{Tipología de buques de crucero}

Un buque de crucero se define como un buque de pasaje destinado a realizar viajes de placer o de recreo. La principal clasificación asociada a los buques de crucero de navegación oceánica alude a su tamaño, clasificándose en pequeños, medianos, grandes, y mega-buques de crucero. Las características de cada uno de éstos se describen a continuación.

Buque de crucero pequeño, tienen una capacidad de 50 a 200 pasajeros, ofrecen un servicio de muy alta calidad y atención personalizada, como por ejemplo, el servicio de cocina funciona por encargo, véase Figura 2.38. Por lo general, están destinados a clientes de alto poder adquisitivo. En este sentido, incluso existen navieras que ofertan los camarotes de sus barcos para adquirirlos en propiedad.

Buque de crucero mediano, su capacidad se sitúa en torno a 500-1.200 pasajeros y su principal ventaja reside en las escasas restricciones de acceso a los muelles de atraque por su tamaño, véase Figura 2.38. 
Buque de crucero grande, con capacidad para 850-3.000 pasajeros, actualmente es el tipo más popular y común de buque de crucero, véase Figura 2.38. Disponen a bordo de multitud de instalaciones y actividades recreativas similares a las de un resort turístico en tierra. Como por ejemplo, restaurantes, discotecas, centros comerciales, teatros, galerías, museos, bibliotecas, casinos, gimnasios, spas, piscinas e instalaciones deportivas.

Mega-buque de crucero, tiene capacidad para más de 3.000 pasajeros, véase Figura 2.38. Se trata de una nueva clase de buques de crucero que surge asociada a la existencia de economías de escala, de tal forma que incrementando el tamaño de los buques es posible aumentar el número de pasajeros, con unos costes de explotación que crecen en menor medida. Además, este concepto ha permitido hacer accesible el producto crucero a una mayor parte de la población, al reducirse los precios de los pasajes, frente a la visión tradicional de un producto elitista reservado para las clases sociales más altas. Los buques pertenecientes a esta clase son los más grandes y sofisticados del mundo desde el punto de vista de la magnitud de las instalaciones para abastecer las necesidades del buque y el pasaje. Actualmente existen buques en operación con capacidad para más de 5.000 pasajeros. En cuanto a las instalaciones de que disponen a bordo son similares a las definidas para el caso de los buques grandes.

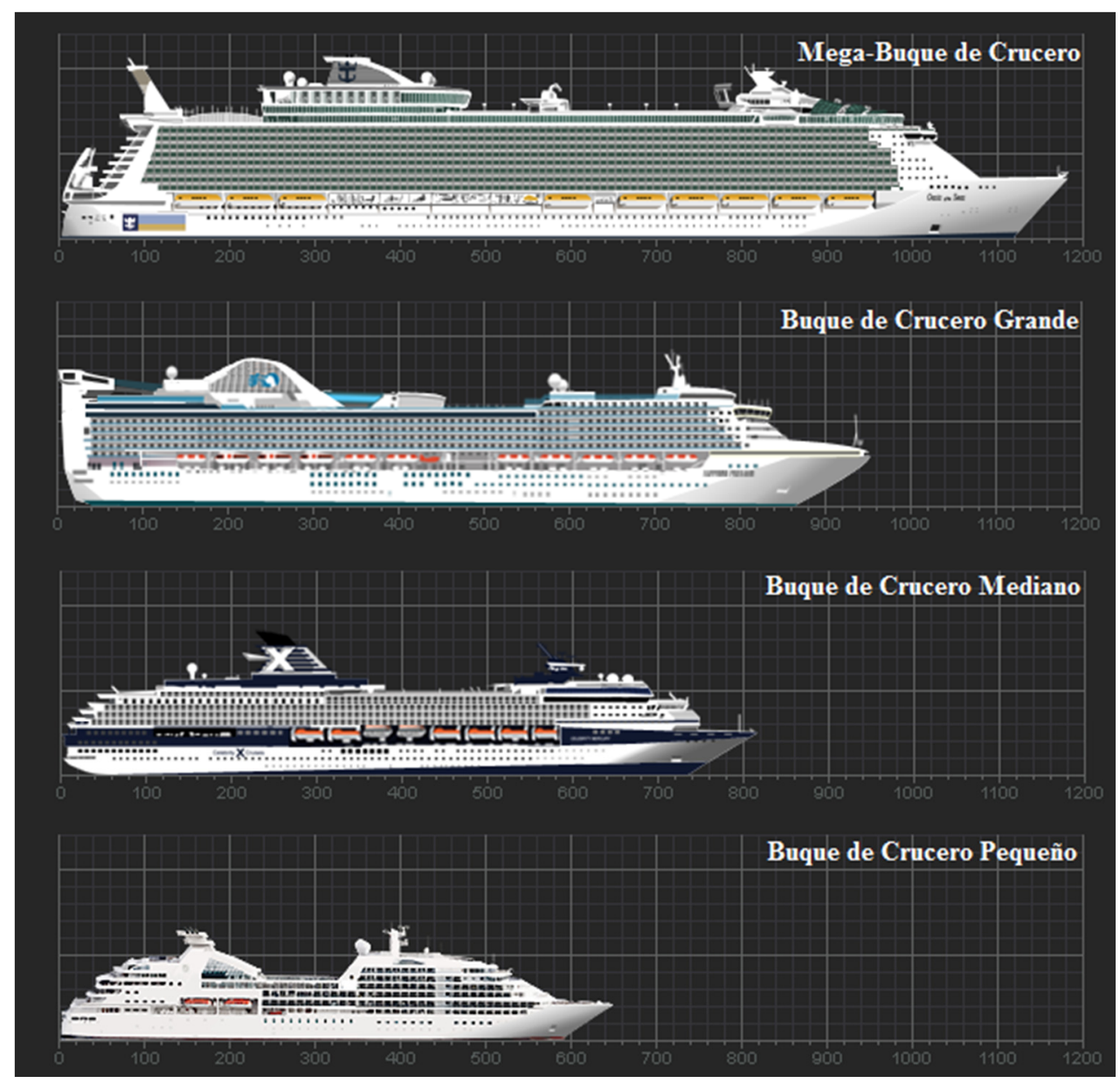

Figura 2.38: Comparativa de tamaños de buques de crucero.

Fuente: Elaboración propia basada en información de Cruises Ships (2013). 
A bordo de un buque de crucero es posible encontrar diferentes tipos de camarotes en función de su situación en cada cubierta, tamaño e instalaciones de que constan. Atendiendo a los criterios anteriores, las diferentes tipologías de camarotes se describen a continuación.

Camarotes interiores, son los más pequeños del buque con una superficie aproximada de entre 11,5 y $16 \mathrm{~m}^{2}$ y los de menor coste. Están situados en el interior del buque, por lo que no disponen de ventanas, véase Figura 2.39. Asociado a este tipo de camarotes, algunas líneas de cruceros montan cámaras de vídeo en el buque y ofrecen las imágenes, sobre todo desde proa, a través de uno de los canales de televisión del buque.

Camarotes con vistas al mar, suelen ser de características similares tanto en tamaño como equipamiento a los camarotes interiores. Sin embargo, incluyen un ojo de buey, ventanal o una ventana panorámica, en función de la categoría y el nivel de la cubierta en que esté situado, véase Figura 2.39. Por este motivo, estos camarotes tienen un coste más elevado que los interiores, asociado, fundamentalmente, con la disponibilidad de vistas al mar.

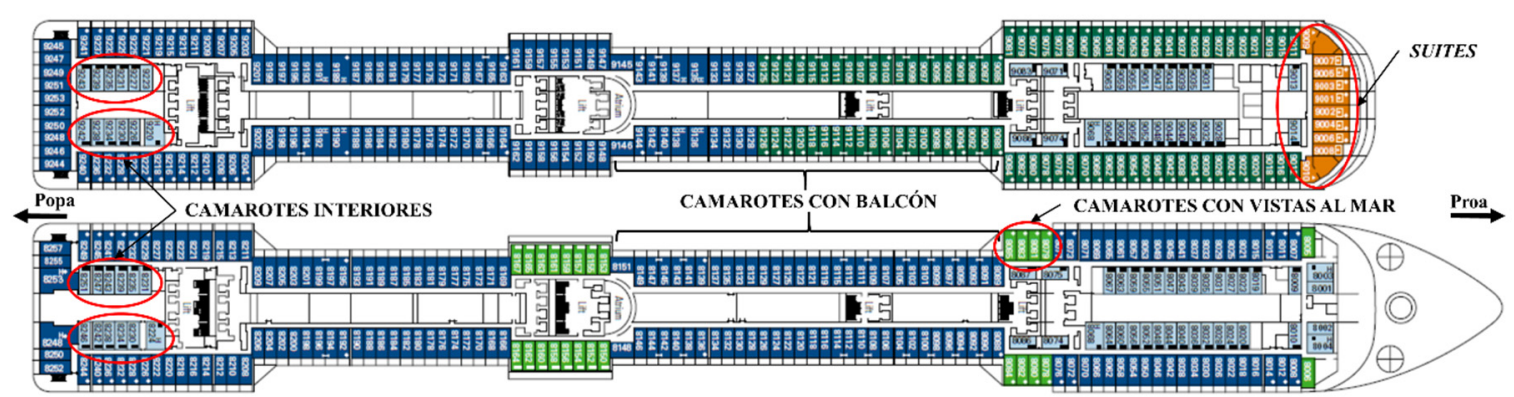

Figura 2.39: Ejemplo de distribución de tipos de camarotes en dos cubiertas.

Fuente: Elaboración propia basada en MSC Cruises (2012).

Camarotes con balcón, disponen de un balcón privado fuera del camarote, véase Figura 2.39. Este tipo de camarotes constituyen el siguiente escalafón de coste y además suelen tener un mayor tamaño que los dos anteriores, con una superficie aproximada de 22 a $26 \mathrm{~m}^{2}$.

Mini-Suites, en algunos buques de crucero es posible encontrar mini-suites. En este tipo de camarotes, el salón y dormitorio están separados por una cortina o elemento similar, no por un mamparo como lo estaría en una suite. Por lo general, disponen de un equipamiento y un balcón de mayores dimensiones que el tipo de camarote descrito anteriormente.

Suites, este tipo de camarotes varía desde suites de dos habitaciones básicas, a lujosos espacios de varias habitaciones y con jacuzzi, véase Figura 2.39, con una superficie que oscila entre los 26 y $53 \mathrm{~m}^{2}$. Las suites son los alojamientos más caros del buque, pero a cambio cuentan con numerosas comodidades. 
Cabe destacar que, en los buques de pequeño tamaño, es habitual que no dispongan de todos los tipos de camarotes que se han descrito anteriormente. Normalmente, éstos dado su tamaño y segmento que cubren, disponen de camarotes que pertenecen a las categorías de camarotes con balcón y suites. Por otro lado, en los buques de crucero de gran tamaño y mega-buques de crucero sí es habitual encontrar toda la variedad anterior de camarotes como consecuencia del mayor espacio disponible.

\subsection{Segmentación del mercado mundial}

En el mercado mundial de cruceros se consideran cuatro segmentos, que son, lujo, premium, contemporary y budget. Cada naviera se centra en uno o a lo sumo dos y cada buque en uno solo. En este sentido, el segmento en el cual se centra el buque está estrechamente ligado al tamaño del mismo. Las características principales de cada uno de los segmentos se describen a continuación (OMT, 2008).

I. Segmento Budget, se caracteriza por:

"El precio es la base",

Atractivo para gente joven y capas de población de menor poder adquisitivo,

No operan en el mercado norteamericano,

Travesías de 3 a 7 días,

Destinos o zona más habitual: Mediterráneo,

Pequeños buques, con el mínimo de instalaciones a bordo.

\section{Segmento contemporary}

Éstos son los más populares y en donde los operadores de cruceros obtienen, con la aplicación intensiva de las economías de escala, uno de los mayores beneficios. Presentan las siguientes características claves:

Disponen de instalaciones de tipo resort con un fuerte énfasis en las actividades a bordo. Por ello, incluyen gran variedad de instalaciones a bordo: beauty salons, golf, pista de hielo, spa, etc.

Se adaptan muy bien a las necesidades de familias con niños de todas las edades,

Ofrecen programas de entretenimiento para niños, películas infantiles en los camarotes, camas tamaño queen size, etc.

Su público objetivo es muy amplio, ofreciendo "algo para todo el mundo", aunque especialmente atractivo para primerizos, familias, parejas y gente joven,

Destinos o zonas más habituales: Alaska, Caribe, Europa Atlántica y Mediterráneo, 
Duración de itinerarios de 3-4 a 7 días,

Grandes buques, siendo la mayoría de las nuevas construcciones post-panamax,

Gran peso de las ventas a bordo de bienes y servicios en el EBITDA (OMT, 2008),

Decoración interior tipo Las Vegas.

III. Segmento premium, se caracteriza por:

Ser un producto algo más sofisticado que el contemporary, más acorde para los repetidores,

Clientela con una media de edad superior a los 40 años y con un nivel de renta media superior al de los dos segmentos anteriores,

Decoración de interiores con colores más suaves y con un gusto más refinado que los barcos contemporary,

$>$ Mayor peso de los cruceros de más de siete noches que en el segmento contemporary,

Incluye en los itinerarios habituales algunos puertos visitados raramente,

Importancia de las excursiones en tierra como generadoras de beneficios,

Ofrecen dos tipos de excursiones: para primerizos y para repetidores.

IV. Segmento de lujo, las siguientes diferencias lo definen:

Ofrecen alto estilo de lujo con énfasis en el destino y en las instalaciones a bordo,

> La exclusividad, llevando menos pasajeros y un ambiente mucho más formal,

- Las habitaciones son espaciosas y, en un alto porcentaje, con vistas al mar y numerosas suites,

Clientela: parejas y solteros con una alta afinidad con resorts de superlujo en tierra, no habiendo instalaciones para niños,

Diseños de interiores más sofisticados, con antigüedades y colecciones de arte de gran valor,

$>$ Buques de menor tamaño,

Los itinerarios se enfocan en puertos y en lugares fuera de lo habitual,

Duración del itinerario superior a 10 días,

Importancia de las excursiones en tierra como generadoras de beneficios.

En este sentido es posible definir tres variables significativas que permiten identificar cada uno de los segmentos, éstas son: tamaño, medido por el arqueo bruto del buque (G.T.); relación de espacio o G.T./Pasajero y relación de servicio o Pasajero/Tripulante. La Tabla 
2.4 incluye una estimación de valores de las variables definidas anteriormente para cada segmento.

Tabla 2.4: Rangos de valores de las variables significativas para los diferentes segmentos de cruceros

\begin{tabular}{lccc}
\hline Segmento & Rango G.T. & G.T./Pasajero & Relación Pasajero/Tripulante \\
\hline Lujo & $10.000-70.000$ & $>50$ & $1,4-1,6$ \\
Premium & $20.000-90.000$ & $40-50$ & $1,8-2,3$ \\
Contemporary & $60.000-120.000$ & $30-50$ & $2,2-2,6$ \\
Budget & $5.000-30.000$ & $20-35$ & $>2,6$ \\
\hline
\end{tabular}

Fuente: OMT (2008).

\subsection{Principales países emisores de pasajeros de crucero}

El turismo de cruceros es un segmento muy reducido dentro de la industria del turismo, con una penetración en la población mundial escasa, en torno al 2\% en 2011. El mercado emisor con mayor importancia relativa en la sociedad es el norteamericano, aproximadamente el 3,4\% de la población realiza un crucero cada año (ECC, 2011). Seguido de EE.UU. se sitúa Canadá y Europa con un 2,4\% y 1,35\% respectivamente. Si bien cabe mencionar que, en el caso de Europa, la penetración en la población es muy dispar de unos países a otros. Sin embargo, en Asia el nivel de implantación es muy bajo ( $0,1 \%$ a $0,2 \%)$, ya que el crucero hasta el momento no está percibido por la población como una modalidad de vacaciones u ocio.

Norteamérica es el principal mercado emisor de pasajeros de crucero, entre el año 1990 y 2013 los pasajeros procedentes de este mercado han representado, de media, el 69,3\% del total de pasajeros a nivel mundial. El incremento de la capacidad desplegada en los destinos europeos (región mediterránea y Norte de Europa), como consecuencia del aumento de la demanda de estos destinos, también lleva asociado una mayor penetración del turismo de cruceros en la población europea, situándose como el segundo mercado emisor de cruceristas a nivel mundial tras Estados Unidos. El mercado emisor europeo entre 1990 y 2013 ha concentrado el 21,9\% del total mundial, véase Gráfico 2.13. La cuota restante del 8,79\% para el periodo 1990-2013 corresponde al resto del mundo y, fundamentalmente, asociada a los mercados de Asia, Sudamérica y Australia-Nueva Zelanda. 


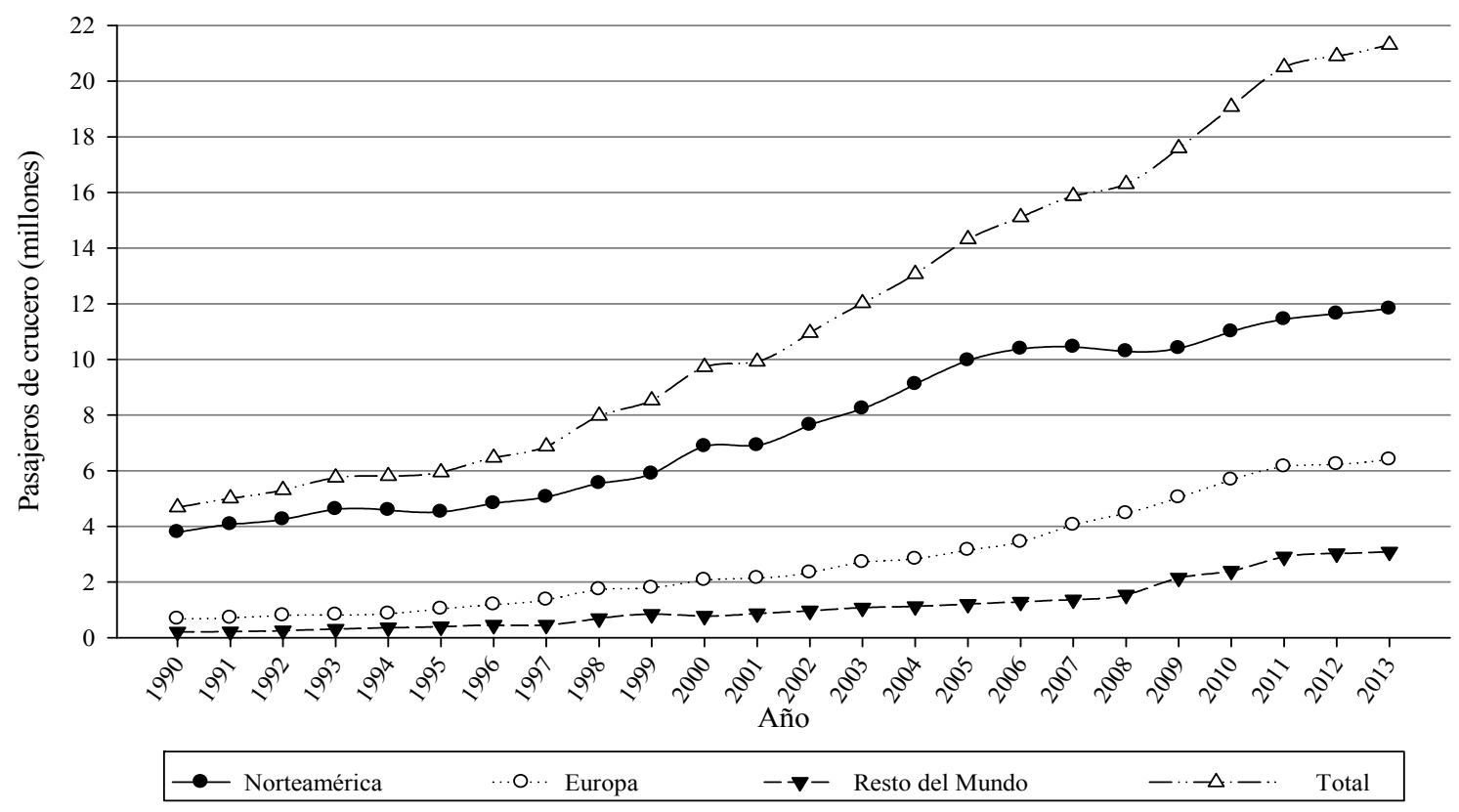

Gráfico 2.13: Evolución de los mercados mundiales emisores de pasajeros de crucero entre los años $1990 \mathrm{y}$ 2013.

Fuente: Elaboración propia basada en datos estadísticos de OMT (2008), ECC (2011a) y CLIA Europe (2014).

Centrando la atención en los dos grandes mercados emisores de cruceristas, entre los años 1990 y 2013 el crecimiento registrado por el mercado europeo ha sido superior al del mercado americano, con un crecimiento medio anual del 10,4\% frente al 5,2\% del mercado norteamericano, véase Tabla 2.5. En este periodo se ha incrementado un $942 \%$ el número de cruceristas de procedencia europea. La menor tasa de crecimiento del mercado norteamericano se explica, en parte, porque éste está alcanzando su fase de madurez con ratios de venta cada vez más constantes (Soriani et al., 2009). Por el contrario, el mercado europeo se encuentra en fase de crecimiento alcanzando mayor penetración en la población.

Tabla 2.5: Tasa de crecimiento de los mercados emisores de pasajeros de crucero entre 1990 y 2013 , tasas agrupadas por quinquenios entre 1990 y 2004, anuales entre 2005 y 2013 y promedio para el periodo

\begin{tabular}{cccc}
\hline Periodo & Norteamérica & Europa & Resto del mundo \\
\hline $1990-1994$ & $4,94 \%$ & $6,18 \%$ & $14,09 \%$ \\
$1995-1999$ & $5,19 \%$ & $9,89 \%$ & $15,98 \%$ \\
$2000-2004$ & $9,24 \%$ & $10,60 \%$ & $15,55 \%$ \\
2005 & $9,33 \%$ & $11,31 \%$ & $7,08 \%$ \\
2006 & $4,22 \%$ & $9,21 \%$ & $6,61 \%$ \\
2007 & $0,67 \%$ & $17,73 \%$ & $6,20 \%$ \\
2008 & $-1,53 \%$ & $10,37 \%$ & $12,41 \%$ \\
2009 & $1,07 \%$ & $12,75 \%$ & $39,61 \%$ \\
2010 & $5,77 \%$ & $12,50 \%$ & $11,63 \%$ \\
2011 & $4,00 \%$ & $8,47 \%$ & $21,25 \%$ \\
2012 & $1,75 \%$ & $1,30 \%$ & $4,12 \%$ \\
2013 & $1,55 \%$ & $2,73 \%$ & $1,98 \%$ \\
$1990-2013$ & $5,16 \%$ & $10,42 \%$ & $12,92 \%$ \\
\hline
\end{tabular}

Fuente: Elaboración propia basada en datos estadísticos de OMT (2008), ECC (2011b) y CLIA Europe (2013). 
El mercado emisor europeo destacó por el reducido incremento en 2012 (1,30\%) respecto a 2011 que se explica por un lado, por la situación geo-política caracterizada por la Primavera Árabe, que obligó a las líneas de crucero a realizar cambios importantes de última hora en determinados itinerarios por el Mediterráneo; y por otro, por el rápido crecimiento de los mercados emergentes (Australasia, América del Sur y China). En este sentido también cabe mencionar que el crecimiento del mercado emisor asiático se vio afectado negativamente por el terremoto de Japón y posterior Tsunami en marzo de 2011, que interrumpió cruceros en la región de Asia.

Ante factores de cambio como los anteriores, la industria de los cruceros puede responder rápidamente dada la movilidad del crucero que permite introducir nuevos destinos de inmediato. Sin embargo, existe la incertidumbre de que estas situaciones puedan afectar a las decisiones futuras de los pasajeros. Esto pone de relieve la importancia de una política de globalización en la industria de cruceros no sólo en términos de implementación/capacidad desplegada, sino también en cuanto a los países emisores de pasajeros. De hecho, los despliegues globales son un factor clave en la apertura de nuevos mercados emisores, en particular, con el aumento del coste - e impuestos - de los billetes de avión que puede suponer una barrera de entrada en la asequibilidad de fly \& cruises, especialmente en el segmento de cruceristas primerizos (ECC, 2013). Esta política de globalización ha permitido a la industria de los cruceros seguir creciendo en base a la comercialización del producto en países como Australia, Brasil y China, que han permanecido, en gran medida, inmunes a la crisis económica que afectó primero a Norteamérica a finales de 2008 y luego se extendió a Europa.

El mercado emisor australiano presenta un rápido crecimiento durante los últimos cinco años. Hay varias razones para esta tendencia alcista. Una de ellas es la fortaleza de la economía local, donde prevalece el bajo desempleo. A lo anterior se une el creciente interés de las navieras de cruceros en Asia, porque el despliegue de buques en esta región encaja perfectamente en los programas de Australia durante los inviernos de Asia. En esta cuestión radica la decisión de Royal Caribbean International de enviar su buque Voyager of the Seas, el mayor buque de crucero posicionado en Asia (ECC, 2013).

En China, sin embargo, el turismo de cruceros es un concepto completamente nuevo, por lo que las cifras se mantienen relativamente bajas a pesar del reciente énfasis en el país por parte de las navieras Costa Cruises y Royal Caribbean International y su despliegue, cada vez mayor, de buques de gran tamaño en el país. Las previsiones indican que en las dos próximas décadas, China se convierta también en un actor clave dentro del tráfico de cruceros. 


\subsubsection{Mercado emisor europeo}

Centrando la atención en el mercado emisor europeo, la penetración en la población es baja, y claramente por detrás del nivel logrado hasta ahora en Norte América. Además, la implantación es muy dispar en los diferentes países europeos, véase Tabla 2.6. En el potencial de crecimiento que implica esta baja penetración del turismo de cruceros en Europa reside la fuerza impulsora que ha generado la inversión realizada por varias navieras europeas como por ejemplo MSC Cruises. Así como, el aumento del despliegue de navieras norteamericanas como Royal Caribbean International.

Tabla 2.6: Penetración del producto crucero en los principales mercados emisores europeos en 2011

\begin{tabular}{lrrr}
\hline País & Población & Pasajeros de crucero en 2011 & Tasa de penetración \\
\hline Reino Unido & 66.900 .000 & 1.700 .000 & $2,50 \%$ \\
Alemania & 81.800 .000 & 1.388 .000 & $1,70 \%$ \\
Italia & 60.800 .000 & 923.000 & $1,50 \%$ \\
España & 46.200 .000 & 703.000 & $1,50 \%$ \\
Francia & 65.400 .000 & 441.000 & $0,70 \%$ \\
Escandinavia* & 25.500 .000 & 306.000 & $0,90 \%$ \\
\hline
\end{tabular}

* Incluye Finlandia.

Fuente: Elaboración propia adaptada de ECC (2011b).

Fundamentalmente, el origen de los cruceristas europeos está asociado a cinco países, que son: Reino Unido, Alemania, España, Italia y Francia, véase Tabla 2.7. Estos cinco países han concentrado el $86,15 \%$ de los cruceristas europeos entre 2003 y 2013. Las dos grandes potencias europeas emisoras de pasajeros de crucero son Reino Unido y Alemania superando el millón de cruceristas anuales desde 2004 y 2009, respectivamente. En otros términos, Reino Unido ha concentrado desde el año 2000 a 2013 el 32,54\% de los pasajeros del mercado emisor europeo y Alemania el 20,77\%.

Tabla 2.7: Cuota de los países europeos emisores de cruceristas entre 2010 y 2013

\begin{tabular}{lrrrr}
\hline País & $\mathbf{2 0 1 0}$ & $\mathbf{2 0 1 1}$ & $\mathbf{2 0 1 2}$ & $\mathbf{2 0 1 3}$ \\
\hline Reino Unido* & $30 \%$ & $28 \%$ & $27,5 \%$ & $27,2 \%$ \\
Alemania & $22 \%$ & $23 \%$ & $22,5 \%$ & $26,5 \%$ \\
Italia & $16 \%$ & $15 \%$ & $14,9 \%$ & $13,7 \%$ \\
España & $12 \%$ & $12 \%$ & $11,4 \%$ & $7,5 \%$ \\
Francia & $7 \%$ & $7 \%$ & $7,1 \%$ & $8,2 \%$ \\
Escandinavia & $3 \%$ & $4 \%$ & $4,2 \%$ & $4,5 \%$ \\
Benelux & $2 \%$ & $3 \%$ & $2,6 \%$ & $2,9 \%$ \\
Suiza & $2 \%$ & $2 \%$ & $1,7 \%$ & $2,4 \%$ \\
Austria & $2 \%$ & $2 \%$ & $2,0 \%$ \\
Otros & $4 \%$ & $4 \%$ & $\mathbf{1 0 0} \%$ & $5,1 \%$ \\
Total & $\mathbf{1 0 0 \%}$ & $\mathbf{1 0 0} \%$ & $\mathbf{1 0 0 \%}$ \\
\hline
\end{tabular}

* Incluye Irlanda.

Fuente: Elaboración propia basada en ECC (2012), CLIA Europe (2013) y CLIA Europe (2014). 
Las regiones de crucero europeas centran la mayor atención de los destinos elegidos por europeos para realizar un crucero. Entre 2005 y 2011, el 76,7\% de los cruceros realizados por europeos tenían como destino regiones de crucero de Europa. Entre éstos, el Mediterráneo y las islas Atlánticas acumularon la mayor cuota con un 59,2\%, véase Tabla 2.8 .

Tabla 2.8: Cuotas de los destinos elegidos por los cruceristas de origen europeo entre 2005 y 2011

\begin{tabular}{lrrrrrrr} 
& \multicolumn{7}{c}{ Año } \\
\cline { 2 - 7 } Destino & $\mathbf{2 0 0 5}$ & $\mathbf{2 0 0 6}$ & $\mathbf{2 0 0 7}$ & $\mathbf{2 0 0 8}$ & $\mathbf{2 0 0 9}$ & $\mathbf{2 0 1 0}$ & $\mathbf{2 0 1 1}$ \\
\hline Mediterráneo e islas Atlánticas & $59,1 \%$ & $58,1 \%$ & $59,9 \%$ & $59,9 \%$ & $58,1 \%$ & $59,3 \%$ & $60,2 \%$ \\
Norte de Europa & $16,0 \%$ & $17,5 \%$ & $16,3 \%$ & $16,7 \%$ & $17,5 \%$ & $18,4 \%$ & $20,0 \%$ \\
Caribe y otros & $24,9 \%$ & $24,4 \%$ & $23,9 \%$ & $23,4 \%$ & $24,4 \%$ & $22,3 \%$ & $19,8 \%$ \\
Total & $\mathbf{1 0 0 \%}$ & $\mathbf{1 0 0} \%$ & $\mathbf{1 0 0} \%$ & $\mathbf{1 0 0} \%$ & $\mathbf{1 0 0} \%$ & $\mathbf{1 0 0} \%$ & $\mathbf{1 0 0 \%}$ \\
\hline
\end{tabular}

Fuente: Elaboración propia adaptada de ECC (2012).

A pesar de estas cifras positivas, no es posible eludir que los últimos años están siendo difíciles para la industria de los cruceros en Europa como consecuencia del periodo de crisis económica en que se encuentra el continente desde el año 2008. Además, a la anterior coyuntura hay que sumarle dos hechos de notable impacto. En el año 2011 las navieras que operaban en el Mediterráneo con escalas en puertos del Norte de África se vieron afectadas por los acontecimientos de la Primavera Árabe. Esto supuso una redistribución de la flota de gran alcance y en corto periodo de tiempo. Un destino clave, Túnez, estuvo fuera de alcance durante meses (o incluso más tiempo para algunas navieras), y los cruceros a Egipto también se vieron afectados de manera significativa. Pero este contratiempo palidecía en comparación con las secuelas del suceso del buque Costa Concordia, en enero de 2012, que afectó a las ventas en todos los mercados emisores europeos, aunque Italia fue inevitablemente la más afectada.

Además, la actual crisis económica de la zona euro también ha deprimido los precios de billetes en este periodo de tiempo. El mercado europeo de mayor importancia, Reino Unido, entró en recesión a principios de 2012, lo cual perjudicó la confianza de los consumidores, justo en la etapa crucial del ciclo de reserva, a pocos meses de que comience la temporada alta de cruceros en Europa.

Existen dos factores de notable importancia que influyen en el desarrollo positivo del mercado europeo. Por un lado, el 43\% de la población europea vive en regiones costeras y además, gran parte de ellos, tiene fácil acceso a los puertos base. Por otro lado, el creciente interés del turismo norteamericano en visitar Europa, especialmente en familia. Por ello, los mercados europeos siguen creciendo en tamaño, aunque cada mercado está en una etapa diferente de desarrollo que conlleva cuotas de mercado que cambian año a año. 


\subsubsection{Mercado emisor británico}

Reino Unido (incluyendo Irlanda) es el mayor mercado emisor de pasajeros de crucero en Europa y el segundo a nivel mundial tras EE.UU. Entre 1998 y 2013 ha registrado un crecimiento medio anual del 7,96\%. El crecimiento registrado por este mercado, sobre todo en la década del año 2000 con variaciones anuales con frecuencia de dos dígitos, ha supuesto que entre 2002 y 2010 se haya duplicado la cifra de pasajeros, véase Tabla 2.9. Sin embargo, en los últimos años se ha ralentizado su crecimiento como consecuencia del clima económico adverso. Aun así desde 2011 a 2013 se han superado los 1,7 millones de pasajeros de crucero.

Tabla 2.9: Cifras del mercado emisor de Reino Unido entre 1998 y 2013

\begin{tabular}{rrr}
\hline Año & Pasajeros & Tasa de variación \\
\hline 1998 & 663.000 & $27,0 \%$ \\
1999 & 746.000 & $12,5 \%$ \\
2000 & 754.000 & $1,1 \%$ \\
2001 & 776.000 & $2,9 \%$ \\
2002 & 820.000 & $5,7 \%$ \\
2003 & 964.000 & $17,6 \%$ \\
2004 & 1.029 .000 & $6,7 \%$ \\
2005 & 1.071 .000 & $4,1 \%$ \\
2006 & 1.204 .000 & $12,4 \%$ \\
2007 & 1.335 .000 & $10,9 \%$ \\
2008 & 1.477 .000 & $10,6 \%$ \\
2009 & 1.533 .000 & $3,8 \%$ \\
2010 & 1.622 .000 & $5,8 \%$ \\
2011 & 1.700 .000 & $4,8 \%$ \\
2012 & 1.701 .000 & $0,1 \%$ \\
2013 & 1.726 .000 & $1,5 \%$ \\
\hline
\end{tabular}

Fuente: Elaboración propia basada en ECC (2012) y CLIA Europe (2014).

Un estímulo clave para este crecimiento ha sido el incremento de buques con puerto base en Reino Unido, y orientados al mercado británico. De tal forma que, el principal incremento de pasajeros viene motivado por el aumento de embarques en puertos de Reino Unido. En 2004, el número de pasajeros que iniciaban su crucero en Reino Unido se situaba en una cifra inferior al 30\%, mientras en 2013 alcanzaba un valor del 49\%, véase Tabla 2.10. La principal tendencia en el mercado británico es que el crecimiento está siendo impulsado por cruceros de corta duración desde puertos de Reino Unido hacia el Mediterráneo y el Norte de Europa Occidental.

Tabla 2.10: Cuotas de cruceros con embarques nacionales y fly \& cruise en el mercado emisor de Reino Unido entre 2004 y 2013

\begin{tabular}{ccccc}
\hline Año & Pasajeros con embarque en Reino Unido & Cuota & Pasajeros fly $\&$ cruise & Cuota \\
\hline 2004 & 316.000 & $29,8 \%$ & 713.000 & $71,2 \%$ \\
2005 & 403.000 & $37,7 \%$ & 669.000 & $62,3 \%$ \\
2006 & 451.000 & $37,6 \%$ & 753.000 & $62,4 \%$ \\
2007 & 468.000 & $35,0 \%$ & 867.000 & $65,0 \%$
\end{tabular}




\begin{tabular}{ccccc}
\hline Año & Pasajeros con embarque en Reino Unido & Cuota & Pasajeros fly $\boldsymbol{\&}$ cruise & Cuota \\
\hline 2008 & 557.000 & $37,7 \%$ & 920.000 & $62,3 \%$ \\
2009 & 594.000 & $38,8 \%$ & 939.000 & $61,2 \%$ \\
2010 & 653.000 & $40,2 \%$ & 969.000 & $59,8 \%$ \\
2011 & 729.000 & $42,9 \%$ & 971.000 & $57,1 \%$ \\
2012 & 807.000 & $47,4 \%$ & 894.000 & $52,6 \%$ \\
2013 & 844.000 & $49,0 \%$ & 882.000 & $51,0 \%$ \\
\hline
\end{tabular}

Fuente: Elaboración propia basada en PSA (2012) y CLIA UK \& Ireland (2014).

El principal destino para los cruceristas británicos es el Mediterráneo, seguido del Norte de Europa, Caribe y las islas Atlánticas. Los cruceros con inicio en puertos británicos se dirigen al Mediterráneo, Noruega, Europa Occidental y el Báltico, mientras que los fly \& cruise se centran en el Caribe y también en el Mediterráneo. El destino Norte de Europa entre el año 2009 y 2013 ha registrado un crecimiento medio del 16,2\%. Mientras que el Caribe en el mismo periodo ha descendido un 9,3\%. El elevado dinamismo del destino Norte de Europa se puede atribuir, en parte, a la necesidad de las compañías de cruceros de reducir distancias y velocidades de navegación para ahorrar combustible y minimizar costes. Por el contrario, los fly \& cruise al Caribe se han resentido, debido al incremento de precio asociado al importe de tasas de vuelo y el impacto de los altos costes de combustible (CLIA UK \& Ireland, 2014).

\subsubsection{Mercado emisor alemán}

El mercado emisor alemán entre el año 2000 y 2013 ha crecido un $445 \%$, con una tasa media anual para este periodo del $12,50 \%$, tasa que duplica a la del mercado británico para ese mismo periodo (6,28\%). Además, desde 2008 a 2012 encadenó cinco años consecutivos de crecimiento de dos dígitos, consolidándose como segundo mercado en Europa y aproximándose a las cuotas de Reino Unido. En 2009, ya superó el millón de pasajeros, véase Tabla 2.11. Esta evolución positiva ha generado que año a año el mercado alemán haya reducido distancia con respecto al mercado de Reino Unido, en 2013 se registró la menor diferencia entre ambos con 39.000 pasajeros más a favor del mercado británico. Con lo que de seguir esta tendencia positiva, el mercado alemán superará al británico estableciéndose como primera potencia emisora de cruceristas en Europa.

El fuerte crecimiento registrado por el mercado alemán se debe principalmente al programa de expansión sostenida de capacidad de la naviera AIDA Cruises, de origen alemán, y líder del mercado. Por ejemplo, en 2011 el 60\% de los alemanes realizaron sus cruceros en buques de navieras alemanas frente al $40 \%$ restante que los realizaron en navieras de otra nacionalidad (ECC, 2011b).

Tabla 2.11: Cifras del mercado emisor alemán entre 2000 y 2013

\begin{tabular}{rrr}
\hline Año & Pasajeros & Tasa de variación \\
\hline 2000 & 379.000 & $15,0 \%$ \\
2001 & 392.000 & $3,4 \%$
\end{tabular}




\begin{tabular}{lrr}
\hline Año & Pasajeros & Tasa de variación \\
\hline 2002 & 428.000 & $9,2 \%$ \\
2003 & 537.000 & $25,5 \%$ \\
2004 & 583.000 & $8,6 \%$ \\
2005 & 639.000 & $9,6 \%$ \\
2006 & 705.000 & $10,3 \%$ \\
2007 & 763.000 & $8,2 \%$ \\
2008 & 907.000 & $18,9 \%$ \\
2009 & 1.027 .000 & $13,2 \%$ \\
2010 & 1.219 .000 & $18,7 \%$ \\
2011 & 1.388 .000 & $13,9 \%$ \\
2012 & 1.544 .000 & $11,2 \%$ \\
2013 & 1.687 .000 & $9,3 \%$ \\
\hline
\end{tabular}

Fuente: Elaboración propia basada en ECC (2013) y CLIA Europe (2014).

En cuanto a los destinos escogidos por el mercado alemán, prevalece el Mediterráneo y las islas Atlánticas, con una cuota del 47\%, seguido del Norte de Europa con el 25\% y en tercer y cuarto lugar, Caribe (13\%) y resto del mundo (15\%), respectivamente.

\subsubsection{Mercado emisor italiano}

El mercado emisor italiano entre 2003 y 2013 ha representado el 14,8\% del total europeo. En este mismo periodo, el crecimiento medio anual ha sido del 10,18\%. Sin embargo, la notable inercia positiva del mercado emisor italiano hasta 2010 se ha visto frenada por dos conceptos, véase Tabla 2.12. De un lado, la crisis económica en la eurozona ha afectado a Italia fuertemente, contrayendo su economía en gran medida. Por otro lado, el trágico accidente del buque Costa Concordia el 13 de enero de 2012 supuso otro revés a la evolución de este mercado, estableciéndose el plazo de recuperación en el horizonte de 2014.

Tabla 2.12: Cifras del mercado emisor italiano entre 2003 y 2013

\begin{tabular}{lrr}
\hline Año & Pasajeros & Tasa de variación \\
\hline 2003 & 346.000 & - \\
2004 & 400.000 & $15,6 \%$ \\
2005 & 514.000 & $28,5 \%$ \\
2006 & 517.000 & $0,6 \%$ \\
2007 & 640.000 & $23,8 \%$ \\
2008 & 682.000 & $6,6 \%$ \\
2009 & 799.000 & $17,2 \%$ \\
2010 & 889.000 & $11,3 \%$ \\
2011 & 923.000 & $3,8 \%$ \\
2012 & 835.000 & $-9,5 \%$ \\
2013 & 869.000 & $4,1 \%$ \\
\hline
\end{tabular}

Fuente: Elaboración propia basada en ECC (2013) y CLIA Europe (2014).

El crecimiento registrado años atrás por el mercado emisor italiano, está motivado en parte, porque Italia cuenta con un total de 11 puertos base, esta amplia red de puertos permite 
que en un tiempo de 90 minutos se tenga acceso a un puerto de embarque. En cuanto a los destinos de los cruceros de ciudadanos italianos, el líder indiscutible es el Mediterráneo, con una cuota del $82 \%$, le sigue el Norte de Europa con un $8 \%$ y a continuación Caribe y destinos emergentes con un $6 \%$ y $4 \%$, respectivamente (ECC, 2013).

\subsubsection{Mercado emisor español}

En términos absolutos entre 1992 y 2013 el número de pasajeros de crucero españoles creció a una tasa media anual del 19,9\%. Durante el primer quinquenio de la década de los 90 el mercado español apenas superaba la cifra de 20.000 pasajeros de crucero anualmente, véase Gráfico 2.14. Entre los años 1992 a 2003 el mercado emisor español registró un crecimiento medio anual del 32,9\% superándose en 2003 la cifra de 300.000 pasajeros de crucero de origen español. En 2004 cayó ligeramente (2,3\%), recuperándose de nuevo durante los tres años siguientes, alcanzándose en el año 2007 un nuevo hito al superar el medio millón de pasajeros de crucero españoles. De nuevo en 2008 se registró una caída, esta vez de mayor magnitud que la anterior (4\%); recuperándose durante los tres años siguientes hasta alcanzar el máximo registro de cruceristas españoles en 2011. Sin embargo, en 2012 y 2013 se registraron sendas caídas (18,1\% y 17,5\%) rebajando la cifra del mercado emisor español por debajo del medio millón en 2013, véase Gráfico 2.14. Análogamente al caso de Italia, el mercado español también se ha resentido como consecuencia de la crisis económica, más si cabe ya que el impacto que ha tenido ésta sobre España ha sido superior al del resto de países emisores de la zona euro.

Las cifras expuestas anteriormente han otorgado a España durante el periodo comprendido entre 2003 y 2013 la posición de cuarto país emisor de pasajeros de crucero en Europa, equivalente al 10,94\% del mercado. Sin embargo, las caídas registradas durante los dos últimos años han propiciado que España haya ocupado en 2013 el quinto puesto siendo superada por Francia.

El destino por excelencia para los pasajeros españoles es el Mediterráneo con un $81 \%$ de la cuota total, los siguientes destinos, también europeos, son el Norte de Europa con un $12 \%$ y las islas Atlánticas con un 2\%. De tal forma, que los cruceros de españoles se concentran en un $95 \%$ en Europa. El 5\% restante se reparte en un $4 \%$ para el Caribe y destinos emergentes $1 \%$. 


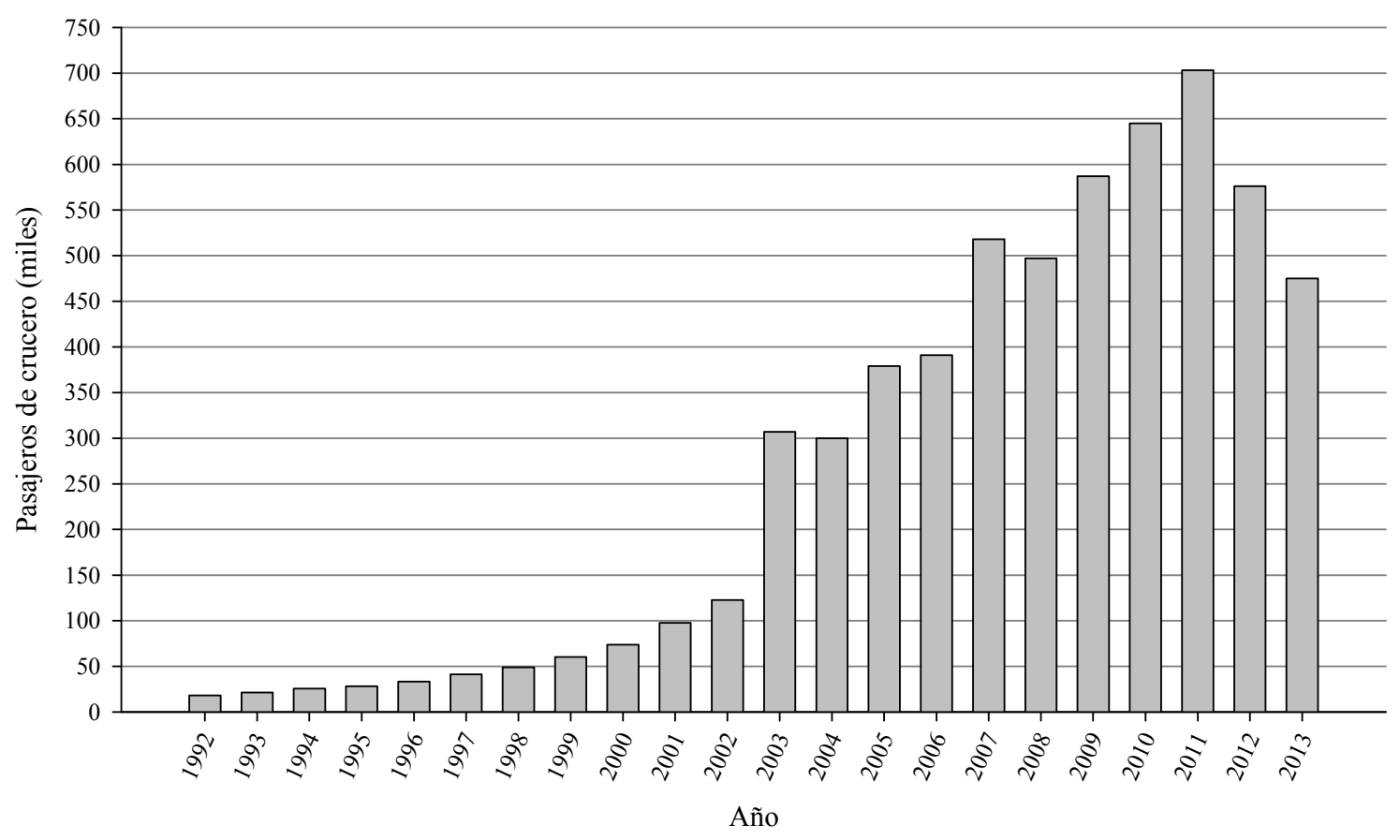

Gráfico 2.14: Evolución de la cifra de pasajeros de origen español entre los años 1992 y 2013.

Fuente: Elaboración propia basada en datos estadísticos de HostelTur (2004), ECC (2013) y CLIA Europe (2014).

\subsubsection{Mercado emisor francés}

El mercado emisor francés es el quinto en Europa con una cuota media de mercado entre 2003 y 2013 del 7,34\%. Durante este mismo periodo ha crecido a una tasa media anual del 9,50\%. Entre 2007 y 2011 acumuló cinco años consecutivos de crecimiento a un ritmo de dos dígitos, véase Tabla 2.13. El crecimiento se ha visto favorecido por dos conceptos clave. De un lado, la creación y desarrollo de marcas/navieras de origen francés. Y por otro lado, el desarrollo de puertos base en Francia, como por ejemplo, Marsella y Le Havre. En 2012 y 2013 junto con Alemania, lideró el crecimiento de los cinco principales mercados emisores europeos. Esta inercia positiva unido a la caída del mercado emisor español, han propiciado que Francia fuera el cuarto país emisor europeo en 2013, posición que históricamente ha ocupado España como se ha comentado anteriormente.

Tabla 2.13: Cifras del mercado emisor francés entre 2003 y 2013

\begin{tabular}{lrr}
\hline Año & Pasajeros & Tasa de variación \\
\hline 2003 & 212.000 & - \\
2004 & 222.000 & $4,7 \%$ \\
2005 & 233.000 & $4,9 \%$ \\
2006 & 242.000 & $3,9 \%$ \\
2007 & 280.000 & $15,7 \%$ \\
2008 & 310.000 & $10,7 \%$ \\
2009 & 347.000 & $11,9 \%$ \\
2010 & 387.000 & $11,5 \%$ \\
2011 & 441.000 & $13,9 \%$
\end{tabular}




\begin{tabular}{lrr}
\hline Año & Pasajeros & Tasa de variación \\
\hline 2012 & 481.000 & $9,1 \%$ \\
2013 & 522.000 & $8,5 \%$ \\
\hline
\end{tabular}

Fuente: Elaboración propia basada en ECC (2011b), ECC (2013) y CLIA Europe (2014).

De forma análoga a los casos anteriores, el Mediterráneo acapara el mayor porcentaje (69\%) de los destinos de crucero de franceses. El segundo destino con mayor demanda es el Caribe con una cuota del 10\%, y a continuación, Norte de Europa (9\%) y destinos emergentes $(12 \%)$.

\subsubsection{Otros mercados emisores europeos}

Escandinavia, Benelux, Suiza y Austria constituyen también mercados emisores significativos, con un crecimiento promedio de dos dígitos en todos ellos entre 2004 y 2013 , véase Tabla 2.14 .

El mercado escandinavo incluye Dinamarca, Finlandia, Noruega y Suecia. El mercado emisor noruego es el mayor en este grupo con una cuota en 2013 del 2,2\% en el mercado europeo, equivalente al $7^{\circ}$ puesto; le siguen Suecia $(1,3 \%)$, Dinamarca $(0,6 \%)$ y Finlandia $(0,4 \%)$, equivalente a los puestos $10^{\circ}, 12^{\circ}$ y $13^{\circ}$ en Europa, respectivamente. Excepto en Finlandia, en el resto de países escandinavos los tres principales destinos son, por orden, Norte de Europa, Mediterráneo y Caribe. En el caso de Finlandia el principal destino lo constituye el Mediterráneo, seguido de Norte de Europa y Caribe (ECC, 2011b). Recientemente, como medida de estímulo en este mercado, se está intentando extender la temporada de cruceros por el Báltico, al operar cruceros de corta duración en primavera y otoño desde Oslo y Estocolmo.

El mercado emisor de Benelux está compuesto por los pasajeros procedentes de Países Bajos y Bélgica. El periodo de expansión asociado al mercado emisor de Países Bajos también está acompañado de un aumento del 25\% de los embarques en puertos de este país. Este crecimiento se debe tanto a escalas en tránsito como de puerto base, principalmente, en Ámsterdam, Rotterdam e Ijmuiden, lo cual lo hace más atractivo para un mayor número de pasajeros al poder embarcar en su propio país. En concreto, una de las navieras que más ha estimulado el embarque desde puertos holandeses ha sido Holland America Line estableciendo un buque con puerto base en Rotterdam durante todo el año. Entre los destinos elegidos por los cruceristas de Países Bajos destacan, el Mediterráneo (48\%), Norte de Europa (17\%) y Caribe (16\%).

En Bélgica no existen marcas/navieras nacionales de cruceros marítimos, pero sí existe una amplia presencia de navieras internacionales e incluso en un número mayor al de otros países. Aunque la penetración del turismo de cruceros entre la población es muy reducida. Respecto a los principales destinos, de forma análoga al caso de Países Bajos, destacan el Mediterráneo (60\%), Norte de Europa (14\%) y Caribe (11\%). 
Tabla 2.14: Cifras de otros mercados emisores europeos

\begin{tabular}{llrrrrrrrrrrr}
\hline \multirow{2}{*}{ Mercado } & & $\mathbf{2 0 0 4}$ & $\mathbf{2 0 0 5}$ & $\mathbf{2 0 0 6}$ & $\mathbf{2 0 0 7}$ & $\mathbf{2 0 0 8}$ & $\mathbf{2 0 0 9}$ & $\mathbf{2 0 1 0}$ & $\mathbf{2 0 1 1}$ & $\mathbf{2 0 1 2}$ & $\mathbf{2 0 1 3}$ & Promedio \\
\hline \multirow{2}{*}{ Escandinavia } & Pax (miles) & 56 & 42 & 62 & 94 & 123 & 173 & 283 & 306 & 324 & 288 & \\
& T. Var. (\%) & & $-25,0$ & 47,6 & 51,6 & 30,9 & 40,7 & 63,6 & 8,1 & 5,9 & $-11,1$ & 23,6 \\
\hline \multirow{2}{*}{ Benelux } & Pax (miles) & 41 & 42 & 64 & 82 & 92 & 110 & 126 & 159 & 169 & 183 & \\
& T. Var. (\%) & & 2,4 & 52,4 & 28,1 & 12,2 & 19,6 & 14,5 & 26,2 & 6,3 & 8,3 & 18,9 \\
\hline \multirow{2}{*}{ Suiza } & Pax (miles) & 50 & 51 & 56 & 64 & 65 & 76 & 91 & 121 & 131 & 152 & \\
& T. Var. (\%) & & 2,0 & 9,8 & 14,3 & 1,6 & 16,9 & 19,7 & 33,0 & 8,3 & 16,0 & 13,5 \\
\hline \multirow{2}{*}{ Austria } & Pax (miles) & 38 & 39 & 44 & 59 & 59 & 80 & 93 & 104 & 108 & 126 & \\
& T. Var. (\%) & & 2,6 & 12,8 & 34,1 & 0,0 & 35,6 & 16,2 & 11,8 & 3,8 & 16,7 & 14,9 \\
\hline \multirow{2}{*}{ Otros } & Pax (miles) & 115 & 117 & 123 & 175 & 211 & 213 & 212 & 224 & 267 & 329 & \\
& T. Var. (\%) & & 1,7 & 5,1 & 42,3 & 20,6 & 0,9 & $-0,5$ & 5,7 & 19,2 & 23,2 & 13,1 \\
\hline
\end{tabular}

Fuente: Elaboración propia basada en ECC (2013) y CLIA Europe (2014).

Bajo la categoría de "otros", véase Tabla 2.14, se incluyen las cifras de pasajeros correspondientes a Portugal, Rusia, Grecia, Chipre, Turquía y Malta. Por ejemplo, entre estos países destaca Portugal con 35.600 pasajeros en 2011. Además, en los puertos portugueses se están llevando a cabo importantes inversiones, no sólo para incrementar su presencia como puertos de escala, sino también para establecer los puertos de Funchal (Madeira), Leixoes y Lisboa como puertos base relevantes.

Finalmente, en la categoría "otros" también se incluyen pasajeros procedentes de Europa del Este, principalmente de Rusia, aunque su crecimiento, así como, el de otros países de la región se ve limitado por dos factores. Por un lado, los problemas de visado al reservar cruceros tipo fly \& cruise. Y por otro lado, la falta de marcas/navieras nacionales con puertos base en países de Europa del Este. 



\section{Capítulo III. Características y funciones de los agentes implicados en la industria de cruceros}

En el turismo de cruceros conjuntos de destinos en tierra y ciudades portuarias se combinan satisfactoriamente junto con diversas comodidades/servicios a bordo del buque. El producto proporcionado por la industria de cruceros es la combinación del buque de crucero y el itinerario, es decir, la suma de los destinos/puertos visitados. Por lo que, el elemento básico de la industria de los cruceros es su sistema de itinerarios. De ahí que autores como Rodrigue y Notteboom (2013) afirmen que esta industria comercializa itinerarios y no destinos. Los tres actores clave involucrados en la elaboración de un itinerario de crucero son, la naviera de cruceros, los puertos y el destino o región a visitar por los cruceristas durante cada escala, denominado hinterland turístico. Este conjunto de ciudades portuarias y sus respectivos hinterlands turísticos delimitan lo que puede ser visitado por los cruceristas, que junto a los servicios ofertados en el buque, enmarca las experiencias y actividades susceptibles de ser realizadas. En consecuencia, en el presente capítulo se determinan las principales características, y su influencia en el proceso de diseño de un itinerario de crucero, de cada uno de los tres actores enumerados anteriormente.

En primer lugar, se analiza el segmento de navieras de crucero haciendo hincapié en la estructura empresarial, la capacidad de cada flota en particular y la incorporación de nuevos buques. A continuación, en el segundo apartado, se estudian las funciones desempeñadas por los puertos de crucero. Y se incluye un estudio pormenorizado para el Sistema Portuario Español, tanto en lo referente a evolución del tráfico de cruceros, como también, a instalaciones disponibles para este tráfico marítimo. En el tercer apartado, se aborda la determinación de las características y funciones de los hinterlands turísticos y la delimitación de éstos aplicada a los puertos de crucero de la costa mediterránea española y atlántica andaluza.

\subsection{El mercado de navieras de crucero}

El buque está directamente relacionado tanto con la componente de transporte presente en el producto crucero, como con el atractivo turístico relacionado con el propio buque, puesto que se puede considerar como un destino en sí mismo. Además de, su carácter alojativo ya comentado en el Capítulo II, durante las últimas dos décadas ha habido un aumento en el tamaño de los buques, incrementando de este modo la capacidad de pasajeros con el fin de aprovechar las economías de escala asociadas al tamaño del buque. Ejemplos de esta tendencia son el Proyecto Génesis desarrollado por la naviera Royal Caribbean International, propietaria de los barcos Oasis of the Seas y Allure of the Seas; los de mayor tamaño del mundo, con una capacidad de 5.400 pasajeros cada uno (RCCL, 2007); y el Norwegian Epic propiedad de Norwegian Cruise Line con una capacidad para 4.100 pasajeros (NCL, 2014). 
Las navieras son las encargadas de la explotación de los buques de crucero, así como, de invertir en la construcción de nuevos buques a los cuales se le asociarán itinerarios a cubrir. El mercado de navieras de crucero está caracterizado durante los últimos años por adquisiciones agresivas, estrategias de internacionalización y concentración de corporaciones empresariales (Gui y Russo, 2011). De ahí el notable carácter oligopolístico que tiene actualmente (Lekakou et al., 2009), estructurado en cuatro grupos, de los cuales tres son grupos multimarca que aglutinan varias navieras y el cuarto grupo lo conforman navieras independientes. El grupo de Las Tres Grandes lo componen las corporaciones empresariales Carnival Corporation \& plc, Royal Caribbean Cruises Limited y Genting Hong Kong Limited. La cuota asociada a los grupos anteriores en octubre de 2014 fue la siguiente; los tres grupos multimarca conocidos como Las Tres Grandes (The Big Three en terminología inglesa) controlaban el $78,47 \%$ de la capacidad total de pasajeros de crucero, mientras el 21,53\% restante estaba en manos de las líneas de cruceros independientes, véase Tabla 3.1. El desarrollo de los sucesivos sub-apartados está dedicado a la determinación de las características de la flota de cada una de las navieras de crucero.

Tabla 3.1: Número de buques, capacidad de pasajeros y cuota de mercado asociada a cada naviera de crucero

\begin{tabular}{|c|c|c|c|}
\hline Naviera/Grupo & $N^{0}$ de Buques & Capacidad de pasajeros & $\begin{array}{c}\text { Cuota de mercado } \\
\qquad(\%)\end{array}$ \\
\hline Carnival Cruise Line & 24 & 62.352 & 13,59 \\
\hline Princess Cruises & 18 & 43.750 & 9,54 \\
\hline Costa Cruises & 15 & 39.308 & 8,57 \\
\hline Holland America Line & 15 & 23.521 & 5,13 \\
\hline AIDA Cruises & 10 & 18.636 & 4,06 \\
\hline P\&O Cruises & 7 & 14.592 & 3,18 \\
\hline Cunard Line & 3 & 6.726 & 1,47 \\
\hline P\&O Cruises Australia & 3 & 5.770 & 1,26 \\
\hline Iberocruceros & 3 & 5.565 & 1,21 \\
\hline Seabourn Cruise Line & 5 & 1.766 & 0,38 \\
\hline Carnival Corporation \& plc & 103 & 221.986 & 48,39 \\
\hline Royal Caribbean International & 21 & 59.822 & 13,04 \\
\hline Celebrity Cruises & 11 & 24.476 & 5,34 \\
\hline Pullmantur & 3 & 6.960 & 1,52 \\
\hline Croisières de France & 2 & 3.656 & 0,80 \\
\hline Azamara Cruises & 2 & 1.388 & 0,30 \\
\hline Royal Caribbean Cruises Limited & 39 & 96.302 & 20,99 \\
\hline Norwegian Cruise Line & 13 & 34.401 & 7,50 \\
\hline Star Cruises & 5 & 7.304 & 1,59 \\
\hline Genting Hong Kong Limited & 18 & 41.705 & 9,09 \\
\hline MSC Cruises & 12 & 30.557 & 6,66 \\
\hline Disney Cruise Line & 4 & 13.400 & 2,92 \\
\hline
\end{tabular}




\begin{tabular}{|c|c|c|c|}
\hline Naviera/Grupo & $N^{0}$ de Buques & Capacidad de pasajeros & $\begin{array}{c}\text { Cuota de mercado } \\
(\%)\end{array}$ \\
\hline Hurtigruten & 12 & 7.721 & 1,68 \\
\hline Thomson Cruises & 5 & 7.020 & 1,53 \\
\hline TUI Cruises & 3 & 6.342 & 1,38 \\
\hline Oceania Cruises & 5 & 4.552 & 0,99 \\
\hline Fred Olsen Cruise Lines & 4 & 3.963 & 0,86 \\
\hline Louis Cruises & 3 & 3.509 & 0,76 \\
\hline Phoenix Reisen & 3 & 2.612 & 0,57 \\
\hline Silversea Cruises & 8 & 2.248 & 0,49 \\
\hline Cruise \& Maritime Voyages & 3 & 2.100 & 0,46 \\
\hline $\begin{array}{l}\text { Portuscale Cruises } \\
\text { (Ex. Classic International Cruises) }\end{array}$ & 4 & 2.033 & 0,44 \\
\hline Crystal Cruises & 2 & 1.992 & 0,43 \\
\hline Regent Seven Seas Cruises & 3 & 1.890 & 0,41 \\
\hline Hapag-Lloyd Cruises & 4 & 1.272 & 0,28 \\
\hline Celebration Cruise Line & 1 & 1.200 & 0,26 \\
\hline Saga Cruises & 2 & 1.148 & 0,25 \\
\hline Compagnie du Ponant & 4 & 856 & 0,19 \\
\hline Windstar Cruises & 4 & 814 & 0,18 \\
\hline Lindblad Expeditions & 7 & 653 & 0,14 \\
\hline Star Clippers & 3 & 567 & 0,12 \\
\hline $\begin{array}{l}\text { Voyages of Discovery } \\
\text { (All Leisure Holidays) }\end{array}$ & 1 & 556 & 0,12 \\
\hline Paul Gauguin Cruises & 2 & 420 & 0,09 \\
\hline $\begin{array}{l}\text { Swan Hellenic } \\
\text { (All Leisure Holidays) }\end{array}$ & 1 & 350 & 0,08 \\
\hline Voyages to Antiquity & 1 & 350 & 0,08 \\
\hline Seadream Yacht Club & 2 & 220 & 0,05 \\
\hline Pearl Seas Cruises & 1 & 210 & 0,05 \\
\hline Blount Small Ship Adventures & 2 & 176 & 0,04 \\
\hline $\begin{array}{l}\text { Hebridean Island Cruises } \\
\text { (All Leisure Holidays) }\end{array}$ & 1 & 50 & 0,01 \\
\hline Navieras independientes & 107 & 98.781 & 21,53 \\
\hline Total & 267 & 458.774 & 100,00 \\
\hline
\end{tabular}

Fuente: Elaboración propia basada parcialmente en datos de Cruise Market Watch (2014b).

\subsubsection{Grupo Carnival Corporation \& plc}

El grupo Carnival Corporation \& plc es el de mayor dimensión de Las Tres Grandes en términos de flota, capacidad de pasajeros y número de navieras que aglutina, véase Tabla 3.1. En concreto, concentra el $48,39 \%$ de la capacidad de pasajeros a bordo de buques de 
crucero (221.986 pasajeros). Este grupo lo componen un total de diez navieras, véase Tabla 3.1 y 3.2 , con una flota asociada de 103 buques.

Tabla 3.2: Navieras de crucero pertenecientes al grupo Carnival Corporation $\&$ plc

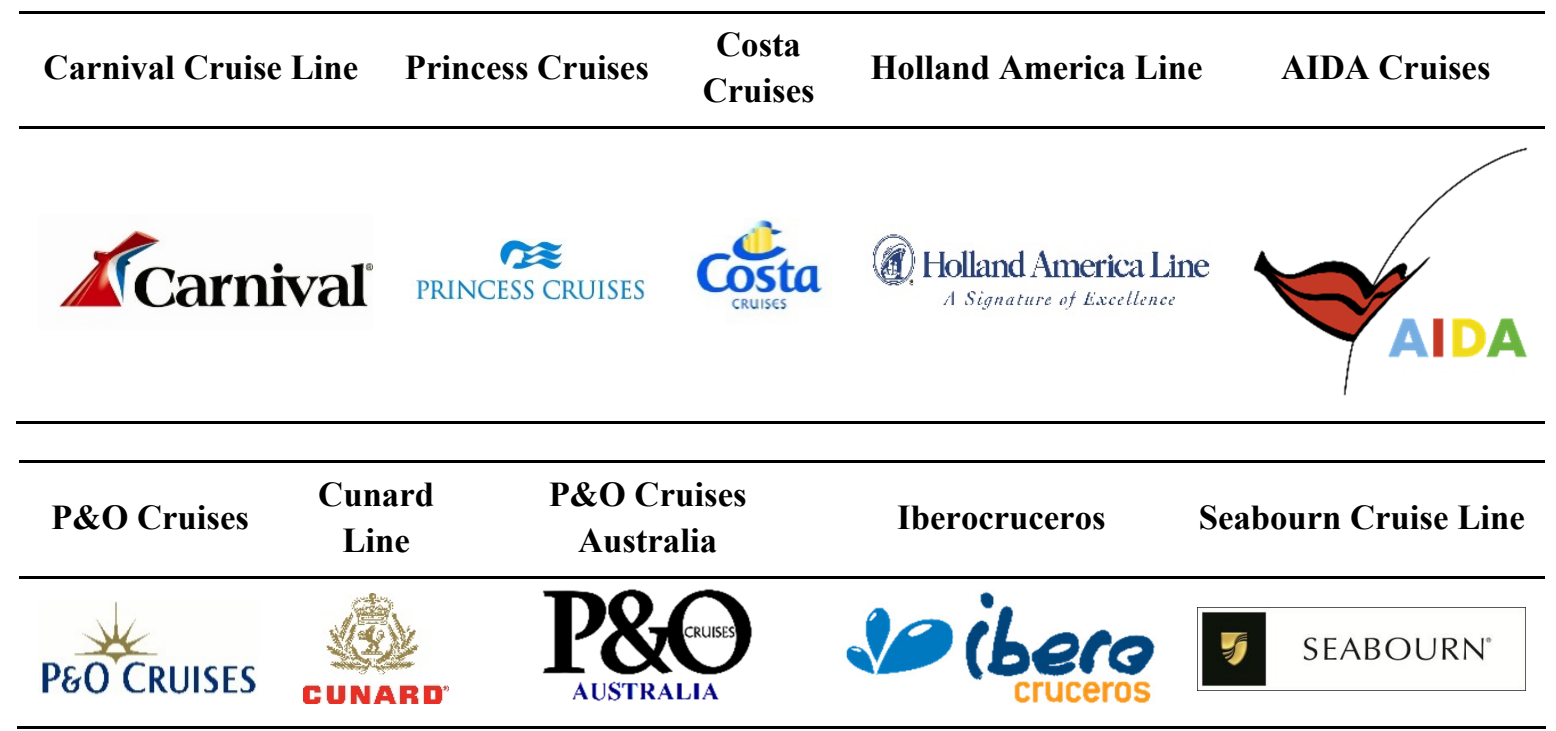

Fuente: Elaboración propia basada en datos de Carnival Corporation (2013).

Carnival Corporation \& plc abarca un amplio espectro de navieras en lo que a tamaño, segmento y estructura de la flota se refiere. En relación con el primer concepto, representando gráficamente la capacidad de pasajeros y el número de buques de cada una de las navieras que integran está corporación empresarial se identifican tres segmentos de tamaño, véase Gráfico 3.1. Los tres segmentos son: superior, capacidad igual o superior a 50.000 pasajeros; central, capacidad igual o superior a 10.000 pasajeros y menor a 50.000 pasajeros; e inferior, capacidad menor a 10.000 pasajeros. En el segmento superior se encuentra una sola naviera, Carnival Cruise Line, ésta es la compañía de cruceros de mayores dimensiones a nivel mundial, tanto en términos de capacidad 13,59\% (62.352 pasajeros) como de flota, siendo, a su vez, el líder del grupo Carnival con una cuota de $28,09 \%$. Esta naviera está orientada al mercado norteamericano.

En el segmento central se sitúan cinco navieras, dos de ellas orientadas, fundamentalmente, al mercado norteamericano (Princess Cruises y Holland America Line) y tres al mercado europeo (Costa Cruises, AIDA Cruises y $P \& O$ Cruises). La combinación de navieras en el segmento central pone de relieve las estrategias de internacionalización que han caracterizado el mercado de navieras con la adquisición de navieras orientadas a los principales países emisores europeos. Princess Cruises es la segunda compañía de mayor tamaño dentro del grupo Carnival, 19,71\% de la capacidad total (43.750 pasajeros), y la tercera más grande a nivel mundial, 9,54\%, en capacidad. Costa Cruises es la compañía de cruceros líder en Europa. En términos de capacidad es la tercera del grupo Carnival, 17,71\% (39.308 pasajeros) y la cuarta a nivel mundial, 8,57\%. Holland America Line (HAL) con su capacidad actual de 23.521 pasajeros, convierten a esta naviera en la cuarta del grupo Carnival, 10,60\%, y la octava, 5,13\%, a nivel mundial. AIDA Cruises es la marca líder y con mayor reconocimiento en el mercado emisor alemán. La capacidad de 18.636 pasajeros 
asociada a sus diez buques le confiere el quinto puesto dentro del grupo Carnival, 8,40\%, y el noveno a nivel mundial, 4,06\%. P\&O Cruises orientada al mercador emisor de Reino Unido tiene una capacidad asociada de 14.592 pasajeros, la cual le otorga el sexto puesto dentro del grupo Carnival, 6,57\%, y el décimo a nivel mundial, 3,18\%.

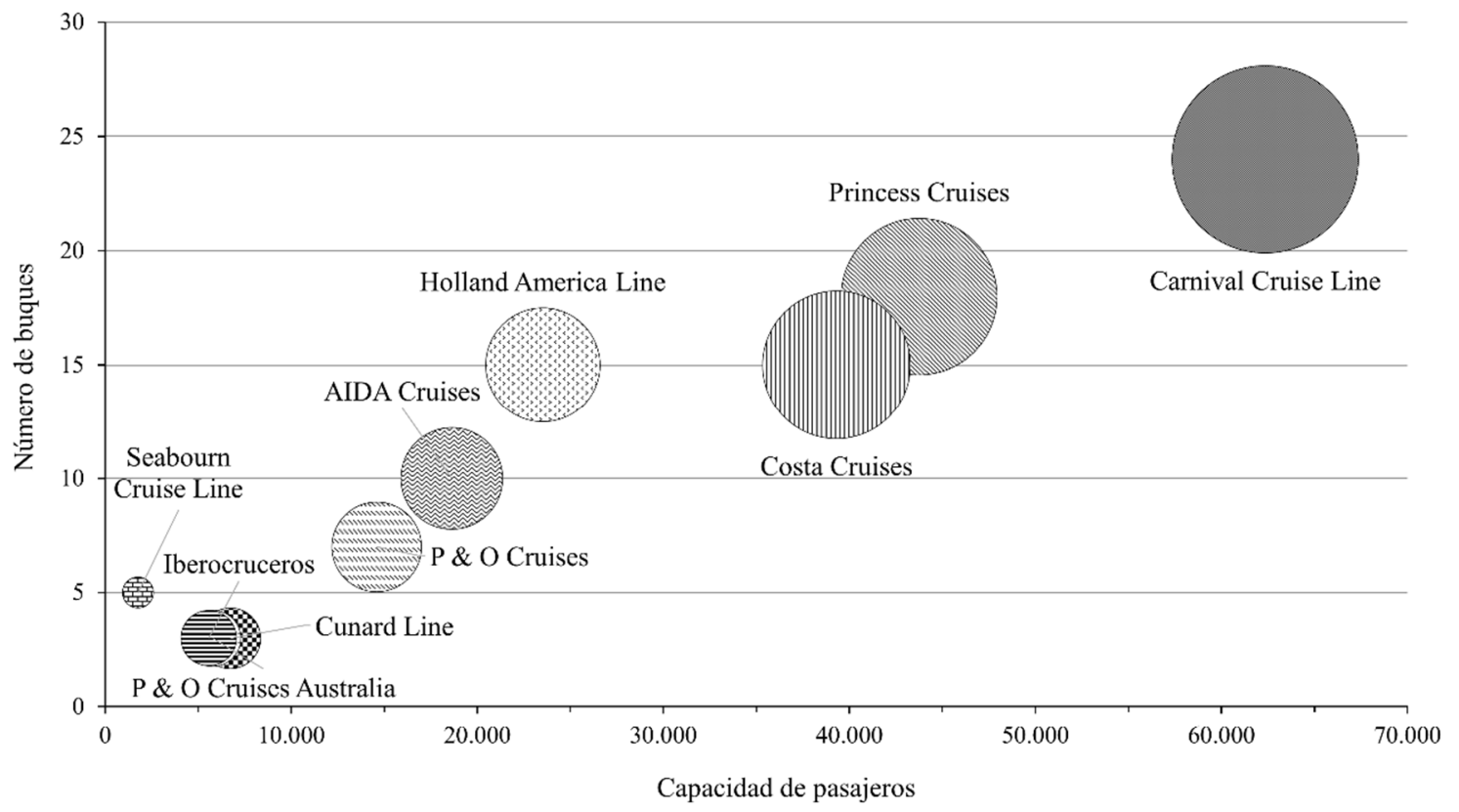

Gráfico 3.1: Relación capacidad de pasajeros vs número de buques de la flota de las navieras de Carnival Corporation \& plc.

Fuente: Elaboración propia.

En el segmento inferior, se encuadran cuatro navieras. Entre éstas se encuentran las dos navieras de la corporación enmarcadas en el segmento de lujo y ultra-lujo, Cunard Line y Seabourn Cruise Line, respectivamente. Por otro lado, hay una naviera orientada al mercado emisor europeo y más en concreto el español, Iberocruceros. Así como, una naviera orientada a uno de los principales mercados emergentes como emisor y destino actualmente, Australia, con la presencia de $P \& O$ Cruises Australia.

Respecto a la estructura de las flotas, éstas están compuestas fundamentalmente de buques de tamaño grande y mega-buques de crucero, véase Tabla 3.3, con la excepción de los buques enmarcados en el segmento de ultra-lujo, los cuales son de pequeño tamaño (las características de los diversos tamaños de buques de crucero están definidas en el Capítulo II, apartado 6). Además, la edad media de las flotas oscila desde los 6,9 años, correspondiente a AIDA Cruises, a 24,3 años en el caso de $P \& O$ Cruises Australia. En este sentido, se observa una transferencia de buques, bien adquiriendo su propiedad o en régimen de fletamento, desde las navieras de mayor tamaño del grupo a las situadas en el segmento inferior, y más en concreto, a Iberocruceros y $P \& O$ Cruises Australia. Los buques transferidos por lo general son de avanzada edad, y además, la transferencia suele coincidir con la incorporación de un buque de nueva construcción en la naviera que se desprende del de avanzada edad. También se han registrado movimientos de buques procedentes de otras navieras que no forman parte de Carnival Corporation. En el Anexo I, apartado 1, se pueden consultar los 
pormenores de la flota de cada una de las diez navieras pertenecientes al grupo Carnival Corporation, así como, el historial de los buques que han sido explotados por varias navieras.

Tabla 3.3: Estructura de la flota del grupo Carnival Corporation \& plc atendiendo al segmento de mercado y geográfico, edad media y composición por tamaños de buque

\begin{tabular}{|c|c|c|c|c|}
\hline Naviera & $\begin{array}{l}\text { Segmento de } \\
\text { mercado }\end{array}$ & $\begin{array}{l}\text { Segmento } \\
\text { geográfico }\end{array}$ & $\begin{array}{l}\text { Edad media de } \\
\text { la flota (años) }\end{array}$ & $\begin{array}{l}\text { Tamaño de } \\
\text { buques }\left(\mathbf{N}^{0}\right)\end{array}$ \\
\hline \multirow{2}{*}{ Carnival Cruise Line } & \multirow{2}{*}{ Contemporary } & \multirow{2}{*}{ Norteamericano } & \multirow{2}{*}{13,2} & Grandes (12) \\
\hline & & & & Mega-buques (12) \\
\hline \multirow{3}{*}{ Princess Cruises } & \multirow{3}{*}{ Premium } & \multirow{3}{*}{ Norteamericano } & \multirow{3}{*}{11,6} & Medianos (2) \\
\hline & & & & Grandes (10) \\
\hline & & & & Mega-buques (6) \\
\hline \multirow{2}{*}{ Costa Cruises } & \multirow{2}{*}{ Contemporary } & \multirow{2}{*}{ Europeo } & \multirow{2}{*}{10,6} & Grandes (10) \\
\hline & & & & Mega-buques (5) \\
\hline \multirow{2}{*}{ Holland America Line } & \multirow{2}{*}{ Premium } & \multirow{2}{*}{ Norteamericano } & \multirow{2}{*}{13,5} & Medianos (4) \\
\hline & & & & Grandes (11) \\
\hline \multirow{2}{*}{ AIDA Cruises } & \multirow{2}{*}{ Contemporary } & \multirow{2}{*}{ Europeo } & \multirow{2}{*}{6,9} & Medianos (3) \\
\hline & & & & Grandes (7) \\
\hline \multirow{2}{*}{$P \& O$ Cruises } & \multirow{2}{*}{ Contemporary } & \multirow{2}{*}{ Europeo } & \multirow{2}{*}{11,0} & Medianos (1) \\
\hline & & & & Grandes (6) \\
\hline Cunard Line & Lujo & Europeo & 7,0 & Grandes (3) \\
\hline \multirow{2}{*}{ P\&O Cruises Australia } & \multirow{2}{*}{ Contemporary } & Australiano & \multirow{2}{*}{24,3} & \multirow{2}{*}{ Grandes (3) } \\
\hline & & Asiático & & \\
\hline Iberocruceros & Contemporary & Europeo & 23,7 & Grandes (3) \\
\hline Seabourn Cruise Line & Ultra-lujo & Norteamericano & 11,8 & Pequeños (5) \\
\hline
\end{tabular}

Fuente: Elaboración propia basada en datos de Carnival Corporation (2013).

Otro aspecto asociado a la estructura de la flota alude al segmento en el que se encuadra la naviera desde el punto de vista del mercado (las características de los diversos segmentos de mercado están definidas en el Capítulo II, apartado 7) y desde el punto de vista geográfico. Respecto al primer parámetro, el grupo Carnival Corporation abarca todo el espectro de segmentos, pues aglutina navieras de los segmentos: contemporary, premium, lujo y ultra-lujo. Esta característica permite ofrecer un crucero especializado para cada tipo de cliente. En cuanto al segmento geográfico, fundamentalmente, está orientada al mercado americano y europeo, pero también, con presencia en los mercados emergentes australiano y asiático.

\subsubsection{Grupo Royal Caribbean Cruises Limited}

El segundo grupo en importancia en el mercado de navieras de crucero es Royal Caribbean Cruises Limited (RCCL) con un 20,99\% de la capacidad mundial de pasajeros a bordo de buques de crucero (96.302 pasajeros), véase Tabla 3.1. Esta capacidad se reparte entre cinco navieras propiedad del grupo, véase Tabla 3.4, con una flota total de 39 buques. 
Tabla 3.4: Navieras de crucero pertenecientes al grupo Royal Caribbean Cruises Limited

\begin{tabular}{|c|c|c|c|c|}
\hline $\begin{array}{c}\text { Royal Caribbean } \\
\text { International }\end{array}$ & Celebrity Cruises & Pullmantur & Azamara Cruises & $\begin{array}{c}\text { Croisières de } \\
\text { France }\end{array}$ \\
\hline $\begin{array}{l}\text { 넌 RoyalCaribbean } \\
\text { INTER NATIONAL }\end{array}$ & Cel & pullmantur & & \\
\hline
\end{tabular}

Fuente: Elaboración propia basada en Royal Caribbean International (2013).

La dispersión de navieras en el grupo RCCL es más acusada que en el caso del grupo Carnival, véase Gráfico 3.2, aunque también aglutina varios tamaños y segmentos de mercado y geográficos. De forma análoga al caso de Carnival, las navieras están estructuradas en tres segmentos de tamaño. En el segmento superior se encuadra una sola naviera, Royal Caribbean International (RCI), ésta es la segunda naviera de cruceros a nivel mundial, tanto en capacidad, 13,04\% (59.822 pasajeros), como en flota ( 21 buques). Además de, la primera perteneciente a la corporación RCCL concentrando el $62,12 \%$ de la capacidad de pasajeros del grupo. En el segmento central se registra la mayor diferencia respecto al grupo Carnival, pues se encuadra una sola naviera en este segmento, Celebrity Cruises. La capacidad conjunta de 24.476 pasajeros de Celebrity Cruises, la sitúan como el séptimo operador mundial (5,34\%) y el segundo del grupo RCCL con una cuota del 25,42\%. Ambas navieras están orientadas al mercado norteamericano.

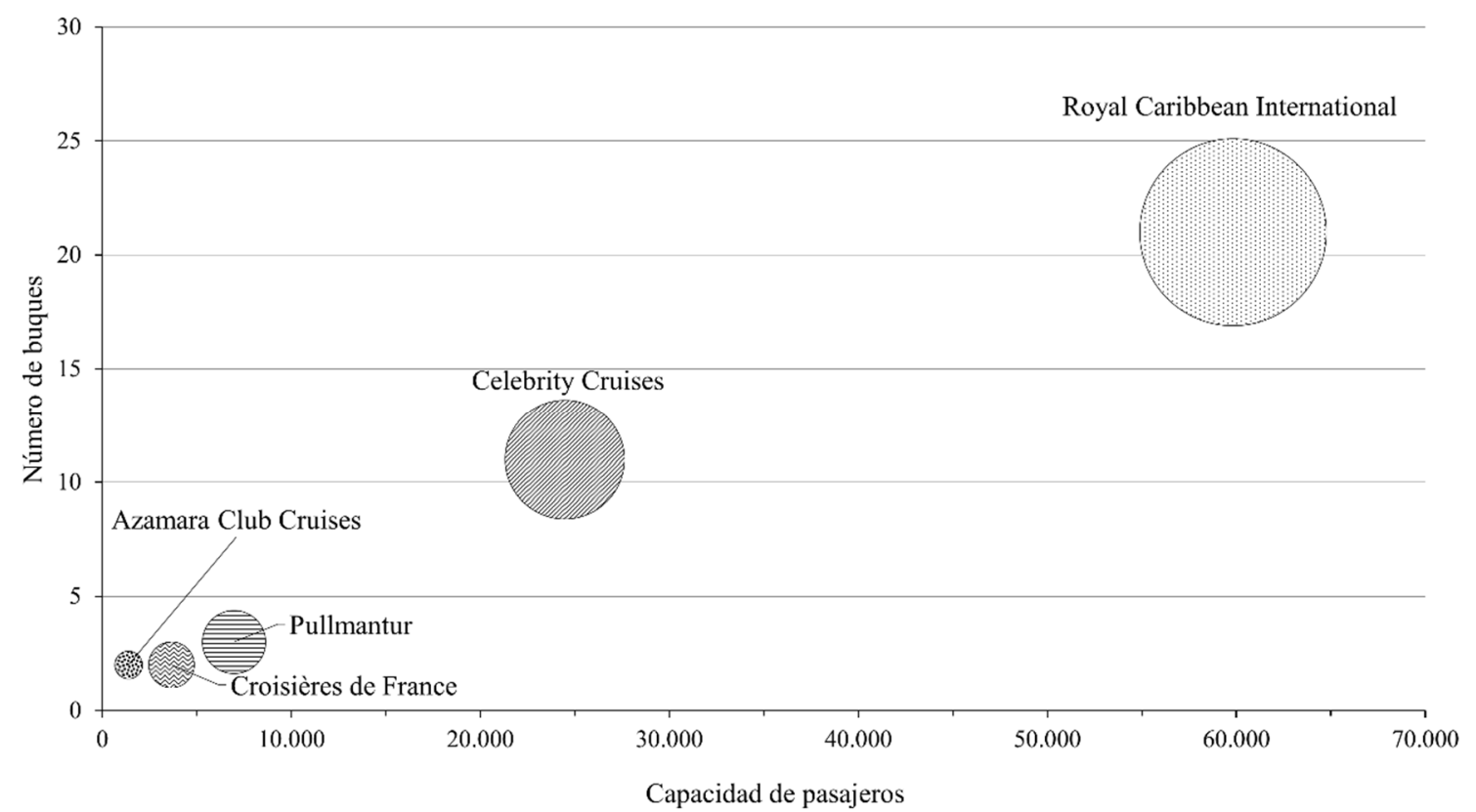

Gráfico 3.2: Relación capacidad de pasajeros vs número de buques de la flota de las navieras de Royal Caribbean Cruises Limited.

Fuente: Elaboración propia.

En el segmento inferior, capacidad menor de 10.000 pasajeros, están localizadas tres navieras especializadas. Dos de éstas están orientadas al mercado europeo, Pullmantur y Croisières de France (CDF), y más en concreto, a los mercados español y francés, 
respectivamente. Por lo que, también ha quedado patente en este grupo las estrategias de internacionalización y fusiones que caracterizan al mercado de navieras de crucero. La capacidad conjunta de la flota de Pullmantur de 6.960 pasajeros, le confieren la posición de tercera naviera del grupo por capacidad $(7,23 \%)$ y la decimoquinta a nivel mundial, con el $1,52 \%$ de la cuota mundial. La capacidad de CDF es ligeramente inferior, los dos buques de la flota otorgan a la naviera una cuota del $0,80 \%$ a nivel mundial, equivalente al 3,80\% dentro del grupo RCCL. La tercera naviera del segmento inferior, Azamara Club Cruises, también tiene un carácter especial, pues está encuadrada en el segmento de lujo. Ésta es la de menor tamaño del grupo RCCL con una cuota asociada del 1,44\% en términos de capacidad.

Las cinco flotas del grupo RCCL se dividen en tres segmentos de mercado, ofreciendo un crucero para cada tipo de cliente, pues abarca la totalidad de los segmentos desde contemporary hasta lujo, véase Tabla 3.5. Además, la flota se compone, fundamentalmente, de buques de gran tamaño y mega-buques de crucero, con la excepción de los dos buques medianos de Azamara Club Cruises orientados al segmento de lujo y un buque pequeño dedicado a cruceros de expedición de Celebrity Cruises.

De forma análoga al caso del grupo Carnival, la flota de las navieras encuadradas en el segmento inferior, con anterioridad, sus buques han sido explotados por otras navieras. En el caso de Pullmantur y CDF, sus buques formaban parte anteriormente de la flota de RCI y Celebrity Cruises, respectivamente. Además, la transferencia de buques entre navieras del mismo grupo, ha coincidido con la incorporación de buques de nueva construcción en RCI o Celebrity Cruises, de ahí la notable diferencia entre la edad media de la flota de las navieras situadas en los segmentos superior y central y las del segmento inferior. En el caso de Azamara Club Cruises, los dos buques de su flota tampoco son nuevas construcciones encargadas por la naviera, sino que fueron propiedad, en primer lugar, de Renaissance Cruises y posteriormente de Pullmantur, antes de adquirir su distintivo actual en Azamara. En el Anexo I, apartado 2, se pueden consultar las características de la flota de cada una de las navieras del grupo RCCL, así como, el historial detallado de los buques que han sido explotados por varias navieras.

Tabla 3.5: Estructura de la flota del grupo Royal Caribbean Cruises Limited atendiendo al segmento de mercado y geográfico, edad media y composición por tamaños de buque

\begin{tabular}{|c|c|c|c|c|}
\hline Naviera & $\begin{array}{l}\text { Segmento de } \\
\text { mercado }\end{array}$ & $\begin{array}{l}\text { Segmento } \\
\text { geográfico }\end{array}$ & $\begin{array}{l}\text { Edad media de } \\
\text { la flota (años) }\end{array}$ & $\begin{array}{l}\text { Tamaño de } \\
\text { buques }\left(\mathbf{N}^{o}\right)\end{array}$ \\
\hline $\begin{array}{l}\text { Royal Caribbean } \\
\text { International }\end{array}$ & Contemporary & Norteamericano & 12,8 & $\begin{array}{c}\text { Grandes (11) } \\
\text { Mega-buques (10) }\end{array}$ \\
\hline Celebrity Cruises & Premium & Norteamericano & 9,6 & $\begin{array}{c}\text { Pequeños (1) } \\
\text { Grandes (5) } \\
\text { Mega-buques (5) }\end{array}$ \\
\hline Pullmantur & Contemporary & Europeo & 24,3 & Grandes (3) \\
\hline Croisières de France & Contemporary & Europeo & 23,0 & Grandes (2) \\
\hline Azamara Club Cruises & Lujo & $\begin{array}{c}\text { Norteamericano } \\
\text { Europeo } \\
\text { Australiano }\end{array}$ & 24,0 & Medianos (2) \\
\hline
\end{tabular}

Fuente: Elaboración propia basada en datos de Royal Caribbean International (2013). 


\subsubsection{Grupo Genting Hong Kong Limited}

Genting Hong Kong Limited es una empresa líder en el sector hotelero, del ocio y el entretenimiento a nivel mundial, con actividades terrestres y marítimas. Centrando la atención en el sector marítimo, este grupo empresarial es propietario de la naviera de cruceros Star Cruises y en un 50\% de la naviera Norwegian Cruise Line (NCL), la cual es co-propiedad también de Apollo Management y TPG Capital, véase Tabla 3.6. Estas dos navieras, dan lugar al tercer grupo operador de cruceros, con una cuota mundial del 9,09\%, equivalente a una capacidad de 41.705 pasajeros y una flota de 18 buques.

Tabla 3.6: Navieras de crucero pertenecientes al grupo Genting Hong Kong Limited

Norwegian Cruise Line
NORW
CRUISE LINE
NCLIAN

Fuente: Elaboración propia basada en Genting Hong Kong Limited (2013).

Las dos navieras del grupo, se encuadran por tamaño, en el segmento central, Norwegian Cruise Line, y en el segmento inferior, Star Cruises, atendiendo a su relación entre la capacidad de pasajeros y el número de buques, véase Gráfico 3.3. La capacidad asociada a la flota de NCL de 34.401 pasajeros, le confiere el quinto puesto a nivel mundial, $7,50 \%$ de la capacidad total y el de mayor volumen dentro del grupo Genting Hong Kong Limited. Mientras que los cinco buques de Star Cruises otorgan a la naviera una capacidad de 7.304 pasajeros, acumulando el $1,59 \%$ de la cuota mundial.

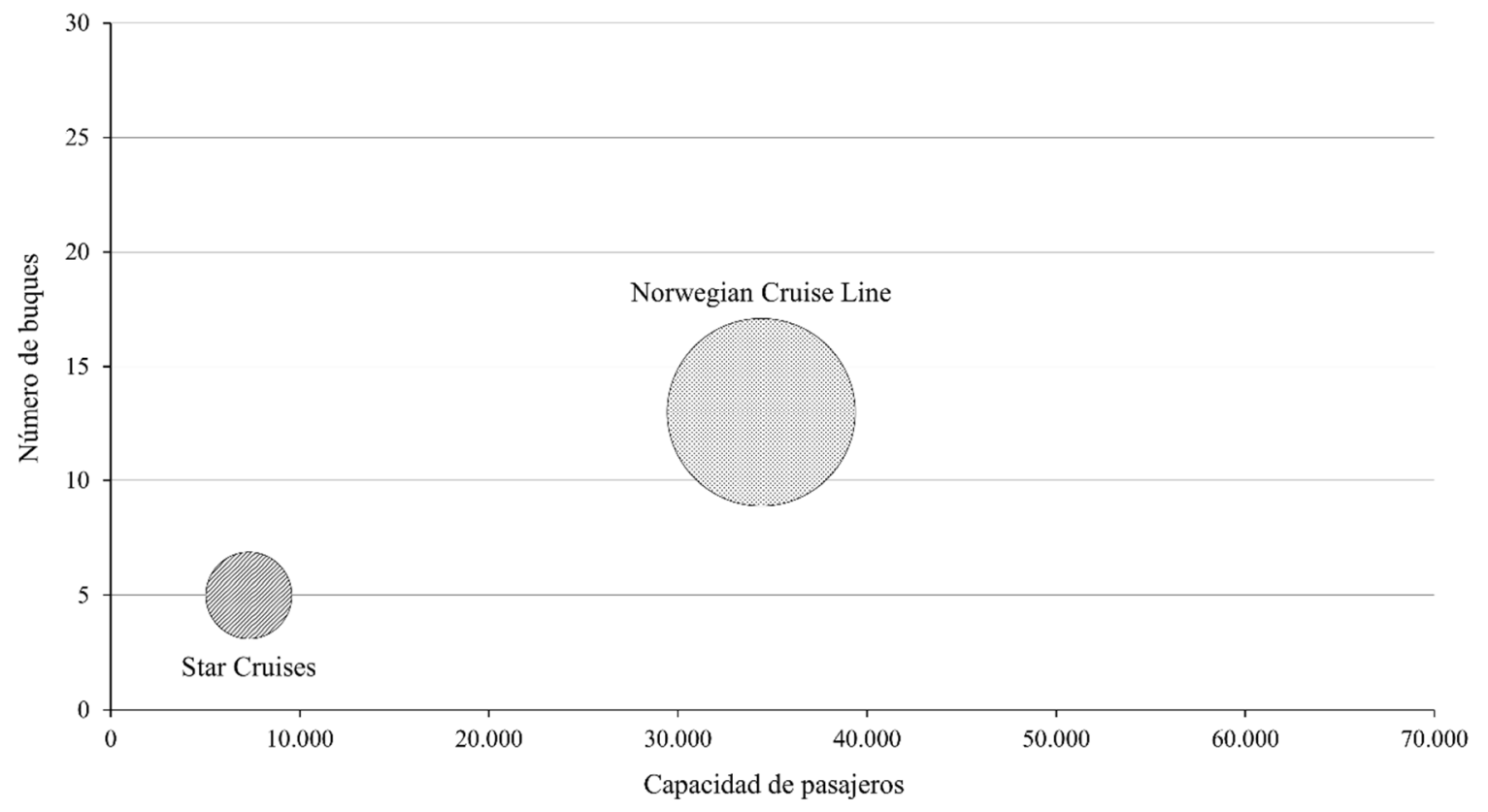

Gráfico 3.3: Relación capacidad de pasajeros vs número de buques de la flota de las navieras de Genting Hong Kong Limited.

Fuente: Elaboración propia. 
Las dos navieras se encuadran en el segmento contemporary, aunque difieren en el segmento geográfico, véase Tabla 3.7. NCL está orientada, fundamentalmente, al mercado norteamericano y en menor medida al europeo. Mientras Star Cruises focaliza su atención en el mercado de Asia-Pacífico. De forma análoga a los dos grupos analizados anteriormente, ambas flotas se componen de buques grandes y en el caso de NCL también de mega-buques de crucero. La flota de Star Cruises se compone de buques que con anterioridad han sido explotados por otras navieras. En concreto, tres de ellos fueron explotados anteriormente por NCL, además, otro de los buques, en su origen, era un buque tipo ferry y tras someterse a un proceso de transformación se adaptó a buque de crucero. En este aspecto radica la notable diferencia de edad media de las flotas, superando en doce años la flota de Star Cruises a la de NCL. En el Anexo I, apartado 3, se pueden consultar las características de los buques de la flota de NCL y Star Cruises, así como, su bagaje por diversas navieras en aquellos casos que sea de aplicación.

Tabla 3.7: Estructura de la flota del grupo Genting Hong Kong Limited atendiendo al segmento de mercado y geográfico, edad media y composición por tamaños de buque

\begin{tabular}{lcccc}
\hline Naviera & $\begin{array}{c}\text { Segmento de } \\
\text { mercado }\end{array}$ & $\begin{array}{c}\text { Segmento } \\
\text { geográfico }\end{array}$ & $\begin{array}{c}\text { Edad media de } \\
\text { la flota (años) }\end{array}$ & $\begin{array}{c}\text { Tamaño de } \\
\text { buques }\left(\mathbf{N}^{\mathbf{0}}\right)\end{array}$ \\
\hline Norwegian Cruise Line & Contemporary & $\begin{array}{c}\text { Norteamericano } \\
\text { Europeo }\end{array}$ & 9,6 & $\begin{array}{c}\text { Grandes (10) } \\
\text { Mega-buques (3) }\end{array}$ \\
\hline Star Cruises & Contemporary & Asia-Pacífico & 21,6 & $\begin{array}{c}\text { Medianos (1) } \\
\text { Grandes (4) }\end{array}$
\end{tabular}

Fuente: Elaboración propia basada en datos de Genting Hong Kong Limited (2013).

\subsubsection{Grupo de navieras independientes}

El 21,53\% restante de la cuota mundial de la capacidad instalada en cruceros se reparte, fundamentalmente, entre 29 navieras independientes en contraposición con el esquema de concentración empresarial descrito anteriormente. Este grupo lo componen navieras con las más variadas características, desde aquellas que ofertan itinerarios tradicionales a cruceros de expedición, pasando por navieras de ultra-lujo o provistas de buques moto-veleros.

El Gráfico 3.4 muestra la relación entre la capacidad de pasajeros y el número de buques para cada naviera. En este grupo predominan las navieras de pequeño tamaño con una flota inferior a cinco buques y menos de 5.000 pasajeros de capacidad conjunta, 24 de las 29 navieras se concentran en el segmento denominado de tamaño inferior en capacidad instalada. Además, se observa una fuerte diferencia de capacidad entre el primer operador independiente y el resto. El primero, MSC Cruises, aglutina una cuota dentro de este grupo del 30,93\%, seguido de Disney Cruise Line con un 13,57\%. En este sentido cabe apuntar, que las navieras de pequeño tamaño, como se ha podido comprobar anteriormente, tienen un carácter particular y especializado desde el punto de vista de los destinos que cubren, el 
servicio a bordo de sus buques, el mercado emisor en el que se centran o el segmento de edad al cual van dirigidos.

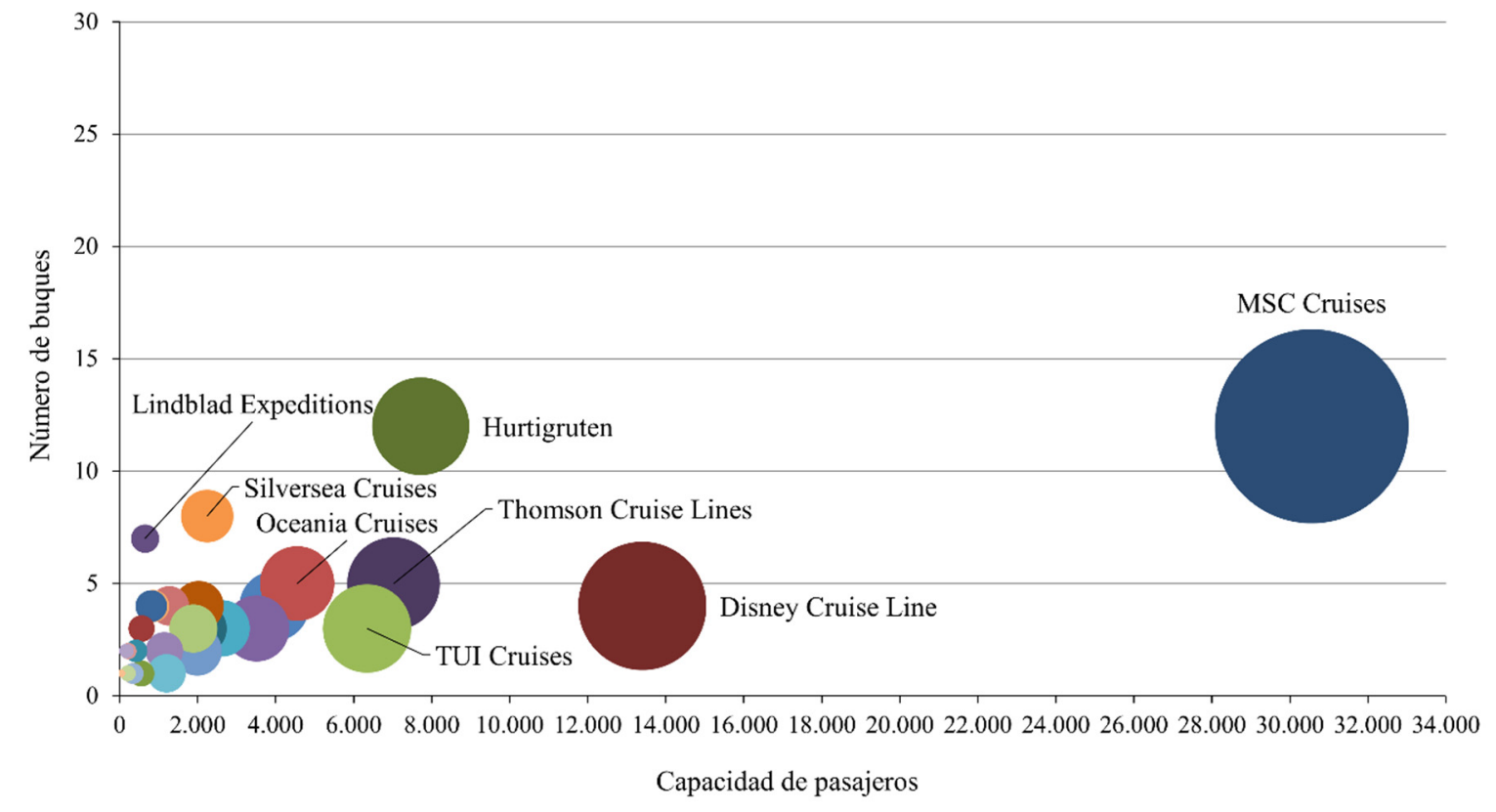

Gráfico 3.4: Relación capacidad de pasajeros vs número de buques de la flota de navieras independientes. Fuente: Elaboración propia.

Además, un denominador común de gran parte de las navieras de este grupo reside en la transferencia de buques entre navieras, bien adquiriéndolos o bajo contratos de fletamento por tiempo. Habitualmente, los buques que registran estas transferencias entre navieras son de avanzada edad. En la Tabla 3.8 se sintetizan las características más representativas de las 29 navieras que componen este grupo.

Enmarcadas en el segmento contemporary hay un total de ocho navieras. Entre éstas destacan MSC Cruises y Disney Cruise Line ya que son las que mayor cuota de mercado aglutinan y menor edad media de su flota. MSC Cruises dispone de una flota de doce buques, constituyendo una de las flotas de cruceros más jóvenes del mercado, con una edad media de 7,08 años. Su capacidad de 30.557 pasajeros la convierte en la sexta naviera de cruceros a nivel mundial con un $6,66 \%$ de la capacidad y la primera independiente. Mientras que Disney Cruise Line actualmente cuenta con una flota de cuatro buques, con una capacidad conjunta de 13.400 pasajeros, equivalente al 2,92\% de la capacidad mundial y el segundo operador independiente. Además, son las dos únicas navieras del grupo independiente que disponen en su flota de mega-buques de crucero, que les permiten alcanzar sus importantes capacidades agregadas. Ambas navieras focalizan su atención en el segmento europeo y norteamericano, respectivamente.

Las seis navieras restantes pertenecientes al segmento contemporary tienen una flota de avanzada edad y compuesta por buques que han sido explotados por otras navieras anteriormente. Además, están especializadas en una región en concreto dentro de un 
mercado emisor, como por ejemplo, en el mercado emisor británico para el caso de Thomson Cruises.

Asociadas al segmento premium hay siete navieras orientadas tanto al mercado emisor norteamericano, como especialmente a sectores específicos del mercado emisor europeo. TUI Cruises y Oceania Cruises destacan por su cuota de mercado y por disponer de las flotas de menor edad dentro de este segmento. TUI Cruises tiene una flota de tres buques, de 12 años de edad media, que confieren a la compañía una capacidad de 6.342 pasajeros, el 1,38\% mundial, y el quinto operador independiente. Mientras que la flota de Oceania Cruises la componen un total de cinco buques, con una capacidad conjunta de 4.552 pasajeros, el $0,99 \%$ del total mundial y el sexto operador independiente.

Tabla 3.8: Estructura de la flota del grupo de navieras independientes atendiendo al segmento de mercado y geográfico, edad media y composición por tamaños de buque

\begin{tabular}{|c|c|c|c|c|c|}
\hline Naviera & $\begin{array}{l}\text { Segmento de } \\
\text { mercado }\end{array}$ & $\begin{array}{l}\text { Segmento } \\
\text { geográfico }\end{array}$ & $\begin{array}{l}\text { Edad } \\
\text { media de } \\
\text { la flota } \\
\text { (años) }\end{array}$ & $\begin{array}{l}\text { Tamaño de } \\
\text { buques }\left(\mathrm{N}^{0}\right)\end{array}$ & Particularidades \\
\hline \multirow[b]{2}{*}{ MSC Cruises } & \multirow[b]{2}{*}{ Contemporary } & \multirow[b]{2}{*}{ Europeo } & \multirow[b]{2}{*}{7} & Grandes (8) & \\
\hline & & & & $\begin{array}{c}\text { Mega- } \\
\text { buques (4) }\end{array}$ & - \\
\hline \multirow[b]{2}{*}{$\begin{array}{l}\text { Disney Cruise } \\
\text { Line }\end{array}$} & \multirow[b]{2}{*}{ Contemporary } & \multirow[b]{2}{*}{ Norteamericano } & \multirow[b]{2}{*}{9,0} & Grandes (2) & \multirow[b]{2}{*}{-} \\
\hline & & & & $\begin{array}{c}\text { Mega- } \\
\text { buques (2) }\end{array}$ & \\
\hline Hurtigruten & Especializado & Europeo & 19,8 & $\begin{array}{l}\text { Medianos } \\
\text { (12) }\end{array}$ & $\begin{array}{c}\text { Cruceros por } \\
\text { Noruega y de } \\
\text { aventura/expedición }\end{array}$ \\
\hline $\begin{array}{l}\text { Thomson } \\
\text { Cruises }\end{array}$ & Contemporary & Europeo & 28,6 & $\begin{array}{l}\text { Medianos } \\
\text { (5) }\end{array}$ & $\begin{array}{l}\text { Mercado emisor } \\
\text { británico }\end{array}$ \\
\hline TUI Cruises & $\begin{array}{l}\text { Premium } \\
\text { superior }\end{array}$ & Europeo & 12,0 & Grandes (3) & $\begin{array}{c}\text { Mercado emisor } \\
\text { alemán }\end{array}$ \\
\hline Oceania Cruises & Premium & Norteamericano & 10,2 & $\begin{array}{l}\text { Medianos } \\
\text { (5) }\end{array}$ & $\begin{array}{c}\text { Destinos atípicos } \\
\text { Concepto } \\
\text { "Destination } \\
\text { Cruising" }\end{array}$ \\
\hline $\begin{array}{l}\text { Fred Olsen } \\
\text { Cruise Lines }\end{array}$ & Contemporary & Europeo & 32,5 & $\begin{array}{l}\text { Medianos } \\
\text { (4) }\end{array}$ & $\begin{array}{c}\text { Mercado emisor } \\
\text { británico }\end{array}$ \\
\hline Louis Cruises & Contemporary & Europeo & 37,3 & $\begin{array}{c}\text { Medianos } \\
\text { (2) } \\
\text { Grandes (1) }\end{array}$ & $\begin{array}{c}\text { Especialista en el } \\
\text { Mediterráneo } \\
\text { Oriental }\end{array}$ \\
\hline Phoenix Reisen & Premium & Europeo & 31,3 & $\begin{array}{c}\text { Medianos } \\
\text { (3) }\end{array}$ & $\begin{array}{c}\text { Mercado emisor } \\
\text { alemán }\end{array}$ \\
\hline $\begin{array}{l}\text { Silversea } \\
\text { Cruises }\end{array}$ & Ultra-lujo & Europeo & 18,1 & $\begin{array}{c}\text { Pequeños (5) } \\
\text { Medianos } \\
\text { (3) }\end{array}$ & Destinos exóticos \\
\hline $\begin{array}{l}\text { Cruise \& } \\
\text { Maritime } \\
\text { Voyages }\end{array}$ & Contemporary & Europeo & 39,7 & $\begin{array}{l}\text { Medianos } \\
\text { (3) }\end{array}$ & $\begin{array}{c}\text { Mercado emisor } \\
\text { británico } \\
\text { Concepto } \\
\text { "Child free" }\end{array}$ \\
\hline
\end{tabular}




\begin{tabular}{|c|c|c|c|c|c|}
\hline Naviera & $\begin{array}{l}\text { Segmento de } \\
\text { mercado }\end{array}$ & $\begin{array}{l}\text { Segmento } \\
\text { geográfico }\end{array}$ & $\begin{array}{c}\text { Edad } \\
\text { media de } \\
\text { la flota } \\
\text { (años) }\end{array}$ & $\begin{array}{c}\text { Tamaño de } \\
\text { buques }\left(\mathbf{N}^{\circ}\right)\end{array}$ & Particularidades \\
\hline $\begin{array}{l}\text { Portuscale } \\
\text { Cruises }\end{array}$ & Contemporary & Europeo & 56,8 & $\begin{array}{l}\text { Medianos } \\
\text { (4) }\end{array}$ & $\begin{array}{l}\text { Mercado emisor } \\
\text { portugués }\end{array}$ \\
\hline Crystal Cruises & Lujo & Norteamericano & 15,0 & $\begin{array}{l}\text { Medianos } \\
\text { (2) }\end{array}$ & $\begin{array}{l}\text { Cruceros temáticos, } \\
\text { concepto } \\
\text { "Experiences of } \\
\text { Discovery" }\end{array}$ \\
\hline $\begin{array}{l}\text { Regent Seven } \\
\text { Seas }\end{array}$ & Lujo & Norteamericano & 13,0 & $\begin{array}{l}\text { Pequeños (1) } \\
\text { Medianos } \\
\text { (2) }\end{array}$ & $\begin{array}{c}\text { Camarotes de } \\
\text { categoría suite en } \\
\text { su totalidad }\end{array}$ \\
\hline $\begin{array}{l}\text { Hapag Lloyd } \\
\text { Cruises }\end{array}$ & Lujo & Europeo & 18,3 & $\begin{array}{l}\text { Pequeños (3) } \\
\text { Medianos } \\
\text { (2) }\end{array}$ & $\begin{array}{l}\text { Mercado emisor } \\
\text { alemán } \\
\text { Cruceros de } \\
\text { expedición }\end{array}$ \\
\hline $\begin{array}{l}\text { Celebration } \\
\text { Cruise Line }\end{array}$ & Contemporary & Norteamericano & 33,0 & $\begin{array}{l}\text { Medianos } \\
\text { (1) }\end{array}$ & $\begin{array}{c}\text { Cruceros a } \\
\text { Bahamas }\end{array}$ \\
\hline Saga Cruises & Premium & Europeo & 33,0 & $\begin{array}{l}\text { Pequeños (1) } \\
\text { Medianos } \\
\text { (1) }\end{array}$ & $\begin{array}{c}\text { Mercado emisor } \\
\text { británico } \\
\text { Cruceros orientados } \\
\text { a personas de edad } \\
\text { superior o igual a } \\
50 \text { años }\end{array}$ \\
\hline $\begin{array}{l}\text { Compagnie du } \\
\text { Ponant }\end{array}$ & Lujo & Europeo & 7,80 & Pequeños (4) & $\begin{array}{l}\text { Destinos exóticos } \\
1 \text { buque motovelero }\end{array}$ \\
\hline $\begin{array}{l}\text { Windstar } \\
\text { Cruises }\end{array}$ & Lujo & Norteamericano & 26,3 & Pequeños (4) & $\begin{array}{c}\text { Destinos exóticos } \\
3 \text { buques } \\
\text { motoveleros }\end{array}$ \\
\hline $\begin{array}{l}\text { Lindblad } \\
\text { Expeditions }\end{array}$ & Especializada & - & - & Pequeños (7) & $\begin{array}{c}\text { Cruceros de } \\
\text { expedición } \\
\text { Destinos exóticos }\end{array}$ \\
\hline Star Clippers & Lujo & Norteamericano & 19,7 & Pequeños (3) & $\begin{array}{c}\text { Buques } \\
\text { motoveleros }\end{array}$ \\
\hline $\begin{array}{l}\text { Voyage of } \\
\text { Discovery }\end{array}$ & Premium & Europeo & 26,0 & $\begin{array}{l}\text { Medianos } \\
\text { (1) }\end{array}$ & $\begin{array}{l}\text { Destinos exóticos } \\
\text { Viajes históricos y } \\
\text { culturales }\end{array}$ \\
\hline $\begin{array}{l}\text { Paul Gauguin } \\
\text { Cruises }\end{array}$ & Lujo & Norteamericano & 16,5 & Pequeños (2) & $\begin{array}{l}\text { Destinos en el } \\
\text { Pacífico Sur }\end{array}$ \\
\hline Swan Hellenic & Premium & Europeo & 25,0 & Pequeños (1) & $\begin{array}{l}\text { Destinos exóticos } \\
\text { Viajes históricos y } \\
\text { culturales }\end{array}$ \\
\hline $\begin{array}{l}\text { Voyage of } \\
\text { Antiquity }\end{array}$ & Premium & Europeo & 41,0 & Pequeños (1) & $\begin{array}{l}\text { Mercado emisor } \\
\text { británico } \\
\text { Destinos exóticos }\end{array}$ \\
\hline $\begin{array}{l}\text { Pearl Seas } \\
\text { Cruises }\end{array}$ & Lujo & Norteamericano & 16,5 & Pequeños (1) & $\begin{array}{l}\text { Cruceros de } \\
\text { expedición }\end{array}$ \\
\hline
\end{tabular}




\begin{tabular}{|c|c|c|c|c|c|}
\hline Naviera & $\begin{array}{l}\text { Segmento de } \\
\text { mercado }\end{array}$ & $\begin{array}{l}\text { Segmento } \\
\text { geográfico }\end{array}$ & $\begin{array}{c}\text { Edad } \\
\text { media de } \\
\text { la flota } \\
\text { (años) }\end{array}$ & $\begin{array}{l}\text { Tamaño de } \\
\text { buques }\left(\mathbf{N}^{o}\right)\end{array}$ & Particularidades \\
\hline $\begin{array}{l}\text { Seadream Yacht } \\
\text { Club }\end{array}$ & Lujo & Norteamericano & 29,5 & Pequeños (2) & $\begin{array}{c}\text { Servicio } \\
\text { personalizado } \\
\text { Concepto "It's } \\
\text { Yachting, not } \\
\text { cruising" }\end{array}$ \\
\hline $\begin{array}{l}\text { Blount Small } \\
\text { Ship Adventure }\end{array}$ & Especializada & Norteamericano & 16,5 & Pequeños (2) & $\begin{array}{l}\text { Cruceros por Rhode } \\
\text { Island, Barrera de } \\
\text { Coral de Belice e } \\
\text { islas del Caribe }\end{array}$ \\
\hline $\begin{array}{l}\text { Hebridean } \\
\text { Island Cruises }\end{array}$ & Lujo & Europeo & 50,0 & Pequeños (1) & $\begin{array}{c}\text { Servicio } \\
\text { personalizado } \\
\text { Mercado emisor } \\
\text { británico }\end{array}$ \\
\hline
\end{tabular}

Fuente: Elaboración propia.

El segmento de lujo y ultra-lujo es el más numeroso con 11 navieras del grupo independiente pertenecientes a este segmento. El servicio personalizado y los destinos exóticos y atípicos que componen sus itinerarios son elementos asociados con frecuencia al segmento de lujo. Además, otro elemento diferenciador de tres navieras de este segmento reside en que disponen de buques con un sistema de propulsión mixto, a motor y a vela. También, la mayor parte de los buques son de pequeño tamaño, permitiéndoles un mayor acceso a puertos atípicos con limitaciones técnicas de entrada a buques de mayor porte. Silversea Cruises es la naviera de este segmento con mayor capacidad de flota, 2.248 pasajeros, equivalente al $0,49 \%$ del total mundial, décimo operador independiente.

Por último, las tres navieras restantes que completan el grupo de independientes tienen un carácter especializado en relación con el tipo y destino de los cruceros. Dos de ellas, Lindblad Expeditions y parcialmente Hurtigruten, están especializadas en cruceros de expedición. Por otro lado, Blount Small Ship Adventures y también parcialmente Hurtigruten están especializadas en un destino en concreto, no apto para buques de gran tamaño. En este aspecto radica la configuración de la flota de estas navieras, estructuradas en buques de pequeño tamaño excepto para Hurtigruten, pues son de mediano tamaño. Esta última naviera es la de mayor tamaño de entre las tres, sus doce buques le confieren una capacidad conjunta de 7.721 pasajeros, el $1,68 \%$ de la capacidad mundial, situándose como tercer operador independiente.

A nivel global gran parte de las navieras independientes cuentan con una flota compuesta de dos buques o incluso uno solo y de edad avanzada. Además, los buques suelen registrar un bagaje por varias navieras. La información detallada de las características de la flota de cada naviera independiente, junto con el historial de los buques que han formado parte de la flota de varias navieras a lo largo de su vida operativa, se incluye en el Anexo I, apartado 4 . 


\subsubsection{Análisis global de la flota de buques de crucero}

A partir de los resultados obtenidos en los apartados anteriores, se ha representado gráficamente la relación capacidad de pasajeros y número de buques de las 46 navieras de crucero analizadas, agrupadas por grupo al que pertenecen, con objeto de obtener una perspectiva de la ordenación de este mercado, véase Gráfico 3.5.

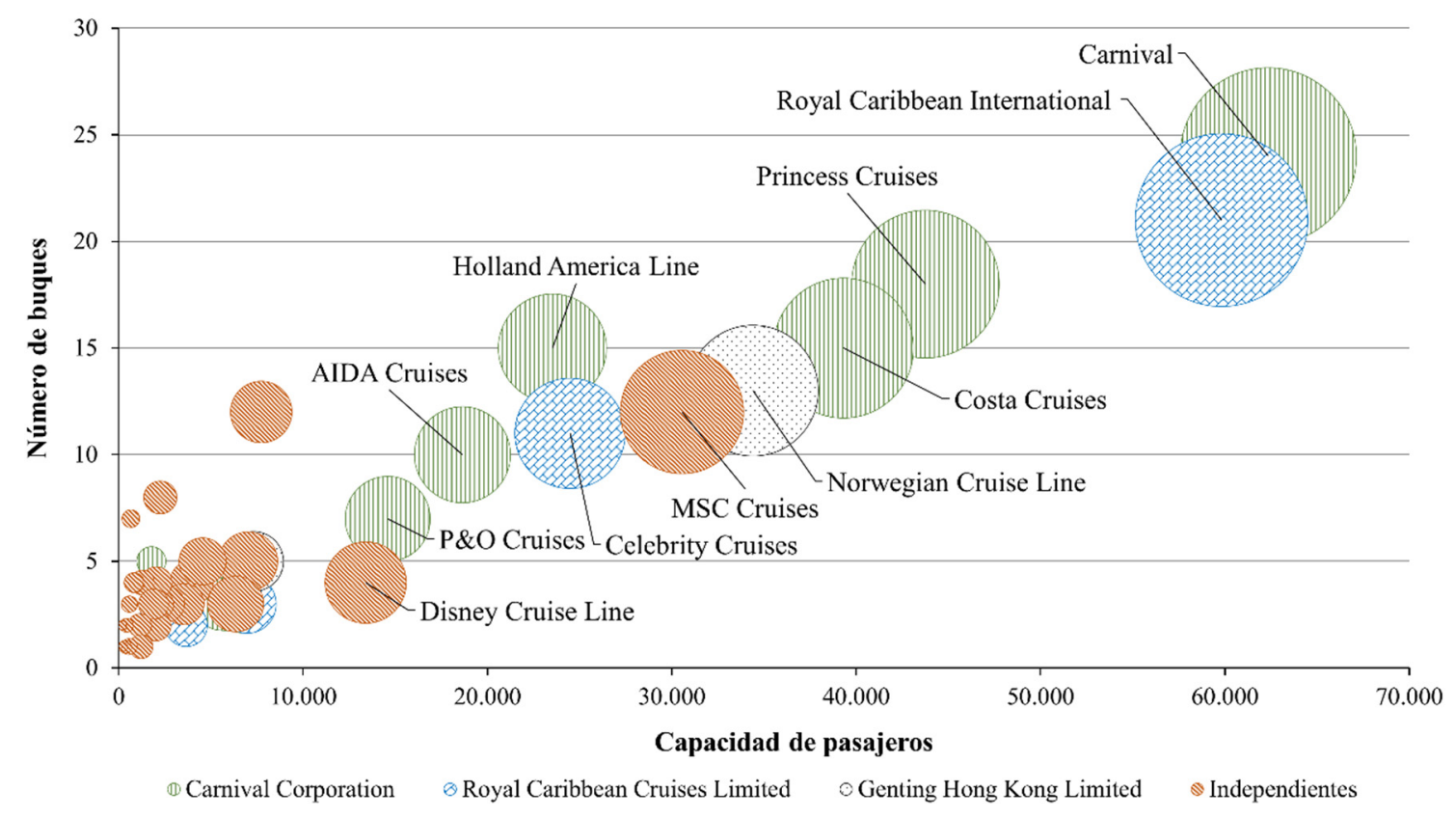

Gráfico 3.5: Relación capacidad de pasajeros vs número de buques por naviera, agrupadas por grupo al que pertenecen.

Fuente: Elaboración propia.

El mercado se puede dividir en tres segmentos por tamaño de la naviera. El segmento superior, capacidad igual o superior a 50.000 pasajeros, lo conforman Carnival y Royal Caribbean, cuyos tamaños marcan una notable diferencia respecto al siguiente segmento, el central. En el segmento central se sitúan las navieras con una capacidad de entre $10.000 \mathrm{y}$ 50.000 pasajeros. Este segmento está colonizado por navieras que pertenecen a Las Tres Grandes a excepción de dos, MSC Cruises y Disney Cruise Line, véase Gráfico 3.5. El grupo más numeroso se da en el segmento inferior, capacidad menor a 10.000 pasajeros. En éste coexisten tanto navieras independientes como las pertenecientes a alguna de Las Tres Grandes. En concreto, las navieras de este segmento de tamaño que forman parte de alguna de Las Tres Grandes tienen un perfil muy específico, tanto desde el punto de vista del mercado emisor en que focalizan su atención, como en el segmento de mercado en el que se encuadran, asociándose en este último aspecto al segmento de lujo. Esta ordenación pone de relieve las estrategias de adquisiciones y fusiones que han imperado en este mercado durante los últimos años. Por tanto, atendiendo a la distribución de tamaños y capacidades del mercado de navieras de crucero, el crecimiento de este mercado lo marcan Las Tres Grandes y en concreto las dos navieras de mayores dimensiones RCI y Carnival. 


\subsubsection{Otras características relevantes de la flota de buques de crucero}

Tras conocer la estructura del mercado de navieras atendiendo a su capacidad y composición de su flota, a continuación, se procede a analizar varios aspectos generales de la flota de buques de crucero. A fecha de octubre de 2014 la flota analizada está compuesta de 267 buques. Para cada uno de ellos se ha analizado el país de abanderamiento y el astillero de construcción. Junto a lo anterior, también se ha estudiado la cartera de pedidos de nuevas construcciones.

Comenzando por el país de abanderamiento, 13 pabellones registran la totalidad de la flota de cruceros, véase Gráfico 3.6. Bahamas es el país con mayor número de buques de crucero bajo su pabellón, $36 \%$ de la flota. Por ejemplo, la flota de Royal Caribbean y Seabourn Cruise Line enarbolan este pabellón. En segundo y tercer lugar se sitúan Panamá y Bermudas con el $13 \%$ y $11 \%$, respectivamente. Bajo estos registros se encuentran los buques de MSC Cruises y Princess Cruises, respectivamente. De tal forma que estos tres países abanderan el $60 \%$ de la flota mundial de cruceros. Éstos son conocidos en el panorama marítimo por su carácter de Pabellón de Conveniencia para numerosos armadores.

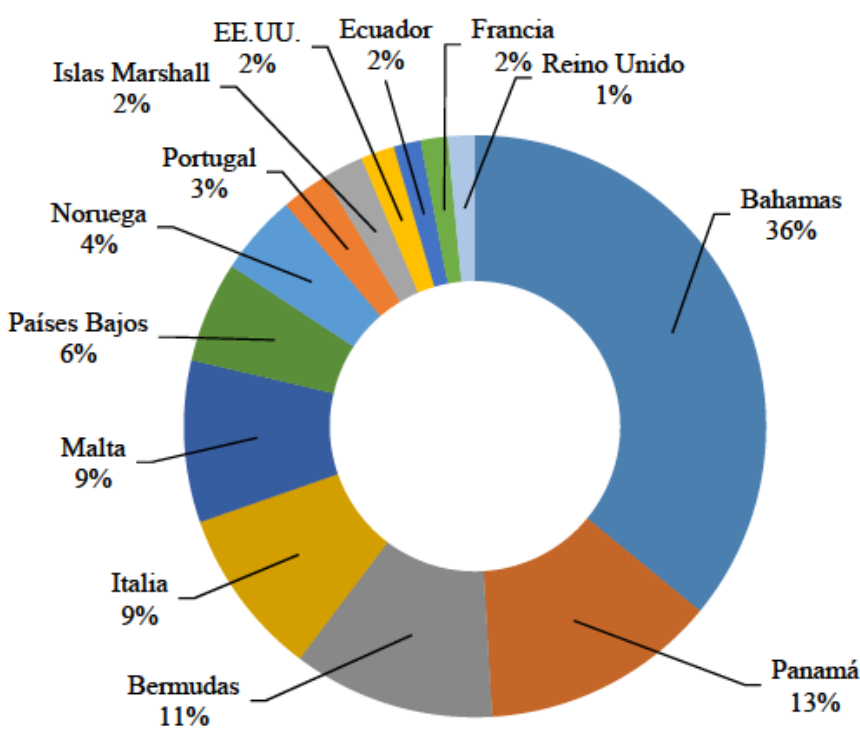

Gráfico 3.6: Distribución de pabellones en la flota mundial de buques de crucero.

Fuente: Elaboración propia.

De los pabellones asociados al $40 \%$ restante de flota, el 34\% corresponden a países europeos. En la mayoría de los casos, se asocia la flota de una sola naviera al porcentaje de abanderamiento registrado por un determinado pabellón. Malta e Italia lideran los abanderamientos de buques de crucero con un $9 \%$ en ambos casos. Malta forma parte de la Unión Europea desde el año 2004, históricamente ha sido considerada como Pabellón de Conveniencia, los buques que enarbolan este pabellón corresponden a Pullmantur, Azamara y varias navieras independientes de origen europeo, como por ejemplo, TUI Cruises. En el caso de Italia, los buques que enarbolan este pabellón están asociados a dos navieras del grupo Carnival únicamente, Costa Cruises y AIDA Cruises. 
Los porcentajes de abanderamiento de Países Bajos (6\%) y Noruega (5\%) corresponden íntegramente a la flota de las navieras Holland America Line y Hurtigruten respectivamente. Los tres países europeos restantes con buques de crucero enarbolando su pabellón, son, Portugal (3\%), Reino Unido (2\%) y Francia (1\%). Bajo pabellón portugués navegan los buques de Iberocruceros (grupo Carnival) y la flota de la recientemente creada Portuscale Cruises. En este caso cabe destacar que estos buques están adheridos al Registro Internacional de Buques de Madeira (MAR), que funciona como segundo registro de Portugal. Respecto a Francia, su cuota del 2\% está asociada a los cuatro buques de la flota de Compagnie du Ponant. Finalmente, en el caso de los buques abanderados en Reino Unido se trata de los tres buques de la flota de $P \& O$ Cruises Australia y el buque Hebridean Princess de Hebridean Island Cruises.

El 5\% restante se distribuye en un 2\% para EE.UU. e Islas Marshall y un 1\% para Ecuador. E1 2\% asociado a la bandera de Islas Marshall corresponde a la flota de Oceania Cruises y el buque de Pearl Seas Cruises. Por último, los buques que enarbolan pabellón de Ecuador realizan cruceros de expedición, y más en concreto, bien durante todo el año o por temporadas por las Islas Galápagos.

Los resultados presentados anteriormente están expresados en función del número de buques. Sin embargo, también resulta interesante conocer la distribución por pabellones de abanderamiento en función del tamaño de los buques, tomando como unidad el arqueo bruto, dada la diversidad de tamaños que existen.

Los tres primeros países de bandera permanecen invariables, dejando aún más patente, si cabe, el tamaño de la flota que abanderan, ya que, el 72,5\% de la flota mundial en términos de arqueo bruto, está bajo estos tres pabellones, véase Tabla 3.9. Malta registra una de las diferencias más llamativas atendiendo a la sexta posición que ocupa según este criterio de clasificación, respecto a la quinta posición por número de buques. En concreto, ha sido superada por Países Bajos, la cual bajo el anterior criterio ocupaba el sexto lugar. De tal forma que el tamaño de los buques registrados en Países Bajos tiene un tamaño medio superior a los que enarbolan pabellón maltés. También llamativo es el caso de Noruega, que ocupa el décimo lugar por arqueo bruto de la flota, frente al séptimo por número de buques. En este caso y como ya se ha comentado anteriormente, su porcentaje se atribuye a los buques de Hurtigruten, buques de pequeño tamaño y especializados varios de ellos en cruceros de expedición. Finalmente, los pabellones minoritarios de EE.UU., Francia y Ecuador además de disponer de un reducido número de buques enarbolando su bandera, éstos también son de pequeño tamaño, concentrando sobre todo buques de expedición y del segmento de lujo.

Tabla 3.9: Número de buques y arqueo bruto asociado a los pabellones de la flota de cruceros

\begin{tabular}{lccc}
\hline Pabellón & $\mathbf{N}^{\mathbf{0}}$ de buques & Arqueo bruto & \% arqueo bruto mundial \\
\hline Bahamas & 96 & 6.470 .311 & 37,14 \\
Panamá & 35 & 3.344 .365 & 19,20 \\
Bermudas & 30 & 2.730 .950 & 15,67
\end{tabular}




\begin{tabular}{lccc}
\hline Pabellón & $\mathbf{N}^{\mathbf{0}}$ de buques & Arqueo bruto & \% arqueo bruto mundial \\
\hline Italia & 25 & 2.001 .464 & 11,49 \\
Países Bajos & 15 & 1.011 .304 & 5,80 \\
Malta & 24 & 975.416 & 5,60 \\
Islas Marshall & 6 & 228.999 & 1,31 \\
Reino Unido & 4 & 206.582 & 1,19 \\
Portugal & 7 & 189.444 & 1,09 \\
Noruega & 12 & 136.234 & 0,78 \\
EE.UU. & 5 & 83.357 & 0,48 \\
Francia & 4 & 34.031 & 0,20 \\
Ecuador & 4 & 10.603 & 0,06 \\
Total & $\mathbf{2 6 7}$ & $\mathbf{1 7 . 4 2 3 . 0 6 0}$ & $\mathbf{1 0 0 , 0 0}$ \\
\hline
\end{tabular}

Fuente: Elaboración propia.

El siguiente aspecto analizado hace referencia al astillero constructor del buque. A pesar de que la construcción naval mercante ha estado en declive en Europa desde finales de los años 70, frente a la competencia de bajo coste de construcción en Asia y más concretamente en Corea del Sur y China, la industria europea ha retenido la cuota de mercado en un número de sectores especializados. El más importante de éstos es la construcción de buques de crucero, en el que la industria europea ha sido el líder mundial durante casi 50 años. De forma análoga a la concentración existente en el mercado de navieras de cruceros, en la construcción de buques de crucero también se da una fuerte concentración tanto geográfica como empresarial. Comenzando por el aspecto geográfico, Europa domina la construcción de buques de crucero, con una cuota sobre los buques que conforman la flota actual del 97,38\%. El porcentaje restante se distribuye en 1,87\% para Japón con la construcción de cuatro buques en el astillero Mitsubishi Heavy Industries, y un $0,75 \%$ a EE.UU. asociado a dos buques de pequeño tamaño de la naviera Blount Small Ships Adventures construidos en el astillero que dispone la familia propietaria de esta naviera.

Centrando la atención en la construcción naval en Europa, tres empresas concentran la construcción de buques de crucero, que son STX Europe, Fincantieri y Meyer Werft, con el 76,53\% de la flota actual construida en sus gradas, véase Tabla 3.10. Además, existe una fuerte localización geográfica, ya que los astilleros dedicados a la construcción de buques de crucero citados anteriormente se encuentran en Francia y Finlandia (STX Europe), Italia (Fincantieri) y Alemania (Meyer Werft).

El grupo STX Europe con sus factorías STX Finland Oy y STX France SA lidera la construcción mundial de cruceros. Si bien, cabe mencionar que, los 94 buques actualmente en servicio construidos en sus instalaciones, que representan más de 6,8 millones de GT de arqueo bruto, comprenden la totalidad de buques construidos por los astilleros del actual grupo STX Europe con sus diversas denominaciones a lo largo del tiempo. El grupo STX Europe, creado en 2006, tiene su origen en la fusión de dos grandes grupos de construcción naval Aker Yards y Alstom. Así mismo, Aker Yards también fue fruto de otra operación de fusión entre Kvaerner Masa Yards y Finnyards. El primero poseía factorías en Helsinki y Turku, anteriormente propiedad de Wartsila Marine Industries, mientras el segundo disponía 
de la factoría de Rauma-Repola. En cuanto a Alstom, bajo su control estaban la factoría de Chantiers de l'Atlantique en Saint Nazaire y otra adicional en Lorient.

Tabla 3.10: Número de buques y arqueo bruto asociado a los cruceros construidos por astilleros europeos

\begin{tabular}{lccc}
\hline Astillero & $\mathbf{N}^{\mathbf{0}}$ de buques & \% Buques & Arqueo bruto \\
\hline STX Europe & 94 & 36,15 & 6.858 .122 \\
Fincantieri & 66 & 25,38 & 5.811 .141 \\
Meyer Werft & 39 & 15,00 & 3.447 .419 \\
Mariotti & 9 & 3,46 & 258.667 \\
Bremer Vulkan & 4 & 1,54 & 200.775 \\
Ateliers et Chantiers du Havre & 3 & 1,15 & 26.184 \\
Fosen Mekaniske Verksteder, Norway & 3 & 1,15 & 43.632 \\
Howaldtswerke-Deutsche Werft (HDW) & 3 & 1,15 & 55.828 \\
Otros & 39 & 15,00 & 447.058 \\
Total & $\mathbf{2 6 0}$ & $\mathbf{1 0 0}$ & $\mathbf{1 7 . 1 4 8 . 8 2 6}$ \\
\hline
\end{tabular}

Fuente: Elaboración propia.

Fincantieri, de origen italiano, es el segundo constructor de buques de crucero a nivel mundial, con 66 buques de la flota actual construidos en sus gradas, lo cual equivale a más de 5,8 millones de GT de arqueo bruto. Este grupo de construcción naval dispone de factorías por toda la geografía mundial, sin embargo, aquellas dedicadas a la construcción de buques de crucero están emplazadas en Italia y más en concreto en, Monfalcone shipyards (Monfalcone, Trieste), Marghera shipyards (Marghera, Venecia) y Sestri Ponente shipyards (Sestri Ponente, Génova). En cuanto a Meyer Werft, es el tercer constructor de buques de crucero del mundo, con 39 buques de los que están navegando actualmente construidos en su factoría de Papenburg (Alemania).

La construcción de buques de crucero asociada al resto de astilleros se trata de buques de pequeño tamaño y en la mayoría de los casos, buques especializados no convencionales. Por ejemplo, los buques construidos por el astillero Mariotti (Génova, Italia) se trata de buques de crucero de lujo (Mariotti, 2013). Las navieras para las cuales ha construido buques de crucero son Seabourn Cruise Line, Regent Seven Seas y Silver Cruises, todas ellas operando en el segmento de cruceros de lujo. En esta misma línea de negocio, se situaba el astillero Ateliers et Chantiers du Havre, al cual se le encargó la construcción de los tres buques que conforman la flota de Wind Star Cruises, cuya principal característica es que disponen de propulsión mecánica y a vela, además de, estar enmarcados en el segmento de lujo. Este astillero cesó su actividad en 1999. En este punto cabe destacar que bajo el epígrafe "otros" se aglutinan astilleros que, por lo general, sólo han construido un buque y además éste es de avanzada edad. Incluso se da la circunstancia que varios de estos astilleros han desaparecido a día de hoy, o bien entre sus líneas de negocio no se encuentra actualmente la construcción de buques de crucero.

Con el fin de ahondar en el estudio, si se analiza el astillero constructor de los buques puestos en servicio desde el año 2000 a 2014 queda aún más patente la hegemonía mundial de los tres principales astilleros. Durante este periodo, se han incorporado a la flota mundial 
138 buques, que representan una capacidad de 310.652 pasajeros y más de 12,3 millones de GT de arqueo bruto. El 89\% de estos buques, véase Gráfico 3.7, han sido construidos por Fincantieri, STX Europe y Meyer Werft, equivalente a 11,8 millones de GT de arqueo bruto. Del total de 138 buques, únicamente dos, equivalente a 231.750 GT de arqueo bruto, han sido construidos en Asia y más en concreto en Japón por Mitsubishi Heavy Industries. A la luz de estas cifras se pone de manifiesto la concentración geográfica en Europa, y en particular en Italia, Francia, Alemania y Finlandia, en la construcción de buques de crucero por parte de tres astilleros.

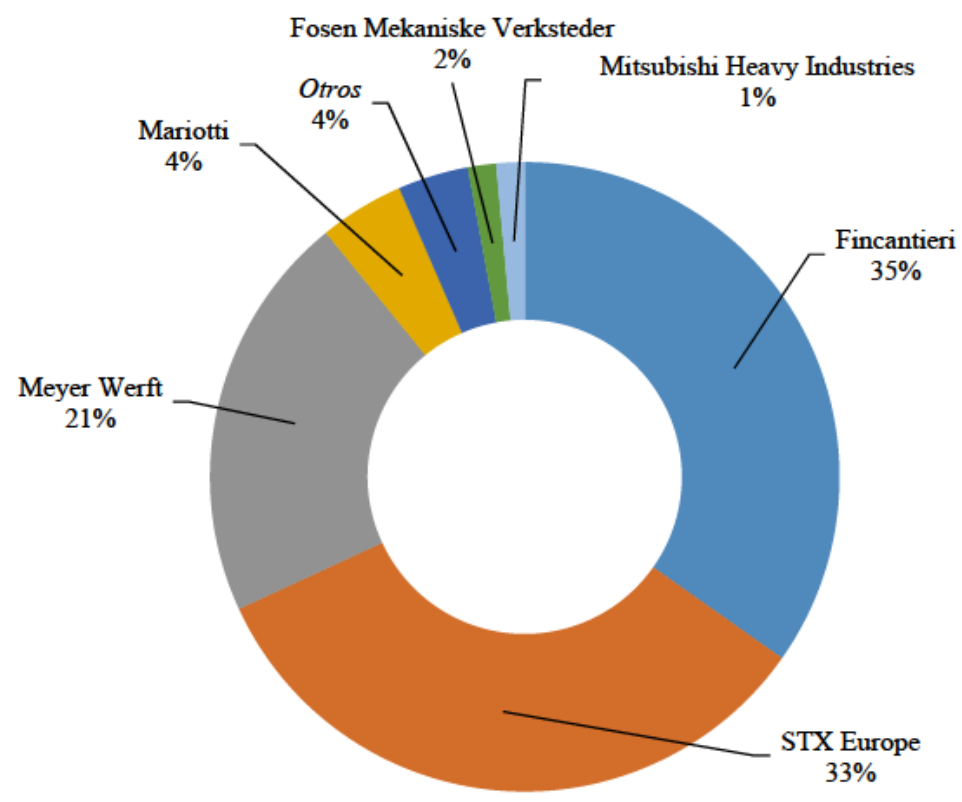

Gráfico 3.7: Distribución de la flota mundial de buques de crucero, puesta en servicio entre el año 2000 y 2014, por astillero de construcción.

Fuente: Elaboración propia.

Este patrón de concentración se presenta también en los buques que están en construcción o forman parte de la cartera de pedidos actualmente, véase Tabla 3.11. De los 30 buques de crucero que componen la cartera de pedidos actual, cuyas fechas de entrega comprenden desde noviembre de 2014 a octubre de 2019, únicamente dos están en construcción en Japón en la factoría, ya comentada, de Mitsubishi Heavy Industries (MHI). Los 28 buques restantes se reparten entre Fincantieri, Meyer Werft y STX Europe, con 12, 9 y 7 buques en cartera, respectivamente.

Además, los astilleros europeos también son líderes en la transformación de buques de crucero con obras asociadas a remodelaciones completas, sustitución de la planta propulsora y alargamientos de casco. Junto a lo anterior, la mayoría de los buques que sirven el mercado europeo realizan sus varadas en astilleros europeos. La excelente reputación de los astilleros europeos ha significado que las compañías de crucero estadounidenses continúan encargando buques en Europa a pesar de la debilidad del dólar estadounidense frente al euro (CLIA Europe, 2014). 
Tabla 3.11: Cartera de pedidos de nuevas construcciones de buques de crucero a octubre de 2014

\begin{tabular}{|c|c|c|c|c|c|c|}
\hline & $\begin{array}{l}\text { Nombre del } \\
\text { buque }\end{array}$ & Naviera & $\begin{array}{l}\text { Arqueo } \\
\text { Bruto }\end{array}$ & Astillero & $\begin{array}{c}\text { Capacidad } \\
\text { de pasajeros }\end{array}$ & $\begin{array}{c}\text { Fecha de } \\
\text { entrega } \\
\text { (mes/año) }\end{array}$ \\
\hline 1 & $\begin{array}{l}\text { Quantum of } \\
\text { the Seas }\end{array}$ & $\mathrm{RCI}$ & 167.800 & Meyer Werft & 4.100 & $11 / 14$ \\
\hline 1 & Le Lyrial & $\begin{array}{l}\text { Compagnie du } \\
\text { Ponant }\end{array}$ & 10.700 & Fincantieri & 264 & $04 / 15$ \\
\hline 2 & Britannia & $P \& O$ Cruises & 141.000 & Fincantieri & 3.611 & $03 / 15$ \\
\hline 3 & $\begin{array}{l}\text { Anthem of the } \\
\text { Seas }\end{array}$ & Royal Caribbean & 167.800 & Meyer Werft & 4.180 & $03 / 15$ \\
\hline 4 & Mein Schiff 4 & TUI Cruises & 99.700 & STX Europe & 2.500 & $04 / 15$ \\
\hline 5 & Viking Star & Viking Cruises & 47.800 & Fincantieri & 930 & $05 / 15$ \\
\hline 6 & AIDAprima & AIDA Cruises & 125.000 & MHI & 3.250 & $09 / 15$ \\
\hline 7 & $\begin{array}{l}\text { Norwegian } \\
\text { Escape }\end{array}$ & NCL & 164.600 & Meyer Werft & 4.200 & $10 / 15$ \\
\hline 1 & $\begin{array}{l}\text { Seven Seas } \\
\text { Explorer }\end{array}$ & RSSC & 54.000 & Fincantieri & 738 & $02 / 16$ \\
\hline 2 & Viking Sky & Viking Cruises & 47.800 & Fincantieri & 930 & $06 / 16$ \\
\hline 3 & Viking Sea & Viking Cruises & 47.800 & Fincantieri & 930 & $04 / 16$ \\
\hline 4 & Mein Schiff 5 & TUI Cruises & 99.700 & STX Europe & 2.500 & $02 / 16$ \\
\hline 5 & Koningsdam & HAL & 99.500 & Fincantieri & 2.660 & $02 / 16$ \\
\hline 6 & - & AIDA Cruises & 125.000 & MHI & 3.250 & $03 / 16$ \\
\hline 7 & $\begin{array}{l}\text { Carnival } \\
\text { Vista }\end{array}$ & $\begin{array}{c}\text { Carnival Cruise } \\
\text { Lines }\end{array}$ & 133.500 & Fincantieri & 4.000 & $04 / 16$ \\
\hline 8 & $\begin{array}{l}\text { Ovation of the } \\
\text { Seas }\end{array}$ & $\mathrm{RCI}$ & 167.800 & Meyer Werft & 4.180 & $05 / 16$ \\
\hline 9 & Oasis 3 & $\mathrm{RCI}$ & 227.700 & STX France & 5.400 & $06 / 16$ \\
\hline 10 & - & Seabourn Cruise Line & 40.350 & Fincantieri & 604 & $10 / 16$ \\
\hline 11 & - & Star Cruises & 150.000 & Meyer Werft & 3.364 & $10 / 16$ \\
\hline 1 & - & MSC Cruises & 167.600 & STX France & 4.500 & $01 / 17$ \\
\hline 2 & - & Princess Cruises & 143.000 & Fincantieri & 3.560 & $02 / 17$ \\
\hline 3 & Mein Schiff 6 & TUI Cruises & 99.700 & STX Europe & 2.500 & $02 / 17$ \\
\hline 4 & $\begin{array}{l}\text { Norwegian } \\
\text { Bliss }\end{array}$ & NCL & 164.600 & Meyer Werft & 4.200 & $04 / 17$ \\
\hline 5 & - & Star Cruises & 150.000 & Meyer Werft & 3.364 & $10 / 17$ \\
\hline 6 & - & MSC Cruises & 154.000 & Fincantieri & 4.140 & $10 / 17$ \\
\hline 1 & Oasis 4 & $\mathrm{RCI}$ & 227.700 & STX France & 5.400 & $02 / 18$ \\
\hline 2 & $\begin{array}{l}\text { Breakaway- } \\
\text { Plus }\end{array}$ & NCL & 164.600 & Meyer Werft & 4.200 & $04 / 18$ \\
\hline 3 & - & MSC Cruises & 154.000 & Fincantieri & 4.140 & $05 / 18$ \\
\hline 1 & - & MSC Cruises & 167.600 & STX France & 4.500 & $04 / 19$ \\
\hline 2 & $\begin{array}{l}\text { Breakaway- } \\
\text { Plus }\end{array}$ & NCL & 164.600 & Meyer Werft & 4.200 & $10 / 19$ \\
\hline
\end{tabular}

Fuente: Elaboración propia basada en datos de Cruise Market Watch (2014b) y Seatrade Insider (2014). 
Por otro lado, la actual cartera de pedidos hasta el año 2019 pone de nuevo de relieve la concentración de Las Tres Grandes pues 19 de los 30 barcos están encargados por alguna naviera de este grupo. En términos de capacidad, esta concentración supone el 71,1\% de la nueva capacidad que entrará en servicio hasta 2019. Dentro de Las Tres Grandes, Royal Caribbean International es la naviera que mayor incremento de flota registrará hasta 2019 con 5 buques, seguido de Norwegian Cruise Line con 4 y AIDA Cruises y Star Cruises con 2 buques cada una.

En el grupo de navieras independientes MSC Cruises lidera el crecimiento de la flota con cuatro buques seguido de TUI Cruises con tres. Las cuatro unidades encargadas por MSC Cruises representan el 62,1\% del incremento de capacidad que registrará el grupo de navieras independientes hasta 2019, equivalente al 17,9\% del total de la cartera de pedidos. Por tanto, este programa de nuevas construcciones consolida a MSC Cruises como el operador independiente de mayor tamaño. El caso de TUI Cruises también tendrá una notable repercusión pues la capacidad adicionada hasta 2019 supone el 26,9\% de la asociada a operadores independientes y el 7,8\% del total. Permitiendo a la naviera de origen alemán escalar un puesto en la clasificación tanto a nivel mundial como dentro del grupo de navieras independientes.

Durante el periodo del año 1990 a 2014, en los últimos catorce años se ha generado el mayor volumen de incorporaciones a la flota de buques de crucero. Tomando como referencia la capacidad de la flota en 2014, en términos de pasajeros, el 67,71\% de la capacidad actual ha sido adicionada entre el año 2000 y 2014. Los mayores incrementos se generaron en la década del año 2000 y particularmente en los periodos de 2001 a 2004, así como, de 2007 a 2010, véase Tabla 3.12. Además, el incremento de flota registrado en estos periodos también deja patente el aumento del tamaño de los buques puestos en servicio, por ejemplo, mediante el cálculo de la relación entre el arqueo bruto y la capacidad de pasajeros.

Tabla 3.12: Incremento de capacidad anual, en pasajeros, arqueo bruto y relación arqueo bruto/pasajero, de la flota mundial de buques de cruceros entre 1990 y 2014

\begin{tabular}{lccc}
\hline Año & $\begin{array}{c}\text { Incremento de capacidad } \\
\text { (pasajeros) }\end{array}$ & $\begin{array}{c}\text { Incremento de } \\
\text { arqueo bruto }\end{array}$ & $\begin{array}{c}\text { Relación } \\
\text { Arqueo bruto/Pasajero }\end{array}$ \\
\hline 1990 & 7.590 & 232.510 & 30,63 \\
1991 & 10.518 & 370.422 & 34,01 \\
1992 & 7.548 & 225.253 & 29,84 \\
1993 & 9.799 & 345.031 & 35,21 \\
1994 & 4.230 & 154.190 & 36,45 \\
1995 & 10.646 & 426.264 & 40,04 \\
1996 & 16.431 & 586.707 & 35,71 \\
1997 & 10.585 & 409.464 & 38,68 \\
1998 & 16.914 & 627.653 & 37,11 \\
1999 & 17.941 & 701.943 & 38,19 \\
2000 & 18.231 & 763.588 & 42,48
\end{tabular}




\begin{tabular}{lccc}
\hline Año & $\begin{array}{c}\text { Incremento de capacidad } \\
\text { (pasajeros) }\end{array}$ & $\begin{array}{c}\text { Incremento de } \\
\text { arqueo bruto }\end{array}$ & $\begin{array}{c}\text { Relación } \\
\text { Arqueo bruto/Pasajero }\end{array}$ \\
\hline 2001 & 26.828 & 1.141 .778 & 42,56 \\
2002 & 23.725 & 938.930 & 39,58 \\
2003 & 24.576 & 1.025 .104 & 41,71 \\
2004 & 24.538 & 1.025 .994 & 41,81 \\
2005 & 9.506 & 368.042 & 38,72 \\
2006 & 15.970 & 629.873 & 39,44 \\
2007 & 22.714 & 848.959 & 37,38 \\
2008 & 25.626 & 1.004 .657 & 39,20 \\
2009 & 24.170 & 959.867 & 39,71 \\
2010 & 27.538 & 1.104 .805 & 40,12 \\
2011 & 18.398 & 676.868 & 36,79 \\
2012 & 21.366 & 777.038 & 36,37 \\
2013 & 14.561 & 549.251 & 37,72 \\
2014 & 13.737 & 518.681 & 37,76 \\
\hline
\end{tabular}

Fuente: Elaboración propia.

Por otro lado, si se integra el incremento de capacidad anual con la evolución de pasajeros de crucero a nivel mundial durante el periodo de 1990 a 2013, se observa como los incrementos de la oferta o capacidad se han correspondido con incrementos de similar cuantía en la ocupación, véase Gráfico 3.8.

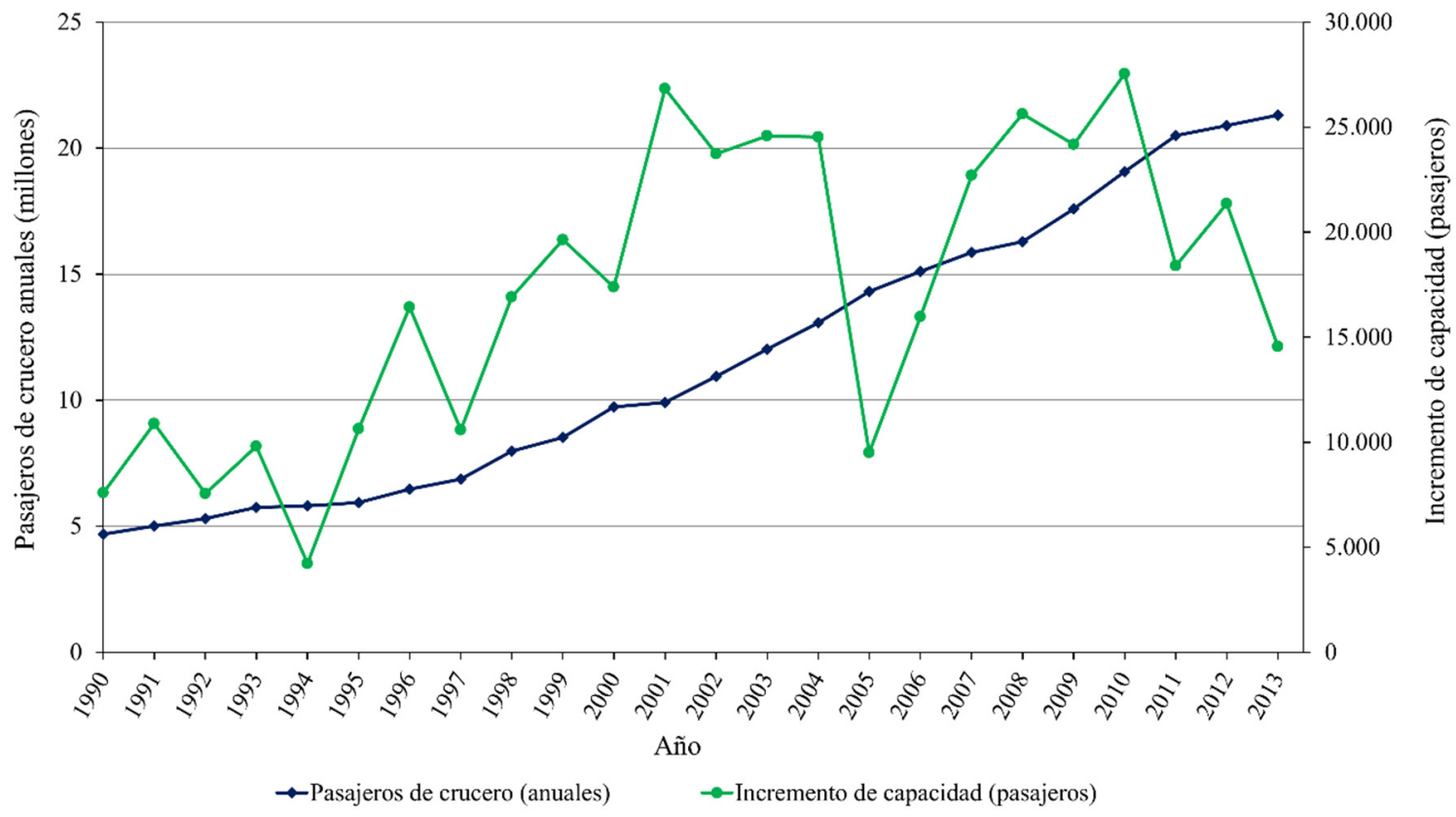

Gráfico 3.8: Evolución de la cifra de pasajeros de crucero a nivel mundial e incrementos de capacidad de la flota mundial de buques de crucero entre 1990 y 2013.

Fuente: Elaboración propia.

Por tanto, atendiendo a los resultados del análisis anterior, destaca que el mercado de cruceros tiene un notable carácter de concentración tanto desde el punto de vista de quién 
suministra el producto, navieras de crucero, como de la industria encargada de proveer a las navieras del vehículo de transporte, construcción naval. Por un lado, el mercado de navieras de crucero es de carácter oligopolístico atendiendo a la concentración empresarial existente en la actual flota de cruceros, dando lugar, por tanto, a una componente de concentración horizontal. Esta concentración también queda patente en las futuras adiciones a la flota, con el dominio de la mayor parte de las nuevas construcciones encargadas por alguna naviera de Las Tres Grandes. Por otro lado, en el ámbito de la construcción naval, se da una concentración tanto empresarial, reducido número de astilleros con capacidad para construir este tipo de buques, así como, geográfica, pues los dominadores del mercado se sitúan en Europa y más en concreto en Italia, Francia, Alemania y Finlandia.

\subsection{Los puertos de crucero}

En este apartado se procede a desarrollar las funciones y particularidades que los puertos desempeñan en el tráfico de cruceros. Por ello el apartado se estructura de la siguiente forma. En primera instancia se ofrece una relación, desde diversos puntos de vista, de las funciones asociadas a un puerto para dar servicio al tráfico de cruceros. A continuación, se presenta un análisis de evolución del tráfico de cruceros en el Sistema Portuario Español entre los años 1994 y 2013 junto con un análisis de posiciones competitivas. A partir de los resultados obtenidos en el punto anterior se seleccionan los puertos que forman parte del análisis empírico desarrollado en el Capítulo IV. Finalmente, para este conjunto de puertos se procede a inventariar las infraestructuras y servicios destinados al tráfico de cruceros, con objeto de servir de base para el desarrollo de las variables a emplear en el posterior análisis econométrico.

\subsubsection{Función desempeñada por el puerto en el tráfico de cruceros}

En el apartado anterior se ha analizado cómo el buque está directamente relacionado con la componente de transporte presente en el producto crucero, junto con el atractivo turístico relacionado con el propio buque puesto que se puede considerar como un destino en sí mismo; los puertos juegan también un papel fundamental en la consecución del transporte, constituyendo el enlace con la componente turística que se desarrolla en tierra durante un itinerario de crucero.

Todos los flujos espaciales, con la excepción de los desarrollados por medios propios, implican movimientos entre terminales. Los modos de transporte requieren consolidar y distribuir su tráfico, tanto si se trata de pasajeros como de mercancías. Por ejemplo en el caso de transporte terrestre, el pasaje tiene que ir primero a estaciones de autobuses o de tren con el fin de llegar a su destino final. Las terminales son, por lo tanto, un enlace esencial en las cadenas de transporte, gran parte de las cuales representan una infraestructura considerable e inversiones de capital sustanciales. Ocupan lugares específicos y ejercen una fuerte influencia sobre su entorno. Al mismo tiempo que realizan funciones económicas específicas y sirven como grupos de actividades especializadas (Rodrigue et al., 2013). 
En el caso del transporte marítimo de pasajeros y más en concreto en el tráfico de cruceros, la terminal de pasajeros está integrada en un recinto complejo y polivalente, el puerto. Con frecuencia se afirma que los puertos sobrepasan la simple función de dar servicios a los buques, pasajeros y carga en el muelle (Vaggelas y Pallis, 2010). Las funciones/servicios/actividades del puerto están definidas por dimensiones espaciales, que van desde simples instalaciones de atraque (interfaz buque/tierra) a servicios de valor añadido. En alusión a estos aspectos se puede citar la definición de puerto dada por el Parlamento Europeo (1999).

El área portuaria se define como un complejo de atraques, muelles y terrenos adyacentes donde se sirve a buques y cargas. Para llegar a esa zona, se requiere contar con infraestructuras relacionadas con el acceso maritimo (canales, esclusas, ayudas a la navegación, etc.) y el acceso terrestre (conexiones con carreteras, red ferroviaria y navegación interior).

En un puerto se desarrollan una cantidad de actividades mayor que en otras infraestructuras de transporte. Comparando un puerto con un aeropuerto, en ambas puede haber coexistencia de pasajeros y carga. Pero en el caso del puerto es posible encontrar una mayor variedad de cargas que darán lugar a tipos específicos de buques, así como, a instalaciones o infraestructuras concretas para el manejo de dichas cargas. Por tanto, en primera instancia resulta conveniente hablar de puerto puesto que éste debe de cumplir con una serie de requisitos que hagan posible la operativa del buque y satisfagan al pasaje. Desde un punto de vista generalista las principales funciones de un puerto son (Ligteringen y Velsink, 2012):

- Función de "tráfico": el puerto es un punto nodal en el tráfico, conectando el agua y diversos modos terrestres.

- Función de transporte: los puertos son plataformas para diversos flujos de carga.

La función de "tráfico" requiere de tres condiciones que deben cumplirse, asociadas a las principales zonas relacionadas con un puerto. Es decir, un buen acceso marítimo (bocana), conexiones intermodales en tierra (hinterland) y suficiente capacidad y servicios en el propio puerto (dársenas y muelles):

- La entrada desde el mar (bocana), tiene que ser accesible y segura;

- Dársenas y muelles, con un espacio adecuado para la maniobra y atraque de los buques y capacidad para el manejo y almacenamiento de carga;

- Conexiones con el hinterland, por carretera, ferrocarril, vías fluviales, tubería, según el tipo de carga y distancia de transporte. 
Por lo general, el tráfico de cruceros constituye una de las líneas de negocio dentro de un puerto. Así pues, dentro de una misma dársena se podrán encontrar distintos tipos de tráfico portuario entre los que puede estar incluido el tráfico de cruceros, reservando para ello normalmente un área específica, véase Figura 3.1. Por tanto, tomando como referencia la definición de puerto dada por la UNCTAD (1991) y acotándola al caso concreto de un puerto de cruceros, de forma similar se obtendría la siguiente:

Un puerto de cruceros es el área donde la interfaz entre el mar y los modos de transporte terrestre se lleva a cabo, y como tal es un nodo de transporte intermodal. Los pasajeros embarcan y desembarcan del buque de crucero y son remitidos a/desde el hinterland con el uso de modos de transporte disponibles entre el hinterland y el puerto.

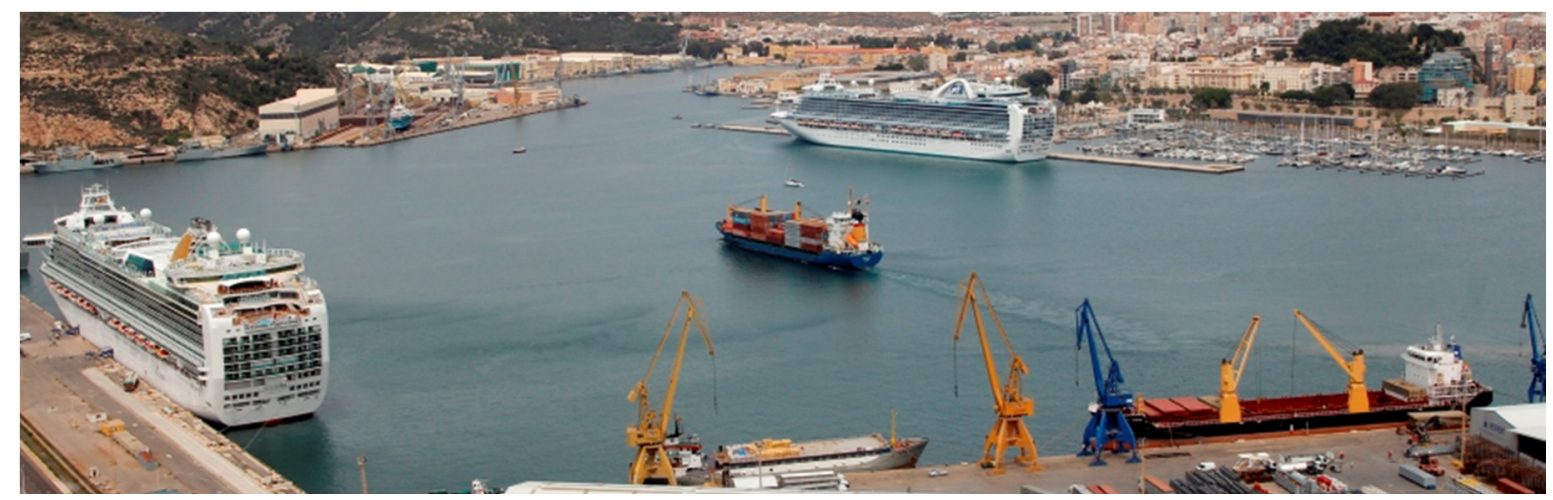

Figura 3.1: Coexistencia de tráfico de cruceros y mercancía general en la dársena de Cartagena del puerto de Cartagena.

Fuente: Elaboración propia adaptada de Autoridad Portuaria de Cartagena (2013).

En este punto se pone de relieve otra característica de los viajes de crucero, su carácter intermodal y que por extensión afecta a los puertos base y de escala. Tanto en el caso de los fly \& cruise, tipo en el que más patente está la intermodalidad, como una vez iniciado el propio itinerario puesto que en cada puerto de escala se pueden combinar diversos modos de transporte para llegar a las atracciones turísticas, véase Figura 3.2 y 3.3. Los puertos de crucero tienen que estar integrados en redes de transporte intermodal, sobre todo los puertos base, pues condiciona el atractivo del puerto (Lekakou et al., 2010). 


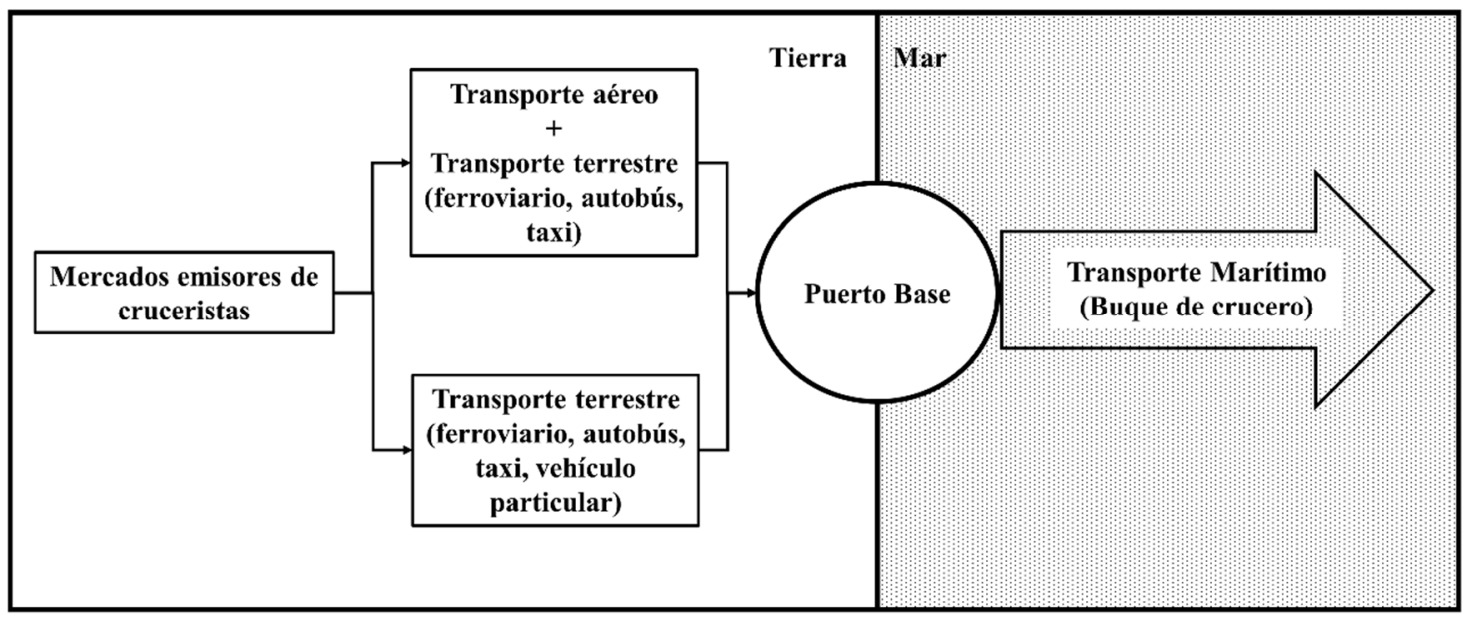

Figura 3.2: Representación conceptual de la intermodalidad presente en el producto crucero con el inicio del itinerario.

Fuente: Elaboración propia.

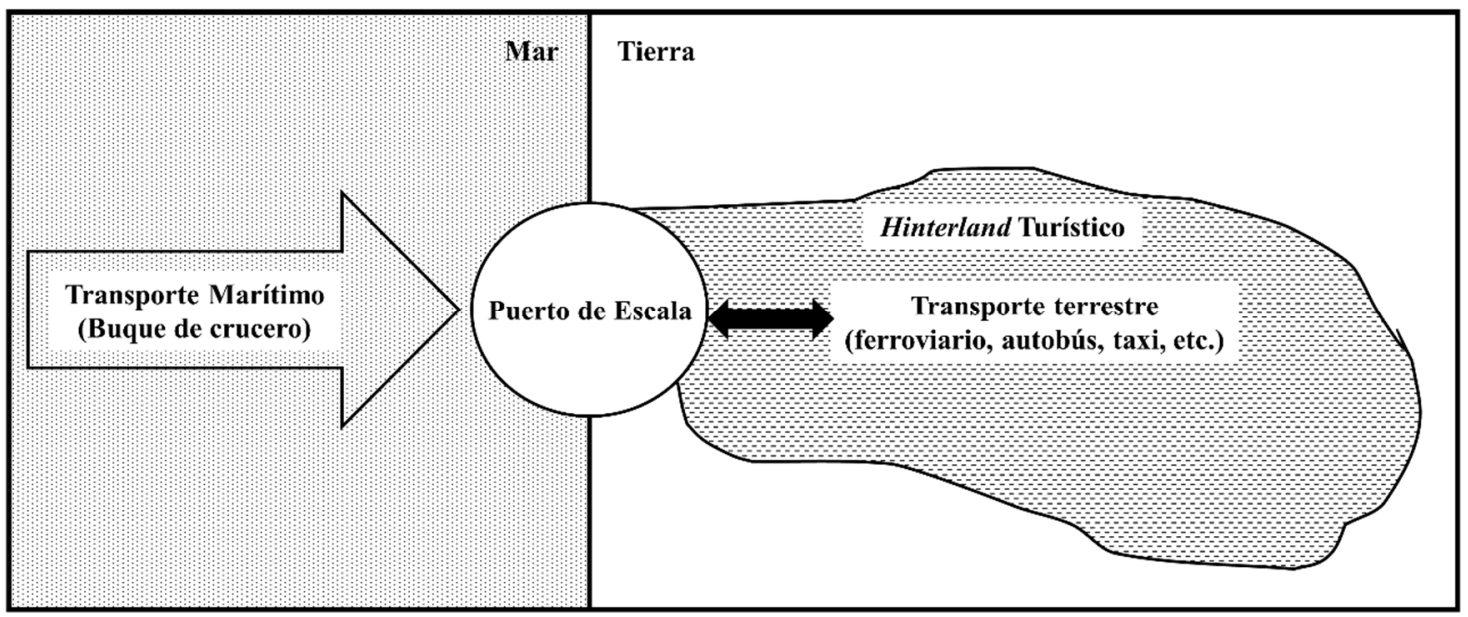

Figura 3.3: Representación conceptual de la intermodalidad presente en el producto crucero asociada a la escala en un puerto.

Fuente: Elaboración propia.

Dentro del recinto portuario, en el área designada para el tráfico de cruceros está emplazada la terminal. Existen diversas definiciones de terminal, algunas de ellas se incluyen a continuación: "Cualquier lugar en el que mercancías y/o pasajeros, bien tiene su origen, termina o se maneja en el proceso de transporte. Las terminales son lugares centrales $\mathrm{y} / \mathrm{o}$ intermedios en los movimientos de pasajeros y carga. A menudo requieren instalaciones y equipos específicos para acomodar el tráfico que efectúen" y "Cualquier instalación donde los viajeros y mercancías se consolidan o dispersan. También pueden ser puntos de intercambio entre un mismo medio de transporte o entre los diferentes modos de transporte" (Rodrigue et al., 2013).

Las anteriores definiciones tienen una transposición directa en el tráfico de cruceros $\mathrm{y}$ en ambos tipos de puertos asociados a este tráfico, pues presentan las siguientes particularidades. En un puerto base la terminal actúa como un lugar central de consolidación y dispersión de pasajeros desde/hacia sus países de origen, véase Figura 3.4, con el inicio y 
fin del itinerario, respectivamente. Mientras que en los puertos de escala, la terminal adopta un papel intermedio en el movimiento de pasajeros de crucero dentro de un itinerario (Esteve-Pérez y García-Sánchez, 2015). A su vez, también actúa como lugar de dispersión y consolidación de los cruceristas hacia/desde el hinterland turístico a visitar, véase Figura 3.5, en el inicio de la escala y en el final de la misma, respectivamente. Además, en ambos casos da lugar a intercambio de medios de transporte. Tanto en el puerto base como en los puertos de escala hay un intercambio a un medio transporte terrestre. En el caso del primer tipo de puerto puede darse también un enlace a transporte aéreo, dado el mercado global en el que se captan los pasajeros de cruceros.

Inicio del crucero

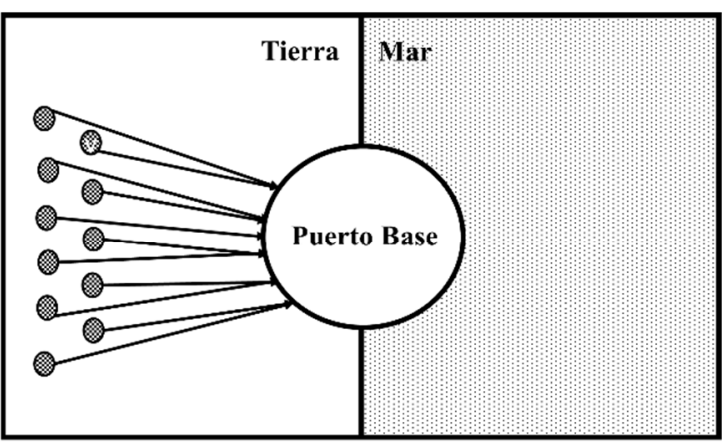

Final del crucero

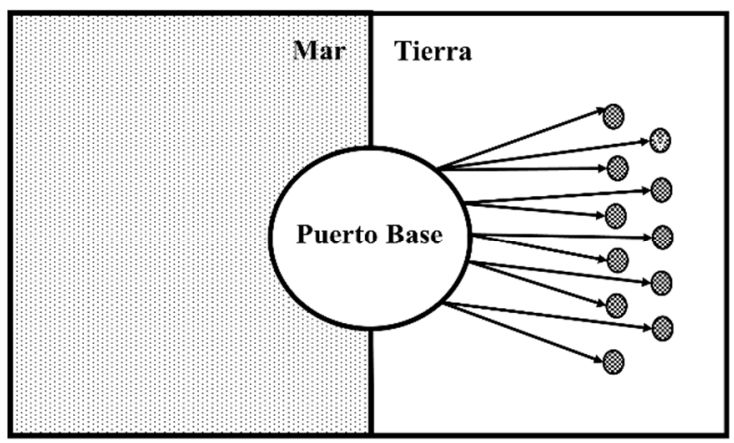

Cruceristas procedentes de diversos países de origen

Figura 3.4: Proceso de consolidación y dispersión de los pasajeros de cruceros desde/hacia sus países de origen en relación con un puerto base de cruceros.

Fuente: Elaboración propia.

Inicio de la escala

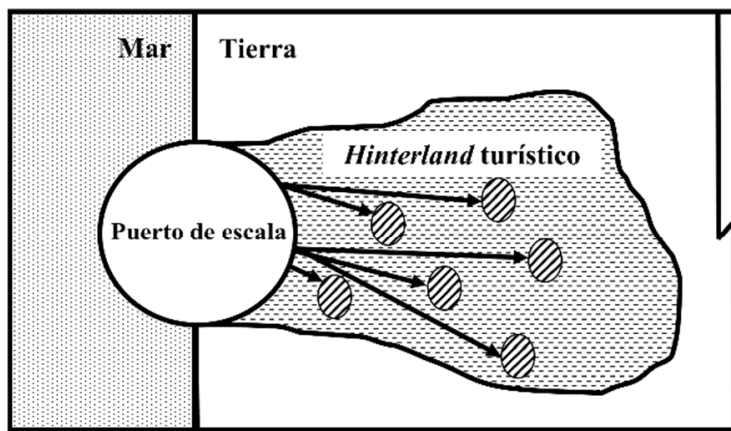

Grupos de cruceristas que visitan lugares concretos del hinterland turístico
Fin de la escala

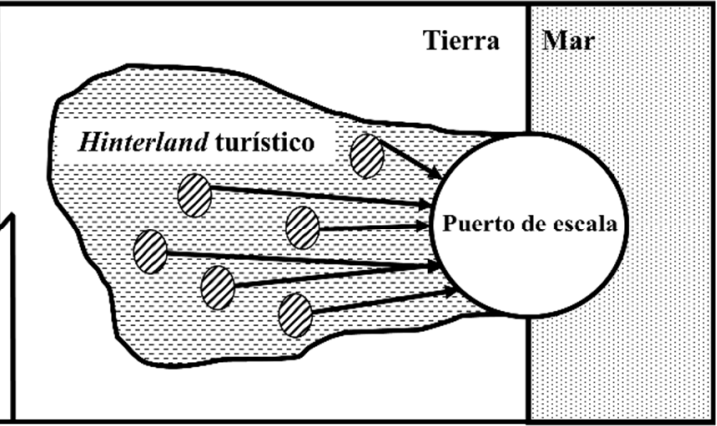

Figura 3.5. Proceso de dispersión y consolidación de los pasajeros de crucero hacia/desde el hinterland turístico en relación con un puerto de escala.

Fuente: Elaboración propia.

Además, en el caso particular de las terminales de cruceros, actúan como una conexión entre el destino y el buque de crucero (Esteve-Pérez, 2014). Si en este punto se integran las dos tipologías de puertos fundamentales que existen en el tráfico de cruceros (puerto base y puerto de escala), descritas en el Capítulo II, se obtiene una nueva perspectiva. En el caso de los puertos base, constituyen el inicio y la finalización de la experiencia de 
crucero. Mientras que en el caso de los puertos de escala, culminan la componente de transporte marítimo, para dar paso al atractivo turístico que se desarrolla en tierra y, viceversa, finalizan la experiencia turística en un destino, para iniciar de nuevo el transporte hacia otro nuevo destino.

Por tanto, desde un punto de vista espacial, la evaluación del atractivo de un puerto de cruceros se centra en cuatro ejes, tanto en el caso de un puerto base como de un puerto de escala, aunque difieren entre sí en el primer eje. Para un puerto base, estos factores son: El primero es la proximidad y accesibilidad a los mercados emisores de pasajeros de cruceros; El segundo son las características naturales del puerto de cruceros; Los servicios que la ciudad portuaria ofrece a los pasajeros de cruceros es el tercer eje, ya que es importante para los pasajeros de cruceros con objeto de tener acceso a algunas instalaciones que harán que su estancia en la ciudad sea más agradable; Por último, el atractivo de las zonas cercanas al puerto de cruceros también es una parte del análisis espacial de un puerto de cruceros. El término atractivo de las zonas cercanas, hace referencia a la existencia de lugares o actividades que sean atractivos para los pasajeros de cruceros y que darán lugar al hinterland turístico del puerto (Esteve-Pérez y García-Sánchez, 2014). En lo que a un puerto de escala se refiere, el primer factor está asociado a la proximidad a un puerto base y a otros puertos de escala, de tal forma que sea posible su inclusión en el itinerario, cumpliéndose una distancia mínima de navegación entre puertos. Los tres ejes espaciales restantes comparten los mismos condicionantes que para el caso de un puerto base. Por tanto, desde el punto de vista espacial se tienen tres zonas geográficas que condicionan la elección de un puerto. Éstas son, el recinto portuario, la ciudad portuaria y el hinterland turístico, véase Figura 3.6.

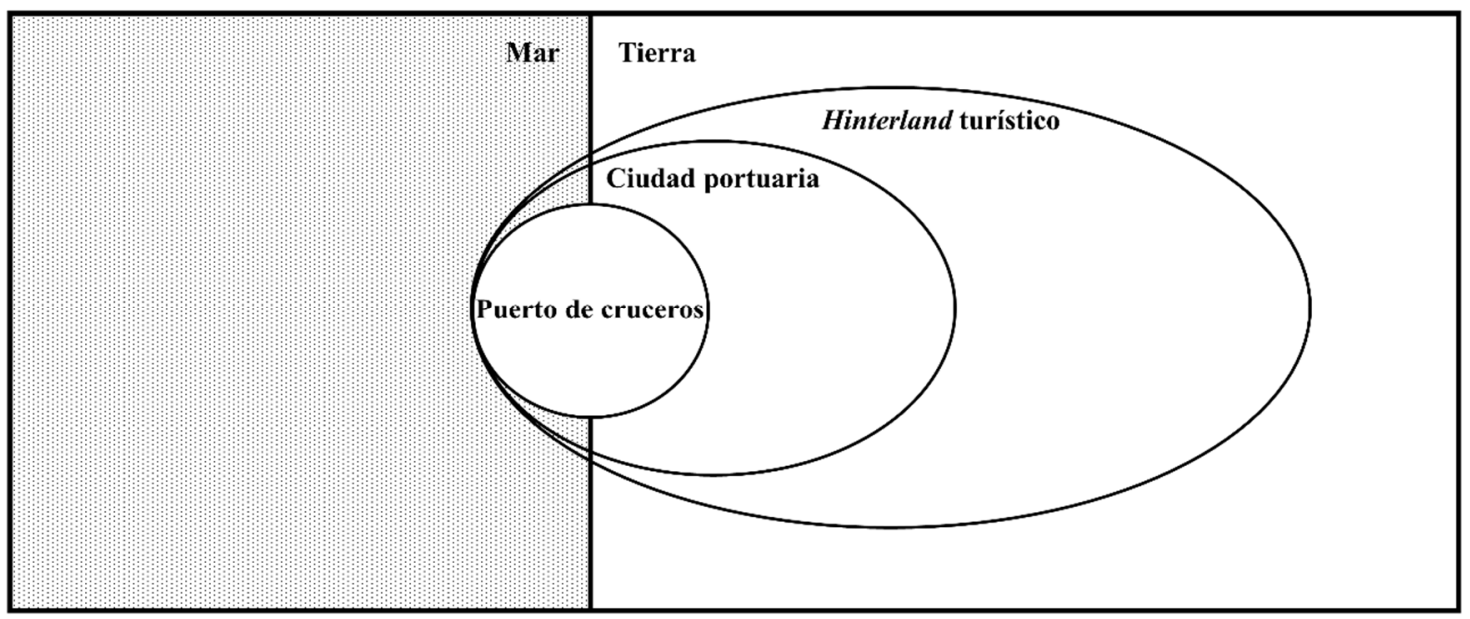

Figura 3.6: Dimensiones espaciales relacionadas con un puerto de cruceros.

Fuente: Elaboración propia.

Respecto a los factores que influyen en la elección de un puerto por parte de una naviera de cruceros y en estrecha relación con los cuatro ejes descritos en el párrafo anterior, Marti (1990) llevó a cabo una primera aproximación mediante el análisis del mercado de cruceros norteamericano. Como principal conclusión obtuvo que existen dos grandes categorías de factores. Éstas son las características del emplazamiento (site conditions), que 
hacen referencia a factores físicos de notable importancia, como por ejemplo, disponibilidad de infraestructuras y superestructuras portuarias para alojar buques de crucero y permitir la operativa con los pasajeros entre el buque y tierra; y características de situación (situation conditions), que se refieren a cualidades físicas o culturales, como la proximidad a los mercados emisores de pasajeros de crucero y el atractivo de la región portuaria. La primera categoría de condicionantes fue mencionada por primera vez por Weigend (1958). Ambos grupos de condicionantes hacen alusión tanto a infraestructuras y superestructuras, como a servicios dedicados al buque y al pasaje.

En este sentido, la adaptación al tráfico de cruceros de la definición de estación o terminal marítima de pasajeros contenida en el Real Decreto Legislativo 2/2011, de 5 de septiembre, por el que se aprueba el Texto Refundido de la Ley de Puertos del Estado y de la Marina Mercante (BOE, 2011), permite adoptar una visión generalizada de las funciones de dicha infraestructura.

Instalación destinada a facilitar el acceso de los pasajeros y sus equipajes, desde tierra a los buques y desde éstos a tierra, que puede incluir edificios para el control y ordenación de pasajeros y equipajes y la prestación de servicios auxiliares.

Desde el punto de vista de las características del recinto portuario, los buques de crucero deben tener acceso a adecuadas infraestructuras portuarias, superestructuras, suministros y servicios, con el fin de poder dar servicio al buque y los pasajeros. Estos condicionantes van a diferir según se trate de un puerto base, un puerto con embarques/desembarques parciales (interporting) o bien, un puerto de escala. Los puertos base van a requerir un mayor número de requisitos por toda la operativa asociada con el embarque y desembarque de pasajeros que inician/finalizan el itinerario y con el aprovisionamiento, por parte del buque, de todos los suministros necesarios para iniciar un nuevo itinerario. Las dos tipologías de puertos restantes tendrán un menor número de condicionantes.

En cuanto a las condiciones del emplazamiento y desde el punto de vista del buque, se tienen condicionantes técnicos que permitan el acceso del buque a puerto y condicionantes de servicios requeridos por éste durante su escala. En primera instancia, el puerto tiene que reunir una serie de características técnicas que permitan el acceso del buque al puerto y por extensión al muelle de atraque. Los principales condicionantes son: disponer de adecuada señalización marítima; características de la zona de fondeo, calado y abrigo del fondeadero; anchura y calado de la bocana; protegido de agentes meteorológicos; anchura de la dársena, calado de la dársena y del muelle de atraque; longitud de atraque disponible y anchura del muelle. Junto a lo anterior, el buque requiere de una serie de servicios para el acceso a puerto, así como, durante su estancia en el mismo. Para el acceso a puerto se requiere disponer de servicio de prácticos y de remolque. En cuanto a este último concepto, la implantación de los sistemas de propulsión azipodal en buques de crucero, los dota de elevada maniobrabilidad y les permite poder prescindir de este servicio durante la entrada y/o salida de puerto. Además, la asistencia de remolcadores no suele tener carácter obligatorio a 
diferencia del practicaje, pero sí tiene que estar disponible, si el práctico del puerto en cuestión junto con el capitán del buque estiman necesario el uso de remolcadores en la maniobra de entrada y/o salida de puerto.

Una vez el buque en puerto, requiere de provisionistas de buques, aprovisionamiento de combustible (bunkering), servicio de recogida de residuos, instalaciones de construcción y reparación naval, inspectores de Sociedades de Clasificación, servicios relacionados con la seguridad e instalaciones para la tripulación, con objeto de poder pertrechar el buque y ponerlo en disposición de iniciar un nuevo itinerario. En la Tabla 3.13 quedan resumidas las infraestructuras y servicios requeridos por un buque en un puerto base.

Tabla 3.13: Infraestructuras y servicios requeridos por un buque de crucero en un puerto base

\begin{tabular}{|c|c|c|c|c|}
\hline & $\begin{array}{c}\text { Aproximación al } \\
\text { puerto } \\
\text { (Fondeadero) }\end{array}$ & $\begin{array}{c}\text { Acceso al puerto } \\
\text { (Bocana/Canal de } \\
\text { Entrada) }\end{array}$ & $\begin{array}{c}\text { Interior del puerto } \\
\text { (Dársena) }\end{array}$ & Atraque/Muelle \\
\hline Infraestructura & $\begin{array}{l}\text { Calado } \\
\text { Protección/Abrigo } \\
\text { Señalización } \\
\text { marítima }\end{array}$ & $\begin{array}{l}\text { Anchura } \\
\text { Calado } \\
\text { Señalización } \\
\text { marítima } \\
\text { Rango de marea } \\
\text { Protección/Abrigo }\end{array}$ & $\begin{array}{l}\text { Anchura (Radio de } \\
\text { giro máximo) } \\
\text { Calado } \\
\text { Rango de marea } \\
\text { Protección/Abrigo }\end{array}$ & $\begin{array}{l}\text { Calado } \\
\text { Longitud/Línea de } \\
\text { atraque } \\
\text { Anchura } \\
\text { Protección/Abrigo } \\
\text { Rango de marea }\end{array}$ \\
\hline Servicios & & $\begin{array}{l}\text { Practicaje } \\
\text { Remolque }\end{array}$ & $\begin{array}{l}\text { Practicaje } \\
\text { Remolque }\end{array}$ & $\begin{array}{l}\text { Amarradores } \\
\text { Suministro de } \\
\text { combustible } \\
\text { Provisionistas de } \\
\text { buques } \\
\text { Recogida de } \\
\text { residuos } \\
\text { Reparación e } \\
\text { inspección naval }\end{array}$ \\
\hline
\end{tabular}

Fuente: Elaboración propia.

En relación con las necesidades requeridas por el pasaje se tiene tanto infraestructura como servicios ofrecidos/disponibles en dicha infraestructura. La principal infraestructura en puerto, asociada al pasaje, está representada por la presencia de terminal de pasajeros. Asociada a esta infraestructura surgen los conceptos de capacidad de la terminal de pasajeros en cuanto a embarque/desembarque de pasaje, manejo de equipajes y cifra de pasajeros a la que se le puede dar servicio simultáneamente. Además, de los medios empleados para realizar el embarque y desembarque de pasajeros. Bien por medio de una pasarela móvil protegida (finger), que conecta el buque y la terminal, con capacidad para mantenerse conectada incluso en el momento de máxima amplitud de la marea, si se da este fenómeno en puerto; o bien, por medio de la pasarela del buque (planchada) directamente apoyada sobre el muelle. 
Los servicios requeridos por el pasaje, y que en su mayoría estarán emplazados en el edificio de la terminal, son: aduana, servicios de inmigración, mostradores de facturación de maletas y cintas de recogida de las mismas, agencias de viaje, servicios bancarios, tiendas, salas de espera (incluso con área VIP), aparcamientos, primeros auxilios, servicios de transporte por el interior del puerto, servicio de seguridad y vigilancia.

Sin embargo, los condicionantes para que un puerto sea incluido en un itinerario de cruceros, o incluso se establezca como puerto base, se extienden más allá de lo comprendido dentro del propio recinto portuario. En primera instancia, en el diseño de un itinerario, la naviera fija la región de destino, para a continuación fijar el/los puertos base, según el itinerario sea cerrado o abierto, a partir del cual se desarrollará el itinerario. La decisión de una naviera de cruceros de hacer escala en un puerto, o incluso más importante, establecerlo como base de sus buques, depende en última instancia de si la zona en que se encuentra el puerto es atractiva para los cruceros. El grado de atractivo está relacionado con la "situación" (situation conditions) del puerto. Esta "situación" se puede dividir en dos ramas, y a su vez relacionarlas con dos ejes espaciales ya comentados anteriormente, situación relativa al mercado de los potenciales pasajeros de crucero y situación relativa a los destinos que los pasajeros de crucero (y por extensión los buques de crucero) desean visitar. De los dos elementos, el segundo es el de mayor importancia (McCalla, 1998). El primero de los elementos guarda una relación directa con el establecimiento de un puerto como base de cruceros. Esta barrera con el desarrollo de los cruceros fly \& cruise se ha difuminado permitiendo que los puertos y buques de crucero puedan dar servicio a mercados emisores alejados de la zona en la que operan.

Los puertos base juegan un papel clave en el posicionamiento de buques y en el diseño de itinerarios en una determinada región de destino (Bagis y Dooms, 2013). Por tanto, los puertos base deben estar estratégicamente ubicados en un área geográfica en la cual existan abundantes y próximos atractivos destinos en tierra y ciudades portuarias con objeto de que las navieras de crucero tengan la posibilidad de diseñar itinerarios flexibles y competitivos. Un puerto no puede ser un puerto de cruceros exitoso, si no se encuentra cerca o dentro de un área donde los cruceros operan (McCalla, 1998). Relacionado con este concepto, aunque aplicado a puertos de contenedores, Hayuth y Fleming (1994) explican el éxito de un puerto en la intermediación y no en la centralización. La intermediación se refiere a la ubicación en ruta, es decir, el puerto se encuentra en una posición entre donde se originan los contenedores y donde van destinados. Un razonamiento análogo se puede aplicar al caso de los puertos de crucero. En este sentido la intermediación vendrá definida por una distancia dada entre el puerto base y los sucesivos puertos que componen el itinerario, culminando con el retorno al puerto base para dar fin al itinerario. Esto da lugar a una relación espacial negativa para un rango de distancias próximas al puerto, que se vuelve positiva en distancias intermedias y vuelve a tomar signo negativo para grandes distancias, véase Figura 3.7. Por tanto, el éxito de desarrollo de un itinerario de cruceros guarda una estrecha relación con que el puerto base esté situado en una posición intermedia respecto a puertos de escala. Así mismo, los puertos de escala también tienen que tener una posición intermedia entre sí con objeto de que se puedan incluir en un itinerario de cruceros. Fundamentalmente cuatro 
componentes establecen los límites en los itinerarios de cruceros: velocidad de navegación del buque, situación del puerto base, duración del itinerario y patrón espacial de los puertos de destino (Marti, 1990). La posición geográfica relativa entre el puerto de embarque/desembarque y los puertos de escala, junto con la velocidad del buque y el tiempo disponible para desarrollar el itinerario, determinan el número de puertos a visitar.

La operativa de un buque de crucero guarda una estrecha relación con la modalidad de prestación del servicio de transporte marítimo en régimen de línea regular, pues el buque desarrolla un itinerario fijo y preestablecido, además de, cumplir con una duración de la escala en puerto rígida, durante la cual los cruceristas visitarán el hinterland. Sin la correcta consecución de las navegaciones interportuarias y las estancias en puerto, no es posible desarrollar el itinerario con éxito, cumpliendo con los tiempos establecidos. A este factor hay que sumarle la sincronización con medios de transporte aéreos y/o terrestres en el caso de los puertos base, para hacer llegar a los cruceristas desde/hacia sus lugares de origen en el inicio y fin del itinerario. Por tanto, como margen de maniobra de la naviera, ante un imprevisto que ponga en peligro el cumplimiento del horario establecido en el itinerario, se tiene la velocidad de navegación del buque y la duración de la escala en cada puerto, en caso extremo, incluso podría optar por anular alguna escala.

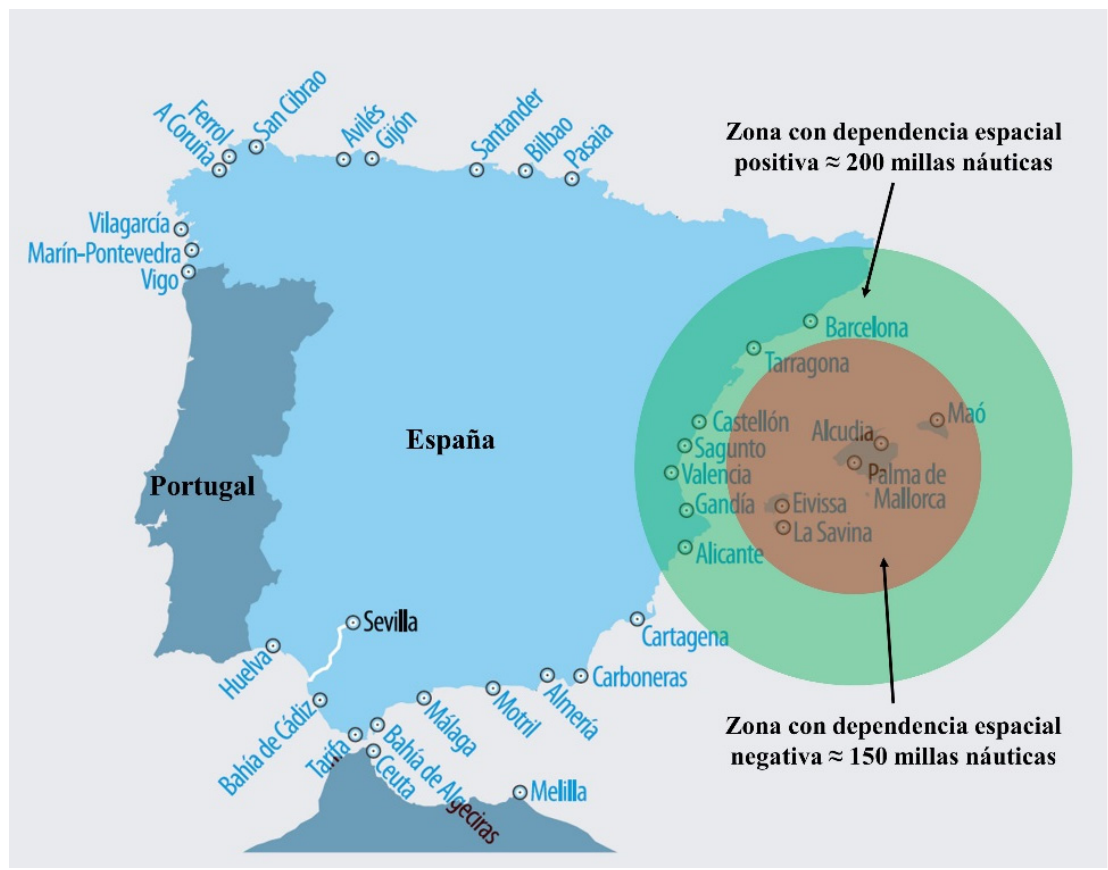

Figura 3.7: Zona de intermediación con relación espacial positiva y negativa asociada al puerto de Palma de Mallorca.

Fuente: Elaboración propia.

Los buques de crucero desarrollan altas velocidades, comprendidas en la gama de 20 a 24 nudos. En este punto se pone de relieve un importante concepto del transporte marítimo, la velocidad económica. La velocidad económica queda definida por la velocidad óptima para maximizar el resultado económico de su explotación (IME y FEIN, 2009). Este concepto deriva, de una parte, de la gran incidencia de los costes de combustible en los 
totales del transporte marítimo y, por otra, de la dependencia exponencial del consumo de combustible con la velocidad de navegación, aspectos de enorme relevancia en el transporte marítimo. Por tanto, en el diseño del itinerario, la naviera tomará en referencia la velocidad económica para determinar la duración y extensión de las navegaciones interportuarias. Así mismo, en el caso que se generen retrasos que alteren el cumplimiento del itinerario, la naviera puede actuar sobre la velocidad, incrementándola, aunque a costa de aumentar el consumo de combustible, penalizando en consecuencia la explotación económica.

En cuanto al tiempo en puerto, la duración de la escala limita los atractivos a visitar y por extensión, la dimensión del hinterland turístico de cada puerto. Ante posibles retrasos, actuar sobre la duración de la escala reduciendo el tiempo en puerto, implica limitar aún más si cabe, el hinterland turístico y por ende los potenciales atractivos a visitar por los cruceristas. Junto a estos dos conceptos hay que tener en cuenta la satisfacción del pasaje en lo que a equilibrio de tiempos en la mar y en puerto se refiere. El perfil operativo generalizado de los buques de crucero en el desarrollo del itinerario consiste en permanecer en puerto durante las mañanas, reservando las noches para las navegaciones interportuarias. La escala suele dar inicio a primera hora de la mañana (entre las 7:00 y las 8:00 horas), extendiéndose hasta primera hora de la tarde (entre las 17:00 y las 19:00 horas). También se combinan tramos de navegación de mayor duración, no realizando escala en puerto uno de los días del itinerario.

El atractivo de un puerto para una naviera, está directamente relacionado con la competitividad portuaria. La competitividad portuaria como factor clave de atracción, no se relaciona solamente con la infraestructura portuaria y prestación de servicios al buque y al pasaje descritos anteriormente, sino también con el coste y la eficiencia de todos estos servicios (Lekakou et al., 2010).

Un aspecto fundamental reside en el tiempo de respuesta ante la operativa que tiene que realizar un buque en puerto base. Además de dar asistencia al pasaje, los puertos base tienen el reto de hacer frente a amplias operaciones de suministro a buques de gran tamaño dentro de marcos de tiempo limitados. Por tanto, el manejo de grandes buques de crucero con un elevado número de pasajeros en un tiempo de respuesta muy corto, es un problema logístico enorme. Los cruceros pasan un promedio de 7-9 horas en puerto, durante el cual los pasajeros desembarcan y embarcan, se realizan los controles de seguridad y varios servicios se prestan al buque. La combinación de grandes buques y la demanda de un rápido tiempo de respuesta ejercen una presión significativa sobre las instalaciones y los servicios portuarios. Por lo tanto, la sincronización de los pasajeros entrantes y salientes necesita ser organizada de forma precisa por el naviero y los operadores portuarios.

Un buque de crucero supone una inversión de 220 a 370 millones de euros, alcanzando los de mayor tamaño los 735 millones de euros. El éxito de su operación depende en gran medida del mantenimiento de un horario muy intenso sin interrupciones. Un estándar aceptado en la industria consiste en que a un buque de crucero no se le puede negar el acceso o generar retraso a/o desde el muelle de atraque (World Bank, 2007). 
Junto a lo anterior, también tiene una importancia notable el coste asociado a los servicios prestados al buque y al pasaje, y las tasas de puerto. Pues redundarán en la cuenta de explotación del buque para cada escala y por extensión, en el resultado que la naviera obtiene al finalizar cada itinerario.

Sin embargo, los condicionantes de un puerto base, se extienden más allá de lo comprendido dentro del propio recinto portuario. Además de la importancia operativa de los puertos base, para las navieras de cruceros las ciudades portuarias también tienen que servir como puerto base. Esto da lugar al glosario de características de situación relacionadas con el eje espacial de la ciudad portuaria. Es necesario disponer de una adecuada infraestructura hotelera, restaurantes, áreas comerciales y de ocio, puntos de información turística, etc. Junto con lo anterior, también se requiere proveer de una adecuada red de transporte intermodal. La interoperabilidad de los modos de transporte es de importancia crucial para las compañías de cruceros, pues el origen de la mayoría de los pasajeros de cruceros está distante del puerto base (Lekakou et al., 2010). De menor a mayor magnitud, la red de transporte intermodal estaría compuesta de los siguientes elementos. En primer lugar, un adecuado número de autobuses y taxis. Seguido de la disponibilidad de estación de tren y aeropuerto internacional. Uno de los elementos más importantes para las navieras de crucero en las ciudades de puerto base, reside en la suficiente conectividad aérea de la ciudad. Este elemento es vital en términos de satisfacción de los pasajeros y cumplimiento de la programación de los itinerarios, dado el mercado global en el que los clientes se reclutan. Atendiendo a estos factores, la capacidad de un puerto para actuar como puerta de entrada a una región de cruceros, tiene una notable importancia en el éxito de ese puerto como puerto de cruceros (McCalla, 1998).

Sin embargo, en un puerto de escala es posible encontrar distintas situaciones o ámbitos operativos. En la mayor parte de los casos, el buque atraca en puerto para desembarcar el pasaje y, tras finalizar el tiempo de escala, embarcarlo de nuevo para seguir el itinerario programado. En lo que a acceso al puerto y por extensión al muelle de atraque del buque se refiere, la infraestructura destinada al buque debe reunir las mismas características que en el caso de un puerto base. Sin embargo, es posible encontrar varias excepciones en las que el buque no accede a puerto debido a la inexistencia de instalaciones portuarias para buques de crucero y opta por fondear y desembarcar y embarcar el pasaje por medio de botes. En este caso, la escala debe tener un enorme atractivo turístico y la naviera opta por realizar la escala fondeando, ya que supone ingresos considerables. En este caso particular los requisitos se minimizan, reduciéndose éstos a la idoneidad del fondeadero y las instalaciones portuarias para recibir a los botes de desembarco (tendering services). Un ejemplo de esta operativa es posible encontrarlo en la escala en la isla de Santorini (Grecia). En referencia a los servicios portuarios destinados al buque durante una escala en tránsito, los requisitos son los mismos, a excepción del aprovisionamiento de combustible y otros pertrechos que se reservan, fundamentalmente, para las escalas en el puerto base, simultaneando la operación de rotación del pasaje con las tareas de aprovisionamiento para el inicio del siguiente itinerario. 
En cuanto a la infraestructura y servicios destinados al pasaje. En las escalas en tránsito, aunque cada vez menos habitual, puede no disponerse de terminal de pasajeros y por tanto de pasarelas de desembarque conectadas a la terminal. En este caso, la pasarela de desembarque/embarque del buque conecta directamente con la explanada del puerto. Los servicios imprescindibles a prestar son los de aduana/control de la inmigración, primeros auxilios e información turística.

Por tanto, cuando un puerto de destino decide invertir en impulsar el tráfico de cruceros, se enfrenta a diferentes dilemas. En primer lugar, favorecer el tráfico de cruceros puede ser nocivo para la actividad de buques de carga en el puerto, ya que normalmente el área de las instalaciones de atraque o fondeo es limitada y la coexistencia de las dos industrias se complica debido a los requisitos en términos de seguridad y limpieza de los buques de crucero. El siguiente aspecto reside en quién paga por las mejoras en infraestructura necesarias para la actividad de buques de crucero. De hecho, el aumento de tamaño de los buques y el crecimiento del sector, genera una elevada presión sobre los puertos, y las navieras de crucero están constantemente solicitando mejores instalaciones. Normalmente, el puerto se encarga de la inversión en instalaciones marítimas, pero los principales beneficiarios de las inversiones son, de manera realista, la ciudad, la región, o los operadores de cruceros privados (Gui y Russo, 2011).

Las formas tradicionales de hacer negocios en los puertos de todo el mundo están siendo desafiadas por las demandas de mejoras en eficiencia portuaria, aumento de la capacidad de respuesta al cliente y reducir los costes de manipulación de la carga en puerto. Ha sido ampliamente observado que el uso de empresas del sector privado en las operaciones portuarias, ofrece una oportunidad para eliminar procedimientos y controles tradicionales y burocráticos, y modernizar las instalaciones y equipos a través de nuevos canales de financiación. También es ampliamente aceptado que los proveedores de servicios con experiencia operativa y administrativa en otros puertos, pueden transferir esta experiencia y extrapolar a un puerto mejores prácticas y tecnologías modernas apropiadas, empleadas en otros lugares. Pero aún más importante, al pasar las riendas de las operaciones portuarias del sector público al sector privado, se genera la posibilidad de desplazar la carga financiera de la expansión y desarrollo portuario a los beneficiarios de los gastos (World Bank, 2007). Una serie de empresas, ya sean de transporte u operadores de terminales, están involucradas en la gestión y explotación de terminales portuarias (Beresford et al., 2004; Brooks y Cullinane, 2006 y Notteboom, 2002).

Esta tendencia tiene su origen en el proceso de globalización de las operaciones portuarias. Durante la década de 1990, una serie de operadores de terminales y las principales compañías de transporte marítimo, se fusionaron para invertir y tomar el control de un gran número de terminales en todo el mundo. Esta estrategia es ampliamente empleada y presente en la actualidad en el segmento de puertos de contenedores. Así, irrumpieron en el panorama portuario operadores como Hutchison Ports Holdings (HPH), Port of Singapur Authority, A.P. Moller Terminals (APM Terminals) y Dubai Ports World (DPW), entre otros. En 2013, 
los cuatros operadores anteriores manipularon el 26,2\% de los contenedores mundiales (Drewry Maritime Research, 2013). Relacionado con esta tendencia surgen profundas consecuencias para la posición estratégica de la gestión portuaria, en relación con algunos de sus principales actores (World Bank, 2007).

La tendencia registrada en el tráfico de contenedores tiene una transposición directa en el tráfico de cruceros. Durante los últimos años se está generando una intervención del sector privado en la gestión y explotación de las terminales de pasajeros. Bien, empresas privadas que actúan como inversores, obteniendo la concesión de las infraestructuras a largo plazo, 25 o 40 años, así como, las compañías de cruceros han comenzado a invertir en las empresas que gestionan las infraestructuras portuarias en régimen de concesión. Las navieras de cruceros operan terminales de cruceros con el fin de ofrecer servicios de mejor calidad y valor añadido para sus clientes, tratando de aprovechar las ventajas de la integración vertical y las economías de escala (Vaggelas y Pallis, 2010). Esta nueva tendencia difiere de la visión tradicional, en que la naviera de cruceros invierte en el buque y los destinos invierten en las instalaciones portuarias (Gui y Russo, 2011). Además, las navieras de cruceros participan en las operaciones portuarias con el fin de mantener su poder en términos de cuotas de mercado (Bagis y Dooms, 2013). De tal forma, que no sólo existe concentración a nivel de navieras de crucero, sino también, en la interfaz entre el buque y el atractivo en tierra.

Esta irrupción del sector privado en la gestión y explotación de terminales de cruceros queda patente tanto en terminales que están en funcionamiento actualmente, como en los desarrollos de nuevas terminales. Ejemplos del primer caso son las terminales de Savona y Barcelona operadas por Costa Cruises, la terminal de cruceros de Marsella co-operada por Costa Cruises, MSC Cruises y Louis Cruises (Comisión Europea, 2009); y la terminal de cruceros de Civitavecchia gestionada equitativamente entre Costa Cruises, Royal Caribbean International y MSC Cruises. Respecto al desarrollo de futuras terminales, en el puerto de Barcelona una nueva terminal, Terminal E, ha sido concesionada a la naviera Carnival Corporation (Diario El Mundo, 2013); en el puerto de La Goulette (Túnez) la nueva terminal está financiada al $75 \%$ por un inversor privado y el 25\% restante por MSC Cruises; y en el puerto de Bodrum (Turquía), la nueva terminal está financiada al 100\% por un inversor privado, de forma análoga a como sucede con la nueva terminal de La Valletta (Malta) (Reyna, 2009). Este tipo de asociaciones entre los sectores público y privado son cada vez más preferidas como una herramienta para atraer capital para la inversión en infraestructura y como una forma de distribuir los riesgos de la gestión de cruceros entre los actores públicos y privados. En los últimos años, las líneas de cruceros se han convertido en un rasgo significativo en el desarrollo de los puertos de cruceros (ECC, 2010).

La existencia de interrelaciones entre los proveedores de servicios y usuarios del puerto puede influir en la estructura de poder en el puerto. Estas interrelaciones pueden afectar a las decisiones relativas a operaciones portuarias, arrendamientos, derechos de atraque y otras cuestiones. El poder de negociación resulta de la fuerza relativa de las partes involucradas en una negociación. Cuanto más fuerte es el poder de negociación de una de las partes, más probable es que dicha parte obtenga la mayor ganancia en una transacción. 
En el sector portuario, las principales partes en una negociación son los usuarios de los puertos y los proveedores de servicios de portuarios (World Bank, 2007).

La provisión de la infraestructura, superestructuras y servicios necesarios para atender el tráfico de cruceros, da lugar a un complejo entramado de empresas y organizaciones públicas y privadas, según el tipo de administración y gestión que aplique el puerto. Fundamentalmente, existen cuatro modelos principales de puertos: público, tool, Landlord y privado (IME y FEIN, 2009 y Wold Bank, 2007). Estos modelos se distinguen por la forma en que difieren con respecto a características tales como:

- Provisión pública, privada o mixta de servicios.

- Orientación local, regional o global.

- Propiedad de la infraestructura (incluyendo los terrenos portuarios).

- Propiedad de las superestructuras y equipos (sobre todo el equipamiento para el manejo de carga de buque a tierra, cobertizos/tingladillos y almacenes).

- Estatuto de los trabajadores portuarios y la gestión.

El puerto público y tipo tool se centran principalmente en la consecución de intereses públicos. Los puertos tipo Landlord tienen un carácter mixto y su objetivo es lograr un equilibrio entre los intereses públicos (autoridad portuaria) y privados (industria portuaria). Los puertos totalmente privados se centran en intereses privados (accionistas). A continuación se procede a desarrollar con mayor detalle las particularidades de cada uno de estos modelos de gestión portuaria.

\subsubsection{Puerto público}

Este tipo de puertos tienen un carácter predominantemente público. Actualmente está en declive, entre los existentes, gran parte están en transición hacia una estructura tipo Landlord, como Colombo (Sri Lanka), Nhava Sheva (India) y Dar es Salaam (Tanzania). Sin embargo, algunos puertos de países en desarrollo todavía se gestionan de acuerdo con el modelo de servicio público. Bajo este modelo, la autoridad portuaria ofrece una gama completa de servicios necesarios para el funcionamiento del sistema portuario. El puerto posee, mantiene y opera todos los activos disponibles (fijos y móviles), y las actividades de manipulación de carga son ejecutadas por personal contratado directamente por la autoridad portuaria.

\subsubsection{Puerto tool}

En el modelo de puerto tipo tool, la autoridad portuaria posee, desarrolla y mantiene la infraestructura portuaria, así como, la superestructura, incluyendo los equipos de manipulación de carga, tales como grúas de puerto y carretillas elevadoras. El personal de la 
autoridad portuaria por lo general opera todos los equipos propiedad de la autoridad portuaria. Otras operaciones de manipulación de carga como, por ejemplo, a bordo de los buques, se lleva a cabo generalmente por empresas privadas contratadas por agencias de transporte u otras figuras autorizadas por la autoridad portuaria. El puerto de Chittagong (Bangladesh) es un ejemplo típico de puerto tool.

La división de tareas mencionada anteriormente dentro del sistema portuario tool identifica claramente el problema fundamental con este tipo de modelo de gestión portuaria: división de responsabilidades operativas. Considerando que, la autoridad portuaria es propietaria y opera el equipo de manipulación de carga, la empresa privada de manipulación de carga generalmente firma el contrato para la prestación de servicios con el armador o el propietario de la carga. Sin embargo, esta empresa no es capaz de controlar totalmente las operaciones de manipulación de la carga en sí misma. El puerto tool tiene varias similitudes con el puerto público, tanto en términos de su orientación pública y la forma en que el puerto se financia. Bajo un modelo de puerto tool, la autoridad portuaria provee de terrenos y superestructuras a las empresas de manipulación de carga.

\subsubsection{Puerto Landlord}

El puerto Landlord se caracteriza por su orientación mixta público-privada. Bajo este modelo, la autoridad portuaria actúa como órgano regulador y como propietario, mientras que las operaciones portuarias (en especial de carga y descarga) se llevan a cabo por empresas privadas. Ejemplos de puertos Landlord son Rotterdam, Amberes, Nueva York, Singapur y los puertos españoles de Interés General. Hoy en día, el puerto Landlord es el modelo dominante en los puertos grandes y medianos.

En el modelo de puerto Landlord, la infraestructura se arrienda a empresas privadas de explotación, o a industrias, como refinerías y plantas químicas. El contrato de arrendamiento a pagar a la autoridad portuaria suele ser una cantidad fija por metro cuadrado al año, por lo general indexada a alguna medida de la inflación. La cuantía del importe de arrendamiento se relaciona con la preparación y coste de construcción iniciales. Los operadores portuarios privados proporcionan y mantienen su propia superestructura incluyendo edificios (oficinas, naves, almacenes, talleres, etc.). Ellos también compran e instalan su propio equipo en los terrenos de la terminal atendiendo a lo que requiere su negocio.

\subsubsection{Puerto privado}

Los puertos privados son pocos en número y se pueden encontrar principalmente en Reino Unido y Nueva Zelanda. La privatización completa es considerada por muchos como una forma extrema de reforma portuaria. Sugiere que el Estado ya no tiene ninguna participación significativa o política pública con interés en el sector portuario. En los puertos totalmente privados, los terrenos portuarios son de propiedad privada, a diferencia de la 
situación en otros modelos de gestión portuaria. Esto requiere la transferencia de propiedad de esas tierras, desde el sector público al sector privado. Además, junto con la venta de los terrenos portuarios a los intereses privados, algunos gobiernos pueden transferir simultáneamente las funciones de reglamentación a las empresas sucesoras privadas.

En los cuatros modelos de gestión descritos anteriormente, los puertos suelen tener un órgano de gobierno conocido como autoridad portuaria, gestor portuario o administración portuaria. El término ampliamente utilizado es el de autoridad portuaria. Sus funciones diferirán según se aplique un modelo de gestión determinado (World Bank, 2007).

La tendencia creciente de la industria de cruceros, está produciendo la necesidad de más puertos y mejoras en las instalaciones de los puertos existentes, para dar cabida al creciente número y tamaño de buques de crucero, y poder así variar sus itinerarios. Los usuarios del puerto, en este caso en concreto las navieras de buques de crucero, tienen un fuerte poder de negociación si los servicios prestados por un puerto en concreto pueden ser replicados en otros puertos cercanos. Básicamente, esto se reduce a la disponibilidad de instalaciones alternativas para la naviera, dentro del rango de navegación a desarrollar entre escalas, lo que pone de nuevo de relieve el fenómeno de dependencia espacial. Cuanto mayor oportunidad haya de utilizar otras instalaciones, esto es, mayor número de puertos comprendido en el intervalo de navegación entre escalas, menor capacidad de negociación del puerto sobre la naviera. Cada puerto debe considerar las posibles acciones de los otros puertos en la negociación con los clientes actuales o potenciales, porque las navieras tienen la posibilidad de llevar su negocio a otro puerto. Esto implica que los puertos tienen que cumplir los requisitos de las compañías de cruceros para que puedan ser destinos atractivos y, de ser posible, convertirse en puertos base (Lekakou et al., 2010).

Para los puertos capaces de satisfacer las necesidades de los operadores de cruceros, el operador debe estar dispuesto a establecer acuerdos a largo plazo para llevar sus buques al puerto de manera regular por un periodo de hasta 25 años. Este acuerdo puede ser la base para obtener financiación, por parte de un promotor, para adquirir las instalaciones y los servicios en el puerto necesarios para dar cabida a buques de crucero. La cuestión clave en este caso reside en las garantías del puerto, si el operador de cruceros interrumpe las escalas antes de que finalice el periodo acordado. Los puertos que quieren ser destino de cruceros deben desarrollar una estrategia en conjunto con los organismos oficiales de turismo para mantener la calidad del producto turístico y maximizar el gasto de los visitantes (World Bank, 2007). Los puertos de crucero compiten en los límites de determinadas regiones geográficas. Estos límites están conformados principalmente de acuerdo a la localización de los puertos base en cada región, cuestión comentada anteriormente en el proceso de diseño de un itinerario de crucero. En un rango de distancias mínimas los puertos de cruceros se necesitan mutuamente para sobrevivir, como en un principio de "beneficio mutuo" (Bagis y Dooms, 2013).

En el siguiente apartado se analiza el tráfico de cruceros en el Sistema Portuario Español. El análisis está estructurado en dos etapas. En la primera etapa, se analiza la 
evolución del tráfico de cruceros en los puertos españoles entre el año 1994 y 2013. Para ello se ha empleado como variable la cifra de pasajeros de crucero. Además, el análisis está segregado en pasajeros de inicio y fin de itinerario (puerto base) y tránsito (puerto de escala). La segunda etapa consiste en un análisis portfolio basado en la matriz de crecimiento-cuota de mercado desarrollada por Boston Consulting Group, con objeto de identificar la posición competitiva de los puertos de crucero españoles. En la segunda etapa, el periodo analizado comprende del año 2000 a 2013. Asociado a este conjunto de puertos, en el apartado 3.2.3 se sintetizan las instalaciones dedicadas a tráfico de cruceros de que dispone cada uno de ellos.

Para obtener las cifras de cruceristas en todo el periodo de análisis se han empleado diversas fuentes de información. Las cifras con periodicidad anual y mensual desde el año 2005 a 2013 se han obtenido del organismo público adscrito al Ministerio de Fomento Puertos del Estado, por medio de las estadísticas de tráfico portuario que publica el mencionado organismo. En el caso de las cifras anuales y mensuales en el periodo comprendido entre el año 1994 y 2004, se ha realizado una solicitud a cada una de las Autoridades Portuarias analizadas, puesto que se trata de cifras que no están accesibles públicamente en la actualidad. Un proceso análogo se ha aplicado para obtener la segregación mensual de pasajeros en régimen de inicio y fin de itinerario y tránsito, para aquellos puertos que registran ambas tipologías de pasajeros, ya que, de forma análoga al caso anterior no se trata de información de acceso público. En concreto, hasta el año 2004 el Ministerio de Fomento no exigió segregar las cifras de pasajeros, en pasajeros de línea regular y pasajeros de crucero. De ahí que, con anterioridad al año 2004, en las estadísticas de tráfico portuario solo se hiciera alusión a la categoría pasajeros sin mayor especificación. Por este motivo, ha sido necesario solicitar las cifras de forma particular a las diversas Autoridades Portuarias.

\subsubsection{Análisis del tráfico de cruceros en el Sistema Portuario Español}

El Sistema Portuario Español (SPE) está estructurado en dos tipos de puertos, de titularidad estatal y de titularidad autonómica. Los puertos de titularidad estatal reciben la denominación de puertos de Interés General, constituyéndose como organismos públicos dependientes del Ministerio de Fomento y con autonomía de gestión. Mientras los puertos de titularidad regional, por lo general, son de tipo deportivo, pesquero o de refugio con actividad comercial menor.

El Sistema Portuario Español de titularidad estatal está integrado por 46 puertos de Interés General, gestionados por 28 Autoridades Portuarias (BOE, 2011), atendiendo al sistema de gestión Landlord Port instaurado en España (IME y FEIN, 2009). La tendencia creciente de la industria de los cruceros no ha pasado desapercibida en España. El tráfico de cruceros se encuentra presente en la mayoría de puertos de la geografía española. De hecho hay un interés creciente por parte de las Autoridades Portuarias en desarrollar y promocionar este tráfico en sus muelles. Entre el año 1994 y 2013 la cifra de cruceristas en el SPE se ha 
incrementado a una tasa media anual del 14,77\%, véase Gráfico 3.9. En otros términos, en 20 años la cifra de cruceristas que arriban a puertos españoles ha crecido en torno a un $1.100 \%$, evolucionando desde aproximadamente 700.000 pasajeros de crucero en el año 1994 a 7.650 .096 en el año 2013.

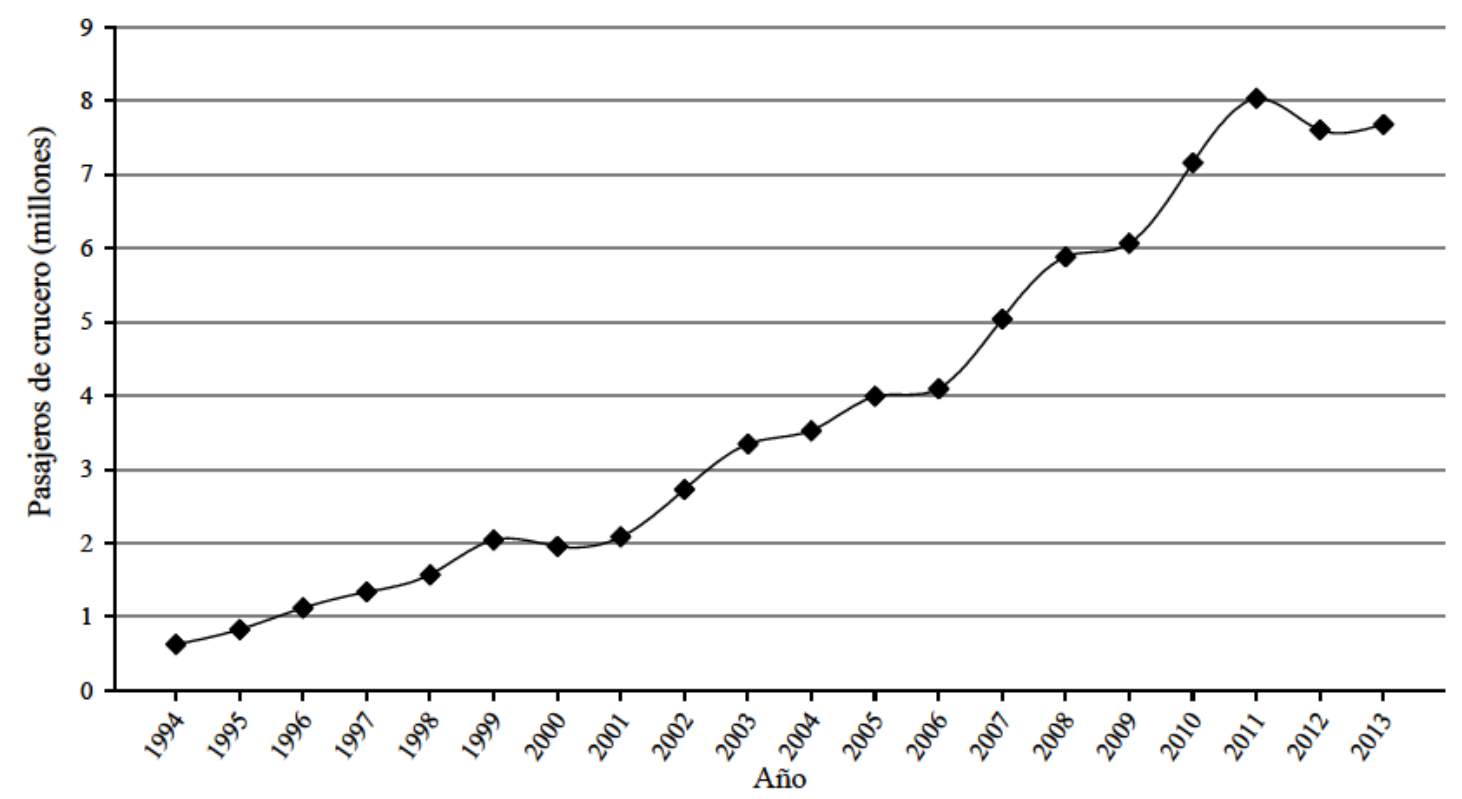

Gráfico 3.9: Evolución de la cifra de pasajeros de crucero en el SPE entre el año 1994 y 2013.

Fuente: Elaboración propia.

Las cifras representadas en el Gráfico 3.9 comprenden el total agregado de pasajeros de crucero en régimen de embarque y desembarque y tránsito. Tomando como referencia las definiciones incluidas en el Real Decreto Legislativo 2/2011, de 5 de septiembre, por el que se aprueba el Texto Refundido de la Ley de Puertos del Estado y de la Marina Mercante (BOE, 2011), por ambos tipos de pasajero se entiende:

- Pasajero de crucero turístico en embarque o desembarque: son los pasajeros de un buque calificado y autorizado para operar como crucero turístico que inician o finalizan su viaje en ese puerto.

- Pasajero de crucero turístico en tránsito en un puerto: son los pasajeros de un buque calificado y autorizado para operar como crucero que inician y finalizan su viaje en otro puerto.

Dada la configuración de la costa española, los 46 puertos de titularidad estatal, se pueden clasificar en tres grupos, atendiendo a la zona costera en la que se encuentran, véase Figura 3.8. Un grupo está compuesto por los puertos localizados en el Mediterráneo español y la costa atlántica andaluza (incluyendo las islas Baleares, Ceuta, Melilla y el puerto fluvial de Sevilla). Otro comprende los puertos de las islas Canarias. Finalmente, el tercer grupo lo componen los puertos de la cornisa cantábrica y la costa atlántica gallega. 


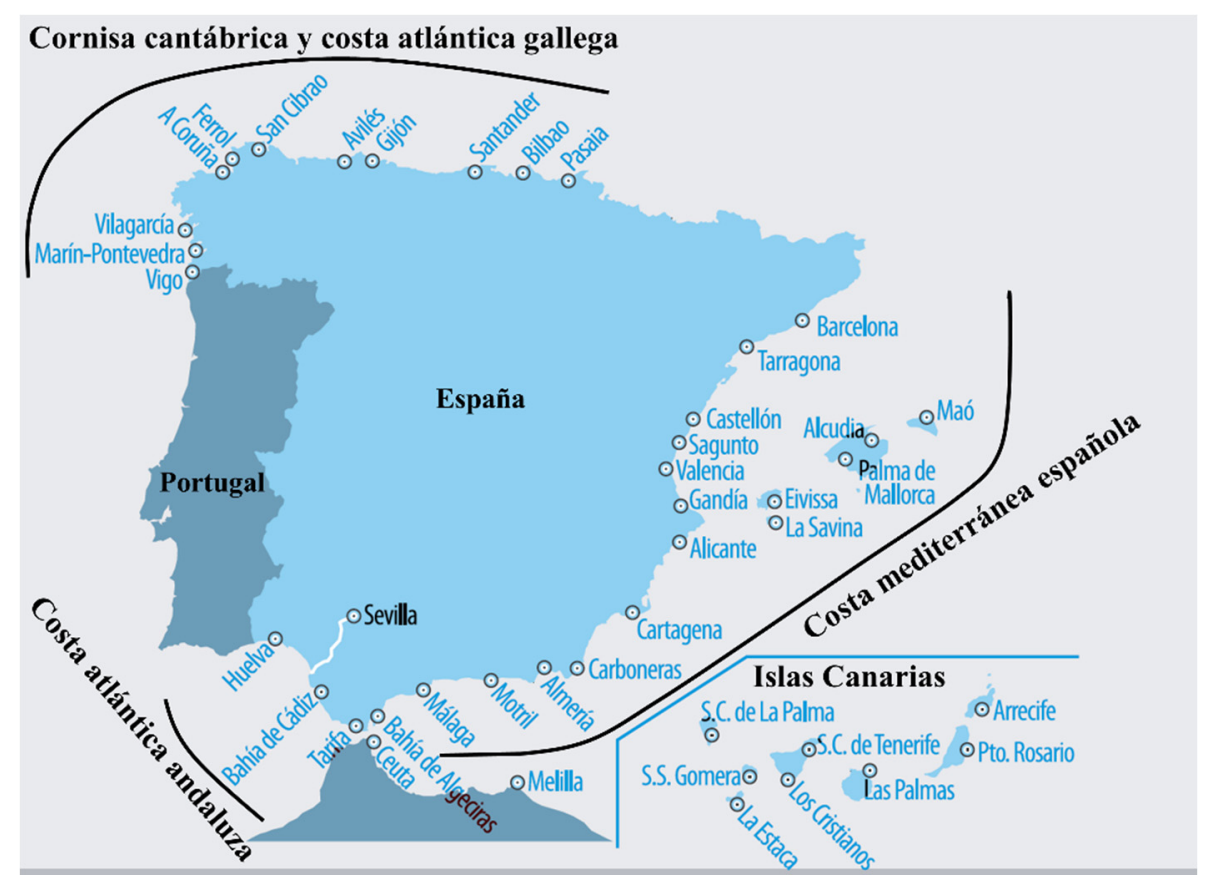

Figura 3.8: Mapa de puertos de Interés General del Sistema Portuario Español. Fuente: Elaboración propia adaptada de Puertos del Estado (2012).

En el grupo del Mediterráneo español y la costa atlántica andaluza hay un total de 16 Autoridades Portuarias: Alicante, Almería, Bahía de Algeciras, Bahía de Cádiz, Baleares, Barcelona, Cartagena, Castellón, Ceuta, Huelva, Málaga, Melilla, Motril, Sevilla, Tarragona y Valencia. Entre las Autoridades Portuarias enumeradas anteriormente, cuatro gestionan varios puertos, es el caso de: Baleares (Alcudia, Ibiza, La Savina, Mahón y Palma de Mallorca), Valencia (Gandía, Sagunto y Valencia), Almería (Almería y Carboneras) y Bahía de Algeciras (Algeciras y Tarifa). Las características de estos puertos son de lo más variado en lo que a tráfico portuario se refiere. Por un lado, hay puertos con tráfico de mercancías únicamente, por otro lado, hay puertos que combinan tráfico de mercancías y pasajeros. Los ejemplos más representativos de estos dos tipos son Castellón y Barcelona, respectivamente.

En las islas Canarias hay dos Autoridades Portuarias, Santa Cruz de Tenerife y Las Palmas de Gran Canaria, cada una de las cuales gestiona seis y cinco puertos, respectivamente. La Autoridad Portuaria de Santa Cruz de Tenerife gestiona los puertos de Santa Cruz de Tenerife, Santa Cruz de La Palma, San Sebastián de La Gomera, La Estaca (El Hierro), Los Cristianos y Granadilla. Mientras que la Autoridad Portuaria de Las Palmas de Gran Canaria gestiona los puertos de Arinaga, Arrecife, Puerto del Rosario, Salinetas y el propio puerto de Las Palmas de Gran Canaria. Los puertos canarios registran tanto tráfico de mercancías como de pasajeros, dada la necesaria conexión marítima del archipiélago.

La costa atlántica gallega y la cornisa cantábrica tiene un total de diez Autoridades Portuarias: A Coruña, Avilés, Bilbao, Ferrol-San Cibrao, Gijón, Marín y Ría de Pontevedra, Pasajes, Santander, Vigo y Vilagarcía de Arousa. Tradicionalmente en esta zona domina el tráfico industrial, es decir, de mercancías frente al de pasajeros. 
La presencia de tráfico de cruceros en los puertos de cada una de las tres zonas costeras descritas anteriormente difiere en gran medida entre ellas. La costa mediterránea y atlántica andaluza ha concentrado entre 1994 y 2013 aproximadamente las tres cuartas partes de los cruceristas en España, véase Tabla 3.14. En segundo lugar se sitúan las islas Canarias con un $20 \%$ y en tercer lugar la costa del mar Cantábrico y atlántica gallega con un $5 \%$.

Tabla 3.14: Tráfico de cruceros en España, por zonas costeras, entre el año 1994 y 2013, pasajeros de crucero y porcentaje sobre el total del SPE

\begin{tabular}{|c|c|c|c|c|c|c|}
\hline Año & $\begin{array}{l}\text { Mediterráneo y } \\
\text { costa atlántica } \\
\text { andaluza } \\
\text { (Pasajeros) }\end{array}$ & $\%$ SPE & $\begin{array}{c}\text { Islas } \\
\text { Canarias } \\
\text { (Pasajeros) }\end{array}$ & $\%$ SPE & $\begin{array}{c}\text { Cornisa cantábrica } \\
\text { y costa atlántica } \\
\text { gallega } \\
\text { (Pasajeros) }\end{array}$ & $\%$ SPE \\
\hline 1994 & 509.112 & - & N.D. & - & 30.297 & - \\
\hline 1995 & 687.803 & - & N.D. & - & 43.368 & - \\
\hline 1996 & 829.080 & 74,11 & 225.668 & 20,17 & 63.947 & 5,72 \\
\hline 1997 & 1.115 .031 & 83,47 & 153.201 & 11,47 & 67.573 & 5,06 \\
\hline 1998 & 1.178 .242 & 75,07 & 298.757 & 19,04 & 92.458 & 5,89 \\
\hline 1999 & 1.616 .085 & 79,21 & 332.592 & 16,30 & 91.624 & 4,49 \\
\hline 2000 & 1.517 .349 & 77,69 & 328.026 & 16,80 & 107.713 & 5,52 \\
\hline 2001 & 1.582 .939 & 76,08 & 406.554 & 19,54 & 91.243 & 4,39 \\
\hline 2002 & 2.006.709 & 73,69 & 599.367 & 22,01 & 117.127 & 4,30 \\
\hline 2003 & 2.464 .840 & 73,74 & 741.254 & 22,18 & 136.444 & 4,08 \\
\hline 2004 & 2.511 .172 & 71,30 & 849.252 & 24,11 & 161.454 & 4,58 \\
\hline 2005 & 2.874 .533 & 72,05 & 926.625 & 23,23 & 188.261 & 4,72 \\
\hline 2006 & 3.076 .772 & 75,22 & 808.658 & 19,77 & 204.746 & 5,01 \\
\hline 2007 & 3.835 .351 & 76,17 & 960.786 & 19,08 & 239.343 & 4,75 \\
\hline 2008 & 4.401 .645 & 74,82 & 1.133 .783 & 19,27 & 347.403 & 5,91 \\
\hline 2009 & 4.540 .721 & 74,88 & 1.192 .267 & 19,66 & 330.632 & 5,45 \\
\hline 2010 & 5.410 .478 & 75,59 & 1.374 .007 & 19,20 & 372.797 & 5,21 \\
\hline 2011 & 5.936 .796 & 73,93 & 1.599 .492 & 19,92 & 493.676 & 6,15 \\
\hline 2012 & 5.401 .934 & 71,06 & 1.718 .386 & 22,60 & 482.128 & 6,34 \\
\hline 2013 & 5.623 .421 & 73,26 & 1.624 .473 & 21,16 & 427.948 & 5,58 \\
\hline
\end{tabular}

Fuente: Elaboración propia basada en datos estadísticos de Puertos del Estado (2014).

Nota: Las cuotas correspondientes a cada zona costera para los años 1994 y 1995 no se calculan ya que para este periodo no están disponibles las cifras de pasajeros de crucero en puertos canarios.

En los últimos 20 años, las tres zonas costeras han registrado un crecimiento medio anual de la cifra de pasajeros de crucero superior al 10\%. Entre 1994 y 2013 la tasa media anual de crecimiento en la costa mediterránea y atlántica andaluza ha sido del 14,25\%, en el caso de la costa del mar Cantábrico y atlántica gallega, el crecimiento fue superior alcanzando el valor del 16,41\%. Para las islas Canarias, la tasa de crecimiento fue del 14,97\% pero referida al periodo de 1996 a 2013 ya que las cifras anteriores hasta 1994 no se encuentran disponibles. En este periodo de 20 años, el principal puerto de cruceros en España ha sido Barcelona, con una cuota media de mercado del 30,8\%, seguido de Palma de Mallorca con un 21,7\%, de tal forma que, conjuntamente, estos dos puertos han concentrado más de la mitad del tráfico de cruceros en el periodo mencionado. 
La importancia del tráfico de cruceros en los puertos españoles no sólo se da a nivel de puertos de escala, sino también como puertos base. España cuenta con puertos base para el tráfico de cruceros en sus tres zonas geográficas. Como definición de puerto base se toma la contenida en el Real Decreto Legislativo 2/2011, de 5 de septiembre, por el que se aprueba el Texto Refundido de la Ley de Puertos del Estado y de la Marina Mercante (BOE, 2011). Como puerto base de cruceros se entiende, puerto en el que, para una escala determinada, se cumpla alguna de las siguientes condiciones:

a) Que en la escala inicien o finalicen el crucero al menos un 50 por 100 del total de pasajeros de esa escala.

b) Que en la escala del crucero, el total de pasajeros que inicien o finalicen su viaje no sea inferior a 250 .

Se entiende que inician o finalizan el crucero aquellos pasajeros que no sean declarados en régimen de crucero turístico en tránsito.

Año a año se ha incrementado el número de pasajeros que inician y/o finalizan su itinerario de crucero en un puerto español, véase Tabla 3.15. Entre el año 2000 y 2013, de media, el 32,40\% de los pasajeros registrados corresponde a régimen de inicio y/o fin de itinerario, con una tasa media anual de crecimiento del 13\%. La costa mediterránea y atlántica andaluza concentran la mayor magnitud de esta categoría de pasajeros, contando como máximo exponente de estas operativas el puerto de Barcelona.

Tabla 3.15: Tráfico de cruceros en España entre el año 2000 y 2013, datos segregados en pasajeros de crucero en régimen de tránsito, inicio y fin de itinerario y total agregado.

Pasajeros de crucero

\begin{tabular}{cccc}
\hline Año & Inicio y fin de itinerario & Tránsito & Total SPE \\
\hline 2000 & 575.070 & 1.371 .284 & 1.946 .354 \\
2001 & 665.842 & 1.415 .748 & 2.081 .590 \\
2002 & 856.050 & 1.876 .553 & 2.732 .603 \\
2003 & 969.855 & 2.372 .264 & 3.342 .119 \\
2004 & 1.002 .071 & 2.520 .548 & 3.522 .619 \\
2005 & 1.093 .030 & 2.896 .414 & 3.989 .444 \\
2006 & 1.347 .931 & 2.742 .245 & 4.090 .176 \\
2007 & 1.684 .234 & 3.351 .246 & 5.035 .480 \\
2008 & 2.173 .088 & 3.709 .948 & 5.883 .036 \\
2009 & 2.023 .236 & 3.959 .317 & 5.982 .553 \\
2010 & 2.544 .480 & 4.643 .083 & 7.187 .563 \\
2011 & 2.830 .622 & 5.197 .048 & 8.027 .670 \\
2012 & 2.619 .311 & 4.983 .261 & 7.602 .572 \\
2013 & 2.584 .048 & 5.091 .784 & 7.675 .832 \\
\hline
\end{tabular}

Fuente: Elaboración propia basada en datos de Puertos del Estado (2014).

A continuación, se analizan de forma aislada los puertos de cada uno de los grupos descritos anteriormente. Para cada uno de los puertos se estudia la evolución de la cifra de pasajeros de crucero entre el año 1994 y 2013. Además, en el caso de los puertos que 
registran pasajeros de cruceros en régimen de inicio y fin de itinerario, el análisis se segrega en ambas tipologías de pasajeros.

Junto a lo anterior también se lleva a cabo un análisis portfolio, con objeto de analizar la posición estratégica de cada puerto en su zona geográfica. Para el análisis portfolio se emplea la matriz crecimiento-cuota de mercado, introducida inicialmente por Boston Consulting Group (BCG) (Henderson, 1979), adaptada a su versión para la industria portuaria, véase Figura 3.9. La matriz representa en el eje de abscisas la cuota de mercado media anual frente al crecimiento medio anual en el eje de ordenadas, para el periodo de análisis. Ésta se divide en cuatro cuadrantes cada uno de los cuales corresponde a una posición competitiva, las cuatro categorías son: elevado potencial, participante estelar, participante minoritario y líder maduro. La aplicación mayoritaria de esta matriz en el ámbito de investigación en el sector portuario, está referida a tráfico de mercancías y más en concreto a mercancía contenerizada. Ejemplos de trabajos de investigación en el sector portuario aplicando esta técnica son los de Haezendonck et al. (2006), Park (2006) y Winkelmans y Coeck (1993). La primera aplicación a tráfico de cruceros data del año 2013, en el trabajo desarrollado por Bagis y Dooms (2013), en el que analizan la posición competitiva de seis puertos de crucero en el Mediterráneo Oriental. La aplicación de esta matriz al análisis del tráfico de cruceros puede presentar ciertas limitaciones, puesto que en el tráfico de cruceros se venden itinerarios y no puertos, generando una interdependencia entre ellos que limita el crecimiento elevado de un puerto respecto a otro. Este aspecto no se registra de forma tan notable en el tráfico de contenedores, tráfico marítimo que ha sido ampliamente analizado mediante la aplicación de esta matriz, como se ha comentado anteriormente.

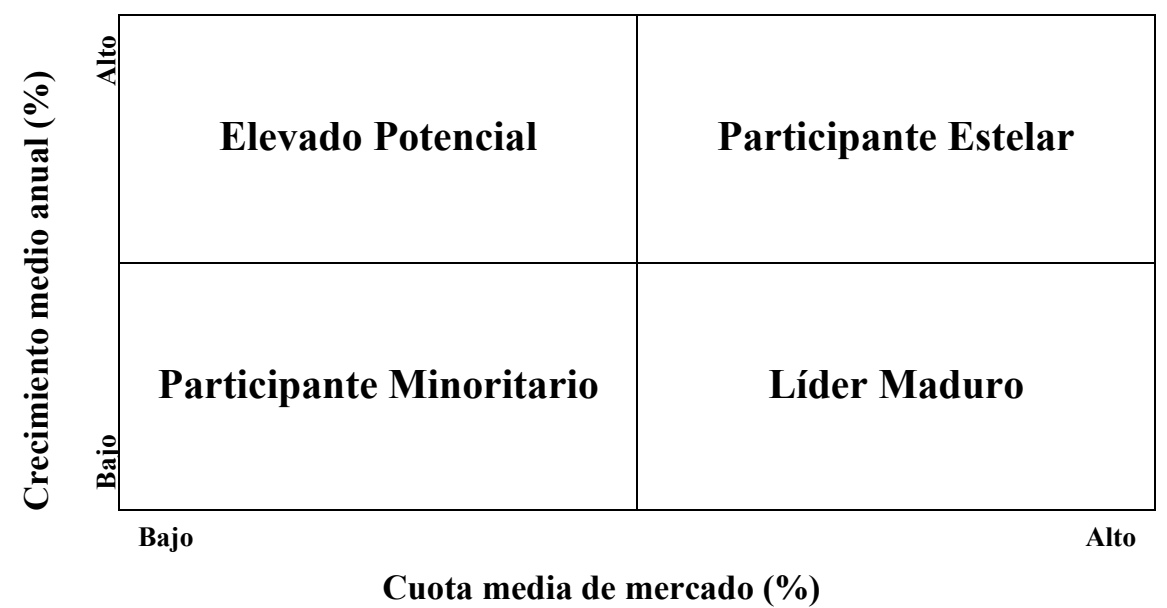

Figura 3.9: Matriz crecimiento-cuota de mercado de BCG aplicada al sector portuario. Fuente: Elaboración propia adaptada de Haezendonck (2001).

\subsubsection{Puertos de la costa mediterránea y atlántica andaluza}

El litoral Mediterráneo y Atlántico andaluz cuenta con el mayor número de puertos de crucero en el Sistema Portuario Español, de los 24 puertos situados a orillas de esta costa, 18 registran tráfico de cruceros, aunque con diferencias significativas entre ellos. Barcelona 
y Palma de Mallorca son los dos principales puertos en esta zona litoral con una tasa media de concentración entre 1994 y 2013 del 40,84\% y 28,62\%, respectivamente, véase Tabla 3.16. Este papel se hace extensivo a la totalidad del SPE, pues en ese mismo periodo, entre ambos concentraron el 53,42\% de los cruceristas registrados en puertos españoles.

Tabla 3.16: Tasas de concentración y variación de la cifra de pasajeros de crucero en los puertos de la costa mediterránea y atlántica andaluza, agrupadas por quinquenios, entre los años 1994 y 2013

\begin{tabular}{lcccccccc}
\hline \multirow{2}{*}{ Puerto } & \multicolumn{2}{c}{$\mathbf{1 9 9 4 - 1 9 9 8}$} & \multicolumn{2}{c}{$\mathbf{1 9 9 9 - 2 0 0 3}$} & \multicolumn{2}{c}{$\mathbf{2 0 0 4 - 2 0 0 8}$} & \multicolumn{2}{c}{$\mathbf{2 0 0 9 - 2 0 1 3}$} \\
\cline { 2 - 8 } & $\begin{array}{c}\text { Conc. } \\
\mathbf{( \% )}\end{array}$ & $\begin{array}{c}\text { Var. } \\
\mathbf{( \% )}\end{array}$ & $\begin{array}{c}\text { Conc. } \\
\mathbf{( \% )}\end{array}$ & $\begin{array}{c}\text { Var. } \\
\mathbf{( \% )}\end{array}$ & $\begin{array}{c}\text { Conc. } \\
\mathbf{( \% )}\end{array}$ & $\begin{array}{c}\text { Var. } \\
\mathbf{( \% )}\end{array}$ & $\begin{array}{c}\text { Conc. } \\
(\mathbf{\% )}\end{array}$ & $\begin{array}{c}\text { Var. } \\
(\mathbf{\%})\end{array}$ \\
\hline Barcelona & 34,28 & 27,49 & 39,38 & 18,04 & 44,40 & 15,02 & 45,30 & 4,92 \\
Palma de & 30,09 & 46,47 & 33,19 & 15,38 & 28,65 & 8,92 & 22,54 & 4,53 \\
Mallorca & & & & & & & & \\
Málaga & 12,55 & 4,75 & 8,70 & 16,74 & 7,66 & 12,64 & 10,57 & 6,64 \\
Valencia & 0,46 & $-34,08$ & 1,22 & 192,14 & 4,00 & 36,79 & 6,49 & 20,91 \\
Cádiz & 5,94 & 16,99 & 6,04 & 23,47 & 5,30 & 11,09 & 6,14 & 12,20 \\
Ibiza & 7,20 & $-0,74$ & 2,39 & 29,03 & 2,69 & 4,12 & 3,04 & 26,50 \\
Cartagena & 0,26 & 174,72 & 0,93 & 83,04 & 0,91 & 26,34 & 1,77 & 37,05 \\
Alicante & 1,52 & 17,67 & 1,55 & 32,29 & 1,72 & 15,94 & 1,51 & $-7,11$ \\
Mahón & 6,24 & 24,06 & 4,66 & 4,60 & 2,27 & 6,67 & 1,31 & 5,30 \\
Almería & 0,66 & 58,32 & 0,85 & 8,82 & 1,25 & 45,21 & 0,66 & $-17,53$ \\
Sevilla & 0,32 & 581,88 & 0,14 & 23,07 & 0,37 & 74,11 & 0,32 & 5,59 \\
Motril & 0,14 & 19,71 & 0,34 & 34,47 & 0,22 & 11,69 & 0,15 & 68,72 \\
Ceuta & 0,00 & 0,00 & 0,23 & $-2,97$ & 0,32 & 148,06 & 0,08 & $-25,41$ \\
Melilla & 0,00 & $-25,00$ & 0,04 & 52,10 & 0,03 & 2,69 & 0,03 & 35,30 \\
Tarragona & 0,28 & 52,29 & 0,11 & 126,91 & 0,17 & 123,28 & 0,03 & 134,97 \\
La Savina & 0,02 & $-19,98$ & 0,19 & 240,89 & 0,02 & 44,57 & 0,02 & 4,00 \\
Castellón & 0,00 & 0,00 & 0,00 & 0,00 & 0,00 & $-20,00$ & 0,02 & 20,76 \\
Huelva & 0,04 & $-42,26$ & 0,04 & $-19,23$ & 0,01 & 250,40 & 0,01 & 39,24 \\
\hline
\end{tabular}

Fuente: Elaboración propia basada en datos de Puertos del Estado (2014).

El puerto de Barcelona, referente como primer puerto de cruceros en el Mediterráneo y Europa y como cuarto puerto de cruceros del mundo en 2013, durante el periodo de 1994 a 2013 acumuló un crecimiento medio anual del 15,78\%, véase Tabla 3.16. Segregando la evolución según las categorías de pasajeros en inicio y fin de itinerario y tránsito, para el periodo 2000-2013, la primera categoría ha registrado un mayor auge con una tasa media anual del 14,04\%, frente al 11,91\% de los pasajeros en tránsito. Durante este periodo, ambos tipos de pasajeros presentan una distribución equilibrada, superando ligeramente los pasajeros en régimen de puerto base $(54,16 \%)$ a los de tránsito $(45,84 \%)$, véase Gráfico 3.10 .

Palma de Mallorca, con su posición estratégica en el Mediterráneo Occidental, ha registrado una evolución positiva en las dos décadas comprendidas entre 1994 y 2013 con una tasa media anual de crecimiento del $17,37 \%$, ligeramente superior a la del puerto de Barcelona para el mismo periodo. Durante el periodo de 2000 a 2013, la categoría de pasajeros en tránsito ha crecido más que la de pasajeros en inicio y fin de itinerario, con una tasa media anual del $11,71 \%$ y 5,88\%, respectivamente. Además, el reparto entre ambas categorías ha sido más equitativo, respecto al caso de Barcelona, distribuyéndose, en este periodo, en pasajeros de puerto base 49,96\% y tránsito 50,04\%, véase Gráfico 3.10. 


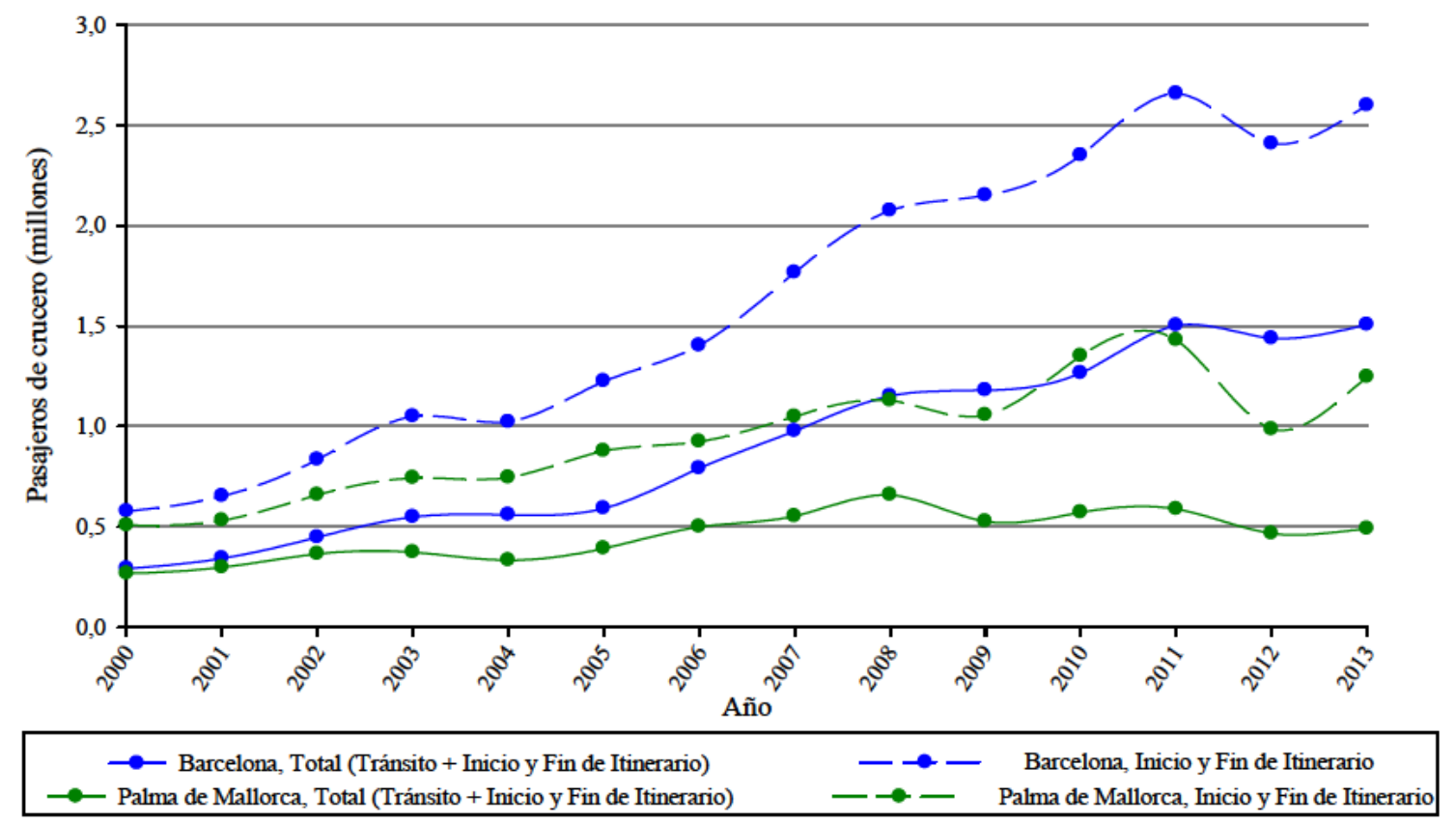

Gráfico 3.10: Cifras de pasajeros de crucero, segregadas en inicio y fin de itinerario y total agregado, para los puertos de Barcelona y Palma de Mallorca.

Fuente: Elaboración propia.

Los siguientes puertos por orden de magnitud de cruceristas son Málaga, Valencia y Cádiz, véase de nuevo Tabla 3.16. Los puertos de Málaga y Valencia están consolidados como puerto base en el Mediterráneo Occidental, registrando pasajeros en régimen de inicio y fin de itinerario durante todo el periodo de 2000 a 2013, Gráfico 3.11. En el caso de Cádiz, únicamente registró en 2010 y 2011 operaciones de puerto base asociadas a la naviera Iberocruceros, perteneciente al grupo Carnival Corporation.

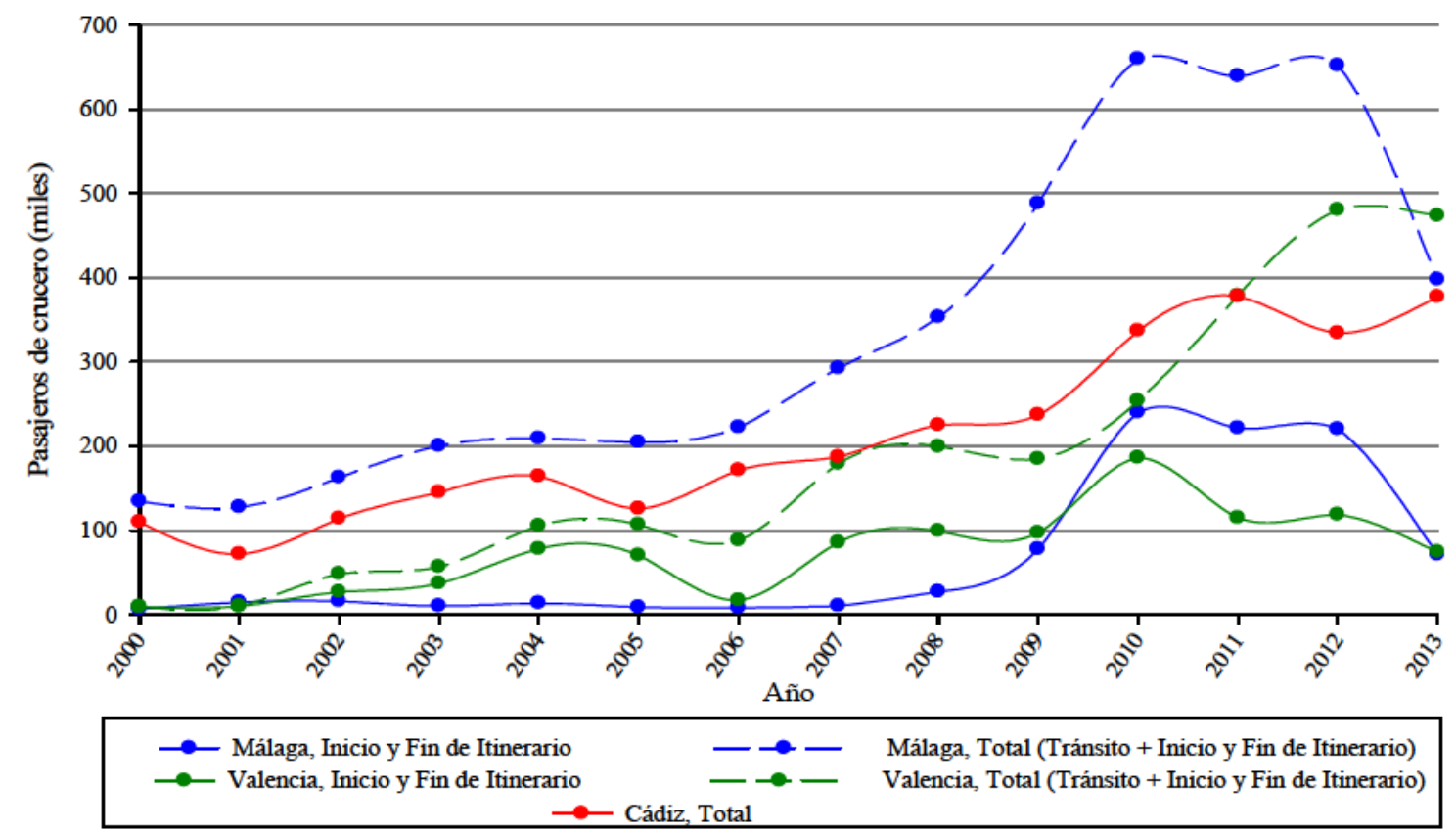

Gráfico 3.11: Cifras de pasajeros de crucero, segregadas en inicio y fin de itinerario y total agregado, para los puertos de Málaga y Valencia y total agregado para Cádiz.

Fuente: Elaboración propia. 
La cifra de cruceristas en el puerto de Málaga ha crecido a una tasa media anual del 10,48\% durante el periodo del año 1994 a 2013, concentrando durante este periodo el 7,76\% de los cruceristas de la costa mediterránea española. Entre el año 2000 y 2013 , el crecimiento registrado ha sido mayor en la categoría de pasajeros de inicio y fin de itinerario, con una tasa media anual del 45,11\%, frente al $8,78 \%$ de la categoría en tránsito. Esta última categoría ha presentado una mayor concentración respecto a la de puerto base, con una distribución media anual del 85,97\% frente al 14,03\%. En relación con este concepto, cabe destacar que desde el año 2010 se ha reducido la diferencia entre ambas categorías, respecto a las magnitudes que se registraban a comienzos de la década del año 2000, Gráfico 3.12.

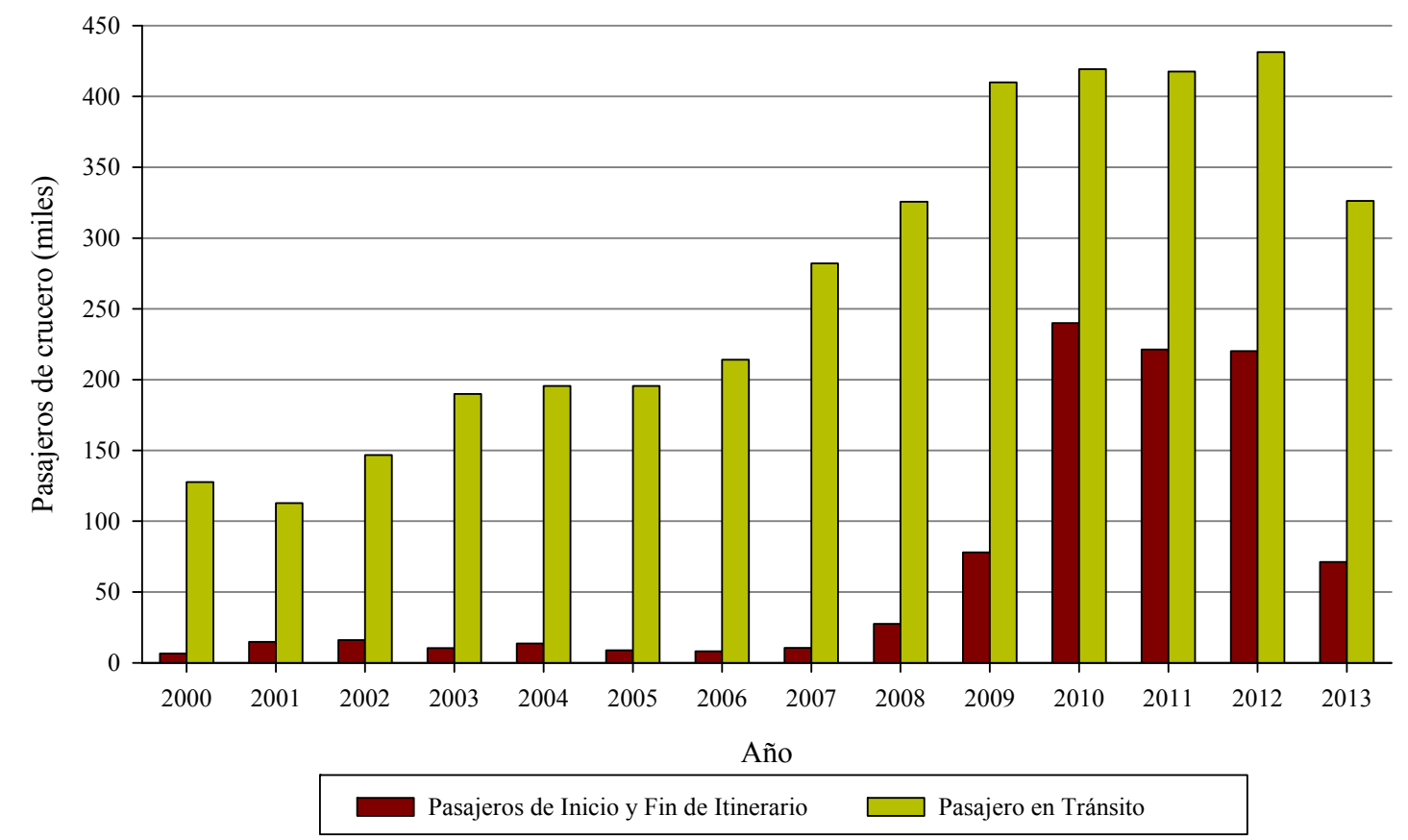

Gráfico 3.12: Cifras anuales de pasajeros de crucero, segregadas en inicio y fin de itinerario y tránsito, en el puerto de Málaga entre el año 2000 y 2013.

Fuente: Elaboración propia.

El puerto de Valencia ha registrado el segundo mayor crecimiento en esta zona litoral, con una tasa media anual del 58,57\% entre 1994 y 2013. Durante el periodo de 2000 a 2013, se ha registrado un crecimiento equilibrado de ambas categorías de cruceristas, con una tasa media anual del $51,73 \%$ en el caso de pasajeros de puerto base y del $46,23 \%$ para pasajeros en tránsito. Desde el año 2011, la cifra de pasajeros en tránsito supera con creces a la de pasajeros en régimen de puerto base, distribuyéndose ambas categorías en un $76,38 \%$ y $23,62 \%$, respectivamente, véase Gráfico 3.13 . 


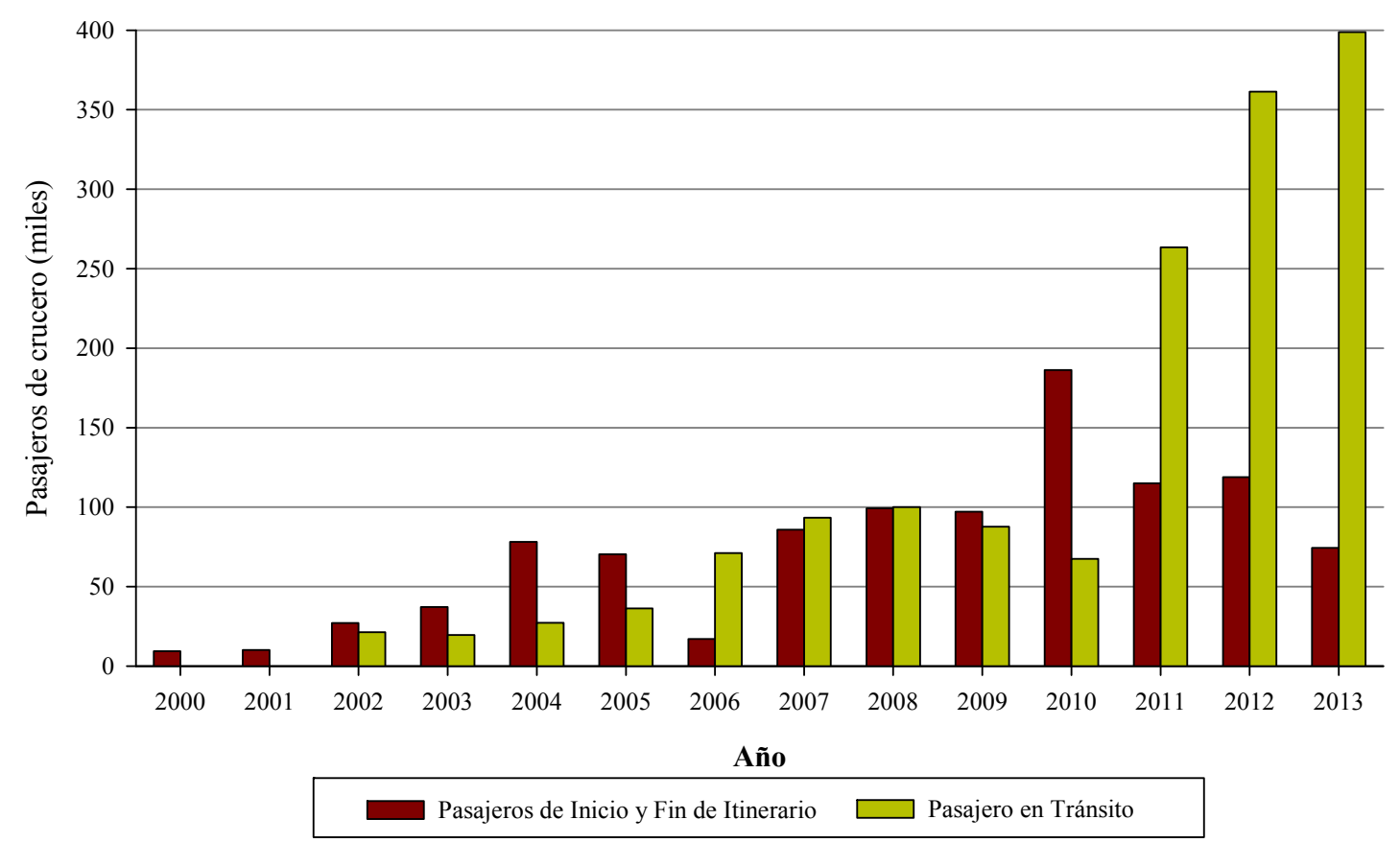

Gráfico 3.13: Cifras de pasajeros de crucero anuales, segregadas en inicio y fin de itinerario y tránsito, en el puerto de Valencia entre el año 2000 y 2013.

Fuente: Elaboración propia.

El puerto de Cádiz también registra un balance positivo en la cifra de cruceristas durante el periodo de 1994 a 2013, con una tasa media de crecimiento del 15,88\%. Su carácter de puerto base no está consolidado, registrando únicamente operaciones de embarque y desembarque de pasajeros en los años 2010 y 2011, como se ha comentado anteriormente. En ambos casos, las operativas con pasajeros de puerto base estuvieron asociadas a la naviera Iberocruceros. En 2010, la cifra total de pasajeros en régimen de puerto base fue de 10.507, distribuyéndose en 5.319 embarcados y 5.188 desembarcados. Mientras que en 2011, la magnitud fue ligeramente inferior a la de 2010, con un total de 7.571 pasajeros, de los cuales 3.771 correspondieron a embarque y 3.800 a desembarque.

Los 13 puertos restantes tienen como denominador común su carácter de puerto de escala. Además, se pueden dividir en dos grupos con patrones de comportamiento distintos. Por un lado, se sitúa un grupo de cinco puertos con una cifra de pasajeros regular a lo largo del todo el periodo, estando consolidado este tráfico en sus muelles, es el caso de: Alicante, Almería, Cartagena, Ibiza y Mahón. Todos ellos en las dos décadas comprendidas entre 1994 y 2013 han registrado, en términos netos, un incremento de la cifra de cruceristas, véase Tabla 3.16.

Los dos puertos de Baleares, Ibiza y Mahón, han sido los que mayor cuota de mercado han concentrado entre estos cinco, guardando una estrecha similitud entre ambas, con un 3,83\% para el primero y 3,62\% para el segundo. En términos de crecimiento medio anual, el de Ibiza (15,54\%) ha sido superior al de Mahón (9,42\%). 
El puerto de Cartagena ha registrado el mayor crecimiento de los cinco puertos de escala con tráfico consolidado, con una tasa para el periodo de 1994 a 2013 del 75,32\%, concentrando el $0,97 \%$ del tráfico de cruceros de esta zona litoral. Sus inmediatos competidores geográficos, Alicante al norte y Almería al sur, también han presentado un balance positivo en este periodo aunque más atenuado, $14,54 \%$ y $21,81 \%$, respectivamente. Sin embargo, durante los dos últimos años acumulan pérdida de tráfico de cruceros en sus muelles, véase Gráfico 3.14. Analizando en mayor profundidad esta cuestión, existe una competencia directa entre los puertos de Alicante, Almería y Cartagena, dada la distancia entre ellos y las cuotas de mercado que han concentrado entre 1994 y 2013, oscilando desde $0,85 \%$ para Almería a $1,57 \%$ para Alicante. Tomando como referencia el puerto de Cartagena, del de Alicante le separan 68 millas náuticas y de las dársenas de Almería una distancia ligeramente superior, 95 millas náuticas. Estas distancias imposibilitan que en un itinerario determinado, estos puertos constituyan escalas consecutivas, atendiendo a la velocidad de navegación de los buques de crucero, pues el tiempo en la mar sería reducido (aproximadamente 4 y 5 horas, respectivamente) frente a estancias en puerto más prolongadas. En esta circunstancia pueden residir las diferencias registradas entre el crecimiento del puerto de Cartagena y los descensos de Alicante y Almería en 2012 y 2013.

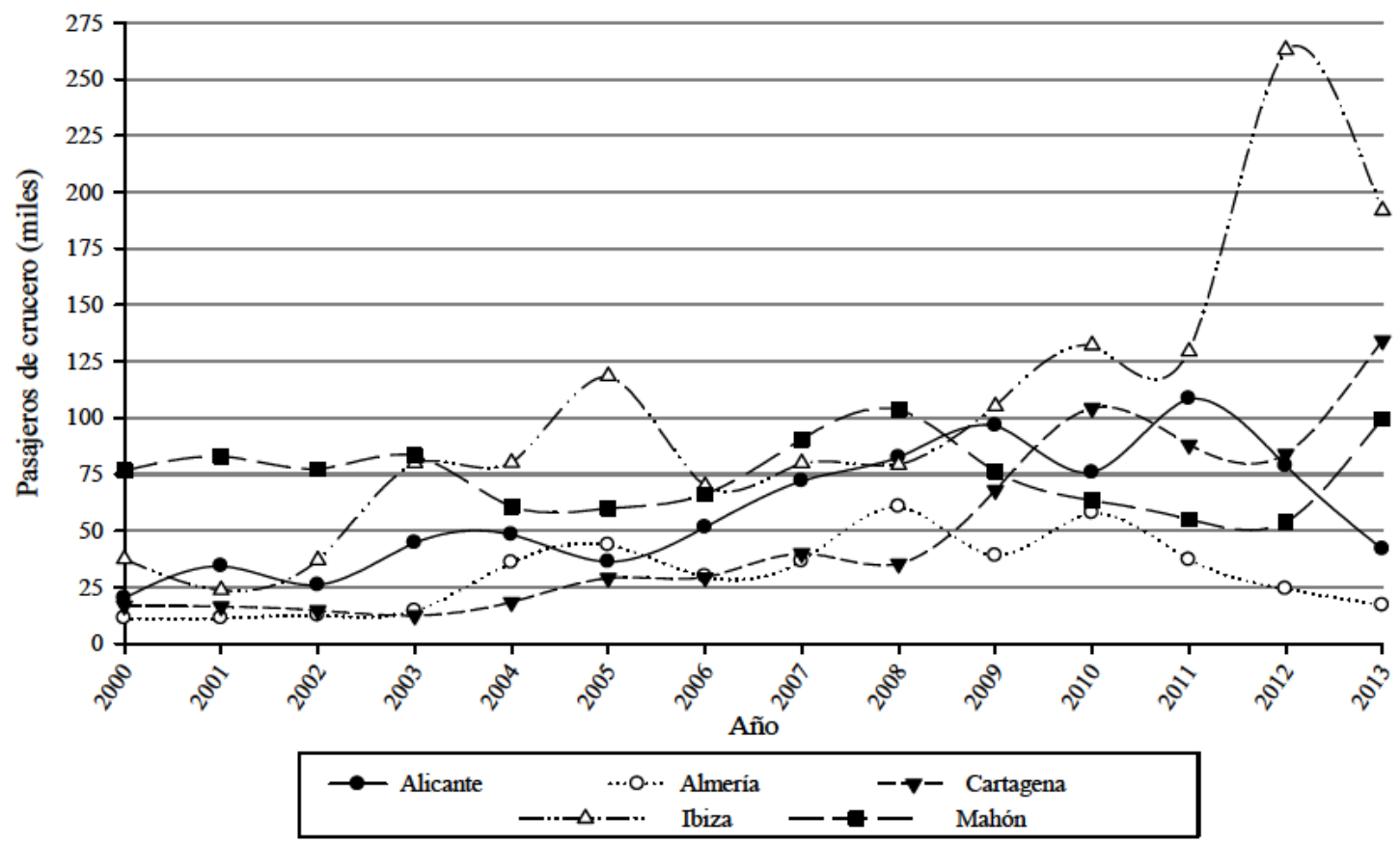

Gráfico 3.14: Evolución de la cifra de cruceristas en los puertos de Alicante, Almería, Cartagena, Ibiza y Mahón entre el año 2000 y 2013.

Fuente: Elaboración propia.

Tal y como se ha comentado anteriormente, este conjunto de puertos tiene un carácter primordial de puertos de escala. Sin embargo, tres de ellos sí que han registrado operativas aisladas de embarque de pasajeros en régimen de puerto base entre el año 2000 y 2013. Almería e Ibiza han registrado únicamente una operación. En particular, Almería registró un embarque de pasajeros en régimen de puerto base asociado al buque Grand Celebration de la naviera Iberocruceros, el 19 de abril de 2011, dando lugar al inicio de un itinerario de seis días de duración por el Mediterráneo Occidental (Autoridad Portuaria de Almería, 2011a). 
En cuanto al puerto de Ibiza, en mayo de 2009 llevó a cabo una operación con 1.222 pasajeros en régimen de inicio y fin de itinerario (Autoridad Portuaria de Baleares, 2013). El puerto de Alicante ha registrado un mayor número de operativas con pasajeros de puerto base, sin llegar a consolidar este carácter. En concreto, desde el año 2005 hasta 2013 registró pasajeros de inicio y fin de itinerario asociado a operativas de interporting, destacando sobre todo, los años 2007, 2009, 2010 y 2011. Las operativas desarrolladas en 2009 estuvieron asociadas a los buques MSC Lirica y MSC Orchestra de la naviera italiana MSC Cruises, puesto que permitían el embarque de pasajeros en su escala en el puerto alicantino (MSC Cruises, 2009).

Por otro lado, el segundo conjunto formado por ocho puertos, representó el $0,93 \%$ de los pasajeros de crucero en el Mediterráneo español y el 0,72\% a nivel nacional, durante el periodo de 1994 a 2013. De entre éstos, tres presentaron un tráfico de cruceros relevante pero todavía no consolidado en sus muelles, con un orden de magnitud inferior a los casos descritos anteriormente y con evolución irregular, son los puertos de Motril, Sevilla y Ceuta, Gráfico 3.15. Nótese que el puerto de Motril estuvo gestionado por la Autoridad Portuaria de Almería-Motril hasta el año 2005, en agosto de este mismo año se segregan, dando lugar a dos Autoridades Portuarias independientes, Almería y Motril (BOE, 2005). Las cifras representadas en el Gráfico 3.15 corresponden a las cifras aisladas para este puerto en el periodo de 2000 a 2013 , durante el cual, el crecimiento medio anual fue del $43,51 \%$. En cuanto al puerto de Sevilla, la principal componente de su tráfico de cruceros está constituida por un crucero fluvial-marítimo desarrollado a bordo del buque La Belle de Cadix de la compañía Croisi Europe. Su evolución entre el año 2000 y 2013, en términos netos, fue positiva, con un crecimiento medio anual del $40,51 \%$, de forma análoga al caso de Ceuta con una tasa del $46,03 \%$.

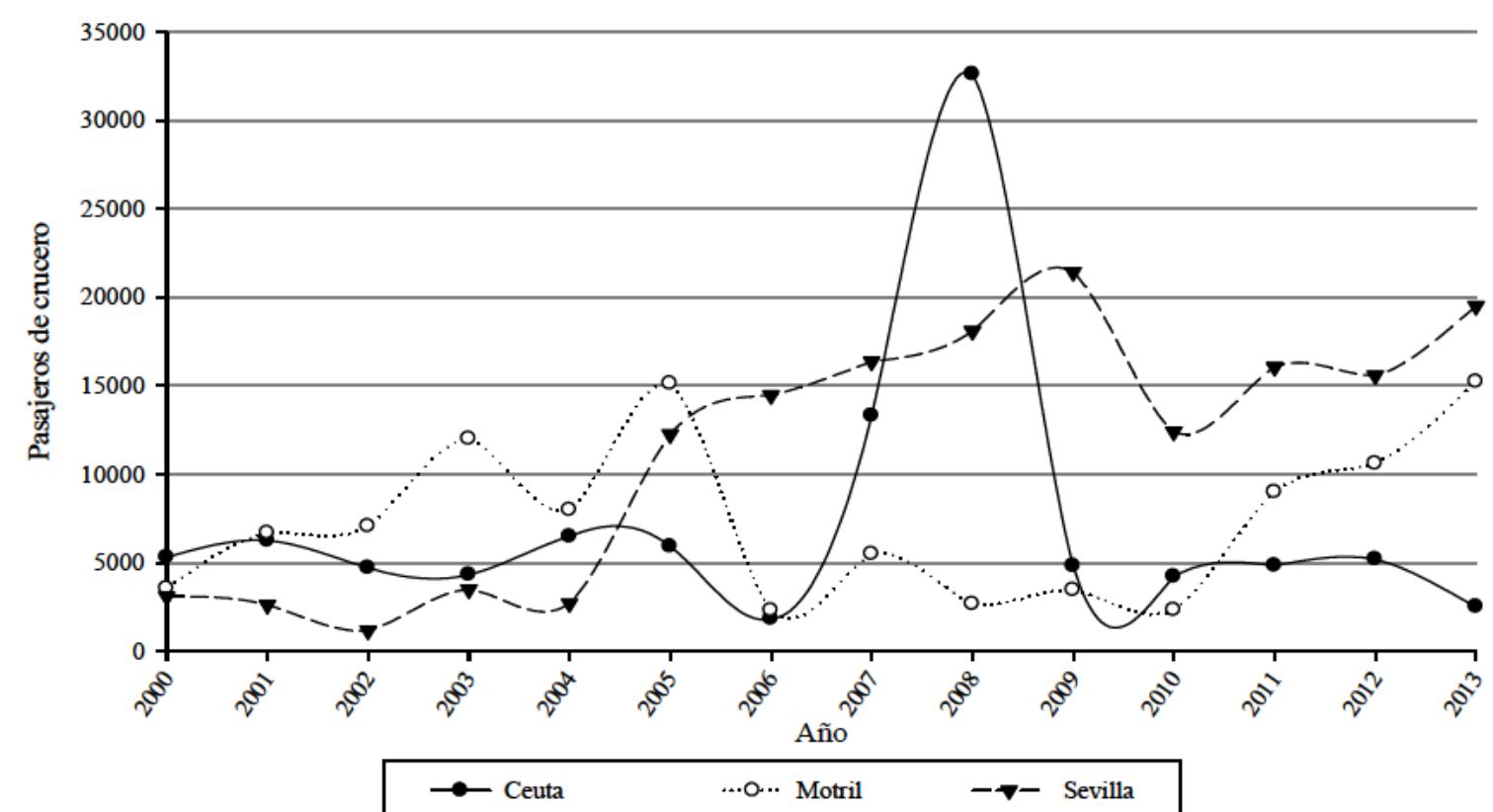

Gráfico 3.15: Evolución de la cifra de cruceristas en los puertos de Ceuta, Motril y Sevilla entre el año 2000 y 2013.

Fuente: Elaboración propia. 
Los cinco puertos restantes han presentado una evolución irregular alternando periodos de crecimiento y descenso, incluso se han dado casos en los que en determinados años no se han registrado escalas de cruceros, véase Gráfico 3.16. Los puertos de Castellón, Tarragona y Huelva tienen un carácter netamente industrial, destacando los tráficos de gráneles sólidos, líquidos y productos químicos, respectivamente. En los tres casos, las Autoridades Portuarias están emprendiendo acciones para potenciar el tráfico de cruceros en sus muelles. Estos conceptos se desarrollan con mayor detalle en el apartado 3.2.3 y en el Anexo II, dedicados a las instalaciones específicas que cada puerto tiene en relación con el tráfico de cruceros. Mientras que los puertos de La Savina (isla de Formentera) y Melilla son de pequeño tamaño, además de estar especializados en otros tráficos portuarios que difieren del tráfico de cruceros.

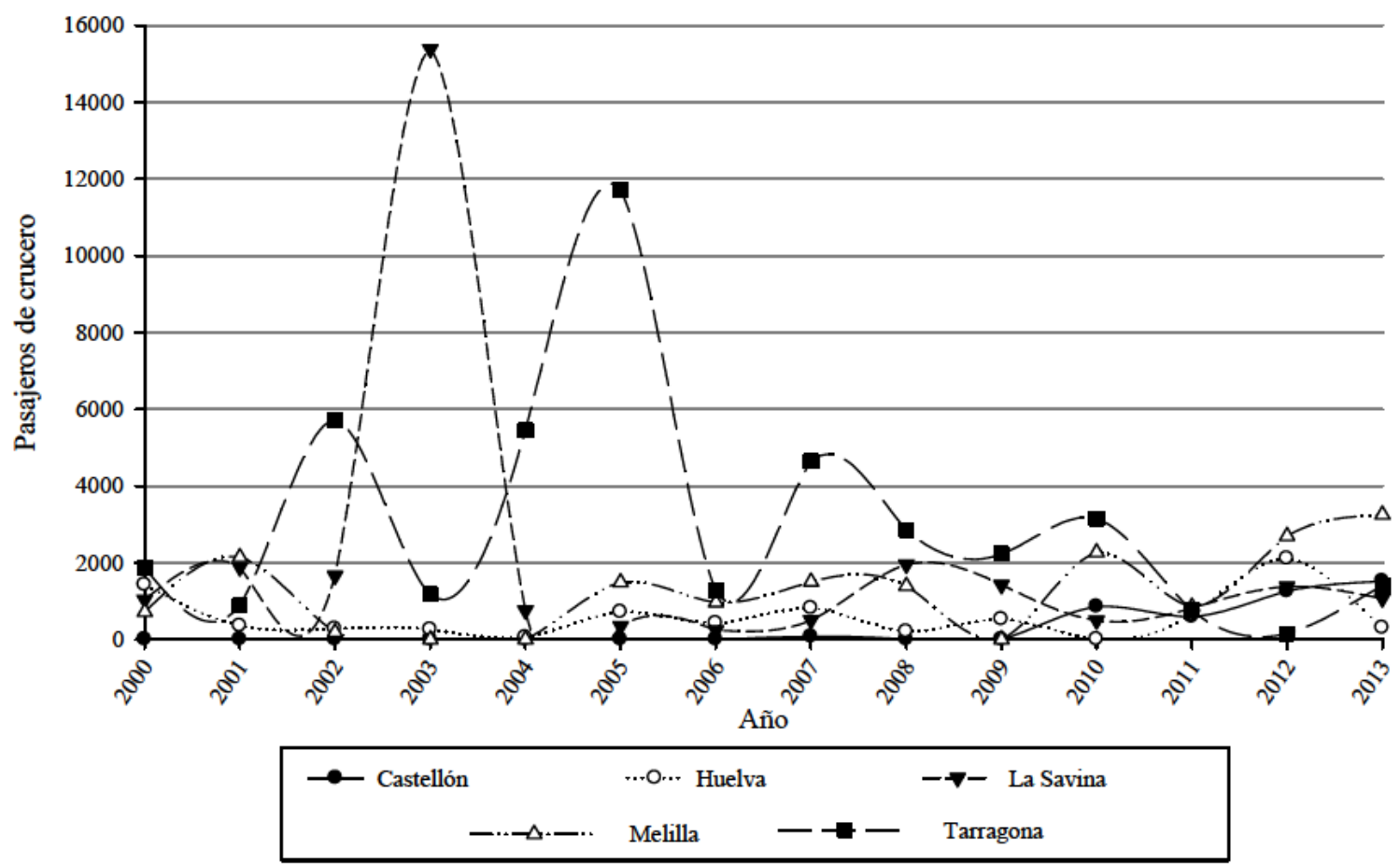

Gráfico 3.16: Evolución de la cifra de cruceristas en los puertos de Castellón, Huelva, La Savina, Melilla y Tarragona entre el año 2000 y 2013.

Fuente: Elaboración propia.

Los puertos de crucero de la costa mediterránea y atlántica andaluza están divididos en tres posiciones competitivas, según los resultados del análisis portfolio realizado para el periodo de 2000 a 2013, véase Gráfico 3.17. Cuatro puertos están localizados en el cuadrante lider maduro, conjuntamente, concentran el $85,9 \%$ de la cuota de mercado entre el año 2000 y 2013. Entre éstos destacan Barcelona y Palma de Mallorca con una cuota del 43,71\% y $27,56 \%$, respectivamente. Estos cuatro puertos tienen el carácter de must see ports en el Mediterráneo Occidental. Este papel se ha mantenido entre el año 2000 y 2013 dado el balance registrado entre la tasa de crecimiento y la cuota de mercado. Focalizando la atención en la tasa de crecimiento, sus tasas en este periodo han oscilado entre el 8,36\% de Palma de Mallorca y el 12,88\% de Cádiz. Estas tasas se sitúan en similares órdenes de magnitud a la de crecimiento medio del tráfico de cruceros en el SPE para el mismo periodo 
del $11,60 \%$ y superan la tasa mundial en torno al $8 \%$. Por tanto, el fundamento de la posición competitiva obtenida está estrechamente ligado con este parámetro.

Seis puertos han obtenido la posición de elevado potencial. El puerto de Valencia tiene la mayor cuota de mercado en este cuadrante con un 4,17\% y muestra un comportamiento dinámico con la mayor tasa de crecimiento durante el periodo de $2000 \mathrm{a}$ 2013. Su tendencia lo puede consolidar como un must see port en los próximos años. A este puerto le siguen Ibiza y Cartagena. Ambos puertos han registrado un crecimiento similar cercano al $22,2 \%$ entre el año 2000 y 2013 . Estos tres puertos han concentrado una cuota de mercado del 8,07\%. Los tres puertos adicionales encuadrados con elevado potencial deben su posición, fundamentalmente, a su elevada tasa de crecimiento, sin embargo, la cuota de mercado que han registrado es muy reducida, véase Gráfico 3.17.

Los ocho puertos restantes están incluidos en el cuadrante de participante minoritario, con una cuota de mercado del 5,41\% en su conjunto. El tráfico de cruceros en varios de estos puertos no es una línea de negocio principal, con magnitudes irregulares a lo largo del periodo. Los resultados obtenidos en el análisis portfolio ponen de relieve una elevada concentración en esta zona geográfica, con 7 puertos de 18 concentrando el 93,97\% de los pasajeros de crucero.

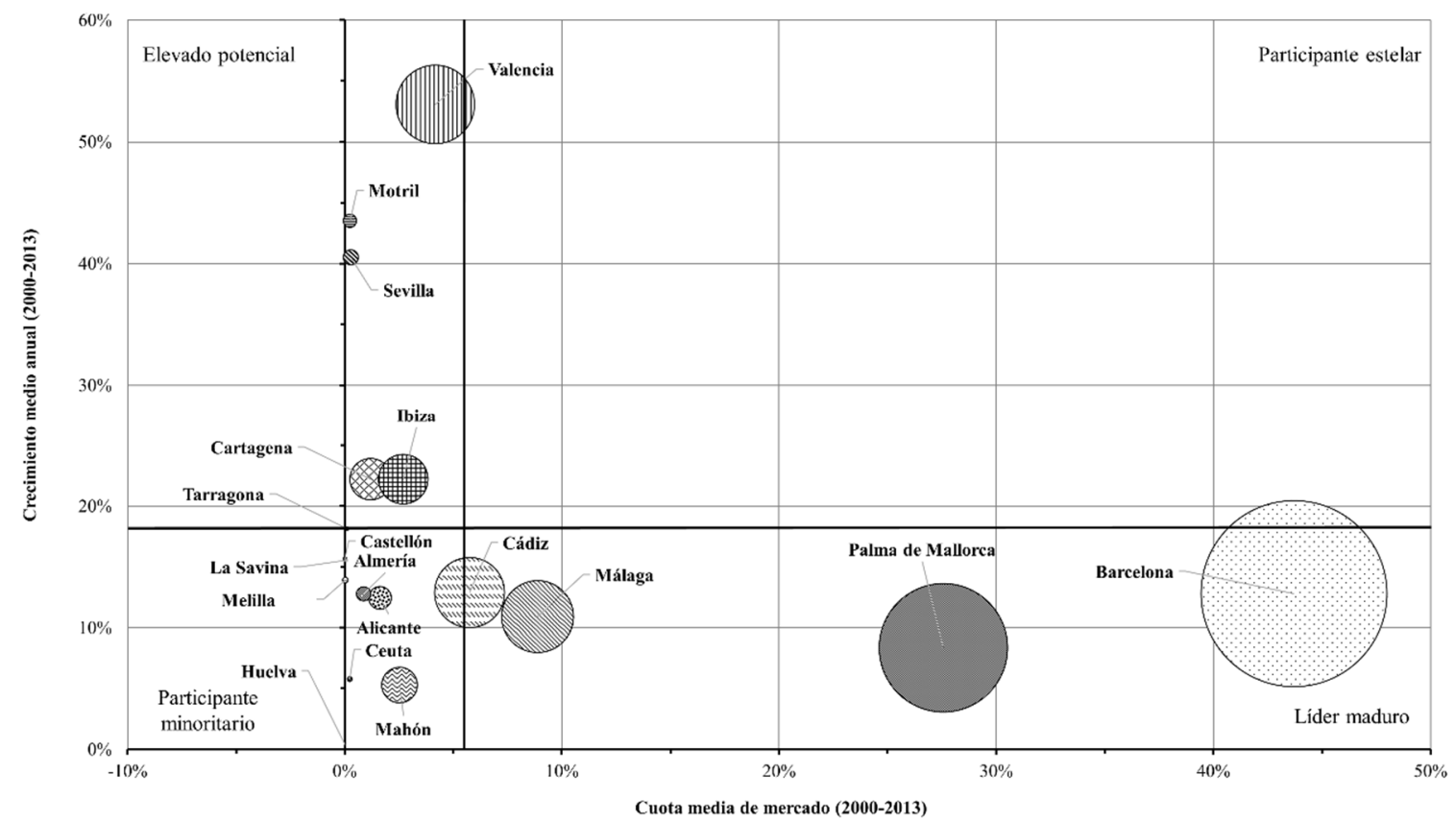

Gráfico 3.17: Análisis portfolio de los puertos de crucero del Mediterráneo español y la costa atlántica andaluza entre el año 2000 y 2013.

Fuente: Elaboración propia.

Tal y como se ha reflejado en el apartado dedicado a las navieras de crucero, durante los últimos 20 años se ha registrado un incremento en el tamaño de los buques incorporados a la flota mundial de buques de crucero, así como, en la cartera de pedidos de los buques actualmente en construcción con objeto de beneficiarse de las economías de escala. Esta tendencia hacia buques de mayor tamaño ha quedado patente, por ejemplo, en el ratio 
pasajeros/escala en los puertos del Mediterráneo español y la costa atlántica andaluza entre los años 1994 y 2013, véase Gráfico 3.18. El mayor incremento se ha generado en la década del año 2000, mientras a comienzos de esta década la cifra media de pasajeros por escala se situaba en torno a 860 , en el año 2010 se superaban los 2.000 pasajeros por escala. Un hecho relevante en relación con la presencia de mega-buques de crucero en el Mediterráneo se ha producido en septiembre de 2014 con la escala en los puertos de Barcelona, Málaga y Palma de Mallorca del buque Oasis of the Seas, constituyendo la primera navegación de este buque por aguas del Mediterráneo, ya que su zona de operación hasta la fecha era el mar Caribe con Miami como puerto base.

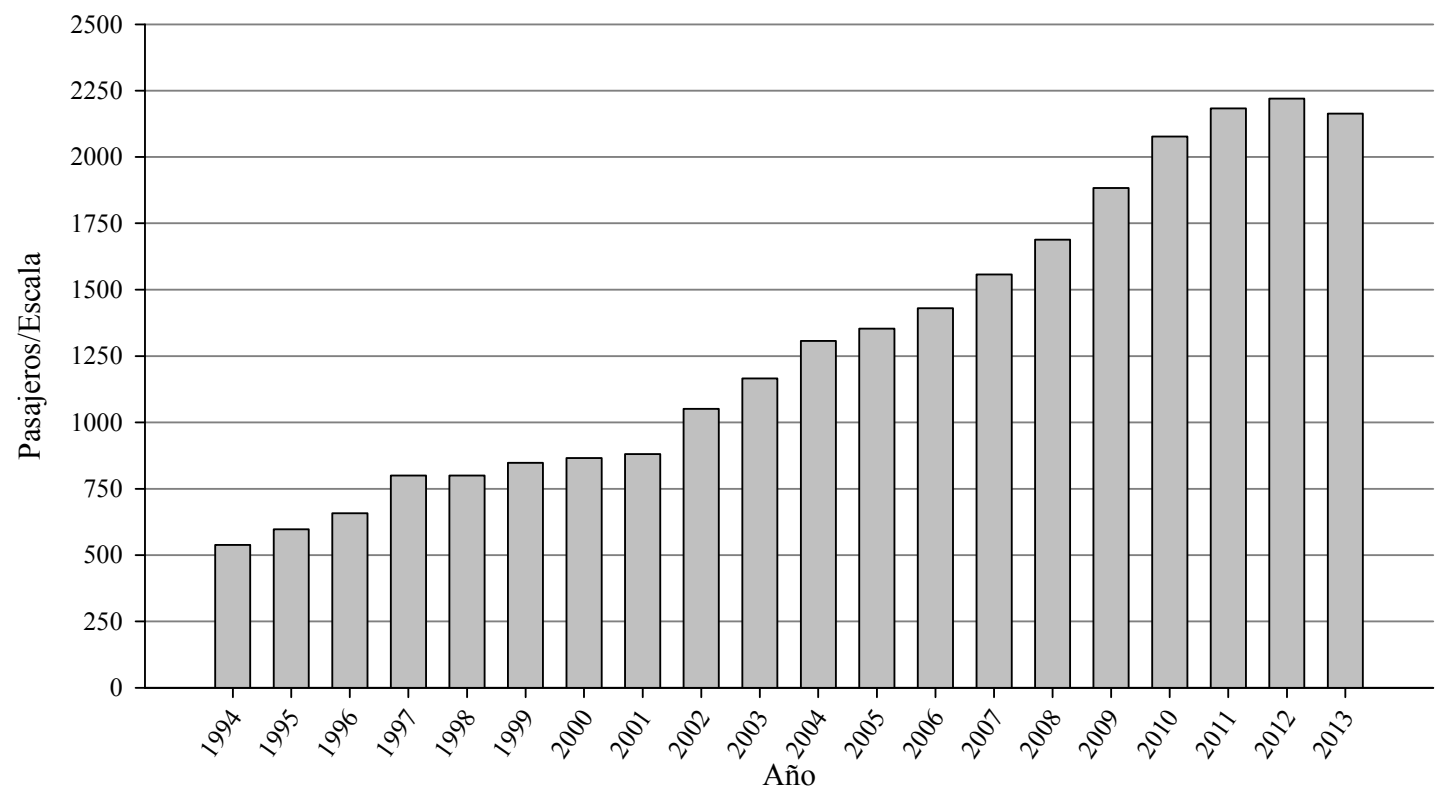

Gráfico 3.18: Evolución del ratio pasajeros/escala en los puertos del Mediterráneo español y la costa atlántica andaluza entre 1994 y 2013.

Fuente: Elaboración propia.

\subsubsection{Puertos de las islas Canarias}

De los 11 puertos de titularidad estatal situados en las islas Canarias, ocho registran tráfico de cruceros, además éstos están repartidos entre las siete islas que conforman el archipiélago. El principal puerto canario de cruceros es el de Santa Cruz de Tenerife, con una tasa media del 39,15\% de los cruceristas registrados en los puertos de las islas Canarias entre 1997 y 2013, véase Tabla 3.17. Tras Santa Cruz de Tenerife se han situado los puertos de Arrecife (isla de Lanzarote) y Las Palmas de Gran Canaria, ambos con tasas de concentración muy similares en el periodo analizado, 21,92\% y 20,72\%, respectivamente. La isla de La Palma, y más en concreto el puerto de su capital Santa Cruz de La Palma, ha concentrado el 11,99\% de los cruceristas que han hecho escala en las islas Canarias. Las islas de Fuerteventura, La Gomera y El Hierro también han registrado actividad crucerística aunque con volúmenes muy inferiores a los casos expuestos anteriormente. Entre éstas destaca Fuerteventura, con una tasa de concentración del 3,95\% asociado al tráfico de cruceros en Puerto del Rosario, véase Tabla 3.17. 
Tabla 3.17: Tasas de concentración y variación de la cifra de pasajeros de crucero en los puertos de las islas Canarias, agrupadas por cuatrienios, entre los años 1997 y 2013

\begin{tabular}{|c|c|c|c|c|c|c|c|c|}
\hline \multirow[b]{2}{*}{ Puerto } & \multicolumn{2}{|c|}{$1997-2000$} & \multicolumn{2}{|c|}{ 2001-2004 } & \multicolumn{2}{|c|}{ 2005-2008 } & \multicolumn{2}{|c|}{ 2009-2013 } \\
\hline & $\begin{array}{c}\text { Conc. } \\
(\%)\end{array}$ & $\begin{array}{l}\text { Var. } \\
(\%)\end{array}$ & $\begin{array}{c}\text { Conc. } \\
(\%)\end{array}$ & $\begin{array}{l}\text { Var. } \\
(\%)\end{array}$ & $\begin{array}{c}\text { Conc. } \\
(\%)\end{array}$ & $\begin{array}{l}\text { Var. } \\
(\%)\end{array}$ & $\begin{array}{c}\text { Conc. } \\
(\%)\end{array}$ & $\begin{array}{l}\text { Var. } \\
(\%)\end{array}$ \\
\hline $\begin{array}{l}\text { Santa Cruz de } \\
\text { Tenerife }\end{array}$ & 43,68 & 25,73 & 38,97 & 26,87 & 37,98 & 5,71 & 36,60 & 6,87 \\
\hline $\begin{array}{l}\text { Las Palmas de } \\
\text { Gran Canaria }\end{array}$ & 21,09 & 60,06 & 18,39 & 15,97 & 19,00 & 15,05 & 23,66 & 13,03 \\
\hline Arrecife & 21,56 & 40,19 & 24,04 & 32,70 & 22,23 & 7,36 & 20,26 & 5,12 \\
\hline $\begin{array}{l}\text { Santa Cruz de la } \\
\text { Palma }\end{array}$ & 8,82 & 48,98 & 13,31 & 33,90 & 13,88 & 6,85 & 11,97 & 8,34 \\
\hline Puerto del Rosario & 1,48 & 36,84 & 3,10 & 221,63 & 5,53 & 20,38 & 5,35 & 4,13 \\
\hline $\begin{array}{l}\text { San Sebastián de la } \\
\text { Gomera }\end{array}$ & 2,91 & 33,33 & 2,14 & 20,43 & 1,10 & 2,33 & 1,89 & 45,63 \\
\hline La Estaca & 0,18 & 0,00 & 0,04 & 35,87 & 0,20 & 38,34 & 0,21 & 32,34 \\
\hline Los Cristianos & 0,28 & 0,00 & 0,01 & 0,00 & 0,08 & 74,70 & 0,06 & 25,13 \\
\hline
\end{tabular}

Fuente: Elaboración propia basada en datos estadísticos de la A.P. de Las Palmas de Gran Canaria (2014a), A.P. de Las Palmas de Gran Canaria (2014b) y de la A.P. de Santa Cruz de Tenerife (2014).

De los ocho puertos con actividad crucerista en las islas Canarias, únicamente Santa Cruz de Tenerife y Las Palmas de Gran Canaria, tienen carácter de puerto base. La magnitud de cruceristas en régimen de inicio y/o fin de itinerario registrada en Santa Cruz de Tenerife entre los años 2004 y 2013 ha sido de mayor magnitud, con un 38,4\% de los cruceristas totales, respecto a la registrada en Las Palmas de Gran Canaria con un 12,1\%, véase Tabla 3.18. En este sentido, desde el año 2011 ambos puertos han registrado un notable crecimiento de la cifra de pasajeros en régimen de inicio y fin de itinerario, destacando Las Palmas, pues en 2013 ha superado a Santa Cruz de Tenerife, en contraposición a la tendencia registrada desde 2004.

Tabla 3.18: Tráfico de cruceros en los puertos de Las Palmas de Gran Canaria y Santa Cruz de Tenerife entre el año 2004 y 2013, cifras segregadas en pasajeros de inicio y fin de itinerario, tránsito y total agregado

\begin{tabular}{ccccccc} 
& \multicolumn{2}{c}{ Las Palmas de Gran Canaria } & \multicolumn{3}{c}{ Santa Cruz de Tenerife } \\
\hline Año & Inicio y fin de itinerario & Tránsito & Total & Inicio y fin de itinerario & Tránsito & Total \\
\hline 2004 & 17.420 & 375.975 & 393.395 & 159.416 & 172.074 & 331.490 \\
2005 & 19.410 & 403.695 & 423.105 & 192.356 & 178.559 & 370.915 \\
2006 & 17.390 & 344.915 & 362.305 & 151.538 & 162.323 & 313.861 \\
2007 & 34.999 & 404.494 & 439.493 & 159.848 & 201.475 & 361.323 \\
2008 & 100.207 & 476.205 & 576.412 & 121.320 & 280.698 & 402.018 \\
2009 & 78.173 & 533.076 & 611.249 & 121.436 & 301.080 & 422.516 \\
2010 & 30.876 & 633.985 & 664.861 & 196.491 & 339.840 & 536.331 \\
2011 & 147.635 & 623.525 & 771.160 & 202.757 & 404.609 & 607.366 \\
2012 & 130.733 & 702.030 & 832.763 & 210.897 & 458.456 & 669.353 \\
2013 & 241.958 & 588.266 & 830.224 & 165.760 & 362.295 & 528.055 \\
\hline
\end{tabular}

Fuente: Elaboración propia basada en datos estadísticos de la A.P. de Las Palmas de Gran Canaria (2014b) y de la A.P. Santa Cruz de Tenerife (2014). 
Los ocho puertos de crucero de esta zona litoral española se dividen en dos posiciones competitivas, líder maduro y elevado potencial, atendiendo a los resultados del análisis portfolio para el periodo comprendido entre los años 2000 y 2013, véase Gráfico 3.19. Los cuatro puertos situados en el cuadrante de líder maduro han concentrado conjuntamente el 93,61\% de la cuota de mercado en el periodo de análisis. Además, el crecimiento medio anual en este mismo periodo ha oscilado entre el 13,05\% para Santa Cruz de Tenerife y el 16,61\% para Santa Cruz de La Palma. Por lo que su posición competitiva se explica, parcialmente, porque la tasa registrada por cada uno de ellos supera ligeramente la tasa de crecimiento en el SPE durante el mismo periodo y duplica a la tasa mundial de crecimiento de la cifra de pasajeros de crucero. Entre los cuatro puertos restantes, enmarcados en la posición de elevado potencial, existen diferencias significativas entre ellos, mostrando dos patrones distintos. Por un lado, los puertos de La Estaca y Los Cristianos han registrado una tasa de crecimiento elevada, sin embargo, su cuota de mercado ha sido muy reducida. Por otro lado, San Sebastián de La Gomera y Puerto del Rosario han concentrado el 4,42\% y $1,80 \%$, respectivamente, de la cuota de mercado en este periodo, unido a una tasa de crecimiento medio anual que supera el $20 \%$. Cuestión en la que radica, fundamentalmente, la posición de elevado potencial obtenida.

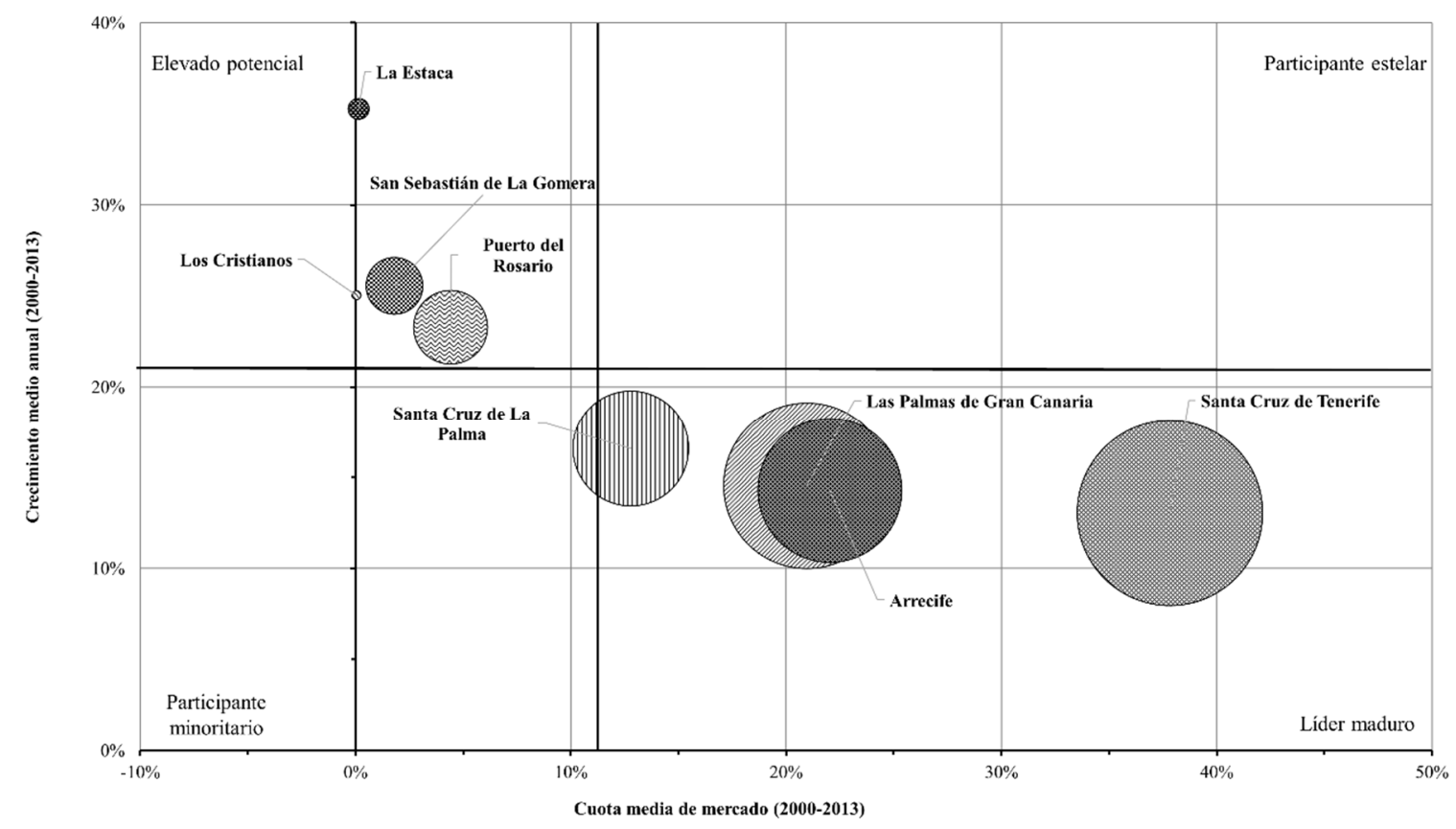

Gráfico 3.19: Análisis portfolio de los puertos de crucero de las islas Canarias entre el año 2000 y 2013.

Fuente: Elaboración propia.

Los principales itinerarios en los que están incluidos los puertos canarios discurren por Marruecos, las islas Atlánticas (Madeira y Azores) e itinerarios de reposicionamiento entre Europa y América y viceversa. 


\subsubsection{Puertos del mar Cantábrico y la costa atlántica gallega}

Entre los 11 puertos situados en la costa atlántica gallega y el mar Cantábrico, cuatro de ellos no registran tráfico de cruceros por tratarse de puertos de marcado carácter industrial como Avilés, Marín y Ría de Pontevedra, Pasajes y San Cibrao. Entre los siete restantes, Vigo ha sido el principal puerto en la zona, con un tráfico de cruceros consolidado acumulando el 59,28\% de los pasajeros de crucero en esta zona litoral entre 1994 у 2013 , extrapolando esta cifra al total de España equivale al 3,11\%. Tras el puerto de Vigo se ha situado el de A Coruña, con una cuota media de pasajeros de crucero para el periodo de análisis del 25,89\%, véase Tabla 3.19. Conjuntamente, los dos principales puertos de esta zona litoral han concentrado el $85,17 \%$ de los pasajeros de crucero. Año a año varios puertos han comenzado a registrar tráfico de cruceros en sus muelles, destacando el puerto de Bilbao por el crecimiento registrado durante estos 20 años con una tasa media anual del $36,29 \%$, hasta situarse como el $3^{\circ}$ puerto por volumen de pasajeros en esta zona costera española.

Tabla 3.19: Tasas de concentración y variación de la cifra de pasajeros de crucero en los puertos del mar Cantábrico y la costa atlántica gallega, agrupadas por quinquenios, entre los años 1994 y 2013

\begin{tabular}{|c|c|c|c|c|c|c|c|c|}
\hline \multirow[b]{2}{*}{ Puerto } & \multicolumn{2}{|c|}{ 1994-1998 } & \multicolumn{2}{|c|}{ 1999-2003 } & \multicolumn{2}{|c|}{ 2004-2008 } & \multicolumn{2}{|c|}{ 2009-2013 } \\
\hline & $\begin{array}{c}\text { Conc. } \\
(\%)\end{array}$ & $\begin{array}{l}\text { Var. } \\
(\%)\end{array}$ & $\begin{array}{c}\text { Conc. } \\
(\%)\end{array}$ & $\begin{array}{l}\text { Var. } \\
(\%)\end{array}$ & $\begin{array}{c}\text { Conc. } \\
(\%)\end{array}$ & $\begin{array}{l}\text { Var. } \\
(\%)\end{array}$ & $\begin{array}{c}\text { Conc. } \\
(\%)\end{array}$ & $\begin{array}{l}\text { Var. } \\
(\%)\end{array}$ \\
\hline Vigo & 62,40 & 12,72 & 57,19 & 13,14 & 63,21 & 25,72 & 54,30 & $-3,47$ \\
\hline A Coruña & 28,77 & 63,99 & 28,95 & 7,77 & 20,43 & 7,68 & 25,42 & 25,58 \\
\hline Bilbao & 0,53 & 40,53 & 5,43 & 50,66 & 8,61 & 39,55 & 12,57 & 15,25 \\
\hline Santander & 3,10 & 31,09 & 2,89 & 57,40 & 2,93 & 93,04 & 3,42 & $-7,45$ \\
\hline Gijón & 0,00 & 0,00 & 2,23 & 17,07 & 1,63 & 88,02 & 2,05 & 24,69 \\
\hline Ferrol & 0,00 & 0,00 & 0,00 & 0,00 & 0,88 & 53,15 & 1,36 & 4,09 \\
\hline $\begin{array}{l}\text { Vilagarcía de } \\
\text { Arousa }\end{array}$ & 5,20 & 35,56 & 3,31 & $-13,80$ & 2,30 & 3,66 & 0,76 & $-12,91$ \\
\hline
\end{tabular}

Fuente: Elaboración propia basada en datos estadísticos de Puertos del Estado (2014).

Vigo, A Coruña y Bilbao son los tres puertos que mayor magnitud de pasajeros de crucero han registrado, además de compartir embarques y desembarques de pasajeros en inicio y fin de itinerario. En este sentido, las cifras registradas de esta categoría de pasajeros están asociadas, fundamentalmente, con operaciones interporting. Desde 2005, año en que comienzan a registrarse los primeros pasajeros de puerto base, hasta 2013, el porcentaje anual aproximado de esta categoría de pasajeros ha sido del $2,47 \%$.

Como resultado del análisis portfolio, los siete puertos de crucero en esta zona geográfica se dividen en las cuatros posiciones competitivas, véase Gráfico 3.20. Vigo adopta la posición de líder maduro con una cuota de mercado del 58,3\% durante el periodo 2000-2013. Además, también tiene carácter de puerto base, este tipo de operaciones las inició en 2009. A Coruña constituye un participante estelar en esta zona geográfica con una cuota de mercado del $24,6 \%$ y un crecimiento medio anual entre el año 2000 y 2013 del 15,6\%. De forma análoga al caso de Vigo, A Coruña también registró pasajeros de inicio y fin de itinerario, comenzando las operaciones de puerto base en 2010. El puerto de Bilbao 
se encuadra como elevado potencial sobre todo por su crecimiento medio del $24 \%$ entre el año 2000 y 2013. Bilbao también registró pasajeros de inicio y fin de itinerario, siendo el pionero en este tipo de operativas en la zona, pues comenzó a registrar esta tipología de pasajeros en 2005. Además, las cifras registradas de pasajeros de inicio y fin de itinerario, han sido superiores a las de los dos puertos anteriores. Tanto Bilbao como A Coruña han registrado un crecimiento medio superior al $11,60 \%$, correspondiente al de la totalidad del SPE para el mismo periodo, de ahí las posiciones competitivas obtenidas.

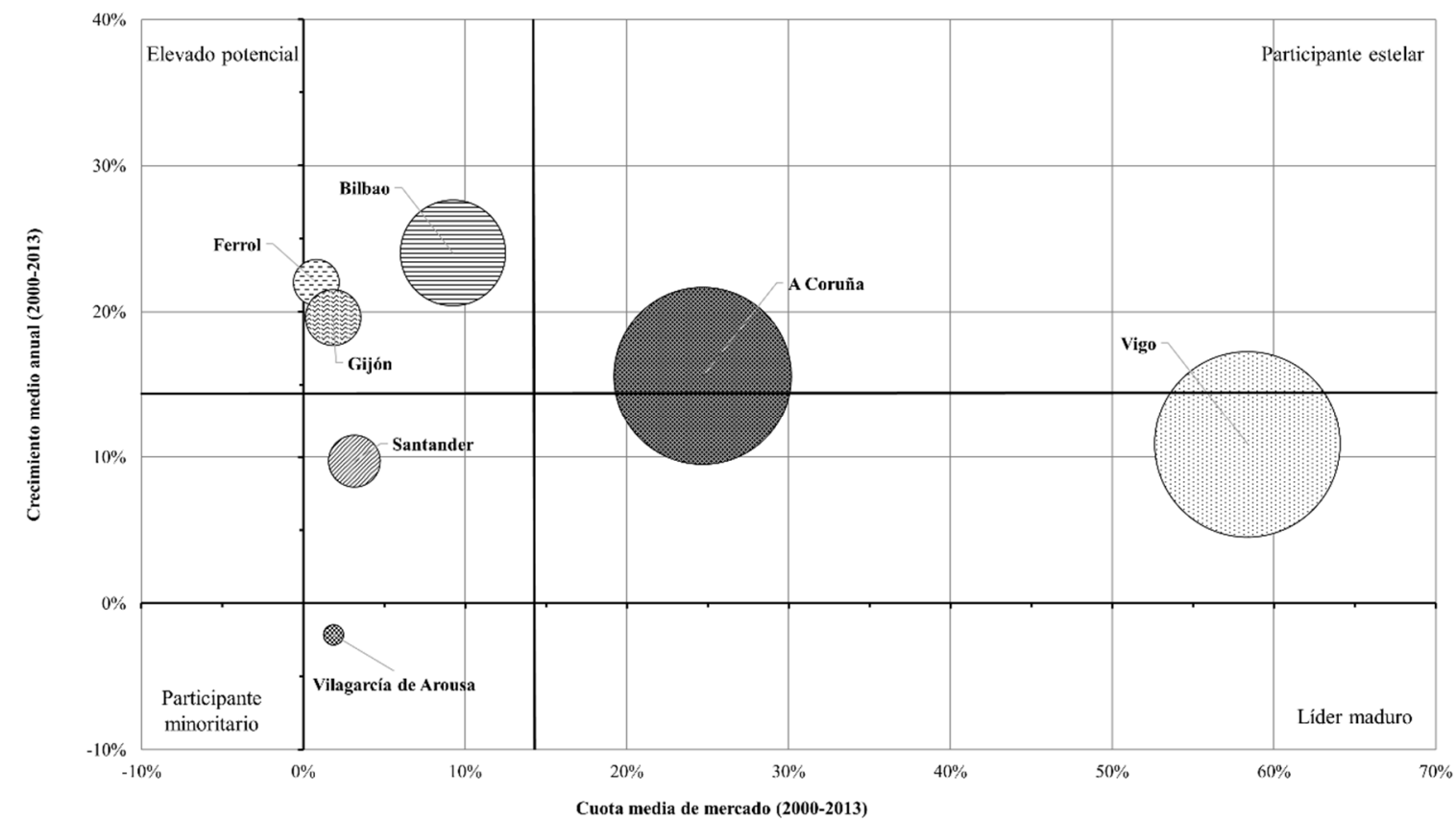

Gráfico 3.20: Análisis portfolio de los puertos de crucero de la costa del mar Cantábrico y atlántica gallega entre el año 2000 y 2013.

Fuente: Elaboración propia.

Analizando con mayor detalle las cifras de pasajeros de los tres puertos anteriores, segregadas en las categorías de inicio y fin de itinerario y tránsito, existen diferencias notables entre ellos. Bilbao cuenta con la trayectoria más dilatada en operaciones de puerto base, iniciando este tipo de operaciones en 2005, véase Tabla 3.20. Año a año ha ido consolidando su papel de puerto base, sobre todo a partir de 2010, alcanzando un porcentaje medio anual de esta categoría de pasajeros del 18,9\% entre 2010 y 2013 . Vigo constituye el siguiente puerto por magnitud de pasajeros de inicio y fin de itinerario, con una cuota del $3,74 \%$ en este mismo periodo. En tercer lugar, A Coruña, con operaciones de puerto base desde 2010, ha registrado, de media, un 1,49\% de pasajeros en inicio y fin de itinerario desde que dio inicio a este tipo de operaciones.

Tabla 3.20: Pasajeros de crucero en los puertos de A Coruña, Bilbao y Vigo entre el año 2000 y 2013, cifras segregadas en pasajeros en régimen de inicio y fin de itinerario y tránsito

\begin{tabular}{ccccccc} 
& \multicolumn{2}{c}{ A Coruña } & \multicolumn{2}{c}{ Bilbao } & \multicolumn{2}{c}{ Vigo } \\
\hline Año & $\begin{array}{c}\text { Inicio y fin de } \\
\text { itinerario }\end{array}$ & Tránsito & $\begin{array}{c}\text { Inicio y fin de } \\
\text { itinerario }\end{array}$ & Tránsito & $\begin{array}{c}\text { Inicio y fin } \\
\text { de itinerario }\end{array}$ & Tránsito \\
\hline 2000 & 0 & 36.559 & 0 & 5.524 & 0 & 57.716
\end{tabular}




\begin{tabular}{ccccccc} 
& \multicolumn{2}{c}{ A Coruña } & \multicolumn{2}{c}{ Bilbao } & \multicolumn{2}{c}{ Vigo } \\
\hline Año & $\begin{array}{c}\text { Inicio y fin de } \\
\text { itinerario }\end{array}$ & Tránsito & $\begin{array}{c}\text { Inicio y fin de } \\
\text { itinerario }\end{array}$ & Tránsito & $\begin{array}{c}\text { Inicio y fin } \\
\text { de itinerario }\end{array}$ & Tránsito \\
\hline 2001 & 0 & 26.954 & 0 & 5.537 & 0 & 52.550 \\
2002 & 0 & 25.247 & 0 & 8.089 & 0 & 73.316 \\
2003 & 0 & 42.644 & 0 & 7.433 & 0 & 72.219 \\
2004 & 0 & 43.819 & 84 & 47.624 & 0 & 93.497 \\
2005 & 0 & 33.757 & 77 & 13.302 & 17 & 131.519 \\
2006 & 0 & 39.988 & 348 & 16.297 & 690 & 128.578 \\
2007 & 0 & 50.261 & 180 & 22.792 & 0 & 150.478 \\
2008 & 0 & 57.517 & 770 & 36.356 & 0 & 216.333 \\
2009 & 0 & 53.574 & 398 & 28.597 & 2.146 & 220.802 \\
2010 & 373 & 70.322 & 7.150 & 36.244 & 20.567 & 213.077 \\
2011 & 3.196 & 125.367 & 14.937 & 62.476 & 9.607 & 244.030 \\
2012 & 3.483 & 137.407 & 12.637 & 53.316 & 1.498 & 238.854 \\
2013 & 735 & 156.155 & 11.680 & 44.324 & 2.992 & 168.808 \\
\hline
\end{tabular}

Fuente: Elaboración propia basada en datos de Puertos del Estado (2014).

En el cuadrante de elevado potencial también se encuadran los puertos de Ferrol y Gijón, aunque con una magnitud de tráfico muy distante respecto a Bilbao. En cuanto a los dos puertos encuadrados como participante minoritario, Santander y Vilagarcía de Arousa, existe una notable diferencia entre ambos, sobre todo en la tasa de crecimiento. La magnitud de pasajeros de crucero registrada por estos cuatro puertos dista, en gran medida, de los tres puertos principales, véase de nuevo la Tabla 3.19, con un tráfico irregular alternando periodos de crecimiento y descenso, véase Gráfico 3.21. Los puertos de la costa del mar Cantábrico y atlántica gallega se incluyen principalmente en itinerarios que recorren la parte occidental del Norte de Europa y las islas Británicas.

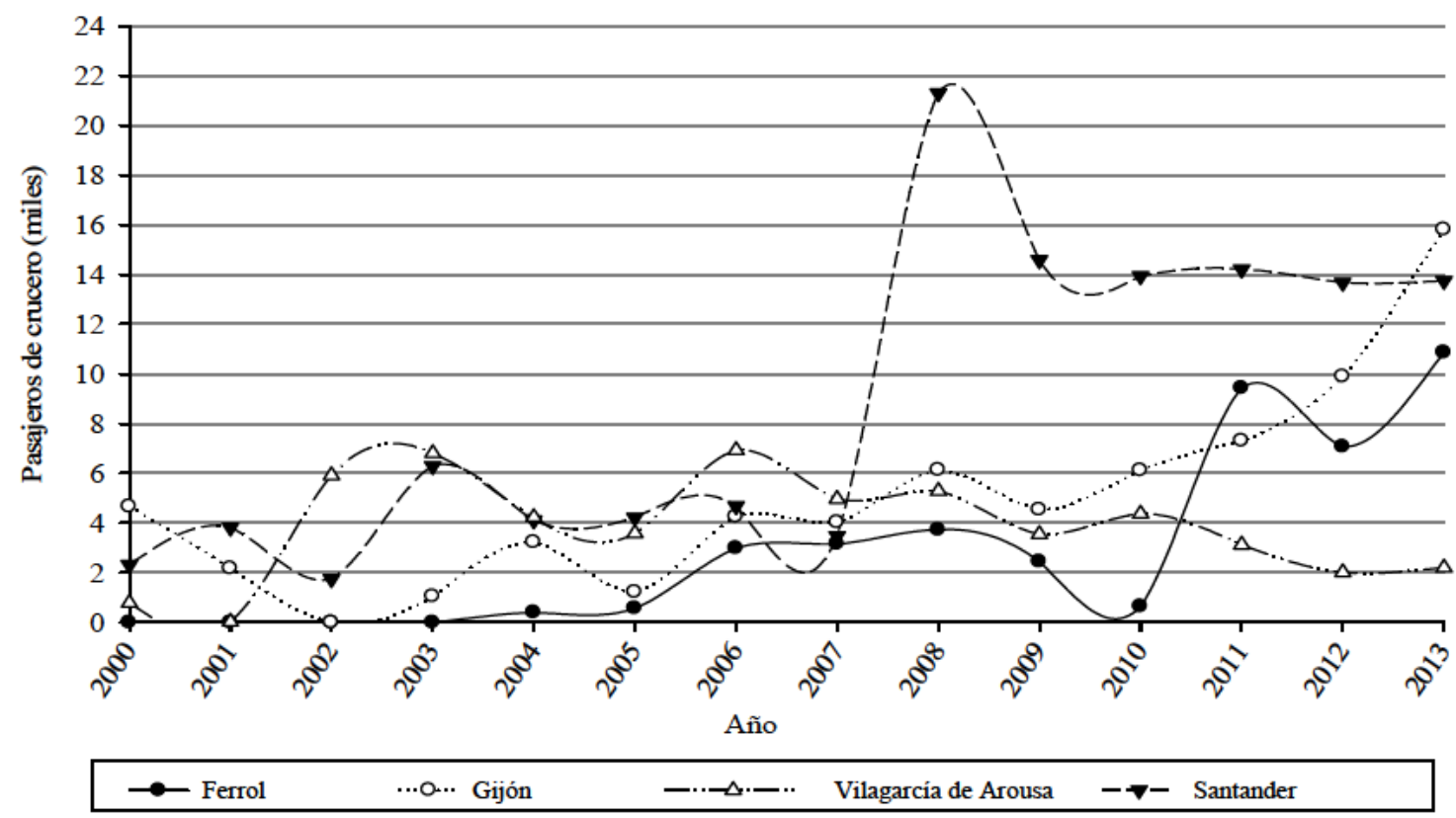

Gráfico 3.21: Evolución de la cifra de cruceristas en los puertos de Ferrol, Gijón, Santander y Vilagarcía de Arousa entre el año 2000 y 2013.

Fuente: Elaboración propia. 
Atendiendo a los resultados obtenidos en el análisis de evolución del tráfico de cruceros en España, durante el periodo de 1994 a 2013, y en el análisis portfolio para cada una de las tres zonas litorales españolas, la mayor concentración de tráfico de cruceros se registra en la costa mediterránea y atlántica andaluza. Por tanto, en el Capítulo IV se desarrolla un análisis empírico focalizado en los puertos de esta zona litoral y centrado en dos aspectos. El primero de ellos hace alusión a la definición de un modelo estadístico con el que explicar la cifra de cruceristas que registran los puertos de esta zona litoral. El segundo, consiste en la determinación de la estacionalidad, y su evolución, del tráfico de cruceros aplicado también a este conjunto de puertos.

Para la definición del modelo estadístico resulta necesario establecer una serie de variables independientes o explicativas. Por ello, en el siguiente apartado se procede a analizar los pormenores de cada uno de los puertos del litoral Mediterráneo y Atlántico andaluz, con objeto de conocer sus características en cuanto a instalaciones dedicadas al tráfico de cruceros se refiere.

\subsubsection{Instalaciones dedicadas al tráfico de cruceros en el litoral Mediterráneo y Atlántico andaluz}

Tomando como referencia el apartado asociado a las funciones del puerto en el tráfico de cruceros y los resultados del análisis de implantación del tráfico de cruceros en el Sistema Portuario Español, en este apartado se procede a identificar las instalaciones y servicios destinados al tráfico de cruceros de que dispone cada uno de los puertos situados en el arco Mediterráneo español y Atlántico andaluz. La síntesis de las instalaciones se ha estructurado atendiendo a los resultados obtenidos en el análisis portfolio. Además, junto a lo anterior, también se caracteriza la distribución mensual de la cifra de pasajeros de crucero en cada puerto para el periodo del año 2000 a 2013, con objeto de que sirva de base para el análisis de la estacionalidad que se desarrollará en el Capítulo IV.

\subsubsection{Puertos líderes maduros}

El primer grupo para el que se caracterizan las instalaciones portuarias es el compuesto por aquellos con posición competitiva de líder maduro. En esta posición competitiva se encuadran los puertos de Barcelona, Palma de Mallorca, Málaga y Cádiz, en la Tabla 3.21 se sintetizan las características de sus instalaciones portuarias. Los cuatros puertos disponen de una longitud de atraque superior a los 1.000 metros, lo cual les permite simultanear escalas de cruceros. Además, también disponen de edificio de terminal de pasajeros. Relacionado con los dos conceptos anteriores, destacan los puertos de Barcelona y Palma de Mallorca, superando en ambos casos los 3.000 metros de longitud de muelle para cruceros y con un notable número de terminales de pasajeros disponibles. Asociado a la gestión de las terminales de pasajeros, en el grupo de líderes maduros queda patente, en tres de los cuatro puertos, la intervención de operadores privados de terminales portuarias 
registrada a nivel global en la industria de cruceros también en España. Junto con lo anterior también queda reflejado el proceso de integración vertical en las operaciones portuarias desarrollado por las navieras de crucero, con la explotación por parte de Costa Cruises de una terminal en el puerto de Barcelona. En los cuatro puertos se disponen de los servicios requeridos durante la escala por el buque y el pasaje.

En cuanto al perfil de estacionalidad de los cuatro lideres maduros, se han identificado dos tipologías. Barcelona y Palma de Mallorca han registrado un perfil con una distribución de un máximo durante la temporada alta y en ambas categorías de pasajeros, véase Tabla 3.21. Por el contrario, Málaga y Cádiz han presentado un perfil que se ajusta a dos máximos durante la temporada alta. En el caso de Málaga, únicamente se ha podido analizar la cifra total, pues no ha sido posible acceder a las cifras segregadas en las categorías de inicio y fin de itinerario y tránsito para el periodo 2000-2013. En el Anexo II, apartado II.1, se puede consultar una descripción detallada de las instalaciones para cruceros de cada uno de estos cuatro puertos. Así como, la representación gráfica agregada por meses y distribuida mensualmente de la cifra de pasajeros de crucero durante el periodo del año 2000 a 2013.

Tabla 3.21: Características técnicas y perfil de estacionalidad de la cifra de pasajeros de crucero de los puertos de Barcelona, Palma de Mallorca, Málaga y Cádiz

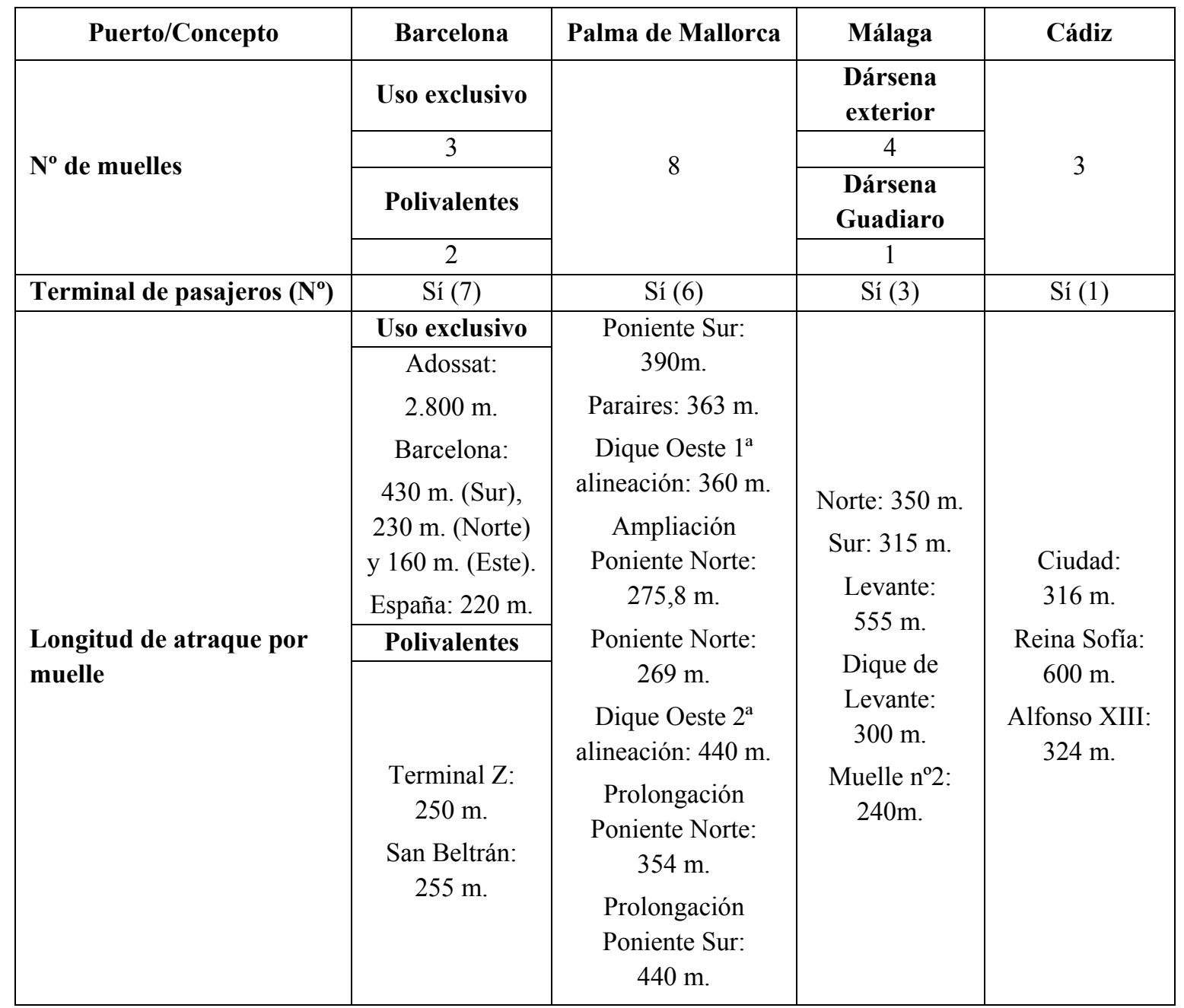




\begin{tabular}{|c|c|c|c|c|}
\hline Puerto/Concepto & Barcelona & Palma de Mallorca & Málaga & Cádiz \\
\hline & & $\begin{array}{l}\text { Alineación Norte } \\
\text { Prolongación Dique } \\
\text { Oeste: } 285 \mathrm{~m} \text {. }\end{array}$ & & \\
\hline $\begin{array}{l}\text { Tipo de gestión de las } \\
\text { terminales }\end{array}$ & Privada & Pública & Privada & Privada \\
\hline $\begin{array}{l}\text { Operadores portuarios } \\
\text { privados }\end{array}$ & $\begin{array}{c}\text { Creuers del } \\
\text { Port de } \\
\text { Barcelona S.A. } \\
\text { Costa Cruises }\end{array}$ & - & $\begin{array}{c}\text { Cruceros } \\
\text { Málaga S.A. }\end{array}$ & $\begin{array}{l}\text { Cádiz Cruise } \\
\text { Terminal S.L. }\end{array}$ \\
\hline Servicios al buque & $\begin{array}{c}\text { Sin } \\
\text { restricciones }\end{array}$ & Sin restricciones & $\begin{array}{c}\text { Sin } \\
\text { restricciones }\end{array}$ & $\begin{array}{c}\text { Sin } \\
\text { restricciones }\end{array}$ \\
\hline Servicios al pasaje & $\begin{array}{l}\text { Sin } \\
\text { restricciones }\end{array}$ & Sin restricciones & $\begin{array}{c}\text { Sin } \\
\text { restricciones }\end{array}$ & $\begin{array}{c}\text { Sin } \\
\text { restricciones }\end{array}$ \\
\hline \multirow{4}{*}{$\begin{array}{l}\text { Perfil de estacionalidad por } \\
\text { categoría de pasajeros }\end{array}$} & $\begin{array}{c}\text { Inicio y fin de } \\
\text { itinerario }\end{array}$ & $\begin{array}{l}\text { Inicio y fin de } \\
\text { itinerario }\end{array}$ & \multirow[t]{2}{*}{ Total } & \multirow[t]{2}{*}{ Total } \\
\hline & 1 máximo & 1 máximo & & \\
\hline & Tránsito & Tránsito & \multirow{2}{*}{2 máximos } & \multirow{2}{*}{2 máximos } \\
\hline & 1 máximo & 1 máximo & & \\
\hline
\end{tabular}

Fuente: Elaboración propia.

\subsubsection{Puertos con elevado potencial}

Un total de seis puertos tienen asociada la posición competitiva de elevado potencial, son: Valencia, Ibiza, Cartagena, Motril, Tarragona y Sevilla, las características de sus instalaciones portuarias para cruceros se resumen en las Tablas 3.22 y 3.23. En este grupo hay una notable heterogeneidad en cuanto a las características de las instalaciones portuarias y comportamiento del tráfico de cruceros. Existe un denominador común a los seis puertos, representado por la longitud de muelle, ya que todos pueden simultanear escalas de buques. La heterogeneidad presente en este grupo permite establecer cuatro ramificaciones.

La primera ramificación la compone el puerto de Valencia. Este puerto, durante el periodo comprendido entre el año 2000 y 2013 registró el mayor crecimiento y cuota de mercado dentro de la posición competitiva elevado potencial. Este comportamiento sugiere que en los próximos años puede consolidarse como un must see port en esta zona del litoral Mediterráneo Occidental. Además, dispone de las instalaciones para buques de crucero más amplias de los seis puertos. Así como, es el único puerto de los seis que cuenta con operadores privados en la gestión y explotación de las terminales portuarias.

La siguiente ramificación está integrada por los puertos de Ibiza y Cartagena, ambos tienen un tráfico de cruceros consolidado unido a un crecimiento significativo en el periodo 2000-2013. También disponen de adecuadas instalaciones dedicadas a buques de cruceros y de todos los servicios requeridos, tanto por el buque como por el pasaje, durante la escala. 
La tercera ramificación está constituida por los puertos de Tarragona y Motril, su tráfico de cruceros es relevante pero todavía no tiene un carácter consolidado, con una cuota de mercado muy reducida durante el periodo entre el año 2000 y 2013. Sus instalaciones y servicios para cruceros no tienen un alto grado de especialización. Por ejemplo, los servicios al pasaje en ambos puertos tienen un carácter provisional, estableciéndose aquellos días que hay escalas de cruceros, quedando cubiertas las necesidades del pasaje durante la escala. Sin embargo, durante el periodo del año 2000 a 2013 han registrado un elevado crecimiento, además también disponen de importantes atractivos turísticos cercanos, representados por las ciudades de Barcelona y Granada. Por lo que de seguir esta evolución, las escalas de buques de crucero en los próximos años pueden adoptar un carácter más regular, incrementando el grado de consolidación de este tráfico marítimo en sus muelles.

La cuarta ramificación está representada por el puerto de Sevilla. Éste tiene un patrón de comportamiento distinto a los cinco puertos anteriores, derivado, fundamentalmente, de su carácter fluvial. Este carácter implica restricciones al buque de mayor tamaño que puede acceder al puerto, asociado a la navegación por el río Guadalquivir y el paso por la esclusa para tener acceso al puerto. Esta restricción relacionada con el tamaño del buque no se registra en los cinco puertos restantes que tienen la posición competitiva de elevado potencial.

De forma análoga al grupo de puertos líderes maduros, en éste también se han registrado dos perfiles de estacionalidad, con uno y dos máximos en temporada alta, véase Tablas 3.22 y 3.23. Para el caso del puerto de Tarragona no se refleja su perfil de estacionalidad, pues el tráfico de cruceros registrado durante el periodo del año 2000 a 2013 ha sido irregular y con valores bajos, no dando lugar a un perfil de estacionalidad sólido. En el Anexo II, apartado II.2, se puede consultar una descripción detallada de las instalaciones para cruceros de cada uno de estos seis puertos. Así como, la representación gráfica agregada por meses y distribuida mensualmente de la cifra de pasajeros de crucero durante el periodo del año 2000 a 2013.

Tabla 3.22: Características técnicas y perfil de estacionalidad de la cifra de pasajeros de crucero de los puertos de Valencia, Ibiza y Cartagena

\begin{tabular}{|c|c|c|c|}
\hline Puerto/Concepto & Valencia & Ibiza & Cartagena \\
\hline \multirow{4}{*}{$\mathbf{N}^{0}$ de muelles } & $\begin{array}{l}\text { Dársena de } \\
\text { Levante }\end{array}$ & \multirow[t]{2}{*}{ Polivalentes } & Uso exclusivo \\
\hline & 2 & & 1 \\
\hline & Ampliación Norte & \multirow{2}{*}{4} & Polivalentes \\
\hline & 2 & & 2 \\
\hline Terminal de pasajeros $\left(\mathrm{N}^{0}\right)$ & Sí (2) & Sí (1) & No \\
\hline \multirow{4}{*}{ Longitud de atraque por muelle } & $\begin{array}{l}\text { Dársena de } \\
\text { Levante }\end{array}$ & \multirow{4}{*}{$\begin{array}{c}\text { Adosado: } 169 \mathrm{~m} . \\
\text { Levante: } 236,3 \mathrm{~m} . \\
\text { Contramuelle de } \\
\text { Levante: } 115,6 \mathrm{~m} . \\
\text { Dique de Botafoc: } \\
392,6 \mathrm{~m} .\end{array}$} & Uso exclusivo \\
\hline & $\begin{array}{l}\text { Poniente: } 330 \mathrm{~m} . \\
\text { Transversal: } 245 \mathrm{~m} .\end{array}$ & & Alfonso XII: $560 \mathrm{~m}$. \\
\hline & Ampliación Norte & & Polivalentes \\
\hline & Muelle $\mathrm{n}^{\circ} 1: 430 \mathrm{~m}$. & & Santa Lucía: 385 m. \\
\hline
\end{tabular}




\begin{tabular}{|c|c|c|c|}
\hline Puerto/Concepto & Valencia & Ibiza & Cartagena \\
\hline & Muelle $n^{\circ} 2: 440 \mathrm{~m}$ & & San Pedro: $405 \mathrm{~m}$. \\
\hline Tipo de gestión de las terminales & Privada & Pública & Pública \\
\hline Operadores portuarios privados & $\begin{array}{c}\text { Acciona } \\
\text { Transmediterránea } \\
\text { Valencia Passenger } \\
\text { Services }\end{array}$ & - & - \\
\hline Servicios al buque & Sin restricciones & Sin restricciones & Sin restricciones \\
\hline Servicios al pasaje & Sin restricciones & Sin restricciones & Sin restricciones \\
\hline \multirow{4}{*}{$\begin{array}{l}\text { Perfil de estacionalidad por } \\
\text { categoría de pasajeros }\end{array}$} & $\begin{array}{l}\text { Inicio y fin de } \\
\text { itinerario }\end{array}$ & \multirow[t]{2}{*}{ Total } & \multirow[t]{2}{*}{ Total } \\
\hline & 1 máximo & & \\
\hline & Tránsito & \multirow{2}{*}{1 máximo } & \multirow{2}{*}{2 máximos } \\
\hline & 1 máximo & & \\
\hline
\end{tabular}

Fuente: Elaboración propia.

Tabla 3.23: Características técnicas y perfil de estacionalidad de la cifra de pasajeros de crucero de los puertos de Motril, Tarragona y Sevilla

\begin{tabular}{|c|c|c|c|}
\hline Puerto/Concepto & Motril & Tarragona & Sevilla \\
\hline \multirow{4}{*}{$\mathbf{N}^{0}$ de muelles } & \multirow{2}{*}{ Polivalentes } & Uso exclusivo & \multirow{2}{*}{ Uso exclusivo } \\
\hline & & 1 & \\
\hline & \multirow{2}{*}{3} & Polivalentes & \multirow{2}{*}{1} \\
\hline & & 1 & \\
\hline Terminal de pasajeros $\left(\mathbf{N}^{0}\right)$ & No & Sí (1) & Sí (1) \\
\hline \multirow{4}{*}{$\begin{array}{l}\text { Longitud de atraque por } \\
\text { muelle }\end{array}$} & \multirow{4}{*}{$\begin{array}{c}\text { Costa: } 299 \mathrm{~m} . \\
\text { Levante: } 284 \mathrm{~m} . \\
\text { Dique: } 560 \mathrm{~m} .\end{array}$} & Uso exclusivo & \multirow{4}{*}{ Delicias: $614 \mathrm{~m}$. } \\
\hline & & Dique Levante: $707 \mathrm{~m}$. & \\
\hline & & Polivalente & \\
\hline & & Costa: $350 \mathrm{~m}$. & \\
\hline $\begin{array}{l}\text { Tipo de gestión de las } \\
\text { terminales }\end{array}$ & Pública & Pública & Pública \\
\hline $\begin{array}{l}\text { Operadores portuarios } \\
\text { privados }\end{array}$ & - & - & - \\
\hline Servicios al buque & Sin restricciones & Sin restricciones & $\begin{array}{l}\text { Puerto fluvial, } \\
\text { restricción asociada a } \\
\text { la navegación fluvial y } \\
\text { al paso por la esclusa }\end{array}$ \\
\hline Servicios al pasaje & $\begin{array}{l}\text { Provisionales, se } \\
\text { establecen con la } \\
\text { llegada de cada } \\
\text { crucero }\end{array}$ & Servicios esenciales & Sin restricciones \\
\hline \multirow{4}{*}{$\begin{array}{l}\text { Perfil de estacionalidad por } \\
\text { categoría de pasajeros }\end{array}$} & \multirow[t]{2}{*}{ Total } & \multirow{4}{*}{ - } & $\begin{array}{c}\text { Inicio y fin de } \\
\text { itinerario }\end{array}$ \\
\hline & & & 2 máximos \\
\hline & \multirow{2}{*}{2 máximos } & & Tránsito \\
\hline & & & 2 máximos \\
\hline
\end{tabular}

Fuente: Elaboración propia. 


\subsubsection{Puertos participantes minoritarios}

Un total de ocho puertos quedan encuadrados en la posición competitiva de participante minoritario, son: Alicante, Almería, Castellón, Ceuta, Huelva, La Savina, Mahón y Melilla, las Tablas 3.24 y 3.25 sintetizan las características de sus instalaciones para buques de crucero. Este grupo es el más heterogéneo de los tres analizados, en la mayor parte de los puertos, los muelles para cruceros tienen un uso polivalente. Este carácter está asociado, fundamentalmente, con tráfico de pasajeros en régimen de línea regular, más que un uso exclusivo para tráfico de cruceros. De forma análoga al grupo anterior, la heterogeneidad presente permite delimitar varios subgrupos, en este caso tres.

El primer subgrupo lo integran los puertos de Alicante, Almería y Mahón. Los tres puertos tienen un tráfico de cruceros consolidado e instalaciones portuarias con elevado grado de especialización destinadas a tráfico de cruceros. A excepción de Almería, Alicante y Mahón disponen de edificio de terminal para atender al pasaje de los cruceros. Además, en el caso de Alicante, la explotación y gestión de su terminal fue adjudicada en octubre de 2013 a un operador privado. Constituyendo el único puerto de este grupo con operador privado de terminal portuaria. Asimismo, estos tres puertos han registrado las cuotas de mercado más elevadas en el cuadrante de participante minoritario.

El segundo subgrupo de puertos está compuesto por los puertos de Ceuta y Melilla. En éstos, el tráfico de cruceros es de carácter irregular y con una cuota de mercado muy reducida durante el periodo entre el año 2000 y 2013. Asimismo, sus instalaciones para cruceros son polivalentes, albergando también otros tráficos. De tal forma que no disponen de forma permanente de los servicios necesarios para el pasaje y éstos se establecen provisionalmente con la escala de cada buque.

Finalmente, el tercer subgrupo está constituido por los puertos de Castellón, Huelva y La Savina. En estos tres puertos el tráfico de cruceros no representa una línea principal de negocio, con cifras de pasajeros de crucero muy reducidas durante el periodo del año 2000 a 2013. De ahí que no dispongan de instalaciones especializadas para este tráfico marítimo. Castellón y Huelva son puertos de marcado carácter industrial y La Savina es de pequeño tamaño, dando servicio, fundamentalmente, al tráfico de línea regular que conecta las islas de Ibiza y Formentera.

De forma análoga a los dos grupos anteriores, se han obtenido dos perfiles de estacionalidad en temporada alta. Sin embargo, los perfiles de estacionalidad únicamente se han podido identificar para cuatro de los ocho puertos, véanse Tablas 3.24 y 3.25, pues en los cuatro restantes, las bajas e irregulares cifras de pasajeros de crucero durante el periodo del año 2000 a 2013 han imposibilitado determinar un perfil de estacionalidad firme. En el Anexo II, apartado II.3, se puede consultar una descripción detallada de las instalaciones para cruceros de cada uno de estos ocho puertos. Así como, la representación gráfica agregada por meses y distribuida mensualmente de la cifra de pasajeros de crucero durante el periodo del año 2000 a 2013, para los cuatro puertos en los que sí ha sido posible 
determinar el perfil de estacionalidad. En el caso de los cuatro puertos restantes, únicamente se incluye la representación gráfica de la distribución mensual de la cifra de pasajeros de crucero, también para el mismo periodo.

Tabla 3.24: Características técnicas y perfil de estacionalidad de la cifra de pasajeros de crucero de los puertos de Alicante, Almería, Mahón y Ceuta

\begin{tabular}{|c|c|c|c|c|}
\hline Puerto/Concepto & Alicante & Almería & Mahón & Ceuta \\
\hline \multirow{4}{*}{$N^{0}$ de muelles } & \multirow{2}{*}{ Uso exclusivo } & Uso exclusivo & \multirow{2}{*}{ Polivalentes } & \multirow{2}{*}{ Polivalente } \\
\hline & & 1 & & \\
\hline & \multirow{2}{*}{1} & Polivalente & \multirow{2}{*}{2} & \multirow{2}{*}{1} \\
\hline & & 1 & & \\
\hline $\begin{array}{l}\text { Terminal de pasajeros } \\
\left(\mathbf{N}^{0}\right)\end{array}$ & Sí (1) & No & Sí (1) & No \\
\hline $\begin{array}{l}\text { Longitud de atraque } \\
\text { por muelle }\end{array}$ & $\begin{array}{l}\text { Muelle n¹4: } \\
\quad 970 \mathrm{~m} .\end{array}$ & $\begin{array}{l}\text { Levante: } \\
236,3 \mathrm{~m} . \\
\text { Ribera } 2^{\mathrm{a}} \\
\text { Alineación: } \\
450 \mathrm{~m} .\end{array}$ & $\begin{array}{c}\text { Muelle de } \\
\text { pasajeros: } \\
640 \mathrm{~m} . \\
\text { Estación Naval: } \\
258 \mathrm{~m} .\end{array}$ & $\begin{array}{l}\text { España Levante: } \\
\qquad 266 \mathrm{~m} . \\
\text { España Poniente: } \\
350 \mathrm{~m} .\end{array}$ \\
\hline $\begin{array}{l}\text { Tipo de gestión de las } \\
\text { terminales }\end{array}$ & Privada & Pública & Pública & Pública \\
\hline $\begin{array}{l}\text { Operadores portuarios } \\
\text { privados }\end{array}$ & $\begin{array}{l}\text { Costablanca } \\
\text { Portuaria S.L. }\end{array}$ & - & - & - \\
\hline Servicios al buque & Sin restricciones & Sin restricciones & Sin restricciones & Sin restricciones \\
\hline Servicios al pasaje & Sin restricciones & Sin restricciones & Sin restricciones & $\begin{array}{c}\text { Provisionales, se } \\
\text { establecen con la } \\
\text { llegada de cada } \\
\text { crucero }\end{array}$ \\
\hline Perfil de estacionalidad & Total & Total & Total & Total \\
\hline pasajeros & 2 máximos & 2 máximos & 1 máximo & 2 máximos \\
\hline
\end{tabular}

Fuente: Elaboración propia.

Tabla 3.25: Características técnicas y perfil de estacionalidad de la cifra de pasajeros de crucero de los puertos de Melilla, Castellón, Huelva y La Savina

\begin{tabular}{|c|c|c|c|c|}
\hline Puerto/Concepto & Melilla & Castellón & Huelva & La Savina \\
\hline \multirow{2}{*}{$\mathbf{N}^{0}$ de muelles } & Polivalentes & Polivalente & Polivalente & Polivalente \\
\hline & 3 & 1 & 1 & 1 \\
\hline $\begin{array}{l}\text { Terminal de } \\
\text { pasajeros }\left(\mathrm{N}^{0}\right)\end{array}$ & No & No & No & No \\
\hline $\begin{array}{l}\text { Longitud de atraque } \\
\text { por muelle }\end{array}$ & $\begin{array}{l}\text { Ribera 1: } 224 \mathrm{~m} . \\
\text { Ribera 2: } 177 \mathrm{~m} . \\
\text { Cargadero } \\
\text { mineral } 1^{\circ} \text { y } 2^{\circ} \\
\text { atraque: } 241 \mathrm{~m} .\end{array}$ & $\begin{array}{c}\text { Prolongación } \\
\text { Dique Este: } \\
350 \mathrm{~m} .\end{array}$ & $\begin{array}{c}\text { Muelle de } \\
\text { pasajeros: } 750 \mathrm{~m} .\end{array}$ & $\begin{array}{c}\text { Muelle de } \\
\text { pasajeros: } 120 \mathrm{~m} .\end{array}$ \\
\hline $\begin{array}{l}\text { Tipo de gestión de } \\
\text { las terminales }\end{array}$ & Pública & Pública & Pública & Pública \\
\hline
\end{tabular}




\begin{tabular}{|l|c|c|c|c|}
\hline \multicolumn{1}{|c|}{ Puerto/Concepto } & Melilla & Castellón & Huelva & La Savina \\
\hline $\begin{array}{l}\text { Operadores } \\
\text { portuarios privados }\end{array}$ & - & - & - & - \\
\hline Servicios al buque & Sin restricciones & Sin restricciones & Sin restricciones & No disponibles \\
\hline Servicios al pasaje & $\begin{array}{c}\text { Provisionales, se } \\
\text { establecen con la } \\
\text { llegada de cada } \\
\text { crucero }\end{array}$ & $\begin{array}{c}\text { Provisionales, se } \\
\text { establecen con la } \\
\text { llegada de cada } \\
\text { crucero }\end{array}$ & $\begin{array}{c}\text { Provisionales, se } \\
\text { establecen con la } \\
\text { llegada de cada } \\
\text { crucero }\end{array}$ & $\begin{array}{c}\text { Provisionales, se } \\
\text { establecen con la } \\
\text { llegada de cada } \\
\text { crucero }\end{array}$ \\
\hline $\begin{array}{l}\text { Perfil de } \\
\text { estacionalidad por } \\
\text { categoría } \\
\text { pasajeros }\end{array}$ & - & - & - & - \\
\hline
\end{tabular}

Fuente: Elaboración propia.

Por tanto, tras este análisis, los puertos de la costa mediterránea y atlántica andaluza se caracterizan por una elevada heterogeneidad de las instalaciones para cruceros disponibles en ellos. Hay puertos con numerosas instalaciones para cruceros, y de notable grado de especialización, como por ejemplo, Barcelona y Málaga. Estas instalaciones sirven tanto a tráfico de cruceros en régimen de inicio y fin de itinerario como en tránsito. Además, las instalaciones disponibles en Barcelona son de las más avanzadas a nivel mediterráneo y europeo. También existen puertos con instalaciones dedicadas a tráfico de cruceros muy especializadas, pero únicamente asociadas a operaciones de tránsito, es el caso de Alicante, Cartagena o Mahón. Además, entre los puertos con estas características pueden darse diferencias significativas de tráfico de cruceros, pero en todos los casos, disponen de las instalaciones y servicios necesarios. Por último, también se registra un grupo de puertos con instalaciones no especializadas para tráfico de cruceros, adoptando un papel de instalaciones polivalentes para varios tráficos marítimos. Estos puertos se caracterizan por dos situaciones, tienen un tráfico de cruceros irregular o este tráfico marítimo no constituye una línea de negocio principal para el puerto. Ejemplos representativos de estos casos son Ceuta y Castellón, respectivamente.

\subsection{Hinterlands turísticos}

En el apartado anterior se ha tratado la importancia de los puertos en un itinerario de crucero, como primera componente terrestre de este producto turístico conectando el buque con la tierra. Asociado al puerto se encuentra su zona de influencia, que constituye una característica de situación (situation conditions) relacionada con el atractivo del puerto para captar tráfico de cruceros. La zona de influencia del puerto comprende la componente terrestre de mayor importancia en un itinerario de crucero. Además, la zona de influencia de un puerto es uno de los conceptos más relevantes en geografía del transporte, recibe la denominación de hinterland. En el caso de un itinerario de crucero, este concepto está asociado tanto con la componente de transporte como con la de ocio y turismo presente en este producto, erigiéndose como el tercer actor clave en la configuración de un itinerario. Por tanto, dadas las características del tráfico de cruceros, de forma particular sea más preciso hablar de hinterland turístico, concepto que en la literatura especializada muestra 
cierta carencia de estudio. El estudio y análisis de este concepto aplicado al tráfico de cruceros constituye una relevante aportación de este trabajo.

Literalmente, hinterland significa tierra detrás de una ciudad o un puerto. En el ámbito portuario, el hinterland es el área de la cual proceden los clientes del puerto. Sin embargo, el significado exacto de este concepto, habitualmente, está sometido a diferentes interpretaciones, dependiendo del autor y el contexto. A continuación se enumeran definiciones generales de hinterland, éste puede ser:

$\checkmark$ Zona interior del puerto a la que se distribuyen las importaciones y de la que se recogen las exportaciones (UNECE, 2010).

$\checkmark$ Terrenos ubicados en la parte posterior de los puertos que tienen un papel importante de apoyo y entrega de cargamentos de exportación a los puertos, y de distribución y atracción de cargas de importación desde los puertos (Weigend, 1958).

$\checkmark$ Espacio terrestre a través del cual un puerto vende sus servicios e interactúa con sus clientes (UNESCAP, 2005).

$\checkmark$ El área de mercado servida por un puerto y desde donde un puerto obtiene su carga (UNESCAP, 2005).

$\checkmark$ Alcance de mercado del puerto, es decir, las zonas en las que se origina la carga, así como, las áreas de destino de la carga que se mueve a través del puerto. Varios puertos tienen hinterlands que se extienden a través de varias regiones, mientras otros puertos pueden tener hinterlands pequeños (UNESCAP, 2005).

$\checkmark$ Área sobre la cual un puerto vende sus servicios e interactúa con sus clientes (Rodrigue et al., 2013).

Acotando las definiciones anteriores al tráfico de cruceros, se obtienen dos acepciones, según se trate de un puerto base o un puerto de escala. En ambos casos se hace alusión al concepto hinterland turístico. En el caso de un puerto base, el hinterland turístico está compuesto por los lugares de origen de los pasajeros que inician su itinerario en ese puerto, y viceversa, por los lugares de origen de los pasajeros que finalizan su itinerario en ese puerto, véase Figura 3.10. Definición relacionada con el origen de los pasajeros. Mientras que el hinterland turístico de un puerto de escala está constituido por el área geográfica disponible para ser visitada (excursiones) por los pasajeros de crucero durante la escala en puerto (Esteve-Pérez y García-Sánchez, 2014), véase Figura 3.11. En este caso la definición está relacionada con los atractivos turísticos asociados a cada puerto de escala una vez iniciado el itinerario. 

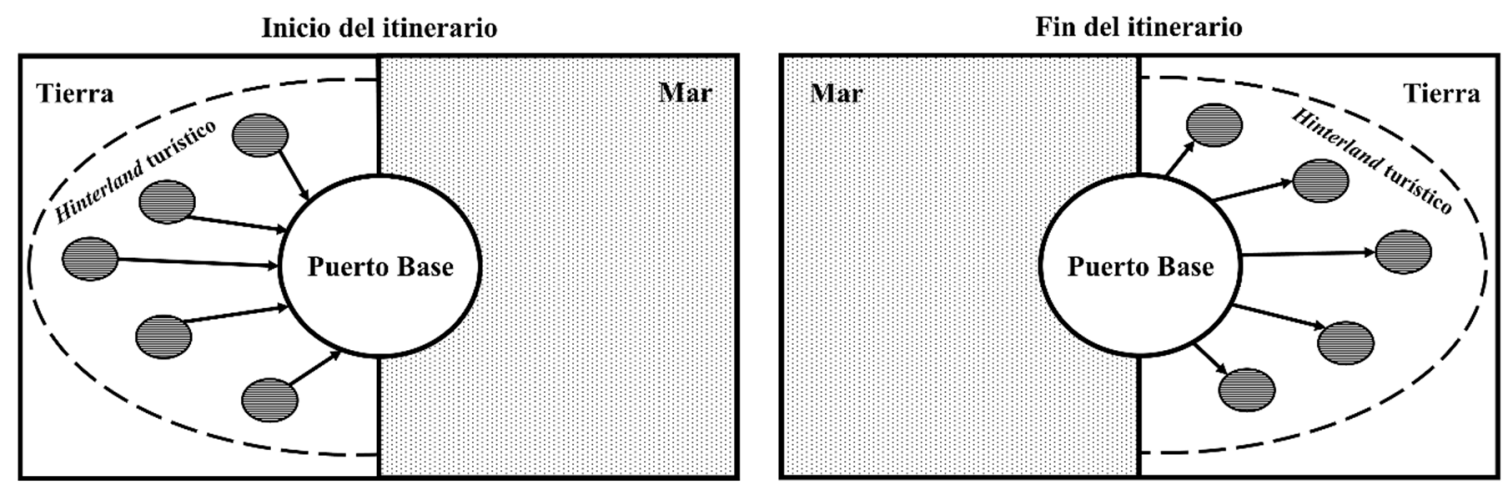

Mercados emisores de pasajeros de crucero

Figura 3.10: Representación conceptual del hinterland turístico de un puerto base de cruceros.

Fuente: Elaboración propia.

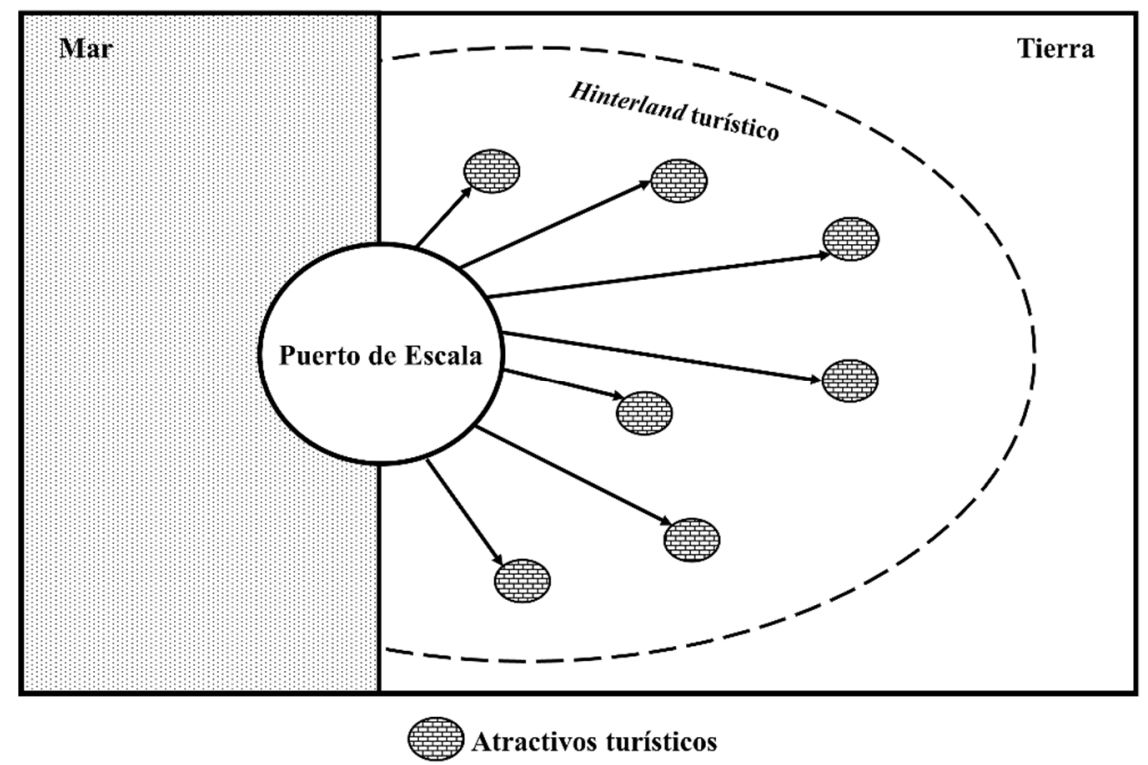

Figura 3.11: Representación conceptual del hinterland turístico de un puerto de escala de cruceros.

Fuente: Elaboración propia.

Ahondando en el análisis del concepto de hinterland, es posible distinguir dos tipos: hinterland primario o cautivo e hinterland competitivo. El término hinterland primario se refiere al área para la cual un puerto es la única terminal de transporte marítimo. Se asume que el tráfico normalmente pasará por esa terminal, porque es la más próxima y por la ausencia de alternativas competitivas. El término hinterland competitivo se usa para describir las áreas a través de las cuales el puerto tiene que competir con otras terminales para captar negocio (Rodrigue et al., 2013). Transponiendo los dos tipos de hinterlands al tráfico de cruceros, el hinterland primario es el área que sólo está disponible para los pasajeros de crucero que escalan en un puerto específico; mientras que el hinterland competitivo es el área que está disponible para los pasajeros de crucero desde más de un puerto (Esteve-Pérez y García-Sánchez, 2014), véase Figura 3.12. 


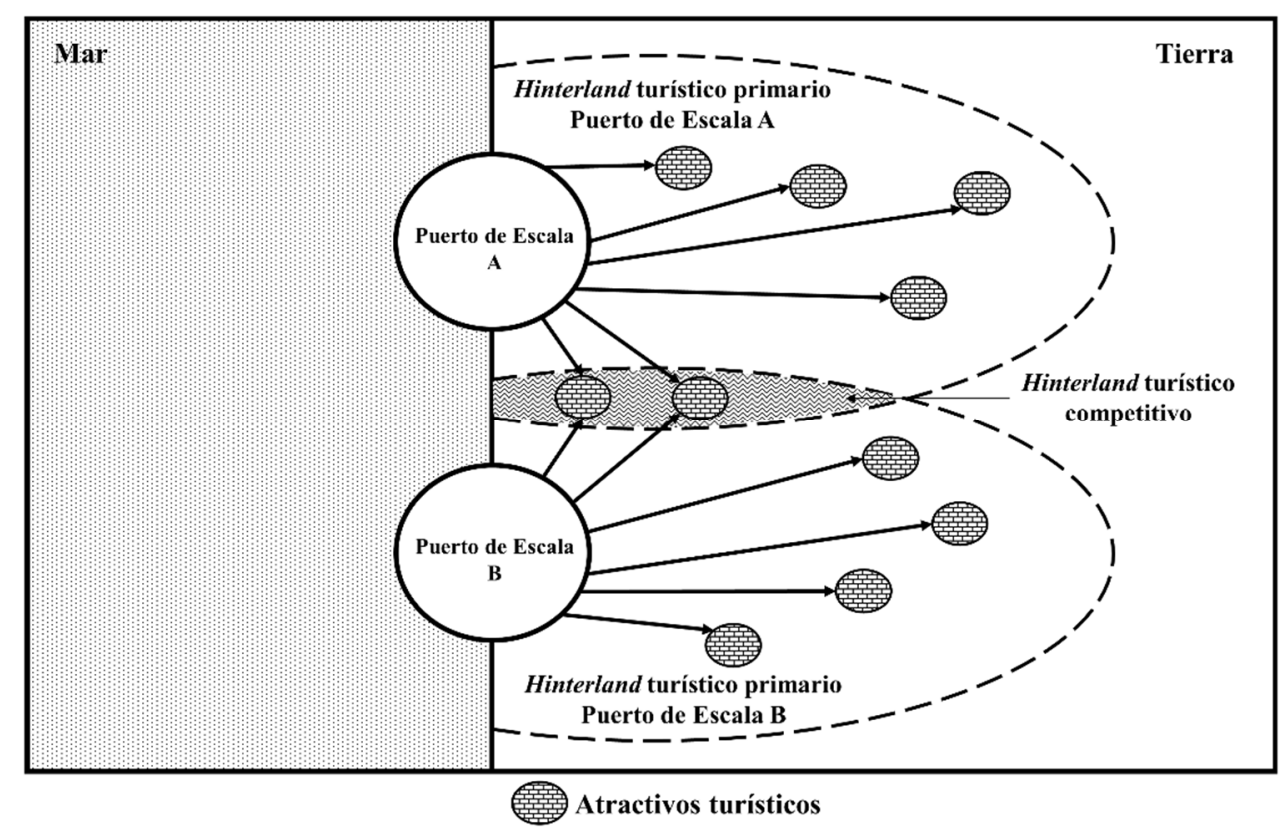

Figura 3.12: Representación conceptual del hinterland turístico primario y competitivo de un puerto de escala de cruceros.

Fuente: Elaboración propia.

Delimitar el hinterland de un puerto es una tarea difícil o incluso imposible en determinados casos. Con carácter general la delimitación del hinterland varía con el tipo de mercancía, el tiempo y el modo de transporte. Además, el hinterland no tiene un carácter estático e inelástico sino que se puede ver alterado por la dinámica del mercado (Notteboom, 2009). En el caso del tráfico de cruceros, tanto en los puertos base como en los puertos de escala, existen varios condicionantes en la delimitación del hinterland turístico.

Respecto a un puerto base, la delimitación del hinterland turístico está supeditada, fundamentalmente, a las conexiones de transporte con los mercados emisores. Para el caso de mercados emisores internacionales, prima la existencia de conexiones aéreas con éstos. Mientras que en el caso del mercado emisor nacional, tales conexiones pueden ser tanto aéreas como terrestres (ferrocarril, vehículo particular, etc.). Unido a lo anterior, el hinterland turístico de un puerto base tiene un carácter dinámico asociado con el establecimiento de nuevas conexiones aéreas o incremento de las infraestructuras y medios de transporte terrestres. Además, también puede ampliarse con la creación de nuevos mercados emisores (Esteve-Pérez y García-Sánchez, 2015). Por ejemplo, en el caso de España, la puesta en funcionamiento de la línea férrea de alta velocidad entre Madrid y Valencia en el año 2010, supuso un notable impulso para el puerto de Valencia en su papel de puerto base para los cruceristas de origen español. Pues esta infraestructura permite conectar el centro de la península ibérica con el puerto valenciano en 90 minutos. En este mismo sentido, también se puede citar la creación de conexiones aéreas entre Málaga y Estados Unidos y el posicionamiento de buques de Royal Caribbean International con base en el puerto malagueño. Por lo tanto, el principal factor limitante en el tamaño del hinterland turístico de un puerto base está asociado a la accesibilidad, desde el punto de vista de transporte, entre el puerto y los mercados emisores de cruceristas. 
En este punto es posible integrar un nuevo concepto en geografía del transporte, el término foreland. Este término hace alusión al espacio marítimo de proyección del hinterland, en referencia a los puertos y mercados conectados por servicios marítimos desde el puerto (Rodrigue et al., 2013). Por lo que, adaptando este término al tráfico de cruceros, un puerto necesita disponer de puertos de escala con atractivos turísticos comercializables y a una distancia adecuada, que permitan configurar un itinerario de crucero, dando así lugar al foreland de un puerto base de cruceros. Sin la existencia de este foreland, un puerto base no puede desarrollar un itinerario de crucero, aun contando con un amplio y adecuadamente conectado hinterland turístico, véase Figura 3.13.

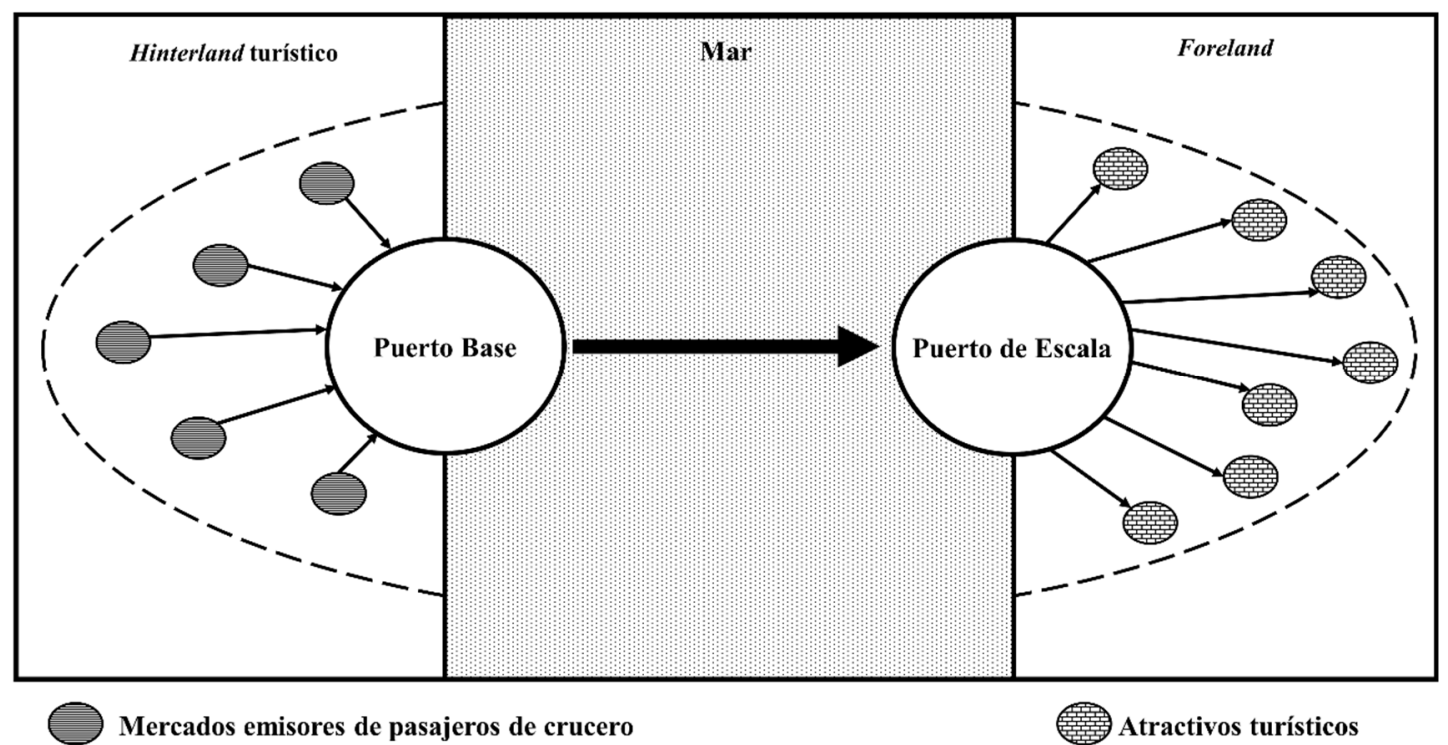

Figura 3.13: Representación conceptual de los conceptos hinterland turístico y foreland de un puerto base de cruceros.

Fuente: Elaboración propia adaptada de Notteboom (2009).

Respecto a la delimitación del hinterland turístico de un puerto de escala, la principal restricción de su tamaño está asociada a la duración de la escala en puerto. Puede darse la situación que un puerto disponga de cercanos e importantes atractivos turísticos comercializables, pero no sean accesibles debido a la falta de infraestructuras de transporte terrestre, que permitan visitarlos en el intervalo de tiempo que el buque permanece en puerto. También puede ocurrir que haya importantes atractivos turísticos, pero a una distancia que aun contando con la infraestructura de transporte adecuada, sean imposibles de alcanzar en el tiempo de escala en puerto. Por lo que el concepto de hinterland turístico de un puerto de escala es también dinámico, pues puede cambiar con el tiempo.

El carácter dinámico del hinterland turístico de un puerto de escala está asociado a los siguientes aspectos. El desarrollo de infraestructuras de transporte terrestre puede generar que, atractivos que no era posible visitar tiempo atrás, ahora sí sea posible acceder a ellos en tiempo y forma. Junto con lo anterior, el desarrollo de nuevos atractivos turísticos próximos al puerto también genera una expansión del hinterland turístico. Además, en la delimitación del hinterland turístico también tiene una notable influencia la operativa seguida en puerto, 
por lo que un cambio en ésta, llevaría aparejado un cambio en la extensión del hinterland (Esteve-Pérez y García-Sánchez, 2015). Así pues, las navieras del segmento contemporary permanecen en puerto entre 8 y 10 horas. Frente a las navieras del segmento de lujo, en las que se está implantando fuertemente pernoctar en los puertos de escala, con la consiguiente oportunidad de ampliar el alcance del hinterland.

Junto al condicionante de disponer de infraestructuras de transporte suficientemente desarrolladas, tanto en el hinterland turístico de un puerto base como de un puerto de escala, existen dos condicionantes más para tener un buen acceso al hinterland en ambos casos. Las infraestructuras de transporte tienen que ser utilizadas de manera eficiente. Y, las cadenas de transporte deben estar bien coordinadas (De Langen y Chouly, 2004; Notteboom y Rodrigue, 2005 y Robinson, 2002).

El cumplimiento de estos requisitos influye en gran medida en el diseño de las rutas y por extensión, en la selección de los puertos que componen el itinerario, comenzando por el establecimiento del puerto base y seguido de la composición de los puertos de escala. Además, en el caso de hinterlands competitivos, la ausencia de congestiones junto con la calidad de los servicios, conduce a mejorar la posición competitiva de un puerto sobre otro (OCDE, 2009). De ahí que autores como Van de Voorde y Vanelslander (2009) afirmen que "la capacidad competitiva de un puerto o cualquier otro operador marítimo no depende exclusivamente de su propia infraestructura y organización; también se ve afectada por una variedad de otras fuerzas del mercado".

Hay que subrayar que las excursiones en tierra proporcionan uno de los ingresos más importantes a las líneas de cruceros y juegan un papel esencial en el atractivo global del itinerario (Vojvodic, 2003). Además, la ampliación del alcance del hinterland por medio de excursiones en tierra, ofrece nuevas oportunidades de incluir una región más amplia en las operaciones de cruceros, descongestionando los centros de las ciudades y proporcionando una explotación más equilibrada de las atracciones turísticas regionales (Gui y Russo, 2011). En este sentido, la integración vertical desarrollada por las navieras de cruceros, también alude a las excursiones en tierra, pues en algunos casos, empresas subsidiarias de la naviera son las que ofertan dichas excursiones (Rodrigue y Notteboom, 2013). El máximo exponente de esta tendencia viene representado por la adquisición de islas privadas en el mar Caribe por parte de varias navieras, como por ejemplo, CocoCay (RCI), Half Moon Cay (HAL), Castaway Cay (Disney Cruise Line), Princess Cay (Princess Cruises) y Great Stirrup Cay (NCL). Permitiendo a las navieras crear un mercado cautivo respecto a las actividades a bordo del buque y en tierra.

Asociado con los aspectos expuestos anteriormente, se ha delimitado el hinterland turístico de cada uno de los puertos de crucero del Mediterráneo español y la costa atlántica andaluza, bajo la perspectiva de puertos de escala. Además, también se ha especificado el hinterland como primario y/o competitivo. Para poder llevar a cabo tal delimitación ha sido necesario consultar a consignatarios y tour-operadores que operan buques de crucero en la costa española, pues la información disponible sobre las excursiones ofertadas desde cada 
puerto es muy escasa. En concreto, el análisis se ha realizado con 15 de los 18 puertos que registran tráfico de cruceros en esta zona litoral española, excluyendo aquellos que han presentado un tráfico irregular y no consolidado, durante el periodo de 2000 a 2013, como se ha podido comprobar en el apartado 3.2.2 del presente capítulo. Los puertos excluidos son Castellón, Huelva y La Savina. La mayor parte de los puertos analizados tienen un nutrido hinterland turístico que engloba una amplia área geográfica, véase Tabla 3.26. Generalmente, el hinterland comprende varias poblaciones en la provincia del puerto. Sin embargo, también hay casos en los que el hinterland se extiende a otras provincias, así como, varios puertos comparten el mismo hinterland o al menos una parte de él.

Tabla 3.26: Hinterlands turísticos asociados con los 15 puertos de escala en la costa mediterránea y atlántica andaluza

\begin{tabular}{|c|c|c|}
\hline Puerto & $\begin{array}{l}\text { Tipo de hinterland } \\
\text { (Primario o Competitivo) }\end{array}$ & Hinterland turístico (Localidades) \\
\hline \multirow[t]{2}{*}{ Alicante } & Primario & $\begin{array}{l}\text { Alicante ciudad, Guadalest, Benidorm y bodegas de la } \\
\text { Marina Baja }\end{array}$ \\
\hline & Competitivo & Elche \\
\hline \multirow[t]{2}{*}{ Almería } & Primario & $\begin{array}{l}\text { Almería ciudad, Parque Natural de Cabo de Gata y } \\
\text { Mojacar }\end{array}$ \\
\hline & Competitivo & Granada \\
\hline Barcelona & Competitivo & Barcelona ciudad \\
\hline \multirow[t]{2}{*}{ Cádiz } & Primario & $\begin{array}{l}\text { Cádiz ciudad, montaña de Cádiz, Jerez de la Frontera, } \\
\text { Vejer de la Frontera, Conil, Medina Sidonia, Puerto de } \\
\text { Santa María, Barbate y Arcos de la Frontera }\end{array}$ \\
\hline & Competitivo & Sevilla \\
\hline \multirow[t]{2}{*}{ Cartagena } & Primario & $\begin{array}{l}\text { Cartagena ciudad, Manga del Mar Menor, Murcia, } \\
\text { Bodegas de Jumilla y Monasterio de la Fuensanta }\end{array}$ \\
\hline & Competitivo & Elche \\
\hline Ceuta & Primario & Ceuta \\
\hline Ibiza & Primario & Isla de Ibiza \\
\hline Mahón & Primario & Mahón y Ciudadela \\
\hline \multirow{2}{*}{ Málaga } & Primario & Málaga ciudad, Marbella, Puerto Banús, Nerja y Mijas \\
\hline & Competitivo & Granada \\
\hline Melilla & Primario & Melilla \\
\hline Motril & Competitivo & Granada \\
\hline $\begin{array}{l}\text { Palma de } \\
\text { Mallorca }\end{array}$ & Primario & $\begin{array}{l}\text { Palma de Mallorca, Valdemosa, Manacor, Pollença y } \\
\text { Alcudia }\end{array}$ \\
\hline \multirow{2}{*}{ Sevilla } & Competitivo & Sevilla \\
\hline & Primario & Córdoba \\
\hline \multirow{2}{*}{ Tarragona } & Primario & Tarragona ciudad, Monasterios de Poblet y Montblanc \\
\hline & Competitivo & Barcelona \\
\hline
\end{tabular}




\begin{tabular}{lll}
\hline Puerto & $\begin{array}{l}\text { Tipo de hinterland } \\
\text { (Primario o Competitivo) }\end{array}$ & Hinterland turístico (Localidades) \\
\hline Valencia & Primario & Valencia ciudad \\
\hline
\end{tabular}

Fuente: Elaboración propia.

Cabe mencionar que el carácter primario del hinterland de algunos puertos se debe a condiciones puramente geográficas y la inexistencia de puertos cercanos, tales como la insularidad en el caso de los puertos de islas Baleares o bien los puertos de la ciudades autónomas de Ceuta y Melilla.

Asociado a la delimitación del hinterland turístico, surge el papel desarrollado por el puerto en el flujo turístico entre éste y el hinterland. Basado en las ideas de Baird (1997), Gui y Russo (2011) y Rodrigue y Notteboom (2013), cinco categorías de puertos se proponen: black hole, semi-black hole, balanced, semi-gateway y gateway. Los cinco tipos de puertos difieren entre sí por la distribución de cruceristas entre la ciudad portuaria y el resto de localidades que conforman el hinterland turístico, véase Figura 3.14.
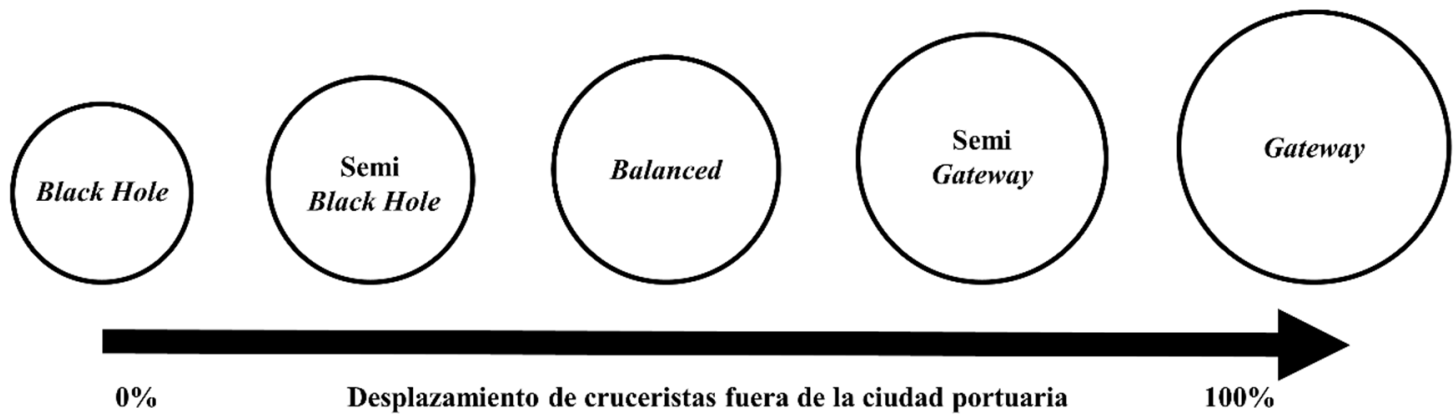

Figura 3.14: Representación conceptual de las cinco tipologías de puertos de crucero atendiendo al flujo turístico del puerto hacia el hinterland.

Fuente: Elaboración propia.

En un puerto black hole, la ciudad portuaria de destino está dotada de importantes atractivos turísticos, por lo que los pasajeros de crucero no muestran interés en moverse de la ciudad para visitar el hinterland. En el otro extremo se sitúa el puerto gateway, cuya única función es la de enlace en la cadena de transporte, requiere de excursiones en tierra con objeto de alcanzar las principales atracciones turísticas cercanas. En un puerto balanced hay una cuota equilibrada de turistas entre la ciudad portuaria y las áreas anexas, debido a que ambas están dotadas de manera similar en términos de atracciones turísticas. En cuarto lugar, un puerto semi-gateway se establece cuando los principales destinos están alejados del puerto, sin embargo, la ciudad portuaria está dotada de ciertos atractivos turísticos que merecen la visita y permanencia de una minoría del pasaje durante la escala. Por último, un puerto semi-black hole ofrece una ciudad portuaria que está dotada de importantes atracciones turísticas que merecen la pena ser visitadas por la mayoría de los pasajeros de crucero, y adicionalmente el hinterland también registra ciertas atracciones que son visitadas por grupos minoritarios de pasajeros. 
La clasificación expuesta anteriormente también se ha aplicado a los 15 puertos de crucero de la costa mediterránea y atlántica andaluza a los que se ha delimitado su hinterland turístico, los resultados se muestran en la Tabla 3.27. En este sentido, requiere mención la imposibilidad de acceder a las cuotas de cada una de las excursiones en cada puerto, por lo que la clasificación se ha realizado conjugando el número de excursiones ofertadas en cada puerto, consultas a profesionales del sector y revisión de la literatura. Esta zona litoral española tiene las cinco categorías de puertos desde el punto de vista del flujo turístico hacia el hinterland. Por un lado, hay potentes destinos turísticos, por ejemplo Barcelona, que acaparan toda la atención de los pasajeros de crucero que llegan a su puerto (puerto black hole), así como puertos cercanos que actúan como enlace (puerto semi-gateway) a estos destinos, este es el caso de Tarragona con su excursión a Barcelona. También hay puertos semi-black hole, como Sevilla, en los cuales la ciudad portuaria prevalece y grupos minoritarios de pasajeros son atraídos por otras atracciones turísticas fuera de ésta. Por otro lado, el puerto de Motril actúa como plataforma de acceso (puerto gateway) a destinos situados tierra adentro y más en concreto, a la ciudad de Granada y su excursión a La Alhambra. Finalmente, también hay puertos con una cuota equilibrada de pasajeros, como por ejemplo Cádiz, en los cuales las excursiones se distribuyen de forma proporcionada entre la ciudad portuaria y localidades de la provincia en la cual el puerto está localizado.

Tabla 3.27: Clasificación de los 15 puertos de crucero de la costa mediterránea y atlántica andaluza de acuerdo con el flujo turístico regional

\begin{tabular}{ccccc}
\hline \multicolumn{5}{c}{ Puertos } \\
\hline Black hole & Semi-black hole & Balanced & Semi-gateway & Gateway \\
\hline Barcelona & Sevilla & Alicante & Almería & Motril \\
Valencia & Palma de Mallorca & Cádiz & Tarragona & - \\
Ceuta & Cartagena & Mahón & - & - \\
Ibiza & - & Málaga & - & - \\
Melilla & - & - & - & - \\
\hline
\end{tabular}

Fuente: Elaboración propia. 


\section{Capítulo IV. Análisis empírico}

Tomando como referencia las particularidades de la industria de cruceros, y en especial, las funciones y características de los tres actores clave en la configuración de un itinerario de crucero, delimitadas en los apartados anteriores de la tesis, en este capítulo se desarrolla un análisis empírico focalizado en dos aspectos de esta industria. En primer lugar, se lleva a cabo un análisis econométrico para determinar las variables relevantes en la cifra de cruceristas que registra un puerto, con una aplicación particular para los puertos de crucero de la costa mediterránea española y atlántica andaluza. En segunda instancia, y para el mismo conjunto de puertos, se desarrolla un análisis de determinación y evolución del perfil de estacionalidad de este tráfico marítimo.

Con el primero se obtienen recomendaciones y sugerencias para los actores terrestres que intervienen en la configuración de un itinerario de crucero, con un análisis no realizado hasta la fecha. Respecto al segundo análisis, la capacidad instalada de infraestructuras y superestructuras sujetas a diferentes participaciones de utilización es analizada, para orientar las inversiones en nuevas instalaciones portuarias para cruceros y sugerir simultaneidad de usos de éstas.

\subsection{Análisis econométrico de las variables influyentes en el tráfico de cruceros registrado por un puerto}

Basado en la información y datos recogidos en los apartados anteriores, se lleva a cabo un análisis econométrico con el fin de explicar la incidencia de variables de diversa naturaleza en la cantidad de tráfico de cruceros registrado en cada puerto. El análisis se estructura en dos etapas. En la primera, se realiza un análisis de componentes principales (ACP). El objetivo de esta técnica es crear grupos de variables que ayuden a tener una comprensión más integral de una serie de conceptos. Es decir, sobre la base de las $n$ variables independientes definidas a continuación, con influencia en las escalas de cruceros registradas en un puerto, se generan $Z_{1}, Z_{2}, \ldots, Z_{n}$ factores para evitar la multicolinealidad. En el segundo paso, se lleva a cabo una regresión de mínimos cuadrados ordinarios con los factores obtenidos en el anterior ACP como variables independientes y los pasajeros de crucero como variable dependiente.

Este método de análisis y tratamiento de datos se puede encontrar en varios trabajos de investigación relacionados con el transporte marítimo. Entre otros, esta técnica econométrica se ha aplicado en los siguientes temas clave de investigación: eficiencia portuaria y coste del transporte marítimo (Sánchez et al., 2003), aspectos de calidad en puertos de pasajeros (Pantouvakis, 2006), tarifas de flete (Wilmsmeier y Hoffmann, 2008) y criterios de selección de terminales de contenedores (Saeed, 2009). 


\subsubsection{Definición de la variable dependiente}

Como indicadores del tráfico de cruceros en un puerto determinado, se pueden considerar tres opciones: el número de pasajeros de cruceros, el número de escalas de buques de crucero y la cantidad de arqueo bruto que representan las escalas de cruceros en el puerto. El número de escalas de buques como variable dependiente tiene asociado un alto grado de incertidumbre debido a las diferencias de tamaño existentes, como se ha descrito en el Capítulo III apartado 1. Con respecto a utilizar la suma del arqueo bruto de los buques de crucero que han hecho escala en puerto, esta variable no tiene en cuenta el nivel de ocupación del buque en cada escala. Se utiliza como variable dependiente el número de pasajeros de crucero registrados en cada puerto, dado que esta variable no tiene las imprecisiones descritas anteriormente.

Respecto a los puertos del Mediterráneo español y la costa atlántica andaluza considerados, y como se ha mencionado en el Capítulo III, varios puertos no han registrado cruceristas prácticamente en el periodo de 2000 a 2013. Por otro lado, hay un grupo de puertos en los cuales la evolución de este tráfico ha sido irregular y de baja magnitud, no alcanzando más de 10.000 cruceristas por año, de media. A la vista de estas cifras, el análisis econométrico se realiza con los diez puertos de esta zona litoral española que han registrado, de media, más de 30.000 pasajeros de crucero por año entre 2000 y 2011, con el fin de determinar qué explica la cifra de cruceristas que han registrado y por tanto, la inclusión de los puertos en los itinerarios.

Tabla 4.1: Cifra media de pasajeros de crucero en los 18 puertos de crucero de la costa española y atlántica andaluza entre el año 2000 y 2011

\begin{tabular}{lc}
\hline Puerto & Cifra media de pasajeros de crucero de 2000 a 2011 \\
\hline Barcelona & $\mathbf{1 . 4 7 8 . 3 8 8}$ \\
Palma de Mallorca & $\mathbf{9 1 6 . 7 8 7}$ \\
Málaga & $\mathbf{3 0 7 . 5 9 9}$ \\
Cádiz & $\mathbf{1 8 8 . 4 9 0}$ \\
Valencia & $\mathbf{1 3 5 . 0 7 0}$ \\
Ibiza & $\mathbf{8 3 . 2 3 6}$ \\
Mahón & $\mathbf{7 4 . 6 3 0}$ \\
Alicante & $\mathbf{5 8 . 0 4 2}$ \\
Cartagena & $\mathbf{3 9 . 3 9 3}$ \\
Almería & $\mathbf{3 2 . 4 6 8}$ \\
Sevilla & 9.565 \\
Ceuta & 8.323 \\
Motril & 6.699 \\
Tarragona & 3.475 \\
La Savina & 2.214 \\
Melilla & 956 \\
Huelva & 471 \\
Castellón & 125 \\
\hline
\end{tabular}

Fuente: Elaboración propia basada en datos estadísticos de Puertos del Estado (2014). 


\subsubsection{Definición de las variables explicativas}

El conjunto de variables explicativas se selecciona sobre la base de los factores relevantes en el diseño del itinerario. Los dos factores principales para incluir un puerto determinado en el diseño de un itinerario son, los requisitos de mercado y consideraciones operacionales (Rodrigue y Notteboom, 2013). Asociado a los requisitos de mercado se han seleccionado variables relacionadas con el atractivo turístico de la ciudad portuaria y del hinterland turístico del puerto. Mientras que en el caso de las consideraciones operacionales, las variables seleccionadas aluden a parámetros técnicos y económicos del puerto. En ambos casos, la lista inicial de variables independientes inducidas por la revisión de la literatura ha sido filtrada por disponibilidades estadísticas y por la existencia de correlación entre variables.

En cuanto a los requisitos de mercado, se ha incluido el conocimiento de los potenciales pasajeros de crucero sobre el atractivo del hinterland turístico del puerto y de la ciudad portuaria. La lista inicial de variables que representan este atractivo se compone de número de plazas hoteleras, pernoctaciones registradas en el hinterland y resultados de satisfacción general de la encuesta HABITUR para la provincia del puerto; y número de museos y temperatura media anual, para la ciudad portuaria. La correlación entre algunas de ellas y las disponibilidades estadísticas, han llevado a que el número de plazas hoteleras y el número de museos sean las variables que representen el atractivo del hinterland turístico del puerto y de la ciudad portuaria, respectivamente. Estas variables pueden ser definidas como variables proxy del atractivo turístico total del hinterland turístico y de la ciudad portuaria. Las variables que han resultado significativas se utilizan ampliamente en el campo de la investigación turística. Por ejemplo, referencias a dichos indicadores se pueden encontrar en los trabajos de Dwyer y Kim (2003) y Sancho y García (2006). La fuente de información para ambas variables es el Instituto Nacional de Estadística (INE).

Respecto a las consideraciones operacionales, para la selección de las variables se han tomado en consideración parámetros técnicos y económicos asociados con el puerto. Respecto a los parámetros técnicos, las variables iniciales aluden a: capacidad de atraque, tipo de puerto de crucero y tipo de gestión de las instalaciones portuarias. Mientras que los parámetros económicos hacen referencia a los costes de escala del buque en puerto. Por tanto, la lista preliminar de variables estaba compuesta por: longitud, calado y anchura de muelles para cruceros, si se trata de puerto base o no, disponibilidad de terminal de pasajeros, tipo de gestión de la terminal portuaria, tasa del buque y tasa del pasaje (tasas portuarias). De manera análoga a los requisitos de mercado, sólo cinco de estas variables han sido seleccionadas, ya que algunas de las variables inicialmente seleccionadas presentan limitaciones estadísticas, además de no añadir capacidad explicativa al modelo. Las cinco variables seleccionadas son: longitud de muelle, condición de puerto base o puerto de escala, existencia de operador privado de terminal portuaria, tasa del buque y tasa del pasaje.

La 'capacidad de atraque' del puerto se mide por la longitud de muelle disponible para buques de crucero. En función de esta longitud, los cruceros que pueden atracar en el 
puerto están limitados en tamaño y número, si hay escalas simultáneas. En este sentido, y atendiendo a los datos incluidos en el Capítulo III apartado 3.2.3, los diez puertos analizados pueden simultanear escalas. El caso de mayor restricción está asociado a simultanear únicamente dos buques. Para realizar este cálculo primero se ha tomado como referencia las esloras de los buques que componen la flota actual y se ha calculado la eslora media, cuyo valor es de $258,5 \mathrm{~m}$. Con este valor de eslora, junto con un margen de seguridad de distancia entre atraques de buques y el valor de longitud de muelle para cruceros en cada puerto, se obtiene el número de escalas simultáneas que un puerto puede acometer atendiendo a este parámetro.

La variable 'puerto base' es una variable dicotómica que toma el valor 1 si el puerto es un puerto base y 0 si es solo de escala. Esta variable pretende tener en cuenta dos efectos. Por un lado, la posibilidad de iniciar y/o finalizar el itinerario en este puerto, además de ser un puerto de escala. Por otro lado, no hay ninguna limitación de tiempo para visitar el hinterland, con pernoctaciones pre- y/o post-crucero asociadas.

La variable 'operador privado de terminal portuaria' se ha tomado como referencia para el tipo de gestión de las instalaciones portuarias; en concreto, si sólo hay gestión pública o existe participación parcial o total de una empresa privada. Teniendo en cuenta el modelo de gestión Landlord del Sistema Portuario Español, varias terminales de cruceros son parcial o totalmente operadas por operadores privados de terminales portuarias, como se ha descrito en el apartado 3.2.3 del Capítulo III. La variable 'operador privado de terminal portuaria' es una variable dicotómica que toma el valor de 1 si hay gestión privada y 0 si la gestión es totalmente pública.

En cuanto a los costes portuarios, este análisis considera dos tipos, tasa del buque y tasa del pasaje. La estructura actual de tasas portuarias en el Sistema Portuario Español tiene su origen en la Ley 48/2003 (BOE, 2003) modificada por la Ley 33/2010 (BOE, 2010). La Ley 33/2010, en su Artículo 12, contempla seis tipos de tasas por la utilización de las instalaciones portuarias. Para el caso del tráfico de cruceros son aplicables dos, la tasa del buque y la tasa del pasaje. Además, la ley mencionada anteriormente incluye que, con objeto de que se pueda tomar en consideración la estructura de costes de cada Autoridad Portuaria y garantizar el principio de autosuficiencia económico-financiera, en un marco de competencia leal entre puertos, cada Autoridad Portuaria podrá proponer en el marco del Plan de Empresa anual dos coeficientes correctores, que se aplicarán, respectivamente, a las cuantías básicas de las tasas del buque (T-1) y del pasaje (T-2). Junto con esto, también se contemplan una serie de bonificaciones para potenciar y consolidar el papel de España como plataforma crucerista.

El hecho imponible de la tasa del buque es la utilización por los buques de las aguas de la zona de servicio del puerto y de las obras e instalaciones portuarias, que permiten el acceso marítimo al puesto de atraque o de fondeo que les haya sido asignado y la estancia en los mismos, en las condiciones que se establezcan. Los elementos cuantitativos de esta tasa son el modo de utilización de las instalaciones portuarias y el tiempo de estancia en el 
puesto de atraque o de fondeo. Respecto al modo de utilización de las instalaciones portuarias, la cuota difiere según el buque se encuentre atracado de costado, de punta, abarloado a otro buque, amarrado a boyas u otros puntos fijos que no tengan la consideración de atraques o bien, fondeado. Además, en la cuota también influye si se trata de un atraque en concesión o autorización. La cuota íntegra de la tasa será la cantidad resultante del producto de la centésima parte del arqueo bruto del buque, con un mínimo de $100 \mathrm{GT}$, por el tiempo de estancia, computado en periodos de una hora o fracción con un mínimo de tres horas por escala y un máximo de 15 horas por escala cada 24 horas, y por la cantidad resultante de aplicar a la cuantía básica $B$ el coeficiente corrector de la tasa del buque y las bonificaciones específicas para el tráfico de cruceros. Por tanto, la tasa del buque se calcula según la ecuación (1),

$$
\text { Tasa del buque }(T-1)=B \cdot R \cdot C \frac{€}{100 G T \cdot h}
$$

Siendo $B$ la cuantía básica de la tasa del buque, establecida en 1,50 €, $R$ el coeficiente corrector anual de aplicación a cada Autoridad Portuaria y $C$ la bonificación asociada al tráfico de cruceros. El criterio establecido para definir la tasa del buque es la cuantía por cada 100 GT y hora de estancia de un buque atracado de costado al muelle, ya que es la posición de atraque habitual de los buques de crucero en puertos españoles, particularizando la cuantía para cada una de la 10 Autoridades Portuarias, según el coeficiente corrector que le sea de aplicación.

El hecho imponible de la tasa del pasaje consiste en la utilización por los pasajeros de las instalaciones de atraque, accesos terrestres, vías de circulación y otras instalaciones portuarias fijas. El elemento cuantitativo de esta tasa para el tráfico de cruceros es la operación marítima de embarque, desembarque o tránsito de pasajeros $\mathrm{y}$, en este último supuesto, los días de estancia en puerto. La cuota íntegra de la tasa aplicable a cada pasajero será la cantidad resultante de aplicar a la cuantía básica $P$, el coeficiente corrector de la tasa del pasaje y el coeficiente asociado al tipo de gestión del atraque y la estación marítima. Por tanto, la tasa del pasaje se calcula según la ecuación (2),

$$
\text { Tasa del pasaje }(T-2)=P \cdot R \cdot C \frac{€}{\text { pasajero } \cdot \text { día }}
$$

Siendo $P$ la cuantía básica de la tasa del pasaje, establecida en 3,40 $€, R$ el coeficiente corrector anual de aplicación a cada Autoridad Portuaria y $C$ el coeficiente correspondiente al tipo de gestión del atraque y la estación marítima. El criterio establecido para definir la tasa del pasaje es la cuantía por cada pasajero en tránsito, particularizada para cada una de las 10 Autoridades Portuarias. 


\subsubsection{Análisis de componentes principales}

El análisis de componentes principales se realiza con el fin de resumir las siete variables explicativas, en factores o dimensiones comunes, discretizadas para los diez puertos utilizando datos del año 2011. El test de Kaiser-Meyer-Olkin (KMO) para la muestra es mayor de 0,50, lo que indica que la muestra es adecuada para aplicar el análisis. La prueba de esfericidad de Bartlett confirma que la matriz de correlación no es una matriz identidad (García et al., 2000). Los resultados presentados en la Tabla 4.2 corresponden a la matriz rotada, la solución sin rotar es difícil de interpretar, ya que, las variables pueden tener cargas altas en múltiples factores. Por lo tanto, utilizando la rotación Varimax, una rotación ortogonal se lleva a cabo en un intento de minimizar el número de variables con cargas altas en el mismo factor, facilitando así su interpretación.

A la luz de los resultados, se puede afirmar que las siete variables pueden ser explicadas por los tres componentes extraídos. Éstos, conjuntamente, representan el 91,1\% de la varianza intrínseca de los datos, cumpliendo el criterio de Kaiser con valores propios superiores a 1. El primer componente explica el 46,5\% de la varianza, mientras que el segundo y tercero explican el $28,8 \%$ y el $15,8 \%$, respectivamente.

Tabla 4.2: Resultados del análisis de componentes principales

\begin{tabular}{lrrrr}
\hline \multirow{2}{*}{ Variables } & Comunalidades & \multicolumn{3}{c}{ Componentes } \\
\cline { 3 - 5 } & & $\mathbf{1}$ & $\mathbf{2}$ & $\mathbf{3}$ \\
\hline Atractivo turístico del hinterland & & & & \\
Número de camas de hotel & 0,809 & 0,883 & 0,053 & 0,164 \\
\hline Características del puerto & & & & \\
Capacidad de atraque & 0,937 & 0,965 & $-0,079$ & $-0,024$ \\
Puerto base & 0,931 & 0,564 & 0,059 & 0,781 \\
Operador privado de terminal portuaria & 0,834 & 0,731 & 0,547 & 0,003 \\
Tasa del buque & 0,990 & $-0,049$ & 0,937 & 0,331 \\
Tasa del pasaje & 0,952 & 0,120 & 0,965 & 0,081 \\
\hline Atractivo turístico de la ciudad portuaria & & & & \\
Número de museos & 0,924 & $-0,109$ & 0,282 & 0,912 \\
\hline \% de varianza explicada (total: 91,110\%): & & $46,482 \%$ & $28,783 \%$ & $15,845 \%$ \\
\hline KMO test $=0,531$ & & & & \\
Chi-cuadrado $=49,365$ & & & & \\
Test de esfericidad de Barlett=0,000 & & & & \\
\hline
\end{tabular}

Nota: Método de rotación: Varimax. La rotación ha convergido en cinco iteraciones. Las fuentes de información de las variables independientes son: BOE (2010), INE (2011) y Puertos del Estado (2012).

Fuente: Elaboración propia.

La interpretación de la primera componente está fuertemente asociada con el atractivo turístico del hinterland y la infraestructura portuaria. Esta componente incorpora las variables 'capacidad de atraque' $(0,96)$, 'número de camas de hotel' $(0,88)$ y 'operador 
privado de terminal portuaria' $(0,73)$. En conjunto, estas variables pueden ser interpretadas como la representación de la infraestructura turística.

En la segunda componente, el factor de carga de 0,94 para la variable 'tasa del buque' y de 0,96 para la variable 'tasa del pasaje', en su conjunto, puede ser interpretado como el indicador del coste de escala en puerto. Más concretamente, estas dos variables definen algunos de los costes de escala para los buques de crucero (IME y FEIN, 2009); es decir, la cantidad que las líneas de cruceros tienen que pagar por el atraque del buque en el puerto.

Finalmente, en el tercer componente, las variables con los factores de carga más altos son: el 'número de museos' como un proxy del atractivo de la ciudad portuaria, con una carga de $0,91, y$ 'puerto base', como una característica del puerto, con una carga de 0,78. Esta componente representa el atractivo turístico de la ciudad portuaria.

Los tres 'factores' anteriores, que corresponden a los tres componentes generados, se han calculado y estandarizado para ser utilizados como variables independientes en la siguiente regresión.

\subsubsection{Resultados de la regresión}

El número de pasajeros de crucero se regresa con los tres factores anteriores. El modelo propuesto es el siguiente:

Pasajeros de crucero $=\Phi($ Infraestructura turística, Costes de escala, Atractivo de la ciudad portuaria)

donde 'Infraestructura turística' es un factor asociado a la infraestructura portuaria y el atractivo del hinterland turístico del puerto, 'Costes de escala' es el factor asociado a los costes de escala en puerto, y 'Atractivo de la ciudad portuaria' es un factor proxy de los recursos turísticos de la ciudad portuaria.

De los resultados obtenidos en la Tabla 4.3, sólo el factor relacionado con la infraestructura turística del hinterland turístico es significativo al 5\%, aunque los tres factores tienen los signos esperados. El coeficiente relacionado con la 'infraestructura turística' (Factor 1) es positivo y significativo estadísticamente. Así, un puerto determinado alcanza un mayor número de pasajeros de cruceros si cuenta con un hinterland turístico atractivo y con instalaciones portuarias adecuadas desde el punto de vista de la capacidad de atraque.

Los costes de escala en puerto (Factor 2) no son estadísticamente significativos, aunque se obtiene el signo negativo esperado en este factor. Así, el modelo no parece tener en cuenta el aspecto económico clave en las escalas de buques de crucero. Esta cuestión se trata con mayor dilación en la sección posterior destinada a análisis de resultados. 
Por último, el coeficiente 'atractivo de la ciudad portuaria' (Factor 3) no es significativo, aunque tiene el signo positivo esperado en este caso. En consecuencia, el número de pasajeros de crucero en un puerto no parece depender tanto del atractivo turístico de la ciudad portuaria, sino más bien del atractivo del hinterland turístico de cada puerto.

Tabla 4.3: Resultados de la regresión

\begin{tabular}{lccr}
\hline Variable & $\begin{array}{c}\boldsymbol{\beta} \text { - coeficientes } \\
\text { estandarizados }\end{array}$ & T-estadísticos & (Sig.) \\
\hline Factor 1, 'INFRAESTRUCTURA_TURÍSTICA' & 0,937 & 7,353 & 0,000 \\
\hline Factor 2, 'COSTES_PORTUARIOS' & $-0,132$ & $-1,039$ & 0,339 \\
\hline Factor 3, 'ATRACTIVO_DE_LA_CIUDAD_PORTUARIA' & 0,078 & 0,614 & 0,562 \\
\hline $\boldsymbol{R}=\mathbf{0 , 9 5 0}$ & & & \\
$\boldsymbol{R}^{\mathbf{2}}=\mathbf{0 , 9 0 2}$ & & & \\
$\boldsymbol{R}^{2}$ ajustado= $\mathbf{0 , 8 5 4}$ & & & \\
Durbin-Watson $(\mathbf{D W})=\mathbf{1 , 4 2 5}$ & & & \\
$\boldsymbol{F}=\mathbf{1 8 , 5 0 9}$ & & & \\
ANOVA (Sig.) $=\mathbf{0 , 0 0 2}$ & & & \\
\hline
\end{tabular}

Fuente: Elaboración propia.

\subsubsection{Discusión de resultados}

Como soporte a los resultados obtenidos, en la literatura especializada existen varias referencias que sustentan los resultados del análisis econométrico presentado en este trabajo. Por ejemplo, en relación con la significatividad de la 'infraestructura turística' (Factor 1), Baird (1997), Lekakou et al. (2010) y Marti (1990) sugieren que sin una infraestructura adecuada, ningún puerto puede desarrollar eficientemente su negocio de cruceros. Además, Lekakou y Pallis (2005) también mencionan que las oportunidades de negocio de los operadores de cruceros están íntimamente relacionadas con la presencia de superestructuras e infraestructuras portuarias. Estas reivindicaciones se refieren a planes financieros para el incremento de atraques, construcción y/o mantenimiento de terminales, así como mejora de instalaciones turísticas en el hinterland, lo que se traduce en el desarrollo de infraestructura portuaria y atractivos turísticos en el hinterland. En relación al atractivo del hinterland, se pueden encontrar alusiones a este concepto en Marti (1990). Sin embargo, es necesario tener en cuenta que una escala es parte de un itinerario, y en consecuencia, la capacidad de atraque y la existencia de must see ports son esenciales para el éxito de un itinerario. Adicionalmente, también deber haber un equilibrio entre el tiempo de navegación y el tiempo en tierra. En este sentido, puede darse una excepción cuando un buque de cruceros elige hacer escala fondeando y utilizar servicios de desembarque en botes, en un puerto de escala con inadecuada capacidad de atraque. Esto sucede porque esa visita genera una demanda significativa para la línea de cruceros, debido al elevado atractivo turístico. Junto con lo anterior, también es importante que el hinterland turístico tenga una buena imagen como destino turístico. 
De acuerdo con Lekakou et al. (2010) y Di Vaio et al. (2011), la participación del sector privado en la gestión de terminales portuarias conduce a un mayor número de pasajeros de crucero. Además, tal y como sugieren Gui y Russo (2011), esto permite a las compañías de crucero asegurarse prioridad de atraque para sus buques, indicando así una fuerte integración vertical por las compañías de crucero, especialmente a nivel de operaciones portuarias. En consecuencia, esto ha resultado en la participación de las compañías de cruceros en la gestión de terminales portuarias, así como, en algunos casos, la adquisición de islas privadas para el uso exclusivo de las líneas de cruceros, como Castaway Cay (Disney Cruise Line) y CocoCay (RCI) en el mar Caribe. De acuerdo con Rodrigue y Notteboom (2013), esta situación ha permitido a las líneas de crucero desarrollar un mercado cautivo para sus buques, así como para las actividades en tierra (por ejemplo excursiones o instalaciones totalmente en propiedad de subsidiarias de las líneas de cruceros).

En cuanto a la no significatividad de los 'costes de escala' (Factor 2), hay numerosas referencias en la literatura, que refuerzan los resultados obtenidos en este trabajo. En primer lugar, tal y como sugieren Gui y Russo (2011), las tasas portuarias han sido la causa tradicional de conflicto entre los puertos y las líneas de cruceros. Sin embargo, como Gui y Russo (2011) apuntan también, las nuevas tendencias en la gestión por el sector privado permiten a las líneas de crucero disfrutar de otros beneficios o incentivos, como retener un porcentaje de las tasas portuarias pagadas por los pasajeros. El modelo presentado, además, no captura una variable económica clave que afecta a la escala en un puerto. El hecho de que los datos asociados a los ingresos por excursiones en cada puerto no están disponibles, puede explicar este resultado.

Finalmente, la no significatividad del 'atractivo de la ciudad portuaria' (Factor 3) sugiere que el atractivo de un puerto de escala está asociado en menor medida con la propia ciudad portuaria y más con el conjunto del hinterland (Factor 1). Los resultados también pueden ser explicados por el hecho de que las estadísticas españolas están disponibles por regiones, pero raramente por ciudad. Adicionalmente, elegir un puerto sobre otro en un itinerario, cuando el hinterland no es particularmente atractivo, puede estar influenciado por la distancia entre puertos, más que por el atractivo de la propia ciudad portuaria, explicando así la no significatividad de la variable ciudad portuaria.

\subsection{Análisis de estacionalidad en el tráfico de cruceros en los puertos de la costa mediterránea y atlántica andaluza}

Un aspecto de vital importancia en el tráfico de cruceros, sobre todo, para los puertos y destinos turísticos, es la distribución temporal de las escalas a lo largo del año. La región del Mediterráneo presenta estacionalidad en la distribución mensual de la cifra de pasajeros de crucero, con temporada baja en invierno, aunque en los últimos años se está registrando una leve desestacionalización, con la permanencia de más buques durante esta época del año. Tomando como referencia la distribución mensual de la cifra de pasajeros de crucero en esta 
región durante los años 2010 y 2013, aproximadamente el 85\% de los pasajeros se concentró entre los meses de abril a octubre, véase Gráfico 4.1.

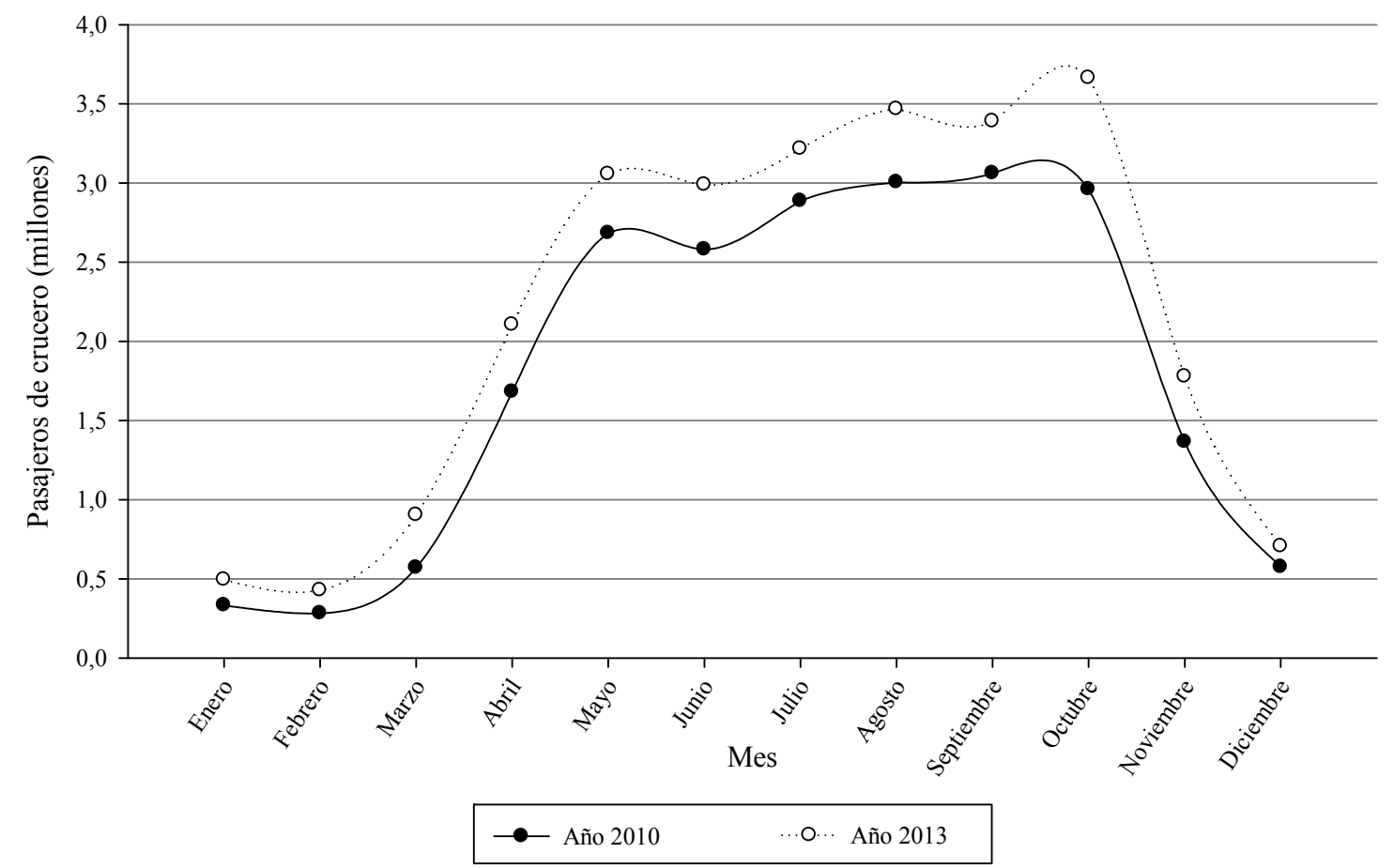

Gráfico 4.1: Distribución mensual de la cifra de pasajeros de crucero en el Mediterráneo durante los años 2010 y 2013.

Fuente: Elaboración propia basada en datos estadísticos de MedCruise (2014).

Segregando las cifras anteriores por sectores del Mediterráneo, y agrupándolas trimestralmente, se obtienen patrones de estacionalidad diferentes para cada uno de los sectores, véase Tabla 4.4. El Mediterráneo Occidental durante los años 2010 y 2013 fue el sector que mostró una distribución más equilibrada, con una cuota del $8,5 \%$ en los meses de invierno.

Tabla 4.4: Distribución de la cifra de pasajeros de crucero agrupada por trimestres durante los años 2010 y 2013 en los cuatro sectores del Mediterráneo

\begin{tabular}{lcccccccc}
\hline \multirow{2}{*}{ Sector } & \multicolumn{2}{c}{ Mar-May } & \multicolumn{2}{c}{ Jun-Ago } & \multicolumn{2}{c}{ Sep-Nov } & \multicolumn{2}{c}{ Dic-Feb } \\
& $\mathbf{2 0 1 0}$ & $\mathbf{2 0 1 3}$ & $\mathbf{2 0 1 0}$ & $\mathbf{2 0 1 3}$ & $\mathbf{2 0 1 0}$ & $\mathbf{2 0 1 3}$ & $\mathbf{2 0 1 0}$ & $\mathbf{2 0 1 3}$ \\
\hline Occidental & $26,3 \%$ & $24,4 \%$ & $33,6 \%$ & $34,3 \%$ & $34,2 \%$ & $32,8 \%$ & $5,9 \%$ & $8,5 \%$ \\
Adriático & $15,9 \%$ & $21,2 \%$ & $41,2 \%$ & $43,6 \%$ & $35,6 \%$ & $34,9 \%$ & $7,3 \%$ & $0,3 \%$ \\
Oriental & $22,9 \%$ & $19,3 \%$ & $34,2 \%$ & $41,4 \%$ & $40,3 \%$ & $36,6 \%$ & $2,6 \%$ & $2,7 \%$ \\
Mar Negro & $16,6 \%$ & $13,9 \%$ & $31,9 \%$ & $42,6 \%$ & $51,4 \%$ & $43,4 \%$ & - & - \\
\hline
\end{tabular}

Fuente: Elaboración propia basada en datos de MedCruise (2014).

Atendiendo a la distribución estacional de pasajeros de crucero en el sector del Mediterráneo Occidental, presentada anteriormente, y las cifras de pasajeros de crucero discretizadas por meses para los puertos del Mediterráneo español y la costa atlántica andaluza, incluidas en el Anexo II, en el presente apartado se estudia el perfil de estacionalidad y su evolución en los puertos de esta zona litoral durante el periodo 2000- 
2013. Este análisis se realiza con objeto de conocer el índice de estacionalidad del tráfico de cruceros en esta zona litoral española y determinar los efectos que ésta puede tener en la explotación de las terminales portuarias. La presencia de estacionalidad desde el punto de vista de la explotación portuaria, genera una capacidad ociosa instalada durante los periodos de temporada baja y puede dar lugar a una sobreexplotación en temporada alta, afectando negativamente a la calidad del servicio ofrecido a buques y pasajeros.

\subsubsection{Método}

El análisis de la estacionalidad se estructura en dos niveles. El primer nivel alude al estudio de la estacionalidad de forma agregada para los puertos de crucero de esta zona litoral, dividiéndose éste en dos etapas. En la primera etapa se ha determinado el perfil de estacionalidad. Mientras que en la segunda etapa se ha determinado la evolución de la estacionalidad. Ambos análisis se han realizado con una serie temporal compuesta de 168 observaciones, correspondientes a 14 años con medidas mensuales, periodo del año 2000 a 2013. A su vez, la segunda etapa se ha estructurado en dos niveles temporales: en primera instancia a nivel interanual y posteriormente, discretizado por meses, en ambos casos, usando también la serie temporal del año 2000 a 2013. Respecto al segundo nivel de análisis, éste comprende el estudio del perfil de estacionalidad segregado por puertos, empleando para ello también la serie de 168 observaciones mensuales, correspondientes al mismo rango temporal que en el caso anterior.

\subsubsection{Análisis agregado de la estacionalidad del tráfico de cruceros en los puertos de la costa mediterránea y atlántica andaluza}

En la primera etapa, determinación de la estacionalidad del tráfico de cruceros, el primer paso ha consistido en la determinación del tipo de modelo asociado a la serie temporal: aditivo o multiplicativo. Para ello se han empleado dos métodos, uno gráfico y otro numérico. Tras identificar el tipo de modelo, se ha calculado la componente estacional de la serie temporal, obteniendo como resultado el patrón de estacionalidad del tráfico de cruceros, véase Figura 4.1.

En la segunda etapa, para el análisis de la evolución de la estacionalidad interanual se han empleado dos coeficientes, el de Variación y el de Gini. Mientras que para el análisis discretizado por meses se ha empleado la tasa de variación mensual (en tanto por uno) respecto al mismo mes del año anterior, aplicada entre el año 2000 y 2013, véase Figura 4.1. 


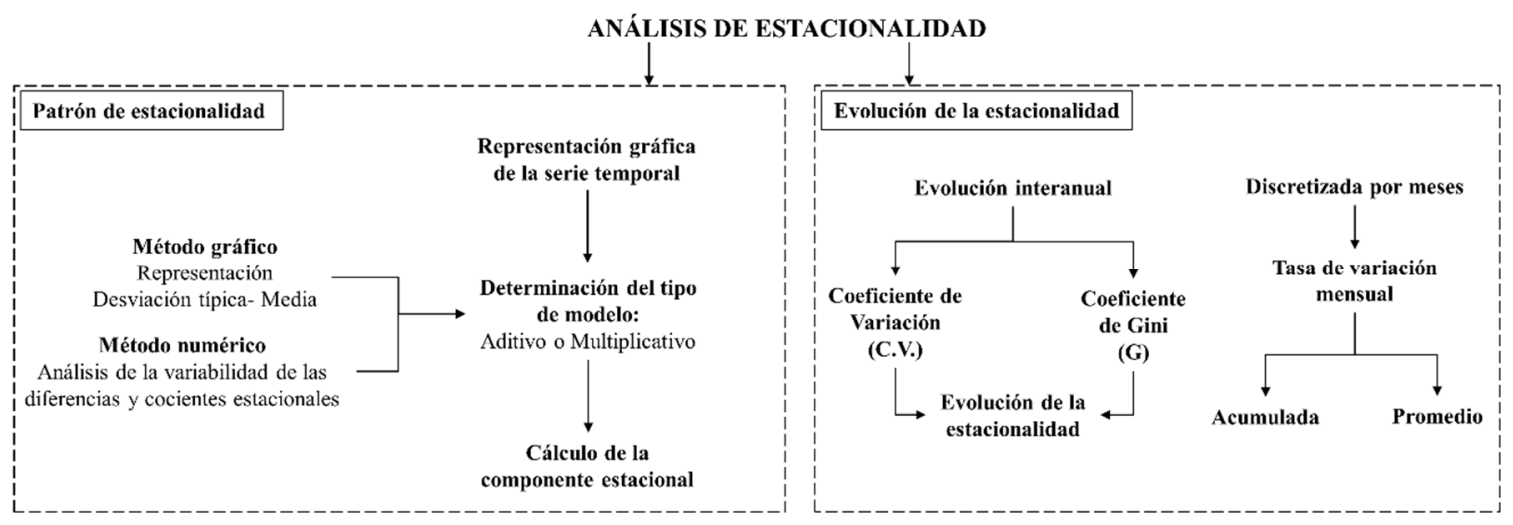

Figura 4.1: Esquema conceptual del proceso de análisis de la estacionalidad aplicado.

Fuente: Elaboración propia.

La serie temporal de pasajeros de crucero en la costa mediterránea y atlántica andaluza está compuesta por los registros mensuales de los 18 puertos que registran este tráfico marítimo entre los años 2000 y 2013. La representación gráfica de la serie se muestra en el Gráfico 4.2.

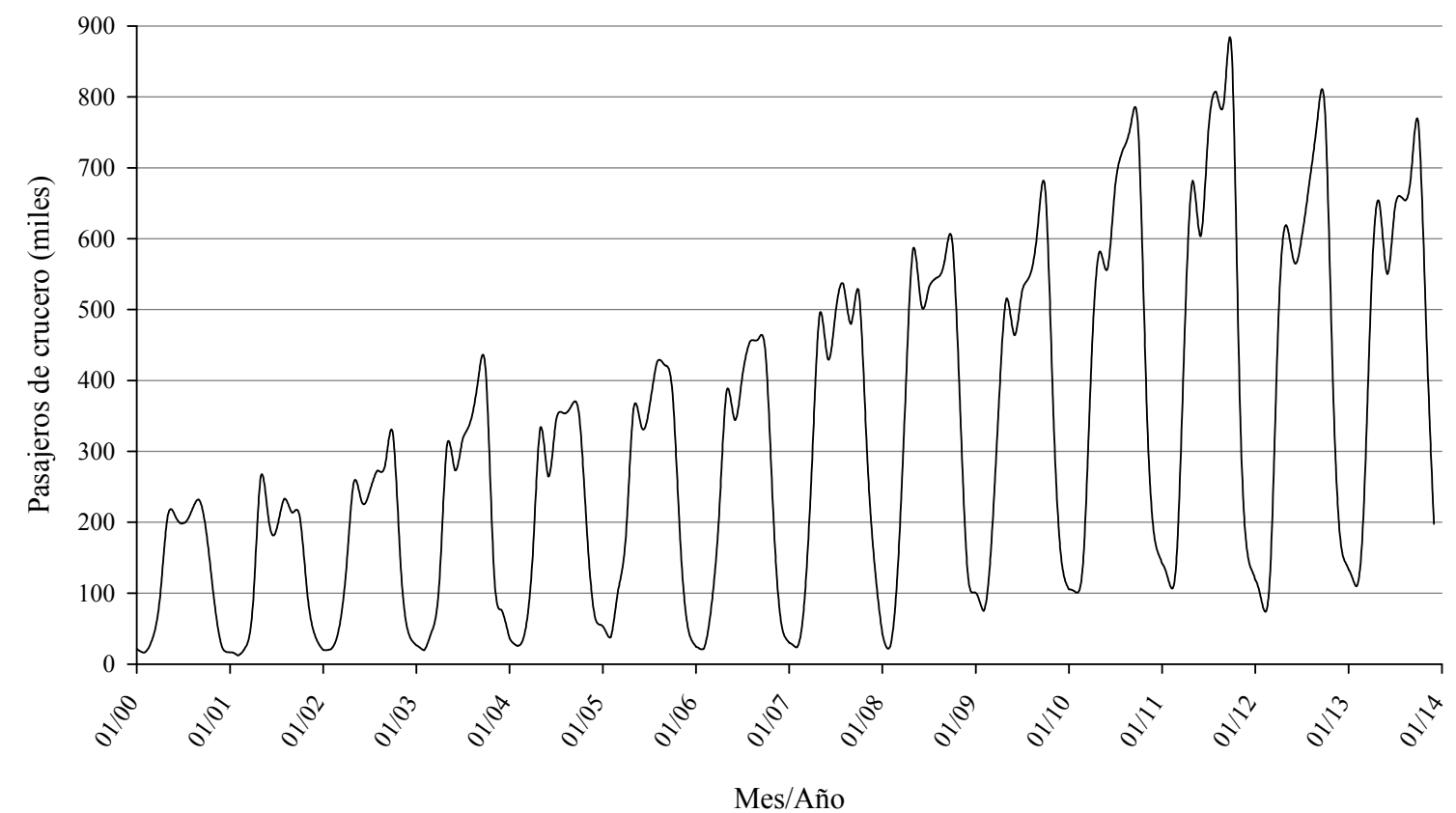

Gráfico 4.2: Serie temporal de pasajeros de crucero en los puertos de la costa mediterránea y atlántica andaluza entre los años 2000 y 2013.

Fuente: Elaboración propia basada en datos estadísticos de Puertos del Estado (2014).

En la determinación del tipo de modelo, aditivo o multiplicativo, en primera instancia se ha calculado y representado gráficamente la desviación típica y la media para cada año de la serie temporal. Con este método, si la nube de puntos se distribuye aproximadamente en torno a una recta paralela al eje de abscisas, el modelo es aditivo. Por el contrario, si las desviaciones típicas crecen al aumentar las medias anuales, el esquema adecuado será el multiplicativo. En el Gráfico 4.3 se observa una tendencia al incremento de la desviación 
típica al aumentar la media, lo cual es característico de un modelo multiplicativo (CSIC, 2006).

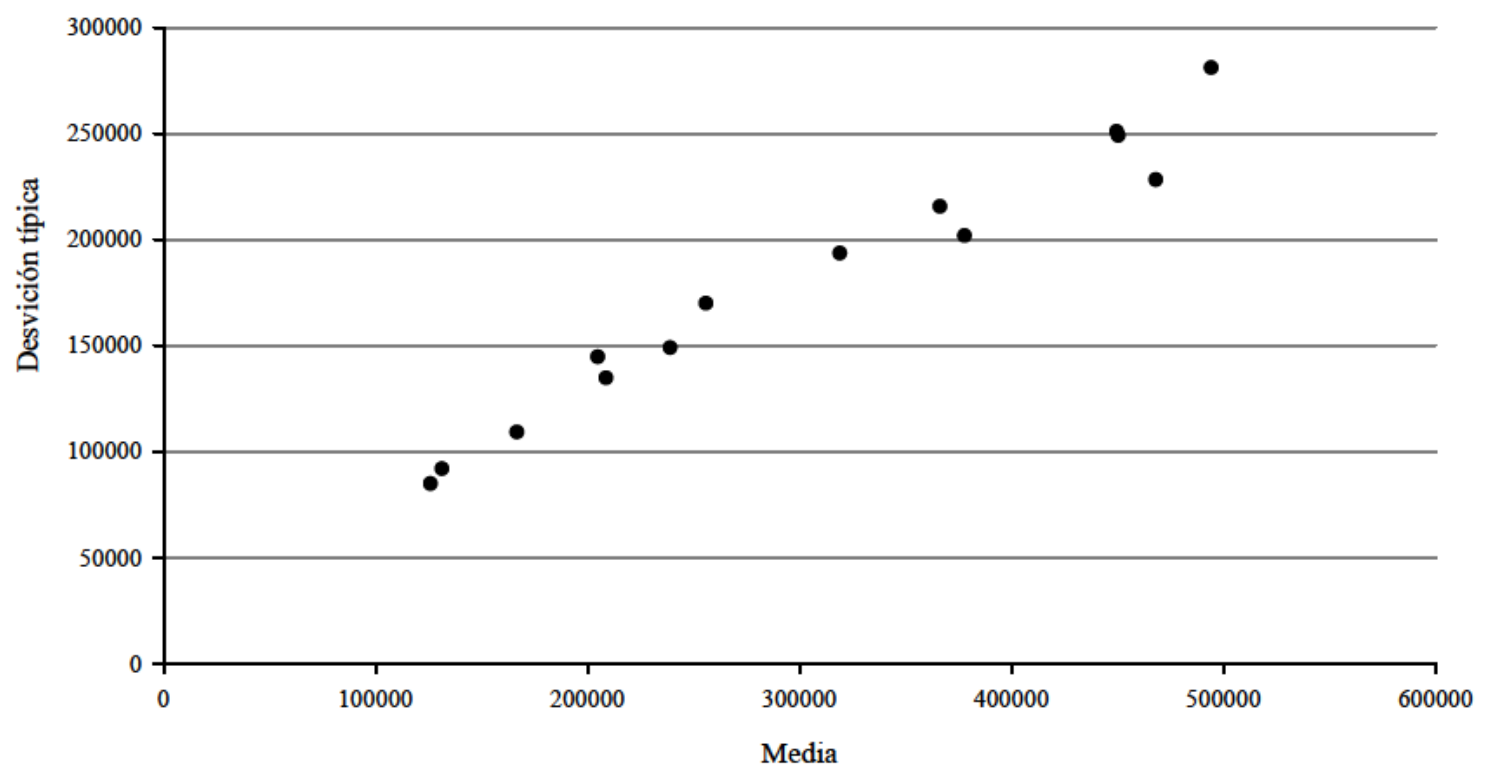

Gráfico 4.3: Distribución de la desviación típica y media anual de pasajeros de crucero en los puertos de la costa mediterránea y atlántica andaluza entre los años 2000 y 2013.

Fuente: Elaboración propia.

Para contrastar el resultado obtenido gráficamente, se ha hecho uso del método numérico consistente en el análisis de la variabilidad de las diferencias y cocientes estacionales. La diferencia estacional $d_{i j}$ se define como la diferencia entre dos datos de la misma estación, en este caso mes, correspondiente a dos años consecutivos $i-1$ e $i$. Se calcula según la siguiente expresión,

$$
d_{i j}=Y_{i j}-Y_{i-1 j}
$$

donde $Y_{i j}$ es el valor de la serie en el año $i$ y mes $j$.

En cuanto al cociente estacional $k_{i j}$ se define como el cociente entre dos datos de la misma estación, en este caso mes, correspondientes a dos años consecutivos $i-1$ e $i$. Calculándose según la siguiente expresión,

$$
k_{i j}=\frac{Y_{i j}}{Y_{i-1 j}}
$$

donde $Y_{i j}$ es el valor de la serie en el año $i$ y mes $j$.

Una vez calculados los valores de (4) y (5) se calculan los coeficientes de variación (C.V.) de cada uno de ellos, definidos por las expresiones (6) y (7). Si C.V. (d) $\leq$ C.V. (k) se elige esquema aditivo, en caso contrario multiplicativo (UPCT, 2009). 


$$
\begin{aligned}
& C . V .(d)=\frac{\sigma_{d}}{\bar{d}} . \\
& C . V .(k)=\frac{\sigma_{k}}{\bar{k}} .
\end{aligned}
$$

Particularizando las expresiones (6) y (7) con la serie temporal de pasajeros de crucero se ha obtenido un valor de $C . V .(d)=1,84$ y $C . V .(k)=0,27$. Por tanto, $C . V .(d)>$ C.V. (k) por lo que la serie temporal se ajusta a un modelo multiplicativo, tal y como también sugería el Gráfico 4.3 anterior.

Tras identificar el modelo como multiplicativo, en este tipo de modelos la componente estacional se mide con un índice denominado índice de variación estacional (IVE). Este índice, expresado en tanto por ciento, representa la fluctuación del valor de la serie respecto al valor de la tendencia media del año (UPCT, 2009). Para el cálculo del IVE se ha empleado el método de la razón a la media móvil. La aplicación de este método requiere en primer lugar, calcular las medias móviles para la serie temporal, en este caso al estar formada por datos mensuales, las medias móviles calculadas son de amplitud $h=12$. El siguiente paso ha consistido en calcular mensualmente el cociente de los valores originales de la serie por las medias móviles obtenidas, a través de la expresión (8).

$$
\bar{e}_{i t}=\frac{Y_{i t}}{t c_{i t}}
$$

siendo $Y_{i t}$ la observación en el año $t$ y el mes $i$ y $t c_{i t}$ la media móvil en el año $t$ y el mes $i$.

A continuación se han calculado las medias sobre dichos cocientes para cada uno de los meses, según,

$$
\bar{e}_{i}=\frac{1}{N-1} \sum \frac{Y_{i t}}{t c_{i t}}
$$

donde $N$ es el número de años (en este caso 14) e $i$ variando entre 1 y 12 al disponer de registros mensuales.

Una vez obtenidos estos parámetros se ha calculado el IVE para cada mes $i$ según la expresión (10).

$$
\operatorname{IVE}(\operatorname{mes} i)=\frac{\bar{e}_{i}}{1 / 12^{\sum \bar{e}_{i}}} \cdot 100
$$

Los resultados obtenidos se muestran en la Tabla 4.5. El tráfico de cruceros en los puertos de la costa mediterránea y atlántica andaluza entre el año 2000 y 2013 ha presentado 
un patrón de funcionamiento estacional. Seis meses (de mayo a octubre) comprenden la temporada alta, de los cuales, cinco han presentado registros superiores a la media anual en un 50\%. Entre los meses de temporada baja, enero y febrero han sido los de menor actividad con unos valores inferiores al $80 \%$ de la media anual. En este mismo grupo, los meses de abril y noviembre, han marcado la transición hacia el inicio y fin de la temporada alta, respectivamente, con las menores diferencias respecto a la media anual.

Tabla 4.5: Índices de variación estacional mensuales para la cifra de pasajeros de crucero registrada en los puertos de crucero del Mediterráneo español y la costa atlántica andaluza entre el año 2000 y 2013

\begin{tabular}{lcc}
\hline Mes & IVE (\%) & Interpretación \\
\hline Enero & 19,37 & $-80,63 \%$ de cruceristas respecto a la media anual \\
Febrero & 14,99 & $-85,01 \%$ de cruceristas respecto a la media anual \\
Marzo & 32,84 & $-67,16 \%$ de cruceristas respecto a la media anual \\
Abril & 89,23 & $-10,77 \%$ de cruceristas respecto a la media anual \\
Mayo & 151,90 & $51,90 \%$ de cruceristas respecto a la media anual \\
Junio & 131,84 & $31,84 \%$ de cruceristas respecto a la media anual \\
Julio & 149,50 & $49,50 \%$ de cruceristas respecto a la media anual \\
Agosto & 163,96 & $63,96 \%$ de cruceristas respecto a la media anual \\
Septiembre & 168,89 & $68,89 \%$ de cruceristas respecto a la media anual \\
Octubre & 167,53 & $67,53 \%$ de cruceristas respecto a la media anual \\
Noviembre & 79,04 & $-20,96 \%$ de cruceristas respecto a la media anual \\
Diciembre & 30,88 & $-69,12 \%$ de cruceristas respecto a la media anual \\
\hline
\end{tabular}

Fuente: Elaboración propia.

Para determinar la evolución de la estacionalidad interanual se han empleado dos coeficientes, de Variación y de Gini. Ambos coeficientes son ampliamente empleados en el análisis de concentraciones en sectores tales como, el turístico, económico y geográfico. Referencias a dichos indicadores se pueden encontrar en los trabajos de Aguiló y Sastre (1984), Nieto, Amate y Román (2000) y Fernández-Morales (2003). El Coeficiente de Variación es una medida de la dispersión relativa de un conjunto de datos, que se obtiene dividiendo la desviación típica del conjunto entre su media aritmética. Cuanto mayor sea el valor del Coeficiente de Variación, mayor heterogeneidad de los valores de la variable y a menor C.V., mayor homogeneidad en los valores de la variable. El C.V. se calcula según la siguiente expresión,

$$
C . V .=\frac{\sigma}{\bar{Y}}=\frac{\sqrt{\sum_{n=1}^{N}\left(Y_{n}-\bar{Y}\right)^{2} / N}}{\bar{Y}},
$$

siendo $\sigma$ la desviación típica, $\bar{Y}$ la media aritmética de la muestra, $Y_{n}$ cada una de las observaciones mensuales y $N=12$ pues se ha trabajado con datos mensuales. El cálculo del C.V. indica una disminución de la estacionalidad de la cifra de pasajeros de crucero, durante el periodo entre el año 2000 y 2013. Un resultado análogo se ha obtenido al segregar la cifra total de pasajeros en las categorías de inicio y fin de itinerario y tránsito, véase Tabla 4.6. 
Tabla 4.6: Valores del coeficiente de Variación anual de la cifra de pasajeros de crucero entre los años 2000 у 2013

\begin{tabular}{lccc}
\hline \multirow{2}{*}{ Año } & \multicolumn{3}{c}{ Coeficiente de Variación } \\
\cline { 2 - 4 } & Pasajeros totales & Pasajeros de inicio y fin de itinerario & Pasajeros en tránsito \\
\hline 2000 & 0,67 & 0,84 & 0,59 \\
2001 & 0,69 & 0,80 & 0,63 \\
2002 & 0,65 & 0,75 & 0,60 \\
2003 & 0,70 & 0,84 & 0,63 \\
2004 & 0,64 & 0,78 & 0,60 \\
2005 & 0,62 & 0,72 & 0,58 \\
2006 & 0,66 & 0,74 & 0,62 \\
2007 & 0,60 & 0,69 & 0,55 \\
2008 & 0,59 & 0,67 & 0,54 \\
2009 & 0,53 & 0,55 & 0,53 \\
2010 & 0,55 & 0,63 & 0,51 \\
2011 & 0,57 & 0,73 & 0,47 \\
2012 & 0,56 & 0,68 & 0,48 \\
2013 & 0,49 & 0,57 & 0,45 \\
\hline
\end{tabular}

Fuente: Elaboración propia.

Adimensionalizando la curva de evolución de la cifra de pasajeros de crucero y la de evolución de la estacionalidad, por medio del cálculo de un número índice, tomando como referencia el año 2000 , se ha obtenido que el incremento registrado en la cifra total de pasajeros de crucero ha llevado aparejado una disminución de la estacionalidad, véase Gráfico 4.4.

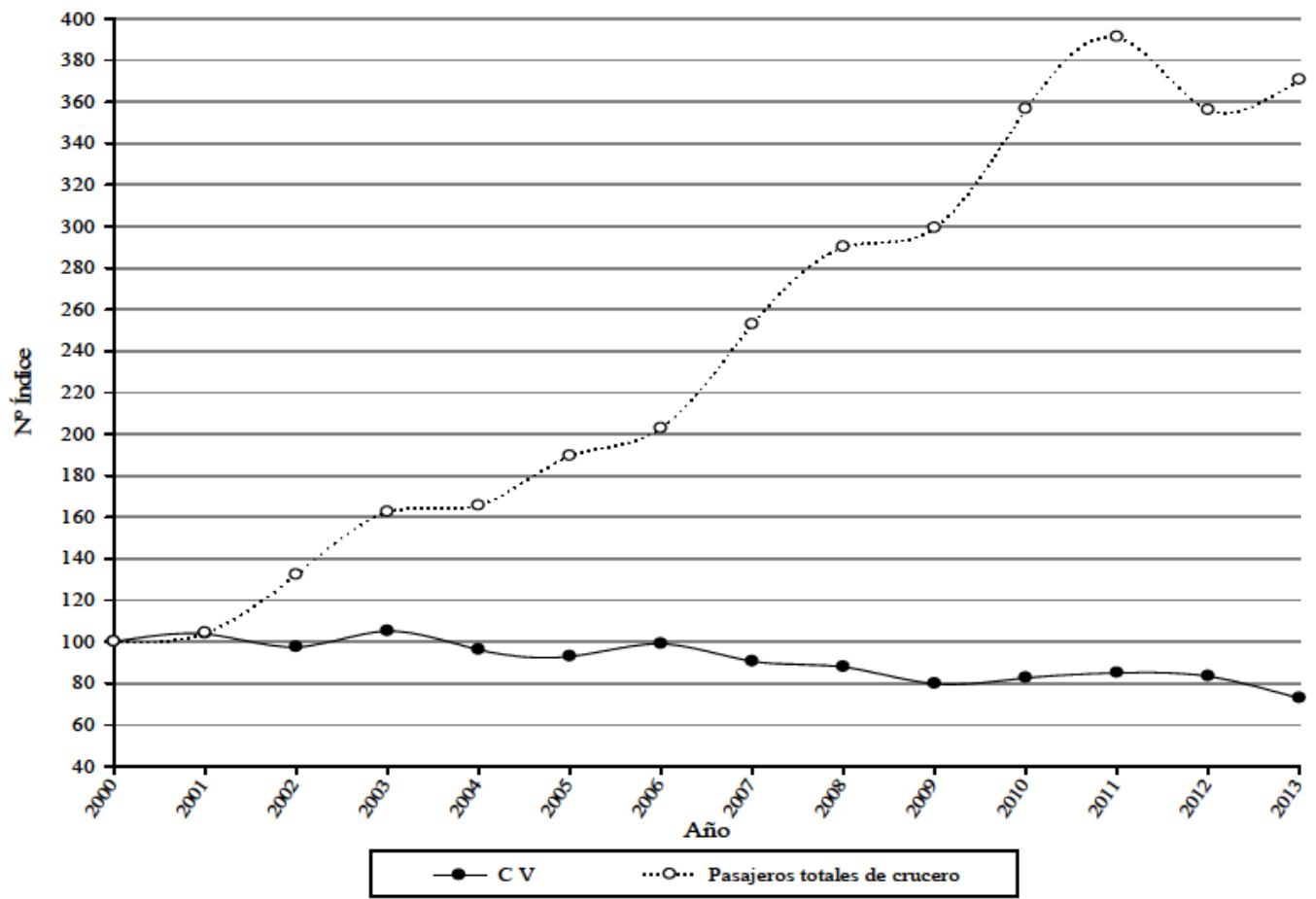

Gráfico 4.4: Curvas de evolución de la cifra de pasajeros de crucero y del C.V. adimensionalizadas para el periodo de 2000 a 2013.

Fuente: Elaboración propia. 
Para corroborar los resultados obtenidos con el C.V. se ha calculado el coeficiente de Gini también para el mismo periodo temporal. El coeficiente de Gini fue desarrollado para medir el grado de concentración (desigualdad) de una variable, en una distribución de sus elementos (Rodrigue et al., 2013). En él se compara la curva de Lorenz de una distribución empírica con la línea de igualdad perfecta. Esta línea supone que cada elemento tiene la misma contribución a la suma total de los valores de una variable. El coeficiente de Gini oscila entre 0 , donde no existe concentración (igualdad perfecta) y 1 donde hay concentración total (desigualdad perfecta), calculándose según,

$$
G=1+\frac{1}{N}-\frac{2}{N^{2} \bar{Y}}\left(Y_{1}+2 Y_{2}+\ldots+n Y_{n}\right) \text { donde } Y_{1} \geq Y_{2} \geq Y_{n}
$$

siendo $N$ el número de observaciones (en este caso $N=12$ pues se trabaja con datos mensuales), $\bar{Y}$ la media aritmética de la muestra e $Y_{1} \geq Y_{2} \geq, \ldots, Y_{n}$ cada una de las observaciones en orden decreciente. Tras realizar el cálculo del coeficiente de Gini tanto para la cifra total de pasajeros de crucero, como segregada en inicio y fin de itinerario y tránsito, se ha obtenido, de forma análoga que con el C.V., una reducción de la estacionalidad entre el año 2000 y 2013, véase Tabla 4.7.

Tabla 4.7: Valores del coeficiente de Gini para la cifra de pasajeros de crucero entre los años 2000 y 2013

\begin{tabular}{cccc}
\hline \multirow{2}{*}{ Año } & \multicolumn{3}{c}{ Coeficiente de Gini } \\
\cline { 2 - 4 } & Pasajeros totales & Pasajeros de inicio y fin de itinerario & Pasajeros en tránsito \\
\hline 2000 & 0,37 & 0,46 & 0,33 \\
2001 & 0,39 & 0,44 & 0,36 \\
2002 & 0,36 & 0,41 & 0,34 \\
2003 & 0,39 & 0,46 & 0,36 \\
2004 & 0,36 & 0,44 & 0,34 \\
2005 & 0,35 & 0,40 & 0,33 \\
2006 & 0,37 & 0,41 & 0,35 \\
2007 & 0,33 & 0,39 & 0,31 \\
2008 & 0,32 & 0,37 & 0,29 \\
2009 & 0,30 & 0,31 & 0,30 \\
2010 & 0,31 & 0,35 & 0,28 \\
2011 & 0,32 & 0,41 & 0,27 \\
2012 & 0,31 & 0,38 & 0,27 \\
2013 & 0,27 & 0,31 & 0,25 \\
\hline
\end{tabular}

Fuente: Elaboración propia.

El coeficiente de Gini representa el área de concentración entre la curva de Lorenz y la línea de igualdad perfecta, ya que expresa una parte de la zona delimitada por el triángulo definido por la línea de igualdad perfecta y la línea de desigualdad perfecta. Representando la curva de Lorenz para los años 2000, 2007 y 2013, se observa la disminución progresiva de la estacionalidad en la cifra de pasajeros de crucero, véase Gráfico 4.5. 


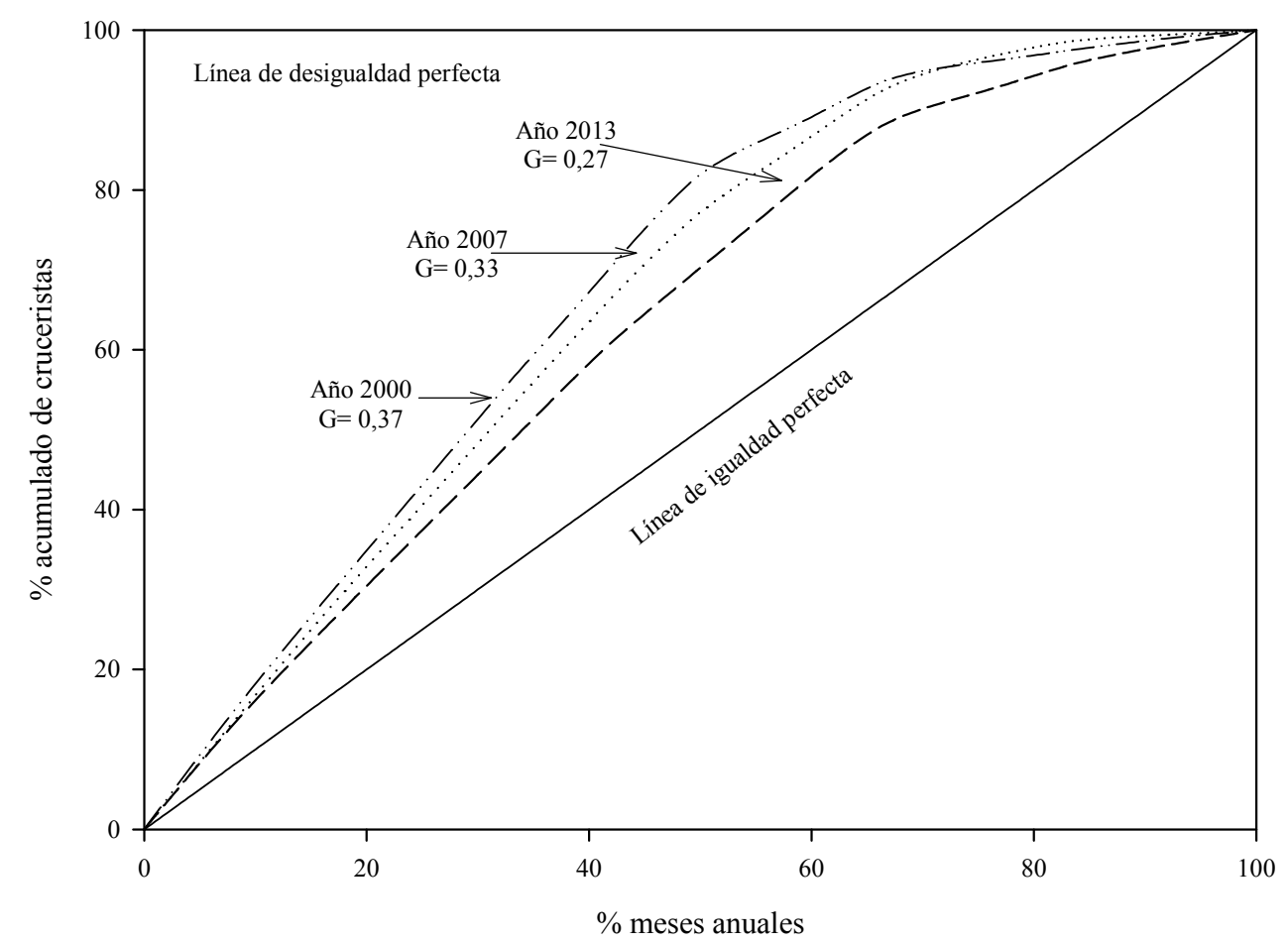

Gráfico 4.5: Curva de Lorenz asociada a la cifra de cruceristas de los años 2000, 2007 y 2013.

Fuente: Elaboración propia.

Por tanto, mediante ambos métodos se ha obtenido una disminución en la estacionalidad durante el periodo 2000-2013. En este punto, se ha procedido a determinar la evolución de la estacionalidad a nivel mensual, con objeto de conocer si la disminución de la estacionalidad está asociada con un incremento de actividad en los meses de temporada baja o bien, con un descenso de actividad en los meses de temporada alta.

En el análisis discretizado por meses se ha empleado la tasa de variación mensual (en tanto por uno) respecto al mismo mes del año anterior, aplicada entre el año 2000 y 2013 según la expresión (13).

$$
T_{12}^{1}=\frac{Y_{t i}}{Y_{t-12}}-1
$$

donde $Y_{t i}$ es el valor de la cifra de cruceristas en el mes $t$ del año $i$ e $Y_{t-12}$ es el valor en el mes $t$ del año anterior.

Calculando la variación mensual acumulada para el periodo del año 2000 a 2013, así como, el promedio mensual de variaciones para el mismo periodo, los meses denominados de temporada baja han registrado un mayor crecimiento respecto a los de temporada alta (mayo a octubre), véase Gráfico 4.6. Esto indica una tendencia hacia una distribución más equitativa, disminuyendo la desigualdad entre meses a pesar de que se registren diferencias significativas entre ellos, es decir, la estacionalidad mensual también se ha reducido. De tal 
forma que, paulatinamente, se tiende hacia una desestacionalización del tráfico de cruceros en los puertos españoles del Mediterráneo.

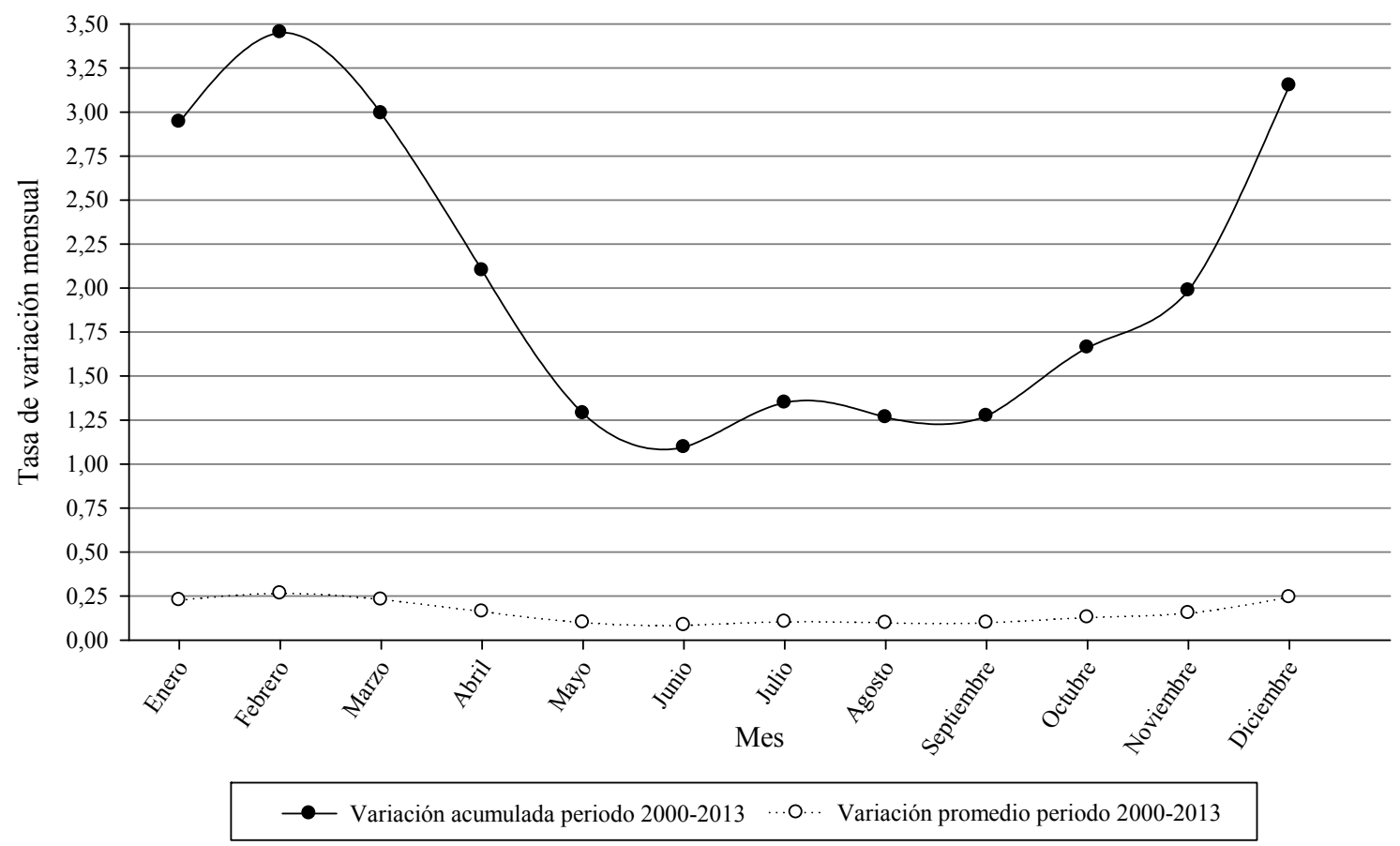

Gráfico 4.6: Tasa de variación mensual acumulada y promedio para el periodo del año 2000 a 2013.

Fuente: Elaboración propia.

\subsubsection{Análisis segregado de la estacionalidad del tráfico de cruceros en los puertos de la costa mediterránea y atlántica andaluza}

A partir de los resultados anteriores, se ha procedido a estudiar de forma aislada cada uno de los puertos situados en esta zona litoral española. De los 18 puertos que registraron tráfico de cruceros, se tuvieron en cuenta en el análisis 13, ya que en cinco, su tráfico fue de baja magnitud, con cifras inferiores a 7.000 pasajeros anuales, de media, durante el periodo 2000-2013 y con evolución irregular. Un primer resultado obtenido radica en que el $92 \%$ de los puertos pueden simultanear escalas de buques de crucero. Los 13 puertos analizados dieron como resultado dos patrones de distribución mensual de la cifra de pasajeros. Por un lado, puertos con un solo máximo anual, localizado entre los meses de julio a septiembre, este es el caso de los puertos de: Barcelona, Ibiza, Mahón, Palma de Mallorca y Valencia, véase Gráfico 4.7. 


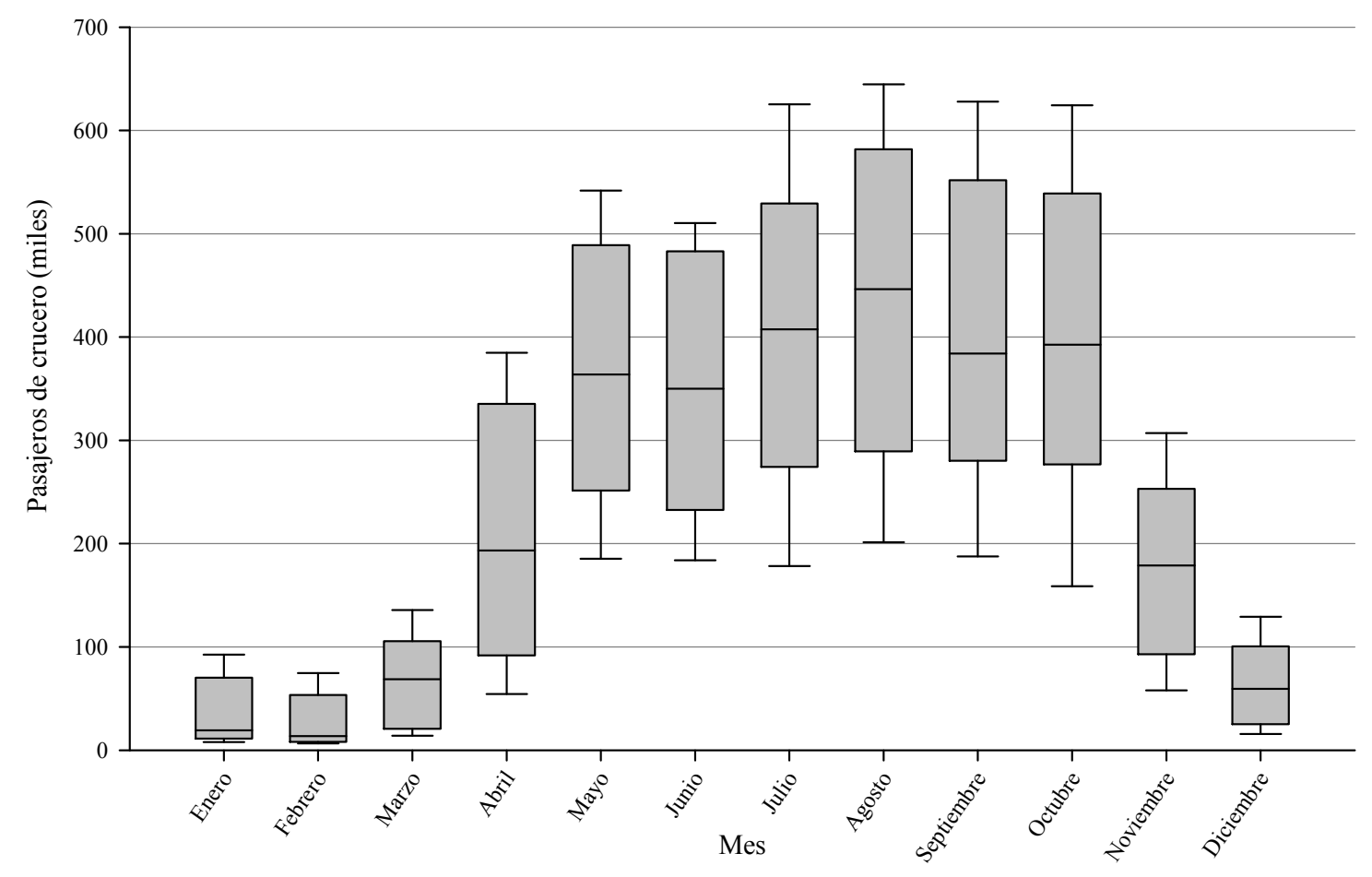

Gráfico 4.7: Representación gráfica de la cifra de pasajeros de crucero mensual acumulada entre el año 2000 y 2013 para los puertos con un solo máximo.

Fuente: Elaboración propia.

Focalizando la atención en este sub-grupo de puertos, se han calculado los IVE para los puertos de Barcelona, Palma de Mallorca y Valencia y representado gráficamente frente al perfil obtenido en el apartado 4.2.2 para el conjunto de puertos de la costa mediterránea y atlántica andaluza. Los Gráficos 4.8 a 4.10 muestran los resultados obtenidos. Estos tres puertos, durante los seis meses de temporada alta (mayo-octubre), superan la cifra media anual de pasajeros de crucero. Alcanzando incluso magnitudes cercanas al $100 \%$ de incremento en el mes de agosto para los puertos de Palma de Mallorca y Valencia, véase Gráficos 4.9 y 4.10. 


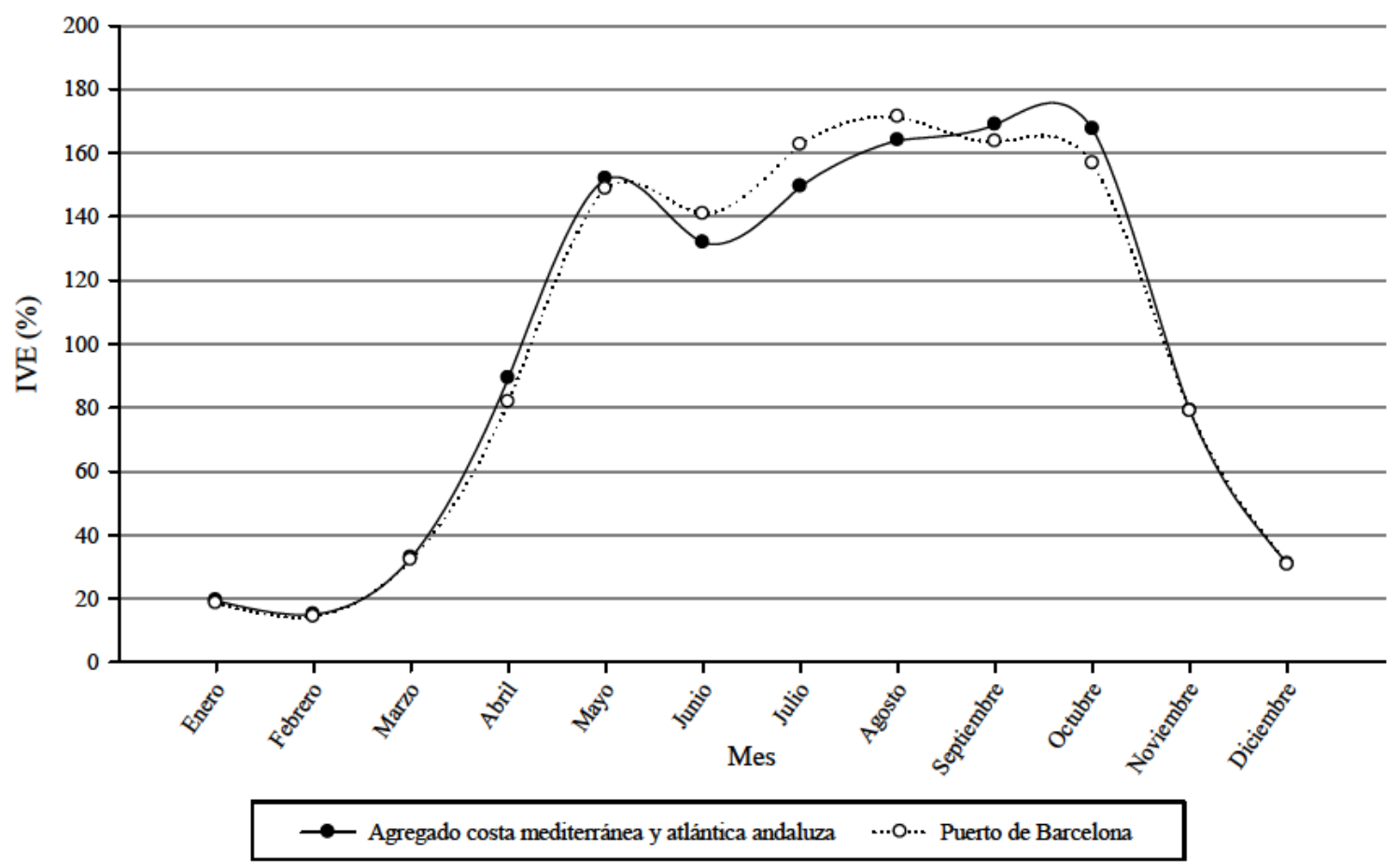

Gráfico 4.8: Comparativa entre las curvas de IVE para el conjunto de puertos de la costa mediterránea y el puerto de Barcelona.

Fuente: Elaboración propia.

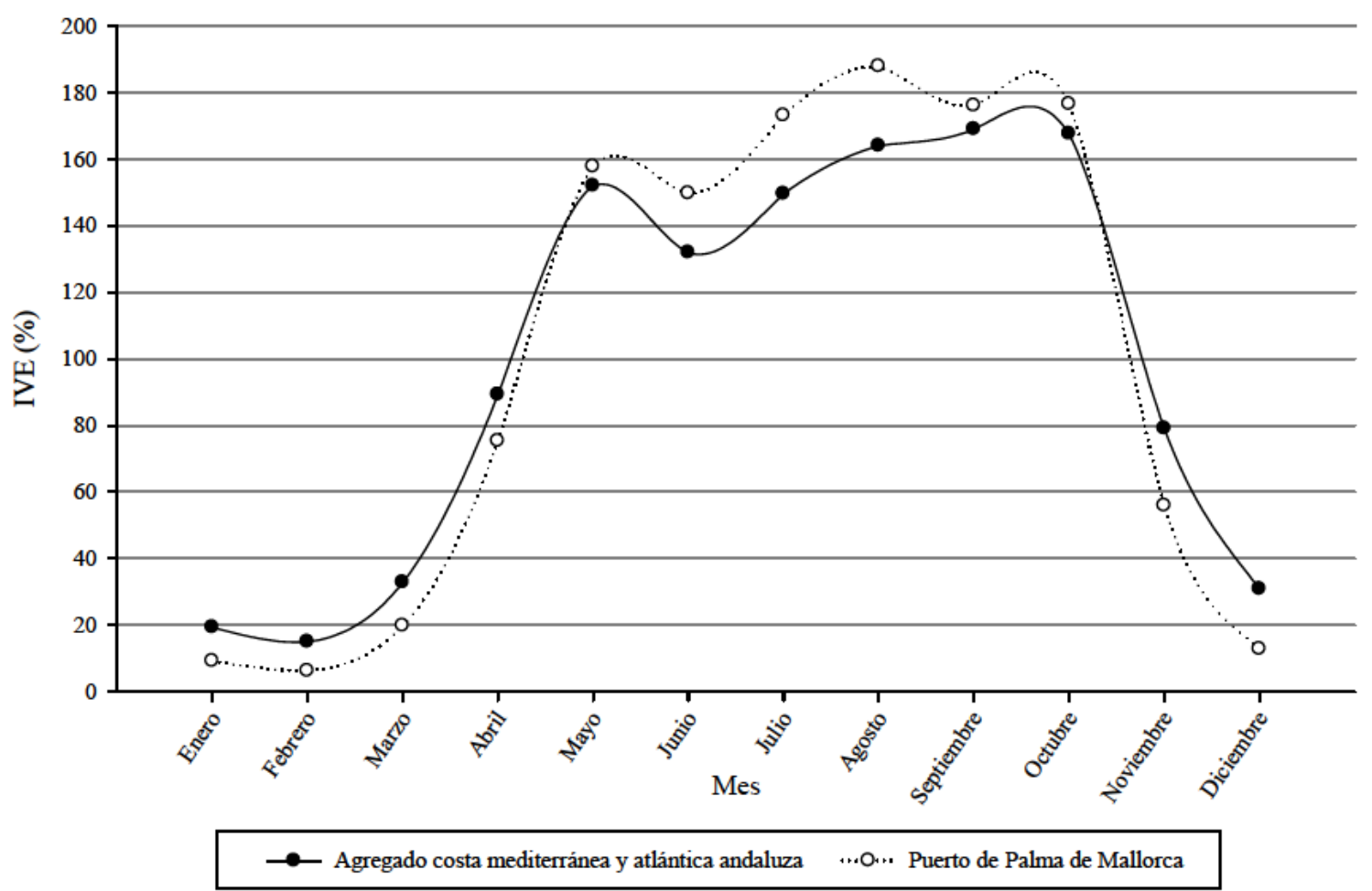

Gráfico 4.9: Comparativa entre las curvas de IVE para el conjunto de puertos de la costa mediterránea y el puerto de Palma de Mallorca.

Fuente: Elaboración propia. 


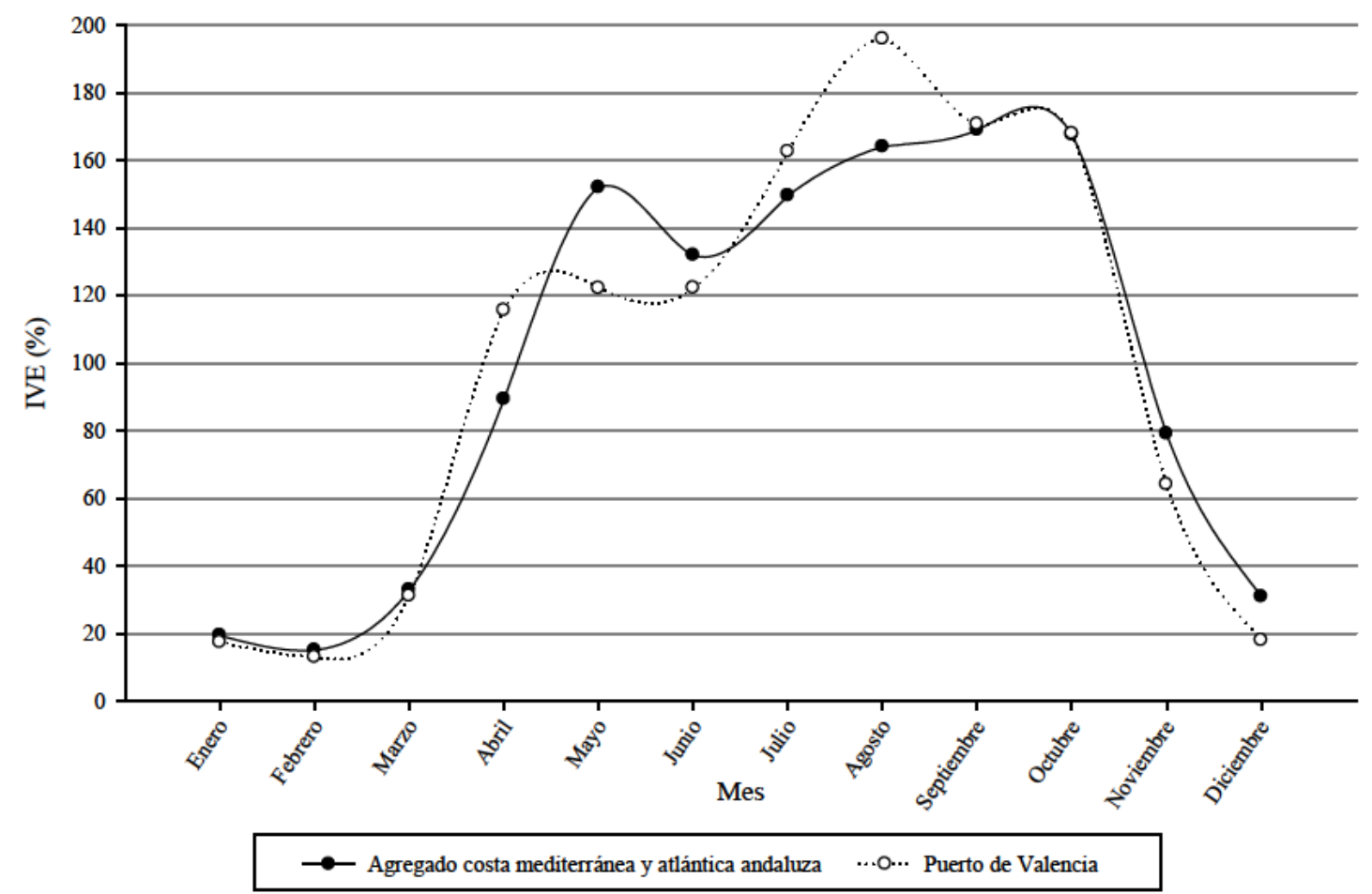

Gráfico 4.10: Comparativa entre las curvas de IVE para el conjunto de puertos de la costa mediterránea y el puerto de Valencia.

Fuente: Elaboración propia.

Por otro lado, puertos con dos máximos anuales, localizados hacia los meses de abrilmayo y septiembre-octubre, es el caso de los puertos de: Alicante, Almería, Cádiz, Cartagena, Ceuta, Málaga, Motril y Sevilla, véase Gráfico 4.11.

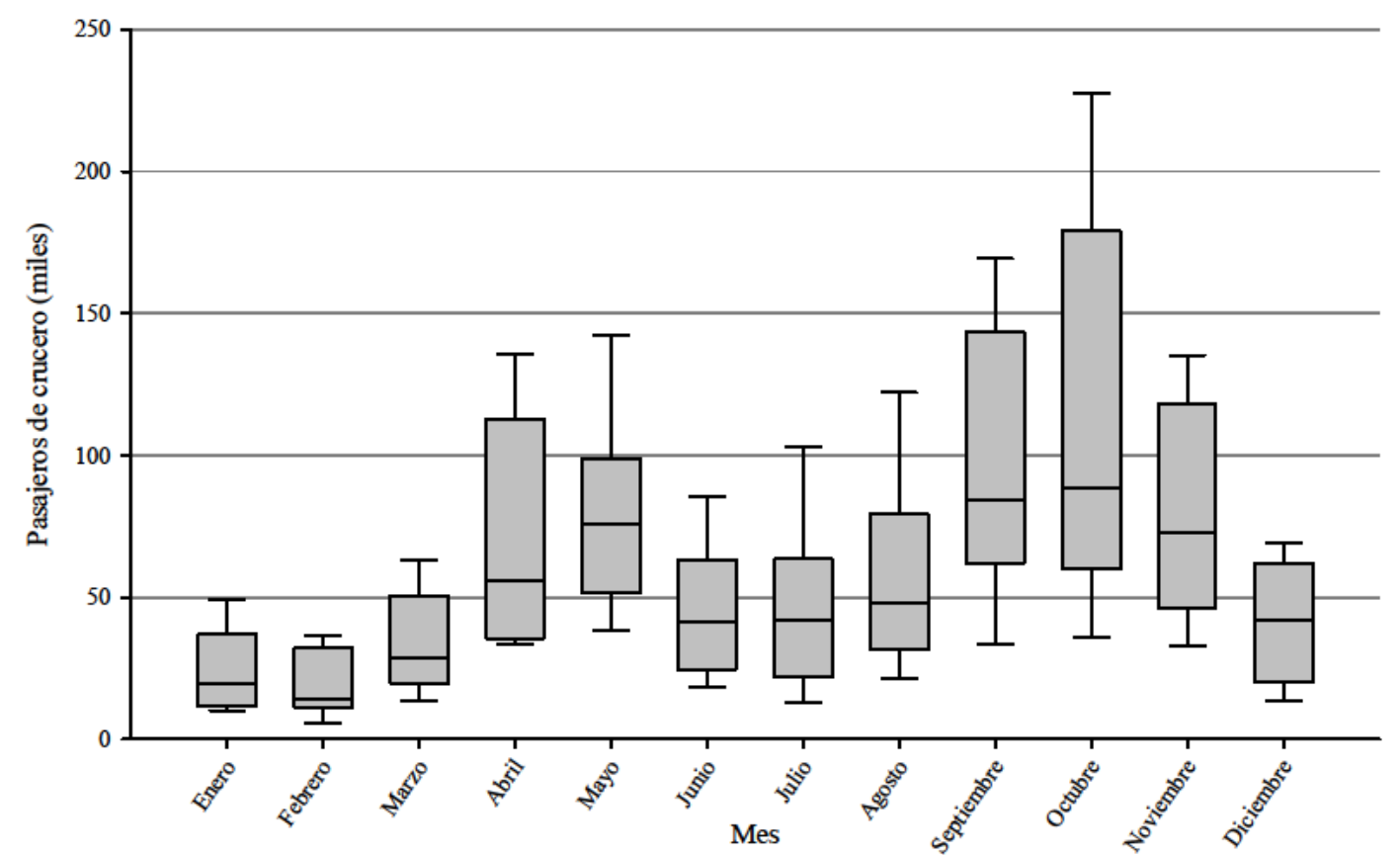

Gráfico 4.11: Representación gráfica de la cifra de pasajeros de crucero mensual acumulada entre el año 2000 y 2013 para los puertos con dos máximos.

Fuente: Elaboración propia. 
De forma análoga al sub-grupo anterior, se han calculado los IVE para tres puertos, en este caso, Cádiz, Cartagena y Málaga y representado gráficamente frente al perfil obtenido en el apartado 4.2.2 para el conjunto de puertos de la costa mediterránea y atlántica andaluza. Los Gráficos 4.12 a 4.14 muestran los resultados obtenidos. La temporada alta en estos tres puertos está subdividida en dos intervalos, abril-mayo y agosto-noviembre, en los cuales se superan la cifra media anual de pasajeros de crucero. Atendiendo a lo anterior, en este sub-grupo el mes de noviembre constituye temporada alta, en oposición al sub-grupo anterior en que el mes de noviembre marcaba el inicio de la temporada baja, con cifras inferiores a la media anual. Por el contrario, hay un valle entre ambos intervalos correspondiente a los meses de junio y julio, en los que la cifra de pasajeros desciende a niveles inferiores a la media anual. Esta situación es opuesta al caso descrito anteriormente de los puertos con un solo máximo en la curva de IVE.

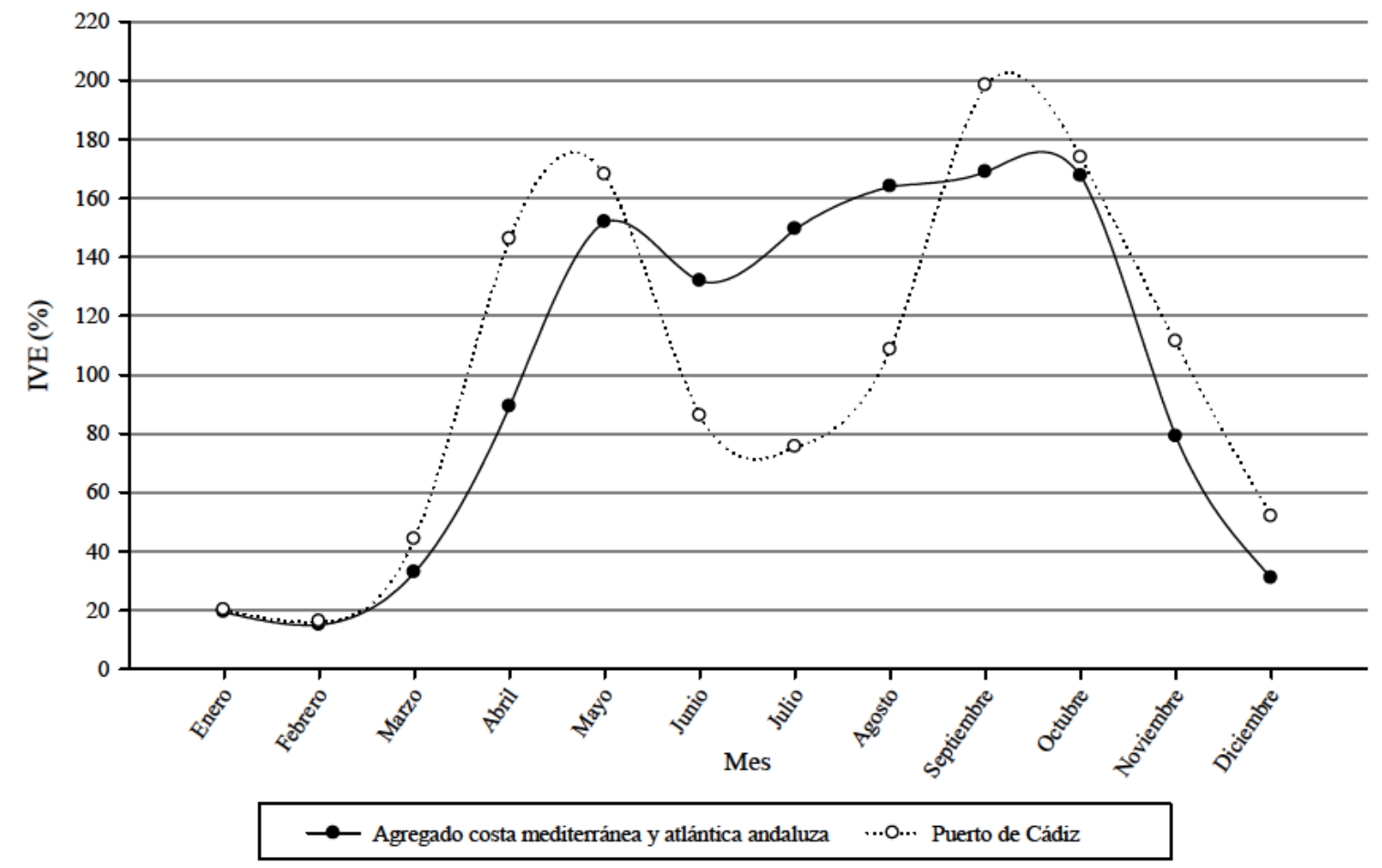

Gráfico 4.12: Comparativa entre las curvas de IVE para el conjunto de puertos de la costa mediterránea y el puerto de Cádiz.

Fuente: Elaboración propia. 


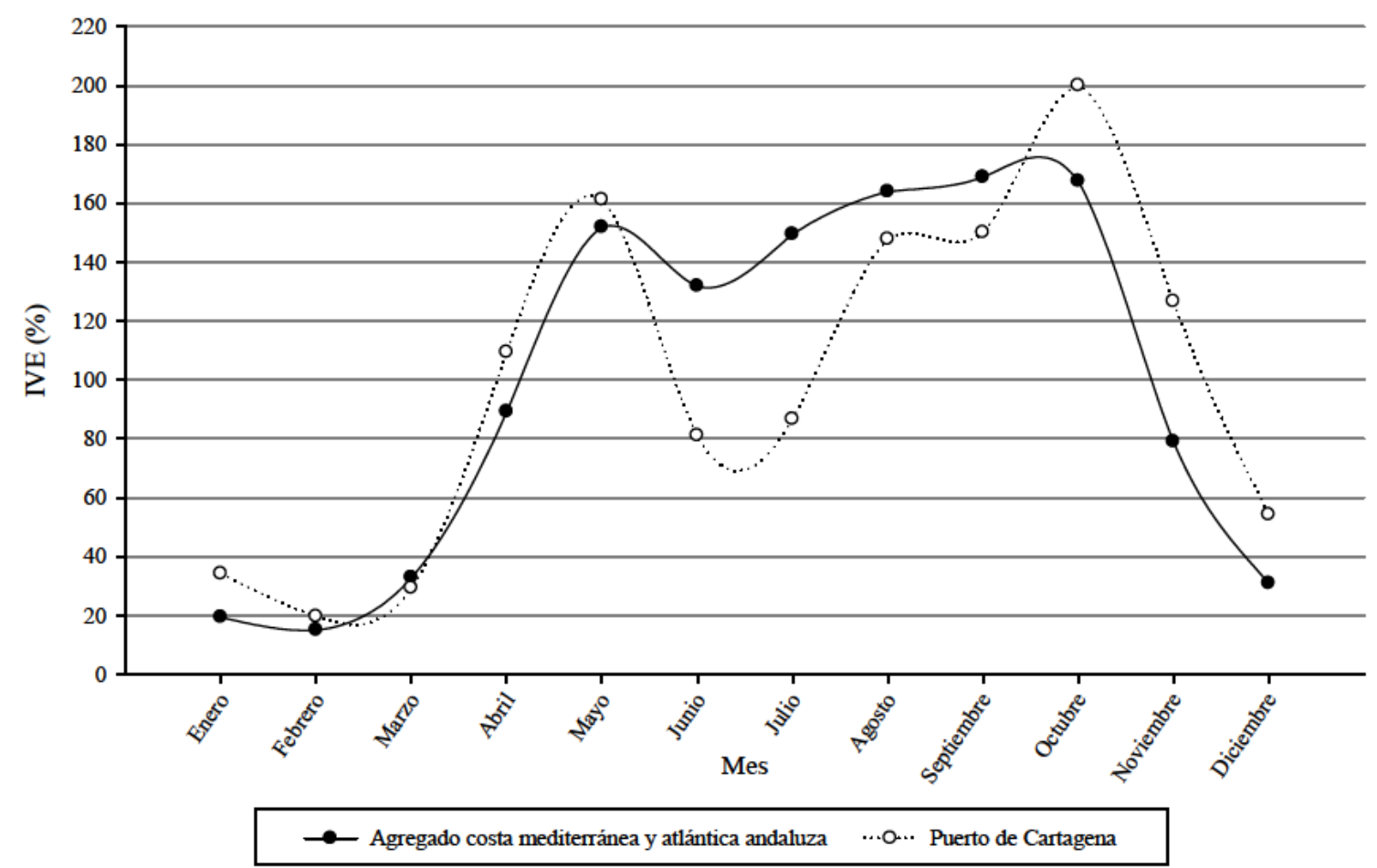

Gráfico 4.13: Comparativa entre las curvas de IVE para el conjunto de puertos de la costa mediterránea y el puerto de Cartagena.

Fuente: Elaboración propia.

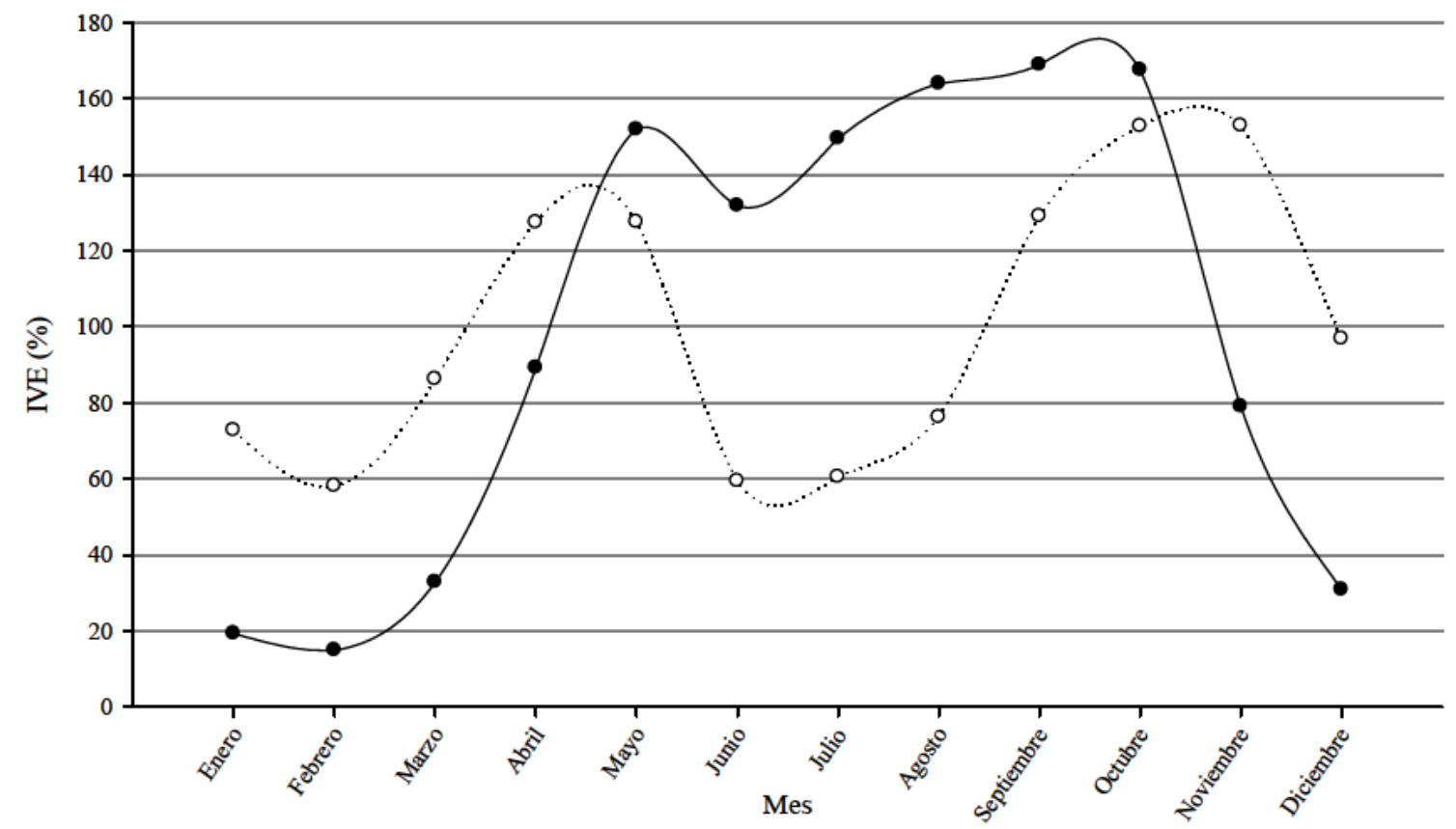

Agregado costa mediterránea y atlántica andaluza $\quad \cdots 0 \cdots$ Puerto de Málaga

Gráfico 4.14: Comparativa entre las curvas de IVE para el conjunto de puertos de la costa mediterránea y el puerto de Málaga.

Fuente: Elaboración propia. 
Tras analizar ambos sub-grupos de puertos integrando su posición geográfica en la costa mediterránea española y atlántica andaluza, y por extensión en el sector del Mediterráneo Occidental, se puede establecer una barrera geográfica imaginaría al sur de las islas Baleares que separa los dos grupos. Los puertos con dos máximos en los registros mensuales de pasajeros de crucero están situados al sur de las islas Baleares. Mientras que los puertos con un sólo máximo están situados al norte, en el cuadrante noroeste del Mediterráneo Occidental. La explicación de estos patrones de funcionamiento parece estar asociada con la rotación de los buques de crucero entre regiones de destino. En concreto, con el inicio de la temporada alta en el Mediterráneo se posicionan buques procedentes principalmente del Caribe y en menor medida de otros destinos de invierno como Sudamérica y Emiratos Árabes. Un porcentaje de estos buques permanecen en el sector del Mediterráneo Occidental más próximo al estrecho de Gibraltar, para realizar una segunda rotación rumbo al mar del Norte y el Báltico, con el inicio de su temporada alta hacia mediados de mayo. En este destino permanecerán hasta el final de la temporada alta en septiembre para reposicionarse de nuevo en el Mediterráneo, donde permanecerán hasta finales de octubre, momento en el cual realizarán una nueva rotación hacia las rutas de crucero de invierno (en el hemisferio norte). Esta operativa explica parcialmente la singularidad de los dos máximos registrados en los puertos situados al sur de las islas Baleares, pues son los más próximos al estrecho de Gibraltar y por tanto, los que menor desplazamiento suponen en el viaje de reposicionamiento hacia los destinos del Norte de Europa.

Este patrón de estacionalidad lleva asociada la generación de una capacidad ociosa en las instalaciones para cruceros, debido a las diferencias de distribución mensual de la cifra de pasajeros de crucero. El índice de ocupación de un muelle para cruceros, resulta de interés para los operadores portuarios, debido a que, cuando un puerto decide invertir en instalaciones para tráfico de cruceros se enfrenta a diversos dilemas. En este sentido, pueden darse incompatibilidades entre los tráficos de carga y cruceros en una misma dársena. Además, los muelles para cruceros requieren de un elevado número de instalaciones que comprenden, entre otros, terminal de pasajeros con las infraestructuras adecuadas para dar servicio al pasaje, accesos a la terminal y capacidad logística de la terminal para atender las necesidades del buque, tal y como se ha descrito en el apartado 3.2.1 del Capítulo III. Estos requisitos quedan todavía más patentes con la flota actual de mega-buques de crucero, con operaciones logísticas complejas, derivadas de su gran tamaño y elevada capacidad de pasajeros. Por lo que, las inversiones necesarias son cuantiosas con el consiguiente riesgo de que, una vez construidas, el itinerario deje de ser rentable y el buque no haga escala en ese puerto.

Durante las épocas del año de menor actividad en el tráfico de cruceros, la utilización de las infraestructuras portuarias está, consecuentemente con lo visto en este apartado, muy por debajo de la actividad que permite la capacidad instalada. Los reducidos índices de ocupación durante estos meses de temporada baja, afectan negativamente a la cuenta de resultados del puerto e implican la existencia de una capacidad ociosa instalada, por otra parte, no fácilmente utilizable para otras actividades portuarias si no se ha previsto con 
anterioridad. Con objeto de reducir los efectos perniciosos de la reducida ocupación de infraestructuras y personal, durante la temporada baja de los cruceros, en la literatura especializada se pueden encontrar algunas proposiciones. En primer lugar, parece relevante lograr asociaciones público-privadas en la gestión y explotación de las terminales para cruceros, ya que incrementará el número de escalas y pasajeros en el puerto (Esteve-Pérez y García-Sánchez, 2014). Estas asociaciones se formalizan con operadores portuarios privados que actúan como inversores, disminuyendo el riesgo de la inversión para el sector público. Las propias navieras de cruceros también están actuando, en ocasiones, como operadores de terminal, continuando con el proceso de integración vertical en las operaciones portuarias. Con esta medida se busca repartir el riesgo de la inversión en instalaciones portuarias para cruceros y/o, según el caso, un compromiso por parte de la naviera de garantizar un número mínimo de escalas durante un periodo de tiempo. Otra medida para combatir los efectos perniciosos de la estacionalidad, reside en dar un uso dual a la terminal de pasajeros. Por un lado, que el edificio de la terminal albergue otras actividades compatibles con el tránsito de pasajeros, como por ejemplo, oficinas, restaurantes o centro de negocios. Finalmente, darle un uso alternativo aquellos días en los que no se registran escalas de buques, tales como celebración de congresos u otros eventos en los días en que no se registra actividad crucerística (Billows, 2013). 


\section{Capítulo V. Conclusiones y futuras líneas de investigación}

\subsection{Conclusiones}

La desaparición de las líneas transoceánicas de transporte marítimo de pasajeros, a finales de la década de 1960 y comienzos de la de 1970, como consecuencia de la mayor eficiencia del transporte aéreo de pasajeros para largas distancias, dio lugar a un nuevo tráfico marítimo y producto turístico, el turismo de cruceros. La nueva concepción del tráfico de cruceros incluía únicamente pasajeros que viajaban por motivos de ocio y en buques específicamente diseñados para tal fin. Visión que difería de la original, asociada al siglo XIX y hasta mediados del XX, en la cual los cruceros de la época se desarrollaban en los buques que cubrían líneas transoceánicas, fundamentalmente, entre ambas orillas del océano Atlántico, y con coexistencia de pasajeros en régimen de transporte puro y por motivos de ocio (cruceristas).

En un crucero se combinan satisfactoriamente conjuntos de destinos en tierra y ciudades portuarias, junto con diversos servicios a bordo del buque, dando lugar a dos componentes de ocio, la marítima y la terrestre. La conjunción de estos aspectos da lugar al elemento central de la industria de cruceros, el itinerario. El tráfico de cruceros ha registrado un notable auge a nivel mundial en las dos últimas décadas, con una tasa de crecimiento media anual desde 1990 a 2013 del 7,84\%, medido por el número de pasajeros de crucero a nivel mundial. Además, las previsiones indican que este auge persistirá, aunque de forma más paulatina, con un crecimiento medio anual hasta 2018 , del 2,85\%. Sin embargo, se trata todavía de un segmento muy reducido dentro del turismo.

La industria de cruceros se caracteriza por una fuerte concentración en los complejos eslabones que conforman el producto crucero. Fundamentalmente, la concentración se hace patente en tres niveles: las regiones de destino de los cruceros, y dentro de éstas, en la red de puertos de crucero; los proveedores del producto (navieras de crucero) y en los mercados mundiales emisores de pasajeros de crucero.

Las regiones de destino de cruceros presentan una fuerte concentración global, pues seis regiones concentran el tráfico de cruceros mundial. Además, entre estas seis existe una concentración heterogénea, ya que las dos primeras regiones, Caribe y Mediterráneo acumularon en 2013 más de la mitad de la capacidad mundial desplegada. El destino de cruceros por antonomasia es el Caribe, con una cuota en 2013 del 34,4\%. Destino en el que se desarrolló el concepto de Fun Ship dando lugar a la concepción actual de resort marino que tienen los buques de crucero. Además, se trata de un destino anual con temporada baja en verano del hemisferio norte.

Europa cuenta con dos regiones de cruceros, Mediterráneo y Norte de Europa. El Mediterráneo, con una cuota en la capacidad mundial desplegada del 21,7\% en el año 2013, 
ha registrado un notable dinamismo durante la década del año 2000, con un crecimiento medio anual del $12,33 \%$, muy superior al crecimiento de la cifra de pasajeros de crucero a nivel mundial. También se trata de una región de cruceros anual, con temporada alta en verano, concentrando en los meses de mayo a octubre el grueso de pasajeros. De los cuatro sectores en que se divide la región del Mediterráneo, el sector Occidental registra la mayor actividad de cruceros, con una concentración en 2013 de aproximadamente el 70\% de los pasajeros y escalas de buques de crucero de toda la región. Por países, las dos principales potencias receptoras de cruceristas tanto en el Mediterráneo como en Europa son, Italia y España, respectivamente.

La segunda región de cruceros europea, el Norte de Europa, muestra un comportamiento de temporada con respecto al Mediterráneo, ya que los cruceros se concentran de mediados de mayo a septiembre. Esta región también ha registrado un crecimiento superior a la media mundial entre el año 2000 y 2010.

Además, las regiones de crucero ya sean anuales o de temporada pueden ser complementarias entre sí, pues con objeto de maximizar los índices de ocupación de los buques, las navieras reposicionan sus buques de una región de crucero a otra, haciéndolos coincidir con la temporada alta en cada una de ellas. Estos viajes de rotación entre rutas dan lugar a los cruceros de reposicionamiento, ofertados también a los cruceristas como viajes de crucero. El ejemplo más representativo de la complementariedad entre rutas, lo representan el Caribe y el Mediterráneo, con temporadas altas contrapuestas, invierno y verano del hemisferio norte, respectivamente.

La concentración que caracteriza a la industria de cruceros también alude a los mercados emisores de pasajeros de crucero a nivel mundial. Dos mercados, Norteamérica y Europa, concentraron más del 90\% de la emisión de cruceristas entre 1990 y 2013. Entre estos dos, prevalece el mercado norteamericano con una cuota del 69,3\% durante ese periodo. Sin embargo, el crecimiento del 10,4\% registrado por el mercado europeo durante este periodo duplicó al del mercado norteamericano, superando además el crecimiento medio mundial de la cifra de pasajeros de crucero.

Focalizando la atención en el mercado europeo, también se registra una notable concentración, pues las dos potencias europeas emisoras de pasajeros de crucero, Reino Unido y Alemania, representaron más de la mitad de este mercado entre el año 2000 y 2013. Además, los dos principales países receptores de cruceristas en el continente europeo, se erigieron también con un papel relevante en la emisión de cruceristas, ya que Italia y España fueron el tercer y cuarto país emisor en este mercado, respectivamente. Sin embargo, la crisis económica registrada desde el año 2008 ha afectado considerablemente a tres de los cuatro países mencionados. El clima económico adverso ha ralentizado el crecimiento en Reino Unido, y en Italia y España ha generado un descenso en su mercado emisor. El efecto dañino de la coyuntura económica ha afectado en mayor medida al mercado emisor español, consecuentemente en el año 2013 perdió la cuarta posición como país emisor europeo en favor de Francia. En contraposición a esta situación, el mercado alemán ha registrado un 
crecimiento medio anual durante el periodo de 2000 a 2013 del 12,50\%, reduciendo su diferencia respecto al mercado de Reino Unido y se postula en los próximos años a superarlo, convirtiéndose así en la primera potencia europea emisora de pasajeros de crucero.

La configuración de un itinerario de cruceros comprende a tres actores clave: la naviera de cruceros, los puertos y el destino de cruceros o hinterland turístico de cada puerto. El sector de navieras de crucero presenta concentración horizontal, estructurado en tres grupos multi-marca, más un cuarto grupo de navieras independientes. El denominado grupo de Las Tres Grandes concentraba a octubre de 2014 más de las tres cuartas partes de la capacidad de pasajeros. Además, el primer operador mundial, Carnival Corporation acapara casi la mitad de la capacidad mundial, lo que le supone una amplia ventaja respecto a su inmediato perseguidor, el grupo Royal Caribbean Cruises Limited. Esta situación da lugar a un mercado oligopólico. La concentración horizontal es fruto de las fusiones y estrategias de internacionalización registradas en los últimos años, como por ejemplo, la adquisición por parte de compañías norteamericanas de navieras especializadas en determinados mercados europeos, con objeto de ampliar su ámbito de operación.

La flota de buques de crucero muestra un reducido tamaño respecto a otros segmentos de transporte marítimo con un total de 267 buques. Además, el buque de crucero tiene un carácter dual, alojativo y de transporte. Esta flota se divide en cuatro tamaños siendo los más numerosos los buques de crucero de gran tamaño y los mega-buques de crucero. Este último tamaño de buque es fruto de la estrategia de las navieras por aprovechar las economías de escala, asociadas al incremento de capacidad de los buques, lo cual ha permitido, de paso, que el producto crucero sea más accesible a amplios estratos de renta en los países.

El análisis de la flota de cada una de las navieras que integran Las Tres Grandes deja patente un patrón de transferencia de buques entre navieras del mismo grupo. Esta transferencia se produce, bien bajo la fórmula de fletamento por tiempo o bien, mediante adquisición de la propiedad. Además, los perfiles de edad media de la flota en las navieras principales de cada grupo, por lo general, son bajos, transfiriendo para ello los buques de mayor edad a otras navieras de la misma corporación empresarial. Normalmente, la naviera receptora del buque con mayor número de años de navegación tiene un público objetivo distinto, que requiere precios inferiores. También se ha observado que los movimientos de buques de una naviera a otra, se hacen coincidir con la incorporación de un buque de nueva construcción en una de las navieras mayoritarias. Junto a lo anterior, sobre todo Carnival Corporation y Royal Caribbean Cruises Limited aglutinan navieras de varios segmentos, en la mayor parte dedicadas al segmento contemporary y en menor medida, al segmento premium y lujo, respectivamente.

En el grupo de navieras independientes hay un amalgama tanto en tamaños y público objetivo. Por un lado, las dos navieras de mayor tamaño en este grupo tienen la flota más moderna, además de concentrar un elevado porcentaje de las nuevas construcciones a adicionar a este grupo. Por otro lado, una gran parte de las navieras que integran este grupo disponen de una flota reducida compuesta por dos o tres buques, o incluso un solo buque, y 
normalmente de avanzada edad. Finalmente, en este grupo también se integran varias navieras de lujo, caracterizadas por tener una flota con buques sofisticados de pequeño tamaño y baja capacidad de pasajeros, con elevado estándar de atención al crucerista.

De forma global, el mercado de navieras de crucero se puede dividir en tres segmentos por tamaño de la naviera. El segmento superior, capacidad superior a 50.000 pasajeros, lo conforman Carnival y Royal Caribbean, cuyos tamaños marcan una notable diferencia respecto al siguiente segmento, el central. En el segmento central se sitúan las navieras con una capacidad de entre 10.000 y 50.000 pasajeros. Este segmento está colonizado por navieras que pertenecen a Las Tres Grandes a excepción de dos, Disney Cruise Line y MSC Cruises. El mayor número de navieras se da en el segmento inferior, capacidad menor a 10.000 pasajeros. En éste coexisten navieras independientes y alguna de las pertenecientes a Las Tres Grandes, fruto de las estrategias de adquisiciones y fusiones que han imperado en este mercado en los últimos años.

La concentración de Las Tres Grandes no sólo se registra en la flota actual de buques de crucero, sino que se observa también, en la cartera de pedidos de buques de crucero hasta el año 2019. Del total de 30 buques que forman la cartera de pedidos actualmente, 19 pertenecen a este conjunto de tres corporaciones empresariales, lo que supone el $71,1 \%$ de la capacidad que entrará en servicio hasta 2019, manteniéndose previsiblemente el oligopolio actual. Asimismo, MSC Cruises con su política de nuevas incorporaciones también se garantiza su papel como naviera independiente de mayor tamaño, pues el 17,9\% de la capacidad a incorporar hasta 2019 lleva su consigna.

En este mismo sentido y en relación con la industria que provee de nuevos buques a las navieras de cruceros, la construcción naval, también existe una fuerte concentración en este sector. La concentración se registra tanto a nivel empresarial como geográfico. Más de tres cuartas partes de los buques en activo actualmente, han sido construidos en las gradas de tres astilleros europeos. Transponiendo esta situación a la actual cartera de pedidos, más del $90 \%$ serán también construidos en estos tres astilleros, cuyas factorías están emplazadas en Alemania, Finlandia, Francia e Italia.

La componente terrestre del producto crucero alude a dos áreas, el puerto y el hinterland turístico. Los puertos constituyen el enlace entre los mercados emisores, la componente turística que se desarrolla en tierra y el buque. Según la función que desarrollen da lugar a los dos tipos de puertos de crucero. Puerto base, que actúa como plataforma de acceso al buque desde los mercados emisores; y puertos de escala, los cuales juegan un papel fundamental en la consecución del transporte marítimo, conectando el buque con los atractivos turísticos terrestres, una vez iniciado el itinerario. Además, ambos tipos de puertos actúan como lugares de consolidación y dispersión de los pasajeros de crucero, tanto desde los mercados emisores como en cada escala, en concreto, al inicio y final de la misma.

El atractivo de un puerto de crucero guarda relación con dos aspectos, las características de emplazamiento y de situación. Las primeras se asocian con infraestructuras 
del puerto y en la ciudad portuaria, mientras que las segundas aluden al atractivo turístico de la región de influencia del puerto, el hinterland turístico y la proximidad a los mercados emisores. Por lo que, en el caso concreto de un puerto de escala, guarda relación con tres ejes espaciales, el propio recinto portuario, la ciudad portuaria y el hinterland turístico. Además, los puertos de crucero se necesitan entre sí en una relación de beneficio mutuo. Ningún puerto aislado captará tráfico de cruceros si no se encuentra integrado en una región de cruceros, aun contando con excelentes instalaciones portuarias y atractivos turísticos. Relacionado también con este aspecto, hay que tomar en consideración el equilibrio de tiempos en la mar y en puerto, en la configuración de un itinerario con objeto de aumentar la satisfacción del pasaje y la rentabilidad del itinerario para la naviera.

Los puertos tienen que cumplir con una serie de requisitos de infraestructura, superestructuras y servicios al buque y al pasaje. Además, el incremento del tamaño de los buques implica que las instalaciones portuarias tienen que adaptarse para poder dar servicio a mega-buques de crucero de forma eficiente. De ahí que las navieras de crucero estén solicitando constantemente mejoras en las instalaciones portuarias, con objeto de acometer las complejas operaciones logísticas con grandes cantidades de pasajeros de crucero de forma rápida y segura.

Tradicionalmente, las navieras invertían en la construcción de buques y los puertos en la construcción y explotación de terminales para cruceros. En los últimos años se ha registrado un cambio de tendencia con la intervención de operadores portuarios privados en la gestión y explotación de terminales para cruceros en régimen de concesión, compartiendo así los riesgos de la inversión. Esta tendencia llega incluso a implicar a navieras de crucero como operadores portuarios, reflejando el proceso de integración vertical a nivel de operaciones portuarias por parte de éstas. Las navieras de cruceros tienen así un enorme poder de mercado, no sólo por la concentración existente en el mercado de navieras, sino también, por la integración de operaciones portuarias, aglutinando de esta forma un mayor número de los eslabones que conforman el producto crucero. Esta vinculación en la explotación de la terminal puede llevar aparejada el compromiso, por parte de la naviera, de garantizar al puerto un número mínimo de escalas durante un periodo de tiempo, aunque siempre hay que tener presente el carácter global de la industria de cruceros, y la capacidad de los buques para abandonar una zona de operación y posicionarse en otra con mejores resultados de explotación.

La concentración expresada anteriormente en algunos eslabones de la cadena que conforman el producto crucero, también se hace patente en cierta medida a nivel portuario. El sistema global de puertos de crucero muestra una alta tasa de concentración geográfica, con disparidad entre el número de puertos base y de escala, siendo notablemente más numeroso el segundo tipo. En el caso del Mediterráneo, diez puertos base concentraron casi el $90 \%$ de los pasajeros de inicio y fin de itinerario en 2013, acumulando los tres primeros más de la mitad de los itinerarios comenzados en esta región. 
El Sistema Portuario Español también ha registrado el dinamismo de la industria de los cruceros, con un crecimiento medio anual del tráfico de cruceros entre 1994 y 2013 que prácticamente duplica a la tasa registrada a nivel mundial. Del total de 46 puertos de Interés General en la costa española, en la actualidad 33 registran tráfico de cruceros distribuidos por todo el litoral español. Sin embargo, la concentración de este tráfico es dispar entre las tres zonas costeras españolas. La costa mediterránea y atlántica andaluza ha concentrado durante el periodo del año 1994 a 2013 la mayor actividad crucerística, con las tres cuartas partes de los cruceristas en puertos españoles, le sigue el archipiélago canario con el $20 \%$ y en tercer lugar la costa atlántica gallega y del mar Cantábrico con el 5\%. Además, en las tres zonas el incremento registrado durante este periodo es superior al 10\%, tasa que supera el crecimiento medio mundial.

La inercia positiva del tráfico de cruceros en puertos españoles, también se ha visto reflejada como puertos base. En otros términos, durante este periodo, del total de cruceristas registrados en puertos españoles, un tercio de éstos tenían como inicio y/o fin de su itinerario un puerto español. España dispone de puertos base en sus tres zonas litorales.

La concentración mencionada anteriormente en el sistema global de puertos de crucero también queda patente en España. Los puertos de las tres zonas litorales españolas se dividen en su amplia mayoría en las posiciones de líder maduro y elevado potencial. Con carácter general, los puertos que se erigen con la posición de líder maduro son must see port en cada zona en concreto y han crecido en el mismo orden de magnitud que lo ha hecho el conjunto de puertos españoles. Los puertos con elevado potencial han alcanzado crecimientos notablemente superiores a la media del Sistema Portuario Español. Sin embargo, en gran parte de los casos la cuota de mercado registrada por estos puertos de elevado potencial es muy reducida. Siguiendo en el ámbito de posiciones competitivas, la necesaria dependencia inter-portuaria en un rango de distancia determinado para configurar itinerarios, impide que un puerto pueda crecer de forma muy superior a sus inmediatos vecinos, concentrando además gran cuota de mercado.

Centrando la atención en las instalaciones y servicios para buques de crucero en los puertos de crucero de la costa mediterránea y atlántica andaluza. Casi todos los puertos pueden simultanear escalas de buques de crucero y además, exceptuando el puerto de Sevilla, no existe restricción en calado para el atraque de buques de crucero. Finalmente, todos ellos cuentan de forma permanente con los servicios requeridos por los buques para tener acceso al puesto de atraque en condiciones de seguridad. En este sentido, la tendencia registrada a nivel global de intervención del sector privado en la gestión y explotación de las terminales de crucero también tiene reflejo en España con las terminales de cinco puertos gestionadas total o parcialmente por operadores portuarios privados. En esta actividad están participando incluso navieras de crucero, como en el caso del puerto de Barcelona con Costa Cruises. Además, esta tendencia sigue en auge, pues una nueva terminal en Barcelona será explotada y gestionada por Carnival, y en el puerto de Cádiz la reciente concesión de explotación de su terminal de pasajeros a un operador privado, lleva aparejada la construcción de una nueva terminal también con gestión privada. 
Revisando con mayor profundidad el análisis del tráfico de cruceros en la costa mediterránea española y atlántica andaluza, se confirma que la cifra de cruceristas ha presentado una distribución estacional a lo largo del año durante el periodo del año 2000 a 2013. La temporada alta comprende los meses de mayo a octubre, mientras que los meses de enero y febrero han sido los de menor actividad crucerística. En cuanto a la evolución de la estacionalidad, durante el periodo de gran crecimiento del tráfico de cruceros, ésta se ha reducido. Esta disminución de la estacionalidad está asociada a un mayor incremento de la cifra de pasajeros en los meses de temporada baja.

El análisis de estacionalidad por puertos para la misma zona litoral permite obtener dos tipos de estacionalidad diferente con un perfil de uno y dos máximos anuales, respectivamente. En este perfil parece desempeñar un papel fundamental la posición geográfica del puerto, respecto a la rotación con las rutas de crucero del Norte de Europa, dando lugar a un perfil de dos máximos, aquellos puertos más cercanos al estrecho de Gibraltar. Este patrón de comportamiento pone nuevamente de relieve la complementariedad entre regiones de destino. En este caso en concreto, la rotación es tripartita, pues los buques hacen una rotación de su zona de operación en invierno a su zona de operación en verano, Caribe-Mediterráneo, pero ésta a su vez se divide parcialmente en dos zonas distintas, Mediterráneo Occidental-Norte de Europa.

La segunda componente terrestre de un crucero, y la de mayor importancia, es el hinterland turístico. Ésta tiene un carácter dual según se trate de un puerto base o un puerto de escala. En el primer caso alude a los mercados emisores de pasajeros, a día de hoy y dado el mercado global en el que se capta a los cruceristas, un puerto puede servir a mercados situados a miles de kilómetros. En el segundo caso, comprende el área geográfica disponible para ser visitada durante el tiempo de cada escala (excursiones). Este ámbito está relacionado directamente con las experiencias turísticas que se desarrollan durante el itinerario y que tienen un papel clave en el atractivo de éste. Esta cuestión pone de nuevo de relieve la interdependencia entre puertos para poder configurar un itinerario de crucero, pues un puerto base necesita un foreland, en este caso puertos de escala, en el que distribuir el tráfico de cruceros que en él se inicia/finaliza.

Además, hay que tener presente que en ambos tipos de puertos la delimitación del hinterland tiene un carácter dinámico, asociado, según el caso, con la creación de nuevos mercados emisores, el incremento de infraestructuras y medios de transporte, la adición de atractivos turísticos y la duración de la escala. En relación con este concepto, la ampliación del hinterland permite una explotación más sostenible de los recursos turísticos, evitando congestiones en hinterlands de pequeño tamaño y gran afluencia de cruceristas. Situación que actualmente registra Dubrovnik, pues todas las escalas de su puerto centran la atención en esta ciudad, dando lugar a fuertes congestiones en los días de temporada alta. La congestión ha llegado hasta tal punto que la limitación de escalas no alude a parámetros portuarios sino al límite impuesto por las autoridades locales, para evitar aglomeraciones de 
cruceristas en la ciudad. También, la ampliación del hinterland trae consigo el efecto positivo de incidir económicamente sobre un área geográfica mayor.

El hinterland turístico de un puerto no siempre tiene un carácter exclusivo, sino que una parte o en su totalidad puede ser compartido por dos o más puertos, dando lugar a hinterlands primarios y competitivos, respectivamente. El marco teórico planteado anteriormente ha permitido delimitar el hinterland turístico de los puertos de crucero de la costa mediterránea española y atlántica andaluza. En primera instancia, este conjunto de puertos dispone de un nutrido hinterland turístico que engloba una extensa área, su delimitación, también ha puesto de relieve la existencia de hinterlands primarios $\mathrm{y}$ competitivos en los puertos de crucero de esta zona litoral.

Además, la integración del concepto hinterland turístico a la infraestructura portuaria, da como resultado una clasificación de cinco tipos de puertos, según el papel que desarrolla éste en el flujo turístico entre ambas componentes terrestres. Las posiciones extremas de la clasificación bajo este criterio, aluden a puertos cuya ciudad portuaria capta toda la atención de los cruceristas que a él arriban (puerto black hole) y puertos que únicamente actúan como enlace con los destinos turísticos situados fuera de la ciudad portuaria (puerto gateway). También se dan posiciones intermedias con mayor o menor equilibrio hacia un sentido u otro o con equilibrio total (puerto balanced), en el que los cruceristas se reparten equitativamente entre la ciudad portuaria y el hinterland turístico. Derivado de la delimitación del hinterland también se han identificado los cinco tipos de puertos entre los situados en la costa mediterránea española y atlántica andaluza.

El dinamismo actual del sector de los cruceros implica notables desafíos futuros para los agentes involucrados en esta industria, de ahí que se haya decidido proponer un modelo con el fin de valorar las variables relevantes en la selección de un puerto de cruceros. Los resultados del modelo propuesto indican que hinterlands turísticos atractivos y mejores infraestructuras portuarias conllevan un incremento de la cifra de pasajeros de crucero. El atractivo del hinterland turístico y la competitividad portuaria están asociados con ambos tipos de hinterlands, primarios y competitivos. Si el puerto únicamente tiene hinterland primario, entonces éste tiene el monopolio en las excursiones ofertadas hacia el hinterland. Cuando dos o más puertos comparten el mismo hinterland, o al menos una parte del mismo hinterland, hay un incremento de la competencia en el flujo de pasajeros de crucero desde los puertos al hinterland. Además, de acuerdo con los resultados obtenidos del modelo, la participación de un operador privado de terminal portuaria implica una mayor cifra de pasajeros de crucero. Sin embargo, los costes portuarios no explican la cifra de pasajeros que llega a un puerto, a pesar de que parte de la literatura argumenta lo contrario. Esto puede estar motivado porque los ingresos por excursiones juegan un papel relevante en cada puerto de escala. Desafortunadamente, se trata de información que no está disponible actualmente. Adicionalmente, el modelo no asigna un papel significativo al atractivo de la ciudad portuaria, lo cual puede ser resultado de las limitaciones estadísticas a nivel de ciudad. Análogamente, cuando el hinterland turístico no es atractivo, el atractivo de la ciudad portuaria puede no ser el elemento central en la explicación de las escalas de buques de 
crucero en un puerto dado. En este caso, en la elección de un puerto para un itinerario, su distancia a los must see ports parece más relevante, permitiendo así un equilibrio entre el tiempo de navegación y los tiempos en puerto.

En relación con las recomendaciones para las regiones de destino involucradas en el negocio de los cruceros, hay tres elementos a los que prestar especial atención, ya que éstos resultan en una mayor cifra de pasajeros de crucero a registrar en el puerto. Estos elementos incluyen infraestructura portuaria disponible en la ciudad portuaria, el tipo de gestión de esta infraestructura y el atractivo del hinterland para los turistas. Existe claramente una necesidad de adecuadas infraestructuras portuarias que puedan albergar buques de crucero y satisfacer sus necesidades. La existencia de economías de escala en la industria de cruceros, confirmada por el incremento en el tamaño de los buques que se han puesto en servicio en los últimos años, implica la necesidad de adaptar las instalaciones portuarias a estos buques. Dado que la gestión privada de las terminales redunda en una mayor cifra de pasajeros de crucero, se sugiere el estudio o análisis de colaboraciones público-privadas en la gestión de las terminales de cruceros. No hay duda del atractivo del hinterland turístico como parte de la experiencia turística en un crucero. Ya que un hinterland turístico más atractivo parece explicar un mayor número de pasajeros de crucero, los gestores de los destinos turísticos deben promocionar los atractivos que se pueden visitar durante la escala en los mercados emisores pues potencialmente resultará en una mayor inclusión del puerto en un itinerario.

\subsection{Futuras líneas de investigación}

La elaboración de la presente tesis deja abiertos diversos frentes de acción de carácter espacial, económico y de capacidad de la industria de cruceros. En primera instancia, asociado a la configuración de un itinerario, resulta de interés realizar una modelización espacial de la toma de decisiones de inclusión de un puerto en un itinerario, con objeto de cuantificar la influencia espacial inter-portuaria y los límites de estancia en la mar desde el punto de vista de los intereses de los agentes implicados en la industria de cruceros. Los resultados de este análisis de econometría espacial pueden condicionar la readaptación de la matriz de Boston Consulting Group, para su aplicación al tráfico de cruceros derivado de la dependencia espacial entre puertos.

La identificación de las variables económicas determinantes, desde el punto de vista de una naviera, para incluir un puerto en un itinerario constituye la siguiente línea de acción futura. Esta acción permitiría obtener una cuantificación económica de la decisión de seleccionar un puerto para un itinerario de crucero y por extensión su influencia en el resultado económico de cada itinerario. Uno de los principales obstáculos de esta futura línea de investigación radica en la accesibilidad de los datos.

El análisis realizado en este trabajo representa una primera aproximación a la explicación de las variables influyentes en la selección de un puerto para un itinerario. En este sentido, es posible establecer un nuevo ámbito de estudio por medio de una segmentación del análisis realizado. En concreto, consistiría en una segmentación por tipos 
de navieras, atendiendo a su segmento de mercado y mercado emisor objetivo, relacionado con las necesidades tanto de infraestructuras como de servicios en puerto. Con esta ampliación del análisis sería posible orientar a cada segmento en sus necesidades particulares. Esta futura línea de investigación puede ampliarse a su vez con la inclusión de la región de destino como determinante significativo de las necesidades en puerto.

Las líneas de acción futuras que se pueden acometer relacionadas con la capacidad de adaptación de la industria de cruceros a su demanda, aluden a dos aspectos. Por un lado, los mecanismos de planificación de aumentos de flota y capacidad desplegada por regiones, atendiendo a la evolución del grado de ocupación y el precio del pasaje. Este aspecto es de significativa relevancia teniendo en cuenta la rigidez que presentan los incrementos de capacidad, tanto por el tiempo necesario para el proyecto y construcción de un buque de crucero, como por las altas inversiones requeridas.

Por otro lado, también se propone la determinación de la capacidad ociosa de las instalaciones para cruceros de un puerto, asociado a su patrón de estacionalidad. Para ello es necesario calcular la capacidad máxima de cada una de las instalaciones para cruceros y cotejarla con la cifra real registrada, con objeto de cuantificar los efectos negativos de la estacionalidad en la explotación de terminales de crucero. Cada puerto está integrado por varios subsistemas interrelacionados que dan servicio a los buques y, para el caso concreto del tráfico de cruceros, también a los pasajeros. La capacidad de un puerto de cruceros será la menor de las capacidades de los distintos subsistemas que lo conforman, estos subsistemas aluden tanto al propio recinto portuario como a la ciudad portuaria y el hinterland turístico.

Finalmente, la anterior línea de investigación futura daría lugar a una adicional y de carácter económico. Ésta estaría relacionada con la determinación de la interdependencia económica entre los agentes terrestres con intereses en la industria de cruceros. Estos agentes aluden a tres zonas geográficas: puerto, ciudad portuaria e hinterland turístico. Concretamente, esta futura línea de investigación se basaría en el desarrollo de la interdependencia económica de estos tres agentes, asociada a compartir los riesgos de inversión para el desarrollo de infraestructuras y servicios destinados a la actividad de cruceros. 


\section{Anexo I. Características de las navieras de buques de crucero}

En el presente anexo se detallan las características de la flota de las navieras que componen cada corporación de Las Tres Grandes, así como, del grupo de navieras independientes. Junto a las características de la flota también se incluye información sobre las incorporaciones más recientes a la flota, el historial operativo de los buques que han sido operados por varias navieras e información sobre los destinos habituales de cada naviera.

\section{I.1 Grupo Carnival Corporation \& plc}

El grupo Carnival Corporation \& plc está integrado por diez navieras, tal y como se ha reflejado en el Capítulo III, apartado 3.1.1. Los siguientes sub-apartados detallan las características de cada una de las diez navieras pertenecientes a este grupo, su ordenación en el texto atiende a la relación de mayor a menor tamaño dentro del grupo.

\section{I.1.1 Carnival Cruise Line}

Carnival Cruise Line, fundada en 1972, es la compañía de cruceros más popular en Norte América, con sus oficinas centrales establecidas en Doral (Florida, EE.UU.). Además de ser una de las más innovadoras con el lanzamiento del concepto Fun Ship hace unos años. Su flota la componen un total de 24 buques, repartidos entre buques de gran tamaño y megabuques de crucero, véase Tabla I.1.

Tabla I.1: Flota de Carnival Cruise Line

\section{¿Carnival}

\begin{tabular}{lccccr} 
Nombre del Buque & $\begin{array}{c}\text { Capacidad de } \\
\text { Pasajeros }\end{array}$ & $\begin{array}{c}\text { Año de } \\
\text { construcción }\end{array}$ & $\begin{array}{c}\text { Eslora } \\
(\mathbf{m})\end{array}$ & $\begin{array}{c}\text { Manga } \\
(\mathbf{m})\end{array}$ & $\begin{array}{c}\text { Arqueo Bruto } \\
\text { (G.T.) }\end{array}$ \\
\hline Carnival Freedom & 2.974 & 2007 & 290,17 & 35,36 & 110.320 \\
Carnival Liberty & 2.978 & 2005 & 290,17 & 35,36 & 110.320 \\
Carnival Valor & 2.974 & 2004 & 290,17 & 35,36 & 110.239 \\
Carnival Glory & 2.974 & 2003 & 290,17 & 35,36 & 110.239 \\
Carnival Conquest & 2.974 & 2002 & 290,17 & 35,36 & 110.239 \\
Carnival Sunshine & 3.006 & 1996 & 272,19 & 35,36 & 102.853 \\
Carnival Breeze & 3.690 & 2012 & 306,02 & 37,19 & 130.000 \\
Carnival Magic & 3.690 & 2011 & 306,02 & 37,19 & 130.000 \\
Carnival Dream & 3.646 & 2009 & 306,02 & 37,19 & 130.000 \\
Carnival Elation & 2.052 & 1998 & 260,60 & 31,39 & 70.367 \\
Carnival Paradise & 2.052 & 1998 & 260,60 & 31,39 & 70.367 \\
Carnival Inspiration & 2.052 & 1996 & 260,60 & 31,39 & 70.367
\end{tabular}




\section{CCarnival}

\begin{tabular}{lccccr} 
Nombre del Buque & $\begin{array}{c}\text { Capacidad de } \\
\text { Pasajeros }\end{array}$ & $\begin{array}{c}\text { Año de } \\
\text { construcción }\end{array}$ & $\begin{array}{c}\text { Eslora } \\
(\mathbf{m})\end{array}$ & $\begin{array}{c}\text { Manga } \\
(\mathbf{m})\end{array}$ & $\begin{array}{c}\text { Arqueo Bruto } \\
\text { (G.T.) }\end{array}$ \\
\hline Carnival Imagination & 2.052 & 1995 & 260,60 & 31,39 & 70.367 \\
Carnival Fascination & 2.052 & 1994 & 260,60 & 31,39 & 70.367 \\
Carnival Sensation & 2.056 & 1993 & 261,82 & 31,39 & 70.367 \\
Carnival Ecstasy & 2.056 & 1991 & 261,82 & 31,39 & 70.367 \\
Carnival Fantasy & 2.056 & 1990 & 260,60 & 31,39 & 70.367 \\
Carnival Miracle & 2.124 & 2004 & 293,52 & 32,31 & 88.500 \\
Carnival Legend & 2.124 & 2002 & 293,52 & 32,31 & 88.500 \\
Carnival Pride & 2.124 & 2001 & 293,52 & 32,31 & 88.500 \\
Carnival Spirit & 2.124 & 2001 & 293,52 & 32,31 & 88.500 \\
Carnival Splendor & 3.006 & 2008 & 290,17 & 35,36 & 113.300 \\
Carnival Victory & 2.758 & 2000 & 272,19 & 35,36 & 101.509 \\
Carnival Triumph & 2.758 & 1999 & 272,19 & 35,36 & 101.509 \\
\hline
\end{tabular}

Fuente: Elaboración propia basada en datos de ECC (2013), Carnival Corporation (2013) y Cruise Market Watch (2014b).

La edad media de la flota se sitúa en 13,21 años, siendo la incorporación más reciente la del mega-buque de crucero Carnival Breeze en 2012 con capacidad para 3.690 pasajeros. Junto con el programa de nuevas construcciones, varios buques han sido remodelados para adaptarlos a los estándares actuales. Uno de los ejemplos más representativos es el del buque Carnival Destiny rediseñado en febrero de 2013, saliendo del astillero renombrado como Carnival Sunshine. Carnival Cruise Line es el proveedor líder de cruceros por el Caribe durante todo el año y además opera cruceros de temporada en Europa, Alaska, Nueva Inglaterra, Canadá, Bermudas, Hawái, la Riviera Mexicana y el Canal de Panamá.

\section{I.1.2 Princess Cruises}

Princess Cruises, fundada en 1965 y de origen norteamericano tiene su sede central en Santa Clarita (California, EE.UU.). Opera una moderna flota de 18 buques, véase Tabla I.2, con una edad media de 11,59 años. Fruto de su programa de nuevas construcciones son las recientes incorporaciones a la flota en junio de 2013 y 2014, respectivamente, de los mega-buques de crucero Royal Princess y Regal Princess. Ambos buques gemelos tienen una capacidad de 3.600 pasajeros. Junto con los mega-buques de crucero, la flota de Princess Cruises cuenta también con buques de gran tamaño y de pequeño tamaño, dedicados estos últimos fundamentalmente a cruceros por destinos exóticos.

Princess Cruises oferta más de 150 itinerarios diferentes, brindando la oportunidad al crucerista de cubrir literalmente el globo terráqueo con navegaciones por los cinco continentes que hacen escala en más de 300 puertos y destinos alrededor del mundo. Estos destinos incluyen el Caribe, Alaska, Canal de Panamá, Europa, México, América de Sur, 
Australia/Nueva Zelanda, Pacífico Sur, Hawái, Tahití/Polinesia Francesa, Asia, India, África, Canadá/Nueva Inglaterra y cruceros de vuelta al mundo (Princess Cruises, 2013).

Tabla I.2: Flota de Princess Cruises

\begin{tabular}{|c|c|c|c|c|c|}
\hline \multirow[b]{2}{*}{ Nombre del Buque } & \multicolumn{3}{|c|}{$\begin{array}{l}\approx \\
\text { ESS CRUISES }\end{array}$} & \multirow[b]{2}{*}{$\begin{array}{c}\text { Manga } \\
\text { (m) }\end{array}$} & \multirow[b]{2}{*}{$\begin{array}{c}\text { Arqueo Bruto } \\
\text { (G.T.) }\end{array}$} \\
\hline & $\begin{array}{c}\text { Capacidad de } \\
\text { Pasajeros }\end{array}$ & $\begin{array}{c}\text { Año de } \\
\text { construcción }\end{array}$ & $\begin{array}{c}\text { Eslora } \\
\text { (m) }\end{array}$ & & \\
\hline Pacific Princess & 680 & 1999 & 181,05 & 25,60 & 30.277 \\
\hline Ocean Princess & 680 & 1999 & 181,05 & 25,60 & 30.277 \\
\hline Ruby Princess & 3.080 & 2008 & 289,86 & 35,97 & 112.894 \\
\hline Emerald Princess & 3.080 & 2007 & 289,86 & 35,97 & 112.894 \\
\hline Crown Princess & 3.080 & 2006 & 289,86 & 35,97 & 113.651 \\
\hline Caribbean Princess & 3.080 & 2004 & 289,86 & 35,97 & 112.894 \\
\hline Diamond Princess & 2.670 & 2004 & 290,17 & 37,49 & 115.875 \\
\hline Sapphire Princess & 2.670 & 2004 & 290,17 & 37,49 & 115.875 \\
\hline Star Princess & 2.590 & 2002 & 289,86 & 35,97 & 109.000 \\
\hline Golden Princess & 2.590 & 2001 & 289,86 & 35,97 & 109.000 \\
\hline Grand Princess & 2.600 & 1998 & 289,86 & 35,97 & 107.517 \\
\hline Regal Princess & 3.600 & 2014 & 329,79 & 37,19 & 141.000 \\
\hline Royal Princess & 3.600 & 2013 & 329,79 & 37,19 & 141.000 \\
\hline Coral Princess & 1.970 & 2003 & 293,83 & 32,31 & 91.627 \\
\hline Island Princess & 1.970 & 2003 & 293,83 & 32,31 & 91.627 \\
\hline Sea Princess & 1.950 & 1998 & 261,21 & 32,31 & 77.499 \\
\hline Dawn Princess & 1.950 & 1997 & 261,21 & 32,31 & 77.499 \\
\hline Sun Princess & 1.950 & 1995 & 261,21 & 32,31 & 77.499 \\
\hline
\end{tabular}

Fuente: Elaboración propia basada en datos de ECC (2013), Carnival Corporation (2013) y Cruise Market Watch (2014b).

\section{I.1.3 Costa Cruises}

Costa Cruises, con sede en Génova (Italia), durante más de 63 años sus buques surcan los mares ofreciendo lo mejor del estilo italiano, hospitalidad y cocina mediterránea. Su flota está compuesta de 15 buques, véase Tabla I.3, con una edad media de 10,6 años. La flota está estructurada en buques de gran tamaño y mega-buques de crucero, además todos ellos enarbolan pabellón italiano.

Como elementos más destacables relacionados con la flota de Costa Cruises, destaca la incorporación de los buques Costa Fascinosa en 2012 y Costa Diadema en octubre de 2014, ambos construidos por el astillero italiano Fincantieri. Además, en enero de 2012 el trágico suceso del buque Costa Concordia frente a la costa de la isla de Giglio (Italia) restó una unidad a la flota de la naviera.

Por otro lado, el buque Costa neoRomantica antes de su remodelación en 2012 ostentaba el nombre de Costa Romantica. En cuanto al buque Costa neoRiviera entre el año 1999 y 2003 perteneció a la naviera Festival Cruises bajo el distintivo Mistral, de 2003 a 
2013 fue propiedad de Iberocruceros con el nombre de Grand Mistral, finalmente en 2013 pasó a manos de Costa Cruises siendo sometido a un proceso de remodelación y adoptando el nombre actual de Costa neoRiviera.

Tabla I.3: Flota de Costa Cruises

\begin{tabular}{|c|c|c|c|c|c|}
\hline Nombre del Buque & $\begin{array}{c}\text { Capacidad de } \\
\text { Pasajeros }\end{array}$ & $\begin{array}{c}\text { Año de } \\
\text { construcción }\end{array}$ & $\begin{array}{c}\text { Eslora } \\
\text { (m) }\end{array}$ & $\begin{array}{c}\text { Manga } \\
\text { (m) }\end{array}$ & $\begin{array}{c}\text { Arqueo } \\
\text { Bruto } \\
\text { (G.T.) }\end{array}$ \\
\hline Costa Diadema & 3.708 & 2014 & 306,00 & 37,00 & 132.500 \\
\hline Costa Fascinosa & 3.700 & 2012 & 289,56 & 35,97 & 114.500 \\
\hline Costa Favolosa & 3.700 & 2011 & 289,56 & 35,97 & 114.500 \\
\hline Costa Deliziosa & 2.260 & 2010 & 292,00 & 32,31 & 92.600 \\
\hline Costa Pacifica & 3.700 & 2009 & 289,56 & 35,97 & 114.500 \\
\hline Costa Luminosa & 2.260 & 2009 & 292,00 & 32,31 & 92.600 \\
\hline Costa Serena & 3.700 & 2007 & 289,56 & 35,97 & 114.500 \\
\hline Costa Mágica & 2.672 & 2004 & 271,27 & 35,97 & 102.587 \\
\hline Costa Mediterranea & 2.114 & 2003 & 292,61 & 32,31 & 85.619 \\
\hline Costa Fortuna & 2.716 & 2003 & 271,27 & 35,97 & 102.587 \\
\hline Costa Atlántica & 2.114 & 2000 & 292,61 & 32,31 & 85.619 \\
\hline Costa neoRiviera & 1.700 & 1999 & 216,00 & 28,80 & 48.200 \\
\hline Costa Victoria & 1.928 & 1996 & 250,85 & 32,31 & 75.166 \\
\hline Costa neoRomantica & 1.356 & 1993 & 235,31 & 31,09 & 57.100 \\
\hline Costa neoClassica & 1.680 & 1991 & 220,07 & 31,09 & 52.926 \\
\hline
\end{tabular}

Fuente: Elaboración propia basada en datos de ECC (2013), Carnival Corporation (2013) y Cruise Market Watch (2014b).

La flota de Costa Cruises se extiende por todo mundo ofreciendo cada año la oportunidad de visitar unos 250 destinos distintos con cerca de 150 itinerarios diferentes por el Mediterráneo, Norte de Europa, mar Báltico, Caribe, Centro-América, América del Sur, Emiratos Árabes Unidos, Lejano Este, mar Rojo y cruceros de vuelta al mundo (Costa Cruises, 2013).

\section{I.1.4 Holland America Line}

Holland America Line (HAL) se fundó en 1873 con el nombre de NetherlandsAmerica Steamship Company, una compañía naviera de carga y pasajeros. Debido a que su oficina central estaba situada en Rotterdam, y ofrecía un servicio hacia Estados Unidos, fue conocida como Holland America Line. A pesar de que el transporte de mercancías y pasajeros eran sus principales fuentes de ingresos, en 1895 la compañía ofreció su primer crucero de vacaciones. En 1973, la compañía vendió la división naviera de carga. Posteriormente en 1989, HAL se convirtió en subsidiaria en propiedad absoluta de Carnival Corporation (HAL, 2013). En la actualidad sus oficinas centrales están ubicadas en Seattle (Washington, EE.UU.). 
La flota de Holland America Line está compuesta de 15 buques de tamaño mediano y grande, véase Tabla I.4, con una edad media de 13,53 años. La totalidad de la flota enarbola pabellón de Países Bajos. Además, 14 de los 15 buques están construidos por la firma italiana Fincantieri a excepción del buque ms Prinsendam construido por Wärtsila Marine Industries.

Tabla I.4: Flota de Holland America Line

\begin{tabular}{|c|c|c|c|c|c|}
\hline \multirow[b]{2}{*}{ Nombre del Buque } & \multicolumn{3}{|c|}{$\begin{array}{l}\text { Holland America Line } \\
\text { A Signature of Excellence }\end{array}$} & \multirow[b]{2}{*}{$\begin{array}{c}\text { Manga } \\
\text { (m) }\end{array}$} & \multirow[b]{2}{*}{$\begin{array}{c}\text { Arqueo } \\
\text { Bruto } \\
\text { (G.T.) }\end{array}$} \\
\hline & $\begin{array}{l}\text { Capacidad de } \\
\text { Pasajeros }\end{array}$ & $\begin{array}{c}\text { Año de } \\
\text { construcción }\end{array}$ & $\begin{array}{c}\text { Eslora } \\
\text { (m) }\end{array}$ & & \\
\hline ms Nieuw Amsterdam & 2.106 & 2010 & 284,99 & 32,00 & 86.273 \\
\hline ms Eurodam & 2.104 & 2008 & 284,99 & 32,00 & 86.273 \\
\hline ms Noordam & 1.924 & 2006 & 284,99 & 32,00 & 82.318 \\
\hline ms Westerdam & 1.916 & 2004 & 289,56 & 32,00 & 82.348 \\
\hline ms Oosterdam & 1.916 & 2003 & 289,86 & 32,00 & 82.305 \\
\hline ms Prinsendam & 835 & 2002 & 205,44 & 28,04 & 37.983 \\
\hline ms Zuiderdam & 1.916 & 2002 & 289,86 & 32,00 & 82.305 \\
\hline ms Amsterdam & 1.380 & 2000 & 237,74 & 32,00 & 62.735 \\
\hline ms Zaandam & 1.432 & 2000 & 236,83 & 32,00 & 61.396 \\
\hline ms Volendam & 1.432 & 1999 & 237,74 & 32,00 & 61.214 \\
\hline ms Rotterdam & 1.432 & 1997 & 237,13 & 32,00 & 61.849 \\
\hline ms Veendam & 1.350 & 1996 & 219,46 & 30,78 & 57.092 \\
\hline ms Ryndam & 1.260 & 1994 & 219,46 & 30,78 & 55.819 \\
\hline ms Maasdam & 1.258 & 1993 & 219,46 & 30,78 & 55.575 \\
\hline ms Statendam & 1.260 & 1993 & 227,99 & 28,65 & 55.819 \\
\hline
\end{tabular}

Fuente: Elaboración propia basada en datos de ECC (2013), Carnival Corporation (2013) y Cruise Market Watch (2014b).

La oferta de cruceros asociada a estos 15 buques comprende aproximadamente 500 itinerarios con 415 puertos de escala en más de 98 países, como por ejemplo, La Antártida, América del Sur, Australia/Nueva Zelanda, Asia, Caribe, Alaska, México, Canadá/Nueva Inglaterra, Europa y Canal de Panamá. Junto a la variada oferta anterior también destaca un crucero de 100 días de duración con escalas en puertos de los cinco continentes (ECC, 2013).

\section{I.1.5 AIDA Cruises}

AIDA Cruises es la marca líder y con mayor reconocimiento en el mercado emisor alemán. En operación desde 1996, tiene establecida su sede central en la ciudad portuaria alemana de Rostock (ECC, 2013). Actualmente opera diez buques del segmento contemporary, véase Tabla I.5, además de ser una de las flotas de cruceros más modernas que navega actualmente con una edad media de 6,9 años. Motivado en parte por la pujanza del mercado emisor alemán, tal y como se puede comprobar en el Capítulo II, AIDA Cruises 
tiene establecido un nutrido programa de nuevas construcciones. El efecto inmediato de este programa ha sido la incorporación a la flota en junio de 2013 del buque AIDAstella con capacidad para 2.194 pasajeros. Junto a este buque en 2015 y 2016 se incorporarán a la flota dos nuevos buques, los de mayor tamaño de la flota, con un arqueo bruto de 125.000 G.T.

Tabla I.5: Flota de AIDA Cruises

\begin{tabular}{|c|c|c|c|c|c|}
\hline Nombre del Buque & $\begin{array}{c}\text { Capacidad de } \\
\text { Pasajeros }\end{array}$ & $\begin{array}{c}\text { Año de } \\
\text { construcción }\end{array}$ & $\begin{array}{c}\text { Eslora } \\
\text { (m) }\end{array}$ & $\begin{array}{c}\text { Manga } \\
\text { (m) }\end{array}$ & $\begin{array}{c}\text { Arqueo } \\
\text { Bruto } \\
\text { (G.T.) }\end{array}$ \\
\hline AIDAstella & 2.194 & 2013 & 252,07 & 32,31 & 71.304 \\
\hline AIDAmar & 2.194 & 2012 & 252,07 & 32,31 & 71.304 \\
\hline AIDAsol & 2.194 & 2011 & 252,07 & 32,31 & 71.304 \\
\hline AIDAblu & 2.192 & 2010 & 252,07 & 32,31 & 71.304 \\
\hline AIDAluna & 2.050 & 2009 & 252,07 & 32,31 & 69.203 \\
\hline AIDAbella & 2.050 & 2008 & 252,07 & 32,31 & 69.203 \\
\hline AIDAdiva & 2.050 & 2007 & 252,07 & 32,31 & 69.203 \\
\hline AIDAaura & 1.266 & 2003 & 203,30 & 28,04 & 42.289 \\
\hline AIDAvita & 1.266 & 2002 & 203,30 & 28,04 & 42.289 \\
\hline AIDAcara & 1.180 & 1996 & 193,24 & 27,74 & 38.557 \\
\hline
\end{tabular}

Fuente: Elaboración propia basada en datos de ECC (2013), Carnival Corporation (2013) y Cruise Market Watch (2014b).

La flota de AIDA Cruises hace escala en más de 170 puertos. Durante el verano los buques navegan por el mar del Norte, Báltico, Mediterráneo, mar Negro y Canadá y Nueva Inglaterra. Mientras que en invierno (del hemisferio norte), los buques de $A I D A$ navegan por el Caribe, Centro-América, América del Sur, las islas Atlánticas, Mediterráneo Occidental, Lejano Oriente, golfo Arábigo y mar Rojo (AIDA Cruises, 2013).

\section{I.1.6 P\&O Cruises}

El origen de $P \& O$ Cruises (Reino Unido) se remonta al año 1837, el año 2012 marcó el 175 aniversario desde que la compañía Peninsular Steam Navigation Company se adjudicó un contrato del Gobierno británico para llevar el correo de Londres a la Península Ibérica (P\&O Cruises, 2013). En ese momento los pasajeros también hacían uso de estas rutas, pero con orientación de viaje de negocios más que de placer. Con el paso del tiempo y tras la creación del concepto de viajes de crucero, convirtieron su flota a buques de crucero exclusivamente.

Con sede en Southampton (Reino Unido), la compañía cuenta con una flota de siete buques y once años de edad media, véase Tabla I.6. En los últimos años la flota ha registrado un incremento de capacidad generado por la incorporación de los buques Azura (el de mayor tamaño de flota) en 2010 y Adonia en mayo de 2011. En este sentido cabe mencionar que el 
actual buque Adonia, construido en el año 2000, ha estado en propiedad de varios armadores anteriormente. En concreto, entre 2000 y 2001 prestó sus servicios a Renaissance Cruises bajo el nombre de R Eight, entre 2003 y 2007 como Minerva II para Swan Hellenic, entre 2007 y 2011 como Royal Princess para Princess Cruises, instante a partir del cual se le dota de la denominación de Adonia bajo la consigna de $P \& O$ Cruises. El incremento de capacidad de la flota culminará en la primavera de 2015 con la incorporación de un nuevo buque de 141.000 G.T. y capacidad para 3.610 pasajeros (Cruise Ships, 2013).

Tabla I.6: Flota de $P \& O$ Cruises

\section{$\frac{W}{\text { PEOCRUISES }}$}

\begin{tabular}{lccccc} 
Nombre del Buque & $\begin{array}{c}\text { Capacidad de } \\
\text { Pasajeros }\end{array}$ & $\begin{array}{c}\text { Año de } \\
\text { construcción }\end{array}$ & $\begin{array}{c}\text { Eslora } \\
\mathbf{( m )}\end{array}$ & $\begin{array}{c}\text { Manga } \\
\mathbf{( m )}\end{array}$ & $\begin{array}{c}\text { Arqueo } \\
\text { Bruto } \\
(\mathbf{G . T} .)\end{array}$ \\
\hline Azura & 3.096 & 2010 & 289,00 & 50,00 & 115.055 \\
Ventura & 3.078 & 2008 & 289,00 & 25,60 & 30.277 \\
Arcadia & 2.016 & 2005 & 285,29 & 32,31 & 83.781 \\
Oceana & 2.016 & 2002 & 261,21 & 32,31 & 77.499 \\
Adonia & 688 & 2000 & 180,44 & 25,60 & 30.277 \\
Aurora & 1.870 & 2000 & 270,05 & 32,00 & 76.152 \\
Oriana & 1.828 & 1995 & 259,99 & 32,31 & 69.153 \\
\hline
\end{tabular}

Fuente: Elaboración propia basada en datos de ECC (2013), Carnival Corporation (2013) y Cruise Market Watch (2014b).

Los destinos por los que navegan los buques de $P \& O$ Cruises incluyen el Caribe, América del Sur, Escandinavia, Mediterráneo, islas Atlánticas y cruceros de vuelta al mundo.

\section{I.1.7 Cunard Line}

Cunard Line fue fundada en 1839 principalmente para el envío de correo entre Reino Unido y Norte América, y como consecuencia de ello, se inauguró en 1840 el primer servicio regular de vapores a través del Atlántico (Carnival Corporation, 2013). De forma análoga al caso de $P \& O$ Cruises, su sede central también está establecida en Southampton, al igual que los orígenes de la compañía.

La flota actual de tres buques, véase Tabla I.7, es una de las más jóvenes, con siete años de media de edad, y sin duda la más famosa de la industria de cruceros con el apoyo de uno de los nombres más longevos en transporte marítimo (Cunard Cruises, 2013). Además, los tres buques operan en el segmento de lujo.

El buque insignia de la flota es el Queen Mary 2, que opera el único servicio regular transatlántico entre Nueva York y Southampton. En lo que respecta a los buques Queen 
Victoria y Queen Elizabeth principalmente ofertan itinerarios de temporada por el Norte de Europa, Mediterráneo, Caribe/Canal de Panamá, Canadá, Nueva Inglaterra, los tradicionales viajes transatlánticos, así como, cruceros de vuelta al mundo; convirtiéndose Cunard en la primera en ofertar un crucero de vuelta al mundo en el año 1922.

Tabla I.7: Flota de Cunard Line

\begin{tabular}{|c|c|c|c|c|c|}
\hline & & 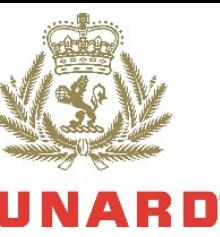 & & & \\
\hline Nombre del Buque & $\begin{array}{c}\text { Capacidad de } \\
\text { Pasajeros }\end{array}$ & $\begin{array}{c}\text { Año de } \\
\text { construcción }\end{array}$ & $\begin{array}{c}\text { Eslora } \\
\text { (m) }\end{array}$ & $\begin{array}{c}\text { Manga } \\
(\mathbf{m})\end{array}$ & $\begin{array}{c}\text { Arqueo } \\
\text { Bruto } \\
\text { (G.T.) }\end{array}$ \\
\hline Queen Elizabeth & 2.092 & 2010 & 293,83 & 32,31 & 92.000 \\
\hline Queen Victoria & 2.014 & 2007 & 293,83 & 32,31 & 90.049 \\
\hline Queen Mary 2 & 2.620 & 2004 & 345,03 & 41,15 & 148.528 \\
\hline
\end{tabular}

Fuente: Elaboración propia basada en datos de ECC (2013), Carnival Corporation (2013) y Cruise Market Watch (2014b).

\section{I.1.8 P\&O Cruises Australia}

$P \& O$ Cruises Australia es la línea de cruceros líder en Australia, con casi 80 años de experiencia en la industria de cruceros (Carnival Corporation, 2013). Actualmente su flota la componen tres buques, véase Tabla I.8, otorgándole una capacidad de 5.770 pasajeros. Aunque con una edad media de 24,30 años, los tres buques de la flota han sido remodelados para actualizarlos a los nuevos estándares normativos.

Tabla I.8: Flota de $P \& O$ Cruises Australia

\begin{tabular}{|c|c|c|c|c|c|}
\hline Nombre del Buque & $\begin{array}{c}\text { Capacidad de } \\
\text { Pasajeros }\end{array}$ & $\begin{array}{c}\text { Año de } \\
\text { construcción }\end{array}$ & $\begin{array}{c}\text { Eslora } \\
\text { (m) }\end{array}$ & $\begin{array}{c}\text { Manga } \\
\text { (m) }\end{array}$ & $\begin{array}{c}\text { Arqueo } \\
\text { Bruto } \\
\text { (G.T.) }\end{array}$ \\
\hline Pacific Dawn & 2.020 & 1991 & 245,06 & 32,31 & 70.285 \\
\hline Pacific Jewel & 1.950 & 1991 & 245,67 & 32,31 & 70.310 \\
\hline Pacific Pearl & 1.800 & 1987 & 246,89 & 32,00 & 63.875 \\
\hline
\end{tabular}

Fuente: Elaboración propia basada en datos de ECC (2013), Carnival Corporation (2013) y Cruise Market Watch (2014b).

Los tres buques con anterioridad han sido operados por otras navieras pertenecientes al grupo Carnival. El actual buque Pacific Dawn, entre 1991 y 1992 navegaba bajo la consigna de $P \& O$ Cruises $U K$ con el nombre de Regal Princess; entre 1992 y 2007 con el 
mismo nombre pero en este caso para la naviera Princess Cruises; y desde 2007 ostenta la denominación actual. En cuanto al buque Pacific Jewel cuenta con el siguiente historial, entre 1991 y 2002 ostentó el nombre Crown Princess para Princess Cruises; entre 2002 y 2003 Arosa Blu para Arosa Cruises; entre 2003 y 2007 AIDAblu para AIDA Cruises; entre 2007 y 2009 Ocean Village Two para Ocean Village; finalmente desde 2009 navega bajo los requerimientos de $P \& O$ Cruises Australia. Por último, el buque Pacific Pearl, entre 1988 y 1997 navegó bajo la consigna de la naviera Princess Cruises con el nombre de Star Princess; entre 1997 y 2003 cambió su nombre a Arcadia para P\&O Cruises UK; entre 2003 y 2010 Ocean Village para Ocean Village; momento a partir del cual adquirió la denominación actual en $P \& O$ Cruises Australia. La amplia gama de destinos cubiertos por estos buques comprende puertos del Pacífico Sur, Nueva Zelanda, Asia y, por supuesto, puertos nacionales australianos.

\section{I.1.9 Iberocruceros}

Iberocruceros, con su sede central en Madrid (España), opera desde el año 2003 principalmente para los mercados emisores español y portugués (ECC, 2013). La naviera pertenece a Costa Cruises que a su vez depende del grupo Carnival como se ha comentado anteriormente (Iberocruceros, 2013).

Actualmente opera una flota de tres buques de tamaño mediano con una edad media de 23,70 años, véase Tabla I.9. Estos tres buques con anterioridad han sido operados por otras navieras de este grupo, de forma análoga al caso expuesto anteriormente para la naviera $P \& O$ Cruises Australia.

Tabla I.9: Flota de Iberocruceros

\section{Dibero}

\begin{tabular}{lccccr} 
Nombre del Buque & $\begin{array}{c}\text { Capacidad de } \\
\text { Pasajeros }\end{array}$ & $\begin{array}{c}\text { Año de } \\
\text { construcción }\end{array}$ & $\begin{array}{c}\text { Eslora } \\
\text { (m) }\end{array}$ & $\begin{array}{c}\text { Manga } \\
\text { (m) }\end{array}$ & $\begin{array}{c}\text { Arqueo } \\
\text { Bruto } \\
\text { (G.T.) }\end{array}$ \\
\hline Grand Mistral & 1.807 & 1999 & 216,10 & 32,00 & 48.200 \\
Grand Celebration & 1.910 & 1987 & 223,42 & 32,00 & 47.262 \\
Grand Holiday & 1.848 & 1985 & 221,89 & 32,00 & 46.052 \\
\hline
\end{tabular}

Fuente: Elaboración propia basada en datos de ECC (2013), Carnival Corporation (2013) y Cruise Market Watch (2014b).

El buque Grand Mistral entre los años 1999 y 2003 navegó con el nombre de Mistral bajo la consigna de la naviera Festival Cruises, en 2003 adquirió la denominación actual ya operado por Iberocruceros. En referencia con el buque Grand Celebration, en la etapa de 1987 a 2008 fue explotado por Carnival Cruise Line con la denominación de Celebration, a partir del año 2008 pasó a ser operado por Iberocruceros. El tercer buque de la flota, Grand Holiday, es el de más reciente incorporación pues presta sus servicios a esta compañía desde 
2010, entre 1985 y 2010 estuvo en posesión de Carnival Cruise Line con el nombre de Holiday. Las principales zonas de operación de los tres buques anteriores son el Mediterráneo, América del Sur y Norte de Europa.

\section{I.1.10 Seabourn Cruise Line}

Seabourn Cruise Line, con sede en Seattle (EE.UU.), pionera en el segmento de cruceros de ultra-lujo se ha ganado elogios unánimes por parte de los expertos del sector desde su lanzamiento en 1987 (Carnival Corporation, 2013). Dispone de una flota de cinco exclusivos buques de tamaño pequeño, véase Tabla I.10, equipados únicamente con suites y un servicio personalizado con un ratio próximo a un tripulante por cada pasajero (Seabourn Cruise Line, 2013).

Tabla I.10: Flota de Seabourn Cruise Line

\section{SEABOURN}

\begin{tabular}{lccccr} 
Nombre del Buque & $\begin{array}{c}\text { Capacidad de } \\
\text { Pasajeros }\end{array}$ & $\begin{array}{c}\text { Año de } \\
\text { construcción }\end{array}$ & $\begin{array}{c}\text { Eslora } \\
(\mathbf{m})\end{array}$ & $\begin{array}{c}\text { Manga } \\
(\mathbf{m})\end{array}$ & $\begin{array}{c}\text { Arqueo } \\
\text { Bruto } \\
\text { (G.T.) }\end{array}$ \\
\hline Seabourn Quest & 450 & 2011 & 198,12 & 25,6 & 32.346 \\
Seabourn Sojourn & 450 & 2010 & 198,12 & 25,6 & 32.346 \\
Seabourn Odyssey & 450 & 2009 & 198,12 & 25,6 & 32.346 \\
Seabourn Legend & 208 & 1992 & 123,14 & 19,2 & 9.961 \\
Seabourn Spirit & 208 & 1989 & 123,14 & 19,2 & 9.975 \\
\hline
\end{tabular}

Fuente: Elaboración propia basada en datos de ECC (2013), Carnival Corporation (2013) y Cruise Market Watch (2014b).

Con una edad media de 11,80 años, su flota está estructurada en dos tipos de buques atendiendo a su capacidad, dos de 208 y tres de 450 pasajeros. Todos ellos enarbolan pabellón de Bahamas y a excepción de un buque (Seabourn Legend) han sido explotados únicamente por Seabourn Cruise Line. El citado buque, entre 1992 y 1996 fue propiedad de Royal Viking Line con los nombres de Royal Viking Queen (1992-1995) y Queen Odyssey (1995-1996), a partir de 1996 adquirió la consigna actual en Seabourn. La flota de cinco buques ofrece cruceros por todo el mundo, incluyendo Europa, Asia, las islas del Pacífico Sur, Australia y América.

\section{I.2 Grupo Royal Caribbean Cruises Limited}

El grupo Royal Caribbean Cruises Limited está integrado por cinco navieras, tal y como se ha reflejado en el Capítulo III, apartado 3.1.2. Los siguientes sub-apartados detallan las características de cada una de las cinco navieras pertenecientes a este grupo, su ordenación en el texto atiende a la relación de mayor a menor tamaño dentro del grupo. 


\section{I.2.1 Royal Caribbean International}

Royal Caribbean International (RCI), fundada en 1968 y con sede en Miami (Florida, EE.UU.), tiene su origen ligado a la fusión de tres navieras noruegas, Anders Wilhelmsen \& Company, I.M. Skauge \& Company y Gotaas Larsen dando lugar a Royal Caribbean Cruise Line, más tarde, en 1997 adoptaría la denominación actual de Royal Caribbean International. La naviera cuenta con una flota de 21 buques, divididos en buques de gran tamaño y mega-buques de crucero, con una edad media de 12,76 años, véase Tabla I.11.

Tabla I.11: Flota de Royal Caribbean International

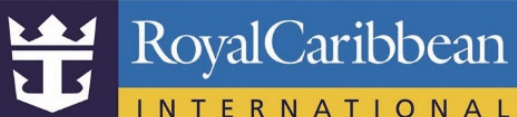

\begin{tabular}{lccccr} 
Nombre del Buque & $\begin{array}{c}\text { Capacidad de } \\
\text { Pasajeros }\end{array}$ & $\begin{array}{c}\text { Año de } \\
\text { construcción }\end{array}$ & $\begin{array}{c}\text { Eslora } \\
(\mathbf{m})\end{array}$ & $\begin{array}{c}\text { Manga } \\
(\mathbf{m})\end{array}$ & $\begin{array}{c}\text { Arqueo Bruto } \\
\text { (G.T.) }\end{array}$ \\
\hline Allure of the Seas & 5.400 & 2010 & 359,97 & 46,94 & 225.282 \\
Oasis of the Seas & 5.400 & 2009 & 359,97 & 46,94 & 225.282 \\
Independence of the Seas & 3.634 & 2008 & 338,94 & 38,71 & 154.407 \\
Liberty of the Seas & 3.634 & 2007 & 338,94 & 38,71 & 154.407 \\
Freedom of the Seas & 3.634 & 2006 & 338,94 & 38,71 & 154.407 \\
Jewel of the Seas & 2.100 & 2004 & 293,22 & 32,31 & 90.090 \\
Serenade of the Seas & 2.100 & 2003 & 293,22 & 32,31 & 90.090 \\
Brilliance of the Seas & 2.100 & 2002 & 293,22 & 32,31 & 90.090 \\
Radiance of the Seas & 2.100 & 2001 & 293,22 & 32,31 & 90.090 \\
Majesty of the Seas & 2.350 & 1992 & 268,22 & 32,31 & 73.941 \\
Vision of the Seas & 2.000 & 1998 & 278,89 & 32,31 & 78.340 \\
Rhapsody of the Seas & 2.000 & 1997 & 278,89 & 32,31 & 78.491 \\
Enchantment of the Seas & 2.250 & 1997 & 301,75 & 32,31 & 82.910 \\
Grandeur of the Seas & 1.950 & 1996 & 278,89 & 32,31 & 73.817 \\
Splendour of the Seas & 1.800 & 1996 & 264,26 & 32,00 & 69.130 \\
Legend of the Seas & 1.800 & 1995 & 264,26 & 32,00 & 69.130 \\
Mariner of the Seas & 3.114 & 2003 & 310,90 & 38,71 & 138.279 \\
Navigator of the Seas & 3.114 & 2002 & 310,90 & 38,71 & 138.279 \\
Adventure of the Seas & 3.114 & 2001 & 310,90 & 38,71 & 137.276 \\
Explorer of the Seas & 3.114 & 2000 & 310,90 & 38,71 & 137.308 \\
Voyager of the Seas & 3.114 & 1999 & 310,90 & 38,71 & 137.276 \\
\hline
\end{tabular}

Fuente: Elaboración propia basada en ECC (2013), RCI (2013) y Cruise Market Watch (2014b).

Junto a los buques enumerados anteriormente, el programa de nuevas construcciones contempla la incorporación de dos buques gemelos, prevista para 2014 y 2015, con capacidad para 4.100 pasajeros y construidos en el astillero alemán Meyer Werft. Royal Caribbean International está situada en el extremo superior del segmento contemporary, además la calidad de su servicio también le permite atraer a cruceristas del segmento premium. Esta disponibilidad de medios le permite ofertar itinerarios de crucero que varían de 2 a 18 noches. En cuanto a la cobertura geográfica, los destinos se extienden por todo el 
mundo, incluyendo, Alaska, Asia, Australia, Bermuda, Canadá, Caribe, Europa, Hawái, América del Sur, Oriente Medio, Canal de Panamá y Nueva Zelanda.

\section{I.2.2 Celebrity Cruises}

Celebrity Cruises, fundada en 1989 y sede en Miami (Florida, EE.UU.), es la línea de cruceros con mayor reconocimiento dentro del segmento premium (ECC, 2013). Su flota de 11 buques, véase Tabla I.12, es una de las más jóvenes e innovadoras con una media de 9,64 años (Celebrity Cruises, 2013). La flota está compuesta en su mayoría por buques de gran tamaño y mega-buques de crucero. Además, también dispone de un buque destinado a realizar cruceros de expedición, el Celebrity Xpedition, de ahí la notable diferencia de capacidad entre éste y los diez restantes de la flota.

Tabla I.12: Flota de Celebrity Cruises

\section{Celebrity Cruises $^{\circledR}$}

\begin{tabular}{lccccr} 
Nombre del Buque & $\begin{array}{c}\text { Capacidad de } \\
\text { Pasajeros }\end{array}$ & $\begin{array}{c}\text { Año de } \\
\text { construcción }\end{array}$ & $\begin{array}{c}\text { Eslora } \\
(\mathbf{m})\end{array}$ & $\begin{array}{c}\text { Manga } \\
(\mathbf{m})\end{array}$ & $\begin{array}{c}\text { Arqueo Bruto } \\
\text { (G.T.) }\end{array}$ \\
\hline Celebrity Century & 1.750 & 1995 & 248,41 & 32,00 & 70.606 \\
Celebrity Constellation & 2.050 & 2002 & 291,39 & 32,31 & 90.280 \\
Celebrity Infinity & 2.050 & 2001 & 294,13 & 32,31 & 90.280 \\
Celebrity Summit & 2.050 & 2001 & 294,13 & 32,31 & 90.280 \\
Celebrity Millennium & 2.050 & 2000 & 291,39 & 32,31 & 90.280 \\
Celebrity Reflection & 3.030 & 2012 & 314,86 & 37,80 & 126.000 \\
Celebrity Silhouette & 2.850 & 2011 & 314,86 & 36,88 & 122.000 \\
Celebrity Eclipse & 2.850 & 2010 & 314,86 & 36,88 & 122.000 \\
Celebrity Equinox & 2.850 & 2009 & 314,86 & 36,88 & 122.000 \\
Celebrity Solstice & 2.850 & 2008 & 314,86 & 36,88 & 122.000 \\
Celebrity Xpedition & 96 & 2001 & 90,22 & 13,11 & 2.329 \\
\hline
\end{tabular}

Fuente: Elaboración propia basada en ECC (2013), RCI (2013) y Cruise Market Watch (2014b).

La flota de Celebrity navega por Alaska, Bermuda, California, Canadá/Nueva Inglaterra, Caribe, Europa, Hawái, la costa del Pacífico, Canal de Panamá y Sudamérica y cruceros de vuelta al mundo con escalas en las islas Galápagos.

\section{I.2.3 Pullmantur}

Pullmantur es un grupo turístico líder en Europa y Latinoamérica con su sede central en Madrid (España), cuyas líneas de negocio fundamentales son cruceros, aviación regular y chárter, tour-operación y circuitos terrestres. Sin embargo, su actividad en el sector de los cruceros no se inicia hasta la década de los 90 del pasado siglo. En sus inicios no operaba como naviera, sino que se encargaba de vender viajes/itinerarios para los buques de la hoy desaparecida naviera Premier Cruises. Tras la desaparición de esta naviera, en el año 2000 Pullmantur adquiere uno de sus buques, el SS Big Red Boat I, convirtiéndose en estos 
momentos en la primera compañía de cruceros española. En noviembre de 2006, la compañía norteamericana Royal Caribbean Cruises Limited adquirió Pullmantur y sus filiales (Pullmantur Cruises, Pullmantur Air y Paditour) aportando un sólido apoyo para liderar la continua expansión de la actividad del grupo. Además apostó fuertemente por Pullmantur Air como medio de transporte aéreo para abastecer los cruceros (Pullmantur, 2013). La flota de Pullmantur está constituida por tres buques, véase Tabla I.13, con una edad media de 24,33 años.

Tabla I.13: Flota de Pullmantur

\begin{tabular}{|c|c|c|c|c|c|}
\hline & & pullmantur & & & \\
\hline Nombre del Buque & $\begin{array}{l}\text { Capacidad de } \\
\text { Pasajeros }\end{array}$ & $\begin{array}{c}\text { Año de } \\
\text { construcción }\end{array}$ & $\begin{array}{c}\text { Eslora } \\
\text { (m) }\end{array}$ & Manga (m) & $\begin{array}{c}\text { Arqueo } \\
\text { Bruto } \\
\text { (G.T.) }\end{array}$ \\
\hline Monarch & 2.350 & 1991 & 268,22 & 32,31 & 73.937 \\
\hline Empress & 1.877 & 1990 & 210,92 & 30,48 & 48.563 \\
\hline Sovereign & 2.733 & 1988 & 268,22 & 32,31 & 73.592 \\
\hline
\end{tabular}

Fuente: Elaboración propia basada en ECC (2013), RCI (2013) y Cruise Market Watch (2014b).

Desde sus inicios como naviera, los buques que ha explotado con anterioridad han pertenecido a otras navieras. En concreto, todos los buques de la flota actual han sido explotados por otras navieras del grupo RCCL siendo su bagaje el que se describe a continuación. El buque Sovereign desde su construcción en 1988 hasta 2008 fue explotado por RCI bajo el nombre de Sovereign of the Seas, a partir de este año el buque adopta la denominación actual en Pullmantur. El buque Empress entre 1990 y 2008 prestó sus servicios para RCI, con dos nombres distintos Nordic Empress (1990-2004) y Empress of the Seas (2004-2008), momento a partir del cual adquiere su nombre actual. Por último, la incorporación más reciente a la flota, el buque Monarch, se registró en 2013, con anterioridad entre 1991 y 2013 fue explotado por RCI bajo el nombre Monarch of the Seas. Los buques de Pullmantur navegan por el Mediterráneo, Báltico, mar del Norte, Caribe y cruceros de reposicionamientos entre destinos de ambas orillas del Atlántico.

\section{I.2.4 Croisières de France}

Croisières de France (CDF) opera como marca subsidiaria de Pullmantur y por extensión de RCCL en el mercado francés. Fundada en 2007, la flota se compone de dos buques, véase Tabla I.14, confiriéndole una capacidad de 3.656 pasajeros (Pullmantur, 2013). Ambos buques con anterioridad han sido explotados por otras navieras del grupo RCCL. El buque Zenith conserva el mismo nombre desde su botadura en 1992, entre 1992 y 2007 fue propiedad de Celebrity Cruises, a partir de 2007 operó bajo la consigna de Pullmantur hasta 2014, año en el que pasa a formar parte de la flota de CDF. En cuanto al buque Horizon, entre 1990 y 2005 formó parte de la flota de Celebrity Cruises, de 2005 a 
2009 fue operado por Island Cruises con la denominación de Island Star, su siguiente etapa, entre 2009 y 2012, cambió su nombre a Pacific Dream para Pullmantur hasta el año 2013 en que recuperó su primer nombre ya en CDF.

Tabla I.14: Flota de Croisières de France (CDF)

\begin{tabular}{|c|c|c|c|c|c|}
\hline Nombre del Buque & $\begin{array}{l}\text { Capacidad de } \\
\text { Pasajeros }\end{array}$ & $\begin{array}{c}\text { Año de } \\
\text { construcción }\end{array}$ & $\begin{array}{c}\text { Eslora } \\
\text { (m) }\end{array}$ & $\begin{array}{c}\text { Manga } \\
\text { (m) }\end{array}$ & $\begin{array}{c}\text { Arqueo } \\
\text { Bruto } \\
\text { (G.T.) }\end{array}$ \\
\hline Zenith & 1.828 & 1992 & 207,87 & 28,96 & 47.413 \\
\hline Horizon & 1.828 & 1990 & 207,87 & 28,96 & 47.427 \\
\hline
\end{tabular}

Fuente: Elaboración propia basada en ECC (2013), CDF (2013) y Cruise Market Watch (2014b).

\section{I.2.5 Azamara Club Cruises}

Fundada en 2007 como Azamara Cruises y relanzada con el nombre de Azamara Club Cruises en 2009, esta naviera tiene como principal línea de negocio clientes de alta gama que persiguen una nueva forma de realizar un crucero (Azamara Club Cruises, 2013). Dispone de dos buques, véase Tabla I.15, con capacidad para 694 pasajeros cada uno, construidos en el año 2000. Lo cual le confiere la quinta posición $(1,44 \%)$ dentro del grupo RCCL, equivalente al $0,30 \%$ de la cuota mundial en términos de capacidad.

Tabla I.15: Flota de Azamara Club Cruises

\begin{tabular}{lccccc}
\hline & & & & & \\
& & & & \\
Arqueo \\
Nombre del Buque & $\begin{array}{c}\text { Capacidad de } \\
\text { Pasajeros }\end{array}$ & $\begin{array}{c}\text { Año de } \\
\text { construcción }\end{array}$ & $\begin{array}{c}\text { Eslora } \\
\text { (m) }\end{array}$ & $\begin{array}{c}\text { Manga } \\
\text { (m) }\end{array}$ & $\begin{array}{c}\text { Bruto } \\
\text { (G.T.) }\end{array}$ \\
\hline Azamara Journey & 694 & 2000 & 181,05 & 25,60 & 30.277 \\
Azamara Quest & 694 & 2000 & 181,05 & 25,60 & 30.277 \\
\hline
\end{tabular}

Fuente: Elaboración propia basada en ECC (2013), Azamara Club Cruises (2013) y Cruise Market Watch (2014b).

Ambos buques gemelos, desde su construcción han prestado sus servicios en diferentes navieras siguiendo trayectorias prácticamente paralelas. Así en el caso del buque Azamara Journey, entre 2000 y 2005 fue propiedad de Renaissance Cruises bajo el nombre de $R$ Six, en 2005 fue adquirido por Pullmantur cambiando su nombre a Blue Dream hasta 2007, año en el que adoptó la actual denominación bajo la consigna de Azamara Cruises. En cuanto al buque Azamara Quest, entre 2000 y 2003 fue también propiedad de Renaissance Cruises como R Seven, en 2003 pasó a Delphin Seereisen como Delphin Renissance hasta 
2006, entre 2006 y 2007 prestó sus servicios para Pullmantur bajo el nombre de Blue Moon, y al igual que su gemelo, en 2007 adoptó la denominación actual en Azamara Cruises.

Azamara Club Cruises navega alrededor del mundo ofreciendo un perfil de cruceros distinto con salidas tardías y estancias nocturnas en puerto con el fin de ofrecer a los cruceristas la oportunidad de disfrutar del destino tanto de día como de noche. La naviera navega por destinos europeos, incluido el Báltico y Escandinavia, islas Británicas, Europa Occidental, la Riviera italiana y francesa, islas Griegas, Croacia, Tierra Santa y el mar Negro.

\section{I.3 Grupo Genting Hong Kong Limited}

El grupo Genting Hong Kong Limited está integrado por dos navieras, tal y como se ha reflejado en el Capítulo III, apartado 3.1.3. Los siguientes sub-apartados detallan las características de las dos navieras pertenecientes a este grupo, su ordenación en el texto atiende a la relación de mayor a menor tamaño dentro del grupo.

\section{I.3.1 Norwegian Cruise Line}

Norwegian Cruise Line (NCL), con sede en Miami (Florida, EE.UU.) y fundada en 1966 con el nombre original de Norwegian Caribbean Line, se ha posicionado como una naviera pionera en cuanto a innovación se refiere. En concreto, las actividades más innovadoras comprenden desde la primera isla privada, pasando por actuaciones exclusivas en alta mar, hasta el concepto de Freestyle Cruising (customizar el crucero), que ha revolucionado la industria permitiendo a los pasajeros mayor libertad y flexibilidad (NCL, 2013).

La flota de Norwegian Cruise Line está compuesta de 13 buques, véase Tabla I.16, con una edad media de 9,58 años. Además, los tamaños predominantes en la flota son buques de gran tamaño y mega-buques de crucero.

Tabla I.16: Flota de Norwegian Cruise Line

\begin{tabular}{|c|c|c|c|c|c|}
\hline \multirow[b]{2}{*}{ Nombre del Buque } & \multicolumn{3}{|c|}{ NOR $\underset{\text { CRUISE LINE }}{\stackrel{\text { NCL }}{\text { VEGIAN }}}$} & \multirow[b]{2}{*}{$\begin{array}{c}\text { Manga } \\
\text { (m) }\end{array}$} & \multirow[b]{2}{*}{$\begin{array}{c}\text { Arqueo Bruto } \\
\text { (G.T.) }\end{array}$} \\
\hline & $\begin{array}{c}\text { Capacidad de } \\
\text { Pasajeros }\end{array}$ & $\begin{array}{c}\text { Año de } \\
\text { construcción }\end{array}$ & $\begin{array}{c}\text { Eslora } \\
\text { (m) }\end{array}$ & & \\
\hline Norwegian Getaway & 3.963 & 2014 & 324 & 40 & 145.655 \\
\hline Norwegian Breakaway & 4.028 & 2013 & 324 & 40 & 144.017 \\
\hline Norwegian Dawn & 2.338 & 2002 & 294 & 32 & 92.250 \\
\hline Norwegian Star & 2.346 & 2001 & 294 & 32 & 91.740 \\
\hline Norwegian Epic & 4.100 & 2010 & 329 & 41 & 155.873 \\
\hline Norwegian Gem & 2.394 & 2007 & 294 & 32 & 93.530 \\
\hline Norwegian Jade & 2.388 & 2006 & 294 & 32 & 93.558 \\
\hline Norwegian Pearl & 2.394 & 2006 & 294 & 32 & 93.530 \\
\hline
\end{tabular}




\begin{tabular}{lccccc}
\hline & \multicolumn{2}{c}{$\begin{array}{c}\text { NORW } \\
\text { CRUISE LINE⿱ }\end{array}$} \\
Nombre del Buque & $\begin{array}{c}\text { NCL } \\
\text { Capacidad de } \\
\text { Pasajeros }\end{array}$ & $\begin{array}{c}\text { Año de } \\
\text { construcción }\end{array}$ & $\begin{array}{c}\text { Eslora } \\
(\mathbf{m})\end{array}$ & $\begin{array}{c}\text { Manga } \\
(\mathbf{m})\end{array}$ & $\begin{array}{c}\text { Arqueo Bruto } \\
\text { (G.T.) }\end{array}$ \\
\hline Norwegian Jewel & 2.374 & 2005 & 294 & 32 & 93.502 \\
Norwegian Spirit & 2.000 & 1998 & 269 & 32 & 75.338 \\
Norwegian Sun & 1.936 & 2001 & 258 & 32 & 78.309 \\
Norwegian Sky & 2.002 & 1999 & 259 & 32 & 77.104 \\
Pride of America & 2.138 & 2005 & 280 & 32 & 80.439 \\
\hline
\end{tabular}

Fuente: Elaboración propia basada en ECC (2013), NCL (2013) y Cruise Market Watch (2014b).

El buque Norwegian Sky fue encargado al astillero Bremer Vulkan por Costa Cruises para la cual navegaría bajo el nombre de Costa Olympia. Sin embargo, durante su construcción fue adquirido por NCL. Otra singularidad de la flota de NCL es la del actual buque Norwegian Spirit, el cual entre 1998 y 2004 formó parte de la flota de Star Cruises con la denominación de SuperStar Leo, a partir de 2004 adoptó la consigna actual en NCL. Las incorporaciones más recientes a la flota han sido las de los buques Norwegian Breakaway en abril de 2013 y Norwegian Getaway en junio de 2014, ambos gemelos. El primero de estos dos es el buque de mayor tamaño con puerto base en Nueva York, ofertando cruceros a las Bermudas durante la época estival. Mientras que el segundo, tiene previsto establecer su puerto base en Miami ofertando cruceros por el Caribe Oriental (ECC, 2013).

Fruto del programa de nuevas construcciones de la naviera, en los próximos tres años la flota se verá ampliada en dos buques. Éstos tendrán un tamaño ligeramente superior al del buque Norwegian Breakaway. Su incorporación a la flota está prevista para otoño de 2015 y primavera de 2017 (NCL, 2013).

En cuanto a los destinos visitados por los buques de NCL, sus zonas de operación se centran en el Caribe, Canadá y Nueva Inglaterra, Alaska, Bermudas, Mediterráneo, mar Báltico y cruceros de reposicionamiento entre ambas orillas del Atlántico (NCL, 2013).

\section{I.3.2 Star Cruises}

Star Cruises, fundada en 1993 y con sede en Hong Kong (China), es la compañía líder en la región de Asia-Pacífico. Sus servicios se centran en los pasajeros de origen asiático, así como, en los norteamericanos, europeos y australianos interesados en destinos asiáticos (Star Cruises, 2013). Asociados al nombre de Star Cruises también aparecen otras navieras como Sun Cruises, adquirida por ésta en el año 2000, o la subsidiaria Orient Lines disuelta en el año 2008. Su flota está compuesta de cinco buques, véase Tabla I.17, con una edad media de 21,60 años. 


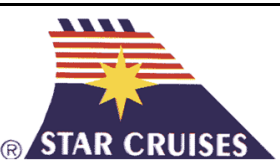

\begin{tabular}{lccccc} 
Nombre del Buque & $\begin{array}{c}\text { Capacidad de } \\
\text { Pasajeros }\end{array}$ & $\begin{array}{c}\text { Año de } \\
\text { construcción }\end{array}$ & $\begin{array}{c}\text { Eslora } \\
\text { (m) }\end{array}$ & $\begin{array}{c}\text { Manga } \\
\text { (m) }\end{array}$ & $\begin{array}{c}\text { Arqueo } \\
\text { Bruto } \\
\text { (G.T.) }\end{array}$ \\
\hline Superstar Virgo & 1.870 & 1999 & 268,53 & 32,31 & 75.338 \\
Superstar Aquarius & 1.511 & 1993 & 229,82 & 32,00 & 51.039 \\
SuperStar Gemini & 1.530 & 1992 & 229,82 & 28,65 & 50.764 \\
Star Pisces & 1.009 & 1990 & 176,78 & 29,57 & 40.053 \\
Superstar Libra & 1.384 & 1988 & 216,10 & 28,35 & 42.285 \\
\hline
\end{tabular}

Fuente: Elaboración propia basada en ECC (2013), Star Cruises (2013) y Cruise Market Watch (2014b).

De forma análoga a la corriente registrada en los dos grupos anteriores, en los que ha habido movimientos de buques de unas navieras a otras de la misma empresa matriz, tres de los cinco buques que opera actualmente Star Cruises con anterioridad han sido explotados por NCL. El buque SupeStar Libra, entre 1988 y 2005 estuvo bajo la consigna de NCL con los nombres de Seaward (1988-1997) y Norwegian Sea (1997-2005), año a partir del cual adoptó su denominación actual en Star Cruises. El buque SuperStar Aquarius estuvo 14 años operado por NCL con dos nombres distintos Windward (1993-1998) y Norwegian Wind (1998-2007). La última incorporación a la flota de Star Cruises, el SuperStar Gemini en 2012, durante sus 20 años de vida anteriores ha ostentado la consigna de NCL con los nombres de Dreamward (1992-1998) y Norwegian Dream (1998-2008). Por último, el buque Star Pisces, entre 1990 y 1994 operó como buque cruiseferry para Rederi AB Slite, en 1994 y tras adaptarse totalmente a buque de crucero comenzó a ser explotado por Star Cruises. A diferencia de las navieras analizadas hasta el momento, ésta únicamente ofrece cruceros en la región de Asia-Pacífico y más en concreto en dos sectores, Extremo Oriente y Sudeste Asiático.

\section{I.4 Grupo de navieras independientes}

El grupo de navieras independientes está integrado por 29 navieras, tal y como se ha reflejado en el Capítulo III, apartado 3.1.4. Los siguientes sub-apartados detallan las características de cada una de las 29 navieras pertenecientes a este grupo, su ordenación en el texto atiende a la relación de mayor a menor tamaño dentro del grupo de navieras independientes.

\section{I.4.1 MSC Cruises}

MSC Cruises es una naviera de cruceros italiana, con domicilio social en Ginebra, fundada en 1987, originalmente su nombre era el de Flotta Lauro Lines. En 1989 la naviera Flotta Lauro fue adquirida por Mediterranean Shipping Company renombrándola con el 
nombre de StarLauro Crociere. En 1995 de nuevo registró un cambio de denominación tomando el actual nombre de MSC Cruises.

Actualmente, MSC Cruises dispone de una flota de doce buques, véase Tabla I.18, constituyendo una de las flotas de cruceros más jóvenes del mercado con una edad media de 7,08 años. Su capacidad de 30.557 pasajeros la convierte en la sexta naviera de cruceros a nivel mundial con un $6,66 \%$ de la capacidad y la primera independiente. Además, es el segundo mayor operador de cruceros en Europa tras el grupo Carnival Corporation \& plc.

Tabla I.18: Flota de MSC Cruises

\begin{tabular}{|c|c|c|c|c|c|}
\hline Nombre del Buque & $\begin{array}{c}\text { Capacidad de } \\
\text { Pasajeros }\end{array}$ & $\begin{array}{c}\text { Año de } \\
\text { construcción }\end{array}$ & $\begin{array}{c}\text { Eslora } \\
\text { (m) }\end{array}$ & $\begin{array}{c}\text { Manga } \\
\text { (m) }\end{array}$ & $\begin{array}{c}\text { Arqueo Bruto } \\
\text { (G.T.) }\end{array}$ \\
\hline MSC Preziosa & 3.959 & 2013 & 333,15 & 38,10 & 139.400 \\
\hline MSC Divina & 3.502 & 2012 & 333,30 & 37,92 & 139.400 \\
\hline MSC Splendida & 3.274 & 2009 & 333,30 & 37,92 & 137.936 \\
\hline MSC Fantasia & 3.274 & 2008 & 333,30 & 37,92 & 137.936 \\
\hline MSC Opera & 1.712 & 2004 & 251,25 & 28,80 & 59.058 \\
\hline MSC Lírica & 1.560 & 2003 & 251,25 & 28,80 & 59.058 \\
\hline MSC Sinfonia & 1.554 & 2002 & 251,25 & 28,80 & 58.625 \\
\hline MSC Armonia & 1.554 & 2001 & 251,25 & 28,80 & 58.625 \\
\hline MSC Magnifica & 2.518 & 2010 & 293,80 & 32,20 & 95.128 \\
\hline MSC Poesia & 2.550 & 2008 & 293,80 & 32,20 & 92.627 \\
\hline MSC Orchestra & 2.550 & 2007 & 293,80 & 32,20 & 92.409 \\
\hline MSC Musica & 2.550 & 2006 & 293,80 & 32,20 & 92.409 \\
\hline
\end{tabular}

Fuente: Elaboración propia basada en ECC (2013), MSC Cruceros (2013) y Cruise Market Watch (2014b).

Los doce buques han sido construidos en el astillero STX Europe de Saint Nazaire (Francia). El último buque en incorporarse a la flota ha sido el MSC Preziosa en marzo de 2013. MSC Cruises navega durante todo el año en el Mediterráneo, y ofrece una amplia gama de itinerarios de temporada en el Norte de Europa, el océano Atlántico, el Caribe, las Antillas francesas, América del Sur, Sur y Oeste de África y el mar Rojo.

\section{I.4.2 Disney Cruise Line}

Disney Cruise Line es una línea de cruceros propiedad de The Walt Disney Company, con sede en Lake Buena Vista (Florida, EE.UU.). Sus inicios se remontan al año 1998 en que comenzó a operar el primero de los buques de su flota, el Disney Magic (Disney Cruise Line, 2013). Actualmente la flota la configuran un total de cuatro buques, véase Tabla I.19, con una capacidad conjunta de 13.400 pasajeros, el 2,92\% de la capacidad mundial.

Con una edad media de nueve años, la flota está estructurada en dos series de buques compuestas de dos buques gemelos cada una. Con la incorporación en 2011 y 2012 de los buques Disney Dream y Disney Fantasy, respectivamente, la naviera ha ampliado su zona 
de operaciones incrementando el número de puertos base, como por ejemplo, Galveston, Texas y Miami. Actualmente los destinos cubiertos por la naviera comprenden: Alaska, costa del Pacífico Americana, Bahamas, Caribe, Europa, Riviera Mexicana, Canal de Panamá y Transatlántico. Como particularidad asociada a los itinerarios ofertados, destaca la escala en una pequeña isla privada propiedad de la compañía en las islas Bahamas, Castaway Cay. Por otro lado, para los cruceros por el Mediterráneo a bordo del buque Disney Magic, el puerto base utilizado es Barcelona.

Tabla I.19: Flota de Disney Cruise Line

\begin{tabular}{|c|c|c|c|c|c|}
\hline Nombre del Buque & $\begin{array}{c}\text { Capacidad de } \\
\text { Pasajeros }\end{array}$ & $\begin{array}{c}\text { Año de } \\
\text { construcción }\end{array}$ & $\begin{array}{c}\text { Eslora } \\
\text { (m) }\end{array}$ & $\begin{array}{c}\text { Manga } \\
\text { (m) }\end{array}$ & $\begin{array}{c}\text { Arqueo } \\
\text { Bruto } \\
\text { (G.T.) }\end{array}$ \\
\hline Disney Fantasy & 4.000 & 2012 & 330,10 & 36,88 & 129.750 \\
\hline Disney Dream & 4.000 & 2011 & 330,10 & 36,88 & 129.690 \\
\hline Disney Wonder & 2.700 & 1999 & 293,83 & 32,31 & 83.308 \\
\hline Disney Magic & 2.700 & 1998 & 293,83 & 32,31 & 83.338 \\
\hline
\end{tabular}

Fuente: Elaboración propia basada en ECC (2013), Disney Cruise Line (2013) y Cruise Market Watch (2014b).

\section{I.4.3 Hurtigruten}

Hurtigruten, fundada en 1893 y con sede en Narvik (Noruega), tiene su origen ligado al reto del capitán Richard With de inaugurar una ruta marítima regular entre el sur de Noruega y las costas del norte, conocida como el Expreso del Litoral. Toda una proeza en aquellos tiempos pues la ruta comprendía un cinturón de miles de islas y arrecifes sin cartografiar ni balizar, bañado por las corrientes más fuertes de Europa, se extendía entre la costa y el océano a lo largo de todo el litoral del país. Actualmente los buques de su flota son de uso mixto y sirven al mismo tiempo como barcos de carga, barcos de transporte de pasajeros entre ciudades y barcos de crucero de placer (Hurtigruten, 2013). Con el tiempo, la ruta de Hurtigruten ha pasado de ser un simple medio de transporte, que es su función real, a ser además una importante atracción turística conocida internacionalmente.

Las características de su flota de doce buques, véase Tabla I.20, se adecúan a los tipos de cruceros que ofertan, viajes por Noruega, cruceros de aventura/exploración y cruceros experienciales. La edad media de la flota, exceptuando los buques MS Lofoten y $M S$ Vesteralen, es de 15,70 años, teniendo en cuenta los dos emblemáticos buques citados anteriormente, la edad media se eleva hasta los 19,83 años. De forma conjunta la capacidad de la flota Hurtigruten es de 7.721 pasajeros, el 1,68\% de la capacidad mundial. 


\begin{tabular}{lccccc}
\hline & HURTIRUTER & & \\
Nombre del Buque & $\begin{array}{c}\text { Capacidad de } \\
\text { Pasajeros }\end{array}$ & $\begin{array}{c}\text { Año de } \\
\text { construcción }\end{array}$ & $\begin{array}{c}\text { Eslora } \\
\text { (m) }\end{array}$ & $\begin{array}{c}\text { Manga } \\
\text { (m) }\end{array}$ & $\begin{array}{c}\text { Arqueo Bruto } \\
\text { (G.T.) }\end{array}$ \\
\hline MS Nordnorge & 623 & 1997 & 123,3 & 19,5 & 11.384 \\
MS Nordkapp & 622 & 1996 & 123,3 & 19,5 & 11.386 \\
MS Polarlys & 619 & 1996 & 123,0 & 19,5 & 11.341 \\
MS Nordlys & 622 & 1994 & 121,8 & 19,2 & 11.204 \\
MS Kong Harald & 622 & 1993 & 121,8 & 19,2 & 11.204 \\
MS Richard With & 623 & 1993 & 121,8 & 19,2 & 11.205 \\
MS Fram & 318 & 2007 & 114,0 & 20,2 & 11.647 \\
MS Midnatsol & 1.000 & 2003 & 135,7 & 21,5 & 16.151 \\
MS Finnmarken & 1.000 & 2002 & 138,5 & 21,5 & 15.690 \\
MS Trollfjord & 822 & 2002 & 135,7 & 21,5 & 16.140 \\
MS Lofoten & 340 & 1964 & 87,40 & 13,2 & 2.621 \\
MS Vesteralen & 510 & 1983 & 108,0 & 16,5 & 6.261 \\
\hline
\end{tabular}

Fuente: Elaboración propia basada en ECC (2013), Hurtigruten (2013) y Cruise Market Watch (2014b).

Los cruceros que recorren la costa noruega realizan diversos itinerarios según la estación del año. En cuanto a los cruceros de aventura, éstos recorren Islandia, Groenlandia, La Antártida y Spitsbergen. Por último, los cruceros experienciales centran la atención en excursiones por los fiordos noruegos, la época del sol de medianoche y las auroras boreales (Hurtigruten, 2013).

\section{I.4.4 Thomson Cruises}

Thomson Cruises, constituye la línea de cruceros asociada a la compañía Thomson Holidays. Dispone de una flota de 5 buques de tamaño mediano, véase Tabla I.21, con una edad media de 28,60 años. Estos 5 buques le confieren una capacidad de 7.020 pasajeros, lo que supone un $1,53 \%$ de la cuota mundial y el cuarto operador dentro de las navieras independientes. Los cinco buques de que dispone actualmente con anterioridad han pertenecido a otras compañías navieras, algunas de ellas ya desaparecidas a día de hoy.

El buque Thomson Dream, entre 1986 y 1988 ostentaba el nombre de Homeric II para la naviera Home lines. Durante el periodo de 1988 a 2002 pasó a ser propiedad de Holland America Line y renombrado como Westerdam. Su siguiente etapa, de 2002 a 2010 , la desarrolló como Costa Europa en la compañía Costa Cruceros. Finalmente, en 2010 pasó a ser operado por Thomson Cruises con la consigna actual de Thomson Dream. Si bien cabe mencionar que este buque fue alargado en 36,1 metros respecto de su eslora original en el año 1989.

El crucero Thomson Celebration desde el año 2005 está operado por Thomson Cruises, con anterioridad, desde su construcción en 1984 navegó bajo la consigna de Noordam para Holland America Line. El buque Thomson Spirit, forma parte de la flota desde 
2002; fue construido en 1983 como Nieuw Amsterdam para Holland America Line, naviera en la que estuvo hasta el año 2000 en que pasó a denominarse Patriot en la United State Line. El buque Thomson Majesty construido en 1992, el de menor edad de la flota; entre 1992 y 1997 fue propiedad de Majesty Cruise Line bajo el nombre de Royal Majesty. De 1997 a 2009 operó bajo la consigna de Norwegian Cruise Line como Norwegian Majesty, durante este periodo el buque fue alargado en 33,76 metros respecto a su eslora original. Tras esta etapa, en 2009 fue adquirido por Louis Cruise Line renombrándolo Louis Majesty; en 2012 pasó a ser operado por Thomson Cruises con su denominación actual de Thomson Majesty.

El actual buque Island Escape, fue construido en 1982 como buque ferry; en 1985 fue reconvertido en buque de crucero y adquirido por Sundance Cruises, renombrándolo como Stardancer. En 1987 pasó a ser propiedad de Admiral Cruises manteniendo el mismo nombre hasta el año 1990. Durante el periodo de 1990 a 2002 estuvo bajo propiedad de Royal Caribbean International con el nombre Viking Serenade. En 2002 cambió de nuevo de propietario y nombre pasando a estar en posesión de Island Cruises hasta 2009 como Island Escape; manteniendo este último nombre pasó a ser propiedad de Thomson Cruises en 2009. En relación con este último buque, desde el 13 de marzo de 2013 los cruceros a bordo de él se comercializan a través de una marca subsidiaria de Thomson Cruises denominada Island Cruises. La principal característica asociada a esta marca la constituye el régimen de "todo incluido" de sus cruceros. Los buques Thomson Spirit y Thomson Majesty son propiedad de Louis Cruises y fletados por tiempo a Thomson Cruises (Thomson Cruises, 2013).

Tabla I.21: Flota de Thomson Cruises

\section{Thomson Cruises}

\begin{tabular}{lccccc} 
Nombre del Buque & $\begin{array}{c}\text { Capacidad de } \\
\text { Pasajeros }\end{array}$ & $\begin{array}{c}\text { Año de } \\
\text { construcción }\end{array}$ & $\begin{array}{c}\text { Eslora } \\
(\mathbf{m})\end{array}$ & $\begin{array}{c}\text { Manga } \\
\text { (m) }\end{array}$ & $\begin{array}{c}\text { Arqueo } \\
\text { Bruto } \\
\text { (G.T.) }\end{array}$ \\
\hline Thomson Majesty & 1.462 & 1992 & 207,0 & 28,0 & 40.876 \\
Thomson Dream & 1.506 & 1986 & 243,0 & 32,0 & 55.000 \\
Thomson Celebration & 1.254 & 1984 & 214,6 & 27,3 & 33.930 \\
Thomson Spirit & 1.254 & 1983 & 214,6 & 27,3 & 33.930 \\
Island Escape & 1.544 & 1982 & 185,0 & 27,0 & 40.132 \\
\hline
\end{tabular}

Fuente: Elaboración propia basada en ECC (2013), Thomson Cruises (2013) y Cruise Market Watch (2014b).

Esta naviera está firmemente implementada en el mercado emisor de Reino Unido. Sus principales destinos son Norte de Europa (Países Escandinavos, Báltico y Reino Unido), Mediterráneo (Occidental y Oriental), Canarias y Marruecos (uno de los destinos de mayor demanda del mercado británico), así como, el Caribe. 


\section{I.4.5 TUI Cruises}

TUI Cruises, fundada en abril de 2008 y con sede en Hamburgo (Alemania), está dirigida al mercado alemán. La compañía es un Joint Venture de TUI AG y Royal Caribbean Cruises Ltd. (TUI Cruises, 2013). Actualmente cuenta con una flota de tres buques de 12 años de edad media, véase Tabla I.22.

Tabla I.22: Flota de TUI Cruises

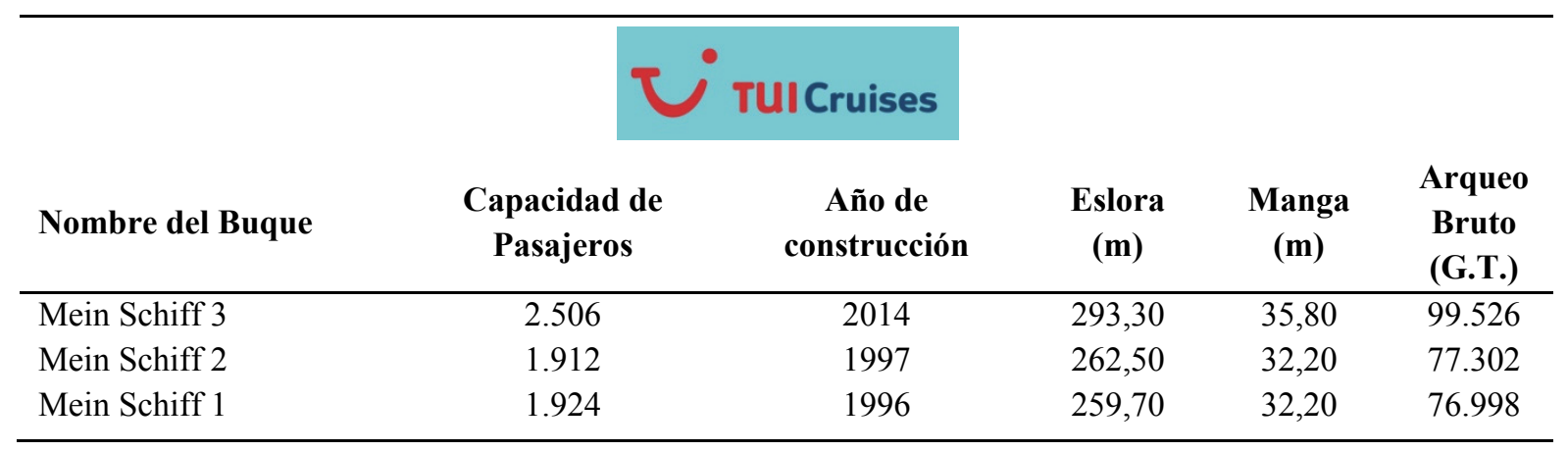

Fuente: Elaboración propia basada en ECC (2013), TUI Cruises (2013) y Cruise Market Watch (2014b).

En total los tres buques confieren a la compañía una capacidad de 6.342 pasajeros, el 1,38\% mundial, y el quinto operador independiente. El primer buque de TUI Cruises, el Mein Schiff 1, comenzó a operar para la compañía en mayo de 2009. Anteriormente, este buque fue propiedad y operado por Celebrity Cruises con el nombre de Celebrity Galaxy entre 1996 y 2009. El segundo buque, Mein Schiff 2, comenzó a formar parte de la flota en mayo de 2011. De forma análoga al caso del Mein Schiff 1, éste con anterioridad fue propiedad y operado por Celebrity Cruises, en este caso con el nombre de Celebrity Mercury entre los años 1997 y 2011.

Ambos buques al ser adquiridos por TUI Cruises fueron sometidos a un proceso de remodelación para adaptarlos a los estándares de la naviera. Los principales conceptos de disposición general de los buques centran la atención en disponer de varias cubiertas y camarotes amplios con balcón o terraza. En concreto, prácticamente la mitad de los 962 camarotes del Mein Schiff 1 y los 956 camarotes en el Mein Schiff 2 cuentan con balcón o terraza de hasta $24 \mathrm{~m}^{2}$.

Derivado del éxito cosechado con la operación de los buques Mein Schiff 1 y 2, la naviera ha optado por un plan de expansión de la flota con la incorporación de dos buques gemelos. Para ello ha firmado un contrato de construcción con el astillero STX Finland Oy. El primero de estos buques (Mein Schiff 3) entró en operación en abril de 2014 y el segundo está previsto para abril de 2015 (Mein Schiff 4). La habilitación de estos buques está configurada en 1.250 camarotes, repartidos en 15 cubiertas con un $90 \%$ de camarotes exteriores y el $82 \%$ provistos de balcón (ECC, 2013).

TUI Cruises ofrece a sus cruceristas su concepto premium todo-incluido. Desde delicias italianas a especialidades de marisco a través de un cóctel en el Bar TUI, casi todas 
las comidas y bebidas en la mayoría de los restaurantes y bares se incluyen en el precio del crucero. No se incluye en este concepto determinados restaurantes especializados, así como, las excursiones en tierra, los artículos en las tiendas de a bordo y los tratamientos de spa. Los cruceristas sólo tienen que pagar un pequeño suplemento en los restaurantes especializados comentados anteriormente. TUI Cruises cubre además de cruceros por el Mediterráneo Oriental y Occidental, rutas por las islas Canarias, Caribe, Báltico, mar del Norte, Gran Bretaña, Islandia y Dubái desde el golfo Pérsico (TUI Cruises, 2013).

\section{I.4.6 Oceania Cruises}

Oceania Cruises, fundada en 2002 y con sede en Miami (EE.UU.), pertenece a Prestige Cruise Holdings, la cual se encarga de administrar los activos de inversión en el mercado de cruceros de Apollo Management, constituyendo el líder del mercado en los segmentos premium superior y de lujo de la industria de cruceros. Entre las principales características que definen el producto cinco estrellas ofertado por la naviera, reside el trato personalizado ofrecido a bordo como resultado de disponer de un ratio de dos tripulantes por cada tres pasajeros. La flota de Oceania Cruises la componen un total de cinco buques, véase Tabla I.23, lo cual supone una capacidad de 4.552 pasajeros, el 0,99\% del total mundial.

Tabla I.23: Flota de Oceania Cruises

\begin{tabular}{|c|c|c|c|c|c|}
\hline Nombre del Buque & $\begin{array}{c}\text { Capacidad de } \\
\text { Pasajeros }\end{array}$ & $\begin{array}{c}\text { Año de } \\
\text { construcción }\end{array}$ & $\begin{array}{c}\text { Eslora } \\
\text { (m) }\end{array}$ & $\begin{array}{c}\text { Manga } \\
\text { (m) }\end{array}$ & $\begin{array}{c}\text { Arqueo } \\
\text { Bruto } \\
\text { (G.T.) }\end{array}$ \\
\hline Riviera & 1.250 & 2012 & 239,00 & 32,00 & 66.084 \\
\hline Marina & 1.250 & 2011 & 239,00 & 32,00 & 66.084 \\
\hline Nautica & 684 & 2000 & 181,00 & 25,00 & 30.277 \\
\hline Regatta & 684 & 1998 & 181,00 & 25,00 & 30.277 \\
\hline Insignia & 698 & 1998 & 180,45 & 25,73 & 30.277 \\
\hline
\end{tabular}

Fuente: Elaboración propia basada en ECC (2013), Oceania Cruises (2013) y Cruise Market Watch (2014b).

Los cinco buques que opera actualmente se agrupan en dos tipologías, con dos y tres buques, respectivamente, cada una de ellas. De forma conjunta la edad media de la flota es de 10,2 años. Los buques Riviera y Marina son los de más reciente incorporación a la flota, ambos construidos por el astillero italiano Fincatieri. En concreto, el buque Marina constituye la primera nueva construcción encargada por la naviera. Los tres buques restantes con anterioridad pertenecieron a la hoy desaparecida naviera Renaissance Cruises. El buque Regatta entre 1998 y 2001 ostentaba el nombre $R$ Two en la naviera citada anteriormente, hasta que en 2002 pasó a ser operado por Oceania con el nombre de Insignia entre 2002 y 2003, año a partir del cual adoptó su actual nombre. La trayectoria del buque Nautica comprende una naviera más que la de su gemelo. De 2000 a 2001 fue propiedad de Renaissance Cruises con la denominación de R Five. Entre 2002 y 2005 fue operado por 
Pullmantur. Finalmente, en 2005 comenzó a operar para Oceania Cruises con su actual denominación en régimen de fletamento por tiempo, adquiriendo su propiedad en 2006. El buque Insignia, construido en 1998, prestó sus servicios en Renaissance Cruises hasta 2004 con el nombre $R$ One, en 2004 Oceania adquirió su propiedad, fletándolo por tiempo a Hapag Lloyd entre 2012 y 2014 bajo la denominación de Columbus 2.

Como compañía de cruceros de mayor tamaño en el segmento premium superior y líder del destination cruising, Ocenia Cruises navega a más de 330 puertos de todo el mundo. Además de los cruceros por regiones de Europa, Asia, Australia, Nueva Zelanda y América, también oferta cruceros transoceánicos y de vuelta al mundo. Los itinerarios combinan a la perfección puertos atípicos y must see ports. La multitud de escalas nocturnas permiten realizar un análisis en profundidad y obtener una enriquecedora experiencia en el destino, además de, permitir a los viajeros sumergirse en la gastronomía, la cultura y la historia de los puertos que se visitan. Los buques de pequeño y mediano tamaño con capacidad para 684 y 1.250 pasajeros permiten visitar pueblos costeros a los que buques de gran tamaño no pueden acceder (Oceania Cruises, 2013).

\section{I.4.7 Fred. Olsen Cruise Lines}

Fred. Olsen Cruise Lines, con sede en Ipswich (Reino Unido), tiene su origen ligado a la creación en el año 1848 de una compañía de transporte marítimo en Noruega por parte de la familia Olsen (Fred Olsen Cruises, 2013a). Hasta el año 1966 no se crea la división de cruceros, englobándose esta línea de negocio dentro del grupo Fred. Olsen. Actualmente, los tráficos que opera el grupo son el de cruceros junto con el de transporte marítimo de pasajeros en régimen de línea regular. Su flota la componen cuatro buques, véase Tabla I.24, con una capacidad conjunta de 3.963 pasajeros, el 0,86\% de la capacidad mundial y séptimo operador independiente. En su flota no dispone de ningún buque de nueva construcción encargado por la naviera, contando la flota con una edad media de 32,5 años.

Tabla I.24: Flota de Fred. Olsen Cruise Lines

\begin{tabular}{|c|c|c|c|c|c|}
\hline Nombre del Buque & $\begin{array}{c}\text { Capacidad de } \\
\text { Pasajeros }\end{array}$ & $\begin{array}{c}\text { Año de } \\
\text { construcción }\end{array}$ & $\begin{array}{c}\text { Eslora } \\
\text { (m) }\end{array}$ & $\begin{array}{c}\text { Manga } \\
\text { (m) }\end{array}$ & $\begin{array}{c}\text { Arqueo } \\
\text { Bruto } \\
\text { (G.T.) }\end{array}$ \\
\hline Braemar & 929 & 1993 & 195,92 & 22,50 & 24.344 \\
\hline Balmoral & 1.350 & 1988 & 218,18 & 28,20 & 43.537 \\
\hline Boudicca & 880 & 1973 & 205,47 & 25,20 & 28.388 \\
\hline Black Watch & 804 & 1972 & 205,47 & 25,20 & 28.613 \\
\hline
\end{tabular}

Fuente: Elaboración propia basada en ECC (2013), Fred Olsen Cruises (2013b) y Cruise Market Watch (2014b).

El buque Balmoral, entre 1988 y 1996 fue operado por Royal Cruise Line bajo la denominación de Crown Odyssey. De 1996 a 2000 adquirió la consigna de NCL bajo el 
nombre Norwegian Crown. Entre el año 2000 y 2003 cambió de nuevo de operador y de denominación, en este caso Crown Odyssey para Orient Lines; de 2003 a 2007 vuelve de nuevo a retomar la denominación que ostentaba en NCL. Finalmente en 2007 Fred Olsen adquirió su propiedad dotándolo de su denominación actual, así como, sometiéndolo a una transformación de alargamiento en 30 metros respecto a su eslora original incluyendo una remodelación completa.

El buque Black Watch, el de mayor edad de la flota, entre 1972 y 1991 formó parte de la flota de Royal Viking Line bajo la denominación de Royal Viking Star. Su siguiente etapa, de 1991 a 1994, la desarrolló en NCL como Westerdam. De 1994 a 1996 fue operado por Royal Cruise Line bajo la denominación de Star Odyssey; en 1996 adoptó la consigna actual en Fred. Olsen, sometiéndose en 2009 a un proceso de remodelación.

El buque Boudicca cuenta con una dilatada experiencia por numerosas navieras. De 1973 a 1991 formó parte de la flota de Kloster Cruise bajo la denominación de Royal Viking $S k y$ (en esta etapa el buque fue alargado en 27,8 metros respecto a su eslora original). Entre 1991 y 1992 cambió su nombre a Sunward operado por NCL; en 1992 adquirió su propiedad Birka Cruises la cual lo renombró Birka Queen. En 1993 fue fletado a Princess Cruises bajo la consigna de Golden Princess. En 1997 de nuevo cambió de propietario, esta vez a favor de Star Cruises con el nombre de Superstar Capricorn. Entre 1998 y 2001 fue fletado a Hyundai Merchant Marine como Hyundai Keumgang. De nuevo en 2001 volvió a formar parte de la flota de Star Cruises con su anterior denominación. En 2004 cambió de propietario, siendo el nuevo Iberojet renombrándolo Grand Latino. Por último, en 2005 Fred Olsen Cruise Lines adquirió su propiedad dotándolo de la denominación actual. Además, en 2011 el buque fue sometido a un proceso de remodelación completo.

El buque Braemar fue construido en 1993 para la naviera Crown Cruise Line con el nombre Crown Dinasty. Ese mismo año fue fletado a Cunard Line renombrándolo Cunard Crown Dinasty. Entre 1997 y 1999 de nuevo fue fletado pero en esta ocasión a NCL, etapa en la cual ostentó la consigna de Norwegian Dinasty. En 1999 retornó a su propietario, el cual lo operó hasta 2001 con su nombre original, Crown Dinasty. En 2001 Fred Olsen Cruise Lines adquirió su propiedad dotándolo de su denominación actual. Además, en 2008 este buque fue remodelado y alargado en 33,2 metros (Fred Olsen Cruises, 2013b).

Fred Olsen Cruise Lines está especializada y dispone de un dilatado arraigo en el mercado de Reino Unido. De ahí que la mayoría de los cruceros zarpen de puertos de Reino Unido (Tilbury, Avonmouth, Dover, Glasgow, Harwich, Liverpool, Newcastle y Southampton), Irlanda del Norte (Belfast), además de, la posibilidad de fly \& cruise, aunque esta opción es minoritaria. Los itinerarios comprenden las regiones europeas más populares, Mediterráneo, Báltico, Noruega e islas Canarias, Caribe, así como, cruceros exóticos y de vuelta al mundo. El tamaño compacto de los buques disponibles en su flota los hace ideales para explorar zonas de difícil acceso como los fiordos, el Ártico o pequeñas islas en el océano Pacifico y Caribe (ECC, 2013). 


\section{I.4.8 Louis Cruises}

Louis Cruises, fundada en 1987, forma parte del grupo empresarial Louis Group fundado en 1935 como compañía de transportes marítimos con sede en Limassol (Chipre). En sus primeros pasos en el mercado de cruceros, operaba cruceros de corta duración desde Limassol a puertos del Mediterráneo Oriental. Louis Cruises ha evolucionado a lo largo de los años y ampliado sus programas de cruceros, convirtiéndose en operador de cruceros especializado en el Mediterráneo Oriental. A día de hoy cuenta con una flota de cinco buques, tres de ellos son propiedad y operados por la naviera, véase Tabla I.25, mientras que los dos restantes (Thomson Spirit y Majesty) están fletados a Thomson Cruises como se ha descrito anteriormente (Louis Cruises, 2013).

Tabla I.25: Flota de Louis Cruises

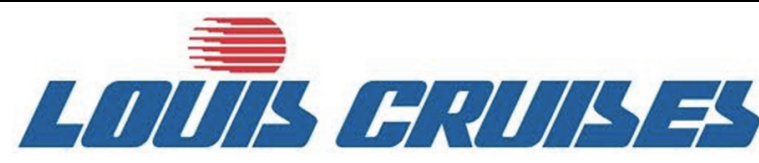

\begin{tabular}{lccccc} 
Nombre del Buque & $\begin{array}{c}\text { Capacidad de } \\
\text { Pasajeros }\end{array}$ & $\begin{array}{c}\text { Año de } \\
\text { construcción }\end{array}$ & $\begin{array}{c}\text { Eslora } \\
(\mathbf{m})\end{array}$ & $\begin{array}{c}\text { Manga } \\
(\mathbf{m})\end{array}$ & $\begin{array}{c}\text { Arqueo } \\
\text { Bruto } \\
\text { (G.T.) }\end{array}$ \\
\hline Louis Olympia & 1.664 & 1982 & 214,88 & 28,40 & 37.584 \\
Louis Cristal & 950 & 1980 & 162,00 & 25,60 & 25.611 \\
Louis Aura & 895 & 1968 & 160,13 & 22,80 & 15.781 \\
\hline
\end{tabular}

Fuente: Elaboración propia basada en ECC (2013), Louis Cruises (2013) y Cruise Market Watch (2014b).

Los tres buques que opera actualmente le confieren una capacidad de 3.509 pasajeros, el $0,76 \%$ de la cuota mundial. Como en casos anteriores, los buques que componen su flota con anterioridad han sido explotados por otras navieras, no constituyendo ninguno de los actuales una nueva construcción encargada por la naviera.

El buque Louis Olympia, entre 1982 y 1999 perteneció a la naviera Royal Caribbean International bajo la denominación de Song of America. Su siguiente etapa, 1999-2005, la desarrolló como Sunbird para Sun Cruises. A continuación ostentó la consigna de Thomson Cruises como Thomson Destiny entre 2005 y 2012. A partir de ese año adquirió la denominación actual en Louis Cruises. El buque Louis Cristal en sus orígenes era un buque ferry, hasta el año 1987 no se transformó en buque de cruceros con el nombre de Sally Albatross en la compañía Silja Line. En 1994 pasó a ser operado por Norwegian Cruise Line como Leeward hasta 1999. Año en el cual cambió su denominación a Superstar Taurus en Star Cruises. Entre 2002 y 2007 volvió a ser operado por Silja Lines pero en este caso como Silja Opera. En 2007 fue adquirido por Louis Cruises adoptando su denominación actual. El buque Louis Aura, el de mayor edad de la flota, dispone de un dilatado bagaje por diversas navieras. Este buque fue construido para Norwegian Cruise Line como Starward, formando parte de su flota entre 1968 y 1995. De 1995 a 2004 formó parte de la flota de Festival Cruises con el nombre de Bolero. En 2004 fue adquirido por una compañía armadora libanesa, Orient Queen Shipping, renombrándolo Orient Queen. Finalmente, en 2006 pasó a 
ser propiedad de Louis Cruises manteniendo su anterior nombre hasta marzo de 2013 en que cambia a Louis Aura.

Louis Cruises se ha convertido en la compañía de cruceros líder en el Mediterráneo Oriental y aún hoy hace escala en puertos en los que ninguna otra compañía está presente (ECC, 2013). Los principales puertos desde los que se ofertan cruceros son El Pireo, Estambul, Limassol, Izmir y Kusadasi hacia las islas Griegas y puertos turcos atractivos (Louis Cruises, 2013).

\section{I.4.9 Phoenix Reisen}

Phoenix Reisen es una empresa de propiedad y gestión privada, fundada en 1973, con sede en Bonn (Alemania). Aunque los cruceros son la principal línea de negocio de la empresa, tanto marítimos como fluviales (de hecho es el líder del mercado alemán de cruceros por el Nilo), la compañía también ofrece vacaciones en la playa, circuitos y programas especiales por Oriente.

Phoenix Reisen es uno de los líderes en el mercado alemán tanto en la figura de operador como de fletador. Actualmente cuenta con una flota de tres buques de navegación marítima y 46 cruceros fluviales repartidos por todo el mundo. Centrando la atención en los buques de navegación marítima, véase Tabla I.26, los cuales son objeto de esta tesis, la edad media de la flota asciende a 31,3 años. De forma análoga a casos expuestos anteriormente, entre su flota no se encuentra ningún buque de nueva construcción encargado por esta naviera. En su conjunto la flota tiene una capacidad de 2.612 pasajeros, lo cual equivale a una cuota del $0,57 \%$ mundial.

Tabla I.26. Flota de Phoenix Reisen

\begin{tabular}{lccccc}
\hline & & & & & \\
Arqueo \\
Nombre del Buque & $\begin{array}{c}\text { Anacidad de } \\
\text { Pasajeros }\end{array}$ & construcción & (m) & (m) & $\begin{array}{c}\text { Bruto } \\
\text { (G.T.) }\end{array}$ \\
\hline Amadea & 600 & 1991 & 193,00 & 25,00 & 28.856 \\
Artania & 1.200 & 1984 & 231,00 & 29,00 & 44.348 \\
Albatros & 812 & 1973 & 205,00 & 27,00 & 28.518 \\
\hline
\end{tabular}

Fuente: Elaboración propia basada en ECC (2013), Phoenix Reisen (2013) y Cruise Market Watch (2014b).

El buque Artania, entre 1984 y 2005 fue propiedad y operado por Princess Cruises con el nombre de Royal Princess. Su siguiente etapa, de 2005 a 2011, la desarrolló como Artemis en $P \& O$ Cruises. En 2011 Phoenix adquirió su propiedad dotándolo con el nombre de Artania. El buque Amadea, el de menor edad de la flota, antes de su incorporación en 2006 a Phoenix Reisen ostentó la consigna de Asuka en NYK Cruises. 
Respecto al buque Albatros, el de mayor edad de la flota, tiene un recorrido mucho más dilatado que el resto de buques de la flota por varias navieras. Entre 1973 y 1991 formó parte de la flota de Royal Viking Line como Royal Viking Sea. En 1991 cambió de propietario a Royal Cruise Line renombrándolo Royal Odyssey. Su siguiente etapa, de 1997 a 2002 la desarrolló en NCL con dos nombres Norwegian Star y Norwegian Star 1. En 2002 de nuevo cambió de nombre, esta vez a Crown, siendo operado por Crown Investment; en su penúltima etapa antes de llegar a Phoenix Reisen en 2005 ostentó la consigna de Crown Mare Nostrum en Spanish Cruise Line.

Los cruceros con Phoenix Reisen tienen un notable carácter clásico, alejado de grandes masas, estableciendo el alemán como idioma oficial. Además, ofrecen un ambiente muy personal, familiar y casual. Disponen de cruceros que se adaptan a las diferentes demandas y presupuestos, con un elevado número de cruceristas repetidores. Los buques combinan el estilo clásico con toques de modernidad, operando en todo el mundo incluyendo la vuelta al mundo cada temporada de invierno (Phoenix Reisen, 2013).

\section{I.4.10 Silversea Cruises}

Silversea Cruises, fundada por la familia Lefebvre de Roma a comienzos de los años 90, tiene su sede en Monte Carlo (Principado de Mónaco). Esta compañía se enmarca en el segmento de cruceros de ultra lujo, con un tipo de buque más pequeño, creado especialmente con capacidad para alcanzar puertos exóticos fuera de las rutas tradicionales (ECC, 2013). En 1994 comenzaron a operar su primer buque, a día de hoy la flota la componen ocho buques, véase Tabla I.27, con una edad media de 18,1 años. Además, los buques Silver Discoverer, Silver Explorer y Silver Galapagos están destinados a realizar cruceros de aventura englobados bajo la marca Silversea Expeditions. La capacidad total de la flota es de 2.248 pasajeros, $0,49 \%$ mundial, y por tanto, décimo operador independiente.

Tabla I.27: Flota de Silversea Cruises

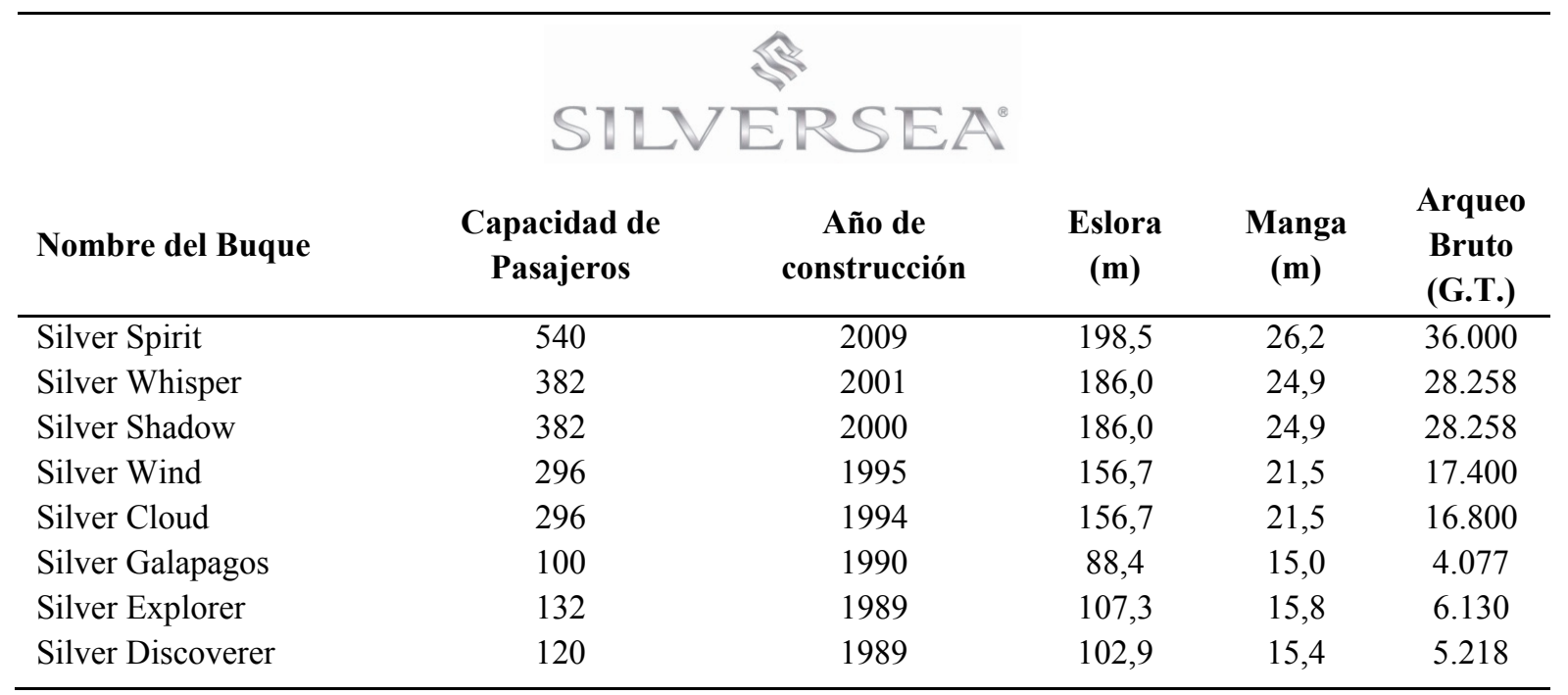

Fuente: Elaboración propia basada en Silversea Cruises (2013) y Cruise Market Watch (2014b). 
Estos buques de ambiente privado y exclusivo se han diseñado especialmente para recibir a un número reducido de pasajeros, ofreciendo más espacio y un alto nivel de servicio personalizado. Los camarotes son de los más espaciosos actualmente, cuentan todos con vista al mar, servicio de mayordomo y balcones privados.

Exceptuando los tres buques destinados a cruceros de aventura, los cinco restantes únicamente han sido operados por Silversea, se trata de nuevas construcciones encargadas por la naviera. El buque Silver Galapagos desde su construcción en 1990 hasta 1998 ostentó la consigna de Reinassance Cruises con el nombre de Reinassance III. Su siguiente etapa, de 1998 a 2012, recibió el nombre de Galapagos Explorer II para Canodros S.A. En 2012 Silversea anunció la adquisición de Canodros S.A. incorporando este buque a su flota con el nombre de Silver Galapagos. El buque Silver Discoverer incorporado a la flota en marzo de 2014 cuenta con todas sus suites con vistas al mar y amplios espacios en cubierta. Además, su reducido calado le permite navegar cerca de la costa y en aguas poco profundas. Junto a lo anterior dispone de 12 embarcaciones neumáticas y otra adicional con fondo de cristal, lo cual permite recalar en costas aisladas y explorarlas en profundidad.

Los cruceros de Silversea cubren un amplio espectro de destinos. Desde rutas tradicionales por el Mediterráneo, Norte de Europa, Báltico, Alaska, Caribe, Canadá y Nueva Inglaterra, con acceso exclusivo a determinadas zonas gracias al reducido tamaño de los buques. Pasando por cruceros exóticos por Asia, África y Sudamérica, así como, cruceros transoceánicos y de vuelta al mundo. Hasta cruceros expedicionarios por el Ártico, Antártida e islas Galápagos (Silversea Cruises, 2013).

\section{I.4.11 Cruise \& Maritime Voyages}

Cruise \& Maritime Voyages, fundada en 2009 y con sede en Purfleet (Essex, Reino Unido) está especializada en el mercado de Reino Unido ofreciendo cruceros con puerto base únicamente en puertos de este país. Su origen está ligado a la reestructuración en el año 2010 de la naviera alemana Transocean Tours. Opera tres buques, véase Tabla I.28, todos ellos en régimen de fletamento por tiempo (Cruise \& Maritime Voyages, 2013). La flota, cuya edad media se sitúa alrededor de 39,7 años, tiene una capacidad total de 2.100 pasajeros, el $0,46 \%$ de la cuota mundial.

Tabla I.28: Flota de Cruise \& Maritime Voyages

\begin{tabular}{|c|c|c|c|c|c|}
\hline Nombre del Buque & $\begin{array}{c}\text { Capacidad de } \\
\text { Pasajeros }\end{array}$ & $\begin{array}{c}\text { Año de } \\
\text { construcción }\end{array}$ & $\begin{array}{c}\text { Eslora } \\
\text { (m) }\end{array}$ & $\begin{array}{c}\text { Manga } \\
\text { (m) }\end{array}$ & $\begin{array}{c}\text { Arqueo } \\
\text { Bruto } \\
\text { (G.T.) }\end{array}$ \\
\hline Astor & 600 & 1987 & 176,50 & 22,61 & 20.606 \\
\hline Discovery & 700 & 1971 & 168,74 & 24,64 & 20.186 \\
\hline Marco Polo & 800 & 1965 & 176,30 & 23,60 & 22.080 \\
\hline
\end{tabular}

Fuente: Elaboración propia basada en Cruise \& Maritime Voyages (2013) y Cruise Market Watch (2014b). 
El buque Marco Polo, el de mayor edad de la flota, tiene una estampa marinera típica de los clásicos buques transatlánticos. Entre 1965 y 1991 formó parte de la flota de la naviera soviética Baltic Shipping Company como Alexandr Pushkin. A partir de 1993 adquirió la denominación de Marco Polo recorriendo varias navieras, Orient Lines (1993-2008), Transocean Tours (2008-2010) y Cruise \& Maritime Voyages desde 2010 hasta la actualidad. Este buque tiene la particularidad de que está orientado para adultos únicamente, de ahí que se comercialicen sus cruceros como "child free", de tal forma que la edad mínima de acceso al buque es de 16 años o superior y siempre deben ir acompañados de adultos.

El buque Discovery está fletado a esta naviera desde febrero de 2013, en bloques de 249 días, gracias a un acuerdo de colaboración con All Leisure Holidays la cual también opera este buque bajo la marca Voyages of Discovery. De forma análoga al caso del buque Marco Polo no dispone de instalaciones dedicadas a niños, si bien los niños y adolescentes menores de 18 años de edad son aceptados siempre y cuando vayan acompañados de adultos. Anteriormente formó parte de la flota de otras navieras como, Island Venture en Flagship Cruises (1971-1974), Island Princess en Princess Cruises (1974-2000), Hyundai Pungak en Hyundai Merchant Marine (2000-2003) y Discovery en Voyages of Discovery (2003-2013).

El buque Astor entró en servicio para la flota de Cruise \& Maritime Voyages el 5 de noviembre de 2013. En 2010 este buque se sometió a un profundo proceso de remodelación. Desde su construcción en 1987 el buque ha sido operado por varias navieras ostentando dos denominaciones, Astor en Marlan Corporation (1987-1988), Feodor Dostoevsky para Baltic Shipping Company (1988-1995) y de nuevo Astor en Transocean Tours (1995-2013).

Los itinerarios ofertados discurren fundamentalmente por el Norte de Europa (Noruega, Báltico, mar Céltico, Islandia, etc.), Azores, Madeira e islas Canarias. Con la reciente incorporación del buque Astor, sus itinerarios comprenden navegaciones por Sudáfrica y Australia, en cruceros de larga duración (Cruise \& Maritime Voyages, 2013).

\section{I.4.12 Portuscale Cruises}

Portuscale Cruises, de reciente creación en febrero de 2013, es la única compañía de cruceros de origen portugués cuya sede se sitúa en Lisboa (Portugal). Su flota la componen cuatro buques de avanzada edad, véase Tabla I.29, que con anterioridad pertenecieron a la desaparecida Classic International Cruises. Actualmente, el único buque operativo de la flota es el Funchal, cuya remodelación finalizó en agosto de 2013. Los tres buques restantes, Lisboa, Azores y Porto, cuyas consignas en International Classic Cruises eran las de Princess Danae, Athena y Arion respectivamente, están en reparación, sometiéndose a un profundo proceso de adaptación a los estándares actuales. 


\begin{tabular}{|c|c|c|c|c|c|}
\hline & & ale Qnuises & & & \\
\hline Nombre del Buque & $\begin{array}{c}\text { Capacidad de } \\
\text { Pasajeros }\end{array}$ & $\begin{array}{c}\text { Año de } \\
\text { construcción }\end{array}$ & $\begin{array}{c}\text { Eslora } \\
\text { (m) }\end{array}$ & $\begin{array}{c}\text { Manga } \\
\text { (m) }\end{array}$ & $\begin{array}{c}\text { Arqueo } \\
\text { Bruto } \\
\text { (G.T.) }\end{array}$ \\
\hline Porto & 312 & 1965 & 117,96 & 16,54 & 5.888 \\
\hline Funchal & 481 & 1961 & 154,60 & 19,05 & 9.563 \\
\hline Lisboa & 690 & 1955 & 162,46 & 21,34 & 16.335 \\
\hline Azores & 550 & 1948 & 160,02 & 21,04 & 16.144 \\
\hline
\end{tabular}

Fuente: Elaboración propia basada en Portuscale Cruises (2014).

Una vez finalizados los procesos de remodelación de los tres buques restantes, la capacidad conjunta representa el $0,44 \%$ de la cuota mundial, equivalente a 2.033 pasajeros. $\mathrm{Su}$ reciente singladura en el mercado de cruceros se centra en itinerarios por Madeira y Azores, el Báltico, Mediterráneo y Marruecos, empleando puertos portugueses como puertos base (Portuscale Cruises, 2014).

\section{I.4.13 Crystal Cruises}

Crystal Cruises, fundada en 1988 y con sede en Los Ángeles (California, EE.UU.), es propiedad de Nippon Yusen Kaisha (NYK) de origen japonés, una de las compañías de transporte marítimo más grandes del mundo. Dispone de dos buques, véase Tabla I.30, enmarcados en el segmento de lujo, que le confieren una capacidad de 1.992 pasajeros, el $0,43 \%$ mundial, el décimo tercer operador independiente. En ambos casos se trata de buques de nueva construcción encargados por la naviera.

Tabla I.30: Flota de Crystal Cruises

\section{SE, CRYSTAL}

\begin{tabular}{lccccc} 
Nombre del Buque & $\begin{array}{c}\text { Capacidad de } \\
\text { Pasajeros }\end{array}$ & $\begin{array}{c}\text { Año de } \\
\text { construcción }\end{array}$ & $\begin{array}{c}\text { Eslora } \\
(\mathbf{m})\end{array}$ & $\begin{array}{c}\text { Manga } \\
(\mathbf{m})\end{array}$ & $\begin{array}{c}\text { Arqueo } \\
\text { Bruto } \\
\text { (G.T.) }\end{array}$ \\
\hline Crystal Serenity & 1.070 & 2003 & 249,90 & 32,30 & 68.870 \\
Crystal Symphony & 922 & 1995 & 238,00 & 30,20 & 51.044 \\
\hline
\end{tabular}

Fuente: Elaboración propia basada en Crystal Cruises (2013).

En 1996 puso en marcha un ambicioso programa culinario de lujo a bordo de sus buques, en el que prestigiosos cocineros y enólogos de todo el mundo participan en alguno de sus itinerarios. En 2009, debutaron con un nuevo programa de cruceros temáticos denominado Experiences of Discovery ${ }^{T M}$, con objeto de enriquecer decenas de itinerarios dándoles un enfoque especial. Fundamentalmente, el programa de a bordo se ve reforzado 
con excursiones en tierra de carácter aventurero (Crystal Cruises, 2013). Los cruceros de Crystal Cruises cubren toda la geografía mundial, incluyendo tanto itinerarios en un sector en concreto, como viajes de larga duración e incluso de vuelta al mundo.

\section{I.4.14 Regent Seven Seas Cruises}

Regent Seven Seas Cruises (RSSC), anteriormente denominada Radisson Seven Seas Cruises, tiene su sede en Miami (Florida, EE.UU.) y es propiedad de Prestige Cruise Holdings, líder del segmento de cruceros upper-premium y de lujo, además de ser propietario también de Oceania Cruises. Se trata de la naviera de lujo con mayores servicios incluidos en sus tarifas. Éstas incluyen alojamiento, compuesto únicamente por suites, desplazamientos aéreos a/desde los puertos base, servicio altamente personalizado, cocina y bebidas de alta gama, rutas turísticas en cada puerto, una noche en hotel de lujo antes del crucero, etc.

La flota de tres buques, tiene una edad media de 13 años, véase Tabla I.31. Dos de los buques, Seven Seas Voyager y Seven Seas Mariner, son gemelos estando equipados únicamente por suites con balcón. Mientras que el Seven Seas Navigator también dispone solo de suites pero con balcón el 90\% (RSSC, 2013). Con uno de los ratios más altos de espacio por huésped en la industria de cruceros, el alojamiento a bordo de los tres buques está considerado entre los más lujosos a flote. La capacidad total asociada a estos tres buques es de 1.890 pasajeros, el $0,41 \%$ mundial.

Tabla I.31: Flota de Regent Seven Seas Cruises

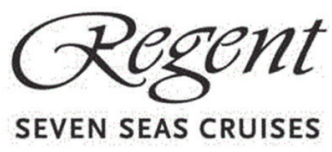

\begin{tabular}{lccccc} 
Nombre del Buque & $\begin{array}{c}\text { Capacidad de } \\
\text { Pasajeros }\end{array}$ & $\begin{array}{c}\text { Año de } \\
\text { construcción }\end{array}$ & $\begin{array}{c}\text { Eslora } \\
(\mathbf{m})\end{array}$ & $\begin{array}{c}\text { Manga } \\
(\mathbf{m})\end{array}$ & $\begin{array}{c}\text { Arqueo } \\
\text { Bruto } \\
\text { (G.T.) }\end{array}$ \\
\hline Seven Seas Voyager & 700 & 2003 & 204,00 & 28,80 & 42.363 \\
Seven Seas Mariner & 700 & 2001 & 216,00 & 28,35 & 48.075 \\
Seven Seas Navigator & 490 & 1999 & 170,00 & 24,70 & 28.550 \\
\hline
\end{tabular}

Fuente: Elaboración propia basada en ECC (2013), Cruise Market Watch (2014b) y RSSC (2013).

En 2008/2009 RSSC completó un multimillonario programa de profunda remodelación de la flota. Casi todas las áreas se han actualizado y algunas estancias públicas fueron rediseñadas sustancialmente. Los tres buques de RSSC visitan más de 300 destinos por todo el globo. 


\section{I.4.15 Hapag-Lloyd Cruises}

Hapag-Lloyd Cruises, con sede en Hamburgo (Alemania) es uno de los líderes en Alemania en el segmento de cruceros de lujo y de expedición. Actualmente, Hapag-Lloyd Cruises es una subsidiaria de $T U I A G$, la cual ostenta la propiedad total dentro de la división de cruceros del grupo, pero funcionalmente es totalmente independiente (ECC, 2013). La flota, de 18,25 años de edad media, la componen cuatro buques, véase Tabla I.32. La capacidad de la flota es de 1.272 pasajeros, $0,28 \%$ mundial.

Tabla I.32: Flota de Hapag-Lloyd Cruises

\begin{tabular}{|c|c|c|c|c|c|}
\hline Nombre del Buque & $\begin{array}{c}\text { Capacidad de } \\
\text { Pasajeros }\end{array}$ & $\begin{array}{c}\text { Año de } \\
\text { construcción }\end{array}$ & $\begin{array}{c}\text { Eslora } \\
\text { (m) }\end{array}$ & $\begin{array}{c}\text { Manga } \\
\text { (m) }\end{array}$ & $\begin{array}{c}\text { Arqueo } \\
\text { Bruto } \\
\text { (G.T.) }\end{array}$ \\
\hline MS Europa 2 & 516 & 2013 & 225,4 & 26,7 & 42.830 \\
\hline MS Europa & 408 & 1999 & 198,6 & 24,0 & 28.890 \\
\hline MS Hanseatic & 184 & 1993 & 122,8 & 18,0 & 8.378 \\
\hline MS Bremen & 164 & 1990 & 111,0 & 17,0 & 6.752 \\
\hline
\end{tabular}

Fuente: Elaboración propia basada en ECC (2013), Cruise Market Watch (2014b) y Hapag Lloyd Cruises (2014).

El MS Europa, es el único crucero que ha sido galardonado con las codiciadas "5 estrellas plus" de la Guía Berlitz Cruise desde su puesta en marcha en 1999. Además, combina itinerarios por toda la geografía mundial. La incorporación más reciente a la flota, el MS Europa 2 en marzo de 2013, está enmarcado en el segmento de cruceros de lujo. Los itinerarios que cubre este buque discurren por el Mediterráneo Oriental y Occidental, de siete días de duración y por la península Arábiga y Asia en itinerarios de 14 a 16 días (Hapag Lloyd Cruises, 2014).

Los buques MS Hanseatic (el único buque de expedición 5 estrellas) y el MS Bremen (cuatro estrellas plus) están diseñados para viajar por regiones y destinos poco comunes, como la Antártida, el Amazonas y los Mares del Sur.

\section{I.4.16 Celebration Cruise Line}

Celebration Cruise Line, ofrece únicamente cruceros a las islas Bahamas de dos noches de duración, partiendo del puerto de West Palm Beach (Florida, EE.UU.). Dispone de un sólo buque, Bahamas Celebration, véase Tabla I.33, con capacidad para 1.200 pasajeros (Celebration Cruise Line, 2013), equivalente a un $0,26 \%$ de la cuota mundial.

Este buque fue construido en 1981 como buque ferry, entre 1981 y 1990 fue propiedad de Jahre Line con el nombre de Prinsesse Ragnhild. En 1990 adquirió su propiedad Color Line manteniendo el mismo nombre. Durante esta etapa el buque es 
alargado en 35,25 metros y transformado en buque de crucero. Finalmente, en 2008 adoptó la denominación actual bajo la consigna de Celebration Cruise Line.

Tabla I.33: Flota de Celebration Cruise Line

\begin{tabular}{lccccc}
\hline & \multicolumn{3}{c}{} & & \\
Nombre del Buque & $\begin{array}{c}\text { Celebration } \\
\text { Capacidad } \\
\text { de Pasajeros }\end{array}$ & $\begin{array}{c}\text { Año de } \\
\text { construcción }\end{array}$ & $\begin{array}{c}\text { Eslora } \\
\text { (m) }\end{array}$ & $\begin{array}{c}\text { Manga } \\
\text { (m) }\end{array}$ & $\begin{array}{c}\text { Arqueo Bruto } \\
\text { (G.T.) }\end{array}$ \\
\hline Bahamas Celebration & 1.200 & 1981 & 205,25 & 24,00 & 16.631 \\
\hline
\end{tabular}

Fuente: Elaboración propia basada en Celebration Cruise Line (2013) y Cruise Market Watch (2014b).

\section{I.4.17 Saga Cruises}

Saga Cruises, con sede en Folkestone (Reino Unido), opera su propia flota de buques de crucero desde 1997. Es la única naviera que ofrece cruceros exclusivos para personas de 50 y más años de edad (aunque está permitido que los acompañantes tengan 40 años o más). Está caracterizada por una elevada relación tripulante-pasajeros. La flota de Saga está compuesta por dos buques, cuya edad media asciende a 33 años, véase Tabla I.34. La capacidad total entre ambos es de 1.148 pasajeros, el $0,25 \%$ mundial, décimo séptimo operador independiente.

Tabla I.34: Flota de Saga Cruises

\begin{tabular}{|c|c|c|c|c|c|}
\hline Nombre del Buque & $\begin{array}{c}\text { Capacidad de } \\
\text { Pasajeros }\end{array}$ & $\begin{array}{c}\text { Año de } \\
\text { construcción }\end{array}$ & $\begin{array}{c}\text { Eslora } \\
\text { (m) }\end{array}$ & $\begin{array}{c}\text { Manga } \\
\text { (m) }\end{array}$ & $\begin{array}{c}\text { Arqueo } \\
\text { Bruto } \\
\text { (G.T.) }\end{array}$ \\
\hline Saga Sapphire & 702 & 1981 & 199,63 & 28,50 & 37.301 \\
\hline Saga Pearl II & 446 & 1981 & 165,00 & 23,00 & 18.591 \\
\hline
\end{tabular}

Fuente: Elaboración propia basada en ECC (2013), Cruise Market Watch (2014b) y Saga Cruises (2014).

Todos los buques de la flota con anterioridad han sido explotados por otras navieras. El buque Saga Sapphire, entre 1981 y 1999 formó parte de la flota de Hapag-Lloyd con el nombre de Europa. Su siguiente etapa, 1999-2004, la desarrolla en Star Cruises con dos denominaciones Super Star Europe (1999-2000) y Super Star Aries (2000-2004). En 2004 cambia su nombre a Holiday Dream siendo operado por Pullmantur. Su penúltima etapa, de 2008 a 2012, la desarrolla en Croisières de France como Bleu de France. En 2012 lo adquirió Saga y tras someterlo a un profundo proceso de remodelación lo dotó de la denominación actual.

El buque Saga Pearl II entre 1981 y 1985 navegaba bajó el nombre de Astor, periodo durante el que ostentó dos propietarios HADAG (1981-1984) y Safmarine (1984-1985). De 1985 a 2001 formó parte de la flota de Deutsche Seereederei como Arkona. Su siguiente 
etapa, 2001-2010, la desarrolló en Transocean Tours renombrándolo Astoria. En 2010 lo adquirió Saga dotándolo de la consigna Saga Pearl II; en 2012 cambió su denominación a Quest for Adventure dentro de la misma naviera. Finalmente, en 2014 el buque fue remodelado renombrándolo de nuevo Saga Pearl II (Cruise Industry News, 2013). El pequeño tamaño de este buque le permite llegar a destinos que no son accesibles a buques de mayor tamaño.

Saga cubre itinerarios de crucero por las islas Canarias, Mediterráneo y Norte de Europa, fundamentalmente. Como puertos base emplean puertos de Reino Unido y más en concreto Dover y Southampton (Saga Cruises, 2014).

\section{I.4.18 Compagnie du Ponant}

Compagnie du Ponant, fundada en 1988 y con sede en Marsella (Francia), se caracteriza por ofertar cruceros de lujo a bordo de buques de pequeño tamaño. Actualmente, dispone de una flota cuatro buques, véase Tabla I.35, que le confieren una capacidad de 856 pasajeros, $0,19 \%$ mundial, décimo octavo operador independiente. De los cuatro buques, tres son gemelos y de reciente construcción; el cuarto buque, Le Ponant, tiene la particularidad de que dispone también de velas como medio de propulsión, estando dotado de tres mástiles. Los tres buques con propulsión mecánica únicamente son nuevas construcciones encargadas por la naviera, enarbolando todos ellos pabellón francés.

Tabla I.35: Flota de Compagnie du Ponant

\begin{tabular}{|c|c|c|c|c|c|}
\hline \multirow[b]{2}{*}{ Nombre del Buque } & \multicolumn{3}{|c|}{ 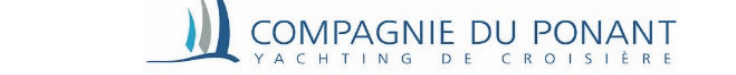 } & \multirow[b]{2}{*}{$\begin{array}{c}\text { Manga } \\
\text { (m) }\end{array}$} & \multirow[b]{2}{*}{$\begin{array}{c}\text { Arqueo Bruto } \\
\text { (G.T.) }\end{array}$} \\
\hline & $\begin{array}{c}\text { Capacidad de } \\
\text { Pasajeros }\end{array}$ & $\begin{array}{c}\text { Año de } \\
\text { construcción }\end{array}$ & $\begin{array}{c}\text { Eslora } \\
\text { (m) }\end{array}$ & & \\
\hline Le Soleal & 264 & 2013 & 142 & 18 & 10.700 \\
\hline L'Austral & 264 & 2011 & 142 & 18 & 10.944 \\
\hline Le Bóreal & 264 & 2010 & 142 & 18 & 10.944 \\
\hline Le Ponant & 64 & 1991 & 88 & 12 & 1.443 \\
\hline
\end{tabular}

Fuente: Elaboración propia basada en ECC (2013), Compagnie du Ponant (2013) y Cruise Market Watch (2014b).

Los itinerarios cubiertos por la flota de Compagnie $d u$ Ponant cubren destinos legendarios y los puertos más reservados del mundo, sólo accesibles a los buques de pequeña capacidad. Los principales destinos cubiertos por la naviera incluyen el Mediterráneo, Norte de Europa, Báltico, Sudamérica, la Antártida y Asia (Compagnie du Ponant, 2013).

\section{I.4.19 Windstar Cruises}

Windstar Cruises, fundada en 1984 y con sede en Seattle (Washington, EE.UU.), basa su operación en buques de pequeño tamaño enmarcados en el segmento de lujo. Las excepcionales características de su servicio permiten que el crucerista perciba que se 
encuentra a bordo de su yate privado. Su flota la componen cuatro buques, de los cuales tres disponen de propulsión mecánica y a vela, cuya edad media alcanza los 26,3 años, véase Tabla I.36. En su conjunto los cuatro buques dotan a la naviera de una capacidad de 814 pasajeros, 0,19\% mundial.

Tabla I.36: Flota de Windstar Cruises

\begin{tabular}{|c|c|c|c|c|c|}
\hline \multirow[b]{2}{*}{ Nombre del Buque } & \multicolumn{3}{|c|}{ 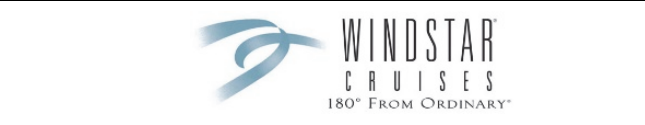 } & \multirow[b]{2}{*}{$\begin{array}{c}\text { Manga } \\
\text { (m) }\end{array}$} & \multirow[b]{2}{*}{$\begin{array}{c}\text { Arqueo Bruto } \\
\text { (G.T.) }\end{array}$} \\
\hline & $\begin{array}{c}\text { Capacidad } \\
\text { de Pasajeros }\end{array}$ & $\begin{array}{c}\text { Año de } \\
\text { construcción }\end{array}$ & $\begin{array}{c}\text { Eslora } \\
\text { (m) }\end{array}$ & & \\
\hline Wind Surf & 310 & 1989 & 162,0 & 20,0 & 14.745 \\
\hline Wind Spirit & 148 & 1988 & 110,0 & 15,8 & 5.736 \\
\hline Star Pride & 208 & 1988 & 123,1 & 19,2 & 9.961 \\
\hline Wind Star & 148 & 1986 & 110,0 & 15,8 & 5.703 \\
\hline
\end{tabular}

Fuente: Elaboración propia basada en ECC (2013), Windstar Cruises (2013) y Cruise Market Watch (2014b).

Los buques gemelos Wind Star y Wind Spirit fueron encargados por la naviera al astillero Ateliers et Chantiers du Havre. Mientras que el buque Wind Surf entre 1990 y 1998 formó parte de la flota de Club Med como Club Med 1, a partir de 1998 ostentó la consigna de Wind Surf para Windstar Cruises. En este sentido, en diciembre de 2012 finalizó el proceso de remodelación de estos tres buques moto-veleros, tras un proyecto de 18 meses de duración (Windstar Cruises, 2013).

La naviera puso en marcha el 19 de febrero de 2013 un programa de expansión de flota, basado en la adquisición de tres buques de la naviera Seabourn. El proyecto de expansión de flota recibe el nombre de Global Windstar, el cual supone la incorporación de los primeros buques de propulsión mecánica, exclusivamente, a la flota de Windstar. Esta naviera registra cuatro años consecutivos de crecimiento. De tal forma que por medio de esta expansión proporciona la capacidad necesaria para ampliar la comercialización de cruceros en buques de pequeño tamaño por todo el mundo.

La primera incorporación a la flota enmarcada en este programa de expansión ha sido la del buque Star Pride en abril de 2014, su anterior denominación en la naviera Seabourn era la de Seabourn Pride. Los itinerarios ofertados a bordo de este buque recorren el Mediterráneo, incluyendo la Riviera Francesa, y el mar Negro. Mientras que en abril y mayo de 2015 tomará posesión de los buques Seabourn Legend y Seabourn Spirit, respectivamente. Tras su periodo de mantenimiento en dique seco comenzarán a operar a lo largo de mayo de 2015. Además, con estas nuevas incorporaciones se ampliarán los itinerarios ofertados, incluyendo nuevos destinos en Asia y Sudamérica.

El reducido tamaño de los cruceros de Windstar les permite tener acceso a lugares exclusivos en los que buques de mayor tamaño no podrían acceder. Los itinerarios se centran en las islas Griegas, Italia, Europa, las aguas azules del Caribe y el exuberante paraíso de Tahití. 


\section{I.4.20 Lindblad Expeditions}

Lindblad Expeditions, con sede en Nueva York (EE.UU.), en 1969 fue la pionera en ofertar viajes de expedición a bordo de un buque privado, el Lindblad Explorer. Posteriormente en 2004 volvió a registrar un nuevo hito en los cruceros de expedición al firmar una alianza de colaboración con National Geographic. Todo ello ha llevado a que esta compañía sea la más respetada en el segmento de cruceros de expedición (Lindblad Expeditions, 2013). Actualmente, cuenta con una flota de siete buques dedicados a navegación marítima, con una capacidad conjunta de 653 pasajeros, véase Tabla I.37.

Tabla I.37: Flota de Lindblad Expeditions-National Geographic

\begin{tabular}{|c|c|c|c|c|c|}
\hline \multirow[b]{2}{*}{ Nombre del Buque } & \multirow[b]{2}{*}{$\begin{array}{c}\text { Capacidad } \\
\text { de Pasajeros }\end{array}$} & (10) & \multirow[b]{2}{*}{$\begin{array}{c}\text { Eslora } \\
\text { (m) }\end{array}$} & \multirow[b]{2}{*}{$\begin{array}{c}\text { Manga } \\
\text { (m) }\end{array}$} & \multirow[b]{2}{*}{$\begin{array}{l}\text { Arqueo Bruto } \\
\text { (G.T.) }\end{array}$} \\
\hline & & $\begin{array}{c}\text { Año de } \\
\text { construcción }\end{array}$ & & & \\
\hline Orion & 106 & 2003 & 103,0 & 14,3 & 4.000 \\
\hline National Geographic Islander & 48 & 1995 & 27,0 & 9,0 & 1.065 \\
\hline National Geographic Explorer & 148 & 1982 & 112,0 & 16,5 & 6.471 \\
\hline National Geographic Endeavour & 169 & 1966 & 89,2 & 14,0 & 3.132 \\
\hline National Geographic Sea Bird & 62 & - & - & - & - \\
\hline National Geographic Sea Lion & 62 & - & - & - & - \\
\hline Sea Cloud & 58 & - & - & - & - \\
\hline
\end{tabular}

Fuente: Elaboración propia basada en Lindblad Expeditions (2013) y Cruise Market Watch (2014b).

La incorporación más reciente a la flota es la del buque Orion en marzo de 2014. Esta incorporación está asociada a la adquisición por parte de Lindblad Expeditions junto con National Geographic de la compañía Orion Expeditions, especializada en cruceros de expedición en la región de Asia-Pacífico.

Los destinos de crucero de Lindblad Expeditions-National Geographic incluyen las regiones polares de la Antártida y el Ártico, Alaska, Baja California, Centro América, las islas Galápagos, el Amazonas, Nueva Zelanda, África, islas Británicas, Egipto, Europa, el Mediterráneo, el noroeste del Pacífico y América del Sur. Dada la operativa de este tipo de cruceros es necesario disponer a bordo de una serie de equipos para poder realizar la exploración en destino. Entre estos equipos, los más característicos son los siguientes, kayaks, un vehículo submarino de control remoto para explorar las profundidades del mar y equipos de buceo para los pasajeros.

\section{I.4.21 Star Clippers}

Star Clippers, fundada en 1989 por el empresario sueco Mikael Krafft, actualmente con sede en Mónaco, es la única línea de cruceros a día de hoy dedicada a la recreación de la época dorada de los grandes veleros al tiempo que proporciona a los pasajeros una 
experiencia a bordo de mega-yates. Su flota la componen tres veleros, véase Tabla I.38, cuya capacidad conjunta es de 567 pasajeros, 0,12\% mundial, vigésimo primero operador independiente.

Tabla I.38: Flota de Star Clippers

\begin{tabular}{lccccc}
\hline Nombre del Buque & $\begin{array}{c}\text { Capacidad } \\
\text { de Pasajeros }\end{array}$ & $\begin{array}{c}\text { STAR CLIPPERS } \\
\text { Año de } \\
\text { construcción }\end{array}$ & $\begin{array}{c}\text { Eslora } \\
\text { (m) }\end{array}$ & $\begin{array}{c}\text { Manga } \\
(\mathbf{m})\end{array}$ & $\begin{array}{c}\text { Arqueo Bruto } \\
\text { (G.T.) }\end{array}$ \\
\hline Royal Clipper & 227 & 2000 & 133,02 & 16,36 & 5.000 \\
Star Clipper & 170 & 1992 & 109,08 & 15,15 & 2.298 \\
Star Flyer & 170 & 1991 & 109,08 & 15,15 & 2.298 \\
\hline
\end{tabular}

Fuente: Elaboración propia basada en ECC (2013), Star Clippers (2013) y Cruise Market Watch (2014b).

A comienzos de los años 90 entraron en servicio los buques gemelos Star Flyer y Star Clipper, constituyendo esta circunstancia un hito histórico al ser los buques de crucero veleros de mayor tamaño jamás construidos. Están equipados con cuatro mástiles alcanzando el mayor de ellos una altura de 68,88 metros. En julio del año 2000, se incorporó el buque insignia de la flota, el Royal Clipper, equipado con cinco mástiles. El calendario de incorporaciones a la flota, le confiere una edad media de 19,7 años.

De forma análoga a otras navieras que también disponen de buques de pequeño tamaño, los buques de Star Clippers visitan puertos en los que los grandes buques de crucero no pueden hacer escala. Además, ofrecen al pasaje actividades, servicios y ambiente de un yate privado. Star Clippers está reconocida como una de las líneas de cruceros especializada de primer nivel (ECC, 2013). A bordo de los buques de esta naviera abundan las aventuras y experiencias únicas, como por ejemplo, subir al mástil para disfrutar de una mejor vista o relajarse en la red del bauprés.

Cada uno de los buques de Star Clippers tiene asignado unos destinos en función de la época del año. Así pues, el buque Royal Clipper durante los meses de invierno y primavera (del hemisferio norte) cubre itinerarios por el Caribe, mientras que en verano y otoño, el buque es reposicionado al Mediterráneo. En cuanto a los buques gemelos Star Clipper y Star Flyer, en invierno y primavera cubren itinerarios por el Caribe y la costa del Pacífico de Costa Rica, respectivamente, reposicionándose ambos al Mediterráneo durante verano y otoño (Star Clippers, 2013).

\section{I.4.22 Voyages of Discovery}

Voyages of Discovery, con sede en Leicestershire (Reino Unido), es una marca comercial del grupo All Leisure Holidays Ltd. Desde sus inicios en 1983 tiene por filosofía proporcionar viajes históricos y culturales de interés y descubrimiento. Inicialmente especializada en el Mediterráneo Oriental y el mar Rojo y Negro, con el tiempo, ha ido 
ampliando su oferta para agregar destinos más emocionantes a los itinerarios (Voyages of Discovery, 2013). Dispone de un sólo buque con capacidad para 556 pasajeros, véase Tabla I.39, equivalente al $0,12 \%$ de la cuota mundial.

Tabla I.39: Flota de Voyages of Discovery

\begin{tabular}{lccccc}
\hline & \multicolumn{2}{l}{$\begin{array}{l}\text { Voyages } \\
\text { of Discovery }\end{array}$} & & & \\
Nombre del Buque & $\begin{array}{c}\text { Capacidad de } \\
\text { Pasajeros }\end{array}$ & $\begin{array}{c}\text { Año de } \\
\text { construcción }\end{array}$ & $\begin{array}{c}\text { Eslora } \\
\text { (m) }\end{array}$ & $\begin{array}{c}\text { Manga } \\
\text { (m) }\end{array}$ & $\begin{array}{c}\text { Arqueo } \\
\text { Bruto } \\
\text { (G.T.) }\end{array}$ \\
\hline Voyager & 556 & 1988 & 152,5 & 20,6 & 15.271 \\
\hline
\end{tabular}

Fuente: Elaboración propia basada en Voyages of Discovery (2013) y Cruise Market Watch (2014b).

Voyages of Discovery opera en Reino Unido, EE.UU. y Canadá, Australia, Nueva Zelanda y Sudáfrica. Los cruceros desde puertos de Reino Unido parten a destinos como Escandinavia, el Báltico y Groenlandia. Mientras que los itinerarios por el Mediterráneo, el mar Negro, Norte de África, Sudamérica, la Antártida, islas del Pacífico, el Caribe y Amazonas, son de tipo fly \& cruise (All Leisure Group, 2013a).

\section{I.4.23 Paul Gauguin Cruises}

Paul Gauguin Cruises, propiedad de Pacific Beachcomber S.C. (líder en la Polinesia Francesa en el segmento de resorts de lujo) desde el año 2010 y con sede en Bellevue (Washington, EE.UU.), tiene una flota de dos buques de pequeño tamaño que operan en el segmento de lujo, véase Tabla I.40. Estos dos buques confieren a la naviera una capacidad de 420 pasajeros, 0,09\% mundial, representando el vigésimo tercer operador independiente.

Hasta diciembre de 2012 únicamente disponían de un buque, Paul Gauguin, que con anterioridad había sido operado por Radisson Seven Seas Cruises y Regent Seven Seas Cruises, tras el cambio de denominación de la compañía en 2006, hasta la adquisición por su actual propietario en 2010. Este buque de cinco estrellas, fue diseñado y construido para navegar por las aguas de Tahití, la Polinesia Francesa y el Pacífico Sur. Construido en 1997, el Paul Gauguin es el buque de crucero de lujo que mayor tiempo lleva operando durante todo el año en el Pacífico Sur. Ningún otro buque de lujo en la historia ha ofrecido este nivel de concentración y atención en un sólo destino durante un periodo tan extenso de tiempo. Aproximadamente el $70 \%$ de sus camarotes cuentan con balcón privado (Paul Gauguin Cruises, 2013).

En diciembre de 2012 comenzó a navegar bajo la consigna de Paul Gauguin Cruises el buque Tere Moana, también de pequeño tamaño con capacidad para 90 pasajeros y encuadrado en el segmento de lujo. Desde su construcción en 1998 este buque formó parte de la flota de Compagnie du Ponant con el nombre de Le Levant, hasta su adquisición por Paul Gauguin Cruises el 30 de diciembre de 2011 (Seatrade Insider, 2013). Antes de 
comenzar a operar para esta compañía el buque se ha sometido a un proceso de remodelación. De forma análoga al Paul Gauguin, el buque Tere Moana está especializado en destinos de clima cálido, con un énfasis en alcanzar itinerarios únicos que los barcos más grandes no pueden ofrecer y explorar puertos escondidos a lo largo de estas regiones. Este buque navega durante los meses de verano (del hemisferio norte) en Europa y en invierno en el Caribe y América Latina.

Tabla I.40: Flota de Paul Gauguin Cruises

\begin{tabular}{lccccc}
\hline \multicolumn{9}{c}{$\begin{array}{c}\text { Paul Ganguiu } \\
\text { cRuises }\end{array}$} \\
Nombre del Buque & $\begin{array}{c}\text { Capacidad } \\
\text { de Pasajeros }\end{array}$ & $\begin{array}{c}\text { Año de } \\
\text { construcción }\end{array}$ & $\begin{array}{c}\text { Eslora } \\
(\mathbf{m})\end{array}$ & $\begin{array}{c}\text { Manga } \\
(\mathbf{m})\end{array}$ & $\begin{array}{c}\text { Arqueo Bruto } \\
\text { (G.T.) }\end{array}$ \\
\hline Tere Moana & 90 & 1998 & 100,00 & 14,00 & 3.504 \\
Paul Gauguin & 330 & 1997 & 156,36 & 21,64 & 19.200 \\
\hline
\end{tabular}

Fuente: Elaboración propia basada en Paul Gauguin Cruises (2013) y Cruise Market Watch (2014b).

\section{I.4.24 Swan Hellenic}

Swan Hellenic, de origen británico fundada en agosto de 1954, tenía como objetivo realizar cruceros por algunos de los lugares más legendarios del mundo. Actualmente constituye una marca comercial del grupo All Leisure Holidays Ltd. tras su adquisición en julio de 2007, anteriormente la marca había sido propiedad de $P \& O$ y Carnival \& plc (All Leisure Group, 2013b). Su sede está establecida en Leicestershire (Reino Unido).

Dispone de un solo buque, Minerva, de 350 pasajeros de capacidad, véase Tabla I.41. La vida marinera del buque Minerva comenzó en 1989 como buque de investigación soviético, Okean. En 1996 se transformó en crucero operándolo Swan Hellenic con el nombre de Minerva. Entre 2003 y 2008 recorrió varias navieras ostentando diversas denominaciones como Saga Pearl, Explorer II y Alexander von Humboldt. Por último, en 2008 fue adquirido por Swan Hellenic renombrándolo de nuevo Minerva. En 2012 el buque se sometió a un profundo proceso de remodelación.

Tabla I.41: Flota de Swan Hellenic

\begin{tabular}{|c|c|c|c|c|c|}
\hline & & SWAN & & & \\
\hline Nombre del Buque & $\begin{array}{c}\text { Capacidad de } \\
\text { Pasajeros }\end{array}$ & $\begin{array}{c}\text { Año de } \\
\text { construcción }\end{array}$ & $\begin{array}{c}\text { Eslora } \\
\text { (m) }\end{array}$ & $\begin{array}{c}\text { Manga } \\
\text { (m) }\end{array}$ & $\begin{array}{c}\text { Arqueo } \\
\text { Bruto } \\
\text { (G.T.) }\end{array}$ \\
\hline Minerva & 350 & 1989 & 132,40 & 20,00 & 12.449 \\
\hline
\end{tabular}

Fuente: Elaboración propia basada en All Leisure Group (2013b) y Cruise Market Watch (2014b).

En sus inicios los cruceros se centraban en el Mediterráneo, ofreciendo viajes por las "aguas de la antigüedad". Hoy en día, sus itinerarios, cuidadosamente diseñados y 
detallados, discurren desde Cabo Norte en Noruega a la India y el Lejano Oriente, pasando por el Adriático, mar Negro, Mediterráneo Occidental y Norte de África (Swan Hellenic, 2013).

\section{I.4.25 Voyages to Antiquity}

Voyages to Antiquity, fundada en 2009 y con sede en Oxford (Reino Unido), centra su línea de negocio en cruceros culturales e históricos. Dispone de un sólo buque, el Aegean Odyssey, también con una capacidad de 350 pasajeros, véase Tabla I.42. Este buque construido en 1973 era en origen un buque tipo Ro-Ro, en 1988 se transformó en buque de crucero bajo propiedad de Dolphin Hellas Cruises. Durante el periodo de 1988 a 2005 el buque estuvo fletado a varias navieras hasta su adquisición por Louis Hellenic Cruise Line en 2005. Posteriormente, en 2009, lo adquirió la naviera de reciente creación Voyages to Antiquity sometiéndolo a un profundo proceso de remodelación y rebautizándolo como Aegean Odyssey, comenzando a navegar en 2010.

Tabla I.42: Flota de Voyages to Antiquity

\begin{tabular}{|c|c|c|c|c|c|}
\hline & & 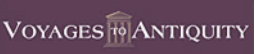 & & & \\
\hline Nombre del Buque & $\begin{array}{c}\text { Capacidad } \\
\text { de Pasajeros }\end{array}$ & $\begin{array}{c}\text { Año de } \\
\text { construcción }\end{array}$ & $\begin{array}{c}\text { Eslora } \\
\text { (m) }\end{array}$ & $\begin{array}{c}\text { Manga } \\
\text { (m) }\end{array}$ & $\begin{array}{c}\text { Arqueo Bruto } \\
\text { (G.T.) }\end{array}$ \\
\hline Aegean Odyssey & 350 & 1973 & 140,51 & 20,42 & 11.906 \\
\hline
\end{tabular}

Fuente: Elaboración propia basada en Voyages to Antiquity (2013).

El tamaño del buque Aegean Odyssey lo hace más apto para la navegación en zonas próximas a islas, así como, para la navegación costera respecto a los buques de gran tamaño. Además, también puede navegar por los grandes ríos del Sudeste Asiático y hacer escala en el corazón de Bangkok, Yangon y Ho Chi Minh. En sus inicios esta naviera ofrecía itinerarios por la parte Central y Este del Mediterráneo, habiéndose ampliado éstos a lugares con gran esencia cultural de África, Sudeste Asiático y más recientemente India. Dado que su mercado se centra en Reino Unido, Estados Unidos y Australia, los cruceros ofertados tienen el carácter fly \& cruise (Voyages to Antiquity, 2013).

\section{I.4.26 Seadream Yacht Club}

Seadream Yacht Club, fundada en 2001 y sede en Miami (Florida, EE.UU.), opera dos buques gemelos de pequeño tamaño enmarcados en el segmento de lujo. La capacidad de los buques es de 110 pasajeros, con una tripulación de 95 personas (Seadream Yacht Club, 2013). El lema de la compañía es “It's yachting, not cruising", actuando el servicio personalizado como elemento diferenciador. Ambos buques, véase Tabla I.43, confieren a la naviera una capacidad de 220 pasajeros, $0,05 \%$ de la capacidad mundial. 
Ambos buques han sido operados por otras compañías antes de su adquisición por parte de Seadream Yacht Club en 2001. El buque Seadream I, entre 1984 y 1986 formó parte de la flota de Sea Goddess Cruises bajo la denominación de Sea Goddess I. De 1986 a 1998 fue operado por Cunard Line manteniendo la misma denominación. En 1998 fue adquirido por Seabourn Cruise Line renombrándolo Seabourn Goddess I. Finalmente, en 2001 adquirió su denominación actual tras su compra por parte de Seadream. El caso del buque Seadream II es análogo al anterior, Sea Goddess II para Sea Goddess Cruises (1985-1986) y Cunard Line (1986-1998); Seabourn Goddess II en Seabourn Cruise Line (1998-2001) y por último en 2001 adquirió su actual consigna en Seadream. Antes de comenzar a navegar para su actual propietario ambos buques fueron sometidos a un profundo proceso de remodelación en 2001, proceso que se ha repetido de nuevo en 2009 en ambos casos (CLIA, 2013f).

Tabla I.43: Flota de Seadream Yacht Club

\begin{tabular}{|c|c|c|c|c|c|}
\hline Nombre del Buque & $\begin{array}{c}\text { Capacidad } \\
\text { de Pasajeros }\end{array}$ & $\begin{array}{c}\text { Año de } \\
\text { construcción }\end{array}$ & $\begin{array}{c}\text { Eslora } \\
\text { (m) }\end{array}$ & $\begin{array}{c}\text { Manga } \\
\text { (m) }\end{array}$ & $\begin{array}{c}\text { Arqueo Bruto } \\
\text { (G.T.) }\end{array}$ \\
\hline Seadream II & 110 & 1985 & 104 & 14,32 & 4.260 \\
\hline Seadream I & 110 & 1984 & 105 & 14,32 & 4.260 \\
\hline
\end{tabular}

Fuente: Elaboración propia basada en Seadream Yacht Club (2013).

Los itinerarios que cubren estos buques discurren por el Mediterráneo, Norte de Europa, Caribe, Costa Rica, Asia-Pacífico y Norte de Australia, además de, cruceros transatlánticos. Su reducido tamaño, les permite hacer escala en puertos de menor tamaño y más exclusivos, a menudo prolongan la escala durante la noche para disfrutar de la vida y ambiente nocturno. El servicio en los buques tiene la categoría cinco estrellas.

\section{I.4.27 Pearl Seas Cruises}

Pearl Seas Cruises, opera un sólo buque dentro del segmento de cruceros de aventura de lujo. El primer y único buque de la flota, Pearl Mist, comenzó a navegar en 2012, véase Tabla I.44. Este buque tiene una capacidad de 210 pasajeros y cuenta con amplios camarotes de entre 28 y $54 \mathrm{~m}^{2}$ de superficie, equipados todos ellos con balcón privado. Los itinerarios que cubre esta compañía discurren por Canadá, los Grandes Lagos, el Estrecho de San Lorenzo y las islas del Caribe con duraciones de 10, 11 y 14 noches (Pearl Seas Cruises, 2013).

Tabla I.44: Flota de Pearl Seas Cruises

$$
\begin{aligned}
& \text { PEARL SEAS } \\
& \text { C R U I S E S }
\end{aligned}
$$

\begin{tabular}{lccccc} 
Nombre del Buque & $\begin{array}{c}\text { Capacidad } \\
\text { de Pasajeros }\end{array}$ & $\begin{array}{c}\text { Año de } \\
\text { construcción }\end{array}$ & $\begin{array}{c}\text { Eslora } \\
\text { (m) }\end{array}$ & $\begin{array}{c}\text { Manga } \\
(\mathbf{m})\end{array}$ & $\begin{array}{c}\text { Arqueo Bruto } \\
\text { (G.T.) }\end{array}$ \\
\hline Pearl Mist & 210 & 2010 & 102,10 & 17,07 & 6.000
\end{tabular}

Fuente: Elaboración propia basada en Pearl Seas Cruises (2013). 


\section{I.4.28 Blount Small Ship Adventures}

Blount Small Ship Adventures, fundada a mediados de los años 60, es una compañía americana cuya principal línea de negocio abarca cruceros costeros por Rhode Island, la barrera de coral de Belice y las islas del Caribe. Además, esta compañía tiene asociado un astillero en el cual se han construido los dos buques que componen su flota, véase Tabla I.45. En concreto, la capacidad de cada buque es de 88 pasajeros, disponen de un calado reducido para poder navegar por aguas poco profundas cerca de la costa, ríos y otras vías navegables. Además, el puente de gobierno es retráctil, lo que le permite navegar por debajo de puentes de baja altura y disponen de una rampa en proa para realizar desembarcos en la playa. Ambos buques enarbolan pabellón de Estados Unidos (Blount Small Ship Adventures, 2013).

Tabla I.45: Flota de Blount Small Ship Adventure

\begin{tabular}{|c|c|c|c|c|c|}
\hline \multirow[b]{2}{*}{ Nombre del Buque } & \multicolumn{3}{|c|}{ BLOUNT } & \multirow[b]{2}{*}{$\begin{array}{c}\text { Manga } \\
(\mathrm{m})\end{array}$} & \multirow[b]{2}{*}{$\begin{array}{c}\text { Arqueo Bruto } \\
\text { (G.T.) }\end{array}$} \\
\hline & $\begin{array}{c}\text { Capacidad } \\
\text { de Pasajeros }\end{array}$ & $\begin{array}{c}\text { Año de } \\
\text { construcción }\end{array}$ & $\begin{array}{c}\text { Eslora } \\
\text { (m) }\end{array}$ & & \\
\hline Grande Mariner & 88 & 1998 & 56,00 & 12,19 & 829 \\
\hline Grande Caribe & 88 & 1997 & 56,00 & 12,19 & 829 \\
\hline
\end{tabular}

Fuente: Elaboración propia basada en Blount Small Ship Adventures (2013).

Se trata por tanto de una compañía de cruceros especializada, con buques de pequeño tamaño que al igual que en casos anteriores le permite tener acceso a puertos alejados de la masificación. En su conjunto la capacidad de 176 pasajeros de su flota representa el 0,04\% mundial, vigésimo octavo operador independiente.

\section{I.4.29 Hebridean Island Cruises}

Hebridean Island Cruises, de origen británico y sede en Skipton (North Yorkshire, Reino Unido), es propiedad de All Leisure Holidays Ltd. Su segmento de mercado es el de lujo cinco estrellas, a bordo del buque de crucero más pequeño a flote. El buque Hebridean Princess con capacidad para 50 pasajeros, véase Tabla I.46, ofrece un servicio excepcional, amplios camarotes y visitas con guías privados (All Leisure Group, 2013b).

Tabla I.46: Flota de Hebridean Island Cruises

\begin{tabular}{|c|c|c|c|c|c|}
\hline & & $\begin{array}{l}\text { HEBRIDEAN } \\
\text { LAND CRUISES }\end{array}$ & & & \\
\hline Nombre del Buque & $\begin{array}{c}\text { Capacidad de } \\
\text { Pasajeros }\end{array}$ & $\begin{array}{c}\text { Año de } \\
\text { construcción }\end{array}$ & $\begin{array}{c}\text { Eslora } \\
\text { (m) }\end{array}$ & $\begin{array}{c}\text { Manga } \\
\text { (m) }\end{array}$ & $\begin{array}{c}\text { Arqueo } \\
\text { Bruto } \\
\text { (G.T.) }\end{array}$ \\
\hline Hebridean Princess & 50 & 1964 & 72 & 14 & 2.112 \\
\hline
\end{tabular}

Fuente: Elaboración propia basada en Hebridean Island Cruises (2013). 
La vida marinera de este buque comenzó en 1964 como car-ferry, en 1989 fue adquirido por Hebridean Island Cruises transformándolo en buque de crucero y bautizándolo Hebridean Princess. Los itinerarios que cubre la naviera discurren por la costa Oeste de Escocia, las islas Hébridas, islas del Norte de Escocia y Noruega (Hebridean Island Cruises, 2013). 


\section{Anexo II. Instalaciones para cruceros y perfil de estacionalidad de los puertos del litoral Mediterráneo español y Atlántico andaluz}

En el presente anexo se detallan las características de las instalaciones y servicios para cruceros en los puertos de la costa mediterránea española y atlántica andaluza. En concreto, el anexo se estructura en tres apartados, en cada uno de ellos se agrupan los puertos atendiendo a la posición competitiva obtenida en el análisis portfolio incluido en el Capítulo III, apartado 3.2.2.1. Además, también se incluye una representación gráfica de la cifra mensual de pasajeros de crucero agregada por meses durante el periodo del año 2000 a 2013 , así como, una representación mensual también para el mismo periodo.

\section{II.1 Puertos líderes maduros}

Con la posición de líder maduro se encuadran cuatro puertos, que son: Barcelona, Palma de Mallorca, Málaga y Cádiz. A continuación se definen las características particulares de las instalaciones para cruceros de cada uno de ellos.

\section{II.1.1 Puerto de Barcelona}

El puerto de Barcelona dispone de tres muelles dedicados exclusivamente a tráfico de cruceros, Adossat, Barcelona y España, y un total de siete terminales específicas para pasajeros de crucero, véase Figura II.1. Estas instalaciones le confieren la capacidad de albergar 10 buques de crucero simultáneamente (Port de Barcelona, 2013).

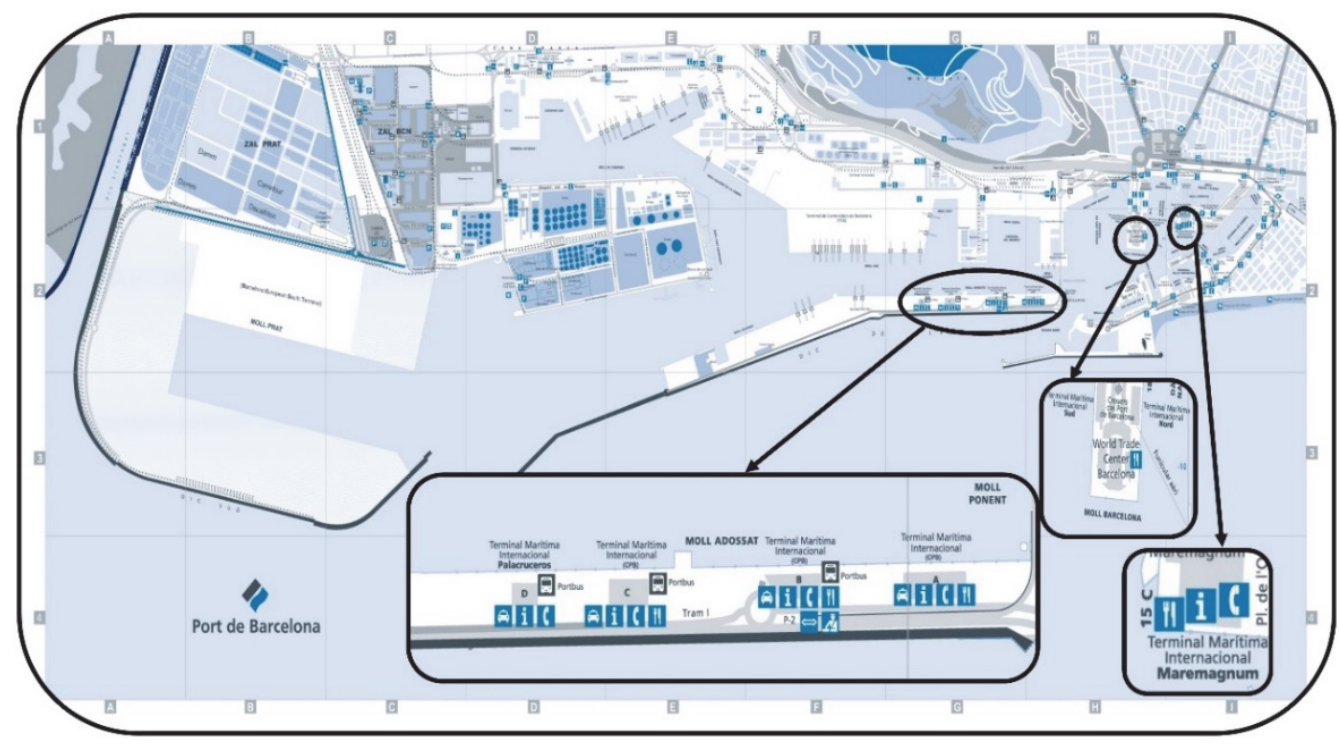

Figura II.1: Ubicación de los muelles para cruceros en el puerto de Barcelona.

Fuente: Elaboración propia. 
El muelle Adossat dispone de cuatro terminales de pasajeros de cruceros, A, B, C y D (Palacruceros), véase Figura II.2, (Autoridad Portuaria de Barcelona, 2012). Las terminales A y B están situadas a $2 \mathrm{~km}$ de la ciudad y concesionadas a la empresa Creuers del Port de Barcelona S.A. (CPB). Ambas terminales cuentan con similares características técnicas, tienen una superficie de $6.500 \mathrm{~m}^{2}$ e incorporan los últimos requerimientos en materia de seguridad, confort y rapidez en el embarque de pasajeros y equipaje asociado a mega-buques de crucero. Las terminales están divididas en dos áreas principales, área de facturación, con $44+21$ mostradores (Terminal A) y $46+20$ mostradores (Terminal B), y zona de recogida de equipajes con 4 cintas transportadoras cada una. Cuentan con dos 2 pasarelas de embarque de pasajeros diseñadas especialmente para la nueva generación de buques (Norwegian Epic, Carnival Dream y Oasis of the Seas) y un sistema de cintas transportadoras de equipaje, lo que permite asegurar que los pasajeros no interfieran con los camiones, montacargas y estibadores a nivel de muelle.

La actual terminal A está construida sobre la antigua Terminal A, la nueva terminal comenzó a estar operativa en abril de 2008 con una inversión asociada por parte de la empresa adjudicataria de 15 millones de euros. En cuanto a la Terminal B se inauguró en 2005 con una inversión asociada de 10 millones de euros. Ambas cumplen con el código ISPS (International Ship and Port Security). Además, ambas terminales están conectadas por una pasarela fija cubierta de 500 metros de longitud, permitiendo operaciones de puerto base para los buques de crucero de mayor tamaño (Oasis class, Sunshine, Breakaway, etc.).

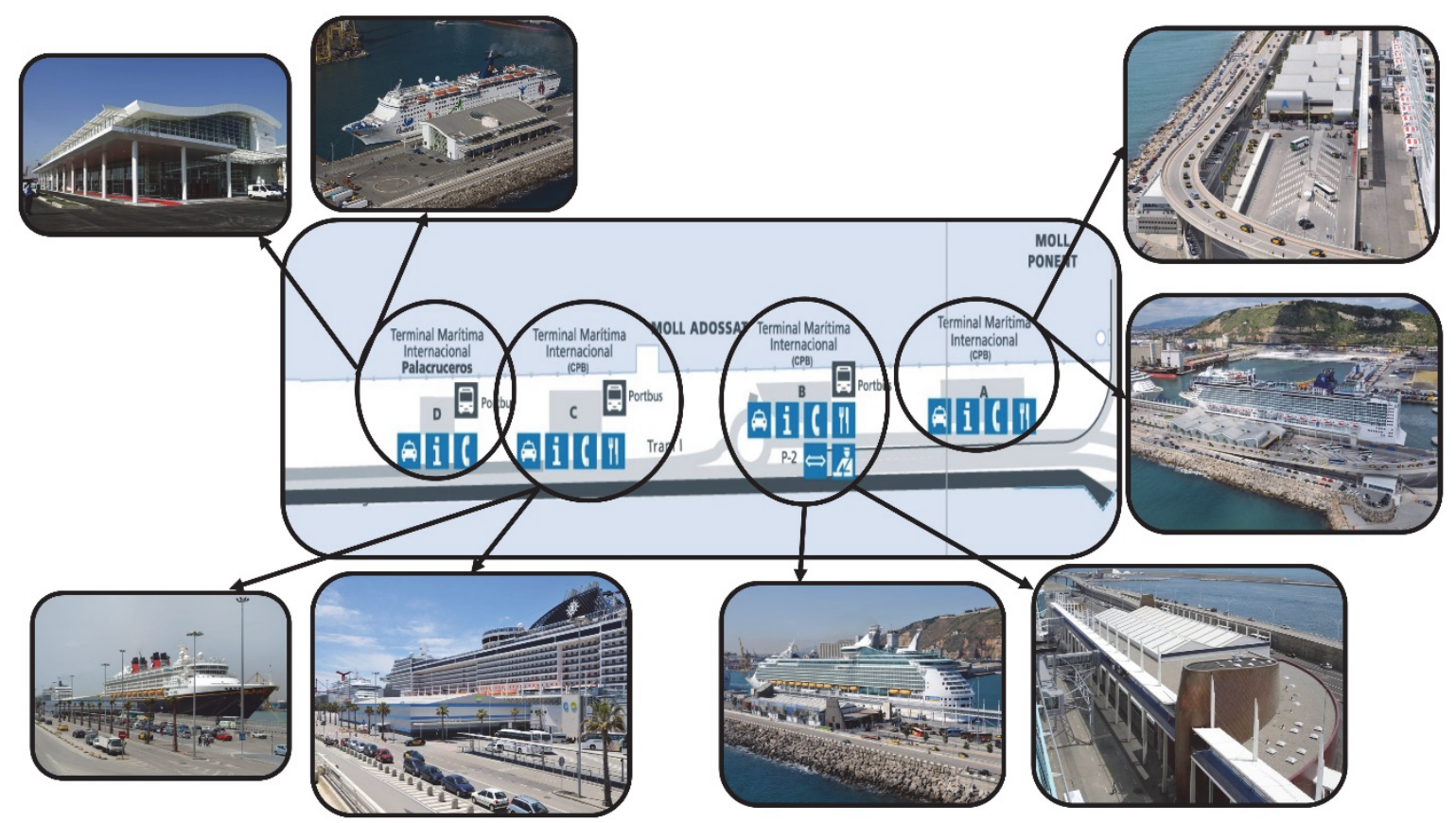

Figura II.2: Instalaciones para buques de crucero en el muelle Adossat del puerto de Barcelona. Fuente: Elaboración propia.

Las próximas escalas en septiembre de 2014 y mayo de 2015 de los buques Oasis y Allure of the Seas en el Mediterráneo, CPB es el único operador de terminal en el 
Mediterráneo preparado para acometer operaciones de puerto base con buques de este tamaño, la primera vez que estos buques desarrollan itinerarios fuera del Caribe. De hecho, para estas operaciones emplearán de forma combinada ambas terminales, embarcando y desembarcado la mitad del pasaje por cada una de éstas (CPB, 2014a).

El muelle de las terminales A y B tiene una línea de atraque de 700 metros con 12 metros de calado, no imponiendo restricción de eslora. La anchura del muelle es de 22 metros, con una altura sobre el cantil de 2,1 metros. Permite un flujo de 4.500 pasajeros en régimen de inicio y fin de itinerario cada una (Port de Barcelona, 2014).

Además, en ambos casos las terminales cuentan con los siguientes servicios: policía de inmigración, detector de metales, máquinas de Rayos X, aire acondicionado, teléfonos públicos, cambio de divisas, tiendas libres de impuestos, tiendas de regalos, servicio de mensajería, bar-restaurante, zona de estacionamiento para autocares, bus directo al centro de la ciudad, parada de taxis y servicio de entrega de equipajes a hoteles, aeropuerto u otros destinos (Port de Barcelona, 2013).

La terminal C, situada a 2,5 $\mathrm{km}$ de la ciudad, también está concesionada a la empresa Creuers del Port de Barcelona S.A. Inaugurada en 2005 fue remodelada en una operación conjunta con la Autoridad Portuaria de Barcelona, con una inversión asociada a Creuers de 5 millones de euros. Con una superficie de $4.100 \mathrm{~m}^{2}$ da servicio a operativas de tránsito e inicio y fin de itinerario. De forma análoga a las terminales A y B, está dividida en dos áreas principales cumpliendo con todos los requisitos del Código ISPS (CPB, 2014b).

Desde 2010 la terminal $\mathrm{C}$ cuenta con un sistema adicional de embarque de pasajeros compuesto de dos pasarelas móviles de conexión al buque y una pasarela fija cubierta que conecta las dos pasarelas anteriores con la terminal. El muelle asociado a esta terminal tiene una línea de atraque de 630 metros con 12 metros de calado, no imponiendo restricción de eslora. La anchura del muelle es de 23 metros, con una altura sobre el cantil de 2,1 metros. Permite un flujo de 3.800 pasajeros en régimen de inicio y fin de itinerario.

Análogamente al caso de las terminales A y B, la terminal C cuenta con los siguientes servicios: policía de inmigración, detector de metales, máquinas de Rayos X, aire acondicionado, teléfonos públicos, cambio de divisas, tiendas libres de impuestos, tiendas de regalos, bar-restaurante, zona de estacionamiento para autocares, bus directo al centro de la ciudad, parada de taxis y servicio de entrega de equipajes a hoteles, aeropuerto u otros destinos. Además, en esta terminal también se ofrecen diversos servicios a las tripulaciones, tales como, una sala con teléfono, internet, etc.

La terminal D (Palacruceros), concesionada a la compañía italiana Costa Cruises ha significado una inversión de 12 millones de euros totalmente financiados por esta naviera, comenzando a operar en 2007. Esta terminal tiene una gestión neutral aunque cuenta con uso preferencial para los cruceros del grupo Carnival, al cual pertenece Costa Cruises. 
El muelle asociado a la terminal D tiene una línea de atraque de 630 metros con 12 metros de calado, no imponiendo restricción de eslora. La anchura del muelle es de 22 metros, con una altura sobre el cantil de 2,1 metros. Permite un flujo de 4.500 pasajeros en régimen de inicio y fin de itinerario.

La terminal D situada a 2,5 $\mathrm{km}$ de la ciudad y con una superficie de $10.000 \mathrm{~m}^{2}$, cuenta como elementos diferenciadores respecto a las otras tres terminales situadas en el muelle Adossat de: Sala VIP, zona infantil, un centro comercial, conexión a internet y sala de tripulación (Port de Barcelona, 2014). Junto a estos servicios también dispone de los enumerados anteriormente para las terminales $\mathrm{A}, \mathrm{B}$ y $\mathrm{C}$.

Creuers del Port de Barcelona S.A. fue fundada en 1999 para operar 5 terminales de buques de crucero públicas en el puerto de Barcelona. Desde entonces ha acumulado un profundo conocimiento de la industria y junto con profesionales y empresas altamente capacitados, ha desarrollado y aumentado el tráfico de pasajeros de crucero hasta convertirlo en el puerto operador de cruceros más grande de Europa en 2013. Esto ha generado que Creuers del Port de Barcelona S.A. sea el operador internacional de terminales de crucero líder en Europa. Además, ha sido galardonada con una total de 35 premios entre $2001 \mathrm{y}$ 2012, en reconocimiento a su excelente labor como operador de terminales de pasajeros de crucero en Barcelona. Entre otros, destaca el premio a mejores operaciones de rotación de pasajeros de forma consecutiva de 2007 a 2013 (CPB, 2014c).

En el muelle Barcelona están emplazadas las terminales internacionales de cruceros Norte y Sur, véase Figura II.3. Ambas están concesionadas también a Creuers del Port de Barcelona S.A., con una inversión asociada de 14,5 millones euros. Además, se hallan integradas en el World Trade Center, un centro de negocios dotado de toda clase de servicios para las empresas. Su proximidad al centro de la ciudad es de 400 metros, de tal forma que permite que los turistas vayan caminando hasta la Plaza de Colón en tan sólo 5 minutos.

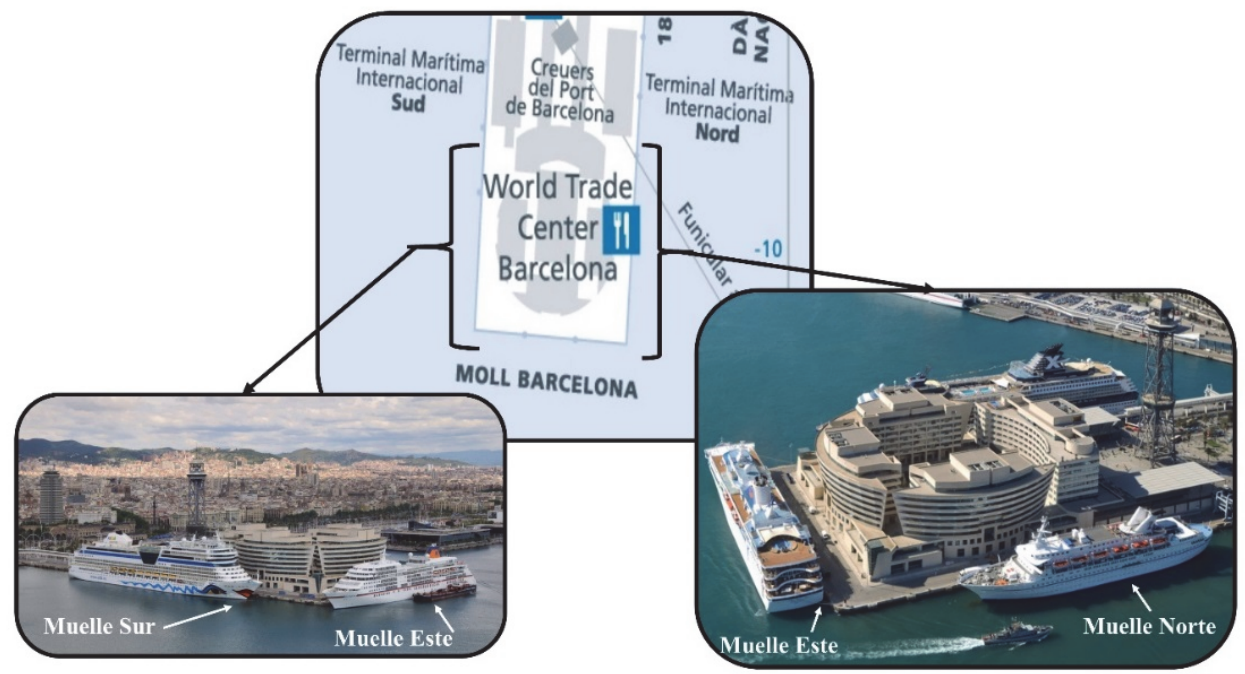

Figura II.3: Instalaciones para buques de crucero en el muelle Barcelona (atraques Norte, Sur y Este) del puerto de Barcelona.

Fuente: Elaboración propia. 
Las terminales Norte y Sur cuentan con tres líneas de atraque, Norte, Sur y Este. El muelle Norte tiene una línea de atraque de 230 metros, lo que le permite recibir un crucero de tamaño medio, aproximadamente 169 metros de eslora. El muelle Sur tiene una mayor longitud de atraque, 430 metros, pudiendo dar servicio a dos cruceros, el de mayor tamaño de 253 metros de eslora. En ambos casos tienen una operativa combinada para tránsito y puerto base. En este último caso, las capacidades son de 800 y 1.400 pasajeros para las terminales Norte y Sur, respectivamente. Mientras que el muelle Este tiene una línea de atraque de 160 metros, utilizándose únicamente para operaciones de tránsito con un límite de 1.500 pasajeros. En los tres muelles el calado es de 8 metros. Su anchura es de 14 metros para el Norte y el Sur y 20 metros en el Este con una altura de muelle de 2,5 metros en los tres casos (Port de Barcelona, 2013).

Las terminales con $5.000 \mathrm{~m}^{2}$ de superficie cada una cuentan con los siguientes servicios: policía de inmigración, detector de metales, máquinas de Rayos X, 1 pasarela de embarque de pasajeros, cintas transportadoras, aire acondicionado, teléfonos públicos, cambio de divisas, tiendas libres de impuestos, tiendas de regalos, bar - restaurante, zona de estacionamiento para autocares, bus directo al centro de la ciudad, parada de taxis, servicio de entrega de equipajes a hoteles, aeropuerto u otros destinos.

En el Port Vell, en el muelle España está situada la terminal M, integrada totalmente en el complejo lúdico Maremàgnum, situado a 400 metros de la ciudad, véase Figura II.4. Es la terminal más pequeña y da servicio a los barcos de capacidad y eslora más pequeños. El muelle España cuenta con una línea de atraque de 220 metros y 8,60 metros de calado, lo que le permite recibir buques de hasta 140 metros de eslora. La anchura del muelle es de 10 metros con 2,35 metros de altura de muelle.

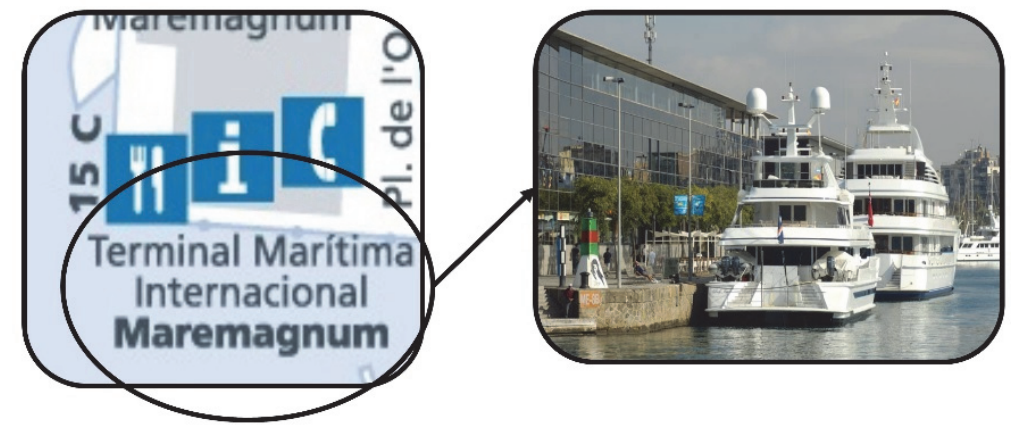

Figura II.4: Instalaciones para buques de crucero en el muelle España del puerto de Barcelona. Fuente: Elaboración propia.

La terminal $\mathrm{M}$ tiene una superficie de $480 \mathrm{~m}^{2}$ con capacidad para 200 pasajeros de puerto base. Además, cuenta con los siguientes servicios: aire acondicionado, teléfonos públicos, tiendas de regalos, bares, restaurantes y cafeterías, escaleras mecánicas, bus directo al centro de la ciudad, acceso a la red metropolitana de transportes públicos y parada de taxis. 
También dispone de otros servicios asociados al complejo Maremàgnum como cine, l'Aquarium, IMAX, etc.

Junto a los muelles descritos anteriormente, el puerto de Barcelona también dispone de dos muelles más con sendas terminales que pueden albergar tráfico de cruceros pero con carácter ocasional. Se trata de la terminal $\mathrm{Z}$ en el muelle Barcelona y la terminal Ferry de Barcelona en el muelle de San Beltrán. Ambas terminales dan servicio a tráficos de línea regular con buques ferry, usadas ocasionalmente por buques de crucero sobre todo en días de gran afluencia y mayoritariamente para operaciones de tránsito.

El muelle de San Beltrán, situado a 400 metros de la ciudad, cuenta con una línea de atraque de 255 metros y 11,00 metros de calado que limita la eslora máxima del buque que puede albergar a 220 metros. La anchura del muelle es de 12 metros con 2,15 metros de altura sobre el cantil. La superficie asociada a la terminal Ferry de Barcelona es de $2.200 \mathrm{~m}^{2}$. El muelle Barcelona, en la parte correspondiente a la terminal Z, dispone de una línea de atraque de 250 metros y 8 metros de calado. La superficie asociada a esta terminal es de $1.400 \mathrm{~m}^{2}$.

Ambas terminales cuentan con los siguientes servicios: aire acondicionado, teléfonos públicos, bar-restaurante, escaleras mecánicas, acceso a la red metropolitana de transportes públicos y parada de taxis.

El puerto cuenta con todos los servicios requeridos por el buque: provisión de agua potable, conexiones telefónicas e informáticas terminal-barco, recogida de residuos, suministro de combustible (gas-oil y fuel oil), provisionistas y servicio de remolque (8 unidades), prácticos y amarradores, 24 horas (Autoridad Portuaria de Barcelona, 2012).

El impulso del tráfico de cruceros continúa en el puerto de Barcelona con la construcción de una nueva terminal en el muelle Adossat, la terminal E. Esta terminal será construida y explotada en régimen de concesión por Carnival Corporation tras alcanzar un acuerdo con la Autoridad Portuaria de Barcelona. La instalación comenzará a estar operativa en 2016 y tendrá aproximadamente $10.000 \mathrm{~m}^{2}$ de superficie y estará preparada para recibir buques de crucero post-panamax, con una capacidad de 4.500 pasajeros en operativas de inicio y/o fin de itinerario. Se estima que la inversión a cargo de Carnival rondará los 20 millones de euros. Mientras que el puerto de Barcelona hará una inversión complementaria de 3,5 millones de euros, de los que dos millones se dedicarán a la elaboración y ejecución del proyecto de urbanización del entorno de la terminal y 1,5 millones a obras de mejora de la señalización del muelle (Diario El Mundo, 2013). Esta instalación tiene como cometido dar servicio a mega-buques de crucero y que tienen al puerto de Barcelona como base de sus rutas por el Mediterráneo.

La distribución mensual de pasajeros de inicio y fin de itinerario y tránsito guarda una estrecha similitud entre ambas categorías durante el periodo de 2000 a 2013. La temporada alta de las dos categorías ha comprendido de mayo a octubre, marcando los meses 
de abril y noviembre el punto de inflexión hacia el inicio y fin de ésta, véase Gráfico II.1 y II.2. En este sentido, en la categoría de pasajeros en tránsito la diferencia del mes de abril respecto a mayo ha sido menos acusada que en la de pasajeros de inicio y fin de itinerario. Para ambas categorías, el primer trimestre del año junto con el mes de diciembre, han constituido los meses de menor actividad. Además, durante el periodo de 2000 a 2013 ha habido un incremento de las dos categorías de pasajeros. Tanto es así que durante todos los meses del periodo analizado se han registrado pasajeros de crucero, véase Gráfico II.3 y II.4.

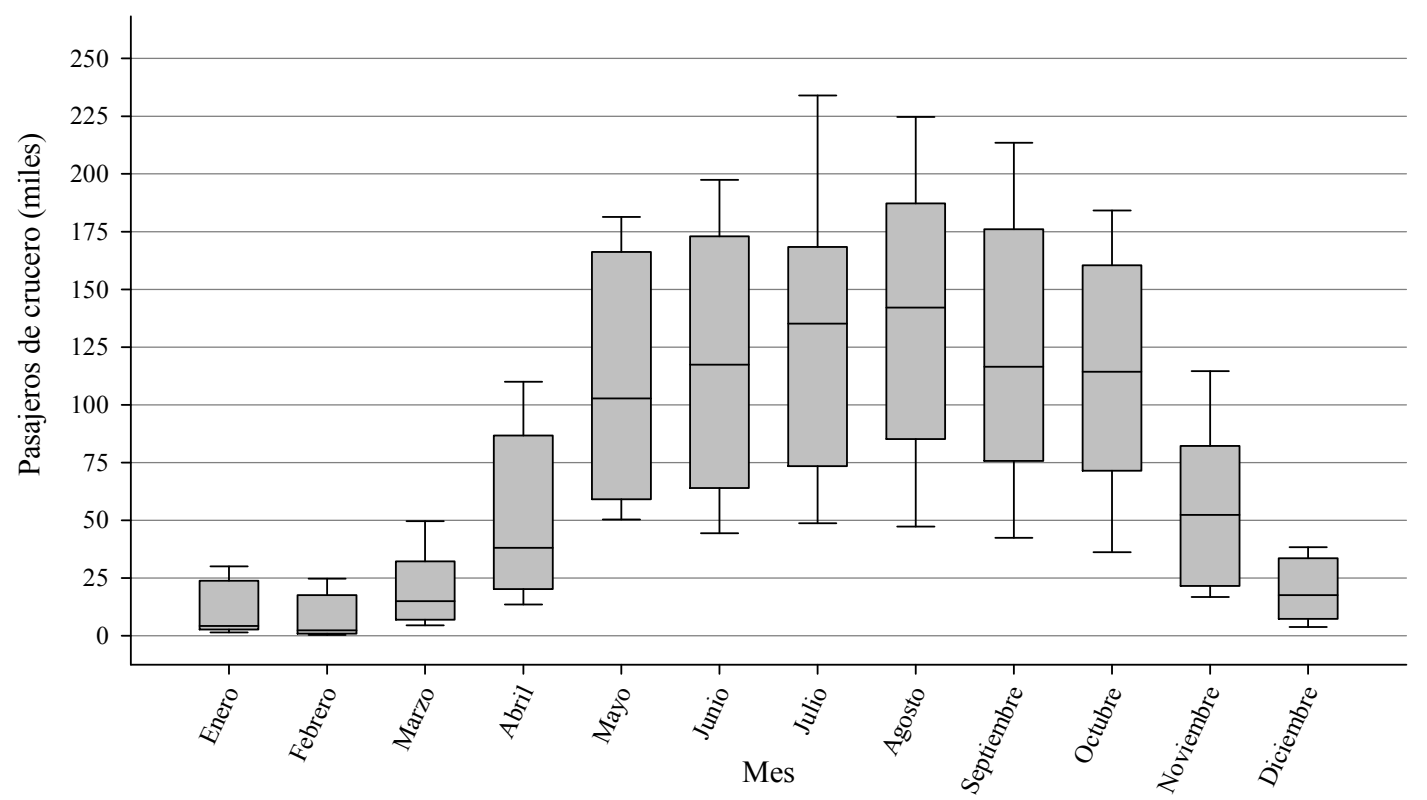

Gráfico II.1: Distribución de la cifra de cruceristas en régimen de inicio y/o fin de itinerario en el puerto de Barcelona, agregada por meses, entre el año 2000 y 2013.

Fuente: Elaboración propia.

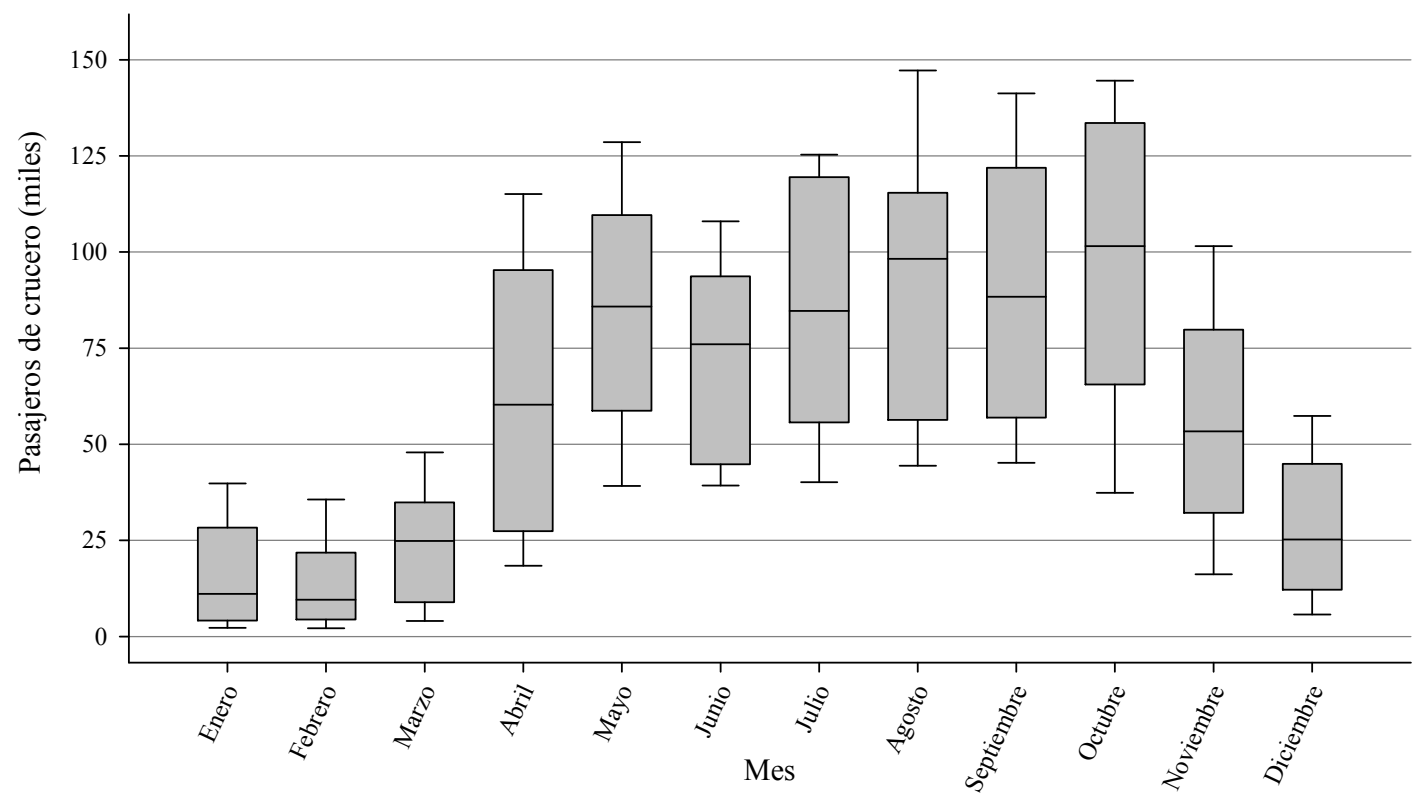

Gráfico II.2: Distribución de la cifra de cruceristas en régimen de tránsito en el puerto de Barcelona, agregada por meses, entre el año 2000 y 2013.

Fuente: Elaboración propia. 


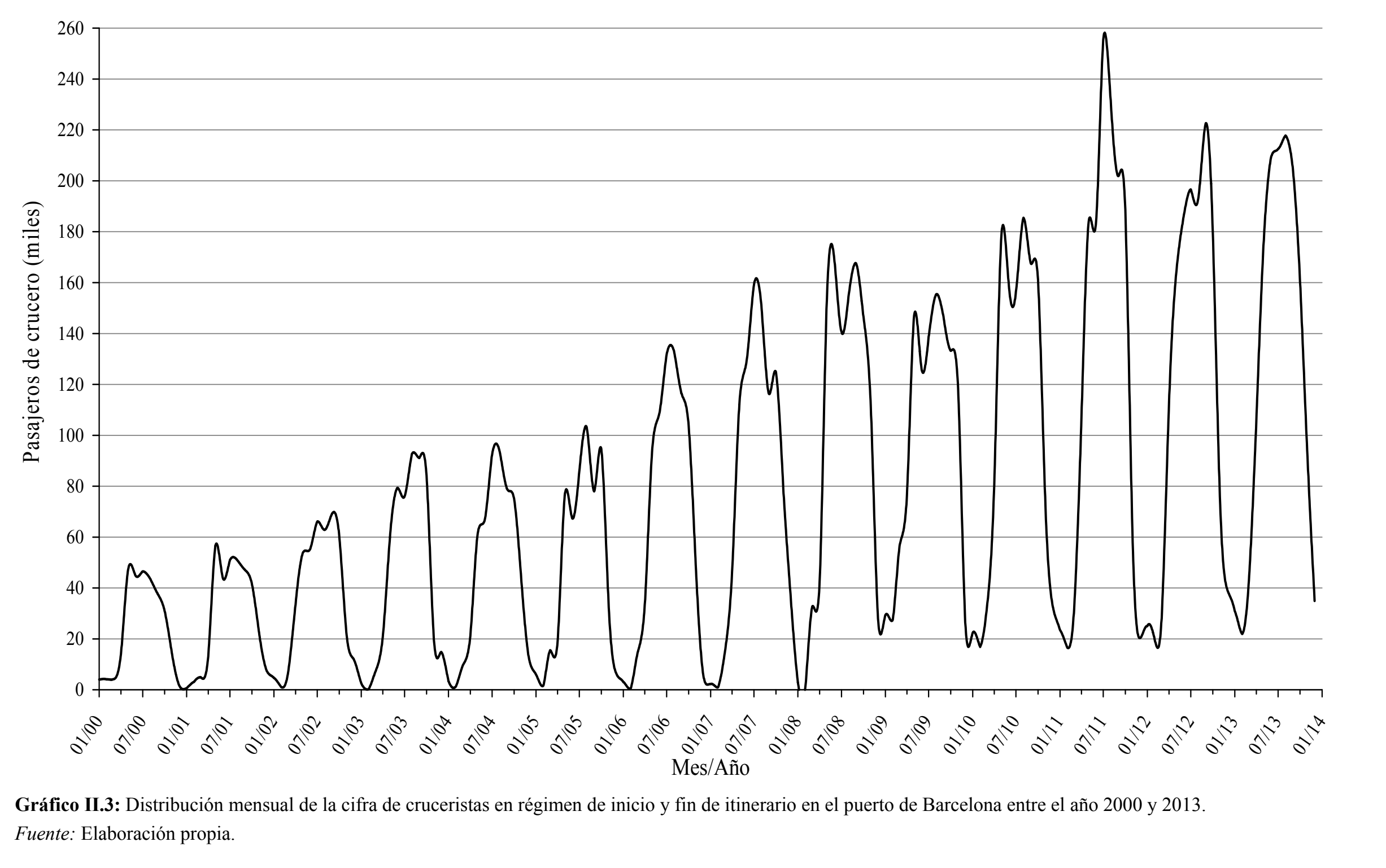




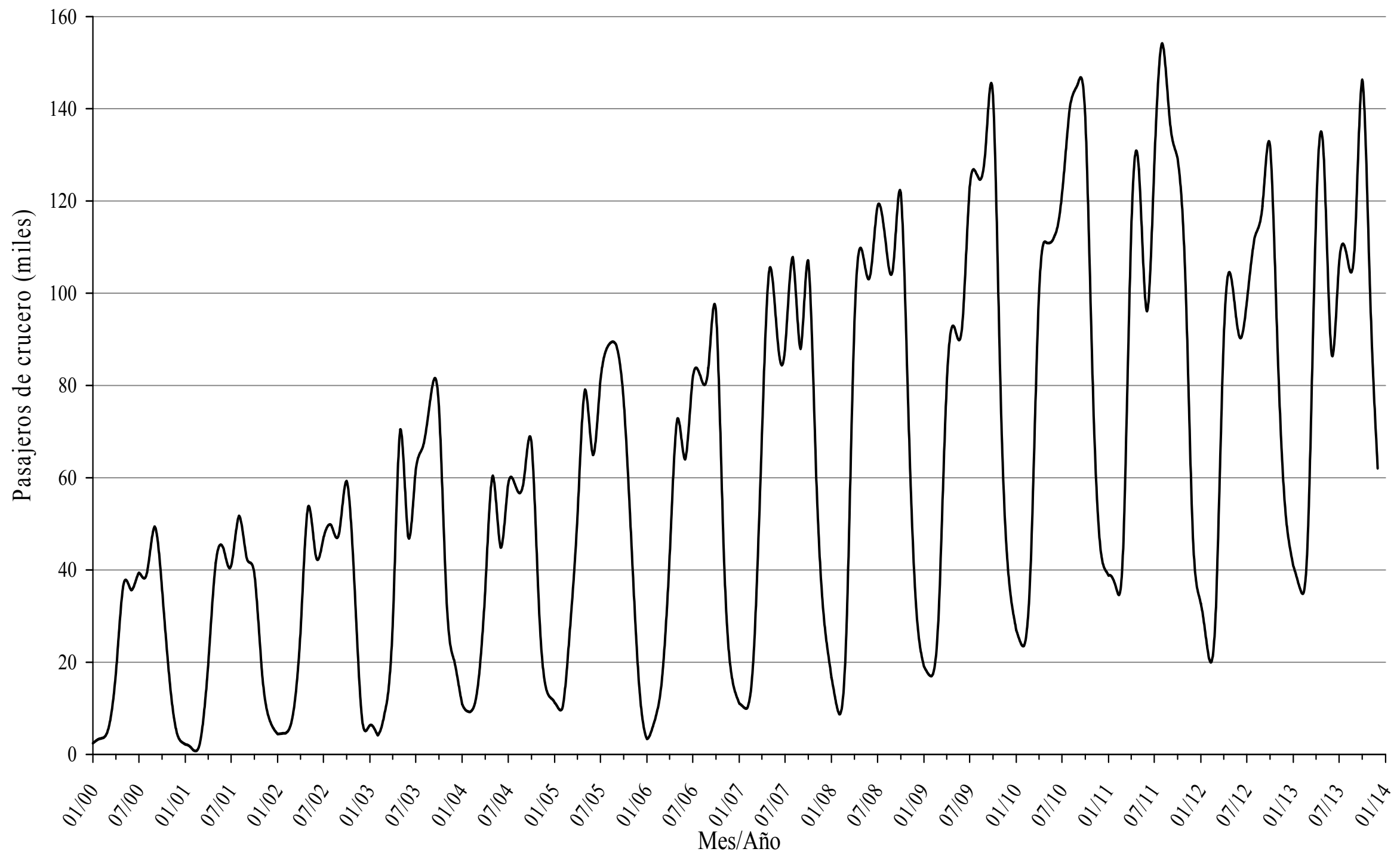

Gráfico II.4: Distribución mensual de la cifra de cruceristas en régimen de tránsito en el puerto de Barcelona entre el año 2000 y 2013. Fuente: Elaboración propia.

$-229-$ 


\section{II.1.2 Puerto de Palma de Mallorca}

El puerto de Palma de Mallorca cuenta con 10 atraques para buques de crucero, véase Figura II.5, lo que le confiere una longitud de atraque total de 3.175 metros. Las características de cada uno de estos muelles están recogidas en la Tabla II.1. Además, cuenta con seis terminales de pasajeros conectadas por siete pasarelas móviles y 1.027 metros lineales de pasarelas fijas (Autoridad Portuaria de Baleares, 2014a).

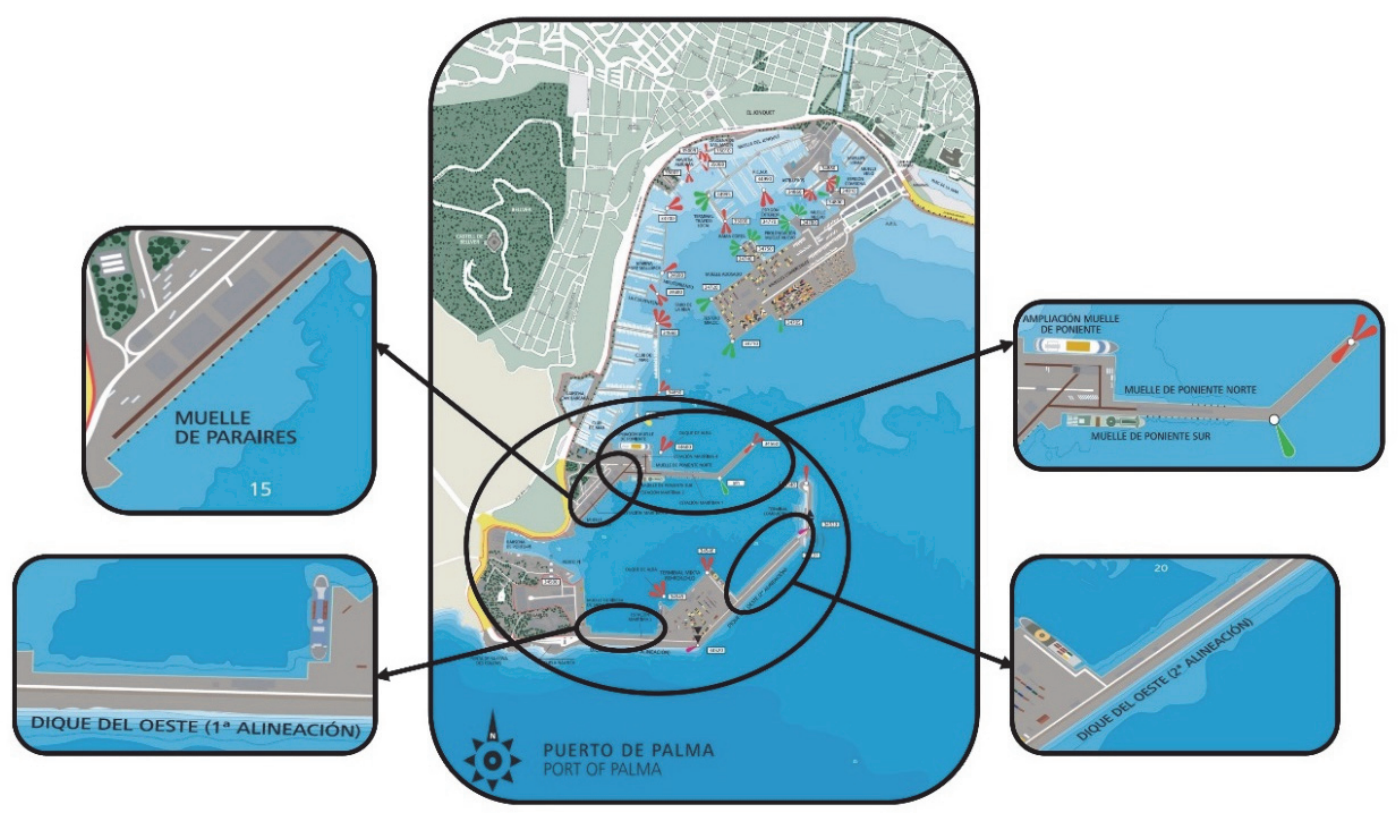

Figura II.5: Ubicación de los muelles de pasajeros de crucero en el puerto de Palma de Mallorca.

Fuente: Elaboración propia.

Tabla II.1: Características de los muelles destinados al atraque de buques de crucero en el puerto de Palma de Mallorca

\begin{tabular}{lrrr}
\hline Nombre del muelle & Longitud de atraque (m) & Calado (m) & Anchura (m) \\
\hline Poniente Sur & 390,0 & $12,0-8,0$ & $35,0-8,4$ \\
Paraires & 363,0 & $12,0-10,0$ & 50,0 \\
Dique del Oeste 1 a alineación & 360,0 & 12,0 & 30,0 \\
Ampliación muelle Poniente Norte & 275,8 & $10,0-6,0$ & 65,0 \\
Poniente Norte & 269,0 & $12,0-8,5$ & $35,0-8,4$ \\
Dique del Oeste 2a alineación & 440,0 & 12,0 & 30,0 \\
Prolongación muelle de poniente Norte & 354,0 & $12,0-8,5$ & - \\
Prolongación muelle de poniente Sur & 440,0 & $12,0-8,0$ & - \\
Alineación Norte Prolongación Dique Oeste & 285,0 & 12,0 & - \\
\hline
\end{tabular}

Fuente: Elaboración propia basada en datos de Autoridad Portuaria de Baleares (2014a).

Estas terminales dan servicio tanto a pasajeros en tránsito como de puerto base. En este último caso, la facturación de los equipajes es posible realizarla de forma combinada con el aeropuerto de Son Sant Joan. Las seis terminales son gestionadas y explotadas por la Autoridad Portuaria de Baleares. El puerto cuenta con servicio de remolcadores (3 unidades), amarradores y prácticos, 24 horas. Además de, servicio de recogida de residuos oleosos, sólidos y líquidos (Autoridad Portuaria de Baleares, 2012). 
Entre el año 2000 y 2013, tanto los pasajeros en tránsito como los de inicio y fin de itinerario se han concentrado en los meses de mayo a octubre, véase Gráfico II.5 y II.6. Los menores registros anuales se han dado durante el primer trimestre del año y en el mes de diciembre. Además, durante este periodo han aumentado las cifras de ambas categorías de pasajeros, dando lugar a varios años en los cuales durante todos los meses se registraron cruceristas de ambos tipos, véase Gráfico II.7 y II.8.

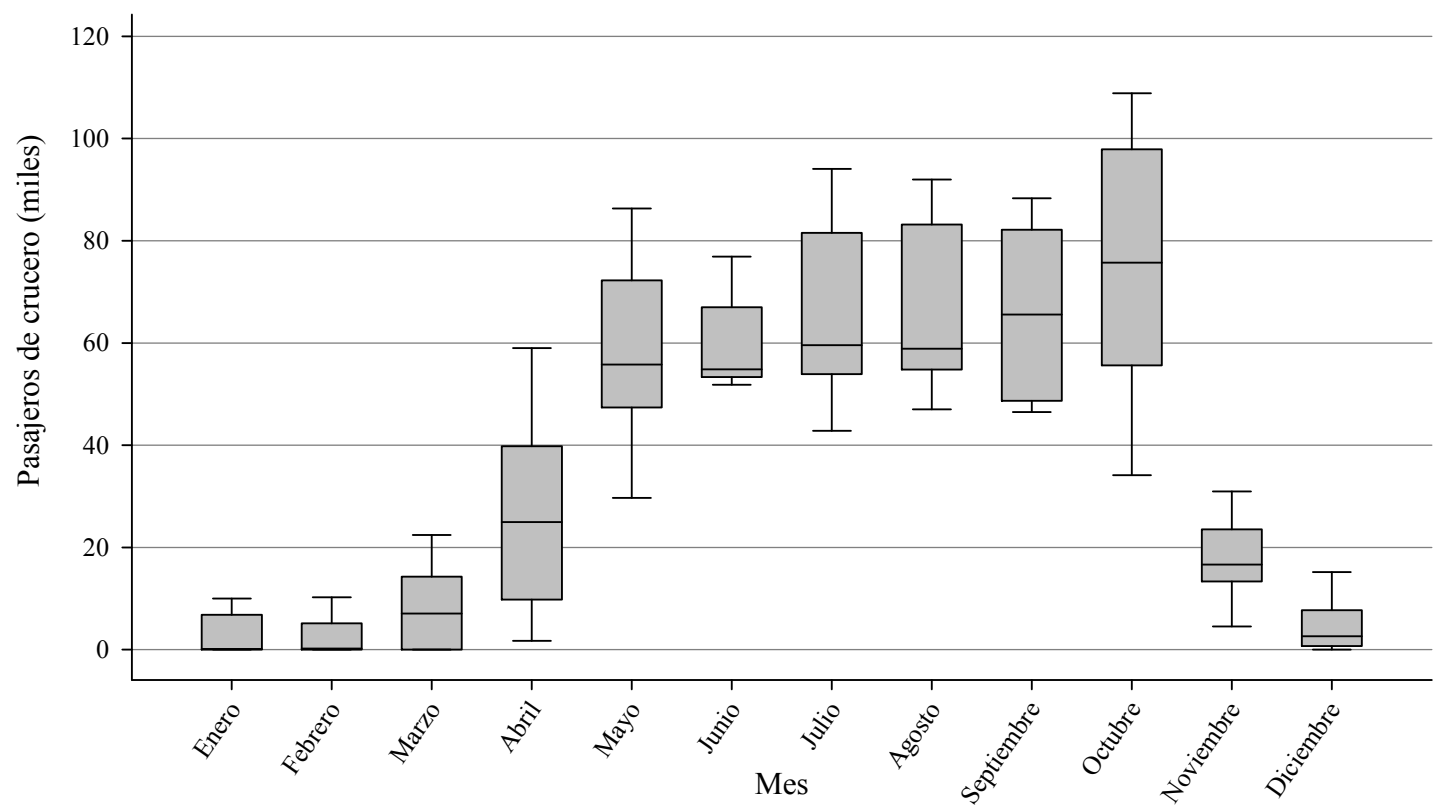

Gráfico II.5: Distribución de la cifra de cruceristas en régimen de inicio y/o fin de itinerario en el puerto de Palma de Mallorca, agregada por meses, entre el año 2000 y 2013.

Fuente: Elaboración propia.

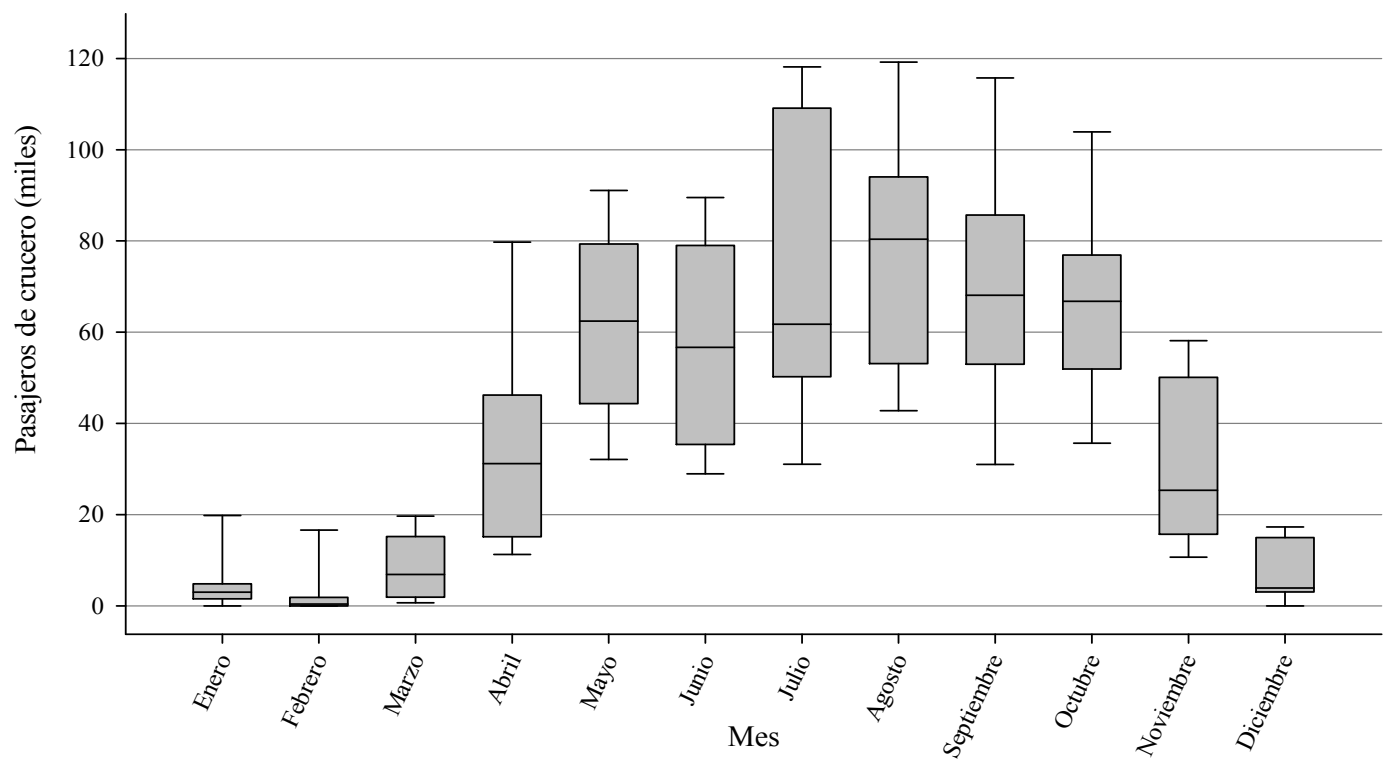

Gráfico II.6: Distribución de la cifra de cruceristas en régimen de tránsito en el puerto de Palma de Mallorca, agregada por meses, entre el año 2000 y 2013.

Fuente: Elaboración propia. 


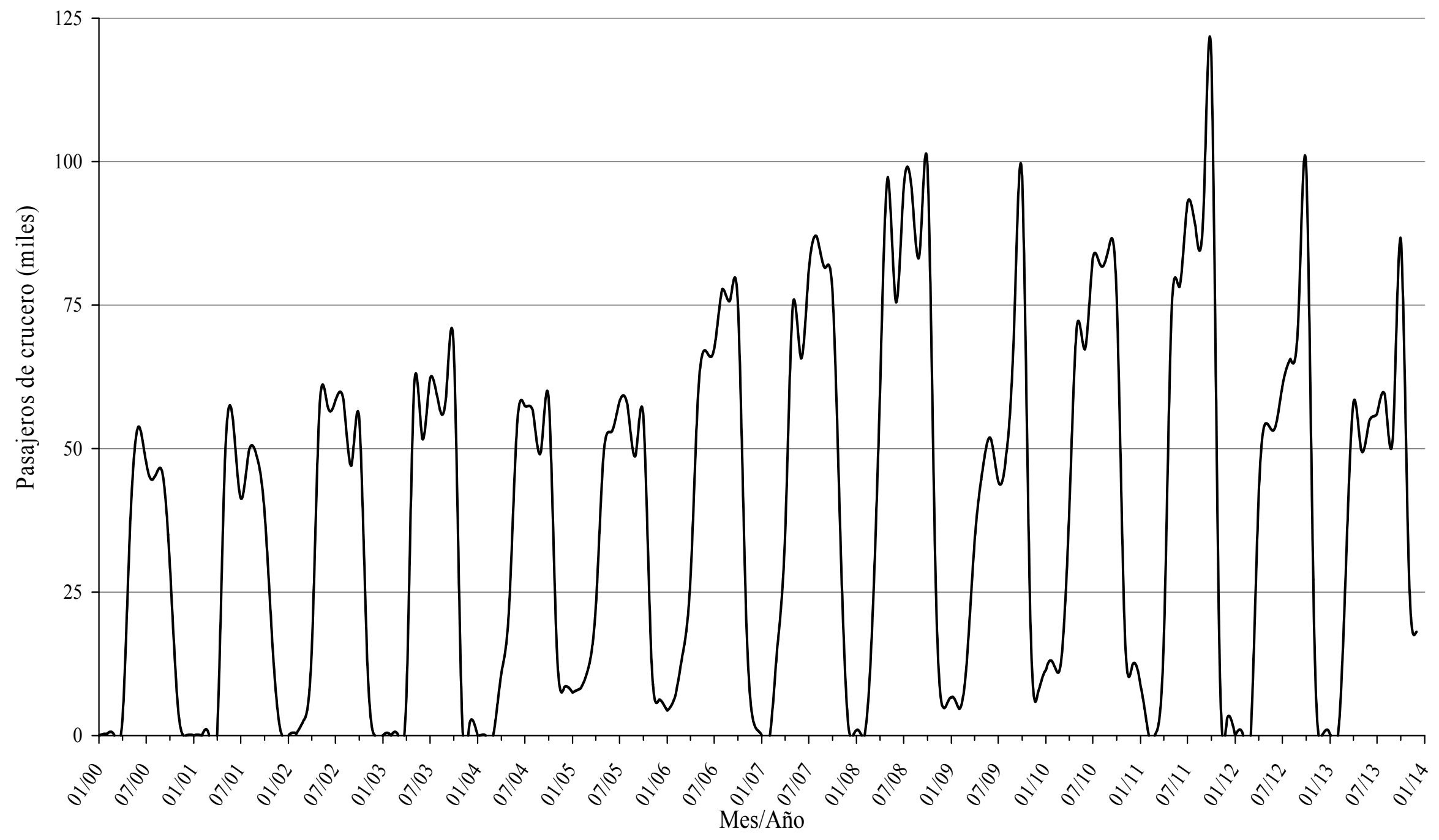

Gráfico II.7: Distribución mensual de la cifra de cruceristas en régimen de inicio y fin de itinerario en el puerto de Palma de Mallorca entre el año 2000 y 2013. Fuente: Elaboración propia. 


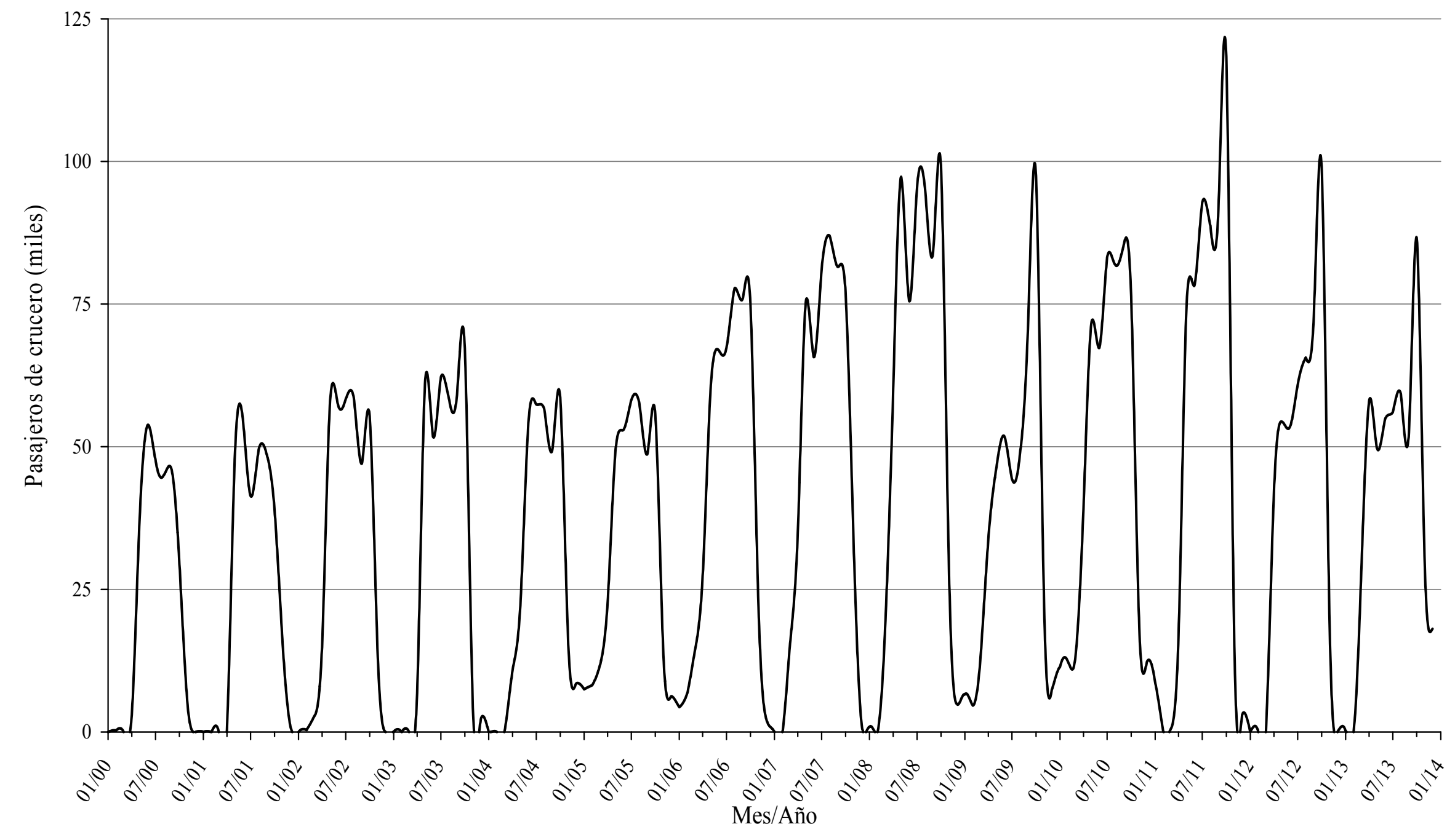

Gráfico II.8: Distribución mensual de la cifra de cruceristas en régimen de tránsito en el puerto de Palma de Mallorca entre el año 2000 y 2013.

Fuente: Elaboración propia. 


\section{II.1.3 Puerto de Málaga}

El puerto Málaga dispone de muelles para el atraque de buques de crucero en la dársena Exterior y en la dársena de Guadiaro, véase Figura II.6. La dársena Exterior concentra el mayor volumen de tráfico de cruceros con las instalaciones específicas para este tráfico situadas en el Dique de Levante. En éste hay disponibles cuatro zonas de atraque, Norte, Sur, Levante y adosado al Dique de Levante. Asociado a estas cuatro zonas de atraque se dispone de dos terminales para pasajeros de cruceros totalmente independientes y emplazadas en la unión entre el muelle de Levante y el antiguo Dique de Levante (Autoridad Portuaria de Málaga, 2012).

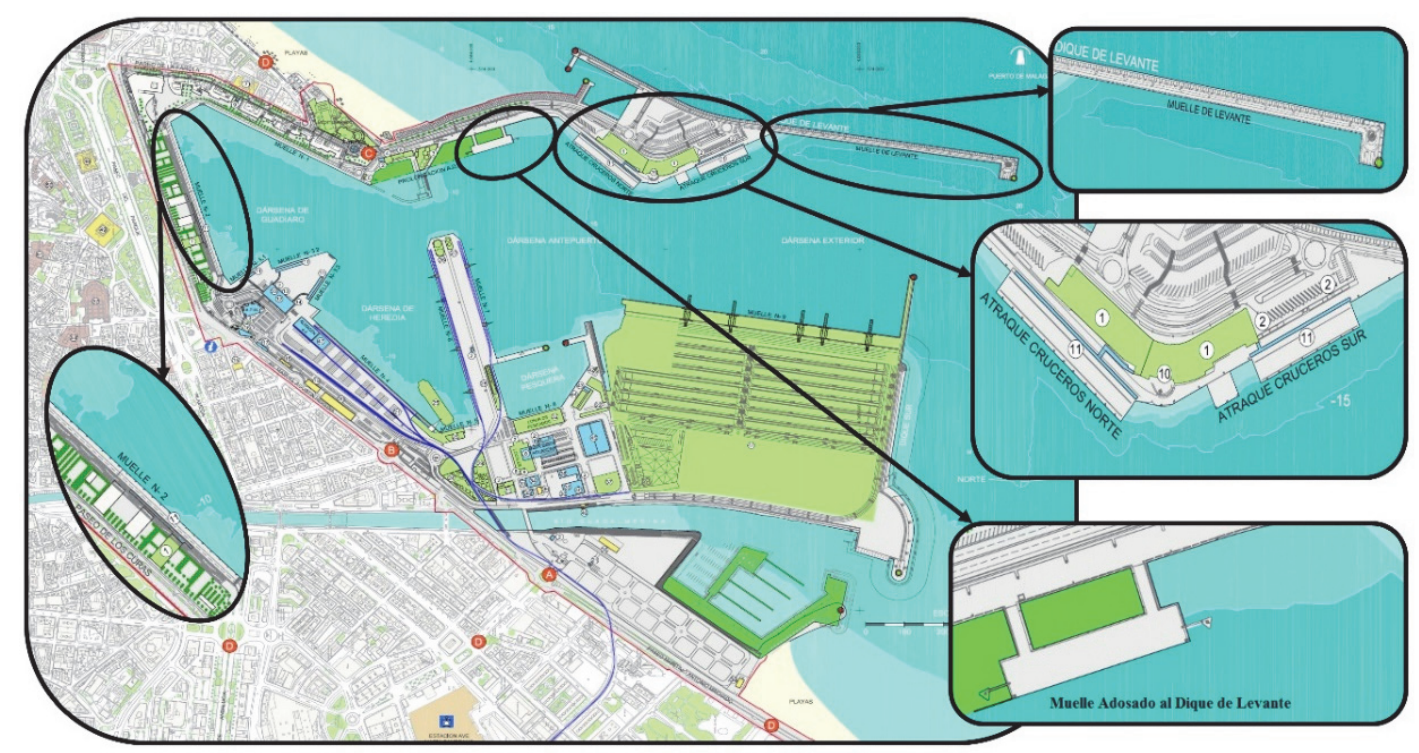

Figura II.6: Instalaciones para buques de crucero en el puerto de Málaga.

Fuente: Elaboración propia.

El atraque Sur admite buques de hasta 315 metros de eslora con un calado de 12 metros. Mientras que el atraque Norte admite buques de mayor eslora, hasta 335 metros, con el mismo calado que en el caso anterior. Además, ambos atraques tienen una anchura de 25 metros con 3 metros de altura. El muelle de Levante no impone restricción a la eslora del buque que puede recibir, dada la longitud de atraque de 555 metros, además el muelle cuenta con un calado de 17 metros, 13,5 metros de ancho y 3 metros de altura, véase Figura II.7. En cuarto lugar, el atracadero adosado al Dique de Levante dispone de $300 \mathrm{~m}$. de línea de atraque, con un calado de $11 \mathrm{~m}$. y $23 \mathrm{~m}$. de anchura. Estas características le permiten recibir buques de hasta $260 \mathrm{~m}$. de eslora y $10,5 \mathrm{~m}$. de calado.

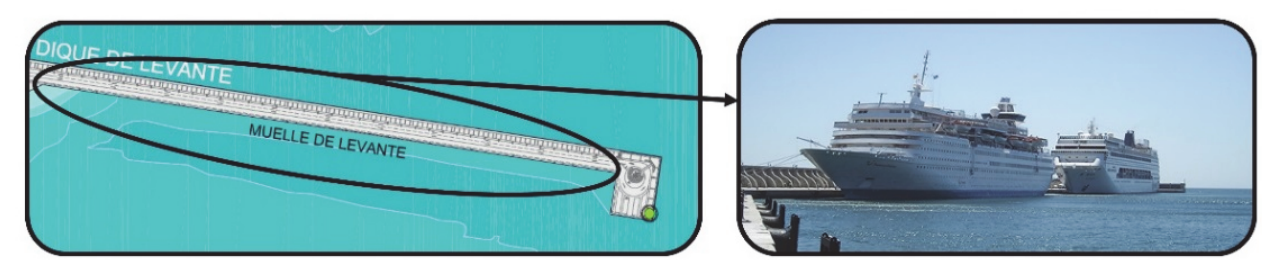

Figura II.7: Muelle de Levante para el atraque de cruceros en el puerto de Málaga. Fuente: Elaboración propia. 
La Estación Marítima de Levante, está dividida en dos terminales para dar servicio a los pasajeros de crucero, terminal A y B, véase Figura II.8. Ambas son totalmente independientes, aunque pueden funcionar conjuntamente si un barco de grandes dimensiones así lo requiere. Como por ejemplo, en las dos escalas del buque Oasis of the Seas en el puerto malagueño en septiembre de 2014 (Diario Sur, 2013). Las dos terminales están concesionadas a la empresa Cruceros Málaga S.A.

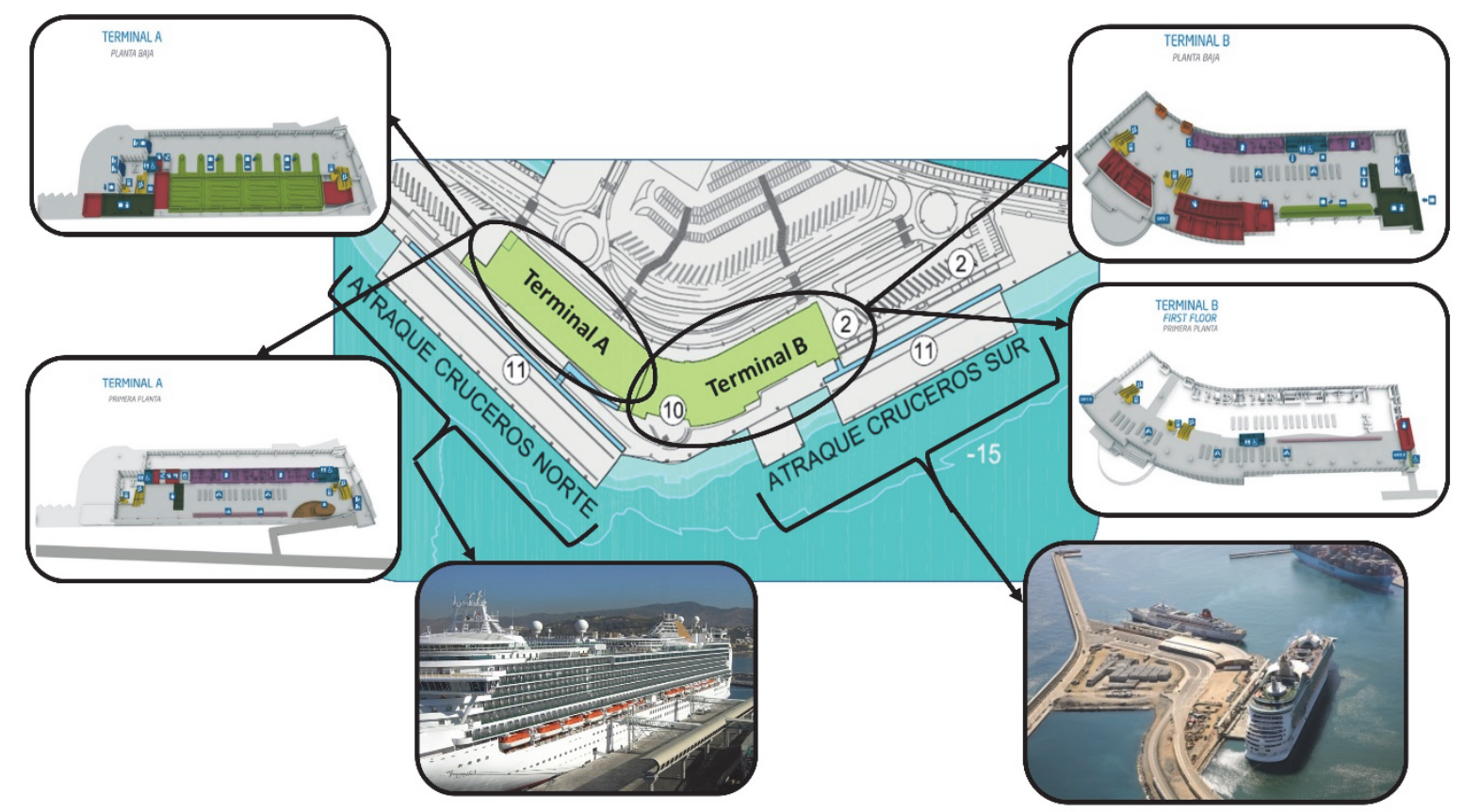

Figura II.8: Terminales de pasajeros A y B y atraques de cruceros Norte y Sur en el puerto de Málaga. Fuente: Elaboración propia.

Cruceros Málaga S.A. corresponde en un 20\% del capital a la Autoridad Portuaria de Málaga y el $80 \%$ restante a Creuers del Port de Barcelona, el mayor especialista en explotación de terminales de cruceros en el Mediterráneo, cuya principal actividad está ligada al puerto de Barcelona, descrita anteriormente en el apartado correspondiente a este puerto. Cruceros Málaga S.A. fundada en agosto de 2007, tiene como principal objetivo la explotación de las terminales de cruceros y prestación de servicios a los pasajeros de crucero en el puerto de Málaga. En relación con este último concepto, sus principales servicios se centran en actividades de embarque y desembarque, y gestión y facturación de equipajes.

La terminal A, situada a 2,50 km del centro de la ciudad, comenzó a operar en mayo de 2011. Da servicio al atraque Norte y está especialmente diseñada como terminal de puerto base, para lo cual se distribuye en dos plantas con una superficie total de $7.715 \mathrm{~m}^{2}$ con objeto de operar de forma separada equipaje y pasajeros, véase de nuevo Figura II.8. También puede recibir buques en tránsito, además de dar servicio al atraque adosado al Dique de Levante (Cruceros Málaga, 2014). 
En la planta baja están situados los mostradores de facturación y recogida de equipaje (4 cintas de equipaje) y la aduana. Mientras que, en la primera planta se dispone el control de seguridad y aduana, 46 mostradores de facturación, área de embarque, área de espera, zona de tiendas, sala VIP y snack área. Sus instalaciones están especialmente concebidas para los mega-buques de crucero tan presentes en la flota, adaptándose a las dimensiones de estos buques las dos pasarelas móviles de que dispone la terminal. La terminal puede dar servicio a 4.000 pasajeros en régimen de puerto base, no existiendo tal restricción en cuanto a pasajeros en tránsito. Su construcción iniciada en diciembre de 2009 ha supuesto una inversión por parte de Cruceros Málaga S.A. de 15 millones de euros.

La terminal B, situada a $3 \mathrm{~km}$ del centro de la ciudad, comenzó a estar operativa en febrero de 2008. Esta terminal tiene una superficie total de $8.367 \mathrm{~m}^{2}$ divididos en dos plantas y desde ella se operan dos atraques para cruceros: el atraque Sur y el muelle de Levante y hasta tres barcos de manera simultánea. Además, esta terminal puede atender indistinta y simultáneamente barcos en tránsito y en base.

La distribución en dos plantas es la siguiente, véase de nuevo Figura II.8. En la planta baja, con una superficie de $6.289 \mathrm{~m}^{2}$, se sitúan los servicios de: facturación y recogida de equipaje, área de espera, 46 mostradores móviles de facturación, control de seguridad y aduana, zona de tiendas, snack área y área de embarque. En la primera planta, de $2.078 \mathrm{~m}^{2}$ de superficie, se dispone de: 40 mostradores de facturación, área de embarque y área de espera. Además, la terminal cuenta con una pasarela móvil para el embarque/desembarque de pasajeros. Estas características dotan a la terminal de una capacidad de 4.000 pasajeros en régimen de puerto base e ilimitada para pasajeros en tránsito (Cruceros Málaga, 2014).

El muelle $n^{\circ} 2$ de la dársena de Guadiaro también puede recibir buques de crucero. La línea de atraque reservada en este muelle para este tipo de buque es de $240 \mathrm{~m}$ con $9 \mathrm{~m}$ de calado, esto permite albergar buques de pequeño y medio tamaño de hasta $200 \mathrm{~m}$ de eslora, véase Figura II.9. El muelle $\mathrm{n}^{\mathrm{o}} 2$ también cuenta con terminal de pasajeros, denominada Estación Marítima "El Palmeral", inaugurada en 2012 y también concesionada a Cruceros Málaga S.A. (Autoridad Portuaria de Málaga, 2014).

La Estación Marítima "El Palmeral", puede albergar tanto operaciones de puerto base como de tránsito. El edificio, de 858,93 $\mathrm{m}^{2}$, está dividido en dos plantas. En la planta baja está emplazada la recogida de equipajes y el control de seguridad. Mientras en la primera planta se encuentran los mostradores de facturación, área de embarque, área de espera y aduana, véase Figura II.9. Además, también cuenta con una pasarela móvil de embarque. Junto a todo lo anterior el edificio goza de una situación privilegiada en pleno centro histórico de la ciudad, permitiendo a los pasajeros acceder caminando a la ciudad en tan sólo 5 minutos. 


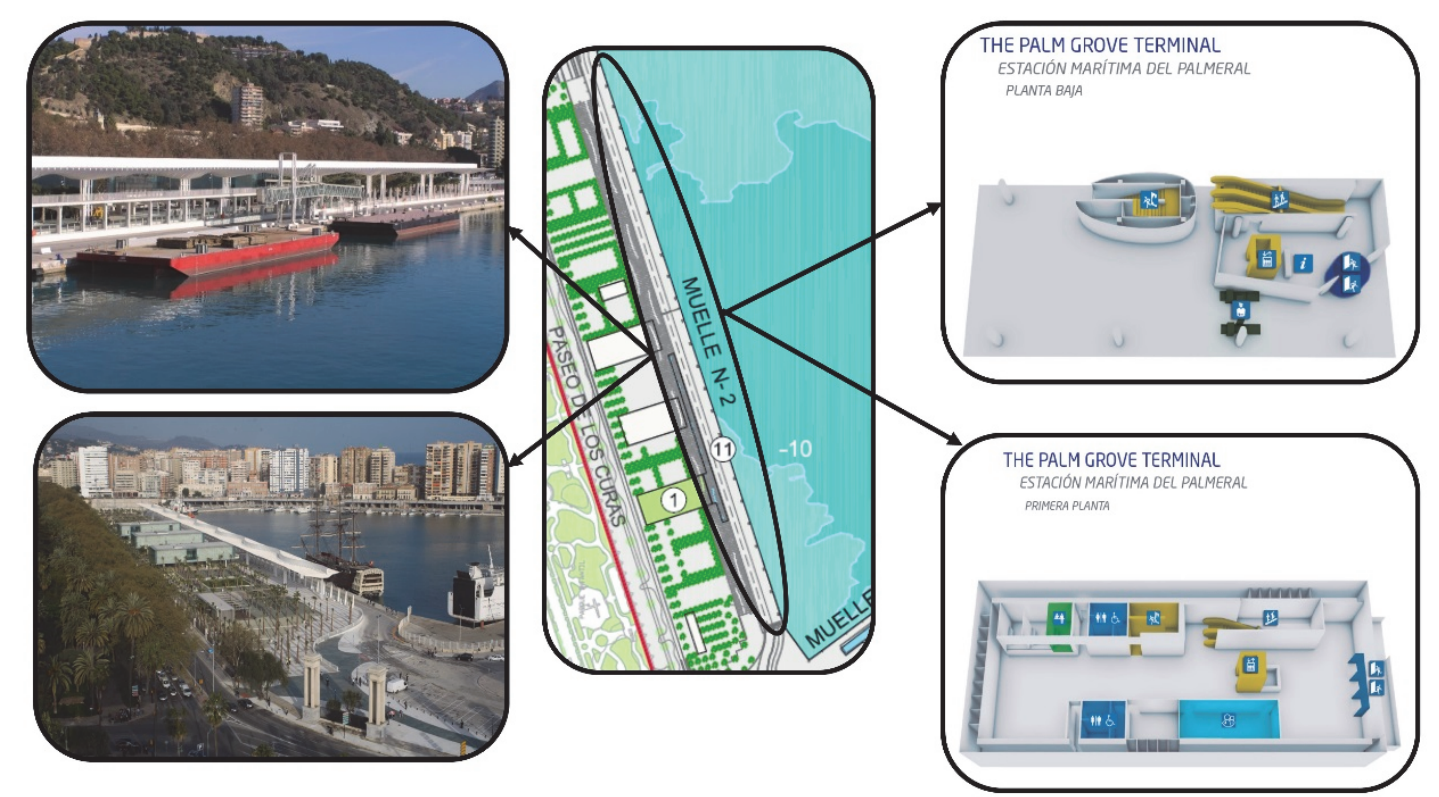

Figura II.9: Terminal de pasajeros El Palmeral y muelle de cruceros $\mathrm{N}^{\mathrm{o}} 2$ del puerto de Málaga.

Fuente: Elaboración propia.

Con carácter general las tres terminales cuentan con los siguientes servicios disponibles para el pasaje: aire acondicionado, aparcamiento de autobuses, cambio de divisas, detectores de metales, policía de inmigración, rayos X, parada de taxis, servicio de autobús a la ciudad, teléfono público, tiendas de souvenirs y tiendas duty free. Además, todas ellas cumplen con el Código ISPS.

Los servicios destinados al buque con que cuenta el puerto son: abastecimiento de agua $\left(30 \mathrm{~m}^{3} /\right.$ hora), conexiones informáticas para operaciones internas, eliminación de aguas residuales, eliminación de basura y desperdicios, y servicio de remolque (2 unidades), amarradores y prácticos (obligatorio), durante las 24 horas del día (Autoridad Portuaria de Málaga, 2014).

En el puerto de Málaga, entre el año 2000 y 2013, el tráfico de cruceros anualmente se ha concentrado en dos periodos, de marzo a mayo y de julio a noviembre, marcando el mes de junio el punto de inflexión entre ambos, véase Gráfico II.9. Para este caso particular se ha analizado la cifra total de cruceristas pues no ha sido posible acceder a las cifras segregadas en las categorías de inicio y fin de itinerario y tránsito entre el año 2000 y 2007, ambos inclusive. Durante todos los meses del periodo analizado se han registrado escalas de buques de crucero, véase Gráfico II.10. Además, queda patente en la evolución de este tráfico en el puerto malagueño la puesta en funcionamiento de la Estación Marítima de Levante en el año 2008, con un incremento significativo de cruceristas. A partir de la apertura de la terminal, en los meses de mayor concentración, se superaron los 25.000 cruceristas, véase Gráfico II.10. 


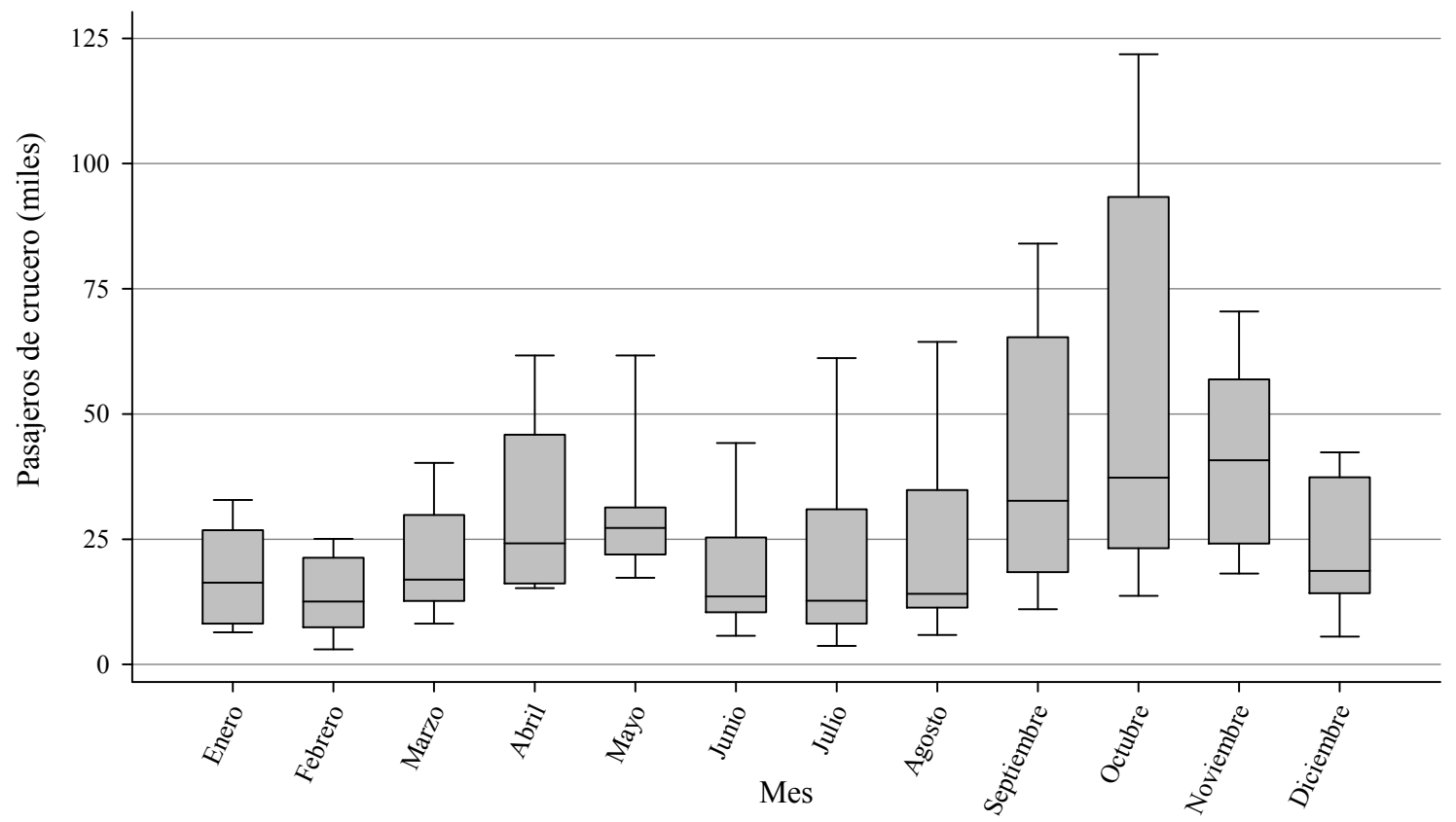

Gráfico II.9: Distribución de la cifra total de cruceristas en el puerto de Málaga, agregada por meses, entre el año 2000 y 2013.

Fuente: Elaboración propia. 


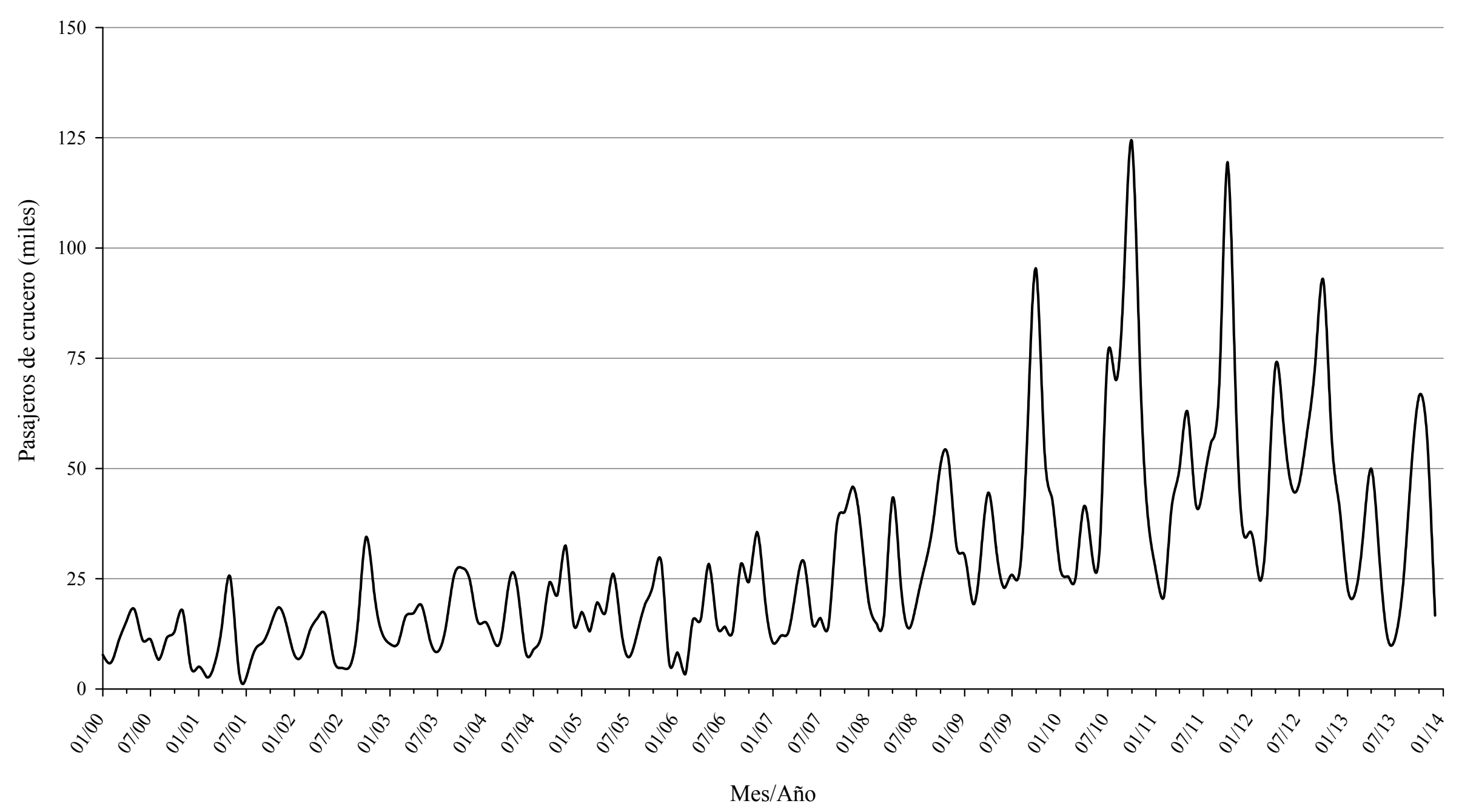

Gráfico II.10: Distribución mensual de la cifra total de cruceristas en el puerto de Málaga entre el año 2000 y 2013.

Fuente: Elaboración propia. 


\section{II.1.4 Puerto de Cádiz}

El puerto de Cádiz dispone de tres muelles para el atraque de buques de crucero, Ciudad, Reina Sofía y Alfonso XIII, todos ellos en la dársena Comercial, véase Figura II.10. El muelle Ciudad cuenta con una línea de atraque de 316,00 metros, y 10,00 metros de calado. El muelle Reina Sofía tiene una línea de atraque de 600 metros con un calado de 11 metros. Mientras que el muelle Alfonso XIII tiene una línea de atraque de menor longitud, 324 metros, y calado, 10 metros. En este muelle se sitúa la terminal de pasajeros de crucero con que cuenta el puerto (Autoridad Portuaria de la Bahía de Cádiz, 2012).

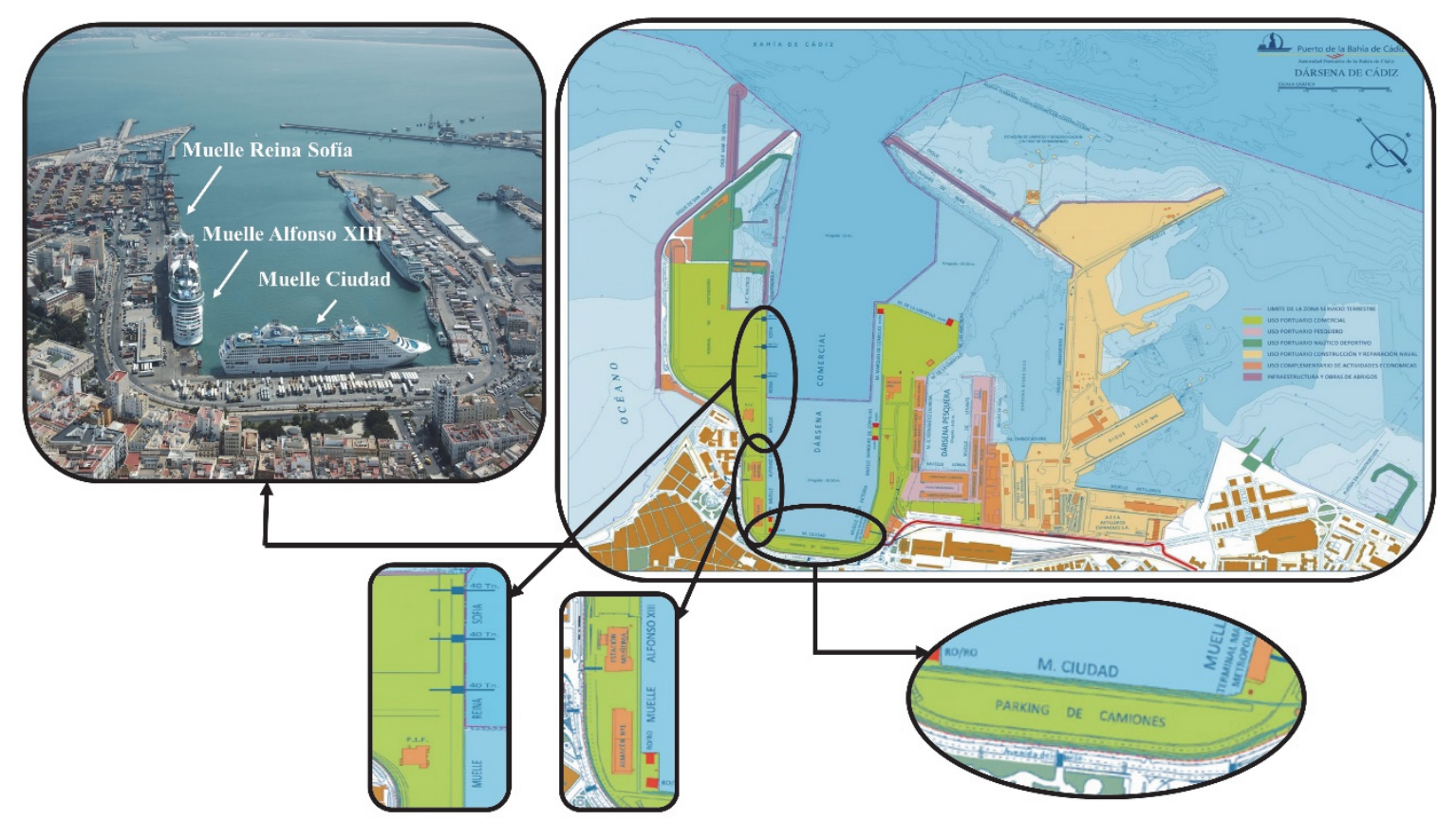

Figura II.10: Ubicación de los muelles para cruceros en el puerto de Cádiz.

Fuente: Elaboración propia.

En cuanto a los servicios para el buque, el puerto cuenta con servicio de remolcadores ( 5 unidades), prácticos y amarradores durante las 24 horas. También cuenta con servicio de suministro de combustible, suministro de agua potable, aprovisionamiento y recogida de residuos (Autoridad Portuaria de la Bahía de Cádiz, 2011). Además de, empresas de reparación naval representada principalmente por Navantia, la cual ha acometido en los últimos años la remodelación de varios buques de la flota de Royal Caribbean International, (Navantia, 2011).

En el muelle Alfonso XIII se sitúa la terminal de pasajeros de crucero, la cual ha sido sometida a un proceso de remodelación para adaptarla a los servicios requeridos por este tráfico, pues anteriormente constituía la estación marítima que daba servicio a los pasajeros de línea regular. La terminal cuenta con una superficie de $1.300 \mathrm{~m}^{2}$ en la que se encuentran disponibles los siguientes servicios: vestíbulo con mostradores de facturación para embarques de pasajeros, zona de desembarque, zona de recogida y entrega de equipajes, mostrador de información turística, zona wi-fi gratuita y tiendas de souvenirs y delicatessen, 
entre otros servicios. Junto a la terminal existe una zona de aparcamiento con capacidad para 16 autobuses. Además, los muelles, y por extensión la terminal, se encuentran muy próximos a la ciudad, aproximadamente a 100 metros (Autoridad Portuaria de la Bahía de Cádiz, 2011).

En agosto de 2013, la Autoridad Portuaria de la Bahía de Cádiz ha adjudicado la gestión y explotación de esta terminal a la empresa privada Cádiz Cruise Terminal S.L. Esta empresa está integrada por dos empresas consignatarias presentes en el puerto de Cádiz. Además, la adjudicación también incluye la construcción de una segunda terminal para pasajeros de crucero en el muelle Ciudad, situado junto a Alfonso XIII (Diario de Cádiz, 2013).

La situación estratégica del puerto de Cádiz, en el frente Atlántico en la boca del estrecho de Gibraltar, permite que sea una escala habitual en los itinerarios que discurren por el Norte de África y en los cruceros de reposicionamiento en el eje Mediterráneo-Caribe y viceversa. En el análisis de la distribución mensual de la cifra de cruceristas entre el año 2000 y 2013 se ve reflejada la característica citada anteriormente, véase Gráfico II.11. Los meses de mayor tráfico han sido abril y mayo, meses de inicio de la temporada alta en el Mediterráneo; y septiembre, octubre y noviembre meses de finalización de la misma. Estos meses coinciden con el posicionamiento de buques desde el Caribe u otros destinos de invierno hacia el Mediterráneo y viceversa al finalizar la temporada. Además, durante este periodo la cifra de cruceristas ha incrementado, rompiendo a partir del año 2009 con la tendencia registrada en años anteriores en los que no escalaban cruceros en determinados meses del año, véase Gráfico II.12.

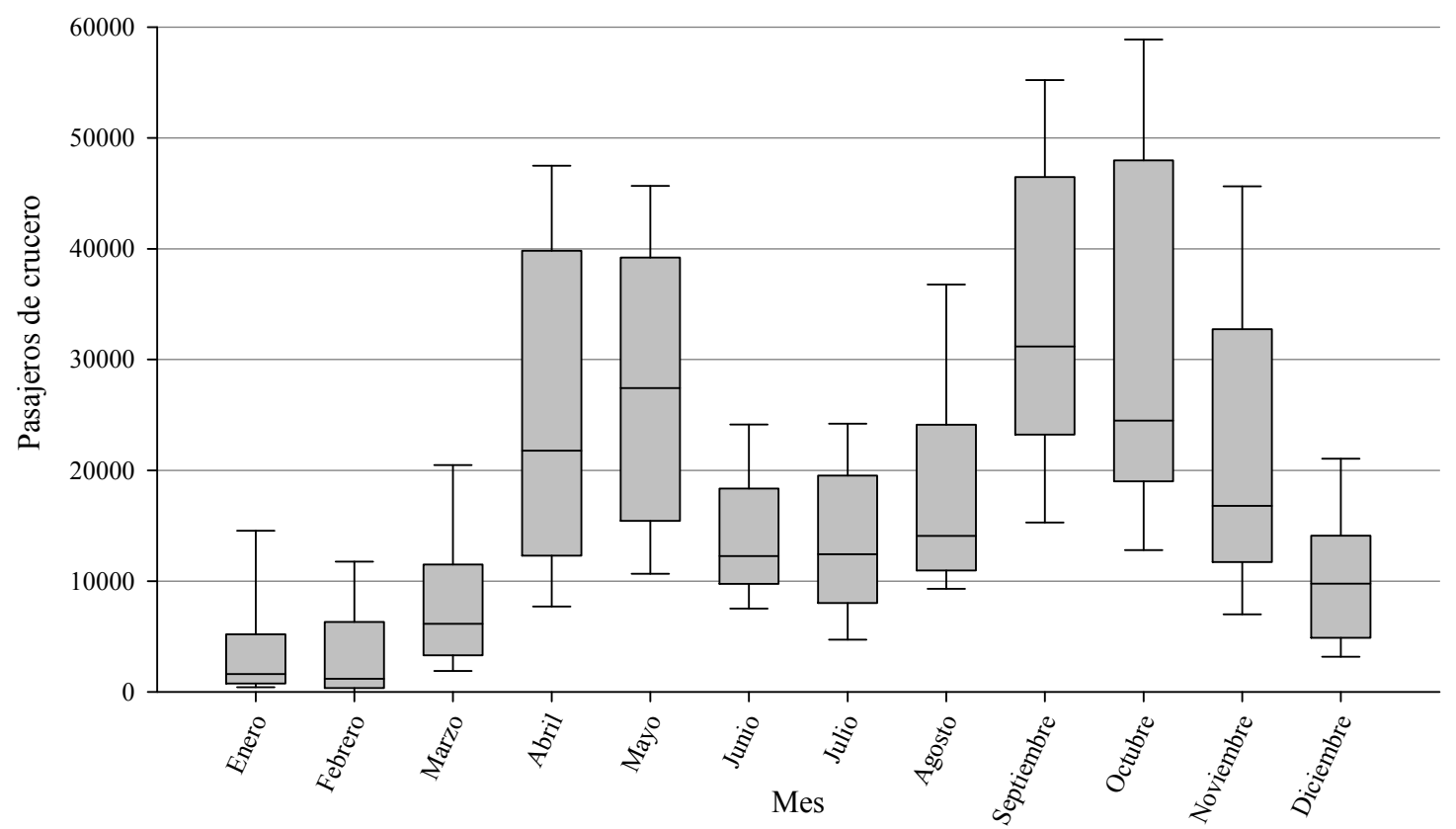

Gráfico II.11: Distribución de la cifra total de cruceristas en el puerto de Cádiz, agregada por meses, entre el año 2000 y 2013.

Fuente: Elaboración propia. 


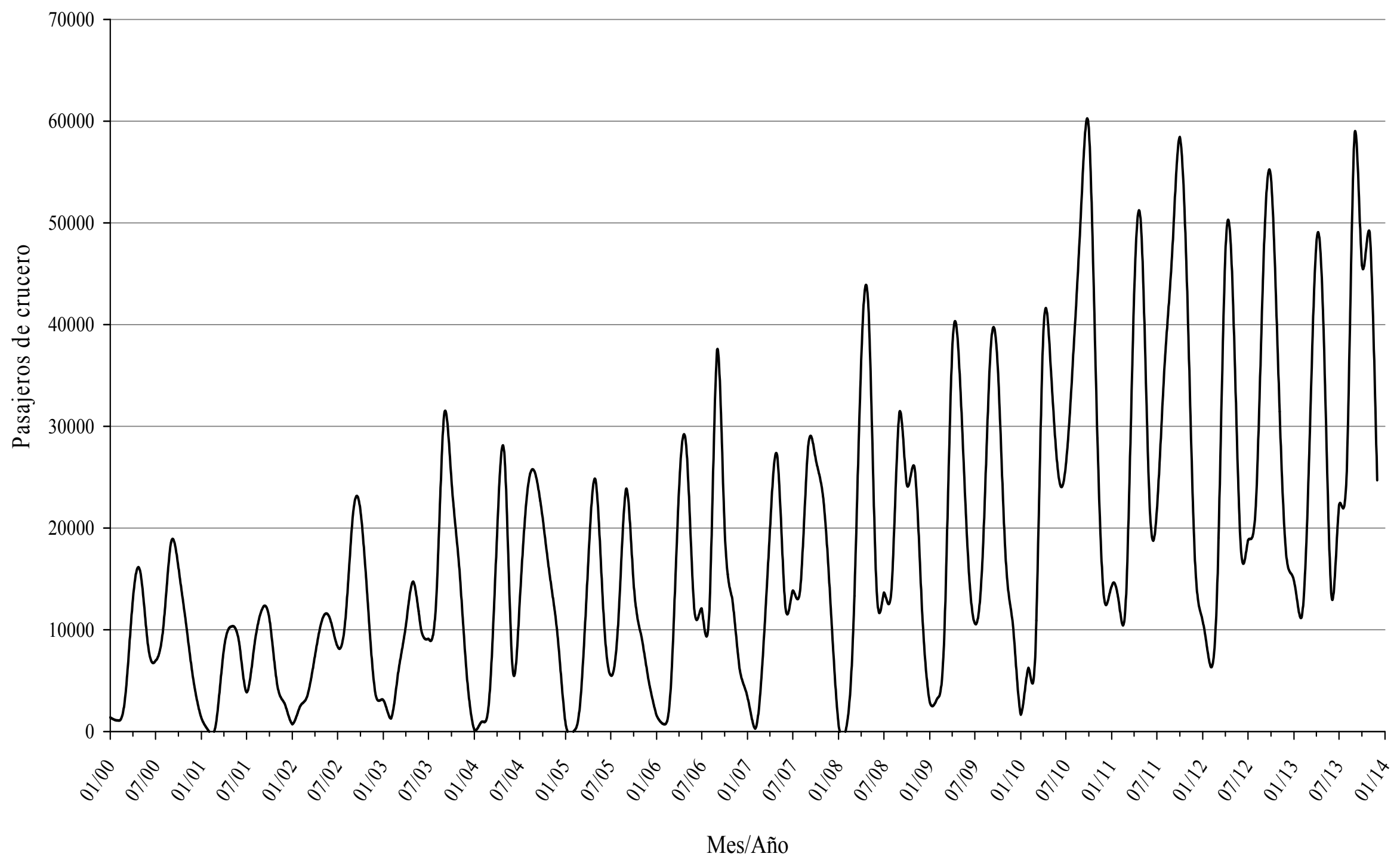

Gráfico II.12: Distribución mensual de la cifra total de cruceristas en el puerto de Cádiz entre el año 2000 y 2013.

Fuente: Elaboración propia. 


\section{II.2 Puertos con elevado potencial}

Con la posición de elevado potencial se identifican seis puertos, que son: Valencia, Ibiza, Cartagena, Motril, Sevilla y Tarragona. A continuación se definen las características particulares de las instalaciones para cruceros de cada uno de ellos.

\section{II.2.1 Puerto de Valencia}

El puerto de Valencia cuenta con cuatro muelles para el atraque de buques de crucero, dos en la dársena de Levante, muelle de Poniente y Transversal; y los dos restantes en la ampliación Norte del puerto, véase Figura II.11. El muelle de Poniente tiene una línea de atraque de 330 metros y un calado que oscila entre 9 y $11 \mathrm{~m}$. dependiendo de la zona. El Transversal dispone de menor línea de atraque, $245 \mathrm{~m}$. con 10,5 m. de calado (Autoridad Portuaria de Valencia, 2012).

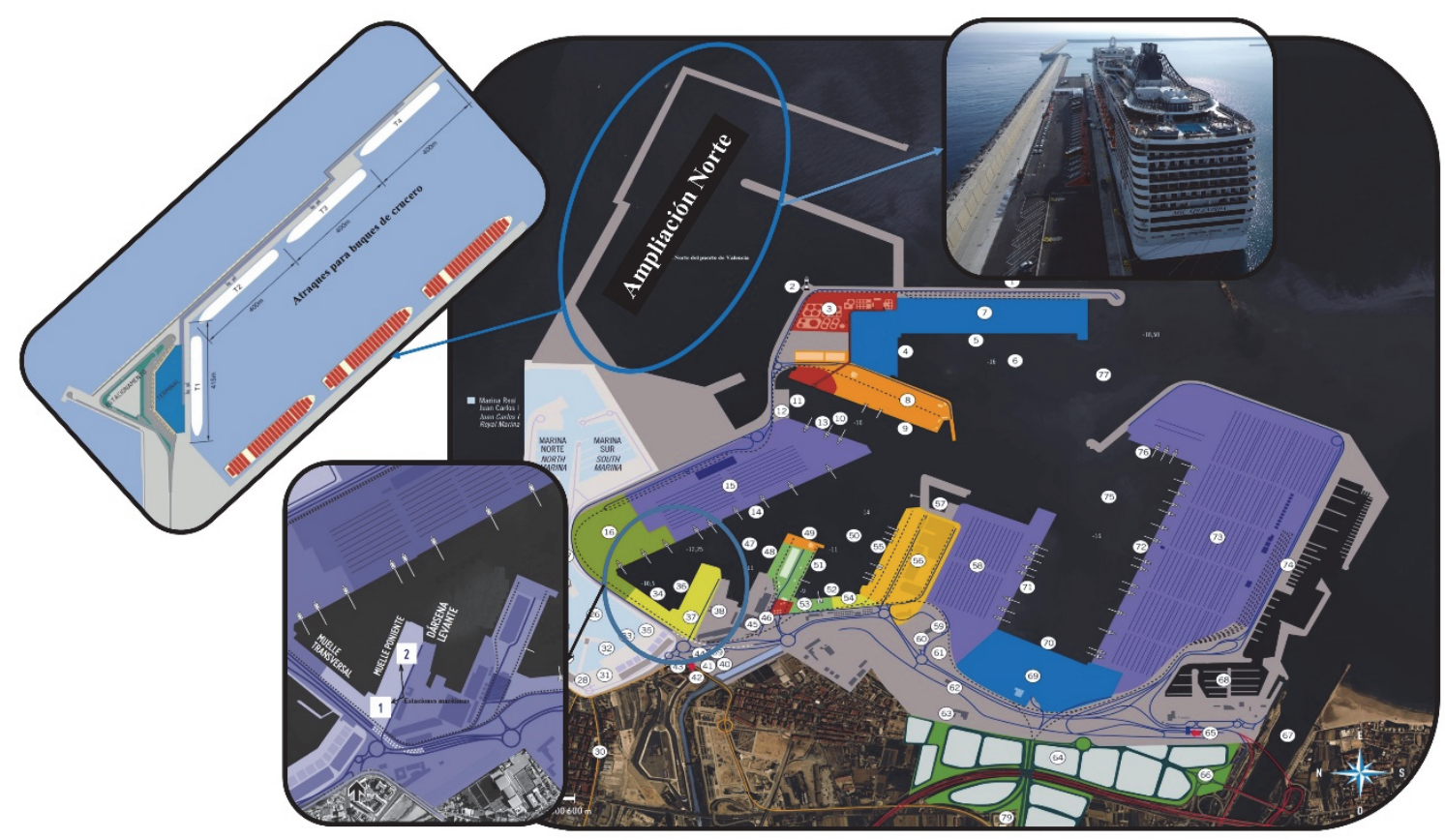

Figura II.11: Muelles destinados a buques de cruceros en el puerto de Valencia.

Fuente: Elaboración propia.

El tercer y cuarto muelle está comprendido en las actuaciones del Plan Director de cruceros de la Autoridad Portuaria de Valencia 2020, el cual contempla nuevas instalaciones para este tráfico en la ampliación Norte del puerto. La primera fase del mencionado Plan inaugurada en agosto de 2013, cuenta con una línea de atraque de $430 \mathrm{~m}$. y $14 \mathrm{~m}$. de calado. La segunda fase cuyas obras concluirán a corto plazo comprende un muelle de $440 \mathrm{~m}$. de línea de atraque. Además, ya hay configurado un tercer muelle de similares características a los anteriores. El proyecto también comprende la construcción de una explanada de 4.350 $\mathrm{m}^{2}$, con una capacidad aproximada de 30 autobuses. Finalmente, en el marco del Plan Director se contemplan hasta un total de cuatro muelles para cruceros en la nueva ampliación 
Norte, según lo requieran las necesidades, véase de nuevo Figura II.11, (Juan Martínez y Pérez García, 2013).

El puerto de Valencia dispone de dos terminales para pasajeros de crucero situadas en el muelle de Poniente y Transversales, operadas por Acciona Transmediterránea y Valencia Passenger Services (VPS). Valencia Passenger Services está formada por las consignatarias Bergé, Pérez y Cía., Roca Monzó y Transcoma. Además, gestiona una terminal "remota" ubicada en la planta baja de la antigua terminal de pasajeros en la Marina Real Juan Carlos I.

Los servicios disponibles en las terminales para el pasajero son: facturación de pasajeros y equipajes, recogida de equipajes, servicio de transporte desde la terminal al barco y viceversa, servicio de transporte desde el barco hasta el centro de la ciudad y viceversa, excursiones en tierra desde el barco a la ciudad o sus alrededores, sala de espera para los pasajeros, cafetería, punto de información al pasajero y punto de información turística (VPS, 2014).

Los servicios disponibles para buques son: remolque (5 unidades), practicaje (obligatorio) y amarradores, durante las 24 horas del día; también están disponibles los servicios de suministro de agua, combustible, aprovisionamiento y recogida de residuos líquidos y sólidos.

El tráfico de cruceros en el puerto de Valencia, entre el año 2000 y 2013, se ha concentrado entre los meses de abril y octubre, constituyendo los meses de marzo y noviembre el punto de inflexión de inicio y fin de la temporada alta, respectivamente. Este patrón se registró tanto en la categoría de pasajeros en régimen de inicio y fin de itinerario, véase Gráfico II.13, como en tránsito, véase Gráfico II.14. La evolución de la primera categoría de pasajeros durante el periodo 2000-2013 presenta dos etapas de crecimiento. La primera entre los años 2002 y 2005 (ambos inclusive). El año 2006 constituyó el punto de inflexión hacia la segunda etapa de crecimiento que se extendió entre los años 2007 y 2013 , véase Gráfico II.15. La segunda categoría de pasajeros ha registrado un comportamiento distinto, diferenciándose cuatro etapas, véase Gráfico II.16. En los años 2000 y 2001 no se registraron pasajeros en tránsito. A continuación, entre 2002 y 2005 se registró tránsito de pasajeros sin superar ningún mes el umbral de 10.000 pasajeros. La tercera etapa, de 2006 a 2010, registró un incremento de la cifra de cruceristas, superando varios meses la barrera de 10.000 cruceristas. Por último, de 2011 a 2013, se registró un nuevo incremento de la cifra de pasajeros en tránsito. En este caso el crecimiento fue de mayor magnitud respecto a la etapa anterior, superándose en los meses de temporada alta el umbral de 30.000 pasajeros. Además, durante esta etapa hubo tránsito de pasajeros en todos los meses del año, operativa que no se había alcanzado anteriormente. 


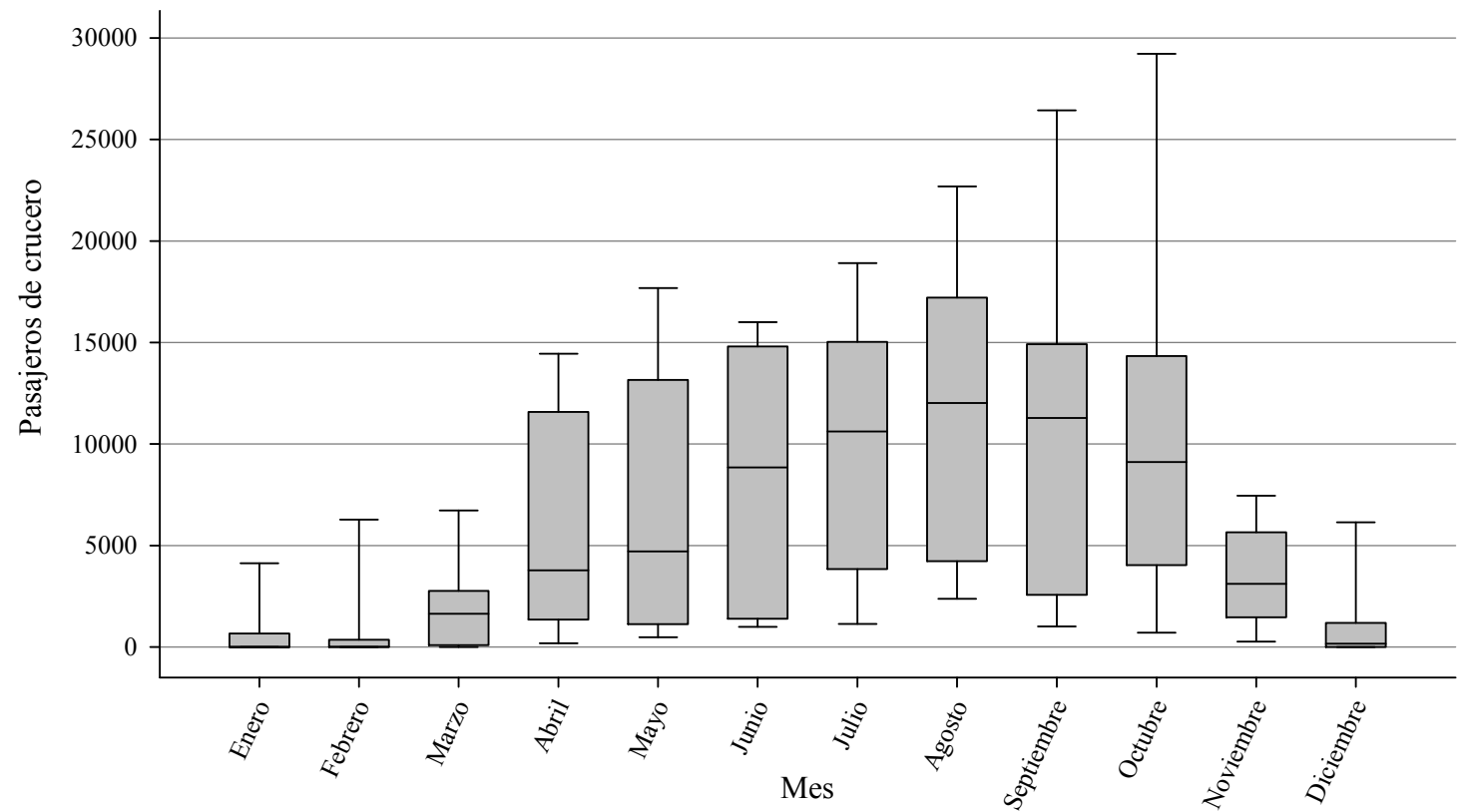

Gráfico II.13: Distribución de la cifra de cruceristas en régimen de inicio y/o fin de itinerario en el puerto de Valencia, agregada por meses, entre el año 2000 y 2013.

Fuente: Elaboración propia.

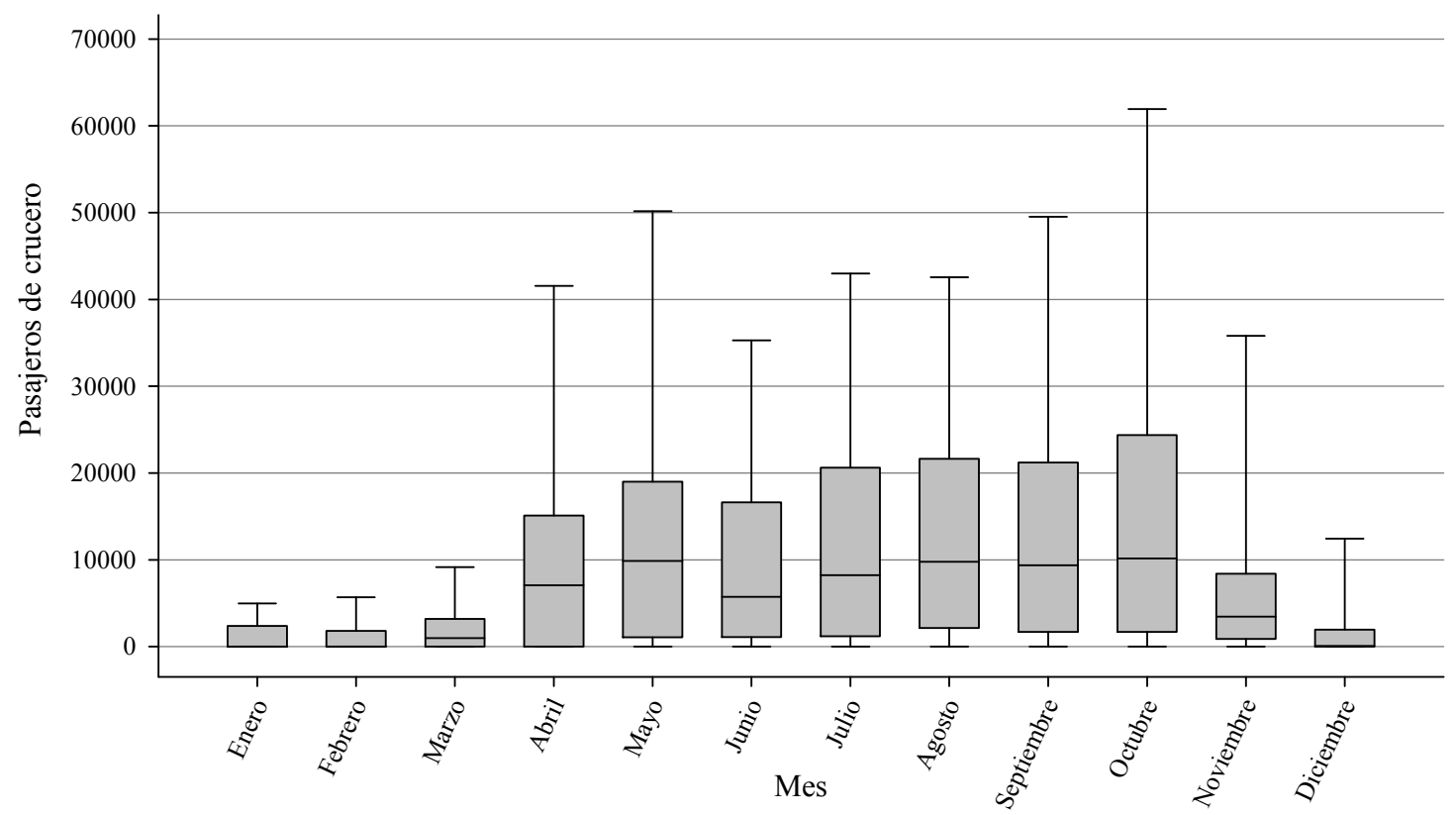

Gráfico II.14: Distribución de la cifra de cruceristas en régimen de tránsito en el puerto de Valencia, agregada por meses, entre el año 2000 y 2013.

Fuente: Elaboración propia. 


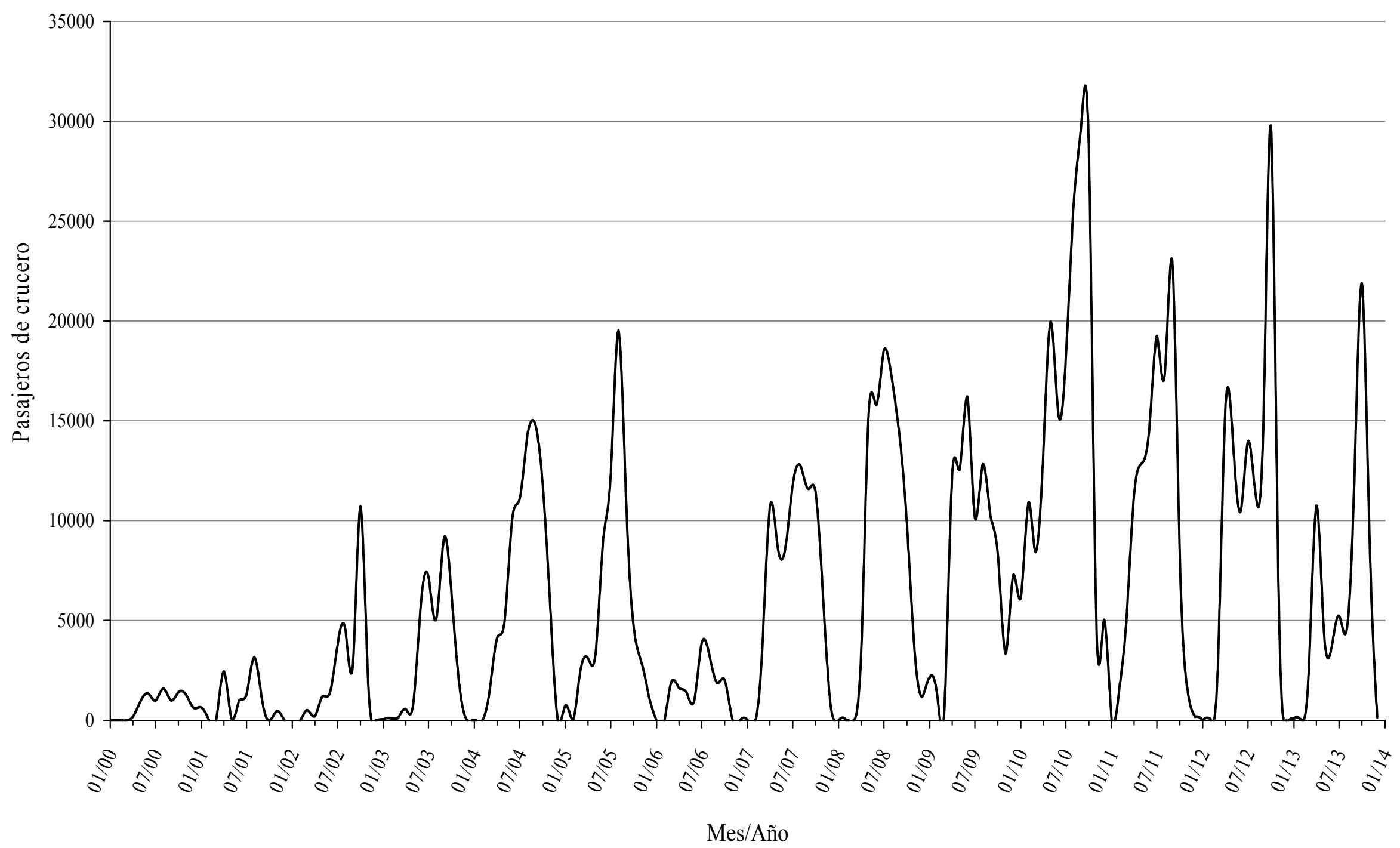

Gráfico II.15: Distribución mensual de la cifra de cruceristas en régimen de inicio y fin de itinerario en el puerto de Valencia entre el año 2000 y 2013.

Fuente: Elaboración propia. 


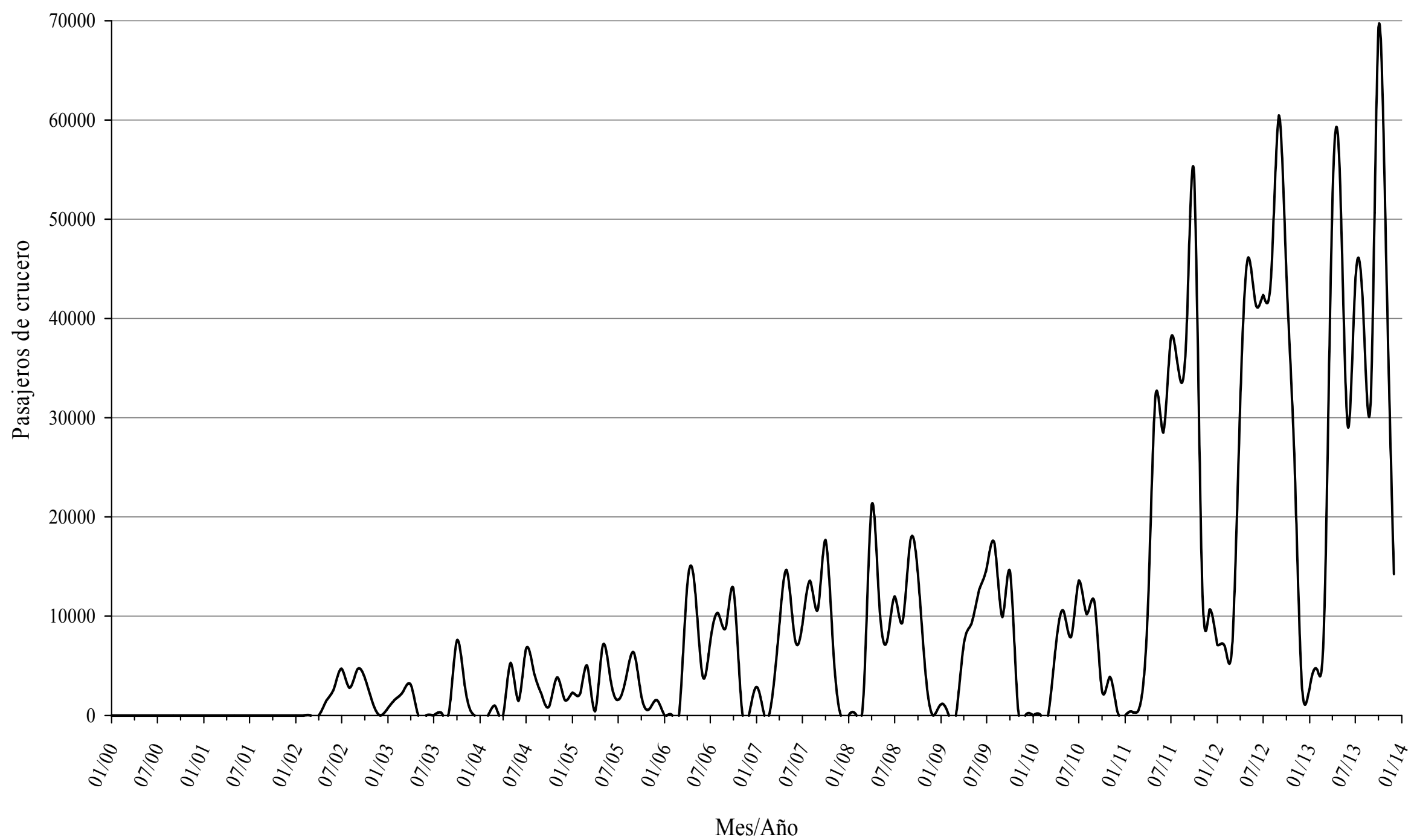

Gráfico II.16: Distribución mensual de la cifra de cruceristas en régimen de tránsito en el puerto de Valencia entre el año 2000 y 2013.

Fuente: Elaboración propia. 


\section{II.2.2 Puerto de Ibiza}

El puerto de Ibiza cuenta con cuatro muelles para el atraque de buques de crucero, muelle Adosado, Levante, Contramuelle de Levante y Dique de Botafoc, véase Figura II.12. Las características de éstos quedan reflejadas en la Tabla II.2. Únicamente dispone de una terminal de pasajeros situada en el Contramuelle de Levante, sin pasarelas móviles ni fijas (Autoridad Portuaria de Baleares, 2014b).

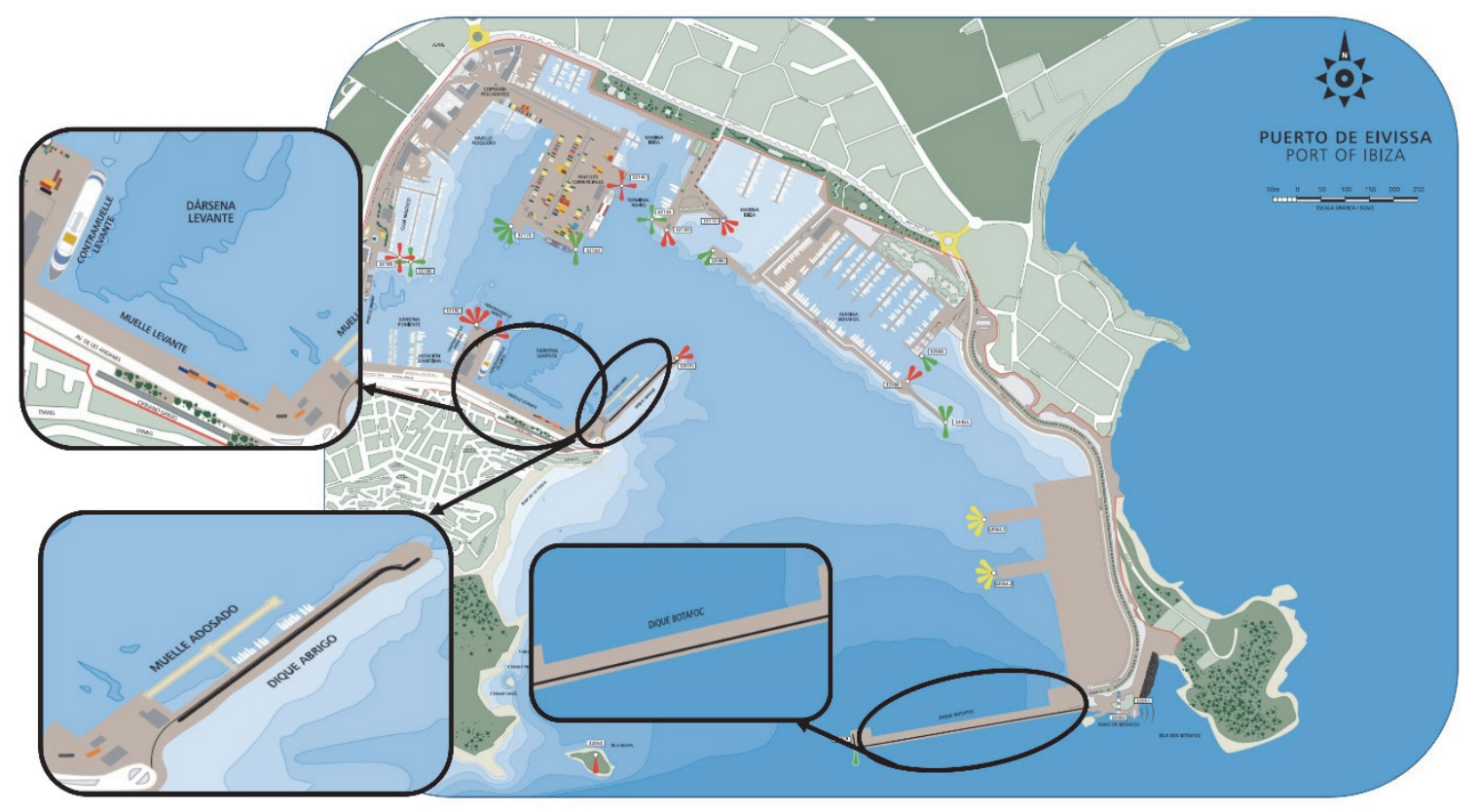

Figura II.12: Ubicación de los muelles para buques de crucero en el puerto de Ibiza.

Fuente: Elaboración propia.

Tabla II.2: Características de los muelles destinados al atraque de buques de crucero en el puerto de Ibiza

\begin{tabular}{lrrr}
\hline Nombre del muelle & Longitud de atraque (m) & Calado (m) & Anchura (m) \\
\hline Muelle Adosado y Duques de Alba & 169,00 & 7,00 & 34,75 \\
Muelle de Levante o de la Consigna & 236,28 & 7,00 & 14,00 \\
Dique de Botafoc & 392,65 & 20,00 & 18,00 \\
Contramuelle Levante & 115,64 & 7,00 & 18,00 \\
\hline
\end{tabular}

Fuente: Elaboración propia basada en datos de Autoridad Portuaria de Baleares (2014b).

El puerto cuenta con servicio de remolcadores (1 unidad), amarre y prácticos, 24 horas. Además de servicio de recogida de residuos oleosos, sólidos y líquidos (Autoridad Portuaria de Baleares, 2012).

El tráfico de cruceros en el puerto de Ibiza entre el año 2000 y 2013, de forma análoga a la mayoría de puertos analizados hasta el momento, se ha concentrado en los meses de abril a octubre con el mes de agosto como máximo exponente, véase Gráfico II.17. Además, durante este periodo ha crecido la cifra de cruceristas registrada, véase Gráfico II.18, superándose a partir del año 2010 la barrera de los 10.000 cruceristas mensuales durante la temporada alta. 


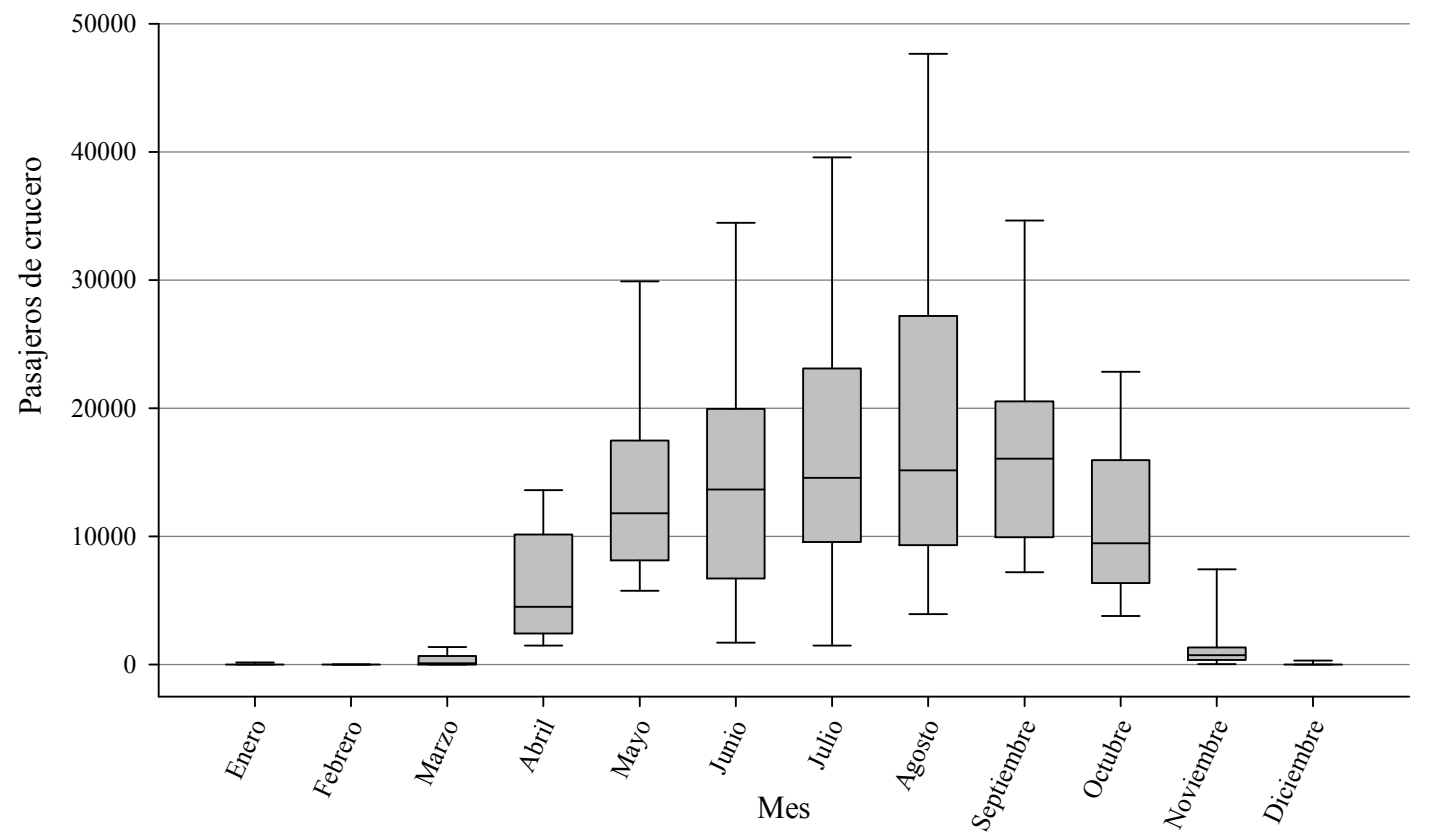

Gráfico II.17: Distribución de la cifra total de cruceristas en el puerto de Ibiza, agregada por meses, entre el año 2000 y 2013.

Fuente: Elaboración propia. 


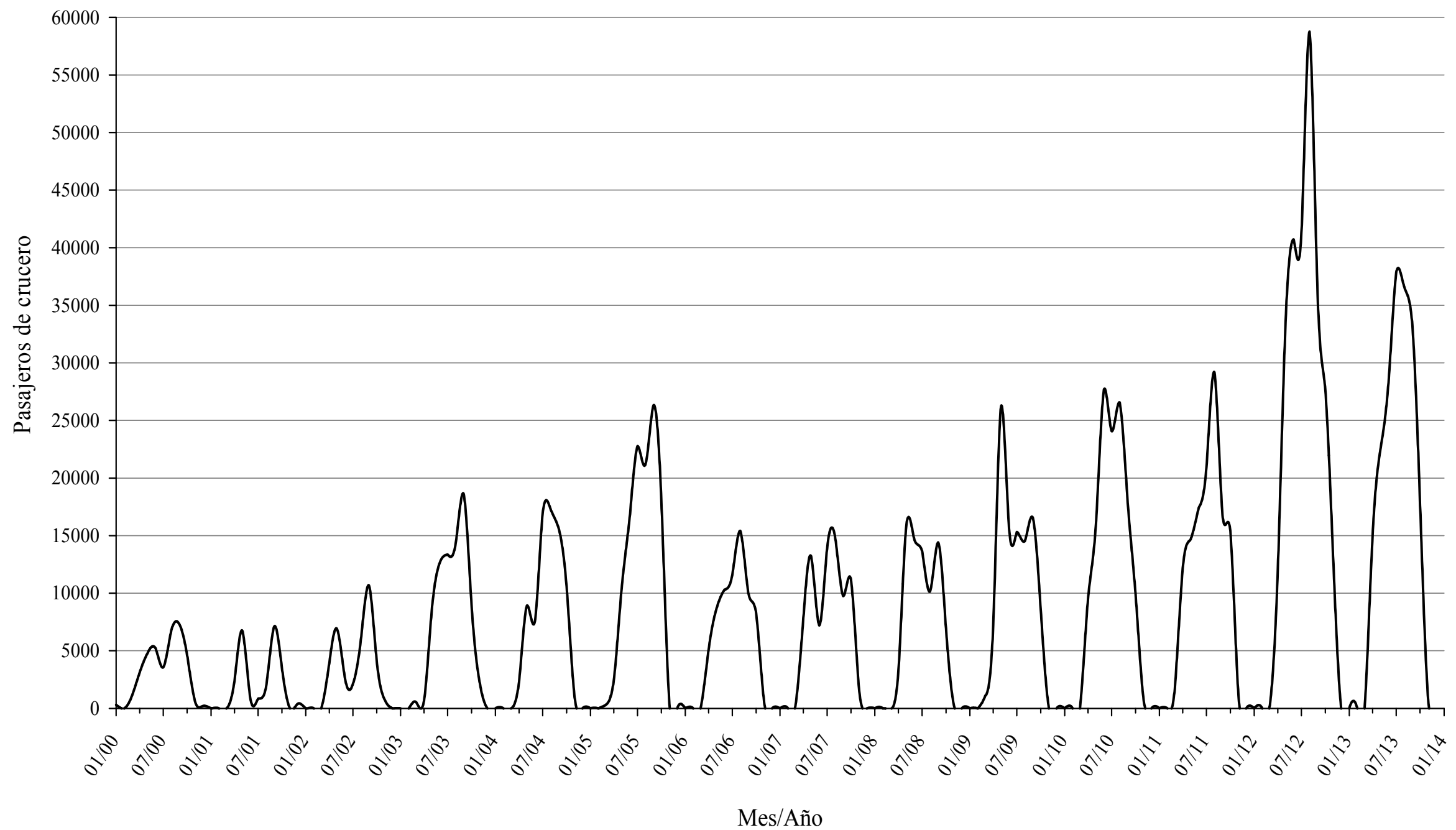

Gráfico II.18: Distribución mensual de la cifra total de cruceristas en el puerto de Ibiza entre el año 2000 y 2013.

Fuente: Elaboración propia. 


\section{II.2.3 Puerto de Cartagena}

El puerto de Cartagena cuenta con un muelle dedicado exclusivamente al tráfico de cruceros, muelle de Alfonso XII, con una línea de atraque de 560 metros, véase Figura II.13. En los días con simultaneidad de escalas que exceden la capacidad del muelle Alfonso XII, los muelles polivalentes de Santa Lucía y San Pedro también pueden recibir este tipo de buques, éstos cuentan con una línea de atraque de 385 y 405 metros, respectivamente. Los tres muelles están ubicados en la dársena de Cartagena y tienen un calado de 12 metros. No existe restricción a la escala de buques de crucero en lo que a eslora y manga se refiere, la única viene impuesta por la compatibilidad entre el calado del buque y el de la dársena (Autoridad Portuaria de Cartagena, 2012).

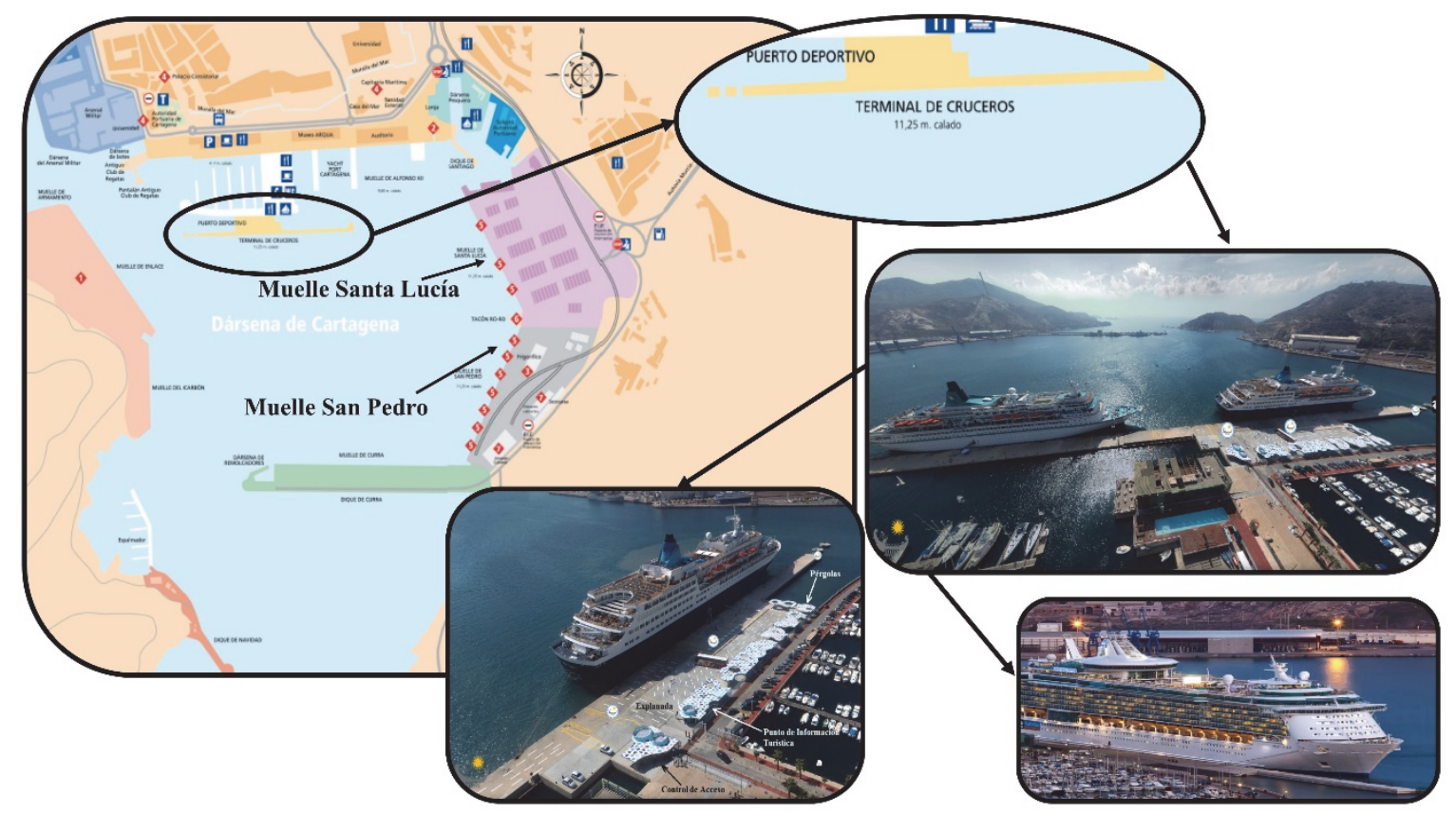

Figura II.13: Instalaciones para buques de crucero en el puerto de Cartagena.

Fuente: Elaboración propia.

En cuanto a los servicios al buque, se dispone de remolcadores, prácticos (obligatorio) y amarradores, las 24 horas del día. El fondeo también está permitido, aunque no es obligatorio, así como el uso de botes/lanchas de desembarco. También hay disponibles servicios de reparación naval representados por la firma Navantia y la industria auxiliar asociada, suministro de combustible, recogida de residuos (sólidos, líquidos y oleosos), suministro de agua y aprovisionamiento (Autoridad Portuaria de Cartagena, 2013).

El muelle Alfonso XII está situado a 200 metros del centro de la ciudad, permitiendo a los cruceristas desplazarse caminando hacia los diversos atractivos con que cuenta la ciudad. El muelle cuenta con una superficie de $5.000 \mathrm{~m}^{2}$, en la que se dispone de aparcamientos para autobuses, parada de taxis y puntos de información turística, no dispone de edificio de terminal de pasajeros. 
La distribución mensual del tráfico de cruceros en el puerto de Cartagena entre el año 2000 y 2013 se ha concentrado en dos periodos, marcando el mes de julio el punto de inflexión entre ambos, de abril a junio y de agosto a noviembre, véase Gráfico II.19. Además, la evolución registrada durante este periodo conlleva un incremento de cruceristas, dando lugar incluso a años en que se registra tráfico de cruceros durante todos los meses, en oposición al patrón registrado a comienzos del periodo, véase Gráfico II.20.

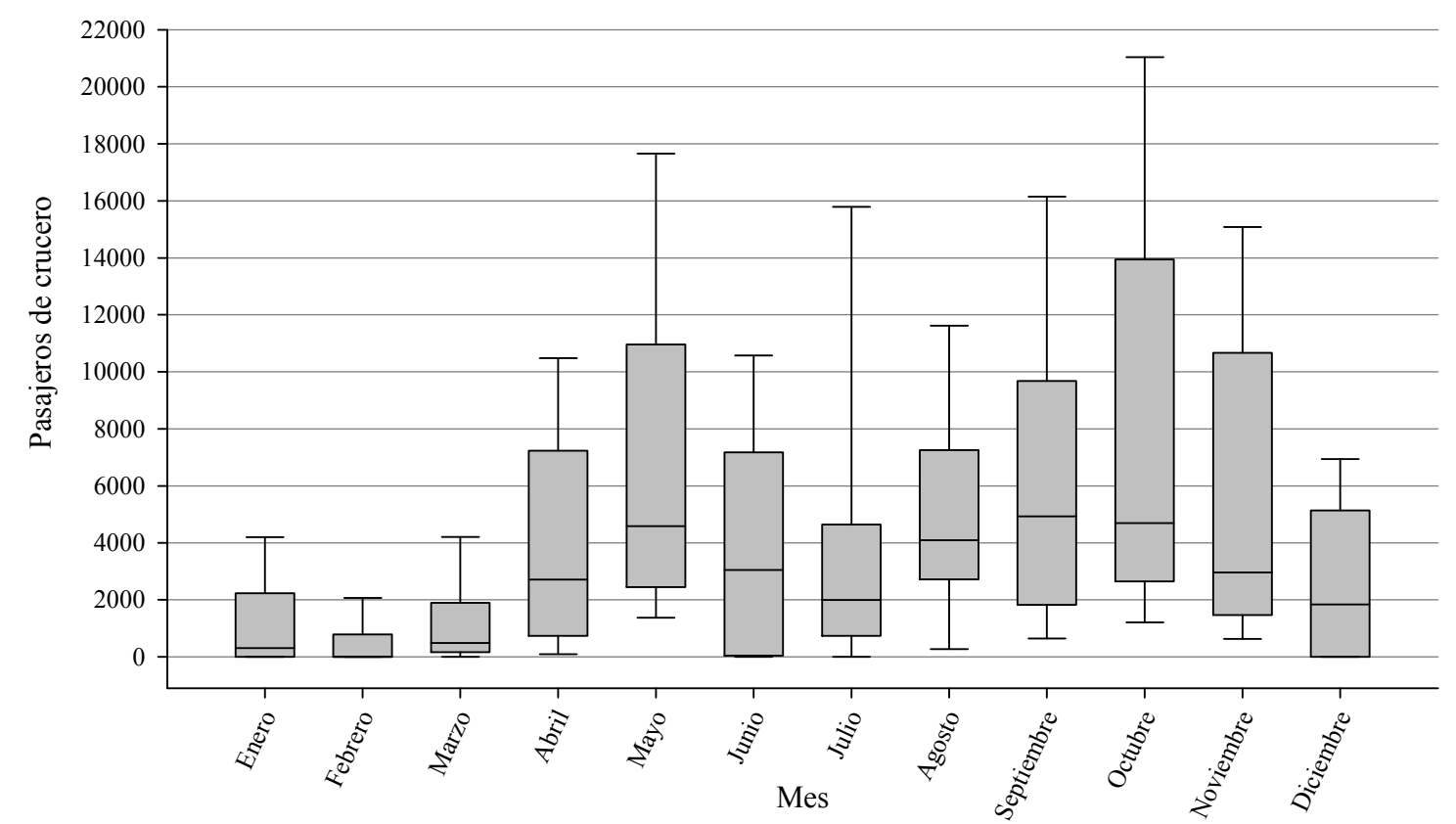

Gráfico II.19: Distribución de la cifra total de cruceristas en el puerto de Cartagena, agregada por meses, entre el año 2000 y 2013.

Fuente: Elaboración propia. 


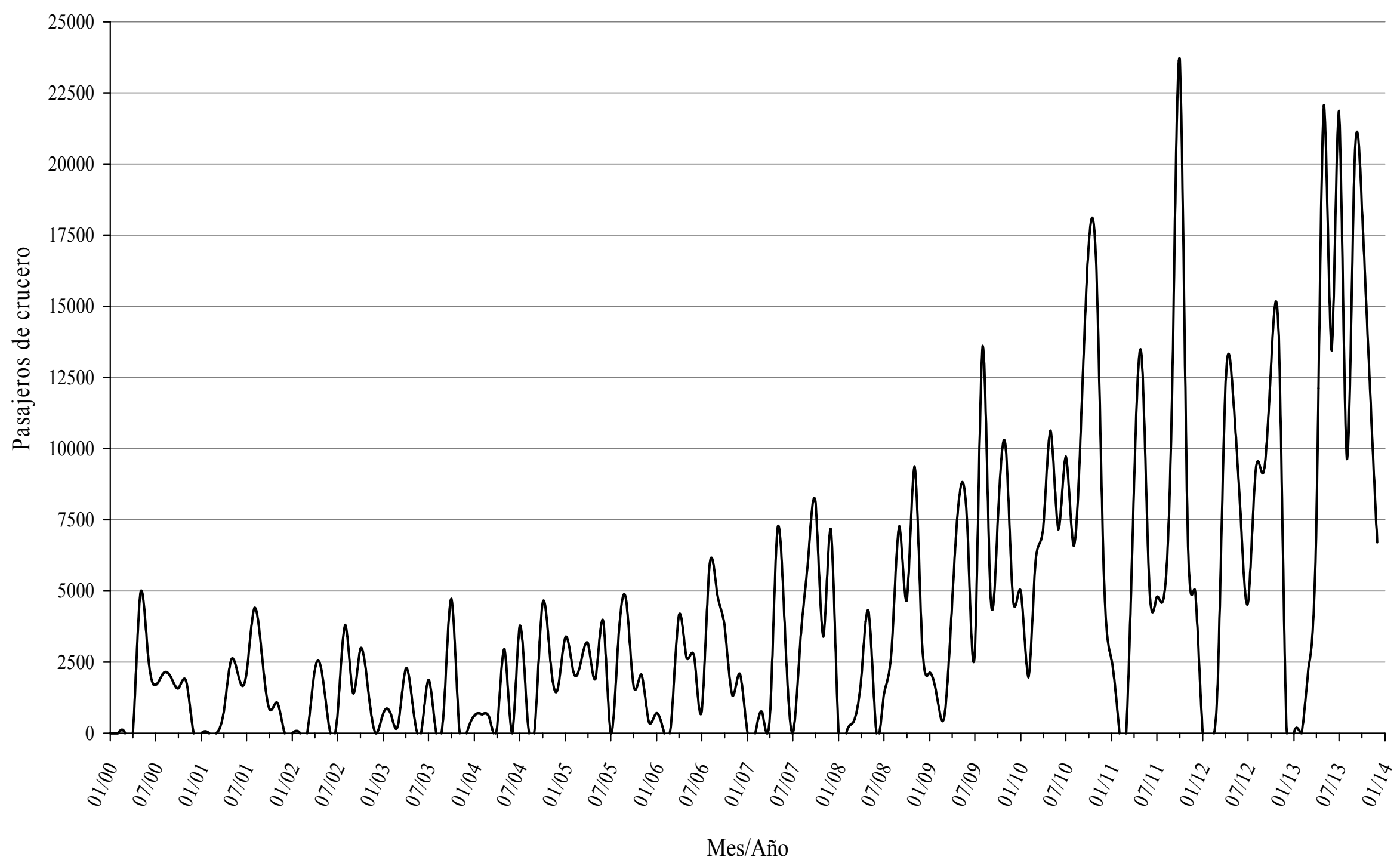

Gráfico II.20: Distribución mensual de la cifra total de cruceristas en el puerto de Cartagena entre el año 2000 y 2013.

Fuente: Elaboración propia. 


\section{II.2.4 Puerto de Motril}

El puerto de Motril dispone de tres muelles en los que albergar buques de crucero, muelle de Costa, Levante y Dique, véase Figura II.14. Estas instalaciones no tienen un uso exclusivo para este tráfico, si no que se trata de muelles polivalentes dando servicio, además de a tráfico de cruceros, a mercancía general, Ro-Ro y graneles sólidos y líquidos. El muelle Costa dispone de una línea de atraque de 299 m., un calado que oscila entre 7,5 y 8,25 m., y una anchura de $40 \mathrm{~m}$. El muelle de Levante tiene una línea de atraque ligeramente inferior al caso anterior con $284 \mathrm{~m}$., un calado que varía entre los 7,5 y $8 \mathrm{~m}$. y $45 \mathrm{~m}$. de anchura. En tercer lugar, el muelle Dique, el de mayor longitud de los tres, cuenta con $560 \mathrm{~m}$. de línea de atraque, $10 \mathrm{~m}$. de calado y $15 \mathrm{~m}$. de anchura (Autoridad Portuaria de Motril, 2012).

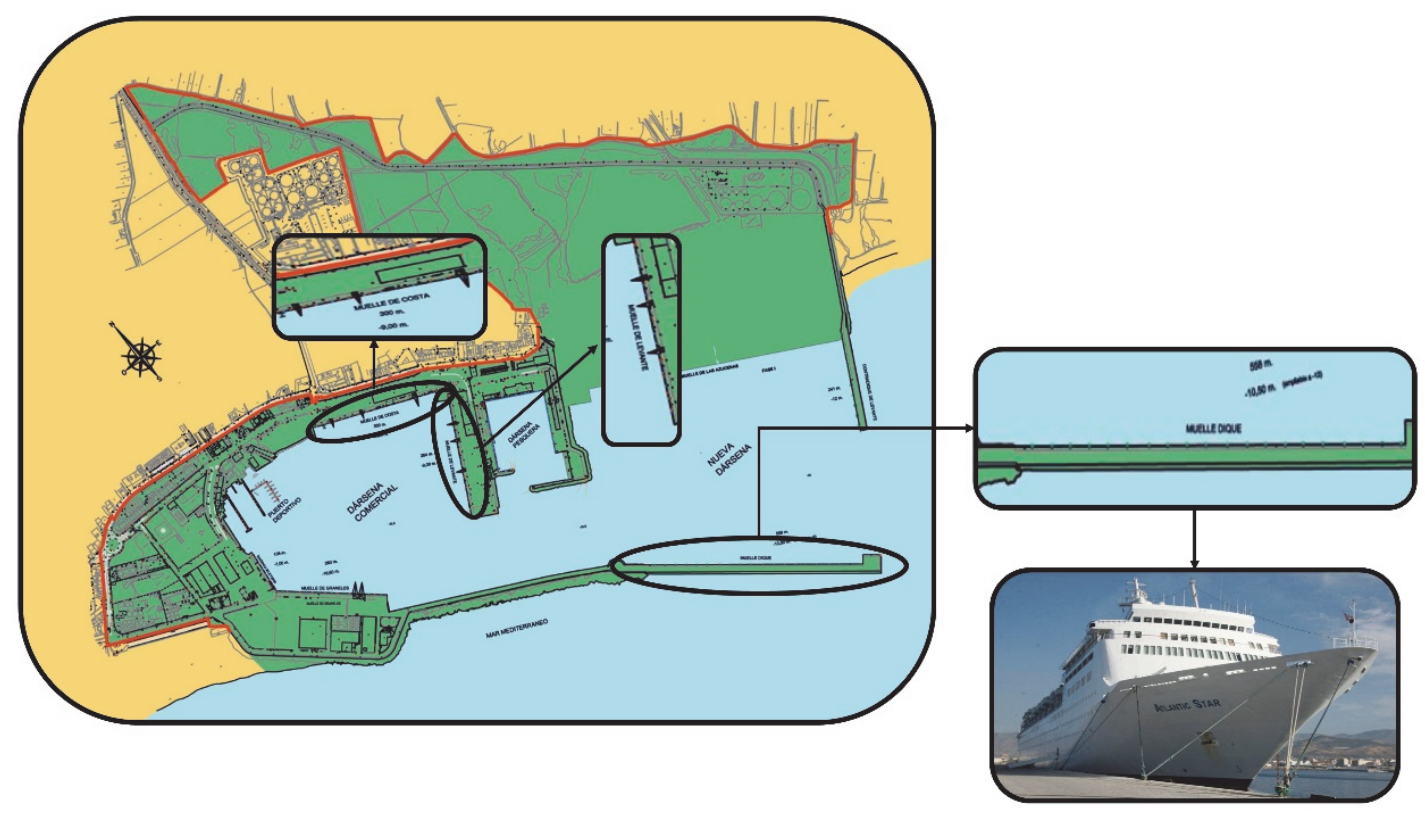

Figura II.14: Muelles destinados a buques de crucero en el puerto de Motril.

Fuente: Elaboración propia.

Los muelles descritos anteriormente no disponen de terminal para pasajeros de crucero. Los servicios ofrecidos al pasaje se establecen de forma provisional con la llegada de cada crucero. Éstos comprenden: punto de información turística a pie de buque y bus lanzadera que conecta el buque con el centro de la ciudad y viceversa.

En cuanto a los servicios al buque se cuenta con: remolque ( 2 unidades), amarradores, practicaje (obligatorio), durante las 24 horas; suministro de combustible, suministro de agua dulce, retirada de residuos oleosos, líquidos y sólidos, y provisionistas de buques.

El tráfico de cruceros en el puerto de Motril durante el periodo de 2000 a 2013 se ha concentrado en los meses de mayo y junio y agosto y septiembre, véase Gráfico II.21. Además, la evolución durante este periodo tiene un notable carácter irregular, dividida en tres etapas, véase Gráfico II.22. En la etapa del año 2006 a 2010 se registró un descenso de la cifra de cruceristas respecto al periodo anterior de 2000 a 2005 (año en que adoptó la 
autonomía como Autoridad Portuaria de Motril), remontando de nuevo a partir del año 2011 hasta 2013.

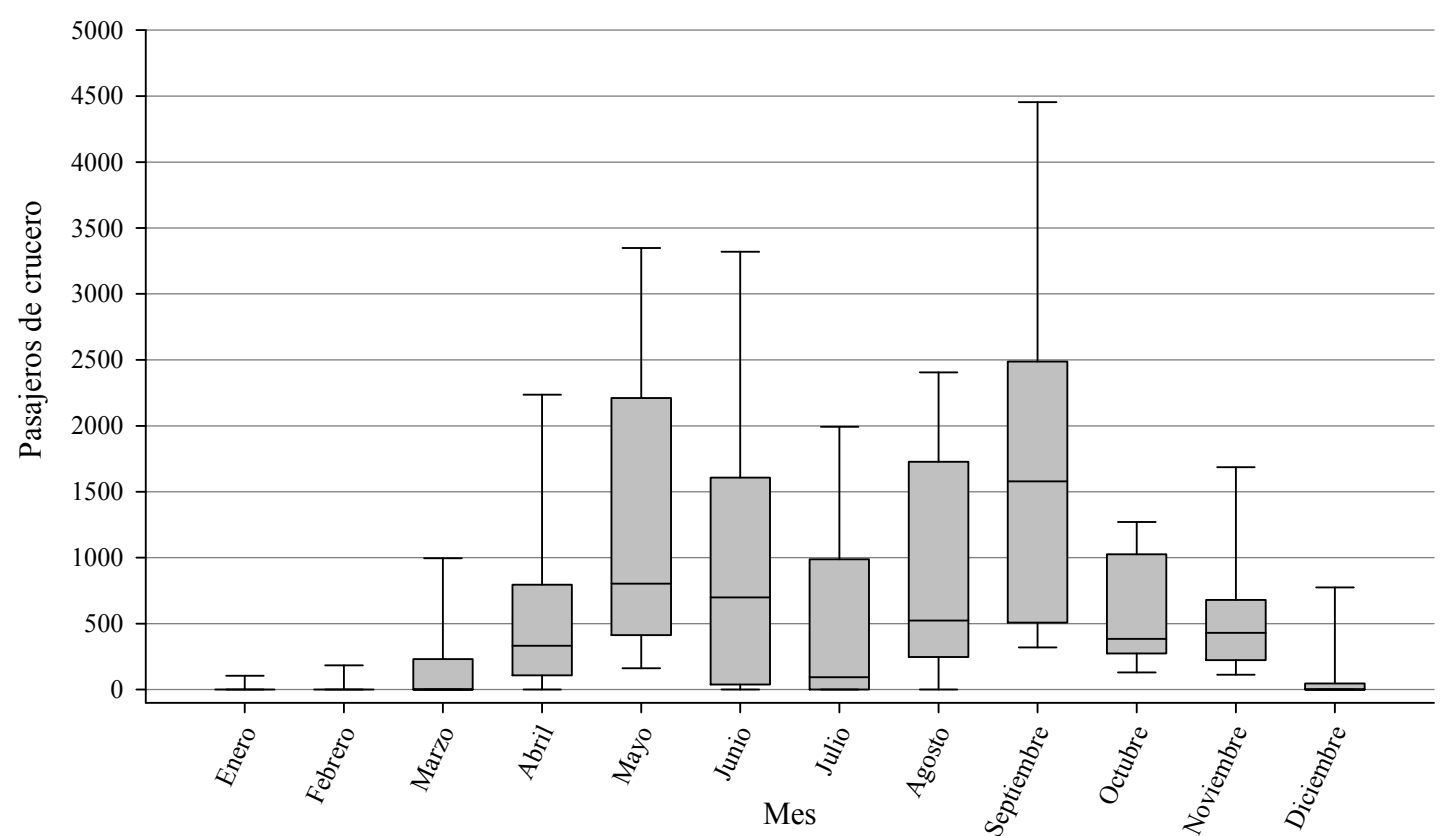

Gráfico II.21: Distribución de la cifra total de cruceristas en el puerto de Motril, agregada por meses, entre el año 2000 y 2013.

Fuente: Elaboración propia. 


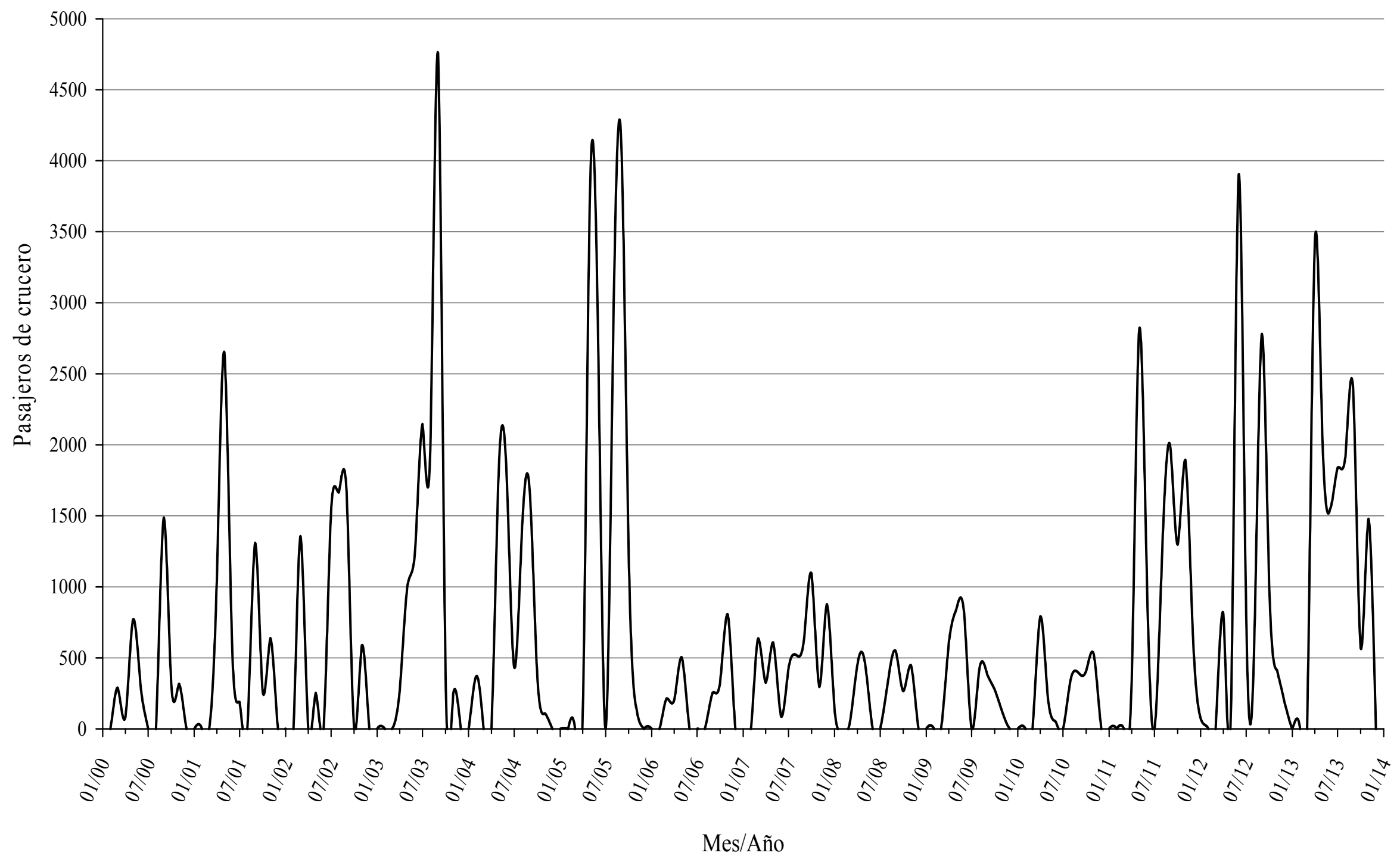

Gráfico II.22: Distribución mensual de la cifra total de cruceristas en el puerto de Motril entre el año 2000 y 2013.

Fuente: Elaboración propia.

$-256-$ 


\section{II.2.5 Puerto de Sevilla}

El puerto de Sevilla, el único de carácter fluvial en la red de puertos de Interés General del Estado Español, registra tráfico de cruceros en el muelle de las Delicias situado en la dársena de Alfonso XIII, véase Figura II.15. Este muelle dispone de una línea de atraque de 614 m., 7,3 m. de calado y $30 \mathrm{~m}$. de anchura. En el muelle de las Delicias se dispone de una terminal de pasajeros de crucero de $144 \mathrm{~m}^{2}$ de superficie en una sola planta (Autoridad Portuaria de Sevilla, 2014).

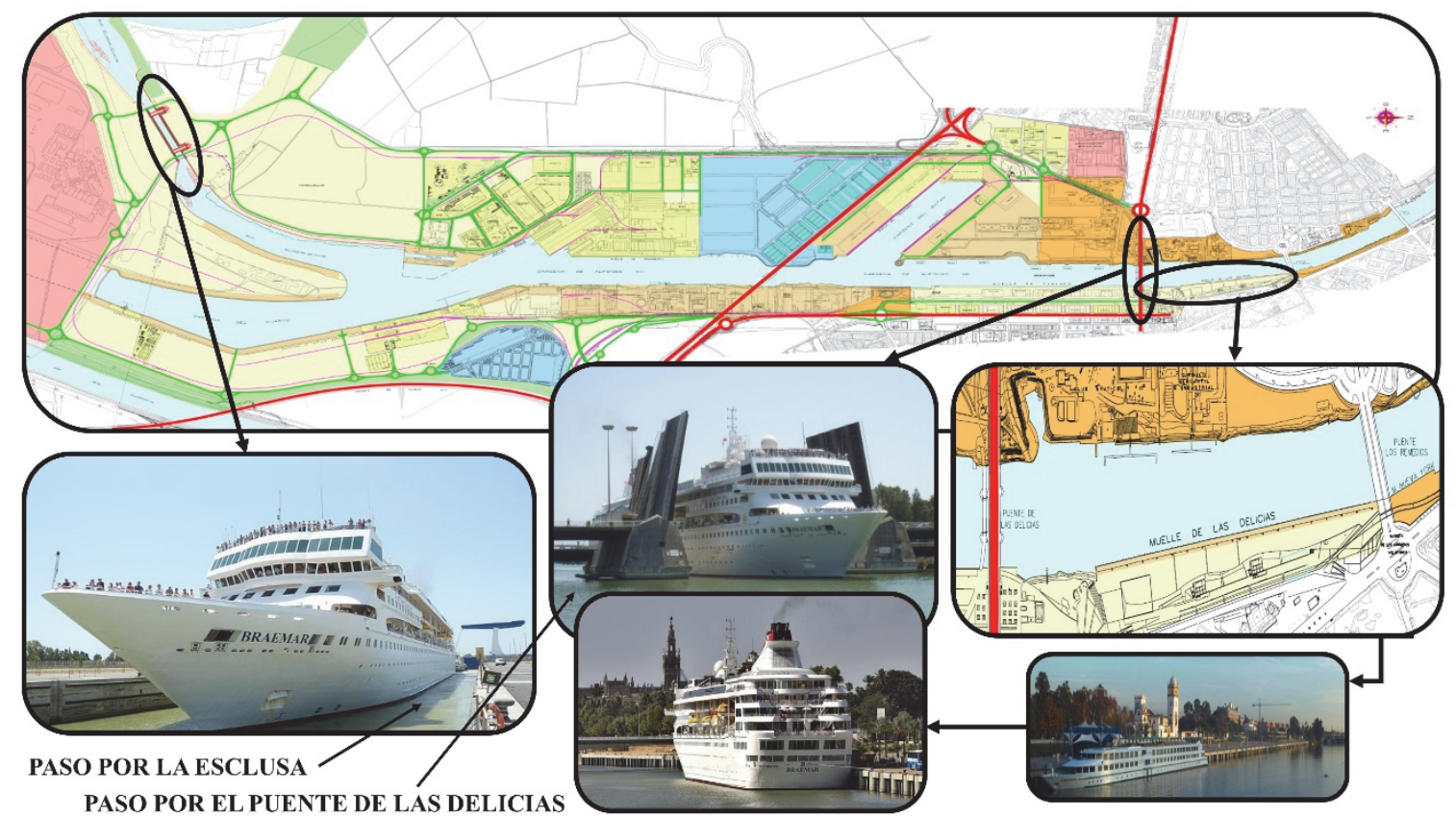

Figura II.15: Esclusa de acceso y muelle destinado a tráfico de cruceros en el puerto de Sevilla.

Fuente: Elaboración propia.

El acceso al puerto de Sevilla implica una serie de restricciones superiores a la del resto de puertos estudiados, pues requiere realizar un primer tramo de navegación fluvial y, a continuación, el paso de una esclusa para acceder finalmente a la ciudad de Sevilla, véase de nuevo Figura II.15. La navegación fluvial se realiza por el río Guadalquivir, desde su desembocadura en el océano Atlántico, en Sanlúcar de Barrameda, hasta Sevilla. Este tramo, que recibe el nombre de Eurovía Guadalquivir E 60.02, tiene una longitud de 89,15 km., con un calado de 7 metros y un puntal aéreo de $42 \mathrm{~m}$. asociado a los puentes que cruzan la vía navegable. Al final de esta vía se sitúa la esclusa que actúa como conexión entre ésta y el recinto portuario de Sevilla. Esta infraestructura supone otra restricción al buque de mayor tamaño que puede acceder al puerto, $280 \mathrm{~m}$. de eslora, $39 \mathrm{~m}$. de manga y $11 \mathrm{~m}$. de calado.

El muelle de las Delicias cuenta con la terminal Delicias, en la que hay disponibles instalaciones de apoyo al pasajero. Estos servicios están asociados, fundamentalmente, al crucero fluvial de Croisi Europe con base en el puerto sevillano. También, navieras de cruceros marítimos, sobre todo asociadas al segmento de lujo, han empleado el puerto de 
Sevilla como base para sus operaciones, como el caso del buque Azamara Quest de la naviera Azamara Club Cruises en noviembre de 2012 (Diario ABC, 2012).

En cuanto a los servicios destinados al buque, disponibles en el puerto, se encuentran: servicio de remolque ( 3 unidades), amarradores y prácticos, las 24 horas del día, suministro de agua potable y combustible y recogida de residuos.

Las cifras de pasajeros de inicio y fin de itinerario entre el año 2000 y 2013 en el puerto de Sevilla se han concentrado en los meses de marzo a mayo y de agosto a noviembre, representando los meses de junio y julio el punto de inflexión entre ambos periodos, véase Gráfico II.23. Hasta el primer trimestre de 2005 los registros de pasajeros en régimen de inicio y fin de itinerario fueron muy reducidos. A partir de abril de 2005 se incrementó notablemente la cifra de esta categoría de pasajeros, registrando los años de 2006 a 2011 un patrón prácticamente análogo en todos ellos. Durante 2012 y 2013 se produjo un nuevo cambio en el patrón de comportamiento, asociado a registros de cruceristas durante todos los meses, en oposición a los registros que se habían dado hasta ese momento, véase Gráfico II. 25 .

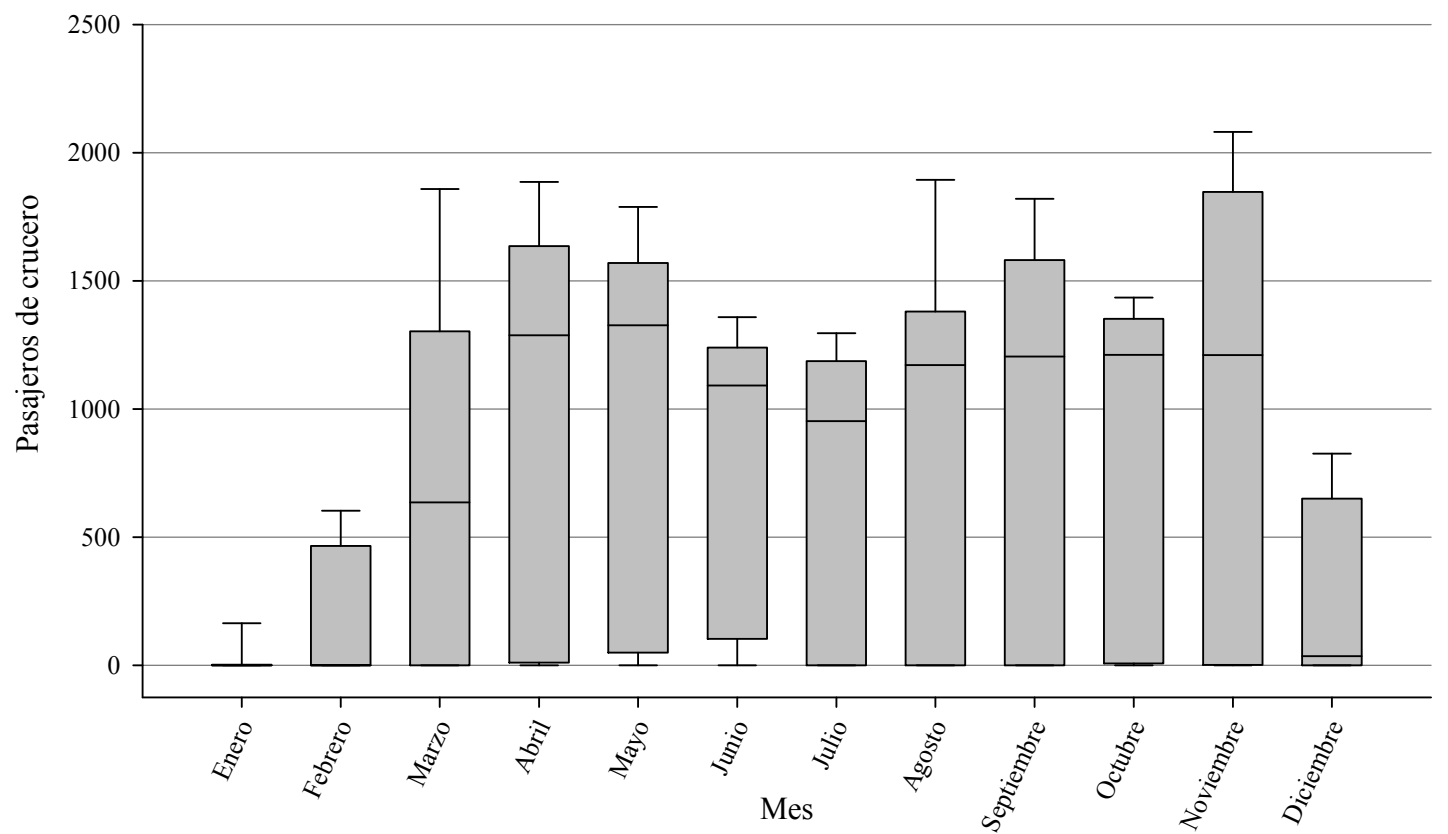

Gráfico II.23: Distribución de la cifra de cruceristas en régimen de inicio y fin de itinerario en el puerto de Sevilla, agregada por meses, entre el año 2000 y 2013.

Fuente: Elaboración propia.

Respecto a los pasajeros en tránsito, durante el mismo periodo, la concentración también se ha dividido en dos etapas, de abril a junio y de agosto a noviembre, marcando el mes de julio el punto de inflexión entre ambos, véase Gráfico II.24. En cuanto a su evolución entre el año 2000 y 2013, ésta es muy irregular, no presentándose un patrón que se repita de forma consecutiva en varios años, véase Gráfico II.26. 


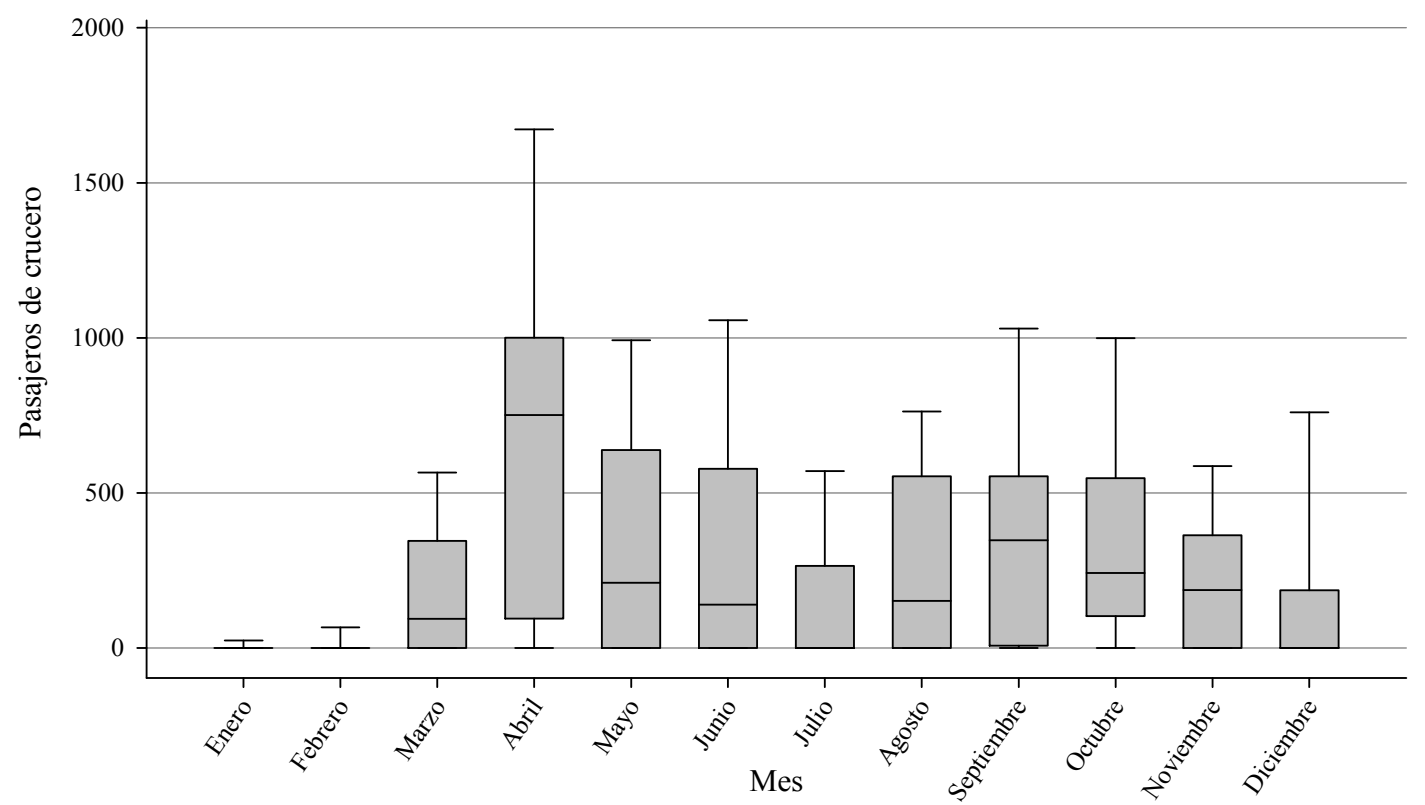

Gráfico II.24: Distribución de la cifra de cruceristas en régimen de tránsito en el puerto de Sevilla, agregada por meses, entre el año 2000 y 2013.

Fuente: Elaboración propia. 


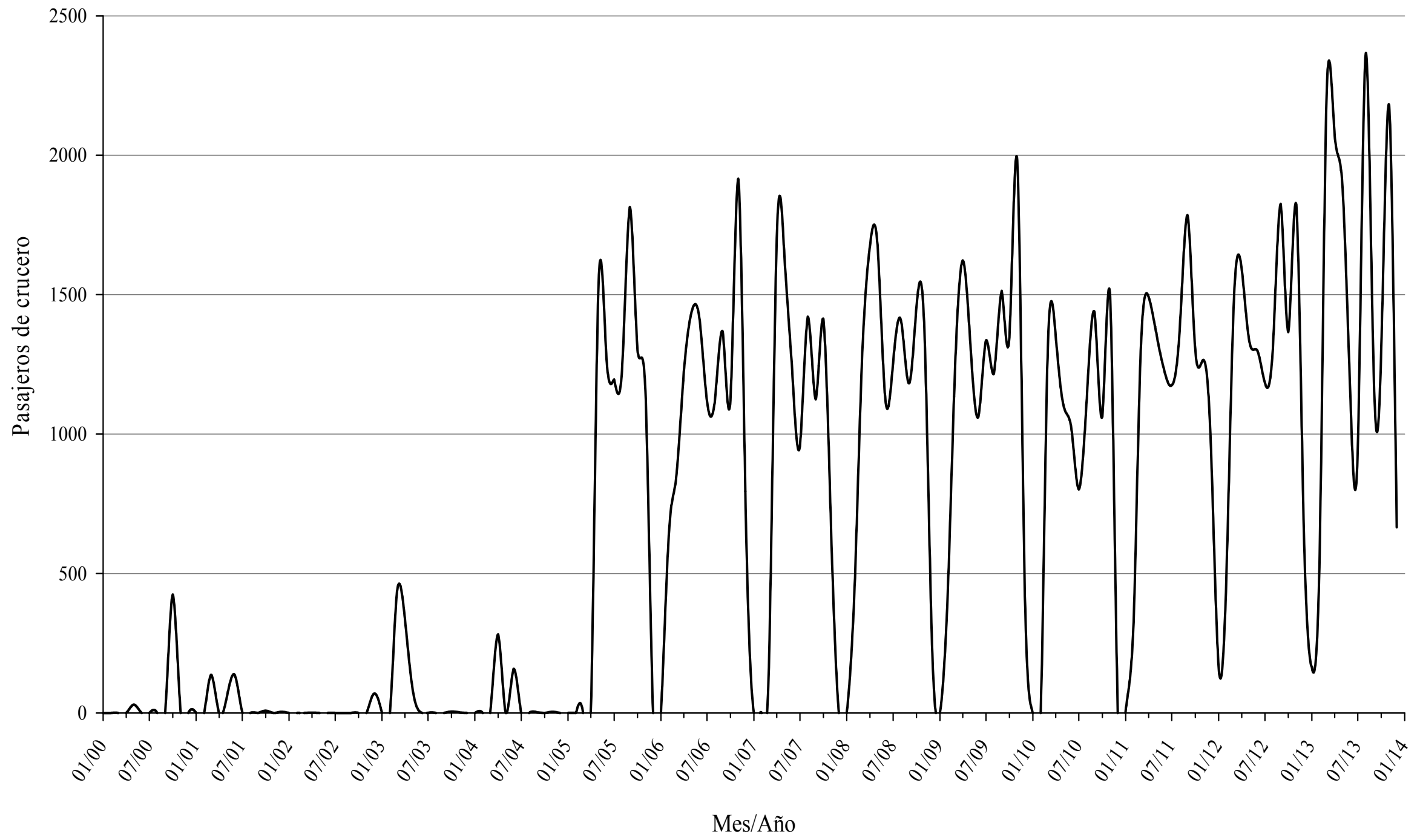

Gráfico II.25: Distribución mensual de la cifra de cruceristas en régimen de inicio y fin de itinerario en el puerto de Sevilla entre el año 2000 y 2013.

Fuente: Elaboración propia. 


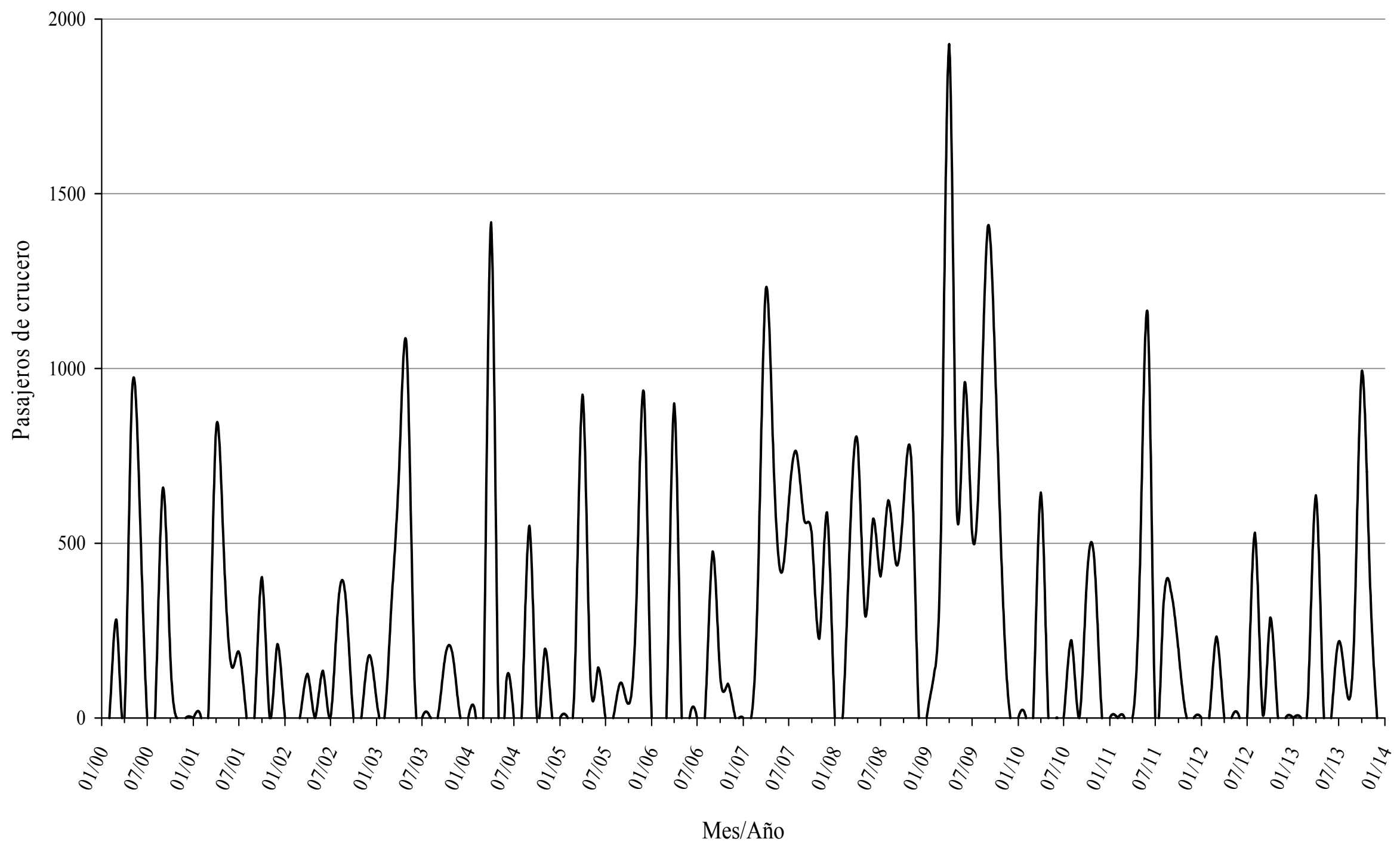

Gráfico II.26: Distribución mensual de la cifra de cruceristas en régimen de tránsito en el puerto de Sevilla entre el año 2000 y 2013.

Fuente: Elaboración propia. 


\section{II.2.6 Puerto de Tarragona}

El puerto de Tarragona dispone de dos muelles dedicados al atraque de buques de crucero, Dique de Levante y muelle de Costa, véase Figura II.16. El muelle Dique de Levante tiene una línea de atraque de 707 metros y $19 \mathrm{~m}$. de calado destinado exclusivamente al atraque de buques de crucero. Estas dimensiones no imponen restricción en lo que a eslora y manga del buque se refiere. Además, cuenta con una estación marítima con los siguientes servicios: zona de recepción, acceso a internet, dos salas de espera y posibilidad de adaptar el espacio con servicios de restauración. En el muelle de Costa, las instalaciones de Marina Port Tarraco también pueden albergar buques de crucero. La línea de atraque de este muelle es de $350 \mathrm{~m}$. con $8 \mathrm{~m}$. de calado, limitando el tamaño máximo de buque a $140 \mathrm{~m}$. de eslora (Tarragona Cruise Port, 2014). Actualmente, el reducido número de escalas de cruceros que registra este puerto se atienden en el Dique de Levante.

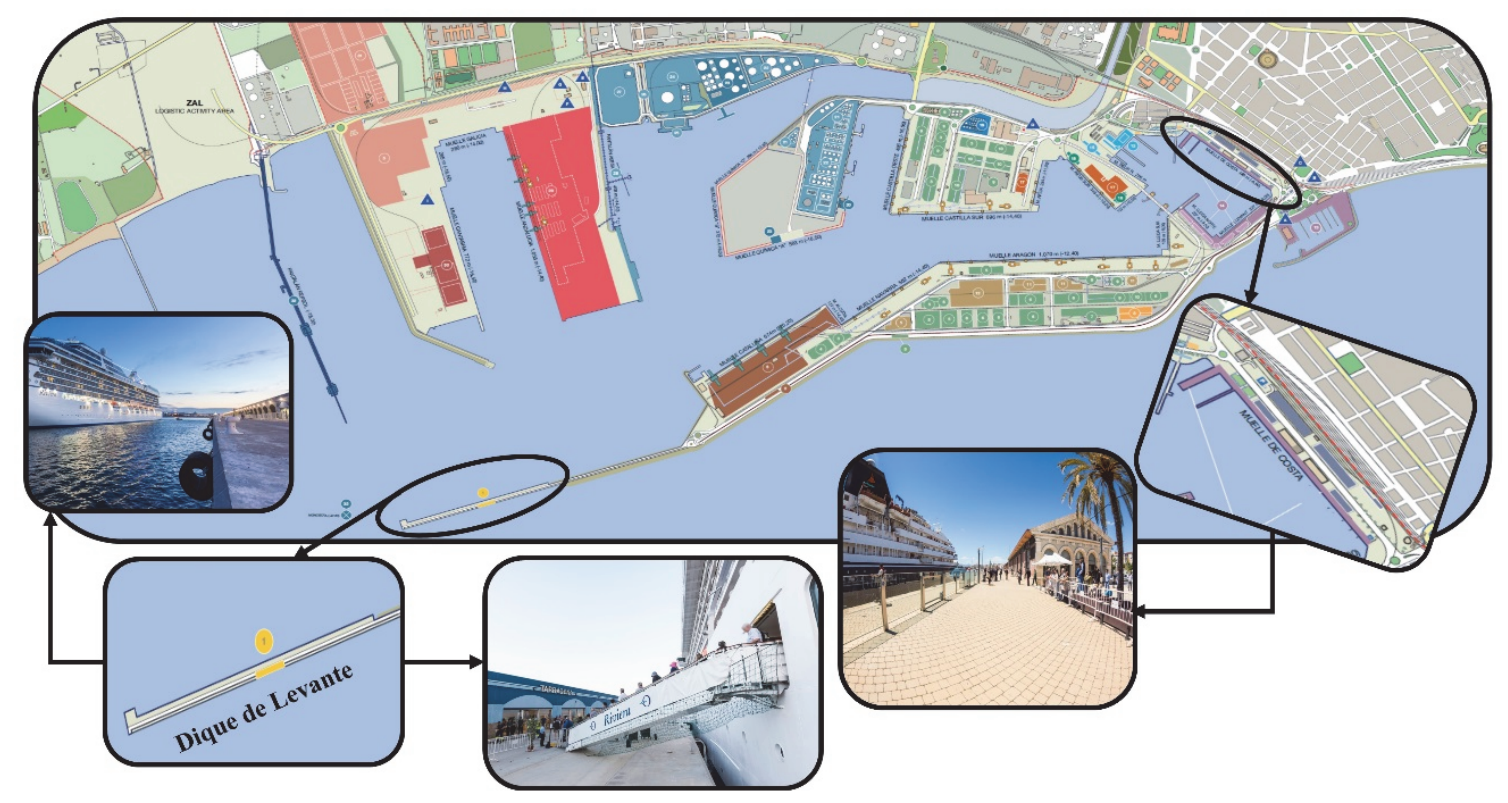

Figura II.16: Muelles destinados a buques de crucero en el puerto de Tarragona.

Fuente: Elaboración propia.

Los buques disponen de servicio de remolque ( 6 unidades), amarradores y prácticos, las 24 horas del día; suministro de combustible, suministro de agua dulce y avituallamiento (Autoridad Portuaria de Tarragona, 2012).

La Autoridad Portuaria de Tarragona ha creado un grupo de trabajo para potenciar el tráfico de cruceros en sus muelles, esta iniciativa está enmarcada en el Plan Director del Puerto 2015-2030. Para ello ha creado la marca "Tarragona Cruise Port" (Autoridad Portuaria de Tarragona, 2014). Entre las primeras acciones a emprender se sitúa la evaluación de un nuevo emplazamiento para la terminal de pasajeros de crucero, pues la estrechez del muelle Dique de Levante, con 15 metros de anchura, impide desarrollar la operativa con los pasajeros de forma adecuada. 
Actualmente se barajan dos escenarios para el emplazamiento de la nueva terminal. El primero de ellos estaría disponible a medio plazo con una inversión asequible. Esta opción se centra en aprovechar las obras del dique Prats, frente al pantalán que explota Repsol, junto a la playa de La Pineda y muy cerca de los terrenos del futuro complejo de BCN World y de Port Aventura, y alargar el espigón para que albergue la terminal. La prolongación de este dique costaría unos 15 millones de euros, a los que se deben añadir otros 28 millones del propio espigón, y esta nueva infraestructura podría estar lista en tres o cuatro años. El siguiente emplazamiento, a largo plazo, está condicionado a que fructifique la estrategia de captar cruceristas, alcanzando cifras sostenidas de 50.000 cruceristas/año. Si se consolida el tráfico en esos órdenes de magnitud, la estrategia de la Autoridad Portuaria de Tarragona pasa por construir una terminal urbana junto al Puerto Deportivo de Tarragona. Esta medida, sujeta a tener masa crítica para construir la terminal definitiva, está contemplada en el Plan Director 2015-2030. Este proyecto costaría entre 80 y 120 millones de euros, porque son necesarios, como mínimo, veinte metros de calado en el muelle (Europa Press, 2014).

Entre el año 2000 y 2013, el puerto de Tarragona no ha registrado un tráfico de cruceros consolidado. Durante este periodo la evolución ha sido irregular unida a etapas en las que no escaló ningún buque, circunstancia que se dio sobre todo entre el año 2010 y 2013 , Gráfico II.27. 


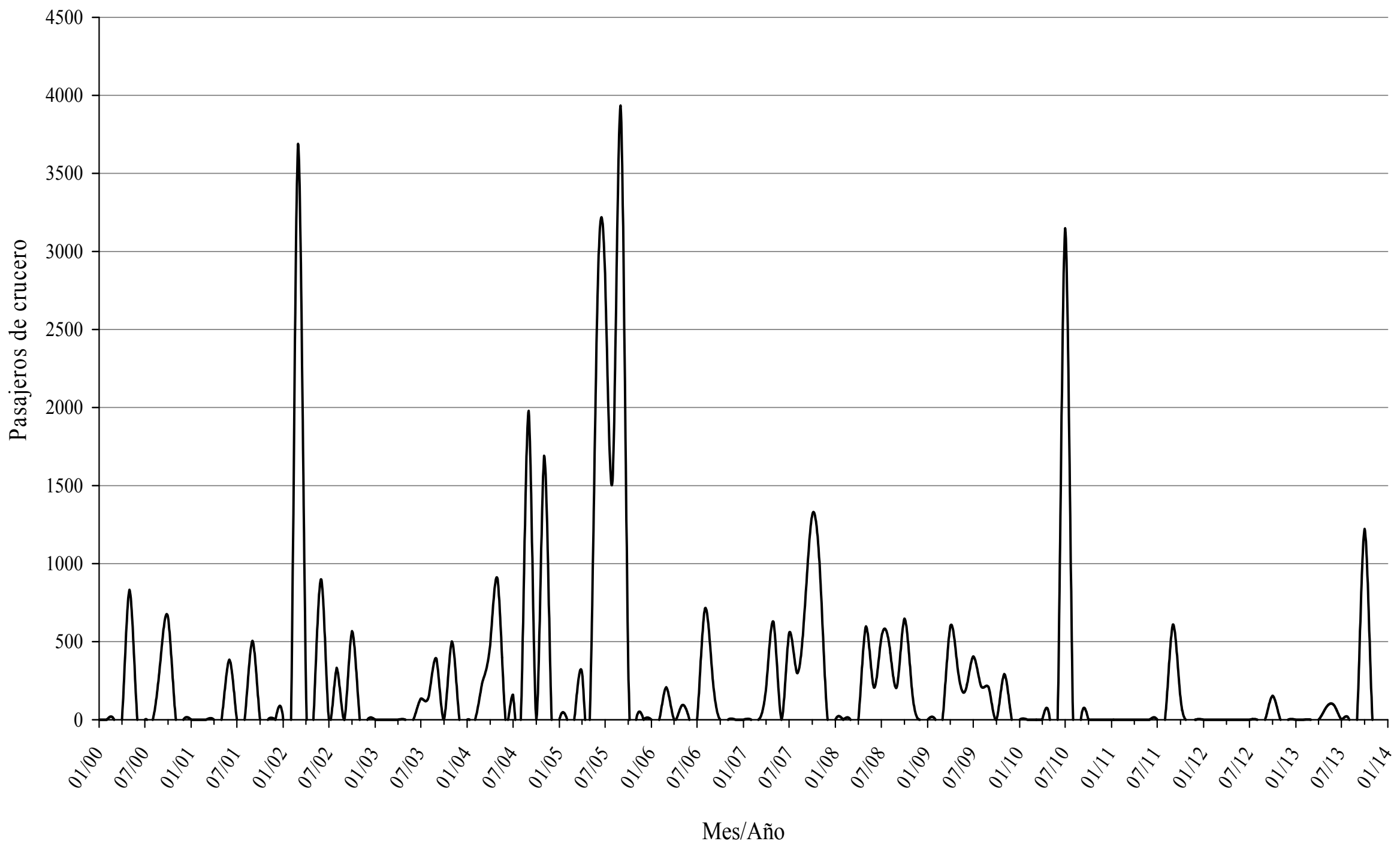

Gráfico II.27: Distribución mensual de la cifra total de cruceristas en el puerto de Tarragona entre el año 2000 y 2013.

Fuente: Elaboración propia.

$-264-$ 


\section{II.3 Puertos participantes minoritarios}

Con la posición competitiva de participante minoritario quedan encuadrados ocho puertos, que son: Alicante, Almería, Mahón, Ceuta, Huelva, Castellón, La Savina y Melilla. A continuación se definen las características particulares de las instalaciones para cruceros de cada uno de ellos.

\section{II.3.1 Puerto de Alicante}

En el puerto de Alicante el muelle número 14 de la dársena Exterior está destinado a albergar tráfico de cruceros, véase Figura II.17. Éste cuenta con una línea de atraque de 970 metros y 11 metros de calado. La anchura del muelle es de 60 metros lo que le confiere una superficie de $5.500 \mathrm{~m}^{2}$, con una altura sobre el cantil de 1,5 metros. Además, también cuenta con terminal de pasajeros, siendo la distancia del muelle a la ciudad de $1 \mathrm{~km}$ (Autoridad Portuaria de Alicante, 2012).

Desde el punto de vista de los servicios destinados al buque cuenta con los siguientes: servicio de remolque ( 2 unidades), servicio de amarradores y servicio de prácticos; en los tres casos disponibles durante las 24 horas. No existe restricción en cuanto al horario de salida o llegada del buque; además las características técnicas del muelle no imponen restricción en cuanto a eslora y puntal máximo del buque (Autoridad Portuaria de Alicante, 2012).

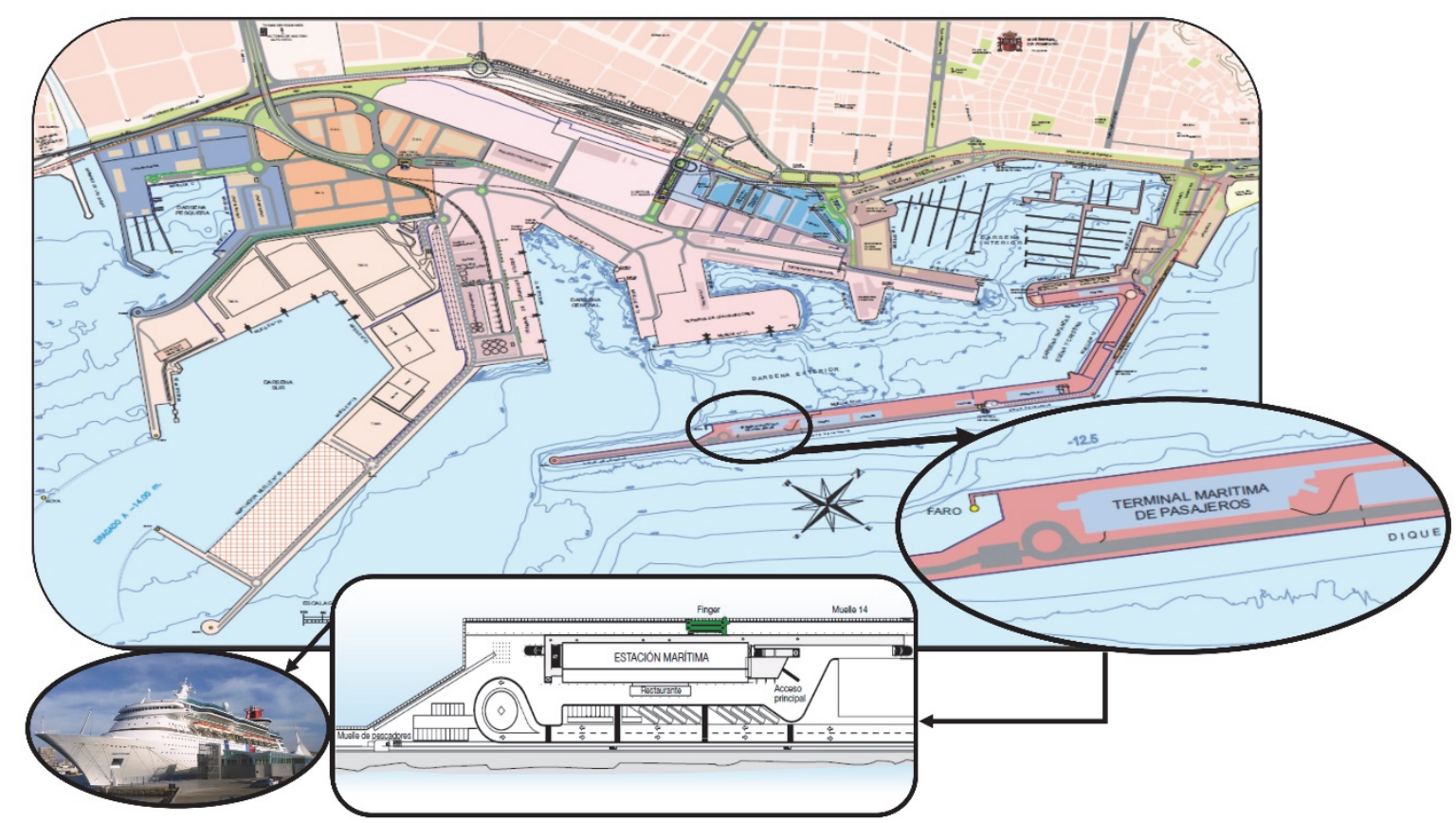

Figura II.17: Ubicación del muelle y terminal de pasajeros de crucero en el puerto de Alicante. Fuente: Elaboración propia.

La terminal de pasajeros tiene una superficie total de $5.400 \mathrm{~m}^{2}$ distribuidos en dos plantas de $2.700 \mathrm{~m}^{2}$ cada una. Respecto a los servicios al pasaje y más en concreto con los 
relacionados con la terminal, ésta dispone de: aire acondicionado, aparcamiento, barrestaurante, oficinas de cambio de moneda, detector de metales, policía de inmigración, quiosco de prensa internacional, rayos-x, servicio de aduana, servicio de información, teléfonos públicos, tiendas de regalos y tiendas duty free. Además, la terminal también dispone de servicio de bus lanzadera al centro de la ciudad y parada de taxis (Autoridad Portuaria de Alicante, 2011). El embarque/desembarque de pasajeros se puede realizar mediante el uso de una pasarela móvil cubierta "finger" que conecta el buque con la terminal o bien emplear la pasarela del buque sobre el muelle, véase Figura II.18 y II.19.

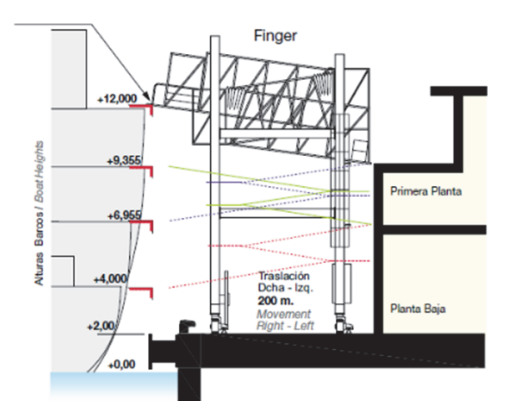

Figura II.18: Pasarela móvil cubierta (finger) para el embarque/desembarque de pasajeros.

Fuente: Autoridad Portuaria de Alicante (2011).

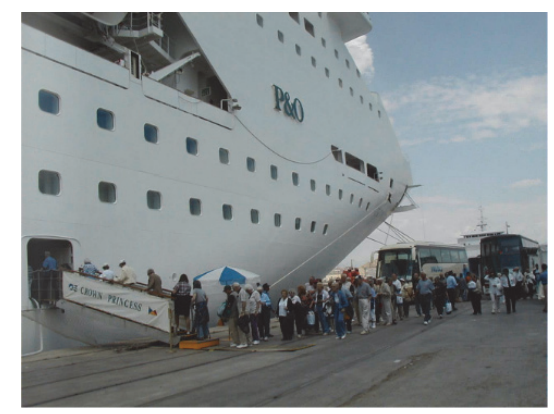

Figura II.19: Embarque de pasajeros con la pasarela del buque.

Fuente: Autoridad Portuaria de Alicante (2011).

La terminal ha sido explotada y gestionada por la propia Autoridad Portuaria de Alicante hasta octubre de 2013, mes en que fue adjudicada su explotación a la empresa privada Costablanca Portuaria S.L. La concesión tiene una duración de 20 años prorrogable hasta un máximo de cuatro años más. Además, es de destacar una de las condiciones recogidas en el pliego del concurso, pues reside en convertir al puerto de Alicante en base de cruceros (Cadena de Suministro, 2013).

Entre el año 2000 y 2013 la mayor concentración de pasajeros se ha registrado en los meses de abril a octubre, meses de temporada alta en la región del Mediterráneo. Además, los máximos se registran al inicio y fin de esta temporada, con el posicionamiento de los buques desde sus destinos invernales (del hemisferio norte) hacia los destinos en la época estival, véase Gráfico II.28. Junto a lo anterior, entre los años 2006 y 2012, se superó el umbral de más de 10.000 pasajeros mensuales durante varios meses. Esta tendencia se vio truncada en el año 2013 con la pérdida significativa de tráfico de cruceros, véase Gráfico II.29. 


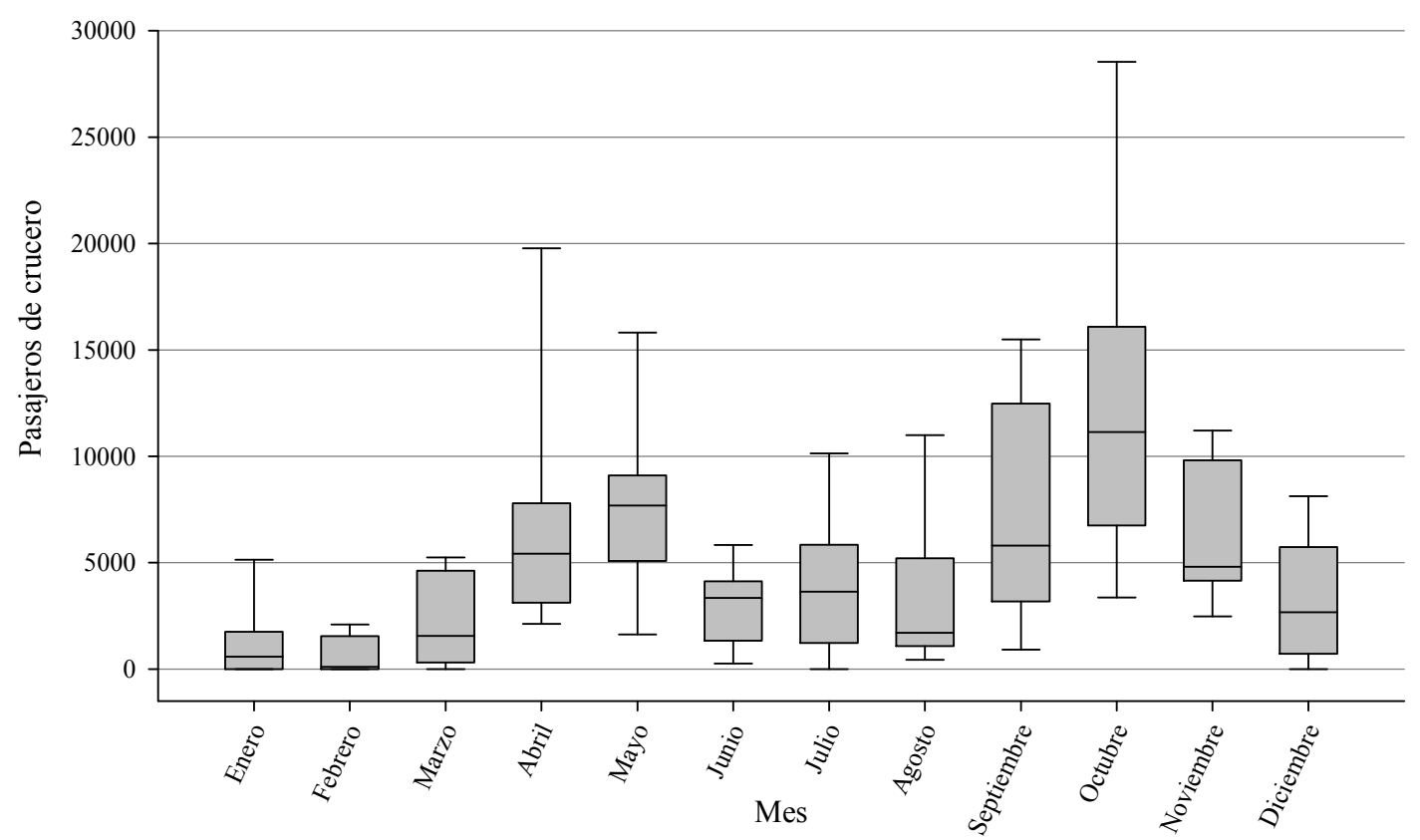

Gráfico II.28: Distribución de la cifra total de cruceristas en el puerto de Alicante, agregada por meses, entre el año 2000 y 2013.

Fuente: Elaboración propia. 


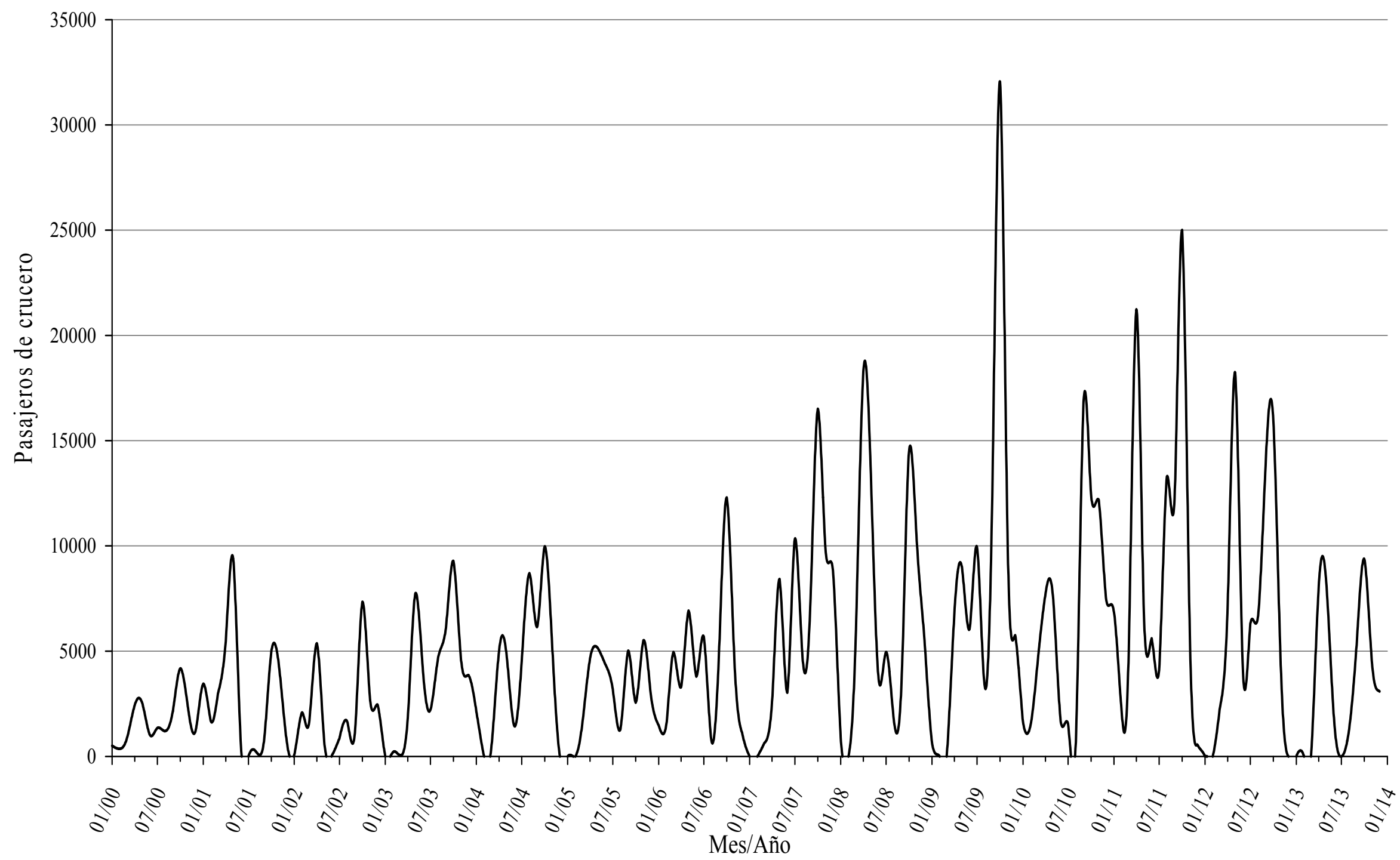

Gráfico II.29: Distribución mensual de la cifra total de cruceristas en el puerto de Alicante entre el año 2000 y 2013. Fuente: Elaboración propia.

$-268-$ 


\section{II.3.2 Puerto de Almería}

El puerto de Almería dispone de dos muelles para el atraque de cruceros, Levante y Ribera $2^{\mathrm{a}}$ alineación, con una línea de atraque de 220 y 450 metros y calado de 9 y 9,5 metros, respectivamente, ambos situados en la dársena Comercial, véase Figura II.20. El muelle Ribera $2^{\mathrm{a}}$ Alineación tiene un uso dual, pues alberga tanto pasajeros de tráfico de cruceros como de línea regular. La configuración de la dársena permite un radio de giro máximo de 370 metros, con un calado máximo de 9 metros, no existiendo restricción de puntal aéreo (Autoridad Portuaria de Almería, 2011b).

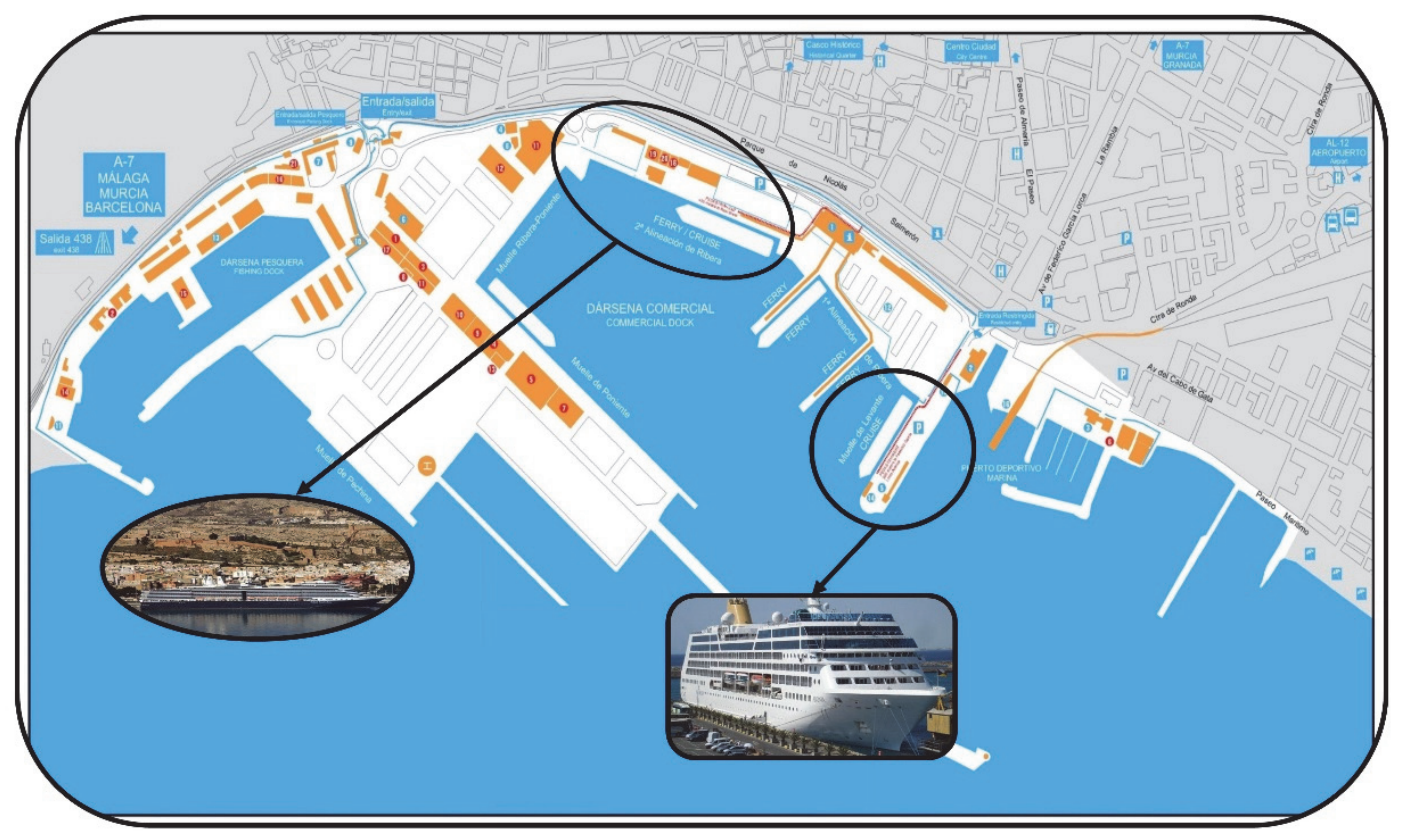

Figura II.20: Ubicación de los muelles de pasajeros de crucero en el puerto de Almería.

Fuente: Elaboración propia.

Ambos muelles no disponen de terminal de pasajeros de crucero. El muelle de Levante, situado a 200 metros de la ciudad, tiene una superficie de $14.240 \mathrm{~m}^{2}$ pavimentada en asfalto. Mientras que el muelle Ribera $2^{\circ}$ Alineación tiene una superficie mayor, 37.270 $\mathrm{m}^{2}$ pavimentada en hormigón, situado a 600 metros de la ciudad. En ambos casos se dispone de aparcamiento para autobuses. En cuanto a los servicios al buque se dispone de: remolque (dos unidades), practicaje y amarradores, durante las 24 horas (Autoridad Portuaria de Almería, 2012). Además, está prevista la construcción de un nuevo muelle para atraque de cruceros de 500 metros de línea de atraque.

En el puerto de Almería las escalas de cruceros se concentran de abril a octubre, véase Gráfico II.30. Durante el periodo 2000-2013, la temporada alta ha presentado una configuración de dos máximos, agrupándose los cruceristas al comienzo y fin de este periodo. Además, durante este periodo de catorce años ha habido un incremento de la cifra de cruceristas en el puerto. Esta tendencia quedó patente sobre todo a partir del año 2004 en 
que se superó la barrera de los 4.000 pasajeros mensuales durante varios meses, véase Gráfico II.31.

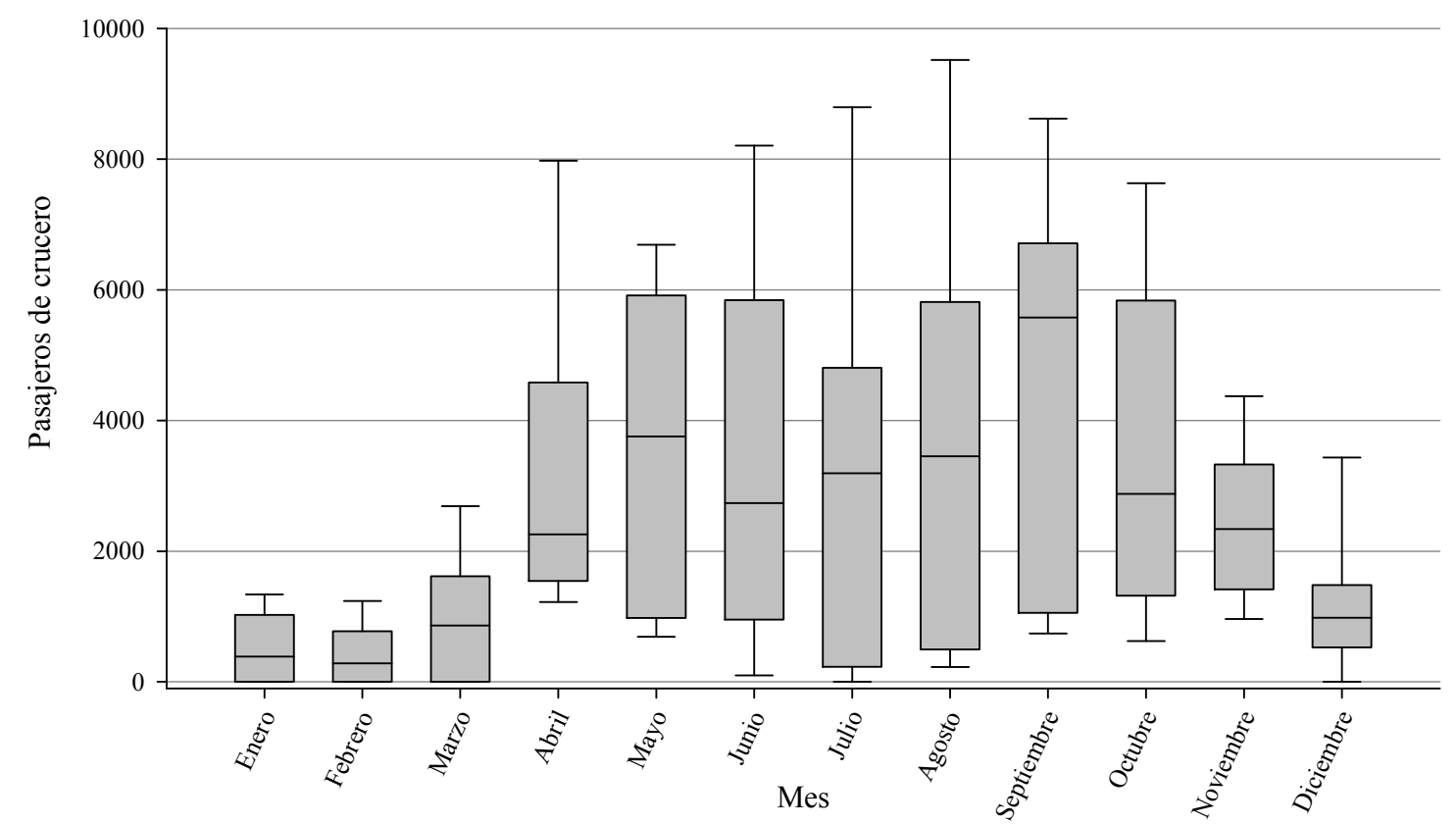

Gráfico II.30: Distribución de la cifra total de cruceristas en el puerto de Almería, agregada por meses, entre el año 2000 y 2013.

Fuente: Elaboración propia. 


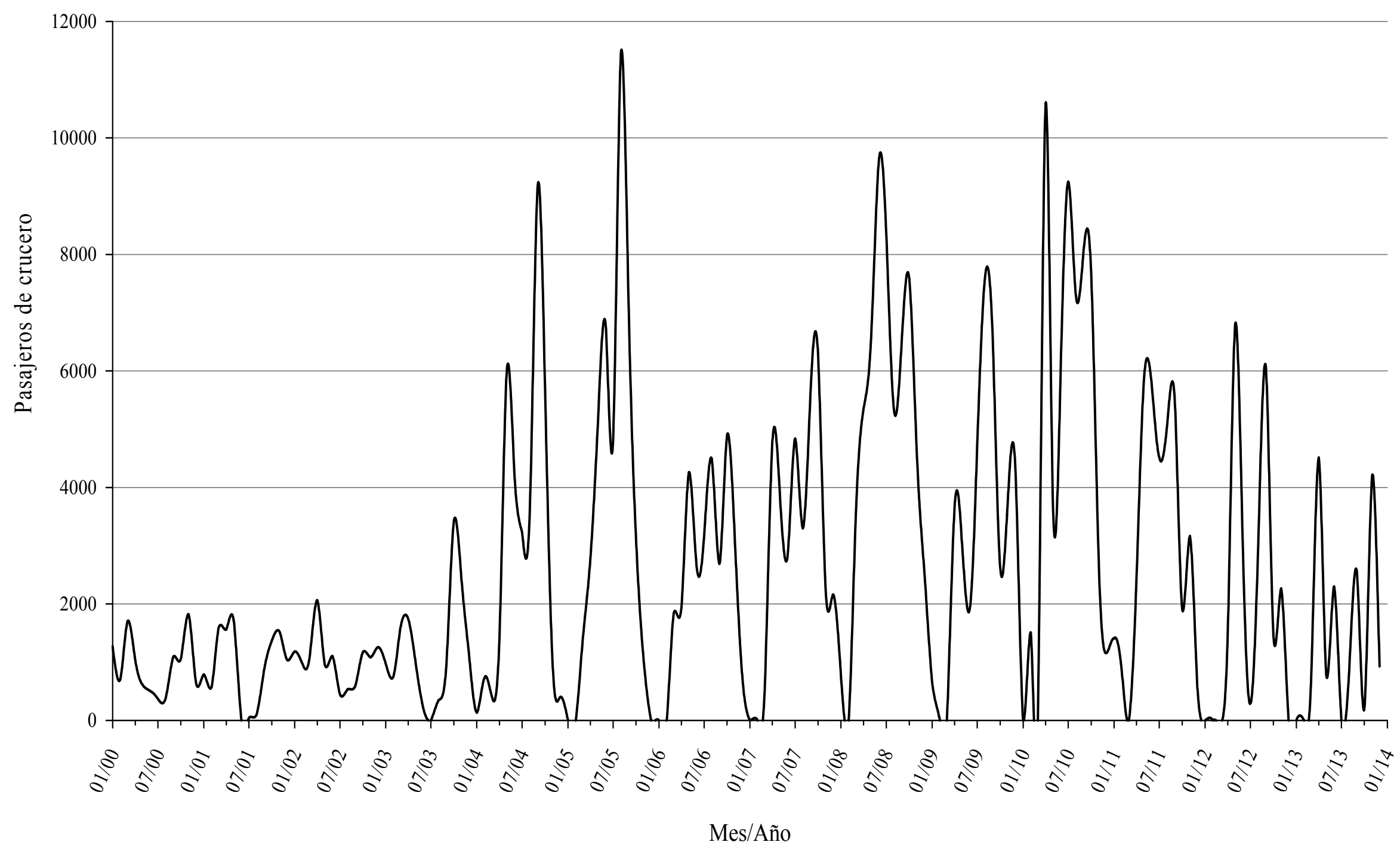

Gráfico II.31: Distribución mensual de la cifra total de cruceristas en el puerto de Almería entre el año 2000 y 2013.

Fuente: Elaboración propia. 


\section{II.3.3 Puerto de Mahón}

El puerto de Mahón dispone de dos muelles para el atraque de buques de crucero, el muelle de Pasajeros y la Estación Naval de Mahón, véase Figura II.21. El muelle de Pasajeros dispone de una línea de atraque de 640 metros, 8,5 metros de calado y 50 metros de ancho. Mientras que el muelle de la Estación Naval de Mahón tiene unas dimensiones menores, 258 metros de línea de atraque, 8 metros de calado y 13 metros de ancho. Únicamente dispone de una terminal de pasajeros, situada en el muelle de Pasajeros conectada por una pasarela móvil y 90 metros lineales de pasarela fija (Autoridad Portuaria de Baleares, 2014c).

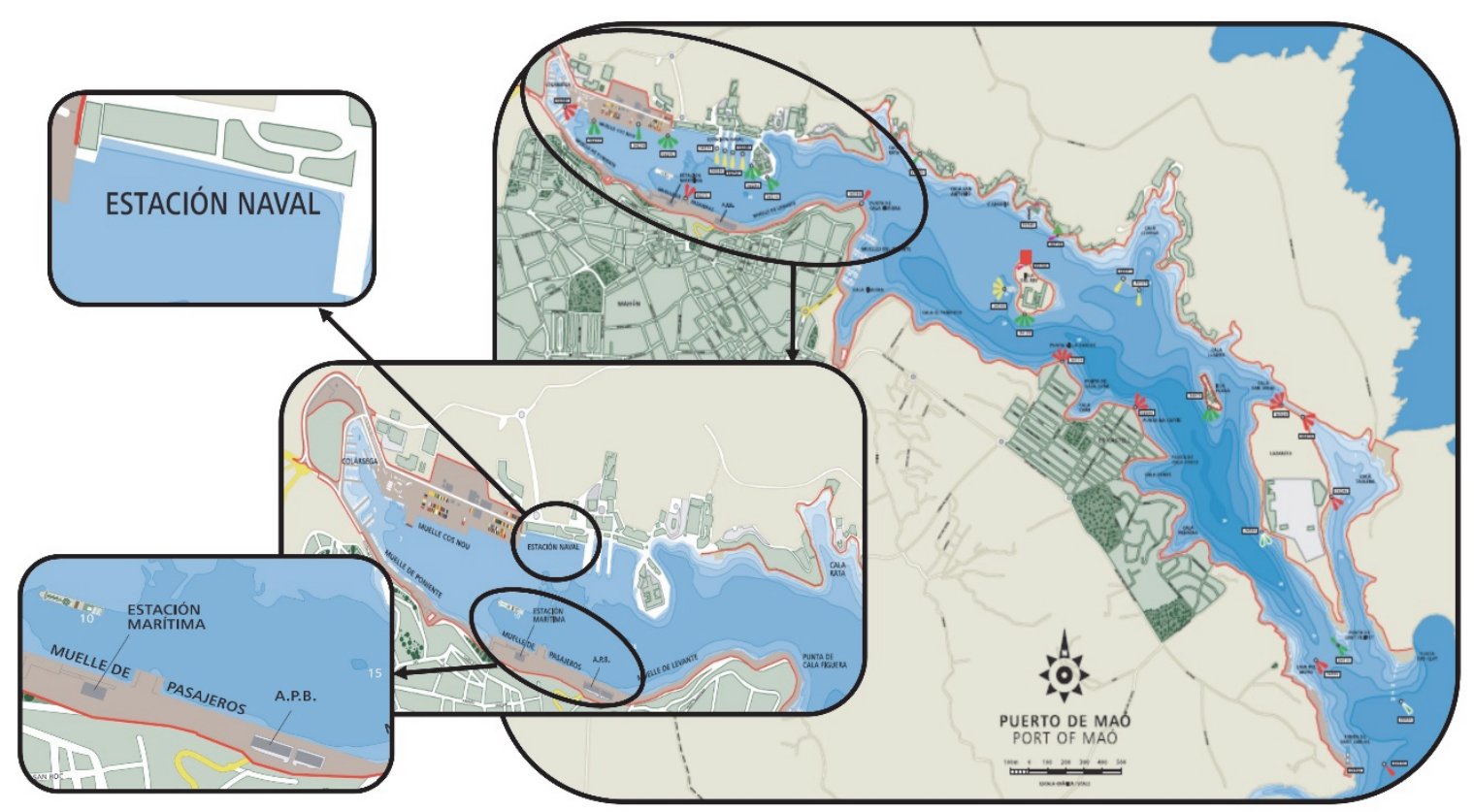

Figura II.21: Ubicación de los muelles para buques de crucero en el puerto de Mahón.

Fuente: Elaboración propia.

El puerto cuenta con servicio de remolcadores (1 unidad), amarre y prácticos, 24 horas. Además de, servicio de recogida de residuos oleosos, sólidos y líquidos.

En el puerto de Mahón, el tráfico de cruceros, entre el año 2000 y 2013, se ha concentrado en los meses de mayo a octubre. La finalización de la temporada alta en el mes de octubre, queda patente con la diferencia de cruceristas registrada durante este mes respecto a noviembre. Además, en el primer trimestre del año, así como, en el mes de diciembre, los registros de cruceristas han sido muy reducidos, véase Gráfico II.32. Durante este periodo, en temporada alta la cifra de cruceristas mensuales se ha situado de media en el umbral de los 10.000, véase Gráfico II.33. 


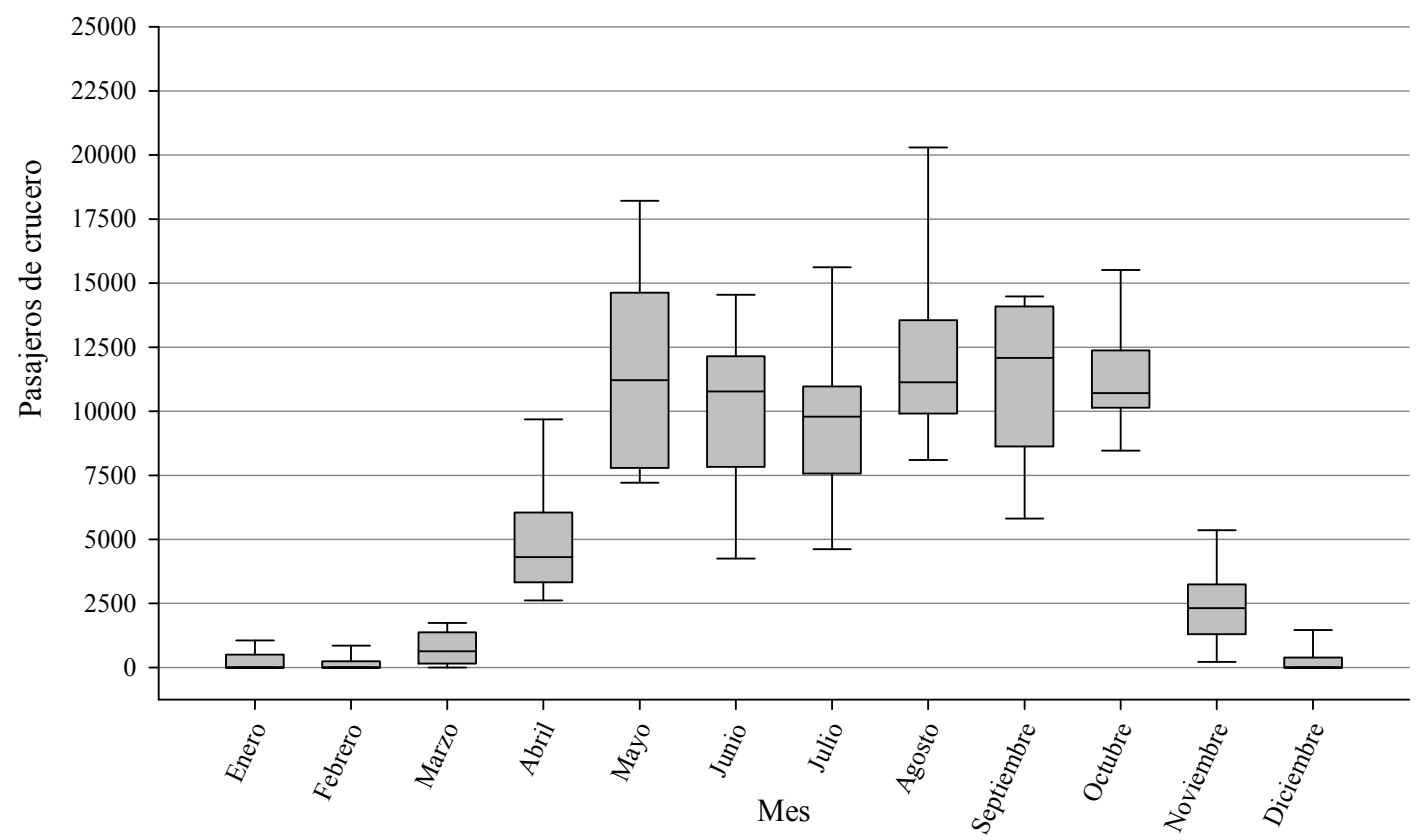

Gráfico II.32: Distribución de la cifra total de cruceristas en el puerto de Mahón, agregada por meses, entre el año 2000 y 2013.

Fuente: Elaboración propia. 


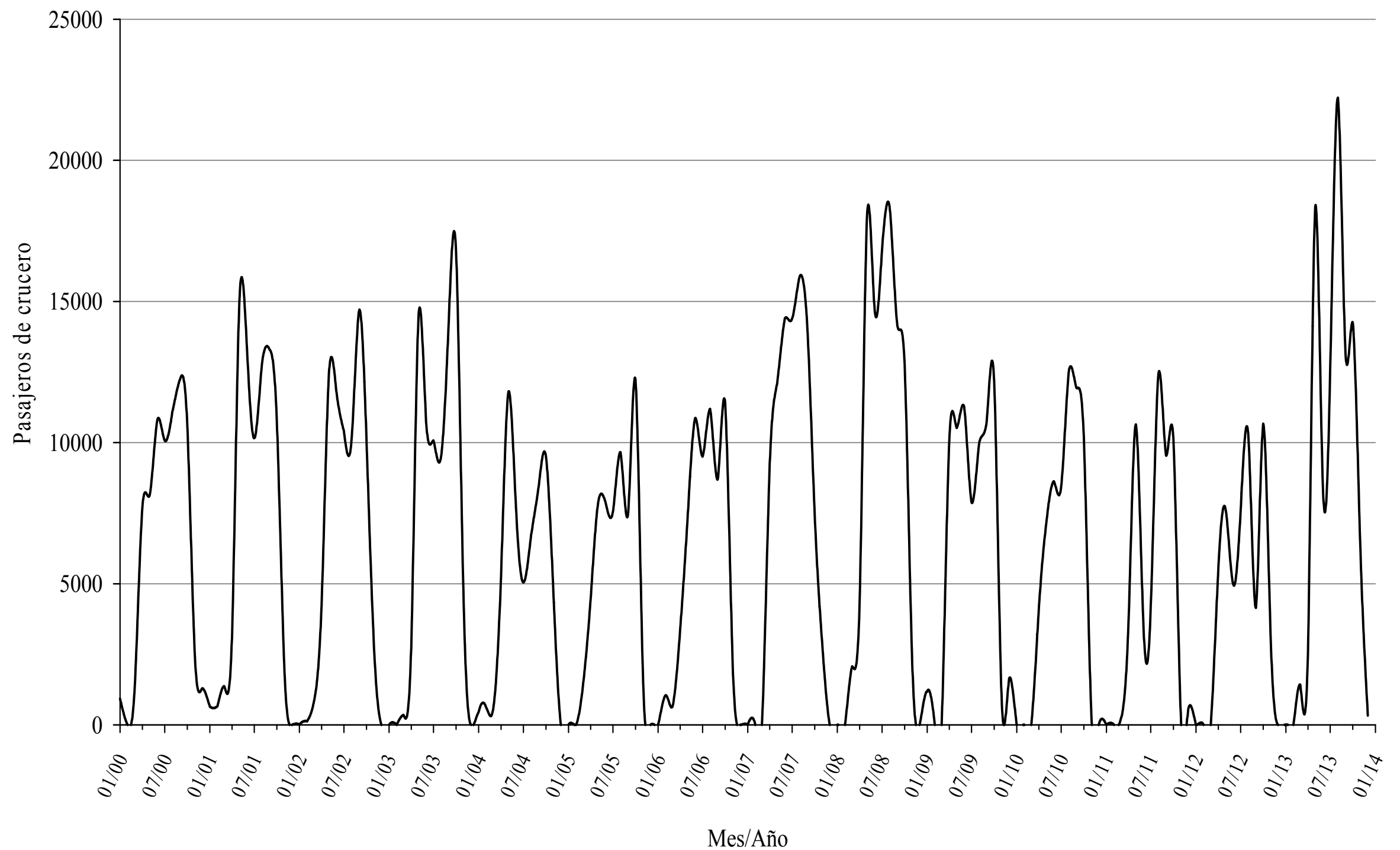

Gráfico II.33: Distribución mensual de la cifra total de cruceristas en el puerto de Mahón entre el año 2000 y 2013.

Fuente: Elaboración propia. 


\section{II.3.4 Puerto de Ceuta}

El puerto de Ceuta tiene una excelente ubicación en el extremo Norte del Continente Africano, a la entrada del mar Mediterráneo, en pleno estrecho de Gibraltar. La actividad de buques de crucero se registra en el muelle España ubicado en la dársena Comercial. Éste cuenta en dos lados, "levante" y "poniente", véase Figura II.22. El lado de "levante" está dividido en tres zonas de atraque que difieren entre sí por la longitud de línea de atraque y calado del muelle. La de mayor calado, que oscila entre 9 y 9,5 metros, tiene una línea de atraque de 176 metros. La zona intermedia dispone de un calado ligeramente inferior, varía entre 8 y 9 metros, con una línea de atraque de 90 metros. La tercera zona, la de menor calado de las tres, tiene una línea de atraque de 84 metros, con un calado que oscila entre 3 y 5,5 metros. En lo que respecta al lado de "poniente", dispone de una línea de atraque de 350 metros con un calado que oscila de 6 a 7,5 metros. La anchura del muelle oscila entre los 60 metros en la parte sur a los 77 metros en la parte norte (Autoridad Portuaria de Ceuta, 2012).

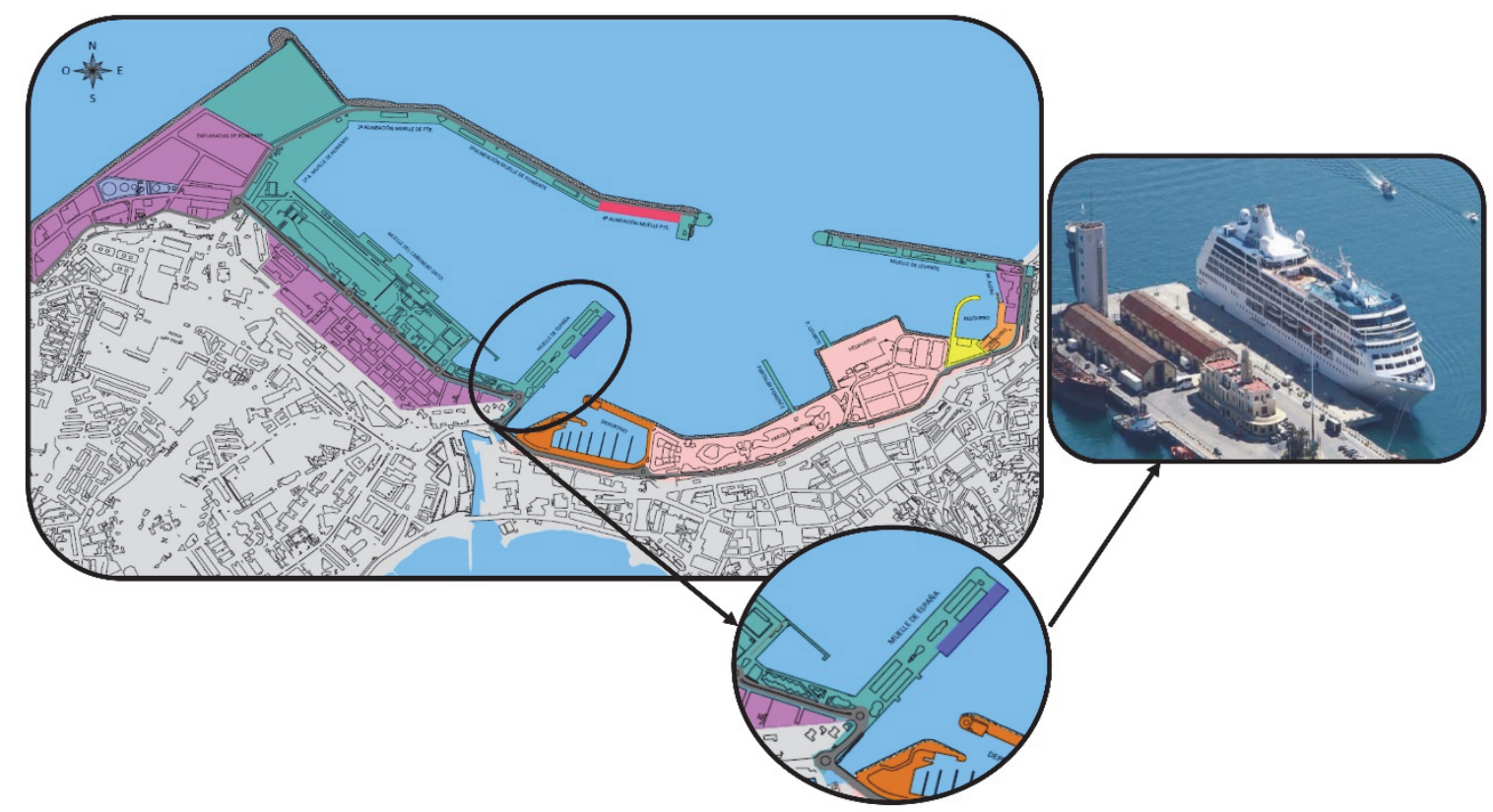

Figura II.22: Instalaciones para buques de crucero en el puerto de Ceuta. Fuente: Elaboración propia.

El puerto cuenta con los siguientes servicios disponibles para los buques de crucero, durante las 24 horas: remolque ( 1 unidad), practicaje (obligatorio), amarradores, suministro de combustible, avituallamiento, agua potable y recogida de residuos. El puerto de Ceuta destaca en el Sistema Portuario Español por la calidad del servicio de suministro de combustible con unos precios competitivos.

El muelle no dispone de terminal para pasajeros de crucero. Los servicios disponibles para los pasajeros en el muelle son: servicio de bus lanzadera a la ciudad, parada de autobuses, servicio de taxi, teléfono público, información turística, punto de salida de excursiones y servicio de vigilancia y control de seguridad. Los pasajeros pueden desplazarse caminando hasta la ciudad, pues está situada a 100 metros, o bien haciendo uso 
de los servicios de transporte que tienen a su disposición, descritos anteriormente. Además, la ciudad de Ceuta cuenta con un régimen fiscal especial, exención del I.V.A. (Autoridad Portuaria de Ceuta, 2014).

El tráfico de cruceros en el puerto de Ceuta no ha constituido una de las principales líneas de negocio del puerto durante el periodo del año 2000 a 2013. Durante este periodo, el mayor volumen de pasajeros se ha concentrado en los meses de abril a octubre y dividido en dos tramos, marcando el mes de julio el punto de inflexión entre ambos, véase Gráfico II.34. Además, en los catorce años analizados, durante el primer trimestre del año, salvo contadas excepciones, no se han registrado escalas de buques de cruceros. Con carácter general durante el periodo analizado la distribución de cruceristas ha sido irregular, véase Gráfico II.35.

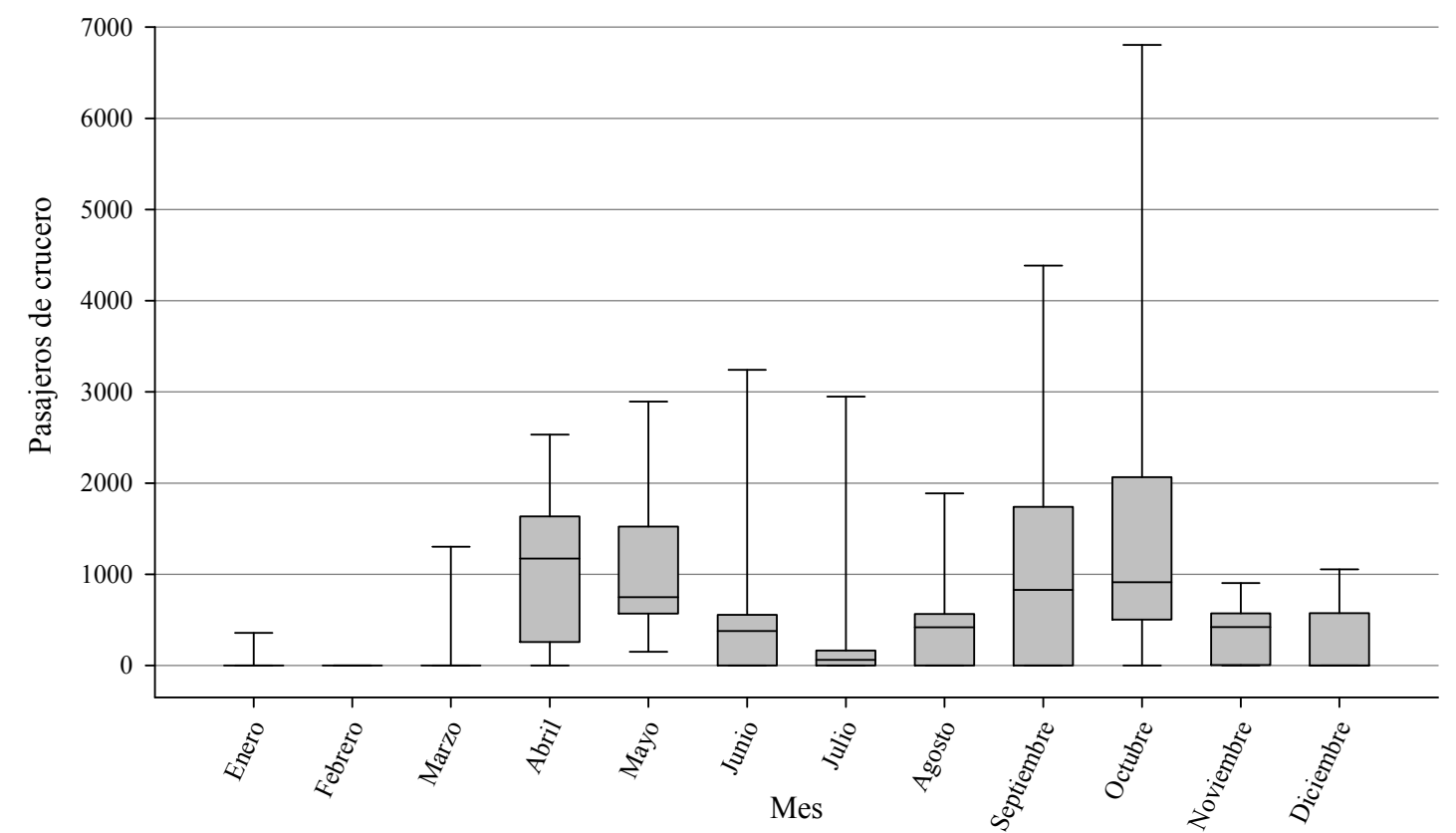

Gráfico II.34: Distribución de la cifra total de cruceristas en el puerto de Ceuta, agregada por meses, entre el año 2000 y 2013.

Fuente: Elaboración propia. 


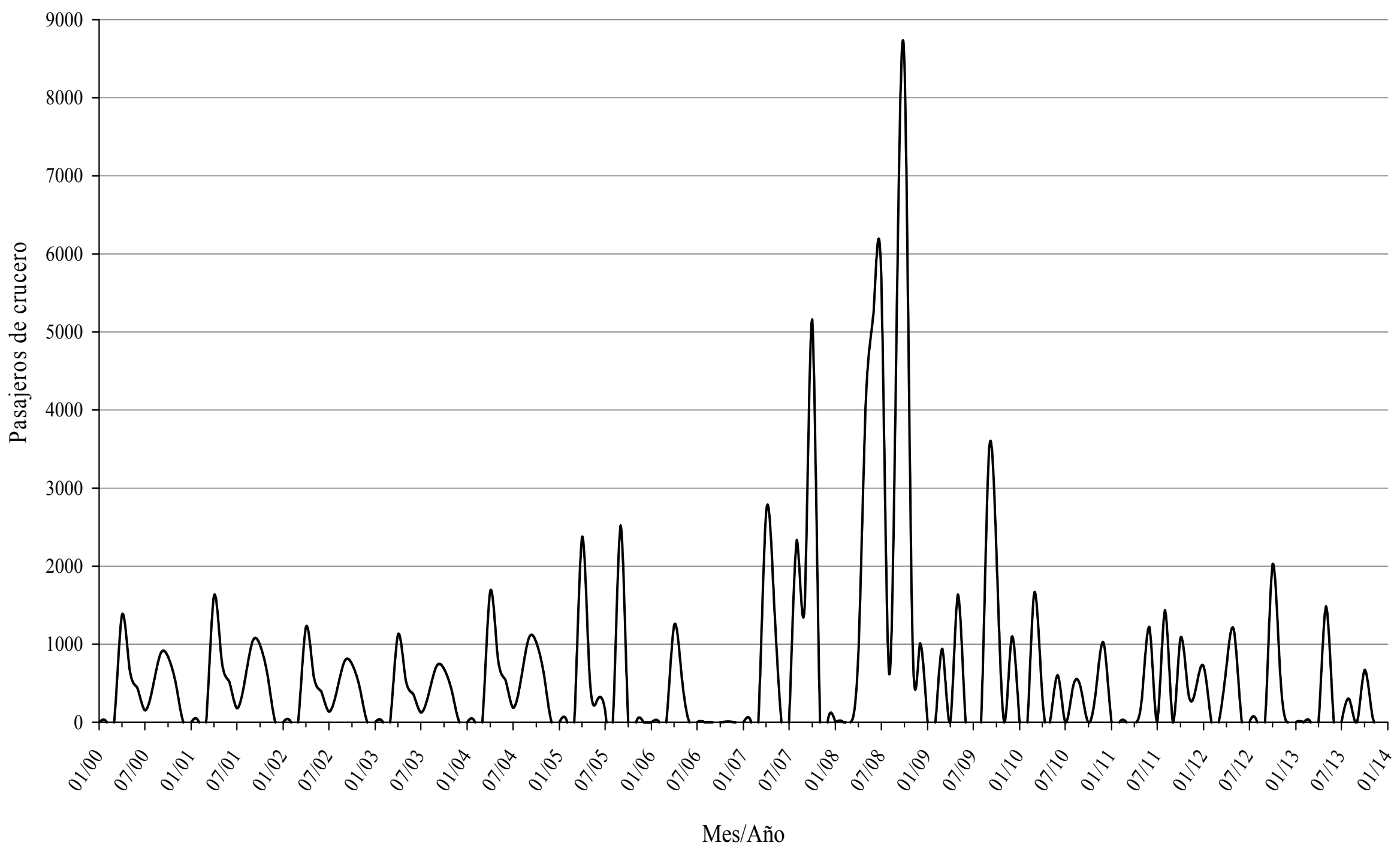

Gráfico II.35: Distribución mensual de la cifra total de cruceristas en el puerto de Ceuta entre el año 2000 y 2013.

Fuente: Elaboración propia.

$-277-$ 


\section{II.3.5 Puerto de Castellón}

El puerto de Castellón dispone de un muelle para buques de crucero de 350 metros de línea de atraque, 16 metros calado y 23 metros de ancho. Éste está situado en la dársena Norte y recibe la denominación de muelle Prolongación Dique Este, véase Figura II.23 (Autoridad Portuaria de Castellón, 2012).

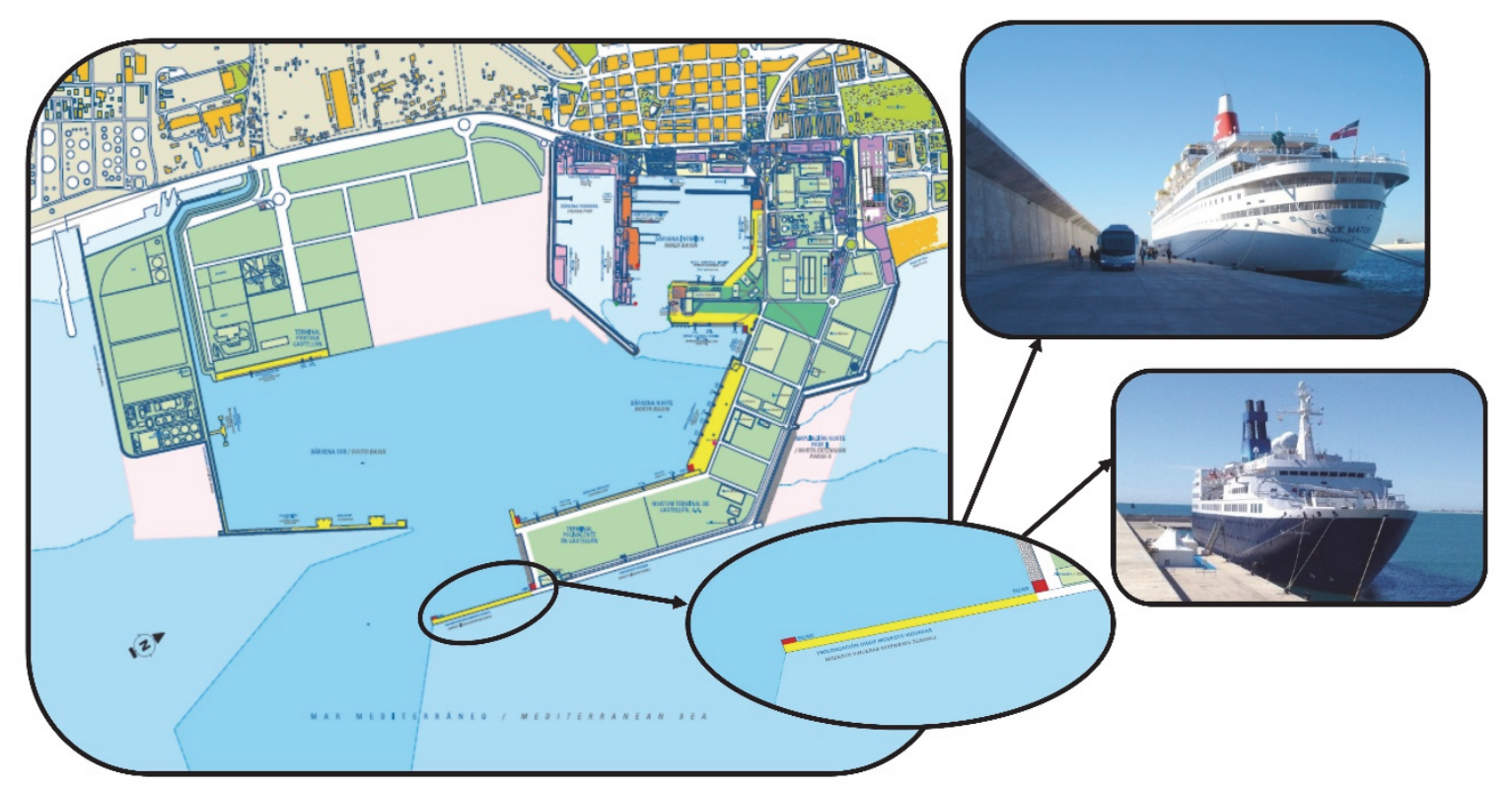

Figura II.23: Instalaciones para buques de crucero en el puerto de Castellón.

Fuente: Elaboración propia.

El puerto dispone de los servicios de remolque (4 unidades), amarradores y prácticos (obligatorio), durante las 24 horas. Previa solicitud, el puerto tiene disponible los servicios de retirada de basuras y desperdicios y suministro de agua dulce. En cuanto a los servicios para el pasaje, el puerto no dispone de edificio de terminal de pasajeros de crucero, pero en los días de escalas de cruceros se encuentran disponibles servicios de: información turística, aduana, policía de inmigración y primeros auxilios (Puerto de Castellón, 2014).

Entre los años 2000 y 2013 el puerto de Castellón no ha registrado un tráfico de cruceros afianzado, caracterizado por escasas e irregulares escalas de buques, tal y como puede observarse en el Gráfico II.36. En concreto, entre enero del año 2000 hasta octubre del año 2007 no se registró ninguna escala de cruceros. 


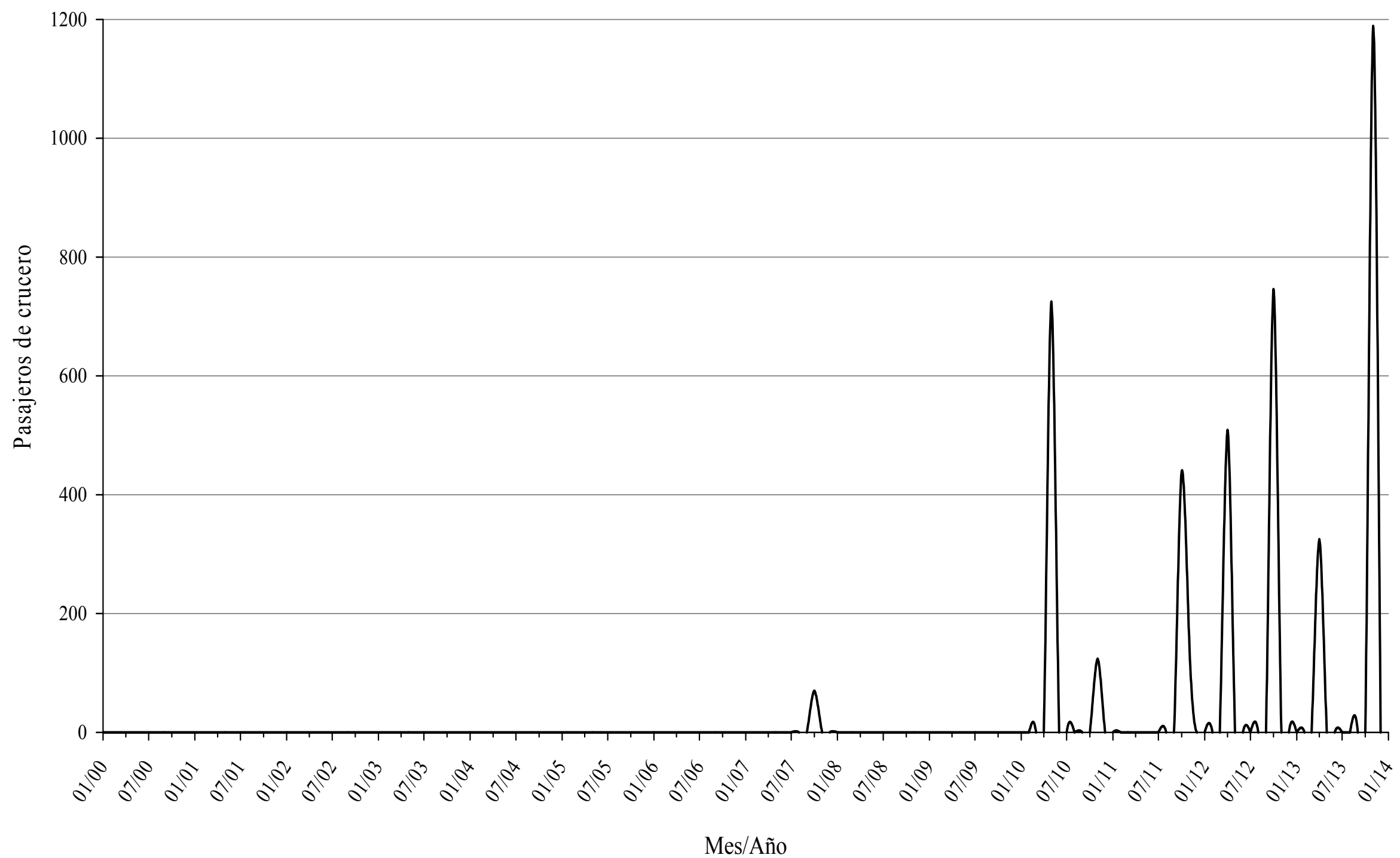

Gráfico II.36: Distribución mensual de la cifra total de cruceristas en el puerto de Castellón entre el año 2000 y 2013.

Fuente: Elaboración propia. 


\section{II.3.6 Puerto de Huelva}

El tráfico de cruceros en el puerto de Huelva no está consolidado, no dispone de instalaciones específicas destinadas a este tráfico. El reducido número de escalas de buques de crucero se atiende en el muelle Sur, el cual dispone de una línea de atraque de 750 metros, 13 metros de calado y 300 metros de anchura de la plataforma, véase Figura II.24. Actualmente este muelle tiene un uso polivalente para mercancía general y pasajeros (Autoridad Portuaria de Huelva, 2012).

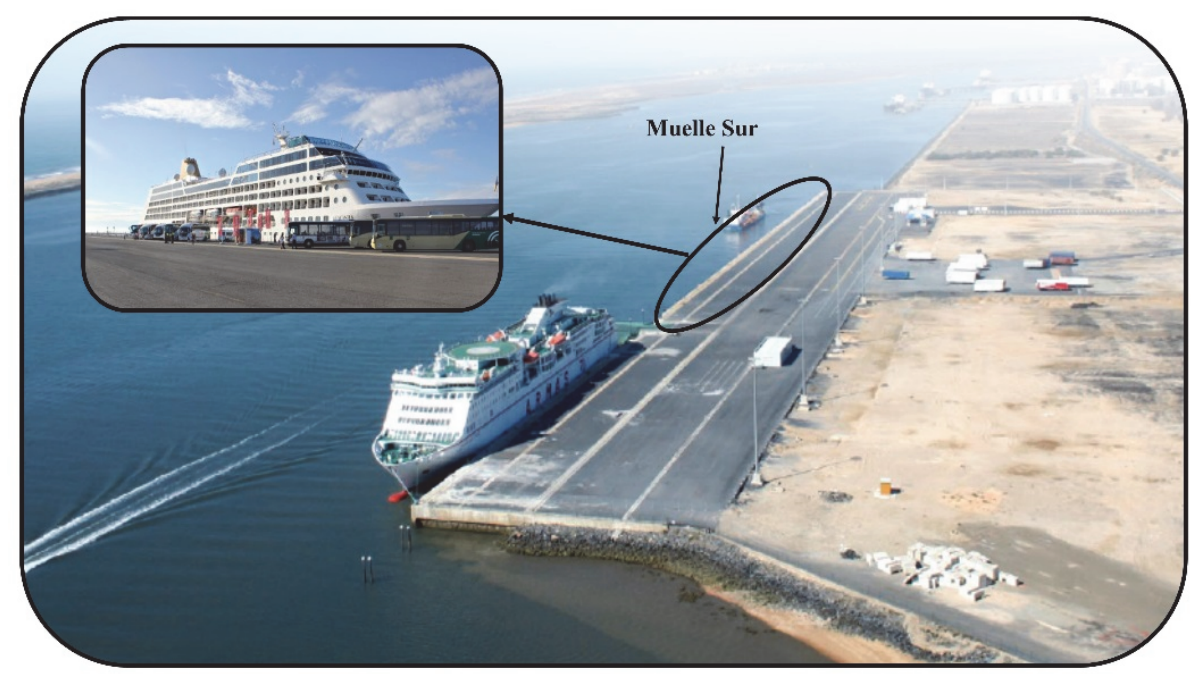

Figura II.24: Detalle del muelle Sur del puerto de Huelva e imagen de buque de crucero atracado en este muelle.

Fuente: Elaboración propia.

Los servicios disponibles para los buques son: remolque (13 unidades), amarradores y practicaje (obligatorio), durante las 24 horas, suministro de combustible, suministro de agua dulce y recogida de residuos.

El tráfico de cruceros en el puerto Huelva entre el año 2000 y 2013 ha tenido un notable carácter irregular caracterizado fundamentalmente por escalas aisladas y puntuales, véase Gráfico II.37. Una de las actuaciones contenidas en el Plan Estratégico del Puerto de Huelva 2012-2017, con visión a 2022, consiste en fomentar el tráfico de cruceros en sus muelles (Deloitte, 2013). 


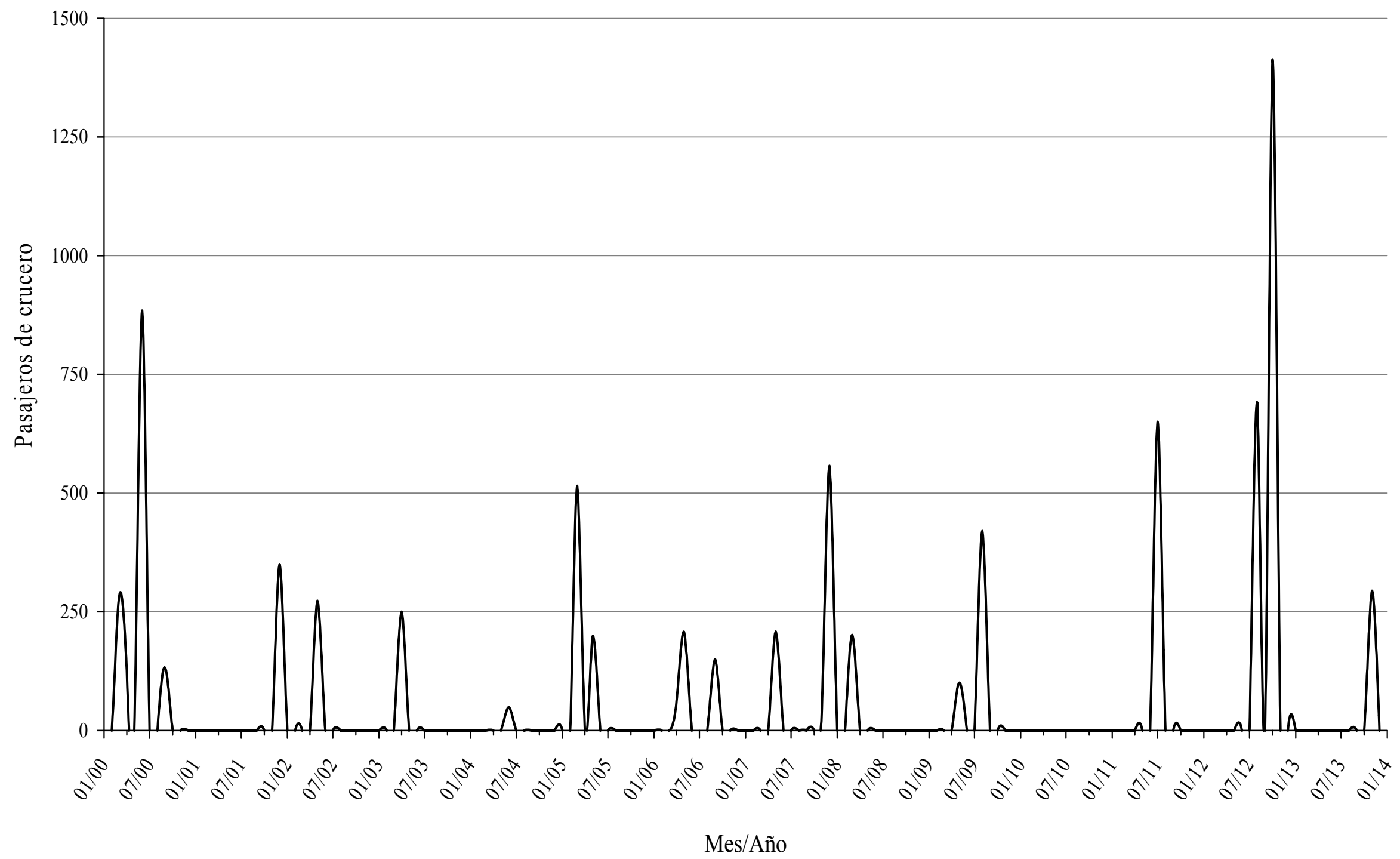

Gráfico II.37: Distribución mensual de la cifra total de cruceristas en el puerto de Huelva entre el año 2000 y 2013.

Fuente: Elaboración propia. 


\section{II.3.7 Puerto de La Savina}

El puerto de La Savina (isla de Formentera), el de menor tamaño de los gestionados por la A.P. de Baleares, únicamente dispone de 1 muelle con una línea de atraque de 120 metros y 4 metros de calado, véase Figura II.25. El puerto no cuenta con servicio de remolcadores, amarradores y prácticos, ni servicio de recogida de residuos oleosos, sólidos y líquidos (Autoridad Portuaria de Baleares, 2014d).

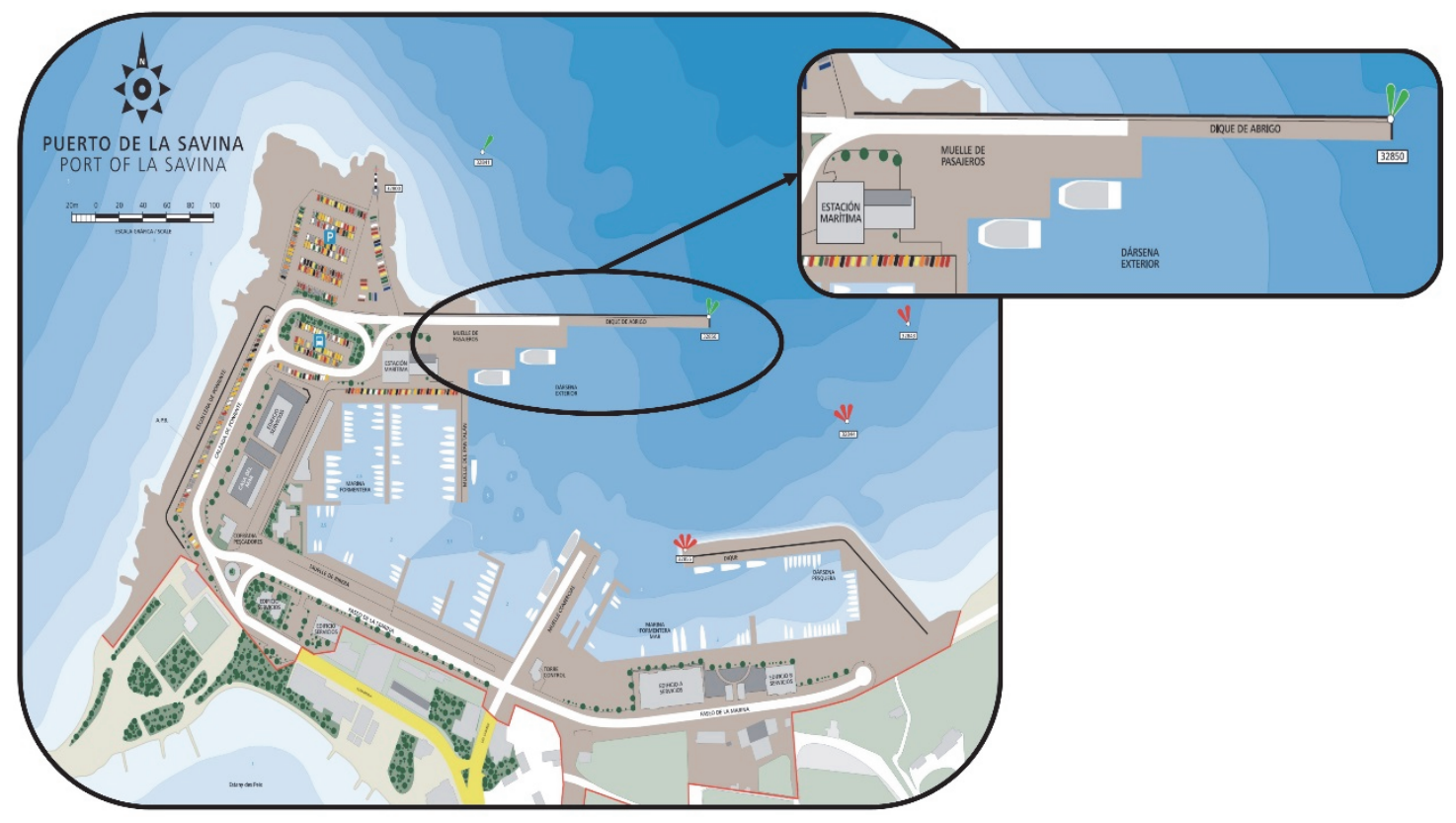

Figura II.25: Ubicación del muelle para buques de crucero en el puerto de La Savina. Fuente: Elaboración propia.

El puerto de La Savina fundamentalmente alberga el tráfico de pasaje en línea regular correspondiente a la conexión con la cercana isla de Ibiza. El tráfico de cruceros no está consolidado en este puerto, con unos registros de notable carácter irregular durante el periodo de 2000 a 2013, véase Gráfico II.38. 


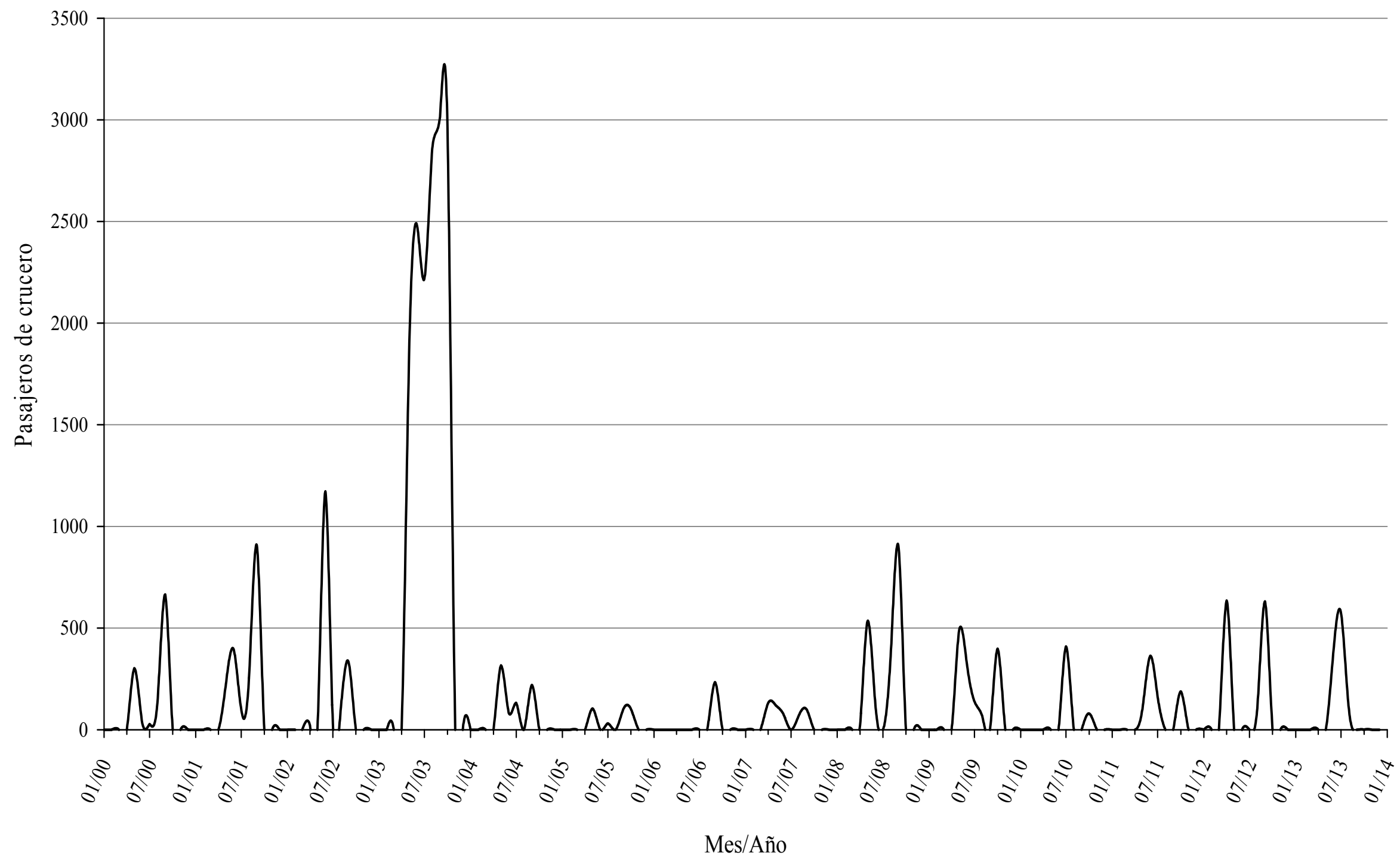

Gráfico II.38: Distribución mensual de la cifra total de cruceristas en el puerto de La Savina entre el año 2000 y 2013.

Fuente: Elaboración propia. 


\section{II.3.8 Puerto de Melilla}

El puerto de Melilla dispone de tres muelles polivalentes destinados, entre otros tráficos, a buques de crucero, son el muelle Ribera 1 y 2 y Cargadero Mineral $1^{\circ}$ y $2^{\circ}$ Atraque, véase Figura II.26. Los muelles Ribera 1 y 2 tienen un uso combinado para mercancía general, Ro-Ro y pasaje. El muelle Ribera 2 cuenta con una línea de atraque de 177 metros, 8 metros de calado y ancho de 18 a 15 metros. El muelle Ribera 1 cuenta con una línea de atraque de 224 metros, 10 metros de calado y ancho de 25 a 15 metros. Mientras que el muelle Cargadero Mineral está destinado a pasaje y embarcaciones deportivas y tiene una línea de atraque de 241 metros, 8 metros de calado y 15 metros de ancho.

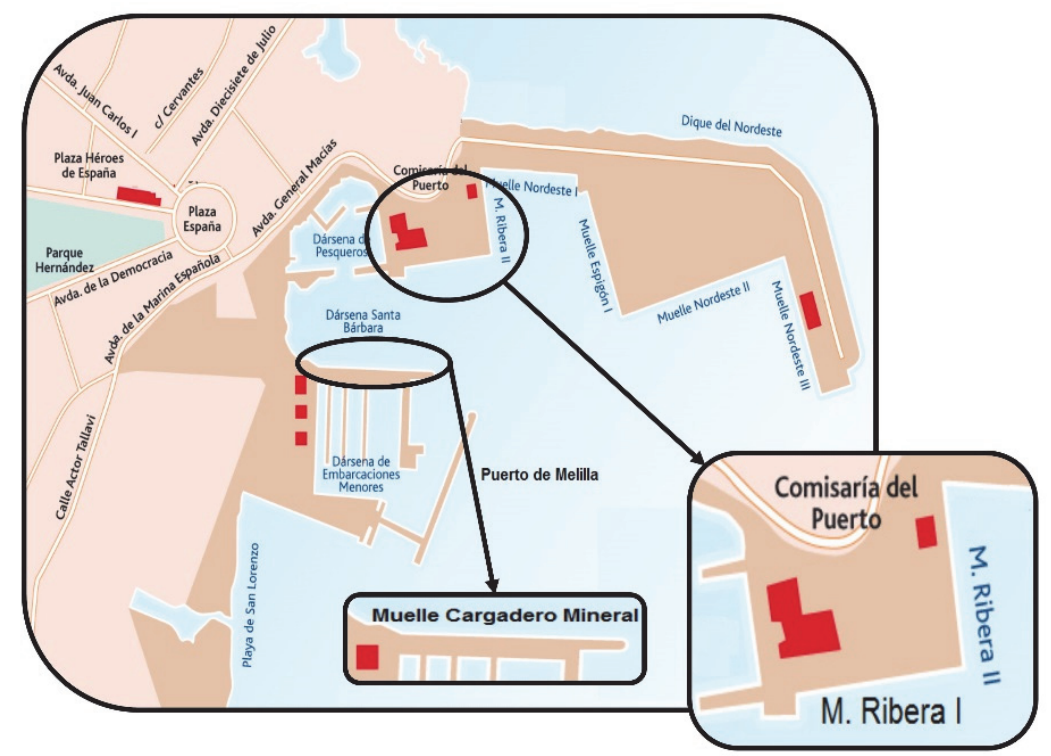

Figura II.26: Muelles destinados a buques de crucero en el puerto de Melilla. Fuente: Elaboración propia.

En el muelle Ribera 1 hay disponible una terminal de pasajeros cuyo uso primordial es servir a los tráficos de línea regular con la Península, fundamentalmente con Málaga y Almería. Eventualmente también puede servir a tráfico de cruceros (Autoridad Portuaria de Melilla, 2012). Los servicios disponibles para los buques, durante las 24 horas del día, son: remolque (1 unidad), amarre y practicaje (obligatorio).

El puerto de Melilla entre el año 2000 y 2013 ha registrado un tráfico de cruceros no consolidado, con un reducido número de escalas y de carácter irregular, véase Gráfico II.39. Además, durante este periodo se registran varios meses, incluso años, en los que no ha escalado ningún buque de crucero. 


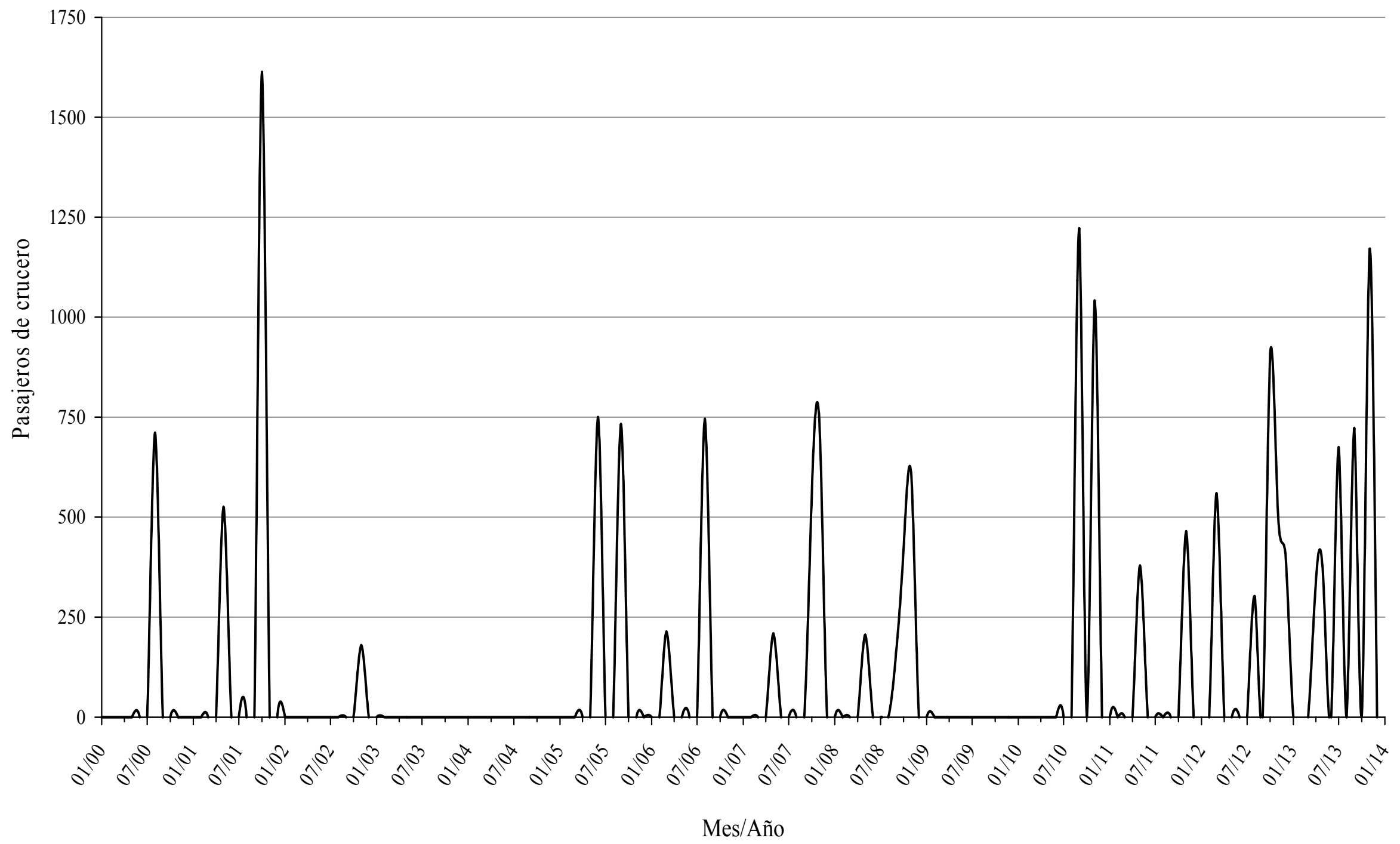

Gráfico II.39: Distribución mensual de la cifra total de cruceristas en el puerto de Melilla entre el año 2000 y 2013.

Fuente: Elaboración propia. 



\section{Referencias bibliográficas}

Aguiló, E. y Sastre, A. (1984), "La medición de la estacionalidad del turismo: El caso de Baleares”, Estudios Turísticos, Vol. 81, pp. 79-88.

AIDA Cruises (2013), "Ziele", disponible http://www.aida.de/kreuzfahrt/ziele.18536.html (consultado 24 julio 2013).

All Leisure Group (2013a), "Voyages of Discovery", disponible en: http://www.allleisuregroup.com/voyages-discovery.html (consultado 18 octubre 2013).

All Leisure Group (2013b), "Swan Hellenic", disponible en: http://www.allleisuregroup.com/swan-hellenic.html (consultado 18 octubre 2013).

AmaWaterways (2013), "Vietnam \& Cambodia", disponible en: http://www.amawaterways.com/vietnam-cambodia-river-cruises (consultado 3 mayo 2013).

American Cruise Lines (2013), "Mississippi River Cruises", disponible en: http://www.americancruiselines.com/cruises/mississippi-river-cruises/new-orleansnew-orleans-riverboat-cruise (consultado 29 abril 2013).

Autoridad Portuaria de Alicante (2011), Alicante Terminal Marítima de Cruceros, Autoridad Portuaria de Alicante, Alicante.

Autoridad Portuaria de Alicante (2012), Memoria Anual Puerto de Alicante 2012, Autoridad Portuaria de Alicante, Alicante.

Autoridad Portuaria de Almería (2011a), "Salida del primer crucero desde el puerto de Almería", disponible en: http://www.apalmeria.com/ (consultado 20 febrero 2014).

Autoridad Portuaria de Almería (2011b), Almeria, an excellent port of call, Autoridad Portuaria de Almería, Almería.

Autoridad Portuaria de Almería (2012), Memoria Anual Puerto de Almería 2012, Autoridad Portuaria de Almería, Almería.

Autoridad Portuaria de Baleares (2012), Memoria Anual Puertos de Baleares 2012, Autoridad Portuaria de Baleares, Palma de Mallorca.

Autoridad Portuaria de Baleares (2013), "Estadísticas de pasajeros de crucero", disponible en: http://www.portsdebalears.com/ (consultado 18 noviembre 2013).

Autoridad Portuaria de Baleares (2014a), "Instalaciones para cruceros turísticos en el puerto de Palma de Mallorca", disponible en: http://www.portsdebalears.com/ (consultado 26 febrero 2014).

Autoridad Portuaria de Baleares (2014b), "Instalaciones para cruceros turísticos en el puerto de Ibiza”, disponible en: http://www.portsdebalears.com/ (consultado 2 marzo 2014). 
Autoridad Portuaria de Baleares (2014c), "Instalaciones para cruceros turísticos en el puerto de Mahón”, disponible en: http://www.portsdebalears.com/ (consultado 27 febrero 2014).

Autoridad Portuaria de Baleares (2014d), "Instalaciones para cruceros turísticos en el puerto de La Savina", disponible en: http://www.portsdebalears.com/ (consultado 3 marzo 2014).

Autoridad Portuaria de Barcelona (2012), Memoria Anual Puerto de Barcelona 2012, Autoridad Portuaria de Barcelona, Barcelona.

Autoridad Portuaria de Cartagena (2012), Cartagena Cruise Port, Autoridad Portuaria de Cartagena, Cartagena.

Autoridad Portuaria de Cartagena (2013), Memoria Anual Puerto de Cartagena 2013, Autoridad Portuaria de Cartagena, Cartagena.

Autoridad Portuaria de Castellón (2012), Memoria anual puerto de Castellón 2012, Autoridad Portuaria de Castellón, Castellón.

Autoridad Portuaria de Ceuta (2012), Memoria Anual Puerto de Ceuta 2012, Autoridad Portuaria de Ceuta, Ceuta.

Autoridad Portuaria de Ceuta (2014), "Puerto de Ceuta destino de cruceros y yates", disponible en: http://w3.puertodeceuta.com/oferta-comercial/cruceros/introduccion (consultado 30 abril 2014).

Autoridad Portuaria de Huelva (2012), Memoria Anual Puerto de Huelva 2012, Autoridad Portuaria de Huelva, Huelva.

Autoridad Portuaria de la Bahía de Cádiz (2011), Cadiz cruise destination, Autoridad Portuaria de la Bahía de Cádiz, Cádiz.

Autoridad Portuaria de la Bahía de Cádiz (2012), Memoria Puerto de la Bahía de Cádiz 2012, Autoridad Portuaria de la Bahía de Cádiz, Cádiz

Autoridad Portuaria de Las Palmas de Gran Canaria (2014a), Serie de cruceristas Autoridad Portuaria de Las Palmas de Gran Canaria 1997-2003, Autoridad Portuaria de Las Palmas de Gran Canaria, Las Palmas de Gran Canaria.

Autoridad Portuaria de Las Palmas de Gran Canaria (2014b), "Estadísticas-Tráfico Acumulado Año Actual", disponible en: http://www.palmasport.es/web/guest/traficoacumulado-anyo-actual (consultado 3 septiembre 2014).

Autoridad Portuaria de Málaga (2012), Memoria Anual Puerto de Málaga 2012, Autoridad Portuaria de Málaga, Málaga.

Autoridad Portuaria de Málaga (2014), "Muelle 2 - GUADIARO", disponible en: http://www.puertomalaga.com/web/guest/muelle2 (consultado 25 marzo 2014).

Autoridad Portuaria de Melilla (2012), Memoria Anual Puerto de Melilla 2012, Autoridad Portuaria de Melilla, Melilla. 
Autoridad Portuaria de Motril (2012), Memoria Anual Puerto de Motril 2012, Autoridad Portuaria de Motril, Motril.

Autoridad Portuaria de Santa Cruz de Tenerife (2014), Serie de cruceristas y cruceros Autoridad Portuaria de Santa Cruz de Tenerife 1994-2013, Autoridad Portuaria de Santa Cruz de Tenerife, Santa Cruz de Tenerife.

Autoridad Portuaria de Sevilla (2014), "Turismo-Cruceros", disponible en: http://portal.apsevilla.com/wps/portal/puerto_es/cruceros_es?WCM_GLOBAL_CO NTEXT=/APS/puertosevilla/potleisure/turismo (consultado 20 abril 2014).

Autoridad Portuaria de Tarragona (2012), Memoria Anual Puerto de Tarragona 2012, Autoridad Portuaria de Tarragona, Tarragona.

Autoridad Portuaria de Tarragona (2014), "El port de Tarragona presenta el nuevo proyecto de cruceros a Cruise Shipping Miami", disponible en: http://www.porttarragona.cat/es/sala-de-premsa/notes-de-premsa/2052-el-port-detarragona-presenta-el-nou-projecte-de-creuers-al-cruise-shipping-miami.html (consultado 10 abril 2014).

Autoridad Portuaria de Valencia (2012), Memoria Anual Puerto de Valencia 2012, Autoridad Portuaria de Valencia, Valencia.

Azamara Club Cruises (2013), “Company Profile”, disponible en: http://www.azamaraclubcruises.com/about-azamara-club-cruises/company-profile (consultado 29 julio 2013).

Bagis, O. y Dooms, M. (2013), “Turkey's potential on becoming a cruise hub for the East Mediterranean Region: The case of Istanbul", trabajo presentado en la Conferencia de la Asociación Internacional de Economistas Marítimos, Marsella, Francia, 3-5 julio, 2013.

Baird, A. (1997), "An investigation into the suitability of an enclosed seaport for cruise ships: The case of Leith", Maritime Policy and Management, Vol. 24 No.1, pp. 31-43.

Beresford, A.K.C., Gardner, B.M., Pettit, S.J., Naniopoulos, A. y Wooldridge, C.F. (2004), "The UNCTAD and WORKPORT models of port development: evolution or revolution?", Maritime Policy and Management, Vol. 31 No.2, pp. 93-107.

Billows, N. (2013), "Multi-Use of Cruise Terminals and Financing", trabajo presentado en el seminario de cruceros de la Asociación Americana de Autoridades Portuarias, San Francisco, EE.UU., 24-25 abril, 2013.

Blount Small Ship Adventures (2013), “About Blount”, disponible en: http://blountsmallshipadventures.com/only-blount/ (consultado 30 octubre 2013).

Boletín Oficial del Estado (BOE) (2003), Ley 48/2003, de 22 de noviembre, de Régimen Económico y de Prestación de Servicios de los Puertos de Interés General, Gobierno de España, Boletín Oficial del Estado, Madrid. 
Boletín Oficial del Estado (BOE) (2005), Real Decreto 940/2005, de 1 de agosto, por el que se segrega la Autoridad Portuaria de Almería-Motril en las Autoridades Portuarias de Motril y de Almería, Gobierno de España, Boletín Oficial del Estado, Madrid.

Boletín Oficial del Estado (BOE) (2010), Ley 33/2010, de 5 de agosto, de modificación de la Ley 48/2003, de 26 de noviembre, de Régimen Económico y de Prestación de Servicios en los Puertos de Interés General, Gobierno de España, Boletín Oficial del Estado, Madrid.

Boletín Oficial del Estado (BOE) (2011), Real Decreto Legislativo 2/2011, de 5 de septiembre, por el que se aprueba el Texto Refundido de la Ley de Puertos del Estado y de la Marina Mercante, Gobierno de España, Boletín Oficial del Estado, Madrid.

Bremenports (2014), "Passenger traffic via Bremerhaven, cruise liners", disponible en: http://www.bremenports.de/en/location/statistics/passenger-traffic (consultado 27 octubre 2014).

Brooks, M.R. y Cullinane, K. (2006), Devolution, port governance and port performance, Elsevier, Londres.

Cadena de Suministro (2013), "El puerto de Alicante adjudica la explotación de la terminal de cruceros a Costablanca Portuaria", disponible en: http://www.cadenadesuministro.es/noticias/ (consultado 2 abril 2014).

Cámara de Comercio, Industria y Navegación de Valencia (CCINV) (2009), El Turismo de Cruceros, CCINV, Valencia.

Carnival Corporation (2013), “Corporate Information”, disponible en: http://phx.corporateir.net/phoenix.zhtml?c=200767\&p=irol-products (consultado 23 julio 2013).

Celebration Cruise Line (2013), "About Celebration Cruise Line", disponible en: http://www.celebracioncl.com/About-Celebration-Cruise-Line.html (consultado 22 octubre 2013).

Celebrity Cruises (2013), "Nuestra Flota", disponible en: http://www.celebritycruises.es/nuestra-flota.asp (consultado 26 julio 2013).

Centro Superior de Investigaciones Científicas (CSIC) (2006), Series temporales, Laboratorio de estadística-CSIC, Madrid.

Comisión Europea (2009), Prior notification of a concentration (Case COMP/M.5423Costa/MSC/MPCT), Comisión Europea, Bruselas.

Compagnie du Ponant (2013), "Destinations", disponible en: http://en.ponant.com/Destinations (consultado 22 octubre 2013).

Costa Cruises (2013), "Destinations", disponible en: http://www.costacruceros.es/e/destinos_crucero.html (consultado 23 julio 2013).

Creuers del Port de Barcelona (CPB) (2014a), "Oasis of the Seas - Terminals A + B", disponible en: http://www.creuers.net/en/terminal-oasis.php (consultado 16 marzo 2014). 
Creuers del Port de Barcelona (CPB) (2014b), "Terminals", disponible en: http://www.creuers.net/ (consultado 16 marzo 2014).

Creuers del Port de Barcelona (CPB) (2014c), “Awards", disponible en: http://www.creuers.net/ (consultado 16 marzo 2014).

Croisières de France (CDF) (2013), "Votre Bateau", disponible en: http://www.cdfcroisieresdefrance.com/\# (consultado 4 agosto 2013).

Croisieurope (2013), “Los Barcos”, disponible en: http://www.croisieurope.es/es/shipsrub80.html (consultado 5 mayo 2013).

Cruceros Málaga (2014), "Terminales de crucero puerto de Málaga", disponible en: http://www.crucerosmalaga.net/ (consultado 23 marzo 2014).

Cruise \& Maritime Voyages (2013), “About Us”, disponible en: http://www.cruiseandmaritime.com/about-us (consultado 22 octubre 2013).

Cruise Europe (2014), "Passengers Statistics 2009-2013", disponible en: http://www.cruiseeurope.com/statistics (consultado 18 septiembre 2014).

Cruise Industry News (2013), "Saga to Retire Ruby", disponible en: http://www.cruiseindustrynews.com/cruise-news/7521-saga-to-retire-ruby.html (consultado 17 octubre 2013).

Cruise Insight (2013), “Cruise Insight world's top cruise ports”, Cruise Insight, Autumn 2013.

Cruise Line International Association (CLIA) (2011), 2011 CLIA Cruise Market Overview. Statistical Cruise Industry Data Through 2010, CLIA, Fort Lauderdale.

Cruise Line International Association (CLIA) (2012), 2012 Cruise Industry Update, CLIA, Fort Lauderdale.

Cruise Line International Association (CLIA) (2013a), "Destinations: Alaska”, disponible en: http://www.cruising.org/vacation/destinations/alaska (consultado 21 mayo 2013).

Cruise Line International Association (CLIA) (2013b), 2013 North America Cruise Industry Update, CLIA, Fort Lauderdale.

Cruise Line International Association (CLIA) (2013c), "Destinations: South America", disponible en: http://www.cruising.org/vacation/destinations/south-america (consultado 21 mayo 2013).

Cruise Line International Association (CLIA) (2013d), "Destinations: Antarctica", disponible en: http://www.cruising.org/vacation/destinations/antarctica (consultado 21 mayo 2013).

Cruise Line International Association (CLIA) (2013e), "Destinations: Australia and New Zealand", disponible en: http://www.cruising.org/vacation/destinations/australia-andnew-zealand (consultado 22 mayo 2013). 
Cruise Line International Association (CLIA) (2013f), "Seadream Yatch Club", disponible en: http://www.cruising.org/vacation/cruiseline/seadream-yacht-club/ships/seadreamii (consultado 30 octubre 2013).

Cruise Line International Association (CLIA) (2014), CLIA 2014 State of the cruise industry report, CLIA, Fort Lauderdale.

Cruise Lines International Association Europe (CLIA Europe) (2013), The Cruise Industry. Contribution of Cruise Tourism to the Economies of Europe 2013 Edition, CLIA Europe, Bruselas.

Cruise Lines International Association Europe (CLIA Europe) (2014), The Cruise Industry. Contribution of Cruise Tourism to the Economies of Europe 2014 Edition, CLIA Europe, Bruselas.

Cruise Lines International Association UK \& Ireland (CLIA UK \& Ireland) (2014), The Cruise Review, CLIA UK \& Ireland, Londres.

Cruise Market Watch (2014a), "Growth of the Cruise Line Industry", disponible en: http://www.cruisemarketwatch.com/growth/ (consultado 17 mayo 2014).

Cruise Market Watch (2014b), "Capacity", disponible en: http://www.cruisemarketwatch.com/capacity/ (consultado 23 octubre 2014).

Cruise Norway (2013), Cruise Norway Manual 2013/2014, Cruise Norway, Bergen.

Cruise Norway (2014), Cruise Norway statistikker 2013 og prognose 2014, Cruise Norway, Bergen.

Cruise Ships (2013), “Cruise Ships", disponible en: http://www.cruiseships.com/cruiseships/ (consultado 10 junio 2013).

Crystal Cruises (2013), “About Us", disponible en: http://www.crystalcruises.com/AboutUs.aspx (consultado 17 octubre 2013).

Cunard Cruises (2013), “Compañía Cunard”, disponible en: http://www.cunardcruceros.com/cunard/quienes.do (consultado 24 julio 2013).

De Langen, P.W. y Chouly, A. (2004), "Hinterland Access Regimes in Seaports”, European Journal of Transport and Infrastructure Research, Vol. 4 No.4, pp. 361-380.

Deloitte (2013), Plan Estratégico del Puerto de Huelva 2012-2017, con visión a 2020, Deloitte, Madrid.

Di Vaio, A., Medda, F.R. y Trujillo, L. (2011), “An analysis of the efficiency of Italian cruise terminals", International Journal of Transport Economics, Vol. 38 No.1, pp. 29-46.

Diario ABC (2012), "El crucero $<<$ Azamara Quest $>>1$ lega este martes al puerto de Sevilla. Diario ABC Sevilla", disponible en: http://sevilla.abc.es/20121103/sevilla/seviazamara-quest-llega-sevilla-201211022148.html (consultado 4 abril 2014).

Diario de Cádiz (2013), “Cádiz Cruise Terminal gestionará la terminal de cruceros del puerto”, disponible en: http://www.diariodecadiz.es/ (consultado 10 noviembre 2013). 
Diario El Mundo (2013), "Nueva terminal de cruceros en Barcelona", disponible en: http://www.elmundo.es/elmundo/2013/09/27/barcelona/1380276238.html (consultado 23 noviembre 2013).

Diario Sur (2013), "El mayor crucero del mundo permitirá el embarque y desembarque en Málaga”, disponible en: http://www.diariosur.es/ (consultado 25 marzo 2014).

Disney Cruise Line (2013), "Ships \& Activities", disponible en: http://disneycruise.disney.go.com/ships-activities/ (consultado 6 agosto 2013).

Drewry Maritime Research (2013), "Drewry's Top Ten Global Container Terminal Operators 2012", disponible en: http://www.drewry.co.uk/news.php?id=232 (consultado 10 noviembre 2014).

Dwyer, L. y Kim, C. (2003), "Destination competitiveness: Determinants and indicators", Current Issues in Tourism, Vol. 6 No.5, pp. 369-414.

Esteve-Pérez, J. (2014), “Turismo de cruceros”, en García-Sánchez, A. (Ed.), Veinte años en la Actividad Turística en España, Síntesis, EN IMPRENTA.

Esteve-Pérez, J. y García-Sánchez, A. (2014), "Cruise market: Stakeholders and the role of ports and tourist hinterlands", Maritime Economics and Logistics, publicación avanzada online 21 de agosto, doi:10.1057/mel.2014.21.

Esteve-Pérez, J. y García-Sánchez, A. (2015), “Key Stakeholders in Cruise Traffic: An Application to Spanish Cruise Ports”, en Kozak, M. (Ed.), Tourism and Hospitality Management, Emerald, EN IMPRENTA.

Europa Press (2014), "El puerto de Tarragona se erige como destino de cruceros con la marca Tarragona Cruise Port", en: http://www.europapress.es/turismo/transportes/navieras/noticia-puerto-tarragonaerige-destino-cruceros-marca-tarragona-cruise-port-20140304190437.html (consultado 9 abril 2014).

European Cruise Council (ECC) (2010), 2010/2011 Report. Grow, Develop, Innovate, Build, Protect, Health, People, Communities, Responsible, Safe, Environment, Enjoyment, Holidays, ECC, Bruselas.

European Cruise Council (ECC) (2011a), Statistics and Markets 2011, ECC, Bruselas.

European Cruise Council (ECC) (2011b), 2010/2011 Report. Grow, Develop, Innovate, Build, Protect, Health, People, Communities, Responsible, Safe, Environment, Enjoyment, Holidays, ECC, Bruselas.

European Cruise Council (ECC) (2012), The Cruise Industry, Contribution of Cruise Tourism to the Economies of Europe 2012 Edition, ECC, Bruselas.

European Cruise Council (ECC) (2013), 2012/2013 Report, ECC, Bruselas.

Farah Nile Cruises (2013), “Cruise Programs", disponible en: http://www.farahnilecruise.com/cruise_programs.php (consultado 27 abril 2013). 
Fernández-Morales, A. (2003), "Decomposing seasonal concentration”, Annals of Tourism Research, Vol. 30 No.4, pp. 942-956.

Fred Olsen Cruises (2013a), "About Fred Olsen Cruise Lines", disponible en: http://www.fredolsencruises.com/About-us/About-Us (consultado 15 octubre 2013).

Fred Olsen Cruises (2013b), “Our Cruise Ships", disponible en: http://www.fredolsencruises.com/Our-Ships/Our-Cruise-Ships (consultado 15 octubre 2013).

G.P. Wild International Limited (2012), Cruise Port Ranking, G.P. Wild International Limited, Haywards Heath.

García Jiménez, E., Gil Flores, J. y Rodríguez Gómez, G. (2000), Análisis factorial, La Muralla-Hespérides, Madrid.

Genting Hong Kong Limited (2013), "Corporate Information", disponible en: http://www.gentinghk.com/en/home/profile.aspx (consultado 31 julio 2013).

Grace, M.L. (2008), "A Brief History of the Cruise Ship Industry", disponible en: http://cruiselinehistory.com/a-brief-history-of-the-cruise-ship-industry/ (consultado 20 mayo 2013).

Greek Cruise Cluster (2014), "Cruise Statistics", disponible en: http://www.greekcruise.gr/index.php/port/cruisestatistics/114 (consultado 29 octubre 2014).

Gui, L. y Russo, A.P. (2011), "Cruise ports: a strategic nexus between regions and global lines-evidence from the Mediterranean", Maritime Policy and Management, Vol. 38 No. 2, pp. 129-150.

Haezendonck, E. (2001), Essays on strategy analysis for seaports, Garant Publishers, Louvain.

Haezendonck, E., Verbeke, A. y Coeck, C. (2006), "Strategic positioning analysis for seaports", Research in Transportation Economics, Vol. 16, pp. 141-169.

Hapag Lloyd Cruises (2014), “Cruises”, disponible en: http://www.hl-cruises.com/cruises/ (consultado 17 octubre 2014).

Hayuth, Y. y Fleming, D.K. (1994), "Concepts of strategic commercial location: the case of container ports", Maritime Policy and Management, Vol. 21 No.3, pp. 187-193.

Hebridean Island Cruises (2013), "Hebridean Princess", disponible en: http://www.hebridean.co.uk/our-ship.html (consultado 18 octubre 2013).

Henderson, B.D. (1979), Henderson on corporate strategy, ABT Books, Cambridge.

Holland America Line (HAL) (2013), “About Us”, disponible en: http://es.hollandamerica.com/enes/about-best-cruise-lines/Main (consultado 23 julio 2013).

HostelTur (2004), "Navegando a toda máquina”, Revista HostelTur, Vol. 127, pp. 7-35. 
Hurtigruten (2013), "Flota", disponible en: http://www.hurtigruten.com/ships/ (consultado 8 agosto 2013).

Iberocruceros (2013), "Empresa. Nuestra Compañía", disponible en: http://www.iberocruceros.com/e/Empresa/iberocruceros.html (consultado 25 julio 2013).

Instituto Marítimo Español (IME) y Fondo Editorial de Ingeniería Naval (FEIN) (2009), Economía del Sector Marítimo, IME y FEIN, Madrid.

Instituto Nacional de Estadística (INE) (2011), “Estadística de plazas hoteleras”, disponible en: http://www.ine.es/inebmenu/mnu_hosteleria.htm (consultado 10 mayo 2012).

Juan Martínez, M.C. y Pérez García, E. (2013), COST Action TU1001 Public Private Partnerships in Transport: Trends \& Theory P3T3-Valencia Cruise Terminal, Spain, COST, Bruselas.

Lekakou, M.B. y Pallis, A.A. (2005), "Cruising the Mediterranean Sea: Market structures and EU policy initiatives", Aegean Working Papers, Vol. 2 No.1, pp. 45-61.

Lekakou, M.B., Pallis, A.A. y Vaggelas, G.K. (2009), "Is this a Home-Port? An analysis of the cruise industry's selection criteria", trabajo presentado en la Conferencia de la Asociación Internacional de Economistas Marítimos, Copenhague, Dinamarca, 24-26 junio, 2009.

Lekakou, M.B., Pallis, A.A. y Vaggelas, G.K. (2010), "Which Homeport in Europe: The Cruise Industry's Selection Criteria", Tourismos: An International Multidisciplinary Journal of Tourism, Vol. 4 No.4, pp. 215-240.

Ligteringen, H. y Velsink, H. (2012), Port and Terminals, VSSD, Delft.

Lindblad Expeditions (2013), “About Us", disponible en: http://www.expeditions.com/about-us/lindblad-history/ (consultado 31 octubre 2013).

Louis Cruises (2013), "Cruise Ships”, disponible en: http://www.louiscruises.com/es/cruiseships/index.html (consultado 4 octubre 2013).

Mariotti (2013), "Luxury Shipbuilding", disponible en: http://www.mariottiyard.it/utente/luxury_en.html (consultado 18 octubre 2013).

Marti, B.E. (1990), "Geography and the cruise ship port selection process", Maritime Policy and Management, Vol. 17 No.3, pp. 157-164.

McCalla, R.J. (1998), "An Investigation into Site and Situation: Cruise Ship Ports", Tijdschrift voor Economische en Sociale Geografie, Vol. 89 No.1, pp.44-55.

MedCruise (2011), The New MedCruise Statistic Report. $2^{\text {nd }}$ edition, MedCruise, Barcelona. MedCruise (2013a), MedCruise 2012/13 Yearbook, MedCruise, Barcelona.

MedCruise (2013b), Cruising the Mediterranean, MedCruise, El Pireo.

MedCruise (2014), Cruise activities in MedCruise ports: Statistics 2013, MedCruise, El Pireo. 
MSC Cruises (2009), "MSC Lirica ha hecho su primera escala en el puerto de Alicante", disponible en: www.mscpressarea.com (consultado 20 marzo 2014).

MSC Cruises (2012), Vessel Datasheet MSC SPLENDIDA, MSC Cruises, Nápoles.

MSC Cruises (2013), "Fleet", disponible en: http://www.msccruceros.es/es_es/Barcos-DeCrucero/Overview.aspx (consultado 5 agosto 2013).

National Geographic Expeditions (2013), “Amazon River Cruise”, disponible en: http://www.nationalgeographicexpeditions.com/expeditions/amazon-rivercruise/detail (consultado 30 abril 2013).

Navantia (2011), "Royal Caribbean International firma contrato con astillero Navantia para revitalización del Splendour of the Seas", disponible en: http://www.navantia.es/ (consultado 25 marzo 2014).

Nieto, J.L., Amate, I. y Román, I.M. (2000), "Estudio de la estacionalidad turística en la provincia de Almería durante el periodo 1980-1998", Revista de Humanidades y Ciencias Sociales del IEA, Vol. 17, pp. 13-26.

Norwegian Cruise Line (NCL) (2013), “About Norwegian Cruise Line”, disponible en: http://www.es.ncl.eu/sobre-norwegian/ (consultado 31 julio 2013).

Norwegian Cruise Line (NCL) (2014), "Ships", disponible en: http://www.ncl.co.uk/ships/norwegian-epic/ (consultado 3 octubre 2014).

Notteboom, T. (2002), "Consolidation and contestability in the European container handling industry", Maritime Policy and Management, Vol. 29 No.3, pp. 257-269.

Notteboom, T. (2009), The Relationship between Seaports and the Intermodal Hinterland in Light of Global Supply Chains: European Challenges, Discussion paper no. 2008-10, OCDE/ITF, París.

Notteboom, T. y Rodrigue, J.P. (2005), "Port Regionalization: towards a New Phase in Port Development", Maritime Policy and Management, Vol. 32 No.3, pp. 297-313.

Oceania Cruises (2013), “About Oceania Cruises”, disponible en: http://www.oceaniacruises.com/corporate/companyprofile.aspx (consultado 4 octubre 2013).

Organización Mundial del Turismo (OMT) (2008), Turismo de Cruceros - Situación Actual $y$ Tendencias, OMT, Madrid.

Organización para la Cooperación y el Desarrollo Económicos (OCDE) (2009), Port Competition and Hinterland Connections, OCDE, París.

P\&O Cruises (2013), "P\&O Cruises. Our Heritage", disponible en: http://www.pocruises.com/about-po-cruises/175-years-of-heritage/ (consultado 24 julio 2013).

Pantouvakis, A. (2006), "Port-Service quality dimensions and passenger profiles: An exploratory examination and analysis", Maritime Economics and Logistics, Vol. 8 No.4, pp. 402-418. 
Park, R.K. (2006), "A Trend Analysis of Competitive Positioning in Korean Seaports by Using the BCG Matrix with CCR, BCC and Scale Efficiency Scores”, Journal of Korea Trade, Vol. 10 No.3, pp. 1-19.

Parlamento Europeo (1999), European sea port policy, Parlamento Europeo, Luxemburgo.

Passenger Shipping Association (PSA) (2012), The Cruise Review, PSA, Londres.

Paul Gauguin Cruises (2013), “m/s Paul Gauguin”, disponible en: http://www.pgcruises.com/ship/ms-paul-gauguin (consultado 30 octubre 2013).

Pearl Seas Cruises (2013), "Destinations", disponible en: http://www.pearlseascruises.com/ (consultado 30 octubre 2013).

Phoenix Reisen (2013), "Seereisen", disponible en: http://www.phoenixreisen.com/seekreuzfahrten.html (consultado 16 octubre 2013).

Port Canaveral (2014), Cruise Guide 2014, Port Canaveral, Cape Canaveral.

Port de Barcelona (2013), “Cruise Ships”, disponible en: http://www.portdebarcelona.cat/es/ (consultado 24 noviembre 2013).

Port de Barcelona (2014), "Barcelona Cruise Facilities", disponible en: http://www.portdebarcelona.cat/es/ (consultado 10 abril 2014).

Port Everglades (2014), Cruise Guide 2015, Port Everglades, Fort Lauderdale.

Port Miami (2012), 2012 Comprehensive Annual Financial Report, Port Miami, Miami.

Port Miami (2013), Cruise Guide 2013-2014, Port Miami, Miami.

Port Miami (2014), Cruise Guide 2014, Port Miami, Miami.

Portos da Madeira (2014), Ships and Passengers Statistics 2009-2013, Portos da Madeira, Funchal.

Portuscale Cruises (2014), "Itineraries", disponible en: http://www.portuscalecruises.pt/enGB/Portuscale-Cruises--The-Discoveries-Continue.aspx (consultado 17 octubre 2013).

Princess Cruises (2013), "Destinations", disponible en: http://www.princess.com/learn/cruise-destinations/ (consultado 23 julio 2013).

Puerto de Castellón (2014), “Cruising at Castellón”, disponible en: http://www.portcastello.com/servicios/cruceros.html (consultado 3 mayo 2014).

Puertos del Estado (2012), Los Puertos: Motores del Desarrollo y de la Dinamización Económica, Puertos del Estado, Madrid.

Puertos del Estado (2014), "Estadísticas mensuales de pasajeros de crucero", disponible en: http://www.puertos.es/estadisticas/estadistica_mensual/index.html (consultado 15 mayo 2014).

Pullmantur (2013), "Historia de la Compañía", disponible en: http://www.pullmantur.es/grupo-pullmantur/historia.html (consultado 29 julio 2013). 
Regent Seven Seas Cruises (2014), “About Us", disponible en: http://www.rssc.com/about/ (consultado 17 octubre 2014).

Reyna, M. (2009), "Current ports and terminals development", trabajo presentado en el seminario de cruceros de la Asociación Americana de Autoridades Portuarias, Mazatlán, México, 18 febrero, 2009.

Robinson, R. (2002), "Ports as Elements in Value-driven Chain Systems: the New Paradigm", Maritime Policy and Management, Vol. 29 No.3, pp. 241-255.

Rodrigue, J.P. y Notteboom, T. (2013), "The geography of cruises: Itineraries, not destinations", Applied Geography, Vol. 38, pp. 31-42.

Rodrigue, J.P., Comtois, C. y Slack B. (2013), The Geography of Transport System, $3^{\mathrm{a}}$ ed., Routledge, Abingdon.

Royal Caribbean Cruises Limited (RCCL) (2007), Annual Report 2007, RCCL, Miami.

Royal Caribbean International (RCI) (2013), “Our Company. Our History”, disponible en: http://www.royalcaribbean.es/ourCompany/ourHistory.do (consultado 26 julio 2013).

Saeed, N. (2009), “An analysis of carriers' selection criteria when choosing container terminals in Pakistan”, Maritime Economics and Logistics, Vol. 11 No.3, pp. 270-288.

Saga Cruises (2014), "Classic Cruising Calendar", disponible en: http://travel.saga.co.uk/holidays/ocean-cruises/classic/classic-cruising-calendars.aspx (consultado 18 octubre 2014).

Sánchez, R.J., Hoffmann, J., Micco, A., Pizzolitto, G.V., Sgut, M. y Wilmsmeier, G. (2003), "Port efficiency and international trade: Port efficiency as a determinant of maritime transport costs", Maritime Economics and Logistics, Vol. 5 No.2, pp. 199-218.

Sancho, A. y García, G. (2006), “¿Qué indica un indicador? Análisis comparativo en los destinos turísticos", Revista de análisis turístico, Vol. 2 No.2, pp. 69-85.

Seabourn Cruise Line (2013), “Company profile", disponible en: http://www.seabourn.com/about-best-cruiselines/Main.action?WT.ac=footer_ourcmnpy (consultado 26 julio 2013).

Seadream Yacht Club (2013), “The Yatch”, disponible en: http://www.seadream.com/theyachts (consultado 30 octubre 2013).

Seatrade Insider (2013), "Headlines", disponible en: http://www.seatrade-insider.com/ (consultado 8 octubre 2013).

Seatrade Insider (2014), “Orderbook", disponible en: http://www.seatradeinsider.com/Orderbook.html (consultado 5 noviembre 2014).

Silversea Cruises (2013), "Destinos", disponible en: http://www.silversea.com/spanish/destinations/ (consultado 17 octubre 2013).

Soriani, S., Bertazzon, S., Di Cesare, F. y Rech, G. (2009), "Cruising in the Mediterranean: Structural Aspects and Evolutionary Trends", Maritime Policy and Management, Vol. 37 No.3, pp. 235-251. 
Star

Clippers

(2013),

"Destinations",

disponible

en:

http://www.starclippers.com/eu/destinations.html (consultado 30 octubre 2013).

Star Cruises (2013), “About Us. Who We Are”, disponible en: http://www.starcruises.com/en/home/aboutus.aspx (consultado 5 agosto 2013).

Swan Hellenic (2013), "Our Cruises", disponible en: http://www.swanhellenic.com/area.html (consultado 18 octubre 2013).

Tarragona Cruise Port (2014), "Port de Tarragona", disponible en: http://www.tarragonacruiseport.com/port-tarragona (consultado 2 abril 2014).

Thomson Cruises (2013), "Cruise Ships", disponible en: http://www.thomson.co.uk/cruise/ships.html (consultado 8 agosto 2013).

TUI Cruises (2013) “Über Uns”, disponible en: http://tuicruises.com/ueber-uns/ (consultado 16 octubre 2013 ).

United Nations Conference on Trade and Development (UNCTAD) (1991), Handbook on the Management and Operation of Dry Ports, UNCTAD, Ginebra.

United Nations Economic and Social Commission for Asia and the Pacific (UNESCAP) (2005), Free Trade Zone and Port Hinterland Development, UNESCAP, Nueva York.

United Nations Economic Commission for Europe (UNECE) (2010), Hinterland Connections of Seaports, UNECE, Ginebra.

Universidad Politécnica de Cartagena (UPCT) (2009), Series temporales, UPCTDepartamento de Métodos Cuantitativos e Informáticos, Cartagena.

Uniworld (2013), "China River Cruises", disponible en: http://uniworld.com/boutique-rivercruises/china/ (consultado 3 mayo 2013).

Vaggelas, G.K. y Pallis, A.A. (2010), "Passenger Ports: Services Provision and their Benefits", Maritime Policy and Management, Vol. 37 No.1, pp. 73-89.

Valencia Passenger Services (VPS) (2014), "Services", disponible en: http://www.vpsterminal.com/services.htm. (consultado 7 abril 2014).

Van de Voorde, E. y Vanelslander, T. (2009), Market power and vertical and horizontal integration in the maritime shipping and port industry, Discussion paper no. 2009-2, OCDE/ITF, París.

Vojvodic, K. (2003), "Cruise port positioning - The case of Korcula", Nase more, Journal of Maritime Science and Technology, Vol. 50 No.5-6, pp. 204-208.

Voyages of Discovery (2013), "About Us", disponible en: http://www.voyagesofdiscovery.co.uk/id-12494/about_us.html (consultado 18 octubre 2013).

Voyages to Antiquity (2013), "Our Cruises", disponible en: http://www.voyagestoantiquity.com/all-cruises.html (consultado 18 octubre 2013).

Weigend, G.G. (1958), "Some elements in the study of port geography", Geographical Review, Vol. 48 No.2, pp. 185-200. 
Wild, P. y Dearing, J. (2000), "Development of and Prospects for Cruising in Europe", Maritime Policy and Management, Vol. 27 No.4, pp. 315-333.

Wilmsmeier, G. y Hoffmann, J. (2008), "Liner shipping connectivity and port infrastructure as determinants of freight rates in the Caribbean", Maritime Economics and Logistics, Vol. 10 No.1-2, pp. 130-151.

Windstar Cruises (2013), "Yacht Renovation", disponible en: http://www.windstarcruises.com/renovations.aspx (consultado 29 octubre 2013).

Winkelmans, W. y Coeck, C. (1993), "Strategic Positioning Analysis as an evaluation instrument for effective port policy”, Planologisch Nieuws, Vol. 13 No.3, pp. 263-270.

World Bank (2007), The evolution of ports in a competitive world-Port reform toolkit 2 nd edition, World Bank, Washington. 


\section{Siglas}

A.P.: Autoridad Portuaria.

AA.PP.: Autoridades Portuarias.

ACP: Análisis de Componentes Principales.

BCG: Boston Consulting Group.

BOE: Boletín Oficial del Estado.

C.V.: Coeficiente de Variación.

CCINV: Cámara de Comercio, Industria y Navegación de Valencia.

CDF: Croisières de France.

CLIA: Cruise Line International Association.

COST: European Cooperation in Science and Technology.

CPB: Creuers del Port de Barcelona S.A.

CSIC: Centro Superior de Investigaciones Científicas.

DPW: Dubai Ports World.

EAU: Emiratos Árabes Unidos.

ECC: European Cruise Council.

FEIN: Fondo Editorial de Ingeniería Naval.

G.T.: Gross Tonnage.

HAL: Holland America Line.

HPH: Hutchison Ports Holdings.

IME: Instituto Marítimo Español.

INE: Instituto Nacional de Estadística.

ISPS: International Ship and Port Security.

ITF: International Transport Forum.

IVA.: Impuesto sobre el Valor Añadido.

IVE: Índice de Variación Estacional.

KMO: Kaiser Meyer Olkin.

MAR: Registro Internacional de Buques de Madeira.

MHI: Mitsubishi Heavy Industries.

NCL: Norwegian Cruise Line.

NYK: Nippon Yusen Kaisha. 
OCDE: Organización para la Cooperación y el Desarrollo Económicos.

OMT: Organización Mundial del Turismo.

PSA: Passenger Shipping Association.

RCCL: Royal Caribbean Cruises Limited.

RCI: Royal Caribbean International.

RSSC: Regent Seven Seas Cruises.

SPE: Sistema Portuario Español.

UNCTAD: United Nations Conference on Trade and Development.

UNECE: United Nations Economic Commission for Europe.

UNESCAP: United Nations Economic and Social Commission for Asia and the Pacific.

UPCT: Universidad Politécnica de Cartagena.

VLCV: Very Large Cruise Vessel.

VPS: Valencia Passenger Services. 